$$
\begin{aligned}
& \text { THE WARBIERS } \\
& \text { OF } \\
& \text { NORTH AMBRICA }
\end{aligned}
$$




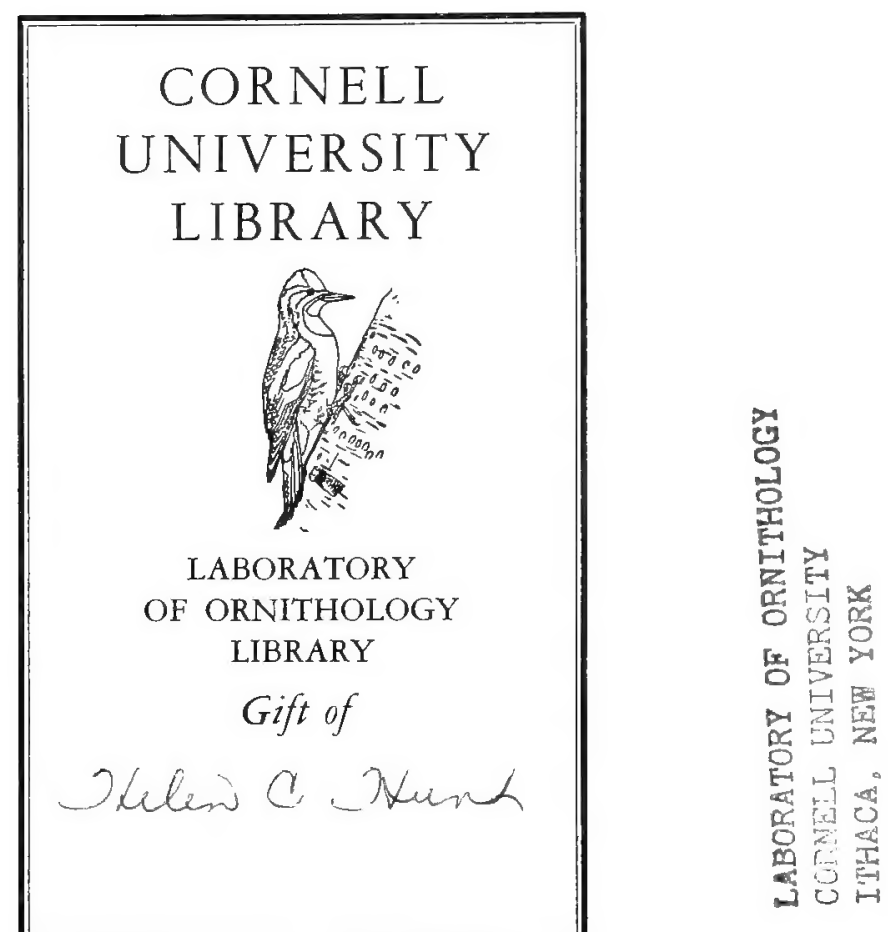


Eqe furm

Helen Cunmengs Huast from Lovie qune 1926 


\section{Cornell University Library}

The original of this book is in the Cornell University Library.

There are no known copyright restrictions in the United States on the use of the text.

http://www.archive.org/details/cu31924022517340 





\section{THE WARB LERS \\ of \\ NORTH AMERICA}




\section{By FRANK M. CHAPMAN}

Curator of Ornithology in the American Museum of Natural History.

Handbook of Birds of Eastern North America.

With Keys to the Species, Descriptions of their Plumages, Nests, etc., and their Distribution and Migrations. With over 200 Illustrations. Also in

Pocket Edition, with flexible covers.

Bird Life. A Guide to the Study of Our Common Birds.

Popular Edition in colors.

Bird Studies With a Camera. With Introductory Chapters on the Ouffit and methods of the Bird Photographer. Illustrated with over 100 photographs from Nature by the Author.

The Warblers of North America.

With Contributions from other Ornithologists and 24 full-page Colored Plates illustrating every species, from Drawings by $\mathrm{L}$. A. F uertes and B. Horsfall, and Half-tones of Nests and Eggs.

Camps and Cruises of an Ornithologist.

With 250 Photographs from Nature by the Author.

Color Key to North American Birds.

Revised Edition. With over 800 pictures.

The Travels of Birds.

Our Winter Birds.

What Bird is That?

D. APPLETUN AND COMPANY, NEW YORK. 



\section{Plate I}

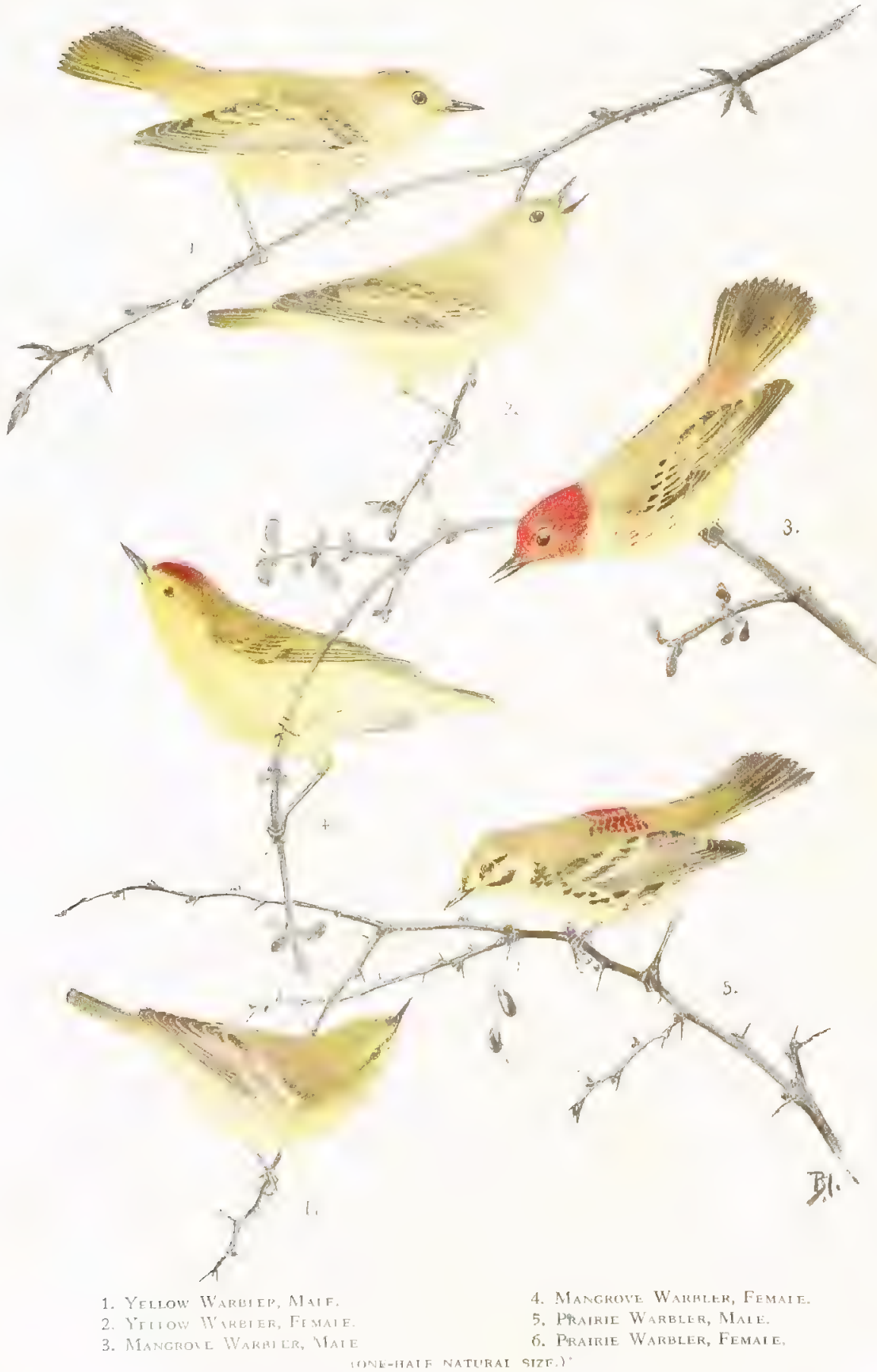






\title{
THE WARBLERS
}

OF

\section{NORTH AMERICA}

\author{
BY \\ FRANK M. CHAPMAN
}

WITH THE COÖPERATION OF OTHER ORNITHOLOGISTS

WITH TWENTY-FOUR FULL-PAGE COLORED PLATES, ILLUSTRATING EVERY SPECIES, FROM DRAWINGS BY LOUIS AGASSIZ FUERTES AND BRUCE HORSFALL, AND HALF-TONES OF NESTS AND EGGS

THIRD EDITION

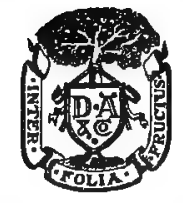

NEW YORK

D. APPLETON \& COMPANY

1907 


$$
\begin{aligned}
& \text { yrNinh } \\
& \text { CuERTES }
\end{aligned}
$$

1907

\section{0}

Copyright, 1907

By Frank M. Chapman

All rights reserved

Published, March, 1907

Reprinted, 1914, 1917,1923 


\section{PREFACE}

7 HE WARBLERS have been described as "our most beautiful, most abundant, and least known birds." The knowledge that at certain seasons our woods, and even the trees of our larger city parks are thronged with an innumerable host of birds, the brilliancy of whose plumage rivals that of many tropical species, comes to the bird student with the force of a surprising discovery. One never forgets one's first Warbler!

Highly migratory, the extended journeys of Warblers are nevertheless performed with a regularity which makes their appearance in the spring a fixed calendar event. The very essence of the season is in their flitting forms and lisping voices; without them May would seem a dreary month and the migration of birds lose half its charm.

But these dainty, fascinating sprites of the tree-tops are elusive. Years of observation may be required to add to one's list of field acquaintances the last of the thirty-odd species which, in eastern North America, may be found at a single locality.

In this quest the field-glass student is handicapped. The small size of Warblers, their activity, the nature of their haunts, their rapid journeys, marked seasonal changes in plumage, and the general resemblance in the song of many species all tend to render recognition in life unusually difficult. This book has, therefore, been prepared with the coöperation of other ornithologists, to meet the demand for a fully illustrated work which will serve as an aid to the field identification of Warblers and to the study of their life-histories.

F. M. C.

American Museum of Natural History, New York City, January, I907. 
Best gems of Nature's cabinet

With dews of tropic morning wet.

- Longfellorw 


\section{CONTENTS}

\section{INTRODUCTORY}

Plan OF THE WORT. . . . . . . . . . . I I

List of CONTRIBUTORS . . . . . . . . . . 5

THE WOOD WARBLERS . . . . . . . . . . . 7

General Characters of Warblers . . . . 7

Plumage of Warblers . . . . . . . . . 7

Distribution OF WARBLERS . . . . . . . . . . II

Migration of Warblers, W. W. Cooke . . . . . . . . I4

SONGS OF WARBLERS . . . . . . . . . . . . . 20

Nesting Habits of Warblers . . . . . . . . 22

Food of WARBLERS, Edward Howe Forbush . . . . . . . $\quad 23$

Mortality aMong Warblers . . . . . . . . . . 33

THE WARBLERS OF NORTH AMERICA . . . . . . 37

Genus I. Mntotilta . . . . . . . $\quad . \quad 38$

I. Mniotilta varia, Black and White Warbler. . . . . 38

Genus 2. Helinaia . . . . . . . 43

2. Helinaia swainsoni, Swainson's Warbler. . . . . 44

Genus 3. Helmitheros . . . . . . . . 48

3. Helmitheros vermivorus, Worm-eating Warbler. - 48

Genus 4. Protonotaria . . . . . . . . . 53

4. Protonotaria citrea, Prothonotary Warbler. . 54

Genus 5. VERMTVORA . . . . . . . . . 59

5. Vermivora chrysoptera, Golden-winged Warbler. $\quad 60$

6. " pinus, Blue-winged Warbler. . . . 65

7. " bachmani, Bachman's Warbler. . . . 77

8. " peregrina, Tennessee Warbler. . . . 83

9. " celata celate, Orange-crowned Warbler. . 86

9a. " " " orestera, Rocky Mountain Orange-crown. 89

9b. " " " lutescens, Lutescent Warbler. . . . 90

oc. " " sordida, Dusky Warbler. . . . 9I

Io. " rubricapilla rubricapilla, Nashville Warbler. . 92

Ioa. " " gutturalis, Calaveras Warbler. . 97

II. “ virginic, Virginia's Warbler. . . . . 98

12. “ lucia, Lucy's Warbler. . . . . . 100 
Genus 6. CoMpSOTHLYPIS

13. Compsothlypis americana americana, Southern Parula

Warbler. . . . usnece, Northern Parula

Warbler. . . . 104

14. " pitiayumi nigrilora, Sennett's Warbler. . Io9

Genus 7. Peucedramus . . IIO

15. Peucedramus olivaceus, Olive Warbler . . . IIO

Genus 8. DENDroica

16. Dendroica astiva astiva, Yellow Warbler. . . II3

I6a. " " sonorana, Sonora Yellow Warbler. . II9

16b. " " rubiginosa, Alaskan Yellow Warbler. . 120

I6c. " " "brewsteri, California Yellow Warbler. . I20

17. “ bryanti castaneiceps, Mangrove Warbler. . . 121

18. “ magnolia, Magnolia Warbler. . . . . I2I

19. “ tigrina, Cape May Warbler. . . . . 128

20. " carulescens carulescens, Black-throated Blue

Warbler . . 133

20a. " " cairnsi, Cairns' Warbler. . . I40

21. “ coronata, Myrtle Warbler. I41

22. “ auduboni auduboni, Audubon's Warbler. . . I47

22a. " " nigrifrons, Black-fronted Warbler. . I51

23. “ nigrescens, Black-throated Gray Warbler. . . I5I

24. “ torensendi, Townsend's Warbler. . . . 154

25. “ virens, Black-throated Green Warbler. . ${ }_{157}$

26. " chrysoparia, Golden-cheeked Warbler. . . I62

27. “ occidentalis, Hermit Warbler. . . . . ${ }^{167}$

28. “ cerulea, Cerulean Warbler. . . . . I70

29. “ fusca, Blackburnian Warbler. . . . . I75

30. " dominica dominica, Yellow-throated Warbler. I8

30a. " " albilora, Sycamore Warbler. . . 184

31. “ gracice gracice, Grace's Warbler. . . . . 185

32. “ pensylvanica, Chestnut-sided Warbler. . . 187

33. " castanea, Bay-breasted Warbler. . . 192

34. “ striata, Blackpoll Warbler. . . . . 196

35. " vigorsi vigorsi, Pine Warbler. . . . . 201

36. “ kirtlundi, Kirtland's Warbler. . . . . 206

37. “ discolor, Prairie Warbler. . . . . . 209

38. “ palmarum palmarum, Palm Warbler. . . . 213

38a. " " hypochrysea, Yellow Palm Warbler. 2I6

Genus 9. SeIURUS . . . . . . . . . . . 218

39. Seiurus aurocapillus, Oven-bird. . . . . 219

40. " motacilla, Louisiana Water-Thrush. . . 226

41. " noveboracensis noveboracensis, Northern Water-

Thrush. . . . . 230

41a. " " notabilis, Grinnell's Water-Thrush. 234

Genus 10. Oporornis . . . . . $\quad$. . 235

42. Oporornis formosus, Kentucky Warbler. . . . . 235

43. " agilis, Connecticut Warbler. . . . 24I 
44. Oporornis philadelphia, Mourning Warbler. . . 244

45. " tolmiei, Macgillivray's Warbler. . . . 249

Genus II. Gecthlypis . . . . . . . . . . 251

46. Geothlypis trichas trichas, Maryland Yellow-throat. . 25I

46a. " " ignota, Florida Yellow-throat. . . 257

46b. " " occidentalis, Western Yellow-throat. 259

46c. " " arizela, Pacific Yellow-throat. . . 260

46d. " " simuosa, Salt Marsh Yellow-throat. . 26r

47. " beldingi, Belding's Yellow-throat. . . . $26 \mathrm{r}$

Genus 12. Chamethlypis . . . . . . . . . 263

48. Chamethlypis poliocephala poliocephala, Rio Grande

Yellow-throat. . . . . . . . . 263

Genus 13. ICteria . . . . . . . . . . . 263

49. Icteria virens virens, Yellow-breasted Chat. . . . 264

49a. " " longicauda, Long-tailed Chat. . . . 268

Genus 14. Wilsonia . . . . . . . . . . 269

5o. Wilsonia citrina, Hooded Warbler. . . . . . 269

51. " " pusilla pusilla, Wilson's Warbler. . . . 274

5Ia. " " pileolata, Pileolated Warbler. . . 278

5Ib. " " chryseola, Golden Pileolated Warbler. . 279

52. " canadensis, Canada Warbler. . . . . 274

Genus I5 CARdelitina . . . . . . . . . . 285

53. Cardellina rubrifrons, Red-faced Warbler. . . . . 285

Genus I6. SetophagA . . . . . . . . . 287

54. Setophaga ruticilla, Amerıcan Redstart. . . . . 287

55. “ picta picta, Painted Redstart. . . . . 295

HYPOTHETICAL LIST . . . . . . . . . . 299

INDEX . . . . . . . . . . . . . . 301 


$$
-
$$




\section{LIST OF ILLUSTRATIONS}

\section{COLORED PLATES}

Plate.

Facing Pagie.

I. Yellow, Mangrove, and Pratrie Warblers. Horsfall. . Frontispiece

II. Blackpoll and Black and White Warblers. Horsfall. . $\quad 38$

III. Blackburnian and Prothonotary Warblers. Horsfall. . 50

IV. Bachman's, SWainson's, and Worm-eating Warblers. Fuertes. 64

V. Blue-Winged, LaWrence's, Brewster's, and Golden-Winged WARBLERS. Fuertes. . . . . . . . . • 72

VI. Olive, Lucy's, and Virginia's Warblers. Fuertes. $\quad .98$

VII. Tennessee, ORange-Crowned, and Nashville Warblers. Horsfall. . . . . . . . . . . . . . 86

VIII. Parula and Sennett's Warblers. Fuertes. . . . . . 104

IX. Cerulean and Black-throated Blue Warblers. Fuertes. . . II2

X. Myrtle and Audubon's Warblers. Fuertes. . . . . . 118

XI. Magnolia and Kirtland's Warblers. Horsfall. . . . . 126

XII. Bay-breasted and Chestnut-sided Warblers. Horsfall. . . I 38

XIII. Yellow-throated, Grace's, and Black-throated Gray Warblers.

Fuertes. . . . . . . . . . . . . 152

XIV. Black-throated Green and Golden-CheEked Warblers. Horsfall. 162

XV. Hermit and Townsend's Warblers. Fuertes. . . . . 170

XVI. Cape May and Palm Warblers. Fuertes. . . . . . 214

XVII. Rio Grande Yellow-throat, Oven-bird, Northern Water-

Thrush, Louisiana Water-Thrush. Fuertes. . . . $~ 226$

XVIII. Kentucky and Connecticut Warblers. Horsfall. . . . 236

XIX. MacGillivray's and Mourning Warblers. Horsfall. . . . 244

XX. Belding's and Maryland Yellow-throats. Fuertes. . . . 252

XXI. Hooded Warbler, Yellow-breasted Chat. Horsfall. . . . 264

XXII. WILson's and CaNada Warblers. Fuertes. . . . . 280

XXIII. American and Painted Redstarts. Horsfall. . . . $\quad 288$

XXIV. Pine and Red-faced Warblers. Horsfall. . . . . . 296

\section{PHOTOGRAPHS OF NESTS AND EGGS}

FIGURES.

Facing Page.

I. Nest of Prothonotary Warbler. . . . . . . . . 58

2. Nest of Parula Warbler. . . . . . . . . . . . . 58

3-32. Eggs of Warklers. . . . . . . . . . . . . 44

33. Nest of Yellow WARBLER. . . . . . . . . . . 188

34. Nest of Chestnut-Sided Warbler. . . . . . . . . . 188

35-64. EGGS OF Warblers. . . . . . . . . . . 144

65-94. Eggs of WARglers. . . . . . . . . . . . 176

95. Nest of Blackpoll Warkler. . . . . . . . . 200

96. Nest OF OVEN-BIRD. . . . . . . . . . . . 200

97-126. EgGS OF WARBLERS. . . . . . . . . . . $\quad{ }^{2} 58$

127. NEST OF REDSTART. . . . . . . . . . . . . . 272

228. Nest of HoOded WARBLer. . . . . . . . . . 272 



\section{INTRODUCTORY}

\section{PLAN OF THE WORK}

The plan on which this work was projected was outlined in 'Bird-Lore' for April, I903 (Pp. 6I-63). Responding to frequent and continued requests for a book treating especially of Warblers, the writer, as editor of that magazine, asked ornithologists to assist in the preparation of the proposed volume by contributing the results of their observations of the habits of Warblers, and added:

"Continued study of our birds emphasizes the absolute necessity of many observers if we are to have anything approaching adequate biographies of even a single species. Habits should be affirmed or denied only on the basis of abundant data; again, what proves true of a species in one part of its range may be incorrect in another; and we need, therefore, not only many observations from one place, but from many places throughout a bird's range before we can write its life-history with an approach to thoroughness. Coöperation, therefore, is the watchword of the bird study of to-day.

"The truth is, the best of bird biographies tell only the story of the individual rather than the species. Life is too short for a single student to acquire a thorough knowledge of more than a few species of birds, and even then his experience is apt to be linited to a small part of their range. In the writer's opinion, the bird biographies in Bendire's 'Life Histories of North American Birds' are among the best, if not the best of any which have been written. This is not solely because of Major Bendire's wide field experience and powers of observation, but also because he secured the coopperation of ornithologists throughout the country. It was not required that they should be skilled in painting pen pictures of bird-life; facts, not rhetorical flights, were wanted, and the result is one of the most satisfactory books of reference of its kind.

"There is an object-lesson for us here. In our enthusiastic appreciation of the bird as a creature of rare grace and beauty, the final touch giving life to woods and fields, let us not forget that as bird students we are here more intimately concerned with the birds' habits 
than with the part they play as the 'jewels of creation,' when, with no loss of appreciation of the esthetic side of bird-life, we may make our bird biographies a storehouse of exact and detailed observations in regard to a bird's distribution, migrations, its manner of courting, singing, nest-building, incubating, caring for its young, the relation between its structure and habit, etc."

The concluding lines were then expanded into an outline biography representing the manner in which it was desired to treat each species; and it may at once be confessed that in only a small number of instances have contributions been received which would permit of the treatment proposed. Of observations on migration, numerical abundance, local distribution, and nesting dates, there have been no lack; valuable descriptions of haunts, actions, and, particularly, of song have been sent, but the minute, intimate study revealing the bird's inner life and relation to its surroundings has, in most instances, yet to be made. Such studies result only from definitely directed and prolonged observation, and, in the development of ornithological science in America, we are only just beginning to receive contributions from naturalists who, not content with the mere ability to name the birds of their own locality and describe their habits in a general way, have chosen some particular subject or species for thorough investigation. However, it is believed that the present volume adequately reflects existing knowledge of the North American Mniotiltidæ and it is hoped, therefore, may prove a stable foundation on which to build a more complete structure.

At the outset the author disclaims any special knowledge of the members of the family of which this book treats. Circumstances, some of which have been before mentioned, have induced him to undertake its preparation; and only the generous coöperation of other workers has enabled him to complete the task.

A special effort has been made to acknowledge fully all sources of assistance. Manuscript contributions have been marked as such, while information which has been previously published is, when prac. ticable, given in the words of its author. In this connection introductory and transition remarks and other editorial ear-marks, which become tiresome through frequent repetition and tend to rob the matter quoted of its own distinctive character through the needless interposition of another personality, have been avoided as much as possible. While the result may be a less finished, it is, to our mind, a more effective whole. 
It should be added that in the selection of material, other things being equal, preference has been given to articles which have appeared in magazines, and in the publications of scientific societies which are comparatively inaccessible; while those books which can be more readily purchased have been used only when other sources of information have failed.

A list of the contributors, or co-authors of this volume is given on a succeeding page, but it is desired here to specify the nature of the material they have contributed, as well as to comment in a more or less explanatory way, on the book's contents.

Preliminary Chapters.-The subjective matter herein contained was prepared by the writer with the exception of the article on 'Migration,' which is by W. W. Cooke, and that on 'The Food of Warblers,' which was written by E. H. Forbush.

Descriptions of Plumages, etc.-The description of plumages, with remarks on genera and comments on species are by the writer. They are based on the collection of the American Museum of Natural History and the admirable series of carefully sexed Warblers in the collection of Dr. J. Dwight, Jr., which is deposited in the museum, but thanks are also due Robert Ridgway, Curator of Birds of the United States National Museum, and Dr. C. Hart Merriam, Chief of the Biological Survey, for permission to examine the birds under their charge, as well as to William Brewster and Dr. L. B. Bishop for an opportunity to study the Warblers contained in their private collections. It is a pleasure to acknowledge here, also, the assistance derived from the second volume of Ridgway's 'Birds of North and Middle America' which includes the Warblers, and Dwight's 'The Sequence of Plumages and Moults of the Passerine Birds of New York.'

The measurement of 'Length' here given is taken from study 'skins', first, because a large series of measurements taken in the flesh, of all the species treated, is not available; and, second, because it is believed that the measurement of the length of a properly prepared skin gives a more nearly correct idea of the size of the living bird, than does the measurement of the recently killed, usually relaxed, and more or less stretched specimen.

Range.-The paragraphs on distribution are, in the main, by W. W. Cooke with additions by the author who is responsible for the range given of the various subspecies of Warblers.

Migration.-The migration tables, assuredly one of the most valuable features of the book, have been prepared entirely by W. W. 
Cooke of the Biological Survey. For the past twenty years ornithologists throughout the country have been sending data on bird migration to the Survey. In the preparation of Bulletin No. I8 of the Survey ('Distribution and Migration of North American Warblers'), it was Professor Cooke's duty to elaborate this unequalled store of migration records, and the matter here given is based on that work, the migration records being presented in a tabular form which makes them easy of reference and comparison.

The Bird and its Hannts.-Under this heading an attempt has been made to present a picture of the bird in nature; sketching its appearance and actions as well as describing its haunts, both while migrating and nesting. Here are also occasionally included remarks on the time, place, or manner of the discovery of the bird or its nest and eggs, with other pertinent historical details, and, in some instances, biographical data which seem more in place here than in any other section of the outline for treatment adopted.

Especially valuable contributions to this department were made by Gerald Thayer, Frank L. Burns, Verdi Burtch, Walter K. Fisher, and Andrew Allison.

Song.-Under this caption the call-notes as well as the songs of Warblers are treated. Always a difficult and unsatisfactory subject to deal with, it is particularly so in the case of the Warblers, the calls and songs of most of which lack sufficient character to be described recognizably. However, the impressions of different observers in widely separated localities are presented, not with the expectation that what they have written will give one an adequate idea of the particular song in question, but that it will lead to its identification when heard.

Miss Paddock, Mrs. Farwell, Gerald Thayer, and Andrew Allison have made notable contributions to this part of the book, and Lynds Jones has permitted liberal use of his 'Songs of Warblers'. The student should also consult Matthews' 'Fieldbook of Wild Birds and their Music' (Putnams) which being readily procurable has not been quoted from.

Nesting-Site and Nest.-The method of treatment of these sections requires but little comment. The abundant literature of the subject has been freely drawn on, reference showing the source of information. The collections of the American Museum, William Brewster, and C. W. Crandall have been used, while particularly acceptable manuscript contributions were made by Andrew Allison, Frank L. Burns, and Verdi Burtch. 
Eggs.-The descriptions and measurements of the eggs were prepared by Mr. C. W. Crandall, well known as a careful, conservative oölogist. Mr. Crandall possesses one of the largest private collections of eggs in the country, and his work is therefore based on abundance of material. The eggs figured are, in the main, from Mr. Crandall's collection with additions from the collections of the American Museum of Natural History and of Mr. J. L. Childs.

Nesting Dates.-Unless otherwise specified the dates here given are the earliest and latest at which full sets of fresh eggs were found. Most of the data here presented were contributed by the ornithologists whose names are given as authority, but the collections of the American Museum and of Mr. C. W. Crandall as well as the literature of the subject have also been drawn on.

Biographical References.-As the heading indicates this bibliographical matter is restricted to articles treating of the habits of the bird in question. Where quotations are made from these articles due acknowledgment is made by cross-reference in the text.

Contributors.-In the preceding comments on the plan of the book, the principal contributors to it have been mentioned. Assistance, however, was received from many others, in some cases merely a nesting date, in others more extended notes. Whenever used such matter is duly acknowledged and we give here an alphabetical list of all contributors of manuscript to the book. The impossibility of including in this list the names of the hundreds of observers on whose work the migration tables are based is regretted, but Professor Cooke assures us that the manner in which these data are presented makes it impossible to give credit where credit is due.

To Waldron DeWitt Miller, Robert C. Murphy, and Ludlow Griscom I am much indebted for assistance in reading proof.

\section{LIST OF CONTRIBUTORS}

Allison, Andrew, Ellisville, Miss.

Attwater, H. P., Houston, Texas.

Bagg, Egbert, Utica, N. Y.

Barrows, Walter B., Agricultural College, Mich.

Bishop, Louis B., New Haven, Conn.

Bowles, C. W. and J. H., Tacoma, Wash.

Brewster, William, Cambridge, Mass.

Burns, Frank L., Berwyn, Pa.

Burtch, Verdi, Branchport, N. Y. 
Christy, Bayard H., Sewickley, Pa.

Cooke, W. W., Biological Survey, Washington, D. C.

Crandall, C. W., Woodside, L. I.

Dille, F. M., Denver, Colo.

Farwell, Mrs. John V., Jr., Lake Forest, Ills.

Fisher, Walter K., Palo Alto, Cal.

Forbush, E. H., Wareham, Mass.

Ganier, A. F., Vicksburg, Miss.

Gault, B. F., Glen Ellyn, Ills.

Holmes, LaRue K., the late, Summit, N. J.

Jackson, T. H., West Chester, Pa.

Jacobs, J. Warren, Waynesburg, Pa.

Jones, Lynds, Oberlin, Ohio.

Kells, Wm. L., Listowel, Ont.

Knight, O. W., Bangor, Me.

Koch, August, Williamsport, $\mathrm{Pa}$

McDavitt, Ina Lord, Vineland, N. J.

Mailliard, J. J., San Geronimo, Calif.

Morgan, Albert, Hartford, Conn.

Paddock, Miss I. M., St. Johnsbury, Vt.

Sears, Miss Annie L., Waltham, Mass.

Spaulding, F. B., Lancaster, N. H.

Stephens, Frank, San Diego, Calif.

Thayer, Gerald H., Dublin, N. H.

Wayne, A. T., Mt. Pleasant, S. C.

Widmann, Otto, St. Louis, Mo.

Wood, N. A., Ann Arbor, Mich. 


\section{THE WOOD WARBLERS}

\section{THE GENERAL CHARACTERS OF WARBLERS}

The American Warblers (Family Mniotiltidx), or Wood Warblers as they are more formally called to distinguish them from the wholly different Old World Warblers (Family Sylviidæ), are small insectivorous birds with generally slender, sharp-pointed, sometimes flattened, but never hooked (as in the Vireonidx) bills. The three or four outer primaries are longest and of nearly the same length, the tarsus is posteriorly ridged (not rounded as in the Tyrannidx), the hind-claw never lengthened (as in the Alaudidxe or Motacillidx).

The broad, bristly billed, flycatching members of the family are too brightly colored to be mistaken for most North American representatives of the true Flycatchers (Family Tyrannidx), from which they differ in other respects, and, among North American birds, the Warblers are to be confused in nature only with the Vireos and Kinglets. From the Vireos they differ in wing-formula and in lacking a hooked bill, while in life they may usually be distinguished from them by their greater activity. The Vireos are more deliberate in movement, they peer, while the Warblers pirouette, or flutter, turning the whole body this way then that, darting or springing here or there, the embodiment of perpetual motion among birds.

The Kinglets are smaller than the smallest Warbler, except Lucy's Warbler. In the Golden-crowned Kinglet the black and orange or yellow crest is always diagnostic, while the Ruby-crown's habit of nervously twitching its wings, and wren-like call note will readily distinguish it from any Warbler.

\section{PLUMAGE OF WARBLERS}

Development of Plumage.-When a Warbler leaves the egg it is apparently naked, but close examination will reveal on the feathertracts of the upper surface of the body a scanty growth of the finest down. This is the 'natal down'. (See Dwight, 'The Sequence of 
Plumages and Moults of the Passerine Birds of New York.') While the bird is in the nest this downy plumage is succeeded by a second plumage which has been termed both the 'first' and the 'juvenal' plumage but which, in my opinion, among altricial birds, may best be known as the nestling plumage.

Where, in the newly hatched bird, there was down, it is forced outward by the rapidly growing feathers of the nestling plumage, on the tips of which it remains for a brief period. Where there was no natal down, the nestling plumage is the first plumage to appear.

When, at the age of about twelve to fourteen days, the young bird leaves the nest, the nestling plumage of its body is virtually complete, but the tail is stumpy and the wings, although they support the bird in its first uncertain flight, are not fully grown. Both wings and tail, however, belong also, as we shall see, to the first fall plumage, and the distinctive nestling plumage may therefore be said to be wholly acquired in the nest.

No time intervenes between the completion of the nestling plumage and the appearance of the first feathers of the first fall plumage, traces of which indeed may often be detected in the feather tracts of the breast before the wings and tail are fully grown.

This first fall plumage is acquired by molt of the feathers of the nestling plumage and the development of a new growth of feathers. The wing and the tail quills and the primary wing-coverts are retained, but the remaining wing-coverts and all the feathers of the body are shed.

Although there may be some feather-growth during the winter, the first fall plumage remains virtually unchanged until the following spring, when, by a molt involving the feathers of various parts of the body, but not those of the wings and tail, the first breeding plumage is acquired.

With the exception of Vermivora bachmani, Peucedramus olivaceus, Dendroica chrysoparia, and Setophaga ruticilla, which apparently do not secure their mature plumage until their first postbreeding molt (at the beginning of their second autumn), the first breeding plumage resembles that of the mature bird, except for such minor differences as may be shown in the intensity of color of the wings and tail.

Following the nesting season, in accordance with the almost universal law of molt, an entirely new set of feathers, including wing and tail quills, is gained, and this, like the plumage of the first fall, 
is unchanged until the succeeding spring when certain feathers of the body may be changed, and, thereafter, this order of molt is apparently followed by the species.

Nestling Plumage.-It is difficult, if not impossible, to frame a law which shall express the relations of the nestling plumage of Warblers to their adult plumage. When, however, the adult is olivegreen above, yellow or whitish below and without spots or streaks, the young is dull olive-green or olive-brown above, dusky olive or grayish below with the belly whitish or yellowish.

Examples are Vermivora peregrina, $V$. rubricapilla, $V$. pinus, Dendroica vigorsi, Geothlypis trichas, Oporornis formosus, Wilsonia pusilla, $W$. citrina, and Icteria virens.

When the plumage of the adult is varied in pattern with streaks or spots, etc., the plumage of the nestling, while it may be widely different, is generally streaked or spotted. Examples are Mniotilta varia, Dendroica coronata, D. auduboni, D. magnolia, D. Striata, D. castanea, D. fusca, D. palmarum, and the Seiuri.

When the adult is gray above the nestling is gray, as in Vermivora lucia, Dendroica nigrescens, and $D$. dominica; and when the adult is brown above the nestling is brown or brownish, as in Helinaia swainsoni, Helmitheros vermivorus, and Seiurus aurocapillus.

As might be expected, indications of common ancestry are betrayed by the nestling plumage. The nestlings of Dendroica coronata and $D$. auduboni, for instance, while quite unlike the nestling of any other Warbler known to me, very closely resemble one another, and the spotted nestlings of Dendroica striata and $D$. castanea are almost indistinguishable. Among the more uniformly plumaged, olive-green birds this similarity in the plumage of the nestling also prevails.

An interesting character shown by the nestling, with but few exceptions, is the presence of wing-bars when they are absent or obscure in the adult. These bars are usually buff but are generally in strong contrast to the wing-coverts, of which they form the tip. With the molt from nestling into first fall plumage, these coverts are shed and the bars lost, a fact which suggests that the unbarred wing represents a higher stage in the development of the species than the barred wing.

When, in the adults, there exists a sexual difference in the color of the wings or tail, the nestling presents a corresponding difference in color, since both wings and tail are retained until after the first nesting season (e. g. Dendroica carulescens). When, however, no such difference exists, the nestlings of both sexes are alike in color. 
First Fall Plumage.-Leaving aside for the moment the question of the relation of the fall plumage of the young to that of the adult, it will be found that most of our Warblers in first fall plumage conform to the general laws of color in relation to sex and age. These may be stated as follows:

1. When the adults are alike or nearly alike in plumage, the young in first fall plumage resemble their parents in spring plumage. Examples are Protonotaria, Helmitheros, Helinaia, Vermivora, pinus, $V$. lucia, Dendroica dominica, the Seiuri, Oporornis formosus, Icteria virens, Setophaga picta, Cardellina.

2. When the adults in breeding plumage differ, the young of both sexes resemble either the breeding female or the adults in the fall. This class includes by far the largest number of Warblers. Examples are Mniotilta, Vermivora rubricapilla, $V$. celata, $V$. peregrina, Peucedramus, Compsothlypis, Dendroica tigrina, D. cestiva, $D$. coronata, $D$. auduboni, $D$. magnolia, $D$. pensylvanica, $D$. striata, $D$. castanea, $D$. fusca, $D$. nigrescens, $D$. virens, $D$. townsendi, $D$. palmarum, D. discolor, Oporornis agilis, 0 . philadelphia, 0 . tolmiei. Exceptions are Vermivora chrysiptera, Dendroica carulescens, and Wilsonia citrina.

Adult plumage.-Essentially adult plumage, as we have seen, is acquired not later than the first spring molt by all our Warblers except Vermivora bachmani, Peucedramus, Dendroica chrysoparia, and Setophaga ruticilla, in which it is doubtless acquired immediately after the first breeding season, or in the following spring.

Once acquired, the adult plumage, as far as color is concerned, may remain virtually unaltered, or it may be changed for a widely different fall plumage to be worn until the approach of the next nesting season, when the mature breeding dress is regained.

These facts may be expressed in two laws as follows:

I. When the sexes are alike, or nearly alike, in color, the fall plumage of both is generally like the spring plumage. Examples are Protonotaria, Helinaia, Helmitheros, Vermivora lucia, $V$. virginia, $V$. pinus, Dendroica dominica, D. gracie, D. kirtlandi, the Seiuri, Chamethlypis, Setophaga picta, and Cardellina.

2. When the male in spring plumage differs from the female, he generally resembles her in fall plumage. There are numerous exceptions to this law but it holds good for most species in which there is marked sexual difference. Examples are: Dendroica tigrina, $D$. coronata, $D$. auduboni, $D$. magnolia, $D$. Pensylvanica, $D$. castanea, $D$. striata, D. fusca. Exceptions are: Vermivora bachmani. 
$V$. chrysoptera, Pencedramus, Dendroica carulescens, Oporornis agilis, and $O$. tolmiei.

\section{DISTRIBUTION OF WARBLERS}

The approximately one hundred and fifty-five species contained in the family Mniotiltidæ are distributed in summer from Argentina to Labrador and northern Alaska, including the West Indies and Galapagos. During the winter few species are found north of the southern border of the United States. The wide range of some species makes a geographical analysis of the group difficult, but by allotting a species to the region in which it occupies the largest area, we have the following results:

$\begin{array}{ll}\text { South America } & 40 \text { species } \\ \text { Galapagos } & \text { Io species } \\ \text { Central America and Mexico } & 30 \text { species } \\ \text { West Indies } & 20 \text { species } \\ \text { North America } & 55 \text { species }\end{array}$

Twenty-six of the 40 South American species are contained in the genus Basileuterus and the remaining I4 belong to the genera Myioborus (9 species), Geothlypis (4 species) and Compsothlypis (I species).

Nine of the Galapagan species belong in the somewhat aberrant genus Certhidea, placed in this family for the first time by Mr. Ridgway, and one is a Yellow Warbler of the West Indian petechia group.

Central America and Mexico, omitting the northern part of the tableland, have 6 species of Basileuterus, 2 of Oreothlypis, I of Compsothlypis, 1 of Vermivora, 6 of Geothlypis, 2 of Chamethlypis, 4 of Granatellus, 3 of Myioborus, I of Euthlypis, 2 of Ergaticus, and 2 of Rhodinocichla.

The West Indies have Io species of Dendroica, I of Catharopeza, 2 of Teretistris, I of Leucopeza, I of Microligea and 5 of Geothlypis.

The constitution of the I6 North American genera is stated on a later page. It is evident, therefore, that, although of tropical origin. the Warblers now reach their highest numerical development in Nortis America.

Of the 16 genera of Warblers found in North America, the following 7 have no species breeding south of our limits: Mniotilta, Helinaia, Helmitheros, Protonotaria, (all monotypic), Oporornis, Seiurus, and Wilsonia. None of the 9 species of Vermivora nest south of the Mexican tableland, all but one entering North 
America. Icteria also extends southward over the Mexican tableland and, with Vermivora, is more North American than Mexican, though doubtless of Mexican origin.

This leaves 7 genera whose breeding range still includes an area in the tropics. Of these the following 6 enter North America through Mexico: Compsothlypis, Peucedramus, Geothlypis, Chamcthlypis, Cardellina, and Setophaga. With the exception of the forms of Geothlypis trichas, which have apparently reached the Bahamas through Florida, none of these genera is known to be represented in the breeding season in the West Indies.

On the other hand, Dendroica is evidently a West Indian genus. Excepting members of the widely distributed Yellow or Golden Warbler group, Mexico has no species of this genus which are not found in the United States, although 3 of our species extend southward into Mexico as geographic forms (i. e. D. auduboni nigrifrons, D. a. goldmani, and D. gracice decora, the latter reaching Honduras).

The West Indies, however, without including the Golden Warblers, have 7 resident species of Dendroica, 5 of which are represented in North America by closely related forms (i. e. D. adelaida and $D$. delicata, by our $D$. dominica and $D$. gracice; $D$. vigorsii achrustera and abacoensis, by $D$. v. vigorsi; $D$. vitellina, by $D$. discolor).

In this evident West Indian origin of Dendroica, we have a probable explanation of the numerical abundance of the birds of this genus in the Eastern states as compared with the Western states. Of the 23 North American species, only one, the phenomenally distributed Yellow Warbler, is found in both the Eastern and Western states, 6 occur in the west but not in the east, one appears to be restricted to east central Texas, and 15 are found in the east but not in the west.

This restriction of forms of West Indian origin to the Eastern states, in connection with their confinement to these islands in winter, leads us to consider Helinaia and Helmitheros, both confined to the east, as of West Indian rather than of Mexican origin.

As might be expected, therefore, forms of Mexican origin (e. g. Icteria and Geothlypis), which spread both to the east and the west, are likely to occupy a larger area than those which enter our limits at their extreme southeastern border. In other words, we share with the west many of the Warblers of Mexican origin, but give her in return few or none of those which have been received from the West Indies.

Continuing the comparison begun under Dendroica, we find, in the first place, that the west has only 2 genera of Warblers not repre- 
sented in the east, i. e. Cardellina and Peucedramus of the Mexican tableland, which cross our border in Arizona and New Mexico. The east, on the contrary, has the 2 genera mentioned above as of probable West Indian origin and also Mniotilta and Protonotaria.

Chamethlypis reaches our border on the lower Rio Grande, and Compsothlypis comes to us through the same door and, evidently finding the arid region of the west a bar to range extension in that direction, has followed the humid coast to the north and east. Doubtless the origin of several other species (e. g. Oporornis formosus and Wilsonia citrina) of eastern Warblers is to be accounted for in a similar manner.

The remaining 8 genera are common to both regions but it is worthy of note that only I of them is presumably of West Indian origin. Omitting, therefore, Chamathlypis and Compsothlypis, as occupying neutral ground, the east has I2 genera of Warblers, the west Io. In species, however, chiefly owing to the large number of species of Dendroica derived from the West Indies, and to those of other genera which have spread from eastern Mexico eastward, the difference between the east and the west is more pronounced. It is expressed in the following figures: Species found in both the east and west, 7 ; species found only in the west, I3; species found only in the east, 32 ; Texas species, 3 ; thus giving the east 39 species as against 20 for the west.

It should be added that this comparison is based on the Warblers of the Atlantic States with those of the Pacific States, no account here being taken of the northwestward distribution of some species to Alaska bringing them properly into the bird-life of western North America, though obviously of eastern origin.

The subject is a wide one and absence of definite knowledge of the past tempts us to speculate on the significance of the present. This outline, however, may well be concluded by the appended

Distributional Synopsis of the Family Mniotiltide.

Mniotilta, I species, eastern North America.

Helinaia, I species, eastern North America.

Helmitheros, I species, eastern North America.

Protonotaria, I species, eastern North America.

Vermivora, 9 species, 8 North America, 1 Mexico.

Oreothlypis, 2 species, Mexico and Central America.

Compsothlypis, 3 species, South America from Argentina north to Central America, Mexico, and eastern North America. 
Peucedramus, I species, Guatemala, Mexico, southern Arizona and New Mexico.

Dendroica, 34 species, South America, Central America, Mexico, West Indies, North America.

Catharopeza, I species, West Indies.

Oporornis, 4 species, North America.

Seiurus, 3 species, North America.

Teretistris, 2 species, West Indies.

Leucopeza, I species, West Indies.

Microligea, I species, West Indies.

Geothlypis, 19 species, South America from Argentina north to Central America, Mexico, Bahamas, and North America.

Chamathlypis, 2 species, Mexico, Texas.

Icteria, I species, North America and Mexico.

Granatellus, 4 species, South America, Central America and Mexico.

Wilsonia, 3 species, North America.

Cardellina, I species, Mexico, Arizona and New Mexico.

Setophaga, 2 species, North America, Mexico, Guatemala.

Myioborus, I2 species, South America, Central America, Mexico.

Euthlypis, I species, Central America, Mexico.

Basileuterus, 32 species, South America north to Central America, and Mexico.

Ergaticus, 2 species, Central America, Mexico.

Certhidea, 9 species, Galapagos Archipelago.

Rhodinocichla, 2 species, Northern South America to Mexico.

\section{MIGRATION OF WARBLERS}

BY W. W. COOKE

Scarcely a Warbler in the United States remains through the winter in the vicinity of its nesting site, while most of the North American members of this family travel many hundreds, or even thousands of miles, to their winter home. Among the few exceptions are a small number of Florida Yellow-throats (Geothlypis trichas ignota) that are resident throughout the year in Florida and southern Georgia, and also a few of the western form of the Orange-crowned Warbler (Vermivora c. sordida) resident on the Santa Barbara Islands, California.

The Pine Warbler has one of the shortest of Warbler migration routes, for it does not pass farther south in winter than the southern 
limit of its breeding range; migration with this species, therefore, is simply the withdrawing of the northern breeding individuals and the massing of the whole species in the southern fourth of its summer home. This same Pine Warbler is also one of the very few species that are confined in the winter season almost entirely to the United States.

One of the greatest travellers among the Warblers is the Blackpoll, of which species comparatively few individuals breed south of Canada, and all winter in South America. The shortest journey that any Blackpoll performs is 3,500 miles, while those that nest in Alaska have 7,000 miles to travel to their probable winter home in Brazil.

Some individuals of most of the species of Warblers desert the United States during the winter and, indeed, there are only a few species that can be found at all in this country during cold weather.

The Myrtle Warbler is the hardiest, many wintering regularly as far north as southern New York, while a few may remain in Massachusetts and in Maine. Most of the Palm Warblers spend the winter in the Gulf States; a few Black and White Warblers occur in winter in northern Florida in company with Orange-crowned and Yellow-throated Warblers, some Oven-birds and an occasional Northern Water-Thrush; while, in southern Florida a few Wormeating, Parula, Black-throated Blue, and Prairie Warblers may be found.

The Black and White, Nashville, Orange-crowned, Myrtle, and Sycamore Warblers occur during the winter in Texas, principally in the southern part. On the Pacific slope, at this season, Audubon's Warbler ranges north to southern Oregon, and Townsend's Warbler is found in southern California.

Most of the species, and by far the larger number of individuals, therefore, go south of the United States in their migration, but the distance they travel varies greatly. The Prairie, Blackthroated Blue, Swainson's, Bachman's, Cape May and Kirtland's Warblers go only to the West Indies. The Worm-eating, Myrtle, Magnolia, Chestnut-sided, Black-throated Green, Hooded, Bluewinged, Nashville, Orange-crowned, Parula, Palm, and Wilson's Warblers and the Chat, go no farther than Central America, while many species spend the winter in South America including some, or all the individuals of the Black and White, Prothonotary, Goldenwinged, Tennessee, Yellow, Cerulean, Bay-breasted, Blackpoll, Blackburnian Kentucky, Connecticut, Mourning and Canada Warblers, 
the Redstart, Oven-bird and both the Water-Thrushes. Nearly all the Warblers of the western United States spend the winter in Mexico and the contiguous portions of Central America.

Knowing that so many Warblers from the eastern United States spend the cold season in South America, and seeing the chain of islands in the West Indies stretching from Florida to Venezuela, one would suppose these islands to be the principal route of migration between the two countries. As a fact no Warbler takes the shortest course between New England and South America, by a direct flight across the ocean, as is done by many of the water birds, and few Warblers reach South America by way of the West Indies. The Blackpoll and the Connecticut Warbler are probably the only ones that use this route regularly and commonly, while the rest of the Warblers of the eastern United States, follow along the coast to Florida, then make a long flight across the Gulf of Mexico and thus, by a roundabout course through Central America, reach their winter home in South America. In the case of the Yellow Warbler, the route actually followed is about two thousand miles longer than a straight course across the Atlantic Ocean, The reasons for taking the longer journey seem to be the impossibility of making so long a single flight $(2,500$ miles) as would be required by the direct course from New England to Venezuela and the scarcity of food in the West Indies due to the small size of the eastern islands.

The Warblers are night migrants; the hundred-mile trip between Florida and Cuba is apparently always made at night and at such a speed that, in spring migration, many birds leaving Cuba after sunset, arrive on the Florida coast before midnight. The longer flight, five to seven hundred miles, across the Gulf of Mexico is also evidently made in a single night without stop or rest. How long a journey is made each night when the bird is flying over land is as yet unknown. But either the flight is short or else, after a single night's journey, the bird stops for several days to feed, for the general advance of a species in its northward migration is only a few miles per day. The Black-and-White Warbler, an early migrant, averages only thirteen miles per day and occupies a whole month in the journey from North Carolina to Massachusetts. The late migrants move faster and the Canadian Warbler, one of the latest, averages thirty miles per day and in a month crosses the whole width of the United States from the Gulf of Mexico to Canada.

Warblers also perform long migration journeys by day. Maynard (Birds E. N. A., Rev. ed., 1896,585 ) describes a flight of 
Warblers observed off the eastern coast of Andros Island, Bahamas, April 26-28, 1884, which lasted three days. Thousands of birds were seen and none of them flew more than twenty feet above the water. This observation is confirmed by Chapman (Bird-Lore, VII, I905, I40) who writes:

"While sailing from Miami, Florida, directly east across the Gulf stream to the Bahamas, in May, I904, I observed three small bodies of migrating Warblers flying toward Florida. The birds were not so high in the air as we might have expected them to be, but were flying low, within a few feet of the water.

"The first group of six or seven birds, among them a Redstart, was seen about 6 A. M., May Io, when we were some six miles from land, which was still, of course, plainly visible. Later in the day, when we were about midway between the Florida coast and the Biminis, the nearest Bahaman land, a compact flock of seventy five to one hundred Warblers passed us, flying slightly north of west. The birds were not more than ten feet above the water and were evidently not guided by sight in their choice of direction.

"On the morning of May II, as we approached the Bahaman banks, between the Biminis and Great Isaacs, a third group of Warblers was seen, and they, like the two preceding, were flying toward Florida within a few feet of the water."

Warblers make the long five hundred mile flight across the Gulf of Mexico from choice, since, if they desired, they could cross from Florida to Cuba and from Cuba to Yucatan without being out of sight of land. So far as now known, no Warbler uses this route in migration, preferring the straight course over the Gulf. It seems probable that even this five hundred mile flight is not severely exhaustive to the average bird as there are good reasons for believing that after crossing the Gulf of Mexico in the spring, many Warblers do not descend to earth as soon as they sight the coast, but continue inland many miles before alighting.

The farther north a Warbler goes the faster it migrates. The Blackpoll Warblers that nest in Alaska occupy a month in the thousand-mile trip from Florida to southern Minnesota, or an average of about thirty-five miles per day; while these same birds make the last part of their journey, 2,500 miles to Alaska, in not over two weeks, or at an average speed of at least two hundred miles per day.

When Warblers are feeding in the daytime during the migration season, they are continually on the move and their general direction is toward their summer home. This movement is not rapid, a person 
on foot can easily keep up with the shifting flocks, but in the aggregate it amounts to quite a portion of the whole distance to be traversed.

The northward or southward migration of Warblers is not a constant, uniform movement, but rather a succession of waves. Yesterday the woods were deserted, to-day almost every tree is alive with a flitting host of bright-hued migrants; in a few hours they have passed, to be followed, at longer or shorter periods, by similar companies.

Warblers have the peculiar habit, during migration, of collecting in mixed flocks composed of many different species. These combined flocks may be large or small, but during the height of the migrating season, it is rather unusual to find a flock composed of a single species. No other group or family of birds presents such composite flocks as the Warblers. In northern Minnesota, twenty-three different species, most of them in large numbers, were seen during one forenoon in a single spot in the woods through which they were passing in practically a continuous flock.

The Warblers, as a whole, are among the later Spring migrants. Feeding on insects, they remain in their southern homes until Spring is well advanced and their food abundant. Their northward movement is more rapid than the advance of the season. Thus some Yellow Warblers arrive in the Great Slave region when the average daily temperature is only $47^{\circ} \mathrm{F}$. But these same Warblers remain so late in South and Central America, that when they reach New Orleans, about April 5, an average daily temperature of $65^{\circ} \mathrm{F}$. awaits them. Thence northward they hasten, covering one thousand miles in a month, and, moving faster than the advance of Spring, find in southern Minnesota a temperature of $55^{\circ} \mathrm{F}$., and when they arrive, late in May, at Great Slave Lake, they have gained $8^{\circ}$ more on the season. During the whole trip from New Orleans to Great Slave Lake, these birds are continually meeting colder weather. The last fifteen days they traverse a district that Spring requires thirty-five days to cross. Late and rapid journeys of this kind offer certain advantages; fewer storms are encountered and food is more plentiful along the way.

The mortality of birds during the time of migration is very great and probably no other family suffers so severely as the Warblers. Small in size, with loose feathers ill adapted to withstand storm or rain, they nevertheless cross and recross the Gulf of Mexico, which doubtless becomes each year the watery grave of untold thousands. Warblers are peculiarly susceptible to the attraction of a bright light, and on stormy or dark nights during the period of migration, many 
kill themselves by striking light-houses. When the dead birds at the foot of any light-house are examined after a disastrous night, more than half are always found to be Warblers.

How the Warblers find their way in the long night journeys is still a disputed point. Some believe that they are guided entirely by sight and that mountain ranges and river courses form prominent land marks to aid in finding the course. Others go to the opposite extreme and attribute to a so-called 'sense of direction,' the bird's wonderful success in retracing its way to the last year's home. Still others think they have explained the case sufficiently when they say the bird finds its way by instinct, while still others deny the efficacy of instinct and affirm that the young birds are led in their southward journey by the old birds, who in turn remember the route from their previous season's passage. All observers are agreed that each Warbler intends to return each year to the general vicinity of the last year's nest and that most of them succeed.

Almost as great a diversity of opinion exists as to the reasons for bird migration, both as to its original cause and the factors that at present work for its continuance. There are two general theories in regard to the origin of migration. One, that the birds, originally non-migratory, increased so in numbers that their home became overcrowded and adventurous birds, passing beyond the usual boundaries, found new and congenial nesting sites. From these they were driven by the winter's shortage of food, to return again the following summer. In this view of the case, the place of residence in the winter is the bird's true home, which it deserts in the summer for the purpose of reproduction.

The second theory is the direct opposite of the one just given. According to this second theory the nesting-site is the bird's real home, from which it was driven originally by the advancing ice of the Glacial Epoch, and the habit of migration thus induced has been continued through the ages. Both theories base the origin of migration on a failure of the food supply, the one a failure in the winter home and the other in the summer.

But whatever the cause, the migration of Warblers as now conducted is at widely different periods. The Myrtle Warbler presses north in the Spring when the trees are still bare of leaves, while the Canada Warbler forms one of the rear guard, after vegetation has reached nearly full summer luxuriance. Instead of waiting until the winter's cold and a shortage of food compel 
them to depart, the more southern breelling individuals of the Summer Warbler and the Redstart begin their fall migration in early July, when the season is warmest, and their insect food supply has not yet reached its maximum.

In the light of the foregoing statements, it is no wonder that the study of bird migration has interested naturalists for generations and that the number of students of the migration of birds is steadily increasing.

\section{SONGS OF WARBLERS}

From a purely musical point of view, Warblers, as a family, take low rank as songsters. Nevertheless, the voices of even the technically least-gifted among them often so potently appeal to our memory that, as we hear them, the pleasures of the past are adiled to our enjoyment of the present. All the sweetness and promise of spring seems stored in Parula's little sizzling gurgle; there is good cheer and sunshine in Yellow Warbler's simple lay; peace and rest in the quaint zeeing of the Black-throated Green. The flight songs of the Seiuri and the unique potpourri of the Chat, however, give these Warblers just claim to a place among our leading song-birds.

If not great songsters, the Warblers are at least great singers. During the winter, I have heard only the Pine Warbler sing, but all the species, so far as I am aware, sing freely during their migrations and many of them have a second, if brief, song period in the Fall.

Acquaintance with their songs is of the greatest assistance in identifying these small, active haunters of the tree-tops, not one in a hundred of which may be satisfactorily seen. It would, therefore, be fortunate for the student of birds with a field-glass if some intelligible method of transcribing Warbler's songs could be devised. But, alas! not only do two people rarely hear the same song alike, but one's best attempts at description after a time are often meaningless to oneself. Still a description of a bird's notes may be an aid to identification, and especial attention has therefore been paid to this phase of Warblers' biographies, while the following classification of Warblers' songs may further assist the student in gaining a clue to the identity of some well-heard but poorly seen singer.

A preliminary arrangement places in one group birds which sing more than once or twice from the same perch; in another, those which pause only while singing and, between songs, continue their search for food or, indeed, sing even while moving. It will be observed 
that in the first group are included all the terrestrial and sub-terrestrial species, the lowly nature of whose haunts do not meet the requirements of a singing-perch, and, abandoning for a time their search for insects, they mount to a favoring branch and give themselves wholly to song. As if in reward for their earnestness we find that this group contains all the notable songsters of the family.

Class I. Warblers Wiitch Sing While Resting.

$$
\text { Group A. Loud, whistled songs. }
$$

Prothonotary, Swainson's, Olive (?), and Kirtland's Warblers, Pine and Yellow-throated Warblers (sing also while moving), Oven-bird, Northern Water-Thrush, Louisiana Water-Thrush, Kentucky, Connecticut, Mourning, and Macgillivray's Warblers, Northern Yellow-throat and races (sing also while moving), Chat, and probably also Belding's and Rio Grande Yellow-throats.

Group B. Warblers which have not loud, whistled songs. Tennessee, Cape May, Blackburnian, Palm.

Class II. Warblers Which Sing While Feeding.

Group $A$. Songs of the wee-chee or cher-wee type, with a whistled quality.

Yellow, Magnolia, Chestnut-sided, Bay-breasted, Grace's, Palm, Hooded, Canadian and Wilson's Warblers, American Redstart.

Group B. Warblers whose songs possess pebbly, twittering notes or which suggest a song of the Chipping Sparrow or Junco type.

Worm-eating, Bachman's, Nashville, Orange-crowned, Tennessee, Virginia's, Myrtle, Audubor's and Palm Warblers.

\section{Group C. Warblers in whose songs there is a pronounced zee quality.}

Blue-winged, Golden-winged, Parula, Black-throated Blue, Cerulean, Golden-cheeked (?), Black-throated Green, Townsend's, Hermit, and Prairie Warblers.

Group D. Warblers with a thin or wiry song.

Black and White, Cape May, Blackpoll, Blackburnian. 
Class III. Warblers With a Flight Song.

Prothonotary, Golden-winged (?), Nashville, Orange-crowned, and Tennessee (?) Warblers, Oven-bird, Northern Water-Thrush, Louisiana Water-Thrush, Mourning Warbler, Northern Yellowthroat and races, Worm-eating Warbler, Chat.

\section{NESTING HABITS OF WARBLERS}

Although only the three Seiuri, among our fifty-five species of Warblers, may be considered truly terrestrial, no less than nineteen species nest upon the ground, and fifteen more usually nest within less than three feet of it. There is, in general, a relation between the color of the bird and the character of its nestingsite. The terrestrial species are, as might be expected, dull colored, but even among the arboreal species which nest on the ground, striking colors are less frequent than among those which nest in trees. A marked exception to this rule, however, is presented by Setophaga picta, which nests in banks, etc., although the female is indistinguishable from the black and red male.

Data do not exist upon which satisfactorily to ascertain the comparative safety of ground and tree sites. While the former are more open to attack by terrestrial predaceous mammals and snakes, a nest in the trees is more likely to be visited by Crows and Jays.

On the other hand, the Cowbird appears to be more partial to a nest upon the ground, nearly one-half of the twenty-four species of Warblers in whose nests its egg has been found being ground nesters. On the whole, we may assume that the tree site is the safer, and the fact that our most abundant Warblers nest in bushes or trees gives this view some support.

We have not as yet many intimate studies of the home-life of Warblers but, so far as recorded observations go, it appears that the nest is built by the female to the accompaniment of the male's song. Occasionally the male is permitted to bring a bit of nesting material but he apparently rarely takes part in the construction of the home.

The male Pine Warbler is said rarely to sit upon the eggs but with this exception, I find no evidence that the male ever assists in incubation. He, however, lives near the nest and may at times feed the female while she is upon it.

The period of incubation in Warblers, as far as it has been ascertained, is ten or eleven days, but so little exact information 
in regard to this subject exists that some variation from this time will doubtless be found.

The young are cared for by both parents and leave the nest when from eight to twelve days old, or on the completion of the nestling plumage. In most cases but one brood is reared.

\section{FOOD OF WARBLERS}

\section{BY EDWARD HOWE FORBUSH}

It is no exaggeration to say that for the preservation of the forests, which supply the raw material for nearly all wood products, man is largely indebted to birds. The service that birds perform in protecting woodland trees against the inroads of injurious insects is more nearly indispensable to him than any other benefaction that his feathered friends confer, for the money value of woods, while great in the aggregate, is not ordinarily large enough to repay the owners the expense of protecting the trees against insect enemies, even were this possible.

A single species of insect may be too much for man to cope with when it infests his woodland. The wild animals and venomous serpents of the woods he may exterminate; but, in spite of all his efforts, insects, dangerous to human life or destructive to property, still infest the land.

Dr. A. S. Packard enumerates over four hundred species of insects that feed upon our oaks. All other forest trees have many enemies of their own. Insects attack all parts of the tree, and in so many insidious ways that man cannot hope to check them all. Were the natural enemies of insects annihilated, every tree of the woods would be threatened with destruction and we would be powerless to prevent the impending calamity. We might save a few orchards and shade trees; we might find means to raise some vegetables; but the protection of all the trees in all the woods would be beyond our powers.

It may be profitable to spray orchards with insecticides but it does not pay to spray wood-lots; to say nothing of the expense of the manual labor that must be utilized in combating insects that cannot be reached by ordinary insecticides. So we must leave the protection of the woods to birds and other natural enemies of injurious insects.

Birds attain their greatest usefulness in woodlands, mainly because the conditions prevailing there closely approach the nat- 
ural, and organic nature has a chance to adjust her balances without much human interference.

Warblers are among the most useful birds of the woods, for to them mainly is given the care of the foliage. Trees cannot live without leaves. Lepidopterous larva, commonly called caterpillars, are among the greatest of leaf-destroyers. They form a great part of the food of Warblers and are fed very largely to their young.

As the spring waxes warm and merges into summer, the opening buds and growing leaves are attacked by a succession of caterpillars of different species, which, were they not checked by birds, would soon strip all trees of their foliage and keep them stripped throughout the season. Trees breathe through their leaves and, lacking them for a considerable period, they must die. Coniferous trees are killed by a single defoliation. Deciduous trees last longer but the end is sure.

Warblers save the leaves by constantly pursuing and killing caterpillars. While living in the woods year after year I have been greatly impressed by the vast annual uprising of these pests and the strong repressive influence exerted by the Warblers upon their increase. Each brood of hundreds of caterpillars that hatches from the hidden egg-cluster is soon so reduced in number that very few live to maturity and, even though the survivors may riddle many leaves, the trees remain practically uninjured and the woods maintain their luxuriant summer verdure.

Thus the presence of Warblers in woodlands goes far towards preserving the trees for their owner. Even should the caterpillars stop short of killing the defoliated trees, the lumberman would still owe to the birds such profit as accrues from woodlands, for without their aid the trees would be so reduced in growth that they would yield no profit. While a tree is stripped of its leaves it makes no wood growth. The wood-ring for that year is smaller than usual, and the annual profit on the tree is proportionately decreased.

Warblers never receive credit for the good they do, because the insects that they eat are mainly of small size, and the majority of larger species eaten by them are taken in infancy and before they have had a chance to work noticeable injury. Warblers destroy many of the young larvæ of such great and destructive insects as the Cecropia and Polyphemus moths while these insects are still too small to attract attention. These larvæ which were so 
injurious on the "tree claims" of the prairie States before arboreal birds became abundant there, are almost never numerous enough to be destructive where such birds are plentiful. The fact that Warblers do away with these insects while the caterpillars are still very small and before they have had a chance to do any real injury, is of great economic significance. It may yet place them on a par, as regards usefulness, with the Cuckoo and other larger birds, which are considered to be among the most useful caterpillar hunters, but which probably prefer the larger caterpillars; for the Warbler, notwithstanding its small size, may be able to destroy more individual caterpillars in their infancy than even the Cuckoo can devour after the same caterpillars have increased several hundred times in size.

Warblers are mainly insectivorous and most species cannot live long without insect food. Hence their economic position is quite different from that of the Vireos, Thrushes, or Sparrows, for example, for these can live either largely or entirely for considerable periods on vegetable food.

Warblers are obliged to spend a great part of their time in a continual hunt for insects. Digestion in most small birds is continuous and the stomach is filled many times each day. It is sometimes so packed with food that when one is dissected the contents will expand to twice, or, as Professor F. E. L. Beal tells me, nearly three times, the size of that organ.

It would seem impossible for digestion to go on under such circumstances, but it nevertheless progresses so rapidly that, unless the food supply is constantly replenished, the stomach is soon empty. The capacity of Warblers for consuming the smaller insects may be shown by the statement of a few facts. According to Dr. S. D. Judd, Mr. Robert H. Coleman stated in a letter to the Biological Survey, that he counted the number of insects caught by a Palm Warbler and found that it varied from forty to sixty per minute. He says "the bird spent at least four hours on our piazza, and in that time must have gathered in about nine thousand, five hundred insects."

Of course the insects in this case must have been very small; but some of the greatest pests are small at maturity, as, for instance, the Hessian fly and the wheat midge,-insects which

1 The Birds of a Maryland Farm, by Sylvester D. Judd, Bulletin No. I7, U. S. Department of Agriculture, Division of Biological Survey, p. I04. 
have caused losses of hundreds of millions of dollars to the wheat growers of the United States.

My former assistant, Mr. F. H. Mosher, one day observed a pair of (Maryland) Yellow-throats feeding upon the aphis that infests the gray birch. One of these birds ate eighty-nine of these tiny insects in a minute. Mr. Mosher watched the pair eating at this rate for forty minutes, and states that they must have eaten over seven thousand plant-lice in that time. ${ }^{2}$ His field-notes also give instances where numbers of caterpillars of considerable size were eaten within very brief periods, by Warblers.

A Chestnut-sided Warbler was seen to capture and eat, in fourteen minutes, twenty-two gipsy caterpillars, that were positively identified, and other insects that could not be seen plainly were taken during that time. A Nashville Warbler ate forty-two of these caterpillars in thirty minutes, with many other insects as well, that either could not be plainly seen or fully identified. A (Maryland) Yellow-throat was seen to eat fifty-two caterpillars within a short time.

A Chestnut-sided Warbler took twenty-eight browntail caterpillars in about twelve minutes. When we consider that the short hairs on the posterior parts of this caterpillar are barbed like the quills of a porcupine and will penetrate the human skin, causing excessive irritation and painful eruptions, we may well wonder if the little bird lived to repeat this performance. But many small birds eat these caterpillars at a time when probably the noxious hairs have not fully developed, and others seem to have learned to divest the larger caterpillars of their hairs by beating and shaking their prey and thus loosening the hairs, which are shed as the porcupine sheds its quills. The insect is then eaten with impunity and eve $n$ fed to young birds.

Still other birds reject the external parts of the larvæ and, tearing them open, eat only small portions of their viscera. A Black and White Warbler was seen to take twenty-eight of these caterpillars in ten minutes and probably took many more. A Yellow Warbler ate thirty-three canker worms in a little over six minutes.

Practically all the Warblers feed very largely at times on measuring worms and other hairless caterpillars. I once noticed

2 Birds as Protectors of Woodlands, by E. H. Forbush, Forty-eighth Annwal Report of the Massachusetts State Board of Agriculture, I900, p. 303. 
that in an orchard infested by canker worms, those trees nearest some woods were soon cleared of the worms, mainly by Warblers, which came from the woods and sprout-land to feed upon them.

Among the favorite caterpillars eaten by Warblers are those of the Tortricidæ, or leaf rollers, which birds are very expert in taking from their places of concealment in the rolled-up leaves. The little case-bearing caterpillars, which are at times so injurious to fruit, shade, and forest trees, also are eaten by Warblers. The larvæ of the night-flying owlet moths (Noctuidæ), which include the army worm and the various cutworms, are not so often eaten by Warblers, but such species as climb trees are attacked by these birds while the ground Warblers probably feed on cutworms to some extent.

There are some caterpillars that are supposed to have a certain immunity from the attacks of birds, either because they are protected by spines, covered with hair, or secrete acrid or other distasteful or poisonous matter which renders them unfit for food. The families of silk-spinning moths, formerly collectively known as the Bombycidx, but now subdivided into many groups, include a number of the insects most injurious to fruit, shade, and forest trees. The larvæ of these insects are hairy. It is widely believed that such caterpillars are never troubled by more than a very few species of birds. But I have learned by observation that in these cases, as in many others, protection often fails to protect. I now believe that when these caterpillars are very young and small, most Warblers eat them with avidity, for they can do so with impunity at this time when the hairs or spines have not developed sufficient strength to be disagreeable.

The forest tent-caterpillar and the apple-tree tent-caterpillar are two hairy native species, while the caterpillars of the browntail moth and the gipsy moth, previously mentioned, are two very destructive introduced species. All of these are eaten by most of the commoner Warblers of New England. The two imported species were fought for years by the Massachusetts State Government, which expended more than a million dollars and then gave up the fight. These two pests are now beyond the bounds of Massachusetts and may be expected to spread over a great part of the United States, in spite of the fact that the fight against them has now been renewed in Massachusetts and taken up in other states. These insects have now become pests of the orchard, garden and forest, feeding on nearly all kinds of trees and vegetation. 
They are even more destructive here than they ever were in Europe, for here they have escaped most of their native enemies. Hence those American birds that have learned to eat them may prove of great economic value. It happens that the browntail larvæ emerge from the egg in the fall, at a time when the Warblers that breed in the Canadian Provinces and the northern tier of states are returning southward in migration, while the gipsy larva begin to hatch as the spring migration begins. The Warblers, in both cases, appear at just the right time and destroy the small larvæ by thousands. The tent-caterpillar and the forest caterpillar also are attacked by them during the spring, and eaten in considerable numbers. The larvæ of butterflies are taken as well as the pupæ and imagoes of many Lepidoptera. Warblers, however, in their selection of food are not confined to any one order of insects. They are well fitted to pursue and capture any of the smaller insects, except those that hide in the ground or in the solid wood, and even they are in danger if they ever show themselves in daylight outside their chosen retreats.

The habits and haunts of the Warblers are so varied that, collectively, the species of this family exert a repressive influence on nearly all orders of insects, from those that live on or near the ground to those that frequent the very tree-tops. The Oven-birds, Water-Thrushes, Yellow-throats, and the other ground Warblers search the ground, the fallen leaves, and undergrowth for the species most commonly found there as well as those that fall from the trees. Where grasshoppers are plentiful the ground Warblers sometimes feed largely on them. The bugs that are found so often on berry bushes, are not overlooked, notwithstanding their rank taste, which is so well known to all who have picked blueberries from the bushes. The eggs of bugs are also eaten.

Another family belonging to this order (Hemiptera), which is often prominent among the food of Warblers, is the Aphididæ or plant-lice, previously mentioned. Most Warblers probably eat certain of these insects or their eggs. Each of these eggs may represent the future form of plant-louse known as the Stem Mother which, no mishap occurring to shorten the natural life of her descendants, would, according to Huxley, produce in ten generations a mass of plant-lice equal in bulk to that of five hundred million human beings, or the population of the Chinese Empire. A few species of Warblers eat bark lice and scale insects. 
Beetles (Coleoptera) form a varying part of the food of Warblers. While a few beneficial species are eaten, the vast majority taken are believed to be either neutral or injurious. The useful ladybugs (Coccinellidæ) apparently are seldom eaten. The tiger beetles and the larger useful ground beetles (Cicindelidæ and Carabidæ) are not much sought by Warblers.

Many of the injurious bark beetles and other boring beetles are greedily eaten. Bark beetles (Scolytidæ) are among the most insidious and deadly enemies of trees. They often complete the destruction of trees that have been defoliated by caterpillars. Unable, as they usually are, to live in the most thrifty and vigorous trees, a tree is no sooner weakened by the loss of its leaves, than these beetles are attracted to it. Their eggs are soon deposited and the resulting larvæ bore away among the vital tissues of the tree along the inner surface of the bark. If their increase is not checked, a year or two of their work is sufficient to destroy the noblest trees of the forest. The Warblers, however, attack these borers as they mature and emerge from their burrows in the pairing season. The Black and White Warbler, which in summer takes the place so well filled in winter by the Brown Creeper, probably leads in the destruction of bark beetles, but many other species eat them, and thus the Warblers again come to the rescue of the trees.

Warblers are not only useful in woodland by destroying borers, they are valuable also in orchards. Professor S. A. Forbes found that fifteen Warblers shot in an orchard infested by canker worms in Illinois, had all eaten Cerambycid beetles, or borers, to the amount of ten per cent. of their stomach contents. Other important elements of the food of Warblers at times are the destructive click beetles and weevils. Leaf-eating beetles also are eaten.

Many Hymenoptera are taken by the flycatching Warblers, such as the Redstart and other species that capture much of their food on the wing. Some of the wasps and bees taken are beneficial, but they are probably most useful when kept within proper bounds by the birds. At times considerable numbers of hymenopterous parasites are taken.

It is probable, however, that the larger numbers of these useful insects are found in the stomachs of Warblers only when the parasites are unduly abundant. A surplus of these insects is of no 
benefit and must always die without issue, even if they are not eaten by birds.

Birds eat not only the useful primary parasites but the injurious secondary parasites that feed on primary parasites. Hence it is questionable whether birds ever do much harm by destroying parasitic hymenoptera, except by some unlucky accident. Whatever injury they may do in this way is probably offset by their destruction of injurious ants. Caddice flies and May flies are eaten by Warblers.

In addition to the insect food, some spiders, myriapods, and snails are taken. Spiders are useful creatures, but if one will go out into the woods and fields some dewy or foggy morning in fall and observe how spiders' webs cover the fields, how they drape the trees, and net the shrubbery, he will see how essential it is that they be held in check lest a spider-plague overwhelm the land.

Dr. Judd tells us that he found that ninety-six per cent. of the food in the stomach contents of fifty-three Warblers taken on a Maryland farm, consisted of insects, and that the arboreal Warblers, other than the Myrtle Warbler are almost purely insectivorous. Still some Warblers are able to subsist for a brief time on vegetable food mainly.

Audubon tells us that in May, I808, during a light fall of snow in Pennsylvania, he took five Chestnut-sided Warblers that had eaten nothing but grass seeds and a few small spiders. Occasionally small seeds or remains of wild berries are found in the stomachs of Warblers, more particularly those of the ground-frequenting species; but I have examined the digestive tract of Warblers taken in the height of the berry season and found only insects and spiders. The Myrtle Warbler, that hardy little bird that so often winters in the north, eats very freely of the fruits of the bayberry, waxberry or myrtle, and cedar: remains of grapes are sometimes found in their stomachs and small seeds are not disdained. The Pine Warbler is said to feed on the seed of pine trees in winter, and I have seen it eat suet almost as freely as does the Chickadee.

On the whole, however, Dr. Judd rightly regards the Warblers as insectivorous, and the value to man of those species that nest in or near an orchard or shade trees is not likely to be overestimated.

The enormous number of insects that breeding Warblers must secure to feed their young may be inferred from the fact that 
each young bird requires fully half its own weight of insects each day. As the young are fed very largely on caterpillars, and as they are reared at a time when these insects are most plentiful there is no doubt regarding the restraining influence exerted upon the increase of such insect life throughout the North Temperate Zone by a family of birds so abundant and widely distributed as the Warblers. The usefulness of these birds in migration consists in their eminently insectivorous habits and in the power possessed by them, in common with most other birds, of assembling quickly where food is plentiful. They thus form a sort of aerial police whose chief function is to put down uprisings of injurious insects. Such insects are of little importance except where they appear in abnormal numbers. Wherever this occurs a counter-check is needed, at once, lest by the geometrical progression of their increase they overwhelm all opposition and sweep everything before them. The migrating Warblers form such a counter-check. They sweep over the country always on the watch for an abundant food supply. Wherever food is plentiful the birds gather. Find a great swarm of young caterpillars or birch plant-lice in the spring and there you will find, in their seasons, practically all the Warblers that pass through that region.

The reduction of the numbers of insects by migrating Warblers may be illustrated by a leaf or two from my own experience. In the spring of 1903 , an old field in Concord, Massachusetts, grown up to birches, was much infested by plant-lice. Although the spring flight of Warblers was small, these birches were frequented by them. In the fall migration the birch field was again the gathering place of Warblers, although elsewhere in the woods the flight of birds was so meagre as to be hardly apparent. In 1904 the aphids were somewhat reduced in number, but the birds followed them up, as in the previous year, until, late in October, most of the plant-lice had disappeared, and the Myrtle Warblers, the latest migrants, leaving the birches, attacked other plant-lice on the wild apple trees. Since then comparatively few birch plant-lice have been seen in the field. This may have been partly due to the action of predaceous insects, parasites, or to adverse meteorological conditions, but the effect produced by the birds was very marked.

One fine Sunday in October, 1904, I saw a flock of Warblers about a few poplar trees near the river. They were feeding on swarms of a mature aphis. I watched them at intervals all day. 
The flock seldom exceeded fifteen birds, mostly Blackpoll and Myrtle Warblers. Before night the swarms of insects that had been so numerous in the morning had dwindled so that it was rather difficult for me to secure a specimen, although the birds still found some. When I went there the next morning a single remaining bird was still finding a few, but I could not see a specimen nor have I seen one there since.

In 1905 I returned to my home at Wareham, Massachusetts, the first week in November, and found a flock of Myrtle Warblers busily hunting over the limbs and twigs of some apple trees and pear trees near my house. From the actions of the birds, I concluded that they had discovered an outbreak of some pest, but at first I could see nothing on the twigs that they were inspecting. By watching them with the glass, however, I soon saw exactly where they were finding food. Then by stepping up to a bird quickly and driving it away before it could seize the object of its quest, I saw that it was feeding on a minute cicada-shaped, black insect. This, indeed, was the only species of living insect I could find on those trees. Three of these insects were secured, and two were sent to Dr. L. O. Howard, chief of the Bureau of Entomology at Washington. He identified them as the imago of the peartree Psylla, a pest which has been very destructive to pear orchards in Maryland and New Jersey. I learned that the birds had been visiting these trees for about two weeks. At the time of my return they had evidently disposed of most of the last brood of the season, for, although they were still finding a good many on the day of my return, they found very few afterwards though they visited the trees daily for a week longer. These insects hibernate on the trees by hiding in the crevices between the twigs and are thus exposed to the attacks of birds all winter. The above brief and imperfect review represents fairly well our knowledge of the economic relations of American Warblers. Probably we shall never have an authentic and scientifically accurate account of the percentages of the component parts of the food of each species, until the investigation of their food is taken up by the Division of Biological Survey of the United States Department of Agriculture, where the greatest study of the food of birds the world has ever seen is now being made. Enough is known, however, to warrant the belief that our Warblers are deserving of all the protection man can afford them. 
MORTALITY AMONG WARBLERS

The mortality among North American Warblers is doubtless higher than that which prevails in any other family of American birds. Their nest mortality is probably above the average while a variety of unfavorable conditions encountered during their exceptionally extended migrations, often cause them to perish by tens of thousands.

A discussion of the comparative safety of terrestrial and arboreal nesting-sites will be found under the head of the 'Nesting Habits of Warblers', here I may simply enumerate the enemies of Warblers while in the nest. Chief among them are foxes, skunks, weasels, martens, opossums, squirrels, cats, snakes, crows, jays, and, except among the more northern species, probably most fatal of all, the Cowbird. Cowbirds' eggs have now been recorded from the nests of no less than twenty-four species of North American Warblers. These species are included in the appended list which is based in the main on Bendire (Life Histories of North American Birds): Black and White Warbler, Prothonotary Warbler, Worm-eating Warbler, Blue-winged Warbler, Golden-winged Warbler, Nashville Warbler, Lucy's Warbler, Northern Parula Warbler, Yellow Warbler, Black-throated Blue Warbler, Cerulean Warbler, Blackburnian Warbler, Chestnut-sided Warbler, Blackthroated Green Warbler, Golden-cheeked Warbler, Prairie Warbler, Oven-bird, Northern Water-Thrush, Louisiana Water-Thrush, Kentucky Warbler, Northern Yellow-throat, Chat, Hooded Warbler, and Redstart.

The Cowbird's habit of selecting as a host a bird smaller than itself is doubtless responsible for this long list of victims. The Warblers may build cunningly concealed nests upon the ground, they may place them in the densest thickets, or in trees at a height of over eighty feet, it is apparently all one to this bird, which, never having had a home of its own, has formed no attachment for any particular site It is not unusual to find three Cowbird's eggs in a single nest, and, in one instance, four are recorded.

Only the Yellow Warbler appears habitually to avoid incubating the intruded egg by building a second, and, should occasion require, a third story to its home, and the fact that with other species the unfortunate Warblers devote the nesting season to the care of their foster children makes this form of persecution far more serious than the loss of merely eggs, which may be replaced by a second or third laying. 
During the nesting season, Warblers sometimes suffer, as do other birds, from prolonged wet and cold weather and severe storms, but it is while they are migrating that they are most exposed to danger from the elements. None of our land birds are greater travelers than the Warblers. Journeying by night and crossing large bodies of water, they sometimes encounter storms with which they are ill-prepared to contend, and die in countless numbers. From a large amount of literature on this subject I extract only one or two descriptions of catastrophes of this nature.

In a paper entitled 'On Some Causes Affecting the Decrease of Birds' (Bull. Nutt. Orn. Club, VI, I881, I89), H. W. Henshaw quotes the account of an eye-witness who writes: "Two years ago there was a heavy storm, lasting some twenty-four hours. It occurred during the first week in September, and the eastern shore of Lake Michigan was strewn with dead birds. I took some pains to count those in a certain number of yards, and estimated that if the eastern shore was alike through all its length, over half a million of birds were lying dead on that side of the lake alone." Added remarks show that many of the birds were Warblers.

On the Gulf of Mexico, A. M. Frazar (Ibid., p. 250) chanced to observe one of doubtless many similar occurrences, which he described as follows:

"April 2, I88I, found me in a small schooner on the passage from Brazos de Santiago, Texas, to Mobile, Alabama. At about noon of that day the wind suddenly changed from east to north, and within an hour it was blowing a gale; we were now about thirty miles south of the mouths of the Mississippi River, which would bring the vessel on a line with the river and the peninsula of Yucatan. Up to the time the storm commenced the only land birds seen were three Yellow-rumped Warblers (Dendroica coronata) that came aboard the day previous, keeping us company the most of the day; but within an hour after the storm broke they began to appear, and in a very short time birds of various species were to be seen in all directions, singly and in small flocks, and all flying towards the Mississippi River. These birds, of course, must have been far overhead and only came down near the surface of the water in endeavoring to escape from the force of the wind. By four o'clock it had come to be a serious matter with them, as the gale was too strong for them to make scarcely any progress. As long as they were in the trough of the sea the wind had very 
little effect on them, but as soon as they reached the crest of a wave it would catch them up and in an instant they were blown hundreds of yards back or else into the water and drowned.

"A great many flew on to the deck of the vessel to be washed about by the next wave that came over the side. Although I made no attempt to count the number of specimens that came aboard, I should estimate them at considerably over a hundred, and a great many more struck the sides and tumbled back into the water. It was sad indeed to see them struggling along by the side of the vessel in trying to pass ahead of her, for as soon as they were clear of the bows, they were invariably blown back into the water and drowned. Most of those that came aboard were washed into the sea again, but the next day we found about a dozen dead bodies that had lodged underneath the galley. The following is a list of the species recognized, and if more time could have been given to observation, I undoubtedly could have made out others."

Among the twenty-three species here recorded by Mr. Frazar, twelve are Warblers, as follows: "Black and White Creeper, abundant; Prothonotary Warbler, large numbers; Worm-eating Warbler, large numbers; Yellow-rumped [=Myrtle] Warbler, a few; Chestnut-sided Warbler, quite a number; Golden-crowned Thrush [=Oven-bird], a few; Kentucky Warbler, large numbers; Mourning Warbler, large numbers; Maryland Yellow-throat, very abundant; Hooded Warbler, large numbers; Yellow Warbler, quite a number; Redstart, the most abundant."

It is, however, not only when migrating over water that Warblers are subject to death by severe storms. Writing from Rockport, Texas, H. P. Atwater says (Auk, IX, 1892, 303):

"Thousands of Warblers undoubtedly perished here last week during the 'norther', which lasted three days commencing on March I6.

"In the evening of that day flocks of Warblers were noticed around the gardens and houses here, and the next day many were found dead or were caught in a half-perished condition. About fifty per cent. of them were Black and White Warblers. (Mniotilta varia). The remainder were about equally divided between Parulas (Compsothlypis americana) and Sycamore Warblers (Dendroica dominica albilora). Many Sycamore Warblers and Parulas were captured alive in the houses.

"On the Igth, among many dead Warblers which were brought to us were a specimen of the Louisiana Water-Thrush (Seiurus 
motacilla) and one Hooded Warbler (Wilsonia citrina). Many Yellow-rumps were in company with the rest, and, though much tamer than usual, none were found dead or were captured. On the Igth I made a trip for the purpose of observation, and found many Black and White Warblers and Parulas lying dead on the ground at the foot of live-oak trees. From many of the ranches in the country round here, came reports of similar occurrences and many dead birds of the species mentioned have been sent to me."

Without giving further instances of similar character, mention may be made of large numbers of migrating Warblers which annually meet their death by striking light-houses or light-towers. Serious accidents of this nature occur only during cloudy or foggy nights when the birds, losing their bearings, descend from the height at which they have been migrating. Apparently fascinated by the far reaching rays of light, they fly toward their source and, striking some unilluminated part of the tower, are often killed.

Of five hundred and ninety-five birds which were killed by striking the Fire Island Light, Long Island, on the night of September 23, I887, no less than three hundred and fifty-six were Blackpoll Warblers, and more than half the twenty five species represented were Warblers. (Dutcher, Auk, V, I888, 182).

Nevertheless. in spite of this unusual mortality, the Warblers, as a family, remain our most abundant birds, an exhaustless food supply and widesfread favorable nesting areas apparently enabling them to hold their own in the face of conditions to which many forms of bird life would succumb. 


\section{THE \\ Warblers of North America}

In treating the fifty-five species and nineteen subspecies of Warblers, which have been found north of Mexico, I have followed the order of arrangement adopted by Mr. Ridgway in his 'Birds of North and Middle America', uniforritity of method being in my estimation, of more importance than the expression of individual opinion. In the belief, however, that in the work just mentioned. Seiurus was inadvertently inserted between Oporornis and Geothlypis, I have here placed it before these closely related genera.

The inclusion in this book of one hundred and twenty-four colored figures of Warblers is thought to make the presentation of an analytical key to species superfluous. The appended summary of their more striking generic characters and habits may, however, prove useful:

\section{SUMMARY OF GENERA}

I. Mniotilta (I species) is a black and white creeping Warbler.

2. Helinaia (I species) is a long-billed, brown, cane-brake Warbler.

3. Helmitheros (I species) is an olive-green, striped-crowned. worm-eating Warbler of dry wooded slopes.

4. Protonotaria (I species) is a golden headed inhabitant of river bottoms.

5. Vermivora (8 species) contains small, sharp-billed, second growth Warblers, mostly without white wing-bars or tail patches.

6. Compsothlypis (2 species) is grayish blue and nests in hanging 'moss'.

7. Pencedramus (I species) is an orange or yellow-headed inhabitant of high pine forests in southern Arizona and southward.

8. Dendroica (23 species) contains the Wood Warblers, brightly colored, fluttering birds, with conspicuous white or yellow 
patches in the tail, usually wing-bars and more or less striking patterns of color; short, rounded cylindrical bill without evident bristles.

9. Seiurus ( 3 species) has the large, thrush-like, spottedbreasted, ground-inhabiting, walking Warblers.

10. Oporornis (4 species) has the ground or bush-inhabiting, pale-footed, gray-headed, blackish or brownish breasted Warblers.

II. Geothlypis (2 species) has the black-masked bush and thicket haunting Warblers.

I2. Chamethlypis (I species) is a chat-like Yellow-throat of southeastern Texas and southward.

I3. Icteria (I species) is a large-bodied, big-billed, shortwinged, yellow-breasted haunter of thickets.

I4. Wilsonia (3 species) contains the yellow-breasted, flycatching Warblers, with flat bills and long rictal bristles.

15. Cardellina (I species) is a short-billed, red-faced, graybacked, flycatching Warbler of southern New Mexico and Arizona and southward.

16. Setophaga (2 species) has the broad-billed, black, and red or orange flycatching Warblers.

\section{Genus MNIOTILTA Vieillot}

The genus Mniotilta contains but a single species which is distinguished among the Warblers for its creeper-like habits. As might be expected, so marked a trait is reflected in the bird's form, the bill being proportionately long, slender, and slightly decurved, with the upper mandible ustually notched at the tip and projecting over the lower. The hind-toe, in comparison with the middle-toe, is longer and has a stouter nail than in any of our other Warblers. The rictal bristles are very small, the tail is nearly square and, compared with the wing, is rather short. The wing is long and pointed, the three outer primaries being of nearly equal length. In color both sexes are black and white, the male being the blacker, the female, especially in the fall, showing a brownish wash.

\section{BLACK AND WHITE WARBLER MNIOTILTA VARIA (Linn.) Plate II}

Distinguishing Characters.-A striped black and white, creeping bird. Length (skin), 4.70; wing, 2.70; tail, 2.00 ; bill, .50. 


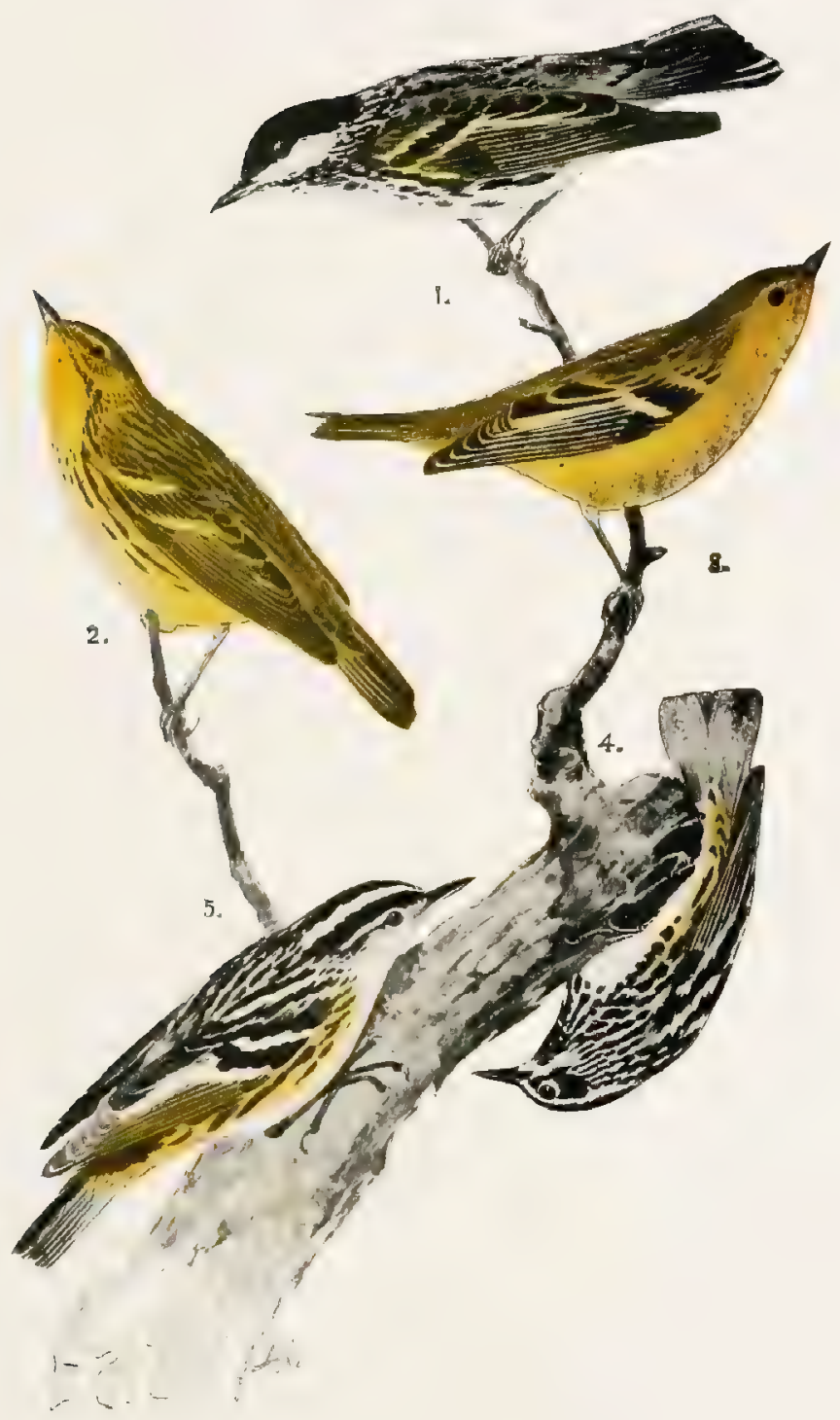

1. Blackpoli Warbler, Adult Male.

4. Black and White Warbler, Male. 3. Blackpoll Warbler, Young and Adult in Fall.

2. Blackpoll Warbier, Adu1t female.

5. Black and White Warbler, Female. 
:

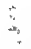

端 
Adult o Spring.-Crown black, a white stripe through its center and over each eye; cheeks entirely or largely black; back black striped with white; upper tail-coverts black, their outer webs margined with white; tail blackish, externally margined with gray, usually all but the central pair of feathers with white patches or margins on the inner web at the tip; wings blackish, externally edged with grayish, tertiaries and coverts black, the first margined, the latter broadly tipped with white forming two wing-bars; throat black usually with more or less white and with white stripes at either side from the base of the bill; breast and sides streaked black and white, center of the belly white.

Adult of Fall.-Similar to adult $\delta$ in Spring, but with more white on the breast and throat, the latter sometimes wholly white.

Young ơ Fall.-Similar to adult of Fall, but with cheeks entirely or largely white with a black postocular streak; the throat and center of the breast white, the black streaks of the underparts being confined to the sides and under tail-coverts.

Adult + Spring.-Similar to adult $\delta^{*}$ in Spring, but above less glossy and more or less washed with brownish, particularly on the rump; the cheeks grayish or whitish with a brownish tinge sometimes extending to the sides of the throat and breast; below white, the streakings duskier, less sharply defined and confined to the sides and crissum, which, with the flanks, is usually strongly washed with brownish. Resembles young $d$ but is less distinctly streaked below and shows brownish tinge.

Adult $q$ Fall.-Similar to adult $q$ in Spring, but the brownish wash everywhere stronger.

Young $q$ Fall.-Not distinguishable from adult $q$ in Fall.

Nestling.-Resembles young + but black duller, brown stronger and more prevalent, especially on the breast.

General Distribution-Eastern North America, north to Newfoundland and the Mackenzie Valley, west to the Rocky Mountains.

Summer Range.-Breeds commonly as far south as to New Jersey, Pennsylvania, and Iowa; less commonly to North Carolina, Missouri, and Kansas; locally and rarely in the Gulf States; west regularly to central Texas, central Kansas, and central South Dakota; north to New Brunswick, Nova Scotia, Newfoundland, Hudson Bay, and Mackenzie (Fort Norman); casually to Lesser Slave Lake and Peace River Landing, Athabasca; occurs westward casually in Colorado (Boulder, Table Rock), and in California (Farallone Islands, May 28, I887; Pasadena, October 8, 1895; Arroyo Seco, Los Angeles Co., October 2, I895; Point Lobos, Monterey Co., Sept. 9, I9or ; Watsonville, Sept. 24, 1903); Washington (Olympia, Sept. 8, 1903).

Winter Range.-Northern Florida (St. Augustine), and southern Texas; south throughout the West Indies to Venezuela and Ecuador. 
Spring Migration.-A few Black and White Warblers winter in southern Florida, so that the only way of knowing the beginnings of spring migration in that district is from the records of the striking of the birds at the lighthouses. Both at Alligator Reef and at Sombrero Key lighthouses in southern Florida, this species begins to strike early in March. Thence, northward the progress is so slowan average of twenty miles per day-that it is the middle of May before the species has reached the Gulf of St. Lawrence.

\begin{tabular}{|c|c|c|c|}
\hline PL $\mathbf{A C E}$ & $\begin{array}{l}\text { No. of } \\
\text { years' } \\
\text { record }\end{array}$ & $\begin{array}{l}\text { Average date of } \\
\text { spring arrival }\end{array}$ & $\begin{array}{l}\text { Earliest date of } \\
\text { spring a arrival }\end{array}$ \\
\hline 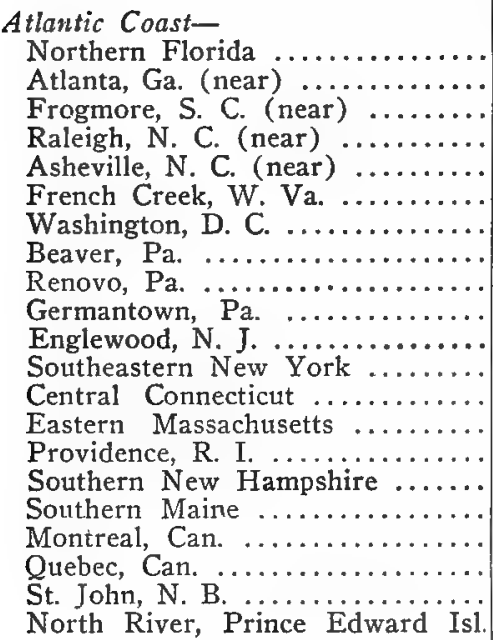 & $\begin{array}{r}4 \\
9 \\
4 \\
16 \\
5 \\
5 \\
6 \\
6 \\
9 \\
7 \\
9 \\
18 \\
15 \\
15 \\
6 \\
8 \\
9 \\
8 \\
7 \\
8 \\
3\end{array}$ & 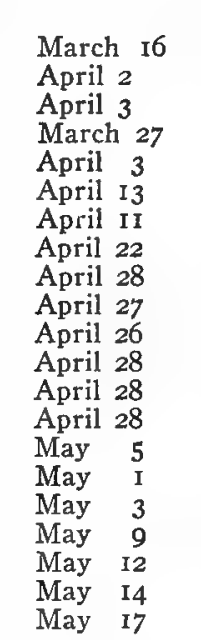 & 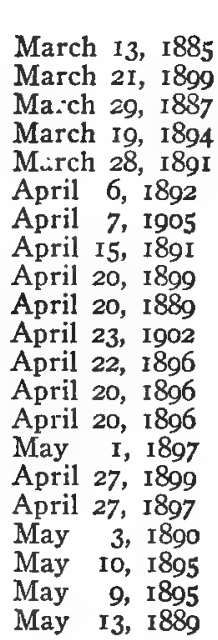 \\
\hline 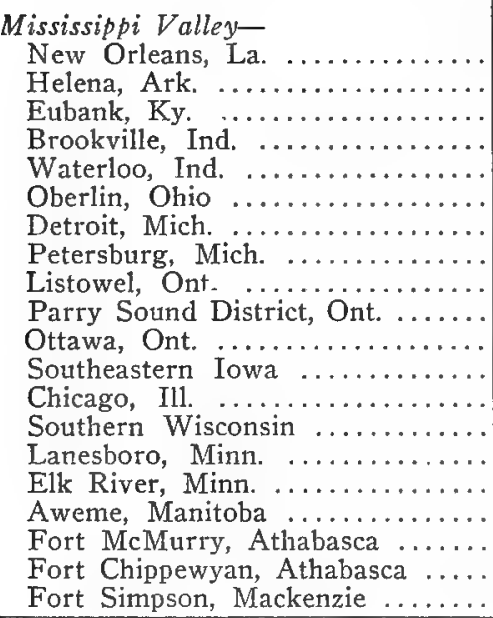 & $\begin{array}{r}3 \\
7 \\
10 \\
10 \\
10 \\
9 \\
14 \\
13 \\
12 \\
6 \\
18 \\
5 \\
11 \\
10 \\
5 \\
5 \\
7\end{array}$ & $\begin{array}{lr}\text { March } & 27 \\
\text { March } & 3 \mathrm{I} \\
\text { April } & 4 \\
& 4 \\
\text { May } & 2 \\
\text { April } & 27 \\
\text { May } & \text { I } \\
\text { April } & 28 \\
\text { May } & 1 \\
\text { May } & 4 \\
\text { May } & 7 \\
\text { April } & \text { I9 } \\
\text { April } & 30 \\
\text { May } & 2 \\
\text { April } & 28 \\
\text { May } & 3 \\
\text { May } & 9\end{array}$ & 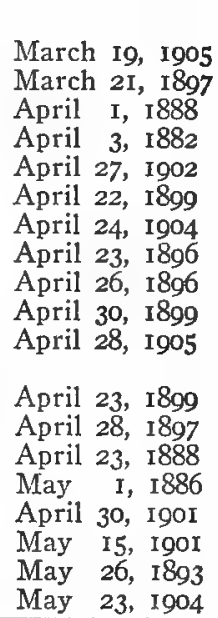 \\
\hline
\end{tabular}


Fall Migration.-The Black and White Warbler is one of the earliest fall migrants; it begins to appear in the Gulf States early in July, and reaches southern Florida by the middle of the month. South of the United States it has been noted in southern Mexico August 13, 1895; in Costa Rica Augist 10, 1883; and in Colombia, South America, August 21, 1898 .

\begin{tabular}{|c|c|c|c|}
\hline PL,ACE & $\begin{array}{l}\text { No. of } \\
\text { years' } \\
\text { record }\end{array}$ & $\begin{array}{l}\text { Average date of } \\
\text { last one seen }\end{array}$ & $\begin{array}{l}\text { Latest date of } \\
\text { last one seen }\end{array}$ \\
\hline 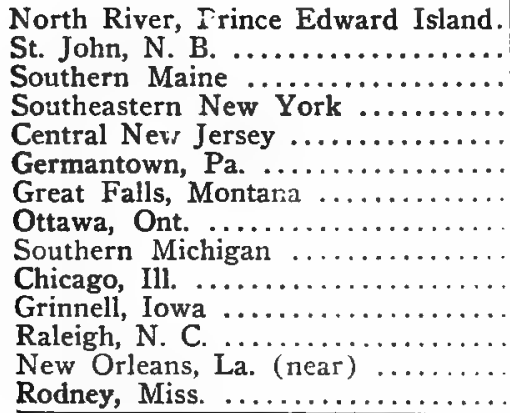 & $\begin{array}{l}2 \\
3 \\
5 \\
5 \\
4 \\
6 \\
\\
4 \\
3 \\
7 \\
3 \\
9\end{array}$ & $\begin{array}{l}\text { September } 4 \\
\text { September 12 } \\
\text { September 19 } \\
\text { September } 24 \\
\text { Septeniber } 24 \\
\text { October I } \\
\text { September } 13 \\
\text { Septemher } 13 \\
\text { September } 22 \\
\text { September } 22 \\
\text { October } 8\end{array}$ & $\begin{array}{l}\text { September 5, } 1887 \\
\text { September I9, } 1891 \\
\text { September 28, } 1898 \\
\text { October 15, 1891 } \\
\text { October 12, 1894 } \\
\text { October 12, 1885 } \\
\text { September 18, I889 } \\
\text { September 20, 1887 } \\
\text { September 15, 1892 } \\
\text { September 27, 1896 } \\
\text { September 23, 1889 } \\
\text { November I0, 1885 } \\
\text { October 21, 1897 } \\
\text { October 3, 1888 }\end{array}$ \\
\hline
\end{tabular}

The Bird and its Haunts.-The Black and White Warbler may be said to be generally distributed throughout deciduous woodlands. When migrating it visits the trees of our lawns and orchards but the nature of its nesting site requires less cultivated surroundings. But wherever seen it may be known by striped markings and creeping habits. Though it may at times borrow the manners of what may be called the Auttering Warblers, they rarely adopt its characteristic method of running actively up tree-trunks, over and under limbs with all the agility of a true Creeper (Certhia) or Nuthatch. The Pine Warbler clings to the bark of trees, the Yellow-throated Warbler climbs to some extent among the upper branches but in its mode of progression none rivals the Black and White Warbler.

When flushed from the nest, the female, with tremulous wings trails painfully over the dead leaves in an evident effort to lead the intruder from her home and its contents.

"The Black and White Warbler is a bird of deciduous and mixed growth, rarely found in the dense spruce forests, and more commonly in scrubby second growth than in the big primeval timber. Not common on the higher parts of Mt. Monadnock, even where,- as on the eastern slopes, - the woods are suitable. Fairly common in summer and abundant in migrations everywhere about the mountain's base." (Thayer, MS.) 
"At Berwyn, Pa., the Black and White Warbler inhabits timbered upland, the rocky wooded hillsides and down to the damp swampy thickets whenever there are sufficient undergrowths of laurel, saplings, etc. It is at all times a woodland bird.

"I have frequently seen the male and the female carrying white grubs and white moths to their young; and feed a big lubberly Cowbird, out of the nest, as late as June 27. Another time, a female fed a young Cowbird, at large, with green grubs taken from the leaves of the chestnut and oak sapling. Three times in as many minutes she dropped morsels down its gluttonous throat, all the while exhibiting the most jealous care, guarding it from harm. It was well able to fly." (Burns, MS.)

Song.-The Black and White Warbler is not a vociferous singer and its high screeping notes, to which the terms thin and wiry are commonly applied, might readily escape the notice of a person not listening for birds' voices. The sharp pit alarm note is rapidly and loudly repeated when the birds fear for the safety of their young.

"The ordinary call-note of the species, both in fall and spring, resembles the syllable $d z t$; it often uttered rapidly, thus: $d z t-d z t-d z t-$ $d z t$, while the bird is creeping about the trunks and large limbs of trees. The usual song-not uttered in fall, I think-is monotonous, consisting of a single lisping syllable repeated rather rapidly, five or six times. A much rarer song $I$ have heard in spring when much migrational activity was being shown; this is much more elaborate, and longer than the other. I heard it once in Amite County in July; when the singer may have been a breeding bird" (Allison, $M S$.)

"This Warbler has at least two main songs, both penetrating and perfectly smooth-toned, as well as thin and wiry. The one commonly described consists of about eight like-toned notes, in barelyseparated couplets, with a slight eniphasis on the second note of each couplet: Ssee-rwwee-ssee-wwee-ssee-wrvee-ssee-wwee,-uttered neither fast nor slowly. This song seems to be comparatively little subject to variation, though by no means free from it. The other, longer and less common song begins in the same way, but continues, after the six or eight ordinary notes, with two or three somewhat hurried repetitions of the phrase, all in a slightly richer and more liquid tone, and one or two on a slightly lower key. Thin and slight though it is, this complete song has something of a rollicking sound, and ranks very high among weak-voiced Warbler songs. The Black and White's common call-note, small and rather sharp, is pretty easily recogniz- 
able, but it is often reduplicated into a 'chippering' very much like the Black-throated Green's." (Thayer, MS.)

Nesting Site.-A depression in the ground at the base of a tree, bush, weeds, stump, rocks, etc., beneath fallen limbs, upturned roots, or in the shelter of a log.

Nest.-Bulky, composed of dead leaves, strips of grape-vine or cedar bark, or soft inner bark of other trees, grasses and rootlets and lined with hairs; sometimes more or less roofed.

Eggs.-4 or 5, usually 5. Ground color of creamy white to white, heavily and profusely spotted and specked with reddish brown, chestnut, hazel and lavender, tending to form a wreath around large end, but quite evenly marked all over. Many types approach those of the Canada and Lutescent Warblers, some few specimens exhibit small blotches. The shape is a rounded oval, less pointed than the majority of our Warblers' eggs. Size; average, .66x.53; extremes, $.72 \times .52, .62 \times .52, .69 \times .55, .64 \times .48$. (Figs. $3-5$.)

Nesting Dates.-Iredell Co., N. C., April I8 (J. P. N. ); West Chester, Pa., June 2, young on wing (Jackson); New York City, May 18 (F. M.C.) ; New Haven, Conn., May 20-June 4, three eggs, two young (Bishop); Cambridge, Mass., full sets of first laying, May I8-30 (Brezester); Bangor, Me., May 27-June 2I (Knight); Listowell, Ont., May 23-June ro (Kells).

\section{BIOGRAPHICAL REFERENCES}

(1) J. P. N. [ORRIs], A Series of Eggs of the Black and White Warbler, Orn. and Oöl., XIII, I888, I83. (2) W. L. Kells, Nesting of some Canadian Warblers, Ottawa Naturalist, XV, 1902, 229.

\section{Genus HELINAIA Swainson}

Helinaia bears a strong general resemblance, both in form and color, to Helmitheros, the bill, however, is longer (nearly equalling the head in length), and much straighter, the arc of the culmen is not convex, its ridge is more developed and sharper, and parts the feathers of the forehead more deeply; the wing is slightly more rounded, the tail-feathers are broader, the under tail-coverts reach to within half an inch, or less, of the the end of the tail, the tarsus is slightly longer than the middle-toe and nail.

In Helinaia swainsoni, the single species contained in this genus, the sexes are alike in color. 


\section{SWAINSON'S WARBLER}

helinaia SWainsoni Aud. Plate IV

Distinguishing Characters.-A brownish bird without white in wings or tail; sexes alike. Length ( $\mathrm{kkin}$ ), 5.00; wing, 2.80 ; tail, I.95; bill, 60 .

Adult d", Spring.-Crown cinnamon-brown, forehead with a more or less indistinct buffy median streak; a whitish line over the eye and a dusky streak through it; back olive-brown; tail the same without white patches; wings, like back, without white bars-or edgings; underparts whitish more or less tinged with yellowish, the sides grayer; bill brownish, legs flesh-color.

Adult d, Fall.-Not seen; doubtless not materially different from the last. Young of, Fall.-Doubtless similar to adult $\delta$ in Fall.

Adult , Spring.-Similar to adult $\delta$ in Spring.

Adult $q$, Fall.-Not seen, doubtless resembles Spring $q$.

Young $q$, Fall.-Similar to $q$ in Spring.

Nestling.-Above cinnamon-brown, paler below, the belly whitish.

General Distribution._Eastern United States; north to Virginia and Indiana; west to the Mississippi River.

Summer Range.-This is one of the rarer Warblers of the United States; its breeding range on the Atlantic coast extends from northern Florida (the lower Suwanee River) to Virginia (Dismal Swamp). It is strictly a swamp lover and along the Gulf coast to Louisiana, it is not uncommon in the few localities that seem suited to its habits. Thence it ranges up the Mississippi River to southeastern Missouri, and up the Wabash to Knox county, Indiana. Accidental twice in Texas (Navarro county, August 24, I880; Port Bolivar, April 17, 1904) and once in Mexico (Vera Cruz, winter, I887-88).

Winter Range.-So far as known, Jamaica, where it has been taken from October I to April 8.

Spring Migration.-The earliest recorded spring arrival in the United States was on March 22, I890 on the lower Suwanee River. The same year the species was taken at the Tortugas, March 25 to April 5. The other records of the first arrival in spring are: Sombrero Key lighthouse April 3, I889; Savannah, Ga., April 8-I6. 1894; Kirkwood, Ga., May 4, I898; Frogmore, S. C., April I-5, 1885; New Orleans, La., April 8, I898; April I, I904; March 30, I905; Bayou Sara, La., April 8, I887; Coosada, Ala., April 12, 1878.

Fall Migration.-This begins rather late when compared with the date of nesting. Fledged young have been seen near Charleston, S. C., by June 9, but the earliest date of striking at Sombrero lighthouse is August I7, I888; other dates at this lighthouse extend from September 14, I884, to October 26, 1885, and at Key West, Fla., from the middle of September to September 20. 

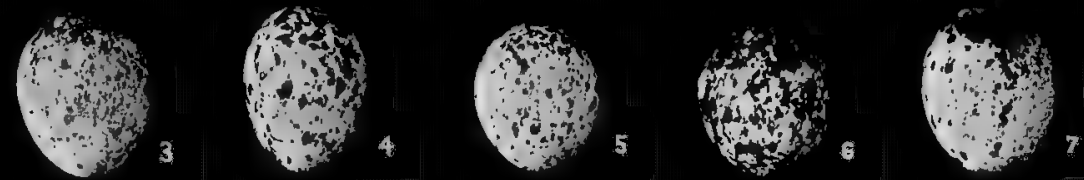

8
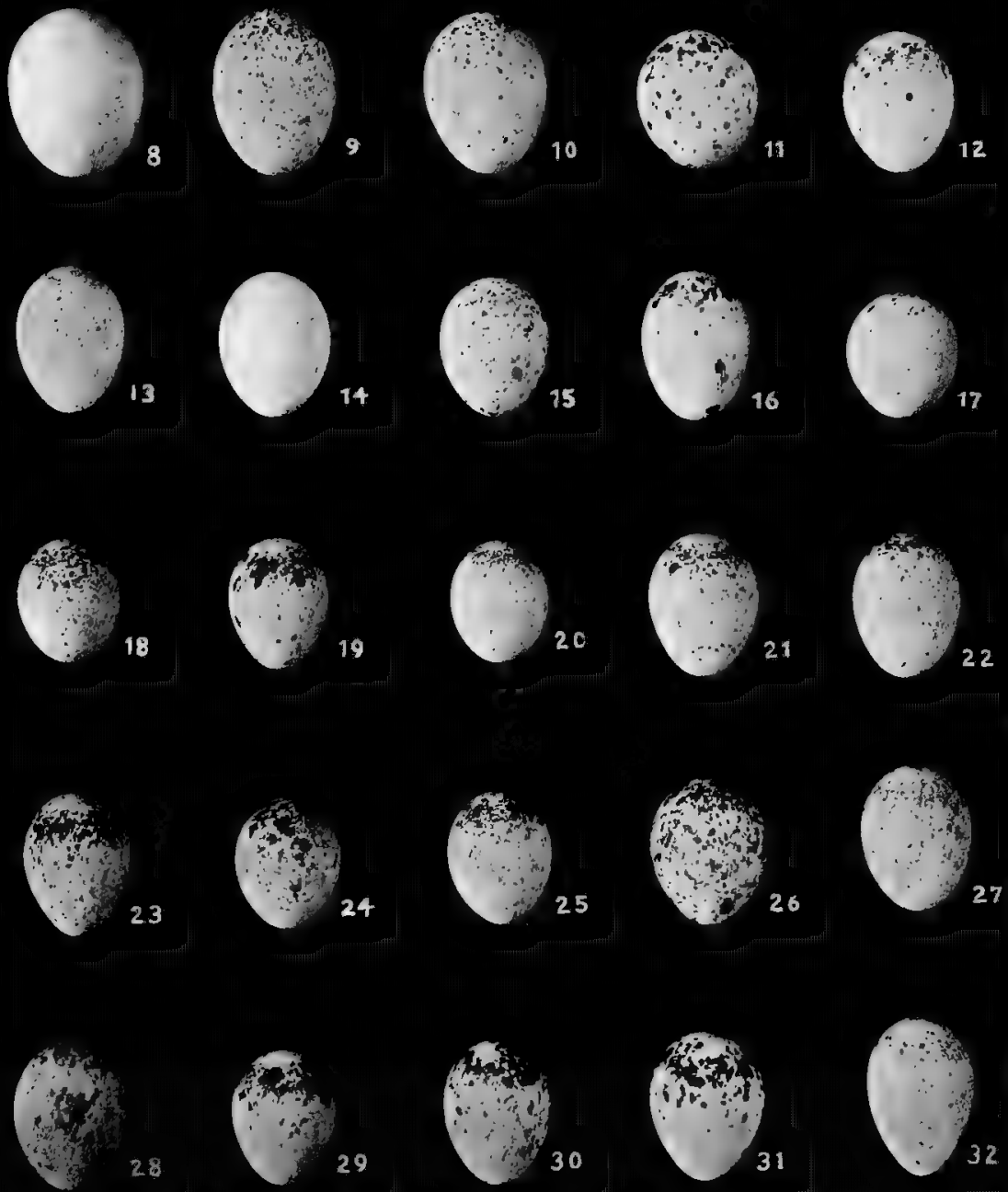

Figs. 3- 5. Black and White Warbler.

" 6, 7. Prothonotary Warbler.

“ 8. Swainson's Warbler.

“ 9-11. Worm-eating Warbler.

“ 12-14. Blue-winged Warbler.

“ 16-17, Golden-winged Warbler.
Figs. 18-20. Lucy's Warbler.

"21,22. Virginia's Warbler.

“ 23-25. Nashville Warbler.

“ 26-28. Lutescent Warbler.

“ 29,30. Tennessee Warbler.

“ 31, 32. Parula Warbler. 

The Bird and its Haunts.-Swainson's Warbler has an interesting history. Discovered by Bachman near Charleston, S. C., in I832, the bird retnained virtually unknown until 1878 . In the intervening years, it is true, four additional specimens had been taken (see Brewster ${ }^{2}$ ) but nothing was published concerning its habits until Brown ${ }^{1}$ observed it in Alabama, on April I2 of the last-named year. During the six following years the species was detected in Texas, and again near Charleston, but it was not until 1884 that, with the exception of Bachman's and Brown's observations, we had any information of this bird in nature. In that year through the definitely directed efforts of Brewster ${ }^{2}$ and Wayne ${ }^{3}$ it proved to be a locally common species near Charleston, as it has since been found to be in many other places, and it is from Brewster's account of his field work in the spring of the year mentioned that the following extracts are made:

"While the facts already given prove incontestably that the present species may occur at times in dry, scrubby, woods, or even in such open situations as orange groves, it certainly haunts by preference the ranker growth of swamps, to which, indeed, it appears to be confined during the nesting season. * * $*$ The particular kind of swamp to which he is most partial is known in local parlance as a 'pineland gall.' It is ustually a depression in the otherwise level surface, down which winds a brook, in places flowing swiftly between well-defined banks, in others divided into several sluggish channels, or spreading about in stagnant pools, margined by a dense growth of cane, and covered with lily leaves or other aquatic vegetation. Its course through the open pinelands is sharply marked by a belt of hardwood trees nourished to grand proportions by rich soil and abundant moisture. *** More extensive swamps, especially those bordering the larger streams, are subject to inundations, which, bringing down deposits of alluvial soil, bury up or sweep away the humbler plants, leaving a floor of unsightly mud, interspersed with pools of stagnant water. Such places answer well enough for the Prothonotary and Hooded Warblers, which, although essentially swamp lovers, are not to any extent terrestrial; but you are not likely to find Swainson's Warblers in them, unless about the outskirts, or in islands elevated above the reach of the floods. Briefly, four things seem indispensable to its existence, viz., water, tangled thickets, patches of cane, and a rank growth of semi-aquatic plants.

"When not singing Swainson's Warbler is a silent, retiring bird, spending nearly his entire time on the ground in the darkest recesses of his favorite swamps, rambling about over the decaying leaves or 
among the rank water-plants in search of small beetles which constitute his principal food. His gait is distinctly a walk, his motions gliding and graceful. Upon alighting in the branches, after being flushed from the ground, he assumes a statuesque attitude, like that of a startled Thrush. While singing he takes an easier posture, but rarely moves on his perch. If desirous of changing his position, he flies from branch to branch, instead of hopping through the twigs in the manner of most Warblers. ***

"Judging by my personal experience, Swainson's Warbler is at all times a singularly unsuspicious bird."

In Mississippi, Allison ( $M S$.) writes that Swainson's Warbler is "Everywhere a bird of the cane-brakes-not the heavy riverswamp brakes of Arundinaria gigantea, but the thick patches of $A$. tecta. These are found in the borders of the deep river swamps, and in the low, rich, parts of somewhat less swampy woods. This Warbler, like the Worm-eating, is constantly rustling among the leaves; but it is nearly always on the ground that it seeks its food, among the fallen leaves at the roots of the trees."

Song.- "A bird emerged from a thicket within a few yards of me, where he had been industriously searching among the fallen leaves, flew into a small sapling, and gave utterance to a loud, ringing and very beautiful song. *** I was impressed by the absorbed manner in which this bird sings. Sitting quietly upon a limb of a small tree, he suddenly throws back his head and pours forth his notes with utmost fervor and abandon. During the intervals of silence he remains motionless, with plumage ruffled, as if completely lost in musical reverie." (Brown $1^{1}$.)

"A performance so remarkable that it can scarcely fail to attract the dullest ear, while it is not likely to be soon forgotten. It consists of a series of clear, ringing whistles, the first four uttered rather slowly and in the same key, the remaining five or six given more rapidly, and in an evenly descending scale, like those of the Cañon Wren (Catherpes mexicanus conspersus. In general effect it recalls the song of the Water-Thrush (Seiurus noveboracensis.) It is very loud, very rich, very beautiful, while it has an indescribably tender quality that thrills the senses after the sound has ceased.

"It is ventriloquial to such a degree that there is often great difficulty in tracing it to its source. *** In addition to its song this Warbler utters a soft tchip indistinguishable from that of Parula americana, but wholly unlike the cry of any ground Warbler of my acquaintance. I heard this note on only one occasion, when the bird 
was excited over some disturbance in the shrubbery, perhaps the presence of a snake.

"Although a rarely fervent and ecstatic songster, our little friend is also a fitful and uncertain one. You may wait for hours near his retreat even in early morning or late afternoon, without hearing a note. But when the inspiration comes he floods the woods with music, one song often following another so quickly that there is scarce a pause for breath between. In this manner I have known him sing for fully twenty minutes, although ordinarily the entire performance occupies less than half that time. Such outbursts may occur at almost any hour, even at noontide, and I have heard them in the gloomiest of weather, when the woods were shrouded in mist and rain." (Brezuster. ${ }^{2}$ )

Nesting Site.- "The nests are generally built in canes, but I have also found them in small bushes, and, in one instance, in a climbing vine by the side of a large public road. The height from the ground varies from two to eight feet, but they are always near or over a pond of water." (Wayne. ${ }^{\mathrm{B}}$ )

Perry ${ }^{4},{ }^{8}$ has found nests in scrub palmettos, myrtle, and gall bushes not always over nor even near running water, but as often on high, dry land.

Nest._"The nest is a remarkable affair-very large, made of water-soaked leaves of the sweet gum, water oak, holly and cane, lined with needles of the pine trees and a little dry moss. The stems of the leaves point upwards, and the nest can easily be mistaken for a bunch of old leaves lodged in the top of a cane." (Wayne. ${ }^{3}$ )

Eggs.-3 or 4, very rarely 4. Ground color white, creamy white and bluish white, unmarked, little or no gloss; in shape very blunted at small end. Size; average, .75x.59; extremes, .79x.57, .72x.59, $.77 x .6 \mathrm{r}, .75 \times .55$. (Fig. 8.)

Nesting Dates.-Charleston, S. C., May 7-July 6 (Wayne.)

\section{Biographical ReFERENCES}

(I) N. C. Brown, A List of Birds Observed in Central Alabama, Bull. Nutt. Orn. Club, III, I878, 172. (2) William Brewster, Swainson's Warbler [in So. Car.], Auk, II, I885, 65. (3) A. T, WAYNE, Nesting of Swainson's Warbler in South Carolina, Orn. and Oöl., XI, I886, I87. (4) T. D. Perry, Nesting of Swainson's Warbler [near Savannah, Ga.], Orn. and Oöl., XI, I886, 188. (5) C. W. Beскнам, Additions to the Avifauna of Bayou Sara, La., Auk, IV, I887, 3C5. (6) T. D. Perry, Some Additional Notes on Swainson's Warbler, Orn. and Oöl., XII, I887, I4I. (7) J. P. N[ORRs], A Series of Eggs of Swainson's Warbler, Orn. and Oöl., XIII, I888, 185. 


\section{Genus HELMITHEROS Rafinesque}

Helmitheros is chiefly distinguished by its stout bill, which, in proportion to the size of the bird, is more robust than in any other genus of this family, except Chamcethlypis; the ridge of the culmen is curved, its base is decidedly ridged and intrudes upon the feathers of the forehead; the bill is unnotched; rictal bristles not evident. The wing is rather pointed, about .80 inches longer than the tail; the three outer primaries are of nearly equal length; the tail is rather short, the feathers of about equal length, obtusely, but decidedly pointed; the under tail-coverts are long, reaching to within nearly .50 inches of the end of the tail. The feet are well developed, the tarsus about equalling in length the middle-toe and nail.

In Helmitheros vermivorus, the single species contained in this genus, the sexes are alike in color.

\section{WORM-EATING WARBLER}

HELMITHEROS VERMIVORUS (Gmel.) Plase IV

Distinguishing Characters.-Head conspicuously striped with black and olive-buff; no white bars or patches; sexes alike. Length (skin), 4.80; wing, 2.80; tail, r.9o; bill, .50.

Adult d", Spring.-Crown with a broad median olive-buff stripe separated from stripes over the eyes, of the same color, by broad stripes of black; a well-marked black or blackish post-ocular stripe, lores sometimes dusky; back, olive-green; tail olive-green without white; wings like back, without white, the bend yellowish; underparts cream-buff, belly, and sometimes throat, whiter.

Adult $\delta$, Fall.-Similar to last but buffy areas averaging slightly deeper.

Young $\delta$, Fall.-Similar to Adult $\delta^{A}$ in Fall, but tertials lightly tipped with rusty.

Adult,, , Spring.-Similar to adult ot in Spring.

Adult $\$$, Fall.-Similar to adult $\delta^{*}$ in Fall.

Young ?, Fall.-Similar to young os.

Nestling.-Buffy-cinnamon; head stripes duskier, wing-quills as in young $\delta$ and $q$, wing-coverts like back, their bases grayer.

General Distribution.-Eastern United States; north to southern New England and Nebraska; west almost to the Plains.

Summer Range.-Common in the heavily timbered bottom lands of Southern Illinois and Indiana and eastward to the lower portions of the valleys of the Hudson and Connecticut rivers. It is not uncommon in the lower parts of the Allegheny Mountains from northwestern South Carolina to southern New York, and from the Dismal Swamp of Virginia northward. Outside of this usual range it has been taken in Vermont (St. Albans, 1891), Massachusetts (Easthampton, Cambridge, September 19, 1881, Taunton, May 9, 1890); 
New York, (Penn Yan, Onondago); Northern Ohio (Cleveland, May 2, I873); southern Michigan; southern Wisconsin (Racine, Milwaukee, Lake Koshkonong) ; central Iowa (Des Moines, Grinnell, May 15, 1886); southeastern Nebraska (Omaha, Lincoln); eastern Kansas (Lawrence, May 6, I873; Atchinson, May 31, 1899).

The species nests rarely south of the latitude of southern Virginia, except in the mountains, but has been recorded as breeding at Raleigh, N. C.; La Grange, Ala.; Rodney, Miss., and northern Louisiana. It occurs in migration throughout the Gulf States to eastern Texas.

Winter Range.-Southern Florida and eastern Mexico to Panama; Cuba and the Bahamas.

Spring Migration.-

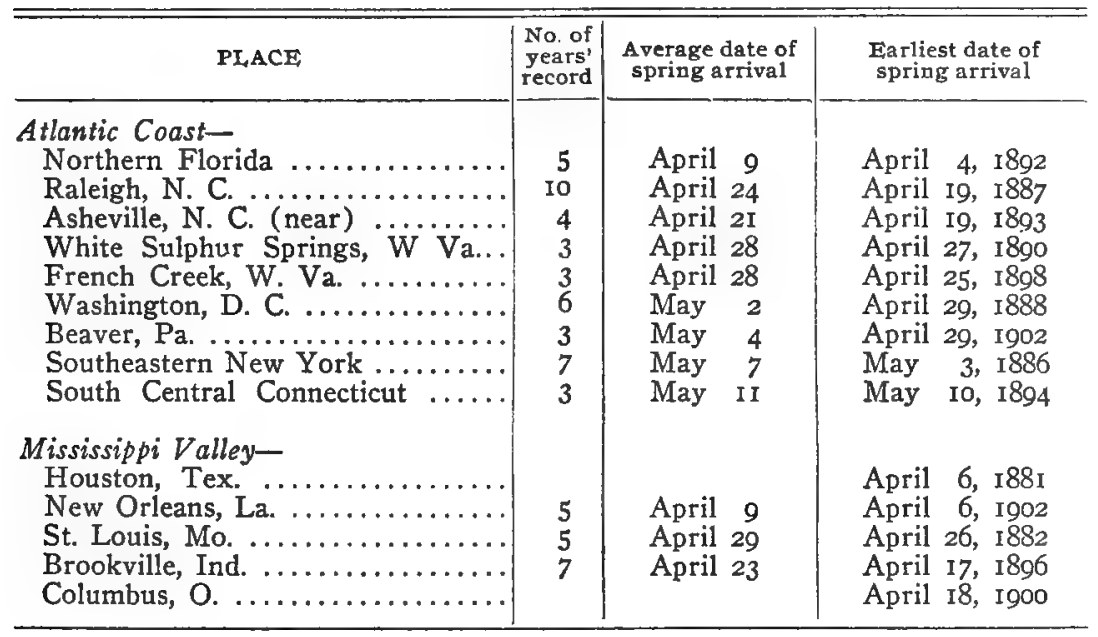

Fall Migration.-The earliest fall migrant was recorded at Key West, Fla., August 30 ; the average date at which they first strike the Florida lighthouses is September I4. Migration at the mouth of the Mississippi is at about the same time, earliest August II. The latest migrants are noted at Raleigh, N. C., September 2; near New Orleans, La., September 30 ; Key West, Fla., about October I.

The Bird and its Haunts.-The Worm-eating Warbler appears to be a locally common bird from southern Pennsylvania southward, but is rather uncommon from this point northward. In a degree it is a connecting link between the terrestrial and arboreal Warblers, and feeds both upon the ground and in the trees. In color, voice, and actions it is far too inconspicuous to force itself on our attention and its presence is usually detected only by the watchful. 
F. L. Burns ${ }^{6}$ reports it as common, but extremely local, at Berwyn, Pa., where it inhabits the wooded hill-slopes. "I do not remember," he says, "having ever met with it in the open, or in small groves of the bottom lands. It is at home in the second growth timber of the hills, and is very deliberate in its movements, seeming never in a hurry and yet never idle. Stepping out with dainty tread and bobbing head, it is a really graceful little walker on ground or tree.

"The bird exhibits a remarkable love for its chosen nesting haunts, building the second and third nest within a radius of a few hundred feet when disturbed, and returning year after year to the same place if successful in raising a brood. I have not observed a single pair building on the exact site of former years, but on several occasions within a few feet of it. While the female takes the leading part, the male is always present and seems busy, a by no means silent partner in the selection of site and construction of nest.

"Incubation does not always commence immediately after completion of set, particularly if the season be young. It is probable that the second night witnesses the beginning of that period and, as far as my experience goes, I believe it is performed by the female alone. The male feeds her when covering newly hatched young. The homecoming of a brooding bird, after a brief airing and feeding, is heralded several hundred yards distant by frequent chips and short flights from branch to branch near the ground, in leisurely fashion and circuitous route, until at length, arriving above the nest, she runs down a sapling and is silent. The bird is a close sitter and if approached from the open front will often allow a few minutes' silent inspection, eye to eye, at arm's length, sometimes not vacating until touched, then she runs off in a sinuous trail, not always feigning lameness before the young are out. When disturbed with young in the nest she flutters off with open wings and tail, and failing to lead one off, will return with her mate, who is seldom far off at this period, circling about the nest or intruder and, if the young are well feathered, she will dash at them, forcing them from the nest and to shelter. Once this brave little bird dashed at me and ran up to my knee, scratching with her sharp little claws at every step. On the return the birds always make the vicinity ring with their protestsa quickly repeated chip. The period of incubation in one instance was thirteen days."

William Brewster presents this picture of the bird in its haunts in West Virginia, where, he says, the bird is "most partial to the 


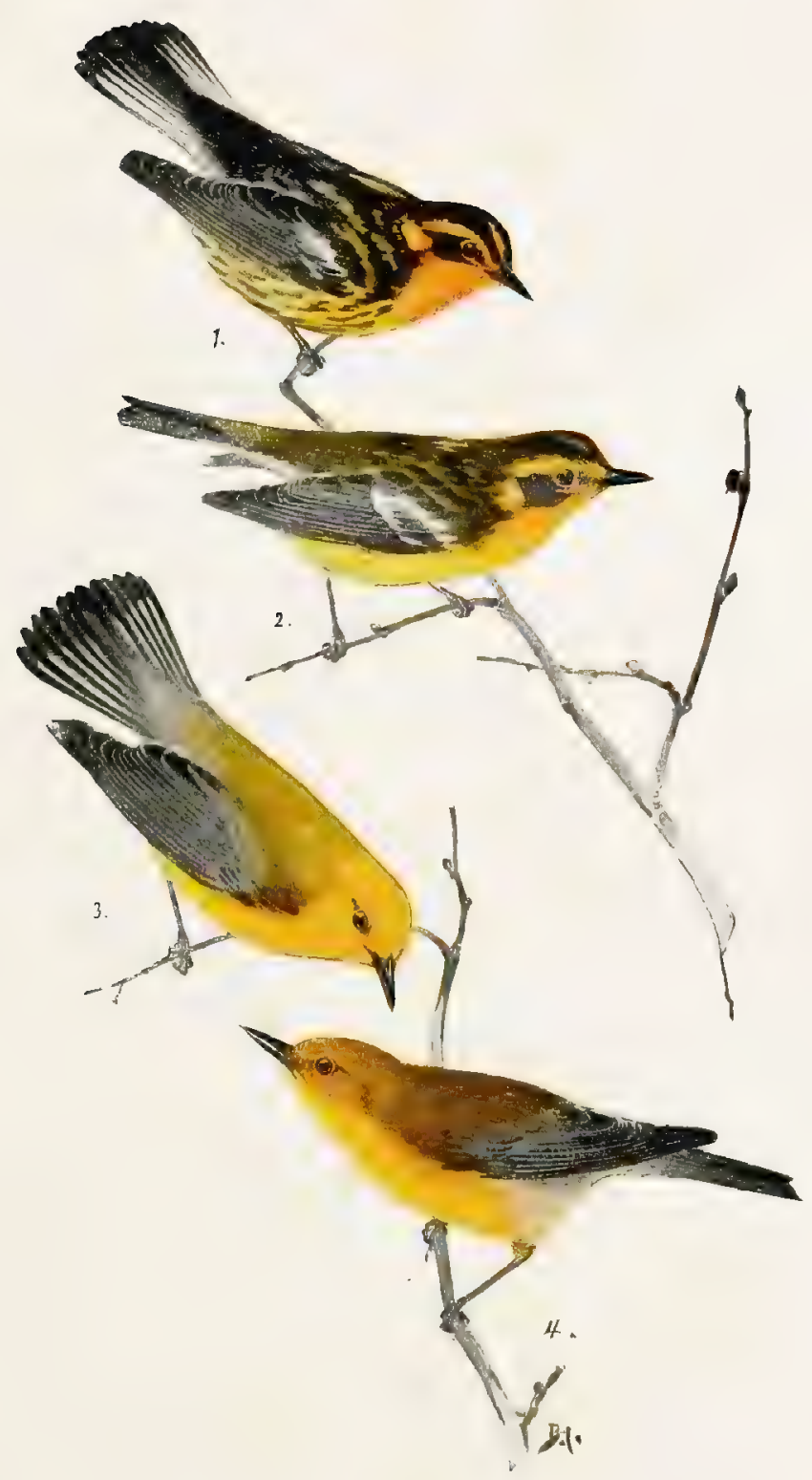

1. Blackbunnian Warbler, Adult Male.

2. Blackburnian Wakblek, Femaie.
3. Prothonotary Warbler, Adult Mate.

4. Prothonotary Warbler, Female. 

retired thickets in the woods along water courses, and seldom or never found in the high open groves. They keep much on the ground, where they walk about rather slowly, searching for their food among the dried leaves. In general appearance they are quite unique, and I rarely failed to identify one with an instant's glance, so very peculiar are all their attitudes and motions.

"The tail is habitually carried at an elevation considerably above the line of the back, which gives them quite a smart, jaunty air, and if the dorsal aspect be exposed in a clear light, the peculiar marking of the crown is quite conspicuous. Seen as they usually are, hovever, dimly flitting ahead through the gloom and shadow of the thickets, the impression received is that of a dark little bird which vanishes unaccountably before your very eyes, leaving you quite uncertain where to look for it next; indeed, I hardly know a more difficult bird to procure, for the slightest noise sends it darting off through the woods at once. Occasionally you will come upon one winding around the trunk of some small tree, exactly in the manner of Mniotilta varia, moving out along the branches with nimble motion, peering alternately under the bark on either side, and anon returning to the main stem, perhaps in the next instant to hop back to the ground again. On such occasions they rarely ascend to the height of more than eight or ten feet. The males are very quarrelsome, chasing one another through the woods with loud, sharp chirpings, careering with almost inconceivable velocity up among the tops of the highest oaks, or darting among the thickets with interminable doublings, until the pursuer, growing tired of the chase, alights on some low twig or old mossy log, and in token of his victory, utters a warble so feeble that you must be very near to catch it at all, a sound like that produced by striking two pebbles very quickly and gently together, or the song of Spizella socialis heard at a distance, and altogether a very indifferent performance." (Brezuster ${ }^{2}$.)

Song.-The resemblance of the Worm-eater's song to that of the Chipping Sparrow is so great that few describers of it fail to comment on the similarity.

Mr. W. DeW. Miller of Plainsfield, New Jersey, tells me that he has on two occasions heard a flight song from this species. It is described by him as much more varied and musical than the ordinary song, though lacking in strength. It was given as the bird flew through the woods at an even level, not rising above the tree-tops, as does the Oven-bird and other flight singers. 
This is probably the song referred to by Jones in the following quotation: "Mr. Burns describes a song that resembles that of a Goldfinch; chat-ah-che-che-chee-chee-chee, which seems to correspond well with a passion song in the manner of utterance."

"Commonly remains in song after its arrival until the second week in July. Sometimes singing ceases a little earlier than this; again, in other years, songs are to be heard until the third week of the month.

"The second song-period of this Warbler I can speak of only from one season's experience. On July IO, I88I, several of these birds were silently inhabiting a small tract of woodland, their first season of song having passed; here on August I4, and again on the 2Ist, they were found in fine plumage and in full song.

"The songs of no three birds known to me are more alike than those of the Worm-eating Warbler, the Chipping Sparrow, and the Slate-colored Junco." (Bicknell. ${ }^{8}$ )

"Call-note a sharp dat like that of Swainson's Warbler, or the Black and White Warbler; it is uttered at all times and seasons. The song is a perfectly monotonous trill; it is uttered during spring migration during momentary pauses in the active creeping of the bird-never in flight. I have seen a bird perch for some time upon an exposed dead limb, uttering the song at short intervals, and meanwhile sitting quite still. This was on April 26, in Tishomingo county - almost too soon for the bird to have had a nest. I have heard no song in the fall." (Allison, MS.)

"I can distinguish no difference between the notes of this species and those of the Chipping Sparrow; the first may be a trifle weaker, perhaps. The series of notes may be uttered while perched, or c1eeping about the lower branches of the trees, sapling tops, bushes, or fallen brush, or while on the ground. With slightly drooping tail and wings, puffing out of body plumage, throwing its head back until the beak is perpendicular, it trills with swelling throat an unvarying Che-e-e-e-e-e-e, which does not sound half so monotonous in the woods as does the Chippy's lay in the open. The first song period is from the time of arrival until June 24 to July 5 , but during the last two weeks, when housekeeping is a thing of the past and the hot days have come, it is seldom heard except in the early morning, beginning about four o'clock, and in the cool of the evening. The second song period is very brief and follows the molt. I have no dates." (Burns, MS.) 
Nesting Site.- "It always nests on the ground, generally on a steep hillside in the woods. A stream of water or a swamp seem to be a desirable condition." (Jackson.$^{8}$ )

Ladd $^{4}$ states that the nest is placed at the foot of either a sapling or small bush, not necessarily on a hillside but sometimes on level ground in open places with little shade.

Nest.- "The nest is invariably lined with the red flower stalks of the hair moss (Polytrichium)." (Jackson. ${ }^{3}$ ) Ladd confirms this habit and adds: "Sometimes fine grass and horse-hair are used as part of the lining." The body or outside of the nests is composed of leaves only. Nests taken by J. N. Clark at Saybrook, Connecticut ( $C . W . C$. ) are composed of decayed leaves and lined with stems of maple seeds.

Eggs.-3 to 6, usually 4 or 5. Ground color white with a wide variation in markings from sparingly to profusely marked with spots, specks, and blotches of chestnut, lavender, light and dark reddish, with a tendency to form wreaths around the larger end, but in most cases a nearly evenly marked egg. In shape some are rounded oval and others much pointed. Size; average, .69x.53; extremes, .75x.58, .64X.48. (Figs. 9-II.)

Nesting Dates.- Iredell County N. C., May ıo (J. P. N.); West Chester, Pa., May 26-June I5 (Jackson); Waynesburg, Pa., May I6-June II (Jacobs); New York City, May 20 (F. M. C.); New Haven, Conn., May 25-June i9 (Bishop).

\section{Biographical References}

(I) R. Ridgway, Field and Forest, I, I875, I0. (2) Wm. Brewster, Observations on the Birds of Ritchie County, West Virginia, Ann. Lyc. Nat. Hist., N. Y., XI, I875, I34. (3) T. H. JACKsoN, Nesting of the Worm-eating Warbler [in S. E. Pa.], Orn. and Oöl., XI, I886, I56. (4) S. B. LADD, Nesting of the Worm-eating Warbler [in S. E. Pa.], Orn. and Ö̈l., XII, I887, IIo; (5) A Series of Eggs of the Worm-eating Warbler, Ibid, I49. (6) F. L. Burns, The Worm-eating Warbler [in Penn.], Bird-Lore, VII, 1905, 137. (7) J. P. $\mathrm{N}$ [oRRIs], A Series of Eggs of the Worm-eating Warbler, Orn. and Oöl., XV, 1890, I18. (8) E. P. Bicknell, A Study of the Singing of our Birds, Auk, I, I884, 2 10.

\section{Genus PROTONOTARIA Baird}

Protonotaria citrea, the single species contained in this genus, has the bill long, stout, aculeate, the upper mandible nearly straight but somewhat decurved at the slightly notched tip, the ridge of culmen is pronounced and slightly parts the feathers of the forehead, 
the rictal bristles are barely evident. The wing is rather broad, not especially pointed, the tail is short, square, or even somewhat rounded, the outer feather being slightly the shortest; the under tail-coverts are long, reaching to within half an inch, or less, of the end of the tail; the hind-toe is shorter but stouter than the middle toe.

In color the sexes closely resemble each other, the male having the head brighter.

\section{PROTHONOTARY WARBLER PROTONOTARIA CITREA (Bodd.) Plate III}

Distinguishing Characters.-The prevailing orange-yellow color, grayish wings and absence of wing-bars will always distinguish this species. Length (skin), 4.90 ; wing, 2.85 ; tail, 1.85 ; bill, .55 .

Adult d, Spring.-Whole head orange-yellow; back yellowish green; rump and upper tail-coverts gray; tail margined with gray, all but the central pair of feather's white on the inner web except at the tip, which is black; wings black, externally margined with gray, lesser coverts like the back, greater coverts tinged with same, first primary covert blackish margined with whitish, bend of wing yellow; below orange-yellow changing to white on the crissum; bill black.

Adult $\delta$, Fall.-Similar to adult $\delta$ in Spring, but hind-head always washed with dusky; bill brownish.

Young $\delta^{\prime}$, Fall.-Similar to adult $\delta^{*}$ in Fall but white on inner webs of tail-feathers more restricted and more or less mottled with blackish; first primary covert grayer.

Adult $\$$, Spring.-Resembles adult $\delta^{*}$, but crown duller, greenish yellow or orange, back the same changing to gray on the rump; tail with less white, the black areas duller; below averaging paler than the adult and with more white on the lower belly.

Adult +, Fall.-Resembles adult $q$ in Spring.

Young $q$, Fall- - Resembles adult $q$ in Fall.

Nestling.-Above dusky olive-green varying markedly to brown; below dusky grayish tinged with yellow or brown on the breast and sides, whiter on the belly.

Gcneral Distribution.-Eastern United States, north to Virginia and Minnesota, west nearly to the Plains.

Summer Range.-The Prothonotary Warbler is pre-eminently a bird of damp. woods in the immediate vicinity of water, and, in general terms, it can be said that its principal summer home is the bottom lands of the Mississippi River and its tributaries to an altitude of one thousand feet; north to northwestern Ohio (St. Mary's Reservoir), northeastern Indiana (Steuben County), southern Ontario (Hamilton), southeastern Michigan (Lansing), central Wisconsin (Shiocton), southeastern Minnesota (Hastings); west to central 
Iowa (Des Moines), eastern Nebraska (Omaha, Lincoln and West Point), central Kansas (Manhattan and Neosho Falls), Oklahoma City and Kiowa Agency), and eastern Texas (Gainesville and Austin).

Along the Atlantic slope, near the coast, the species is common north to the Dismal Swamp of Virginia, and rare locally, thence to western Delaware (Choptank River). It breeds south to northern Florida. It has occurred accidentally in Pennsylvania (Arcola, May I5, 1887; near Philadelphia, May 1879; Allegheny County, May 17, I892; Chester County, May; Lancaster County); New Jersey, (Haddonfield) ; New York (Montauk Point, L. I., August 26, I886; Jamaica, May I849; Yonkers, June 2, I895) ; Rhode Island, (South Kingston, April 20, I884; Lonsdale, April 29, I892 and April I9, I893) ; Massachusetts (South Abington; Northampton, May I883; Concord, May 9, I886, August 17 and 23, I886; Auburndale, June I9, I890; Hyde 1'ark, May 21, I892; Mattapan Station September I5, 1894); New Brunswick (St. Stephens, October 30, I862), and Arizona (Tucson, May I, I884).

Winter Range.-Nicaragua to Venezuela; rarely north to Yucatan.

Spring Migration: Atlantic Coast.-The earliest record in the United States for this species is Sombrero Key Light, Florida, March I I, I888; the average date of arrival in northern Florida is the first week in April, the earliest, being Suwanee River, March 22, 1890, and Perdido Lighthouse, March 22, I885. At Charleston, S. C., eight struck the light April 8, I902. At Cumberland, Ga., the earliest record is April IO, I902; on April 15, 1902 this was the most common among the birds that swarmed about the light; it was again abundant the next night. The average at Raleigh, N. C., is April I8.

Mississippi Valley.-At New Orleans, La., the earliest record is March I3, I888, the average being March I8. Additional records are: Central Mississippi, average April 6, earliest April 3, I889; Lomita, Texas, March 26, I880; Matagorda Island, Texas, March 31, I900; Dallas, Texas, April 8, I898, April 6, I899; Manhattan, Kansas, April 25, I891, April 26, I894, April 26, 1895; St. Louis, Mo., April I8, I884, April 20, I885; Wabash County, Illinois, April I9, I878; Knox County, Indiana, April I8, I88I; Vigo County, Indiana, April Io, 1896; Elkhart County, Indiana, April 27, I89I, and Shiocton, Wis., May 4, I882.

Fall Migration.-The earliest records of fall migration are at Raleigh, N. C., July 14, I893 and I894, and at Key West, Fla., July 
28, I888, and August 8, I889. The earliest records south of the United States are on the coast of southeastern Nicaragua, September 2, I892, and in northern Colombia, South America, September 25. The latest date at Raleigh, N. C., is August 26, and at Omaha, Nebr., August 25 to September Io. The latest Florida record is of a bird that struck the light at Sombrero Key, September 25, I888, and the latest from New Orleans is September 24, I893. The only fall record for the West Indies is of one taken at New Providence, Bahamas, August 28, r898.

The route of the Prothonotary Warbler in its fall migration is interesting; the breeding birds of the Middle Atlantic States apparently pass southwest to northwestern Florida and then take a seven-hundred-mile flight directly across the Gulf of Mexico to southern Yucatan, instead of crossing to Cuba and thence to Yucatan.

The Bird and its Haunts.-The charm of its haunts and the beauty of its plumage combine to render the Prothonotary Warbler among the most attractive members of this family. I clearly recall my own first meeting with it in the Suwanee River region of Florida. Quietly paddling my canoe along one of the many enchanting, and, I was then quite willing to believe, enchanted streams which flowed through the forests into the main river, this glowing bit of bird-life gleamed like a torch in the night. No neck-straining examination with opera-glass pointed to the tree-tops, was required to determine his identity, as, flitting from bush to bush along the river's bank, his golden plumes were displayed as though for my special benefit.

If all our Warblers had received the attention which the Prothonotary's attractions have won for him, the preparation of this volume would have been a much easier and more satisfactory task. Space, indeed, prohibits adequate quotations from the monographs of which this bird has been the subject, and for more detailed information than can here well be presented, the student is referred to the papers cited beyond. From the one by William Brewster ${ }^{2}$, the following admirable pen picture of the Prothonotary and its haunts is extracted:

In the heavily timbered bottoms of the Wabash and White Rivers, Brewster writes, two things were found to be essential to the Prothonotary's presence, "namely, an abundance of willows and the immediate proximity of water. Thickets of button bushes did indeed satisfy a few scattered and perhaps not over particular individuals and pairs, but away from water they never were seen. So marked 
was this preference, that the song of the male heard from the woods indicated to us as surely the proximity of some river, pond, or flooded swamp, as did the croaking of frogs or peeping of hylas.

"In general activity and restlessness few birds equal the species under consideration. Not a nook or corner of his domain but is repeatedly visited through the day. Now he sings a few times from the top of some tall willow that leans out over the stream, sitting motionless among the yellowish foliage, fully aware, perhaps, of the protection afforded by its harmonizing tints. The next moment he descends to the cool shades beneath, where dark, coffee-colored water, the over-flow of pond or river, stretches back among the trees. $* * *$

"This Warbler usually seeks its food low down among thickets, moss-grown logs, or floating debris, and always about the water. Sometimes it ascends tree-trunks for a little way like the Black and White Creeper [=Warbler], winding about with the same peculiar motion. When seen among the upper branches, where it often goes to preen its feathers and sing in the warm sunshine, it almost invariably sits nearly motionless. Its flight is much like that of the WaterThrush (either species) and is remarkably swift, firm, and decided. When crossing a broad stream it is slightly undulating, though always direct."

Of the Prothonotary farther south in the Mississippi Valley, Allison (MS.) writes:

"The typical haunt is low, flat, woodland, preferably with some standing water; this is usually a river bottom, though a 'bay-gall,' or low swamp among pine-lands, wooded with white bay, black-gum, etc., often answers the purpose. In Louisiana, a piece of ground recently deposited by the Mississippi River, and covered with a thick growth of willows, is attractive to this Warbler. It joins less than many other species with the roving bands of migrant Warblers in the upland woods."

Song.- "The usual song of the Prothonotary Warbler sounds at a distance like the call of the Solitary Sandpiper with a syllable or two added,- - a simple peet, tweet, tweet, tweet, given on the same key throughout. Often when the notes came from the farther shore of a river or pond we were completely deceived. On more than one occasion, when a good opportunity for comparison was offered by the actual presence of both birds at the same time, we found that at the distance of several hundred yards their notes were absolutely indistinguishable; nearer at hand, however, the resemblance is lost, 
and a ringing penetrating quality becomes apparent in the Warbler's song. It now sounds like peet, tsweet, tsweet, tsweet, or sometimes tweet, tr-sw'eet, tr-sweet, tr-sweet. When the bird sings within a few yards the sound is almost startling in its intensity, and the listener feels inclined to stop his ears. The male is a fitful singer, and is quite as apt to be heard in the hot noontide or on cloudy days, when other birds are silent, as during the cool morning and evening hours. The ordinary note of alarm or distress is a sharp one, so nearly like that of the Large-billed Water-Thrush (Seinrus motacilla) that the slight difference can only be detected by a critical ear. When the sexes meet a soft tchip of recognition common to nearly all the Warblers is used. In addition to the song above described the male has a different and far sweeter one, which is reserved for select occasions, an outpouring of the bird's most tender feelings, intended for the ears of his mate alone, like the rare evening warble of the Oven-bird (Seiurus aurocapillus). It is apparently uttered only while on the wing. Although so low and feeble as to be inaudible many rods away, it is very sweet, resembling somewhat the song of the Canary given in an undertone, with trills or 'water notes' interspersed. The flight during its delivery is very different from that at all other times. The bird progresses slowly, with a trembling, fluttering motion, its head raised and tail expanded. This song was heard most frequently after incubation had begun." (Brewster ${ }^{\mathbf{1}}$.)

Nesting Site.-Brewster ${ }^{1}$ writes that to give an account of all the situations in which he has found nests of this species "would entail a description of nearly every conceivable kind of hole or cavity that can be found in tree-trunks. The typical nesting-site, however, was the deserted hole of the Downy Woodpecker or Carolina Chickadee. The height varied from two to fifteen feet, though the usual elevation was about four." Barnes's ${ }^{2}$ observations agree with Brewster's but he adds that, rarely, nests are found as high as twenty-five feet. Both writers state that the height of the nest and its distance from the water depend upon the fall in the water after the site has been selected.

A wide, and apparently not infrequent departure from the type of nesting-site just described is the vicinity of houses (Ganier ${ }^{5}$ ) and, in one instance, a railroad briı'ge (Roberts ${ }^{4}$ )when, bluebird-like, the bird accepts nest-boxes or similar situations.

Nest.-The nest is constructed by the female. The male accompanies her on her search for material and rarely brings a small bill 


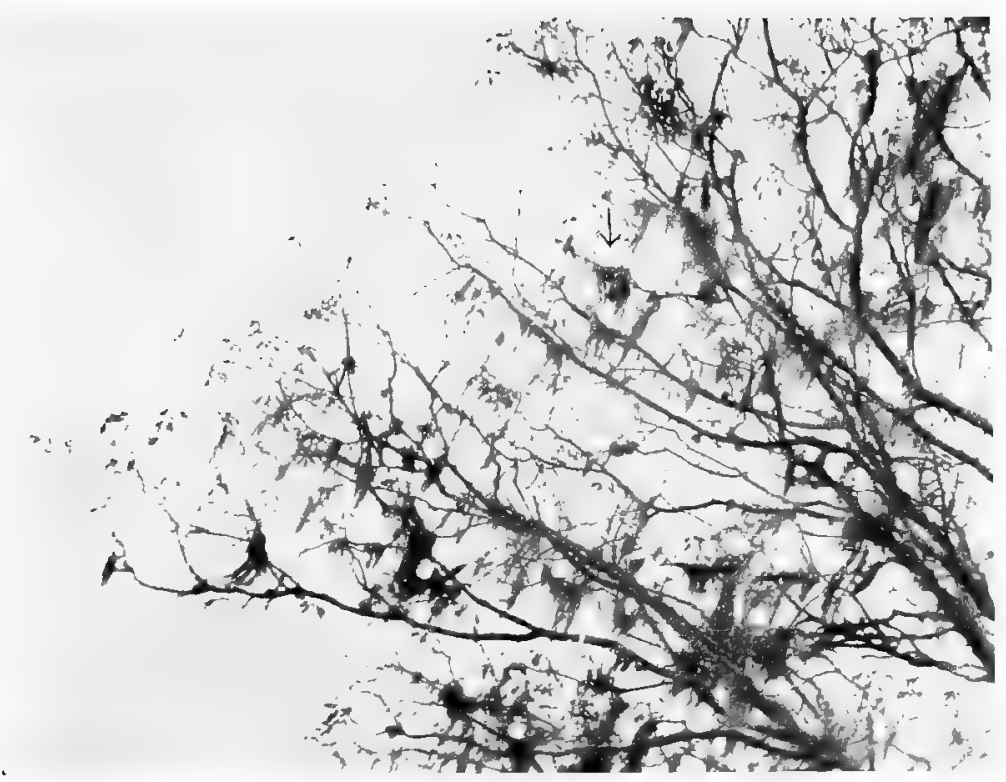

NEST OF PARULA WARBLFR.

The arrow indicates the location of the nest. The bird may be secn at the left of nest. Photograpl by FrANK M. ChAPMAN, at Gardiner's Island, N. Y.

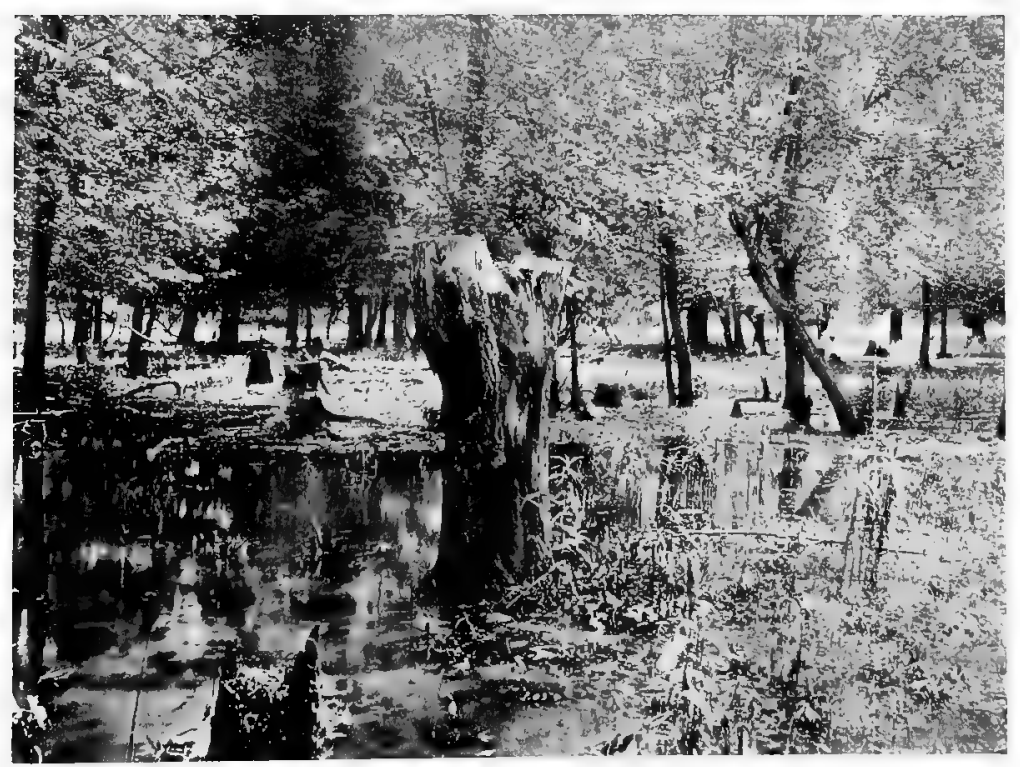

NTSTING STUMP OF PROTIIONOTARY WARBLER.

The arrow indicates the nest entrance.

Plotographed by Thomas S. RoberTs, at Red Wing, Minn. 

full but leaves it "on the outside of the hole for her to carry in and arrange.

"The female begins by bringing some fine straws or grasses which are arranged in a nice nest in the bottom of the hole. Next she procures some fine strips of grape-vine bark, and lines her nest, and lastly covers this all over carefully and thickly with moss which grows on the bark of trees standing in the water. $* * *$ They very rarely use any feathers or hair, and sometimes build their nest entirely of one of the above materials." (Barnes ${ }^{2}$.)

Nests collected by Wayne in South Carolina were made of lichens and lined with cypress leaves $(C . W . C$.$) .$

Ganier ( $M S$.) writes that in Mississippi the birds "frequently excavate their own hole in the soft cottonwood stumps," a habit not mentioned by other writers I have consulted.

Eggs.-5 to 7, usually 6. Ground color a rich creamy white to buffy, very glossy and very heavily and profusely blotched and spotted with rich chestnut-red, many lavender and purplish shades occurring. The heaviest and richest marked of North American Warblers' eggs; in shape a rounded oval tending to become nearly spherical, the larger end having the heavier markings. An extreme type has rich cream ground with a few scattering spots of purplish brown. Size; average, .70x.57; extremes, $.76 \times .59, .65 \times .57, .70 x .53, .72 x .61$. (Figs. 6, 7.)

Nesting Dates.-Charleston, S. C., May 3; June 23, two eggs with large embryos (Wayne); Lewis County, Mo., May I3 (J.P.N.) ; Mt. Carmel, Illinois, May 8 (Brewster) ; Lacon, Illinois, May 2I-July 7 (C.W.C. ) ; Pierce County, Wis., May 3I (C.W.C.).

\section{BIOGRAPHICAL REFERENCES}

(I) William Brewster, The Prothonotary Warbler (Protonotaria citrea) [in Illinois and Indiana], Bull. Nutt. Orn. Club, III, I878, 153. (2) R. M. Barnes, Nesting of the Prothonotary Warbler, Orn. and Oöl., XIV, I889, 37. (3) W. E. Loucrs, Life History of the Prothonotary Warbler, Bull. Ill. State Lab. Nat. Hist., IV, I894, I0; also Osprey, II, I898, 99, III, I29. (4) T. S. RoBerts, The Prothonotary or Golden Swamp Warbler (Protonotaria citrea) a Common Summer Resident in southeastern Minnesota, Auk, XVI, 1899, 236. (5) Albert Ganier, Nesting of the Prothonotary Warbler, Bird-Lore, II, Igoo, 89. (6) J. P. N[orris], A Series of Eggs of the Prothonotary Warbler, Orn. and Oöl., XV, 1890, 177.

\section{Genus VERMIVORA Swainson}

Small size and a short, straight, slender, unnotched, exceedingly acute bill distinguish all the species of this genus, except $V$. 
bachmani, in which the bill is slightly decurved; the rictal bristles are not evident; the wing averages about .70 inches longer than the tail; the tail-feathers are rather narrow, terminally rounded or obtusely pointed; the under tail-coverts are about three-fourths as long as the tail; the feet are blackish, the tarsus decidedly longer than the middle-toe and nail.

Compared with Dendroica the species of Vermivora, as a whole, are plain in color and in pattern of coloration.

$V$. chrysoptera and $V$. pinus are the only species having wingbars; while with $V$. bachmani and, to a lesser degree, $V$. peregrina, they differ from other members of the genus in having the tail marked with white.

Vermivora contains nine species and two forms of doubtful status, all but one of which, $V$. crissalis of the Sierra Nevada of Colima, Mexico, are North American. Four species are eastern, one of them, $V$. peregrina, extending, however, northwestward to Alaska, two are found in the Rocky Mountain region and southward into Mexico, and two, $V$. celata and $V$. rubricapilla, range from the Atlantic to the Pacific, their color showing some response to the varying climatic conditions encountered in so vast an area.

Although arboreal in habit, the species of this genus nest upon the ground, with the exception of $V$. lucice which nests in holes, etc., and $V$. bachmani, which builds in low bushes.

\section{GOLDEN-WINGED WARBLER}

\section{VERMIVORA CHRYSOPTERA (Linno) Plate V}

Distinguishing Characters.-General color gray; a yellow patch on the wings; cheeks and throat black in the d", gray in the $q$. Length (skin), 4.30; wing, 2.45; tail, I.90; bill, .46.

Adult o", Spring.-Crown yellow bordered by a white line above eye; cheeks black; back gray sometimes tinged with olive-green; tail gray, the outer three or four feathers with white patches on the inner vane; wings externally gray, the inner feathers edged with olive-green, outer vane of greater coverts largely yellow, median coverts broadly tipped with yellow, forming a yellow wing-patch; throat and upper breast black bordered by a white line at either side, rest of underparts grayish, white on the median line.

Adult d, Fall.-Similar to the last but more or less washed with olivegreen above and with yellow below.

Young $\sigma^{\circ}$, Fall.-Similar to adult $\delta$ in Fall but black throat-patch slightly smaller and sometimes tipped with grayish, the chin white connecting the two white stripes on either side of the throat. 
Adult q, Spring.-Crown greenish yellow, a white line above eye, cheeks gray; back gray more or less washed with olive-green; tail and wings as in $\checkmark$ but yellow of wing-bars more restricted; throat gray bordered by whitish stripes; middle of belly whitish, sides gray.

Adult \%, Fall.-Not seen.

Young $q$, Fall.-Similar to adult $q$ in Spring but crown greener, back and underparts washed with olive-green, chin whitish.

Nestling.-Dusky olive-green above, below dusky olive; wings and tail as in young in Fall, greater and median wing-coverts olive-green tipped with greenish forming two conspicsous bars. The early development of the plumage of the throat soon distinguishes the sexes.

General Distribution.-Eastern United States; north to New Hampshire and Wisconsin; west to the Mississippi River.

Summer Range.-The principal summer home is in Michigan, southern Ontario and northern Wisconsin; a few occur east to New York (Penn Yan, May 1872; Buffalo, May 12, I888), New Hampshire (Durham, Hampton Falls, Jaffrey, Manchester and Concord), and the species is not uncommon locally in Massachusetts and Connecticut. It breeds south to northern Illinois, northern Indiana and Ohio, while in the mountains, the breeding range takes a southerly dip from Pennsylvania to northern Georgia, where at an elevation of 2,000 to 4,000 feet, the bird is, locally, almost as common as in Michigan. The species has been noted in Manitoba (Winnipeg about May 24, 1887), Iowa (Iowa City, May 17, 1885), and New Mexico (Fort Thorn, April 1854.)

The southern Mississippi Valley is crossed in migration, but the species is very rare in eastern Texas and occurs only rarely or casually in South Carolina, Georgia and Florida; accidental in Mexico and the West Indies.

Winter Range.-Guatemala to Colombia.

\section{Spring Migration.-}

\begin{tabular}{|c|c|c|c|}
\hline PIACE & $\mid \begin{array}{l}\text { No. of } \\
\text { years' } \\
\text { record }\end{array}$ & $\begin{array}{l}\text { Average date of } \\
\text { spring arrival }\end{array}$ & $\begin{array}{l}\text { Earliest date of } \\
\text { spring arrival }\end{array}$ \\
\hline 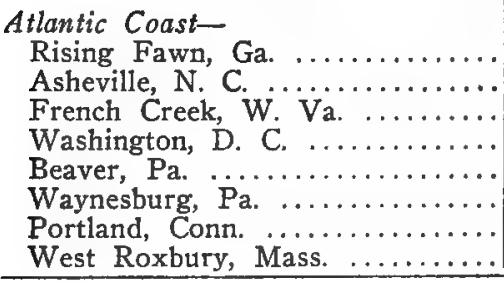 & $\begin{array}{r}4 \\
4 \\
3 \\
3 \\
18 \\
5\end{array}$ & $\begin{array}{lr}\text { May } & 2 \\
\text { May } & 3 \\
\text { April } & 30 \\
\text { April } & 30 \\
\text { May } & 12 \\
\text { May } & 9 \\
\end{array}$ & $\begin{array}{lrl}\text { April II, } & 1885 \\
\text { April } 22, & 1893 \\
\text { April } 30, & 1893 \\
\text { May I, } 1905 \\
\text { April } 24,1902 \\
\text { April } 26, & 1896 \\
\text { May 3, } & 1896 \\
\text { May } 4, & 1891 \\
\end{array}$ \\
\hline
\end{tabular}




\begin{tabular}{|c|c|c|c|}
\hline PLACE & $\begin{array}{l}\text { No. of } \\
\text { years? } \\
\text { record }\end{array}$ & $\begin{array}{l}\text { Average date of } \\
\text { spring arrival }\end{array}$ & $\begin{array}{l}\text { Earliest date of } \\
\text { spring arrival }\end{array}$ \\
\hline $\begin{array}{l}\text { Framingham, Mass. } \ldots \ldots \ldots \ldots \ldots \\
\text { Mississippi Valley- }\end{array}$ & IO & May Io & May $\quad 8,1895$ \\
\hline St. Louis, Mo. .... & 6 & May & April 26, I888 \\
\hline Keokuk, Ía. & 4 & April 30 & April 22, 1894 \\
\hline Waterloo, Ind. & 6 & April 30 & April 27, 1896 \\
\hline Petersburg, Mich. & IO & May & April 25, 1886 \\
\hline Livonia, Mich. .. & 5 & May & May 5,1897 \\
\hline Detroit, Mich. & 9 & May & 2,1905 \\
\hline Sonthern Ontario & 8 & May & 2,1900 \\
\hline Lanesboro, Minn. & & & 8, 1887 \\
\hline Elk River, Minn. & & & May $12, I 888$ \\
\hline
\end{tabular}

Fall Migration.-A fall migrant has been seen at New Orleans, La., as early as July 23, I898, and one was taken on the northern coast of South America, September 6, showing that the Golden-winged Warbler is among the early migrants. The last ones seen were noted at Lanesboro, Minn., September 8, I889; Livonia, Mich., September 21, I89I; Chicago, Ill., September 25, I895; Englewood, N. J., September 2, I886; French Creek, W. Va., September 15, 1892; Chester County, S. C., September 22, 1887, and New Orleans, La., September 2I, I897.

The Bird and its Haunts.-This beautiful Warbler is by no means a rare bird throughout the greater part of its breeding range and in some localities is abundant, nevertheless it is usually sufficiently uncommon as a transient spring migrant to make its appearance worthy of special comment in our note-books. Students of the fall migration, however, will some years find it an abundant August migrant.

The complex and as yet not clearly understood relations existing between this species, the Blue-winged Warbler and the intermediate forms known as Brewster's and Lawrence's Warblers make, as has been said under the Blue-wing, a study of their nesting habits, particularly in that region where the range of this species overlaps that of the Blue-wing, a matter of untusual interest.

About Cambridge, Mass., Brewster ${ }^{7}$ writes that the Golden-wing "frequents deciduous woods and thickets, preferring to all other places springy runs shaded by gray birches, old pastures growing up to birches and wild apple trees, and dry hillsides covered with a young sprout growth of oak, hickory or maple. As a rule it shuns evergreen trees, but at its seasons of migration I have occasionally seen it feeding, with Warblers of other species, in the tops of large white pines." 
In southwestern Pennsylvania, we learn from J. Warren Jacob's ${ }^{5}$ monograph of this species, it prefers fields "abundantly supplied with damp or springy places, with rank-but closely rooted grass, clumps of bushes, briers, etc., and the adjacent forest skirted with like growth." He adds: "I have never found a nest on the creek bottom lands, but always well up the side or on top of a hill."

In southern Michigan, Gibbs" states, "the Golden-wing evidently prefers low sections of land, and appears most at home in quarters where deep woods border marshy tracts. I have yet to meet with the birds in very high and dry localities, although they are sometimes seen in elevated swampy spots. I have never found the bird in oak openings, hickory lands or sandy soil."

In its general actions the Golden-wing resembles the Blue-wing. It has the same peering ways and habit of examining a branch tip or leaf while hanging back downward. Jacobs ${ }^{5}$ writes: "This bird must be a great destroyer of leaf lice and small caterpillars that infest the tips of branches and the underside of leaves, for they are continually searching and picking at the opening buds and waxen leaves at the ends of new twigs, the male pausing frequently to sing. At tines their actions [remind] one of the Gnatcatcher in flitting hither and thither snatching up small winged mites."

The same author states that two days seem to be ample time for the birds to complete a nest, and in more than one instance he has known a nest commenced one day to contain an egg "the second day thereafter." The period of incubation, he adds, is ten days and the young leave the nest when ten days old.

Song.- "I have only heard the song on three occasions, but the song is too distinctive a one ever to be forgotten. It was uttered almost by the hour. An indolent, rather wheezy note, repeated three or four times without variation; always the same note, a lazy, droning song with a little of the Black-throated Blue's huskiness in it. The syllables sh, hush, hush, hush, recall it to me, the last three slightly quicker than the first." (Farwell, MS.)

"The song of $H$. chrysoptera consists normally of four notes -shree-e-e, zwee, zwee, zwee,- - the first about two notes higher than the following three, being slightly prolonged. It is varied somewhat at times, with the second note like the first; again it is reduced to three two, or even a single note. The song will immediately attract attention from its very oddity. By some it is considered harsh, but to me it has a soft penetrating quality, unexcelled, this effect being heightened by the uncertain source of the song." (Eames. ${ }^{8}$ ) 
"While the female is inctbating the eggs, her mate moves about the tips of branches and tops of saplings, searching for food, all the while singing his little ditty, which is a simple little bit of bird music hard to put into print. At some distance the song can be distinguished by the syllables zee-ze-ze-ze-ze, beginning slowly and proceeding more rapidly and ending in a slightly higher pitch. When near the bird this song sounds somewhat different, and is now hard to imitate in type. The best I can do is to write it zee-u-ee'-zee-u-ee'$z e e-u-e e^{\prime} z e e-u-z w e e^{\prime}$, with the $u$ barely articulated. I have several times heard the song continued to the middle of July, and again on still, sultry days in August. At this time, however, it is not so strong and complete as during the early summer. While emitting this song, the bird stands quite erect, stretched up to its full height, the throat extended until the feathers ruffle. The head pointing about 70 degrees upward when the first syllable is uttered, is turned farther upward at the close of the song. The alarm note of both sexes, when the nest or young is disturbed, consists of a sharp chip like that of the Chipping Sparrow, but sharper and repeated oftener." (Jacobs. ${ }^{5}$ )

Nesting Site.-The following quotation from Jacob's ${ }^{5}$ admirable monograph of this species seems to apply to the bird thronghout its nesting range: "The nest is hardly ever placed away from some substantially stupporting stalks of weeds-new or dead-briers, elders, sprouts, etc., of not sufficient abundance to hinder a good growth of grass. One nest was placed above ground, being three inches up in a clump of iron-weeds in a marshy place."

Nest.- "The domicile is rather compact and neatly cupped, but on the whole is very bulky for a bird so small. The base is composed of dry oak and beech leaves, and other leaves which dry hard, glossy, and without crumpling; on top of this heap a more compact structure is made, the leaves being placed points downward; then comes a goodly supply of strips of grapevine bark and shreds of inner tree bark, so placed that the rough ends extend beyond the rim of the nest. A lining is then put in place consisting of fine grass stems and, in some cases, long horse-hairs. A strict lining is not alway put in place, some birds being content to rest the eggs on the grapevine bark and a few intermingling grass stems. Although constructed of coarse materials, the inside of the nest presents a neat appearance, the long shreds of bark and grasses crossing diagonally, much resembling basket work. The opening is not straight down, but slightly tilted, the jaggy leaf-stems and bark sometimes reaching two or three inches above the rim of the nest proper. *** Two days seem to be 


\section{Plate IV}

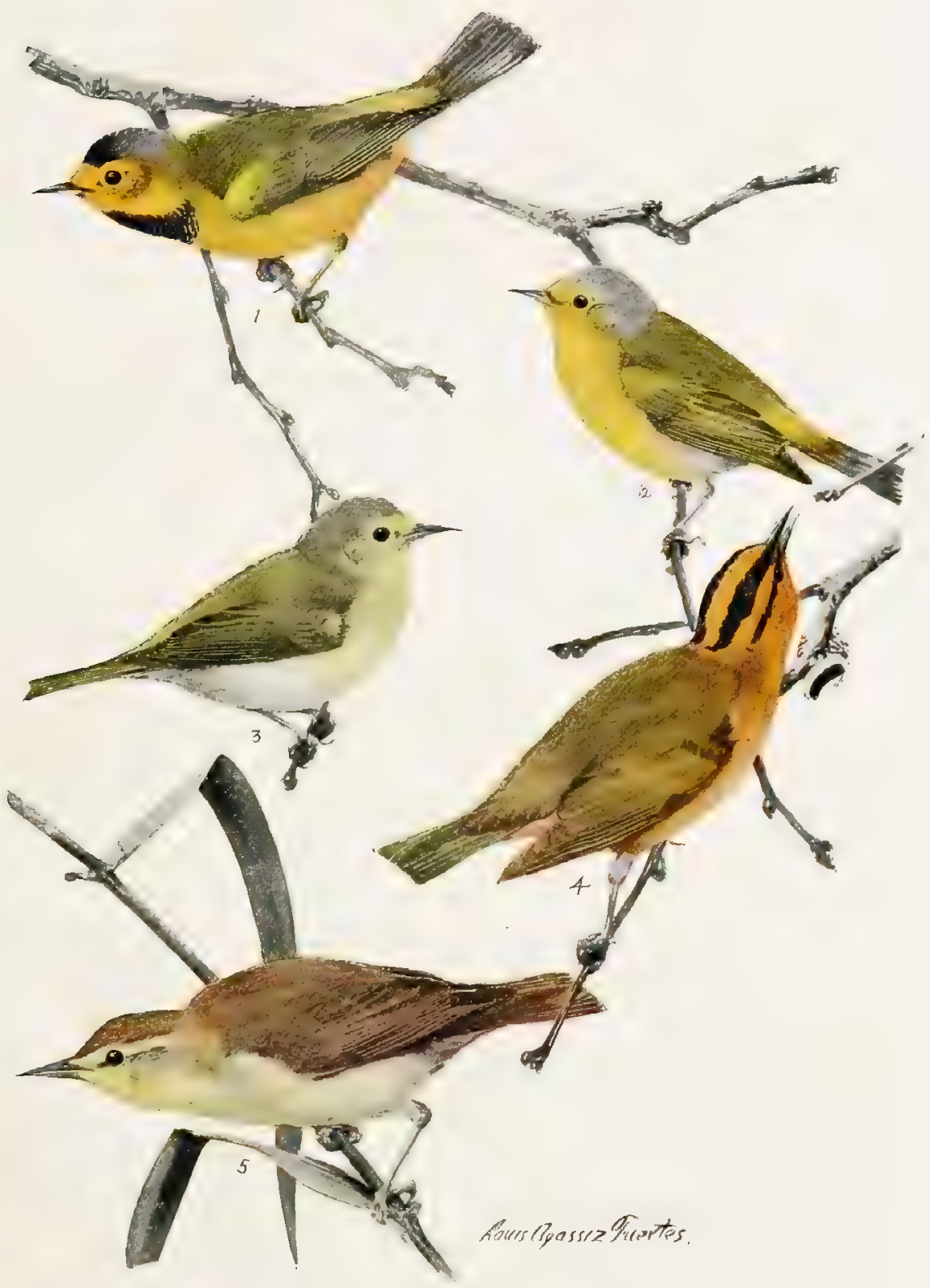

1. Bachman's Warbler, Adult Male.

3. Bachman's Warbler, Young Female

2. Bachman's Warbler, Adult Female.

4. WORM-EATING WARBLER, AdULt.

5. SWainson's Warbler, AdULT.

(One-half natural size.) 


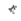

.

r

$\pi$ 
ample time for the birds to complete a nest, and in more than one instance I have [found that] a nest commenced one day contained an egg the second day thereafter." (Jacobs. ${ }^{5}$ )

Eggs.-4 to 6, usually 5. Ground color white, markings the same as in the eggs of the Blue-winged Warbler, except that they are more profuse and of larger size, tending to form small blotches in many cases. Size; average, .66x.5I ; extremes, .73x.55, .58x.5I, 61x.48. (Figs. I5-17.)

Nesting Dates.-Weaverville, N. C., May 22, Tarboro, N. C., June 22 (C. W. C.); Waynesburg, Pa., May I4-June I3 (Jacobs); Bethel, Conn., May 29-May 3 I (Bishop); Monroe County, Mich., May $17-J u n e ~ 18$ (J. P. N.).

\title{
BIOGRAPHICAL REFERENCES
}

(I) J. WARRen, Nesting of the Golden-winged Warbler (Helminthophila chrysoptera) in Massachusetts, Bull. Nutt. Orn. Club, I, I876, 6. (2) 'Scolopax' [-MorRIS Gibes], Nesting Habits of the Golden-winged Warbler, Oölogist, XI, I894, 3II. (3) J. P. N[ORRIs], A Series of Eggs of the Golden-winged Warbler, Orn. and Oöl., XV, I890, 2r. (4) J. H. SAGE, Notes on Helminthophila chrysoptera in Connecticut, Auk, X, 1893, 208. (5) J. W. JACOBS, The Haunts of the Golden-winged Warbler, with notes on Migration, Nest Building, Song, Food, Young, Eggs, Etc., published by the author, Waynesburg, Pa. (6) E. H. EAMES, Notes on the Blue-winged Warbler and Its Allies, Auk, VI, I889, 305. (7) WM. BREWSTER, Birds of the Cambridge Region, 322.

\section{BLUE-WINGED WARBLER}

\author{
VERMIVORA PINUS (Linn.) Plate V
}

Distinguishing Characters.-A black or blackish line through the eye; forehead yellow or yellowish; two white wing-bars. Length (skin), 4.10; wing, 2.45 ; tail, 1.85 ; bill, .46 .

Adult 8 , Spring.-Crown yellow, nape and back olive-green; a black or blackish line to or through the eye; tail gray, three outer feathers with large white patches on their inner vanes, fourth and fifth sometimes with white; wings externally grayish, inner feathers more or less margined with olivegreen; median coverts tipped with white on both vanes, greater coverts chiefly on outer vane forming two white wing-bars, below uniform yellow, the crissum whitish.

Adult d, Fall.-Similar to last but crown more or less tipped with greenish. Young $\delta^{*}$, Fall.-Similar to adult $\delta$ in Fall, but crown somewhat greener. 
Adult $q$, Spring.-Resembles adult $\delta$ in Spring, but crown more like back, eye-stripe duskier, generally less white in tail and on wing-coverts. Much like young Fall $\delta^{\prime \prime}$, but eye-stripe duskier.

Adult $\&$, Fall.-Similar to last.

Young + , Fall.-Similar to preceding, but crown still greener.

Nestling.-Dusky olive-yellow above, paler and more yellow below.

General Distribution.-Eastern United States; north to Connecticut and Iowa; west nearly to the Plains.

Summer Range.-Southern Ohio, Indiana, Illinois, northern Kentucky, northern Missouri and southern Iowa. Eastward the bird breeds more rarely and locally in some of the lower portions of southern Pennsylvania (West Chester, Carlisle, East Penn, Kirkland, Laughlintown); Maryland (Laurel, Gwynn's Falls); Washington, D. C., more commonly northward to southeastern New York (Riverdale, Ossining, Oyster Bay); New Jersey (Englewood; Morris County); Connecticut (New Haven, Stratford, Stamford, Brantford, Portland, Bridgeport, Saybrook) ; rarely in Rhode Island (Gloucester).

The species occurs rarely or casually in Massachusetts (West Roxbury, May I7, I878, Boston, May 29, I902, Dedham, May, 1857, Dorchester, May 15, 1897); western New York (Penn Yan); southern Michigan (Petersburg, May I0, I894, Battle Creek, May I3, I902, Detroit, May 29, I902); southern Wisconsin (LaCrosse, May 7, I885), and southern Minnesota (Minneapolis, May I7, I880), west to Nebraska (Omaha, Peru); Kansas (Emporia and Onaga).

The most southern breeding records are in the Creek Nation, Oklahoma; on the St. Francis River in extreme southeastern Missouri; Tishomingo County, Mississippi; and on the coast of Georgia near the mouth of the Altamaha River. Throughout most portions of the southeastern States from South Carolina to eastern Texas, the species is a rare migrant; accidental once in the West Indies.

Winter Range.-Northern Mexico to Colombia. There is but one record for the West Indies, that of a specimen taken on Abaco Island, Bahamas, April 7.

Spring Migration.-South of the United States the Blue-winged Warbler has been recorded on only one occasion during the spring migration, when Chapman noted a single bird at Jalapa, Vera Cruz, April 7, 1897. The migration, however, was evidently well under way at that date for the earliest arrivals of this species noted in the United States are at New Orleans, La., March 22, 1898, and on the Tortugas, Fla., March 23, I89o. 


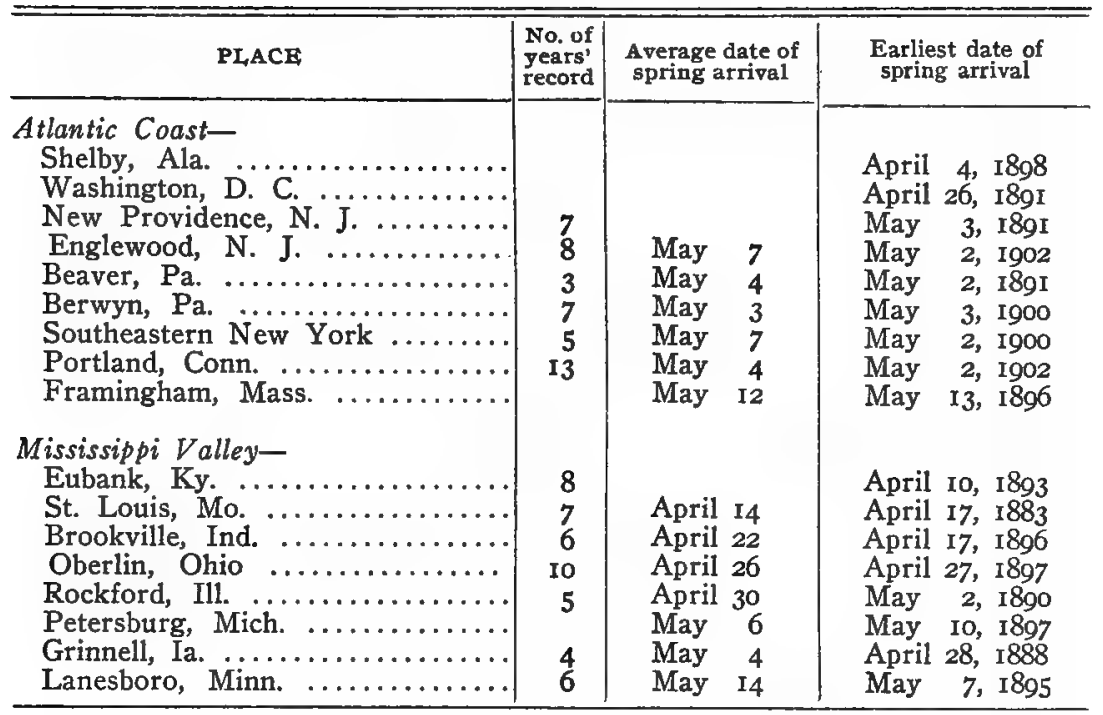

Fall Migration.-The last one noted at Lanesboro, Minn., was on September I, I889, but the southern part of the breeding-ground is not deserted until early in October.

The Bird and its Haunts.-Although the Blue-wing is locally common, its insignificant song and generally quiet ways make it a comparatively inconspicuous bird, likely to be noticed only by those who look for it. It is not, as a rule, a deep woods Warbler, though I have found it nesting in heavy forest, but prefers rather, bordering second growths, with weedy openings, from which it may follow lines or patches of trees to haunts some distance from the woods.

It is rather deliberate in movements for a Warbler, and is less of a flutterer than the average member of the genus Dendroica. Some of its motions suggest those of the tree-inhabiting Vireos, while at times, as the bird hangs downward from some cocoon it is investigating, one is reminded of a Chickadee.

The Blue wing's unsettled relations with the Golden-wing and with Brewster's and Lawrence's Warblers, create a special interest in its life history, and the fact, that among this group of birds song is not always diagnostic, makes it well worth while to attempt to see the singer of every supposed Blue-wing song.

The following study of the Blue-wing is contributed by F. L. Burns, of Berwyn, Pennsylvania:

"This species is here an inhabitant of the rather open swampy thickets, upland clearings, neglected pastures and fence rows, where 
the grass and weeds have not been choked out by a too thick growth of briers, bushes, saplings and vines. While not precisely a bird of the semi-cultivated fields, it has a wider local range than any of our home Warblers with the possible exception of the Chat.

"Perched inconspicuously near the top and well out in the branchlets of a tree or sapling, preferably facing an opening, if in a thicket; it is in itself so minute an object as to be passed unseen by many, more especially as it is much less active than most of our Warblers. With body feathers puffed out to a delightful plumpness, except for the backward sweep of the head while in the act of singing, it remains motionless for quite a while. When it moves it is with a combination of nervous haste and deliberation, and its song may be heard from quite another part of the landscape with no apparent reason for the change. While it has its favorite song perches, it is quite a wanderer and not infrequently sings beyond possible hearing of its brooding mate, but oftener within fifty to two hundred feet of the nest.

"Deposition of eggs occurred daily, in one instance, when five eggs were laid, and before nine a. $\mathrm{m}$. Incubation commences soon after the completion of set, the female sitting on eggs on the afternoon of the day in which she completes the set. In an exceptional case in which three eggs formed the clutch, the embryo was large in one, commenced to form in the second, and the third egg was fresh, showing that several days elapsed between deposition, and the commencement of incubation before the set was complete.

"The task of incubation falls on the female alone. It appears that an airing is taken in the early morning or a little before midday, and again in the early evening, though perhaps not regularly every day. I have not seen the male about the nest with food at this period. The female will allow a close approach, looking into one's eyes with that hunted look so common in wild animals, and often flushing without a protesting note. The period of incubation in the one instance was exactly ten days.

"On June 13 , at 6.30 p. m., five young just hatched were blind, naked and prostrate from chin to sternum. The shells were disposed of immediately, in what manner I am unable to state; the female was reluctant to vacate.

"On June 15, at 2.45 p. m., the young were able to raise their heads slightly and a fluffy bit of down had appeared about the head, also a dark stripe along the back bone. The female appeared, accompanied by the male, and fed the young with small green larvæ-such 
as may be found on the underside of oak and chestnut leaves-and then shielded the callow young from the hot rays of the sun.

"On June I6, at 6.30 p. m., when the young were three days old, a downy puff appeared between the shoulders, wing quills being dark. The strongest bird had the eyes partly open and the mouth wide open for food.

"On June 18, at 7 p. m., the heads and bodies were no longer flesh-colored but were well enough covered to appear dark. The eyes were open. At a cluck from me their mouths flew open. Both parents fed them with green-colored larvæ. When the male rested a moment on a brier above the nest, the female flew down and drove him away, fed the young, re-appearing with excrement in her beak, which was carried in an opposite direction from the regular approach via maple bough and poplar sapling. The male fed young from a mouthful of very minute larvæ or eggs, which were gathered from the silken nests in the unfolding leaves of a nearby poplar; after this $(7.30 \mathrm{p} . \mathrm{m}$.) the female covered the young for the night.

"On June 20, at from 6.50 to 7.35 p. m., the young had been seven days in the nest. They were well feathered and of a yellowishgreen cast, the short tails being tipped with yellow. The parents were more suspicious. The female came to the maple bough with something in her beak and flew down to the briers and back again several times before she dropped to the edge of the nest and fed her young. The male appeared immediately but swallowed a green grub himself upon discovery of me twenty-five feet away. The female came again in five minutes with a brownish object in her bill, but appeared more timid and refused to drop to the nest until the male set her an example of courage.

"On June 21, at 6.12 p. m., the young were fully fledged in green plumage above and dirty yellow beneath. They showed fear of me for the first time, eyeing me in the same manner as the parent bird when on the nest. They were evidently ready to vacate at a moment's notice or hasty movement on my part. The parents appeared, scolding rapidly. The female fed the young as soon as I retired to my old stand under a bush, with a rather large green grub (6.20 p.m.) and flew out to the top of a blackberry bush, followed immediately by the topmost fledgeling. It could do little more than run. The adults flew to within a yard of my head, making a great outcry, and in the midst of the excitement the remainder of the young vacated the nest with feeble chips. The male gave his attention to them, while the female followed me as I beat a hasty retreat to 
enable them to collect their little family before dark. Eight days had elapsed since incubation was completed, and it is not at all unusual for the young of this species to leave the nest while so tiny and ragged."

Song.-The strong suggestion of inhaling and exhaling which characterizes the simple and most common song of this species, has been noted by many observers.

"The ordinary call song of this species has a decided insect

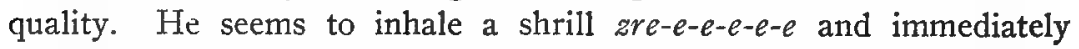

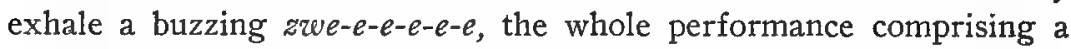
perfect double run through about half an octave of the scale. Often

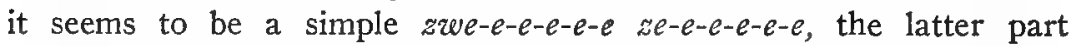
merely a sputter. At its best the song is a drowsy locust-like shrill, belonging rather to mid-summer than to spring.

"There is another song which is usually given during the early summer months, but which I have heard shortly after the arrival of the bird in the last days of April or the first days of May. This song is far more varied and has a far better claim to be called a song. Mr. Chapman renders it wee, chi-chi-chi-chi, chir, chee-chur.

"There are two definite song periods, the first beginning with the bird's arrival and ending about the middle of June, during which time the insect song is given almost entirely; the second one beginning late in July or early in August and continuing to the third week in August, this period being characterized by the more varied song, but not to the entire exclusion of the other." (Jones.)

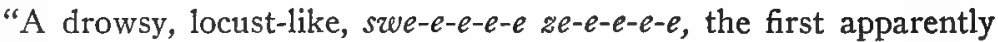
inhaled and the last exhaled. *** Another song heard on the first day of arrival, on one occasion, uttered by several males in company, possibly transients here, and maybe the mating song, suggests the Chickadee's che-de-de-e, che-dee-e, and che-de-de-dee, uttered repeatedly in one form or other in some excitement, and while running out on the branchlets. The call and alarm note is a rather weak chip, uttered more or less rapidly and not distinguishable from that of several other of our local Warblers. The male sings upon arrival up to about the I6th of June (June II-24 in a series of years) marking the end of the breeding season. A second period of song in 1902 occurred July 2-7, perhaps a belated breeder. I have not recognized the female as a singer." (Burns, $M S$.)

Nesting Site.-On the ground sometimes in a bunch of weeds, goldenrod being frequently chosen, but often placed independently of its immediate surroundings. A favorite locality is the bushy border 
of woods or second growths or partly grown clearings, but I have found nests in the heart of heavy forests and also well out in the fields near hedge-rows.

"Never far from a grove, thicket or woods; sometimes nesting on, but usually just above, the ground in a clump of grass, goldenrod, or wild aster, raspberry or blackberry sprouts, or at the foot of a small sapling or wild rose-bush. The nest is always surrounded by grass, weeds, briars, wild grapevine, etc. One nest was placed within a foot of the wheel track of a much frequented public road. The bird to the best of my knowledge, does not use the same site or even within a few feet of it the second time; but apparently the same individuals return to the same tract regularly and nest in some part of it." (Burns, MS.)

Nest.- "Outwardly composed of the broad blades of a coarse grass, the dead leaves of the maple, beech, chestnut, cherry and oak trees; the leaf points curving upward and inward forming a deep cup-like nest in which the bird's head and tail seem almost to meet over her back. Occasionally grass stems coarse strips of wild grapevine bark, shreds of corn fodder, and fragments of beech and wild cherry bark appear in the make-up. Lined most frequently with wild grapevine bark laid across, instead of bent around in a circle, shredded finest on top, to which is added an occasional long black horse-hair or split grass stem, with now and then a final lining of split grass stems in place of fine bark. The shape varies in accordance to situation, outwardly a short cornucopia, a round basket, and once a wall-pocket affair, would best describe the shapes I have noticed." (Burns, MS.)

Eggs.-4 or 5, nearly always 5. Ground color white to slightly creamy; the variations in markings range from entirely unmarked to as heavily marked as some eggs of the Northern Yellow-throat, but in all cases the markings are most delicate specks and spots of burnt umber, seal brown, chestnut, lavender, and rich purplish shades, mostly at the larger end, but in some examples, sparingly distributed over the entire egg. Shape, rounded oval; one of the daintiest eggs of all our Warblers. Size; average, .64x.5I; extremes, .68x.53, $.59 \times .46$. (Figs. 12-14.)

Nesting Dates.-West Chester, Pa., May 27-June Io (Jackson); New York City, May 23-June 19 (F. M. C.) ; New Haven, Conn., May 20-June I6 (Bishop); Oberlin, O., May Io-June Io (Jones); De Kalb County, Ind., May 26 (Gault). 


\section{BIOGRAPHICAL REFERENCES}

(I) F. T. Jenks, The Blue-winged Warbler; Its Nesting Habits, Orn. and Oöl., VI, I881, 57. (2) J. N. Clark, The Blue-winged Warbler, Orn. and Oöl., VIII, I883, 37. (3) I. S. REIFF, A Few Days among the Blue-winged Warblers [near Philadelphia?], Orn. and Oöl., XVIII, I893, 6. (4) E. H. EAMES, Notes on the Blue-winged Warbler and Its Allies, Auk, VI, I889, 305. (5) B. S. Bowdise, Some Breeding Warblers of Demarest, N. J., Auk, XXIII, I906, I6.

\section{INTERMEDIATES BETWEEN}

\section{VERMIVORA CHRYSOTERA and V. PINUS}

Distinguishing Characters.-Between the Golden-winged and Blue-winged Warblers there exists a series of intergrades known variously as Lawrence's Warbler (Vermivora lazurencei) and Brewster's Warbler (Vermivora leucobronchialis). Typical lawrencei is a yellow bird with a black throat and auriculars, in short, pinus with the black markings of chrysoptera. Typical leucobronchialis, meaning the extreme development of the leucobronchialis type, is white below, gray above with the forehead and wing-bars yellow. A discussion of the status of these interesting birds follows a description of their plumages.

\section{LAWRENCE'S WARBLER}

\section{VERMIVORA LAWRENCEI (Herrick) Plate V}

Adult 80, Spring.-Crown yellow; lores and upper part of auriculars black; back bright olive-green; tail grayish, inner vanes of the three outer feathers largely white, fourth with much less white; wings grayish, inner feathers edged with olive-green; wing-bars as in $H$. pinus or chrysoptera or white but as broad as in chrysoptera; chin and sides of the throat yellow, throat and upper breast black, rest of underparts yellow, the sides greener. A specimen in the Bishop collection has the chin yellow, the sides of the throat white.

Adult , Spring.-Cheek stripe and throat dusky olive, rest of plumage as in $q$ pinus but wing-bars sometimes as in chrysoptera; another specimen resembles $q$ chrysoptera but is greener above and more yellow below.

Nestling.-Like similar plumage of pinus but cheek-stripe and throat-patch dusky.

General Distribution.-Northern New Jersey, lower Hudson valley, eastward to the Connecticut valley in Connecticut.

Summer Range.-Specimens have been taken or observed near Chatham, N. J. (Herrick), Hoboken, N. J. (Lazerence), Morristown, N. J. (Brewster), Englewood, N. J. (Dwight), Bronx Park, New York City (Bildersee, Beebe), Rye, N. Y. (Voorhees), Stamford 


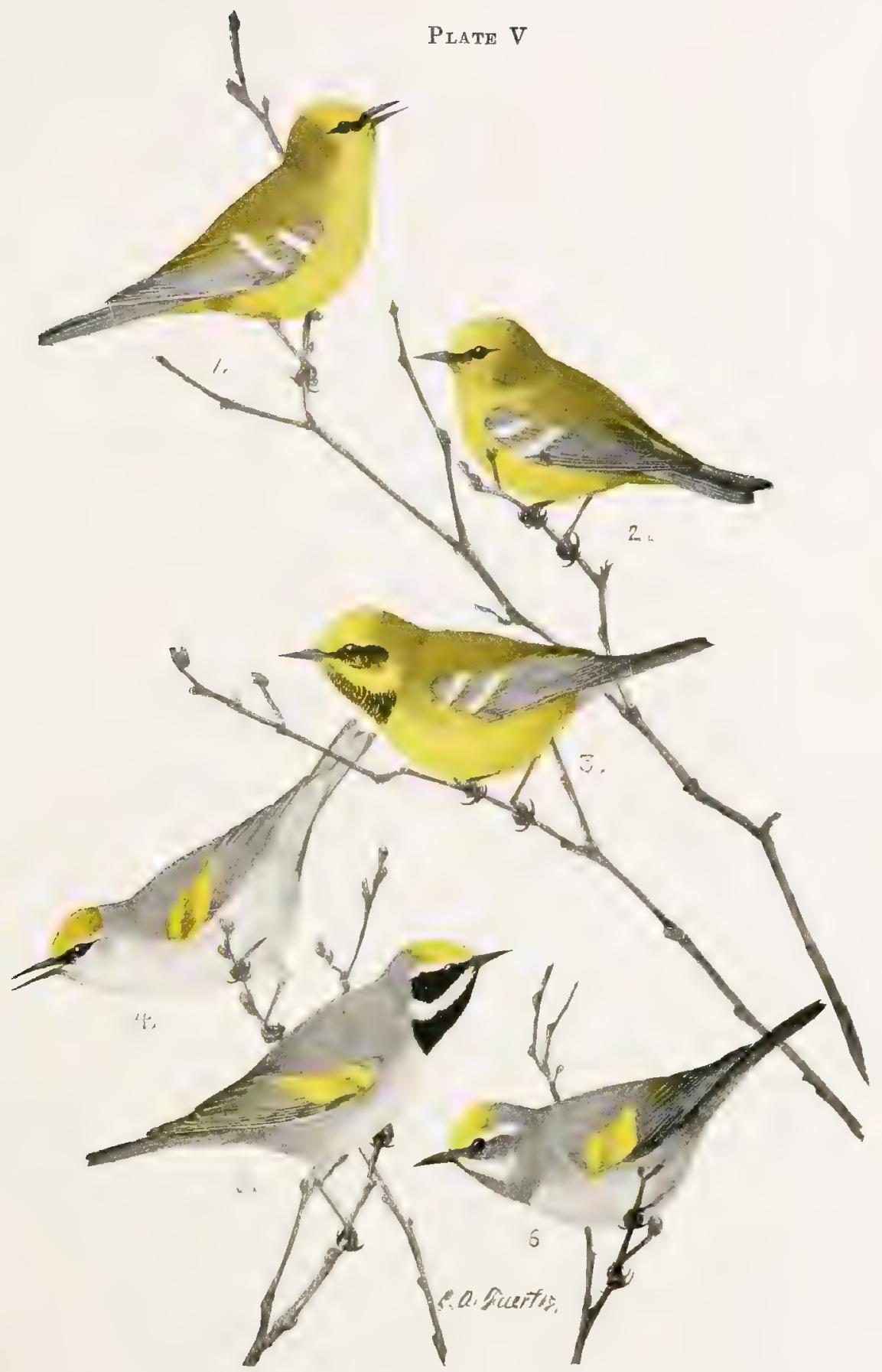

1. Blue-winged Wakbler, Male.

4. Brewster's Warbler, Male.

2. Blue-winged Warblek, Female.

5. Golden-iWinged Warblek, MaLe.

3. Lawrence's Warbler, Male.

6. Golden-winged Warbler, Female 
Conn. (Bishop), Bridgeport, Conn. (Eames), New Haven, Conn. (Bishop), Portland, Conn. (Sage).

Winter Range.-Unknown.

Spring Migration.-Bridgeport, Conn., May 16; Portland, Conn., May 14.

The Bird in its Haunts.-Observations on the song, etc., of this species are given under Brewster's Warbler.

\section{BREWSTER'S WARBLER \\ VERMIVORA LEUCOBRONCHIALIS (Brewst.) Plate V}

Adult d', Spring.-Crown yellow, a black or blackish line from bill to or through the eye, back gray with, as the bird tends towards pinus, more or less greenish; tail as in pinus, wings externally grayish, the inner feathers edged with greenish, wing-bars generally broadly yellow as in chrysoptera, but not infrequently white as in pinus and often variously intermediate between the two; underparts white rarely without more or less yellow tinge on the breast increasing in intensity and extent as the bird approaches pinus.

Adult + , Spring.-Similar to adult $\sigma^{*}$ in Spring but crown duller, eye-stripe duskier, back with more green, breast with more yellow.

Nestling.-Unknown; all the nestlings taken or described having leucobronchialis for $\delta^{\prime \prime}$ or 9 parent, being, singularly enough, like the nestling of pinus.

General Distribution.-Eastern United States, north to Connecticut and, rarely Massachusetts, west to Michigan.

Summer Range.-The bird has been found breeding at Englewood, N. J., (Chapman), Bridgeport, Conn. (Eames), North Haven, Conn. (Bishop), Bethel, Conn. (Meeker), Portland, Conn. (Sage); there are also records in the breeding season for Ossining, N. Y. (Fisher), various places in Connecticut (Bishop et al), Newtonville, Mass. (Brewster), Hudson, Mass. (Purdie), Lexington, Mass. (Faxon), Oberlin, O. (Jones), Ottawa Co., Mich. (Gibbs.)

Winter Range.-During its migrations this species has been taken near Philadelphia and Washington, and New Orleans. There are no winter records.

Spring Migration.-Washington, D. C., May I, and 8; Clifton, Pa., May I2; Maplewood, N. J., May II ; Englewood, N. J. May I5; Parkville, L. I., May I6; Bridgeport, Conn., May 6; Portland, Conn., May Io; Oberlin, O., May 23.

Fall Migration.-Ossining, N. Y., Aug. 24; Chester Co., Pa., Aug 31 .

The Bird and its Haunts.-The haunts and general habits of Lawrence's and Brewster's Warblers do not appear to differ from those of the Golden-winged and Blue-winged Warblers. 
Song.-As the following records show some individuals of these birds sing like $V$. pinus, some like $V$. chrysoptera while the song of others is intermediate in character.

From Bridgeport, Conn., Eames ${ }^{8}$ writes: "Seven birds, typical of $V$. leucobronchialis, expressed their good spirits by precisely the song of the preceding ( $V$. chrysoptera) except in one trifling point. Another, with a bright yellow breast-patch, had, in addition, a few original variations of its own. Still another, with a close resemblance to $V$. pinus, repeated songs of $V$. chrysoptera only, but they were all harsh and disagreeable in comparison. *** A perfectly typical bird repeated but one style of song. This surprised me greatly, it being precisely the same as the commoner song of $V$. pinus. I heard this many times on two different occasions before shooting the bird, and it was always the same. But one more bird, with a faint greenish color on the back, a strong patch of yellow on the breast, and a wash elsewhere on the under parts, used the latter song exclusively.

"The only $V$. lawrencei I ever knowingly listened to, as before mentioned, favored me with its song for nearly two hours, and during the several hundred repetitions, it never varied in the least particular from the characteristic song of $V$. pinus, its song consist-

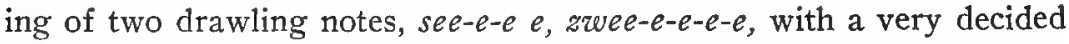
$z$ sound. The first series is somewhat higher pitched than the last and hardly as long continued."

"Continued experience leads me to think that the song of this puzzling bird ( $V$. leucobronchialis) is not, as has been stated, any criterion by which to distinguish it. Sometimes they sing exactly like chrysoptera, again like pinus, and often have notes peculiar to themselves." ( Sage $^{18}$.)

"During the ten or fifteen minutes which the bird ( $V$. leucobronchialis) was under observation I had the pleasure of hearing it sing many times, even seeing it open its bill in the act of song. This song exactly resembled the rising and falling tse notes of $V$. pinus but was slightly weaker than the average song of that species." (Chapman ${ }^{5}$.)

From a male Lawrence's Warbler which was nesting with a Blue-winged Warbler, Bildersee ${ }^{18}$ records the following three songs and the observation is independently confirmed by Beebe ${ }^{17}$ :

"(a) Shree-e-e, zwe-e-e-e, the first syllable like that of the song of the Golden-winged Warbler, the second like that of the song of the Blue-wing. This was the song most frequently heard.

(b) Shree-e, shree, shree, shree, the typical song of the Goldenwinged Warbler. 
(c) Chip-a-chip-a-chip-a-shree, the first phrase of this song is exactly like the song heard during the second song period of the Blue-winged Warbler, the second being a typical Golden-wing syllable.

Besides these three songs we heard a sharp call-note-tzip-and a thin scolding note when we came too near the nest."

Nesting Habits. - The more significant discoveries in regard to the breeding of Brewster's and Lawrence's Warblers are scheduled below :

Englewood, N. J. V. pinus \&, feeds two young, both were taken, one proving to be pinus the other lawrencei (Dwight ${ }^{20}$ ).

Englewood, N. J. $V$. leucobronchialis of evidently mated with $V$. pinus of the three of their offspring taken were typical of pinus. (Chapman ${ }^{4}$.

Englewood, N. J. $V$. leucobronchialis $\&$, with strong yellow wash on breast, mated with typical pinus $\delta$; eggs destroyed. (Chap$\left.\operatorname{man}^{8}\right)$.

New York City. V. lawrencei is, mated with pinus $q$. The six young were apparently typical of pinus. (Bildersee ${ }^{10} ;$ Beebe ${ }^{17}$ ).

Ossining, N. Y. $V$. chrysoptera of feeds two young, one of which collected, is typical of pinus; the other, which escaped, was seen to resemble the mother and had no yellow on the breast. (Fisher ${ }^{3}$ ).

Bethel, Conn. $V$. chrysoptera of, breeds with $V$. pinus o, the only one of the five young secured was typical of $V$. pinus. (Meeker ${ }^{21}$ ).

Bridgeport, Conn. $V$. leucobronchialis $\hat{\delta}$, and $V$. pinus $\circ$, feed young showing "a marked general similarity to the young of pinus." $\left(\right.$ Eames $\left.^{8}\right)$.

North Haven, Conn. V. leucobronchialis feeds two young, one typical of pinus, the other like pinus but with yellow wing-bars. $\left(\right.$ Bishop $\left.{ }^{10}\right)$.

Portland, Conn. $V$. pinus, of breeds with $V$. chrysoptera $\%$, the five young resemble those of pinus. $\left(\right.$ Sage $\left.^{12}\right)$.

Portland, Conn. $V$. leucobronchialis $q$ breeds with $V$. chrysoptera $\delta$; nest and eggs taken. (Sage $\left.{ }^{18}\right)$.

Discussion of Status.-The relationships of these Warblers have been the subject of much discussion. It has been stated of one or the other or both, that they were distinct species, hybrids, color phases, and mutants, but, we may now be said to have passed the purely theoretical stage in our study of these birds, incontrovertible observations and large series of specimens furnishing us with defin- 
itely ascertained facts. The interbreeding of leucobronchialis with pinus, and with chrysoptera, of pinus with chrysoptera, and of lawrencei with pinus is recorded on unquestionable evidence. Here alone, therefore, we have indisputable knowledge of sets of relations which in their subsequent stages are bound to produce the most varied results, accounting for every phase of plumage of the lawrencei type of which we have any knowledge.

Doubtless our most satisfactory observations in this connection have been supplied by Dr. Walter Faxon who writes: "In the summer of 1910, there bred within the confines of a camp of about fifteen acres in Lexington, Mass., a pair of Golden-winged Warblers and two male Golden-winged Warblers mated with two female Brewster's Warblers. . . The progeny of the three pairs were closely observed from the juvenile (in one case, from the natal) plumage up to the first winter plumage, when the adult characters were acquired; the young of the pair of Golden-wings were all Golden-wings; one of the Brewster's Warblers that was mated with a Golden-wing brought forth a homogeneous brood of Brewster's Warblers, while the other produced a mixed brood of Brewster's Warblers and at least one Goldenwinged Warbler. A striking thing about it was this: the young birds of mixed parentage were absolutely pure in plumage,--either Brewster's Warblers or Golden-wings, without any tendency to combine as 'intermediates' the characters of the two parents." (Mem. Mus. Comp. Zool., XL, No. 6, Aug. 1913, 311.)

Two years later, in the same locality, Dr. Faxon (1. c.) made even more definite and conclusive observations in regard to the breeding of these birds which apparently fully justify his "satisfaction of demonstrating the true nature of Brewster's Warbler, removing the question forever from the realm of conjecture."

In a word, he found a typical male Golden-winged Warbler mated with a typical Blue-winged Warbler, and kept their young (number not stated) under observation from June 15, about two days after they had left the nest, until they "all grew up to be Brewster's Warblers."

The same season a male Brewster's Warbler was found mated to a female Golden-wing and of their young one "grew up to be a typical Brewster's Warbler, while the other, its own brother, became a typical Golden-wing." These two birds and one from the brood first mentioned were banded, and a beginning was thus made for the study of succeeding generations. 


\section{BIOGRapHICAL REFERENCES}

(1) WM. Brewster, On the Relationship of Helminthophaga leucobronchialis Brewster, and Helminthophaga lawrencei, Herrick, Bull. Nutt. Orn. Club, VI, I880, 218. (2) R. RIDGWAy, Helminthophila leucobronchialis, (and $H$. lawrencei; a discussion of their relationships), Auk, II, I885, 359. (3) A. K. FISHER, Evidence Concerning the Interbreeding of Helminthophila chrysoptera and $H$. pinus (at Sing Sing, N. Y.), Auk, II, 1885, 378. (4) F. M. Chapman, Additional Captures of Helminthophila leucobronchialis (at Englewood, N. J.), Auk, IV, 1887. 348. (5) The Song of Helminthophila leucobronchialis, Auk, VII, I890, 291. (6) On the Breeding of Helminthophila pinus with $H$. leucobronchialis at Englewood, N. J., Auk, IX, 1892, 302. (7) E. H. EAmes, Notes on Helminthophila leucobronchialis (in Conn.), Auk, V, 1888, 427. (8) Notes on the Blue-winged Warbler and its Allies, (Helminthophila pinus, $H$. leucobronchialis, $H$. lawrencei, and $H$. chrysoptera) in Connecticut, Auk, VI, 1889, 305. (9) L. B. BISHOP, Helminthophila pinus, H. chrysoptera, H. leucobronchialis, $H$. lawencei, in Connecticut in the Spring of 1888, Auk, VI, 1889, 192. (I0) Helminthophila leucobronchialis (breeding in Conn.), Auk, XI, 1894, 79. (II) The Status of Helminthophila leucobronchialis and Helminthophila lawrencei, Atk, XXII, I905, 2I. (I2) J. H. SAGE, The Interbreeding of Helminthophila pinus and $H$. chrysoptera, (at Portland, Conn.), Auk VI, I899, 299. (13) Notes on Helminthophila chrysoptera, pinus, leucobronchialis and lawrencei in Connecticut, Auk, X, 1893, 208. (14) Nesting of Helminthophila leucobronchialis in Connecticut, Auk, XII, I895, 307. (I5) G. H. ThAYER, The Coloration and Relationships of Brewster's Warbler, Auk, XIX, 1902, 401. (16) I. Bildersee, Notes on the Nesting of Lawrence's Warbler, Bird-Lore, VI, 1904, I31. (I7) C. WM. BeEBE, Breeding of Lawrence's Warbler in New York City, Auk, XXI, 1904, 387. Relates to the same bird as No. 16. (18) W. E. D. Scort, Of the Probable Origin of Certain Birds, Science, XXII, I905, 27I. (I9) J. A. Allen, The Probable Origin of Certain Birds, Science, XXII, 1905, 431. (A reply to Scott.) (20) J. Dwight, JR., Plumages and Molts of the Passerine Birds of New York, Ig00, 246. (2I) J. C. A. MEekER, A Male Golden-winged Warbler mated with a female Blue-winged Warbler, Auk, XXIII, I906, I04. (22) C. J. Maynard, (Discussion of status of Brewster's and Lawrence's Warblers) Warblers of New England, I905, 83.

\section{BACHMAN'S WARBLER}

\section{VERMIVORA BACHMANI (Aud.) Plate IV}

Distinguishing Characters.-Bill slightly decurved; $\delta$ with the forehead, throat, or, at least, chin yellow, the breast black; $q$ with forehead more or less tinged with yellow, the feathers of the crown wholly gray. The young $q$, with but little yellow below, resembles the young of the Orange-crowned and Tennessee Warblers. It differs from the former chiefly in the yellowish frontlet, entirely gray crown-feathers, and white crissum; while the Tennessee Warbler is greener above with the head the same color as the back. The $\delta$ apparently does not acquire mature plumage until the second year. Length (skin), 4.40; wing, 2.40 ; tail, 1.80 ; bill, .48. 
Adult d", Spring.-Forehead broadly yellow, bordered by a black band across the crown; eye-ring yellow; hindhead and nape gray; back olive-green; tail fuscous, the outer three, and sometimes all but the middle pair of feathers, with white patches on the inner web near the tip; wings margined with gray on primaries, olive-green on other feathers; lesser coverts and bend of wing bright yellow, no white bars; chin, sides and, sometimes, upper part of throat yellow; lower throat and breast black, belly yellow usually becoming brownish white on the lower belly and crissum.

Adult $\sigma^{\prime}$, Fall.-Similar to adult $\sigma^{\prime}$ in Spring, but black of crown widely tipped with gray, black breast narrowly tipped with yellow and grayish.

Young $\delta^{*}$, Fall.-Throat-patch smaller than in adult $\delta$, less black or none on the head; throat-patch tipped with yellowish or grayish; less white, or none, in the tail.

Young od, Spring.-Not appreciably different from young of in Fall, the full black breast-patch and frontlet evidently not being acquired the first year.

Adult \&, Spring.-Forehead and eye-ring yellowish; crown and nape gray; back olive-green; tail fuscous with little or no white on inner vanes of outer feathers; wings as in $\sigma^{\prime}$, but lesser coverts olive-green; underparts yellow, fading to brownish white on the lower belly and crissum; a dusky wash on the breast, where, in some specimens, there is a more or less well-developed black patch.

Adult + , Fall.-Resembles adult $q$ in Spring.

Young + , Fall.-Similar to adult $q$ in Spring, but with less yellow on forehead and underparts; back grayer; below dusky yellowish.

Young $q$, Spring.-Similar to young $q$ in Fall.

Nestling.-A $\delta$, passing from nestling to first Fall plumage, taken by A. T. Wayne near Charleston, S. C., is described by William Brewster as follows:

"Top and sides of head and forepart of back faded hair brown with a trace of ashy on the middle of crown; remainder of upper parts dull olive-green; wings and tail (which are fully grown) as in the first winter plumage excepting that the greater and middle wing-coverts are rather more broadly tipped with light brown, forming two well-marked wing-bars; chin and throat brownish white tinged with yellow; sides of jugulum smoke gray, its center yellowish; sides of breast gamboge yellow shading into olive on the flanks; middle of breast, with most of abdomen, yellowish white; under tail-coverts ashy white. All the feathers on the under parts which are strongly yellow or olive, and those on the upper parts, which are decidedly ashy, or greenish, appear to belong to the autumnal plumage or, as it is now called, the first winter plumage, but all the other feathers on the head and body are evidently those of the first plumage." (The Auk, 1905, p. 393.)

General Distribution.-Southeastern United States, north to Missouri and North Carolina; south in winter to West Indies.

Summer Range.-This Warbler has been secured in the breeding season in North Carolina, South Carolina, Kentucky, Arkansas and Missouri; as a young of the year in Virginia; during migration in Florida and Louisiana. Accidental in Indiana.

Winter Range.-So far as known, Cuba. 
Spring Migration.-One of the earliest migrants; it crosses to the United States in March; Sombrero Key, Fla., March 3, I899, Suwanee River, Fla., March 12, I89o, Branford, Fla., March I4, 1892, Old Town, Fla., March Io, I893, Wacissa River, Fla., March I3, I894, Leon County, Fla., March 22, I904; Bay St. Louis, Miss., March 26, I902; Lake Pontchartrain, La., February 27 to March I4, I89I.

Fall Migration.-The southward migration begins so early that in July many individuals reach their winter quarters. Earliest record at Key West, Fla., July I7, I889; latest September 5, I888.

The Bird and its Haunts.-In many respects the history of Bachman's Warbler is not unlike that of Swainson's. Both were discovered near Charleston, S. C., by that keen naturalist, Dr. Bachman, and both remained virtually unknown for the succeeding half century. Bachman procured "a few specimens" of this bird in the summer of 1833 and sent them to Audubon, who described the species the following year in the second volume of his Ornithological Biographies.

With the exception of its occurrence in Cuba, the Warbler remained unknown to naturalists until October, I886, when Charles S. Galbraith, a millinery collector, brought to George N. Lawrence a specimen which he had secured the preceding spring near Lake Pontchartrain, La. This specimen, now in the American Museum of Natural History, is prepared for a hat-piece. The feet are missing, the wings are stiffly distended, the head bent backward in typical bonnet pose, and, had it not been for an interest in ornithology which led Galbraith to take his unknown birds to Mr. Lawrence for identification, this rara avis might have become an unappreciated victim on Fashion's altar.

In any event, it was decreed that Bachman's Warbler should no longer remain among the 'lost species' and the following spring it was brought to the attention of ornithologists, again in an unconventional manner, through an individual which struck the Sombrero Key lighthouse, off southern Florida, March 2I (Merriam ${ }^{3}$ ).

Galbraith$^{2}$, also, procured six additional specimens in Louisiana, and the efforts of collectors being now especially directed toward this species, it proved to be an abundant migrant in Florida and southern Louisiana. Atkins ${ }^{4}$ reported it from Key West in late July and early August, Chapman ${ }^{8}$ from Brevard County, Florida, in March, and Brewster $^{7}$ and Chapman from the lower Suwanee River in the same month. 
Eleven years passed after the re-discovery of this Warbler before its nest was found when, as related beyond, the well-directed researches of Otto Widmann ${ }^{8}$ established the species as breeding commonly in the St. Francis River region of Missouri and Arkansas.

As with most Warblers the character of the haunts of Bachman's Warbler during migration depends upon the nature of the country through which it is passing. At Key West, where the forest is low and with undergrowth, Atkins f $^{5}$ found it "alike in trees, low bushes, and shrubbery, sometimes on, or quite near the ground," but it seemed "to prefer the heavy and more thickly grown woods to trees or bushes more in the open." But on the banks of the Suwanee, where the trees were exceptionally high and with little or no undergrowth, the bird was rarely found below the upper branches, usually of cypress trees, where it was associated with other migrating Warblers.

Very different are the bird's breeding haunts in the wet, forested bottom-lands of the St. Francis River region, as described by Widmann ${ }^{8}$, with their "blackberry brambles among a medley of halfdecayed and lately felled tree-tops, lying in pools of water."

Atkins ${ }^{5}$, writing of southbound migrants at Key West, speaks of them as "active and constantly in motion," but Mr. Brewster" and I found the many individuals which we saw in March, on the Suwanee, to be rather deliberate in their movements, resembling, in this respect, the Blue-winged Warbler. At times they hung back downward, titmouse-like, as they explored the under surface of a leaf, or, again, they penetrated a bunch of hanging leaves.

Widmann ${ }^{8}$, writing of the species on its breeding ground, says it may be "easily overlooked, even in a region where it is common. Its small size, its protective coloration, and its quiet ways, combine to make it next to invisible among the heavy foliage of its habitat. * * * Even if in song it takes minutes to find the bird, though he is generally seated on a dry, or thinly-leafed branch at a height of twenty to forty feet from the ground. The reason why it is so difficult to locate him is his habit of pouring out his song into different directions, now to the right, then to the left, even turning entirely around on his perch. When he leaves he is liable to fly quite a distance, far enough to get lost out of sight for the moment, and in the wildness of his home, it takes several minutes to follow him over fallen trees, and around impenetrable thickets or pools of water."

Wayne ${ }^{12}$ writes: "Bachman's Warbler is a high-ranging bird, like the Yellow-throated Warbler, and generally sings from the top of a sweet gum or cypress. It alpears to have regular singing stations 
during the breeding season, and upon leaving a tree, it flies a long distance before alighting. *** I have occasionally seen the males in low gall-berry bushes within six or eight inches of the ground, but their usual resorts are among the topmost branches of the tallest trees."

Song.- "The song is unlike that of any other species of Helminthophila with which I am acquainted, and most resembles the song of the Parula Warbler. It is of the same length and of nearly the same quality or tone, but eight notes being given in the same key and with equal emphasis. Despite these differences it would be possible to mistake the performance, especially at a distance, for that of a Parula singing listlessly. The voice, though neither loud nor musical, is penetrating and seems to carry as far as most Warblers'. Besides the song the only note which we certainly identifier was a low, hissing zee-e-eep, very like that of the Black-and-White Warbler." (Brezuster. ${ }^{7}$ )

$\mathrm{Mr}$. Otto Widmann ${ }^{8}$ writes of a male under his observation for eight hours "the bird kept singing nearly all the time at the rate of ten times a minute with the regularity of clockwork, and the sharp rattling notes reminded me of an alarm clock. In this regard it recalls one of the performances of Parula, whose rattle is of the same length and quality, except that it has a certain rise at the end, by which it is easily distinguished. To my ear the Bachman's song comes nearest to that of the Worm-eating Warbler, which is fortunately not found in swampland, but the Chipping Sparrow is, and, if the presence of the Bachman's Warbler is not suspected, it is indeed possible to mistake its song for a shrill variety of the Chippy's well-known ditty."

"The song is wiry or insect-like, and resembles the song of the Worm-eating Warbler very closely, while it also bears a strong resemblance to the song of the Parula Warbler and Chipping Sparrow" (Wayne ${ }^{12}$ ). Embody, ${ }^{11}$ also, compares the song to that of a Chipping Sparrow.

Nesting Site-Bailey's description of the supposed nesting site and eggs of this species (Bull. Nutt. Orn. Club, VIII, $188_{3}, 3^{8}$ ) is evidently based on a collector's error and credit for the discovery of the nest and eggs of Bachman's Warbler belongs to Otto Widmann ${ }^{8}$ who found them on May 14, I897 in Dunklin County, Missouri. The nest was two feet from the ground and "was tied very slightly to a vertical blackberry vine of fresh growth and rested lightly on another which crossed the former at a nearly right angle. From 
above it was entirely hidden by branchlets of latest growth and the hand could not be inserted without first cutting several vines." A second nest, was taken by Mr. Widmann, in Dunklin County, May I3, I898 and is recorded by Short ${ }^{10}$ as similar in structure to the type nest and like it placed in a blackberry bush, where it was not "attached to the branches but simply supported between half a dozen of them."

Since the above was written Bachman's Warbler has been found breeding by Wayne on April I7, 1906 and later dates, near Charleston, S. C., and by Embody, on May I4, I906, in Logan County, Ky. In both instances the birds inhabited heavily timbered, swampy land with more or less stagnant water. The nests were in low bushes, briers, or canes and were one to three feet from the ground.

Nest.-The first nest found by Widmann is described by Ridgway" as a "somewhat compressed, compact mass composed externally of dried weed and grass-stalks and dead leaves, many of the latter partly skeletonized; internally composed of rather fine weed and grass-stalks, lined with black fibers, apparently dead threads of the black pendant lichens (Ramalina, species?) which hang in beard-like tufts from button-bushes (Cephalanthus), and other shrubs growing in wetter portions of the western bottom lands. The height of the nest is about three and one-half inches; the greatest breadth is about four inches, its width in the opposite direction being about three inches. The cavity is about one and one-half inches deep and one and onehalf by two inches wide." Six nests found by Wayne are described as being chiefly constructed of fine grass, cane leaves, and skeletonized leaves of other kinds, and some contained Spanish 'moss'.

Eggs.-Both the nests discovered by Widmann contained three eggs which, as they were left until the bird began to sit, evidently constituted a complete set. Wayne, however, found two nests each with four eggs. The eggs of Widmann's first set are described by Ridgway" as "of very regular ovate form and entirely pure white in color." They measured $.63 \times .48 ; .64 \times .49 ; .63 \times .49$. The eggs of the second set are described by Short" as "pure china white and glossy." In size they agreed with those of the first set.

Nesting Dates.-Dunklin County, Mo., May I3 and I7 (Widmann) ; Logan Co., Ky., May I4 (Embody); Charleston, S. C., April I7; May I3, two young, juvenal plumage (Wayne).

Biographical References

(I) Geo. N. Lawrence, The Rediscovery of Bachman's Warbler in the 
United States, Auk, IV, I887, 35. (2) Ibid., 262. (3) C. Hart Merriam, Another Specimen of Bachman's Warbler, Auk, IV, 1887,262 . (4) W. E. D. Scort, Bachman's Warbler at Key West, Florida, in July and August, Auk, V, 1888, 428; also (5) ibid., VII, 1890, 313. (6) FRANK M. ChapMan, Helminthophila bachmani on the East coast of Florida, Auk, VI, 1889, 278. (7) WM. Brewster, Notes on Bachman's Warbler [in Florida], Auk, VIII, I89I, 149. (8) O. WIDMANN, The Summer Home of Bachman's Warbler No Longer Unknown. A Common Breeder in the St. Francis River Region of Southeastern Missouri and Northeastern'Arkansas, Auk, XIV, 1897, 305. (9) R. Ringway, Description of the Nest and Eggs of Bachman's Warbler, Auk, XIV, I897, 309. (Io) E. H. SHoRT, Bachman's Warbler, Oölogist, XXII, 1905, 103. (II) Geo. C. Embody, Bachman's Warbler Breeding in Logan County, Kentucky, The Auk, XXIV, Jan. 1907. (12) A. T. WAYNE, The Nest and Eggs of Bachman's Warbler taken near Charleston, S. C., Auk, XXIV, Jan. I90\%.

\section{TENNESSEE WARBLER}

\section{VERMIVORA PEREGRINA (Wils.) Plate VII}

Distinguishing Characters.-No conspicuous wing-bars; adult $\delta$ grayish white below, crown and nape bluish gray; adult $q$ with crown greener, and tinged with yellow below; young greenish yellow below, above entirely yellow olive-green. Length (skin), 4.40; wing, 2.60; tail, I.70; bill, .40 .

Adult s, Spring.-Crown and nape grayish blue the former rarely with traces of chestnut, a whitish line above the eye and, usually, a dusky line through it; back bright olive-green; tail edged with olive-green, the two outer feathers usually with more or less dull white at the end of the inner vane; secondaries edged with olive-green, the median and greater coverts narrowly tipped with paler green or greenish white; underparts grayish white, the breast often tinged with buff or yellowish, the sides with greenish.

Adult $\delta^{*}$, Fall.-Similar to adult $\sigma^{*}$ in Spring, but crown tipped with olivegreen, underparts with more buffy or greenish.

Young o, Fall.-No gray on crown, upper parts entirely bright olive-green; line over eye yellowish; underparts greenish yellow, whiter on the belly and crissum; wings and tail as in the adult.

Adult $q$, Spring.-Similar to adult $d$ in Spring, but crown washed with olive-green, underparts more yellowish; closely resembling, therefore, the adult $\sigma$ in Fall.

Adult + , Fall.-No gray on crown; upperparts entirely bright olive-green, below white washed with yellow; resembles young $\delta$ in Fall but averages less bright above and less yellow below.

Young $\uparrow$, Fall.-Resembles adult $q$ in Fall but brighter above and yellower below; not always distinguishable from young $\delta$ in Fall but averaging yellower below.

Nestling.-Dusky olive-green above, dusky yellowish white below; greater and median coverts rather broadly tipped with whitish. 
General Distribution.-North America; north to Labrador and Alaska; west to the Rocky Mountains and British Columbia.

Summer Range.-New Hampshire (White Mountains, Lake Umbagog); Maine (Androscoggin, Penobscot, Piscataquis and Washington Counties); northern New York (Lewis County); northeastern Minnesota; eastern British Columbia (Carpenter Mountain), and north to the upper Yukon Valley, Labrador, and the Gulf of St. Lawrence. Accidental in California (Pasadena, September 27,1897 ).

The species is most common in the Mississippi Valley in its migrations, and extends west rarely to Colorado; it is not common anywhere east of Allegheny Mountains, but occurs rarely throughout all of eastern United States. Accidental in West Indies.

Winter Range.-Southern Mexico to Venezuela.

Spring Migration.-

\begin{tabular}{|c|c|c|c|}
\hline PLACE & $\begin{array}{l}\text { No. of } \\
\text { years } \\
\text { record }\end{array}$ & $\begin{array}{l}\text { Average date of } \\
\text { spring arrival }\end{array}$ & $\begin{array}{l}\text { Earliest date of } \\
\text { spring arrival }\end{array}$ \\
\hline 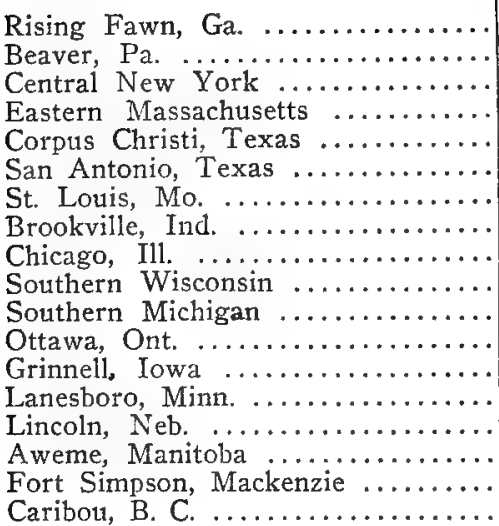 & $\begin{array}{r}7 \\
3 \\
10 \\
6 \\
7 \\
6 \\
6 \\
6 \\
3\end{array}$ & $\begin{array}{lr}\text { May } & 9 \\
\text { May } & \text { 13 } \\
\text { May } & 14 \\
& \\
& \\
\text { April } & 27 \\
\text { May } & 4 \\
\text { May } & 9 \\
\text { May } & 16 \\
\text { May } & 15 \\
\text { May } & 16 \\
\text { May } & 5 \\
\text { May } & 11 \\
\text { May } & 7 \\
& \\
\text { May } & 29\end{array}$ & 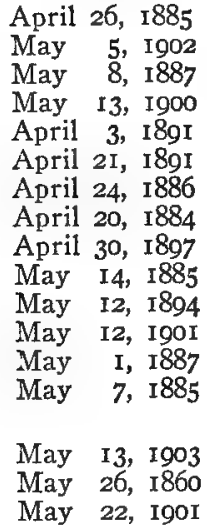 \\
\hline
\end{tabular}

Fall Migratnon.-

\begin{tabular}{|c|c|c|c|}
\hline PLACE & $\begin{array}{l}\text { No. of } \\
\text { years' } \\
\text { record }\end{array}$ & $\begin{array}{l}\text { Average date of } \\
\text { first one seen }\end{array}$ & $\begin{array}{l}\text { Earliest date of } \\
\text { first one seen }\end{array}$ \\
\hline 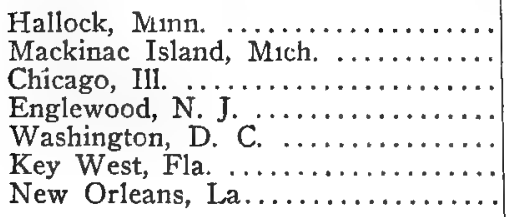 & 5 & August 20 & 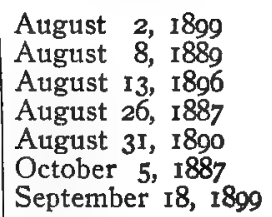 \\
\hline
\end{tabular}




\begin{tabular}{|c|c|c|c|}
\hline PI $\mathbf{A C E}$ & $\begin{array}{l}\text { No. of } \\
\text { years' } \\
\text { record }\end{array}$ & $\begin{array}{c}\text { Arerage date of } \\
\text { last one seen }\end{array}$ & $\begin{array}{l}\text { Latest date of last } \\
\text { one seen }\end{array}$ \\
\hline 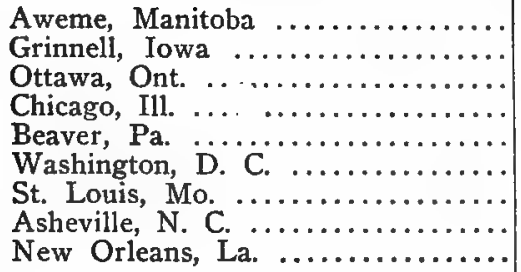 & $\begin{array}{l}5 \\
4\end{array}$ & $\begin{array}{l}\text { October } 2 \\
\text { September } 30 \\
\text { October } 28\end{array}$ & $\begin{array}{l}\text { October 3, I901 } \\
\text { October 1, I886 } \\
\text { September 30, I889 } \\
\text { October 9, I894 } \\
\text { October I1, 1890 } \\
\text { October 12, 1890 } \\
\text { October 20, 1885 } \\
\text { October 29, 1894 } \\
\text { November 3, I900 }\end{array}$ \\
\hline
\end{tabular}

The Bird and its Haunts.-The Tennessee Warbler awaits a biographer. We know that generally it is rather rare in spring but sometimes not uncommon in fall, and that during its migrations it is associated with other arboreal Warblers.

In the summer Maynard ${ }^{1}$ found it to be very common in wooded localities about Umbagog, the male, while singing being perched on some high dead branch. Faxon ${ }^{4}$ who found a singing male of this species in a "thick growth of black spruce, balsam fir, and mountain ash" on Graylock Peak, Mass., on July 15,I888, quotes Brewster as saying that he found it "in a white spruce and larch swamp in Anticosti" and that at Lake Umbagog he observed it in "larch swamps, but sometimes on mountain sides-always among coniferous trees." Merriam", however, writes that in the Adirondack region it "generally prefers hardwood areas."

In British Columbia Brooks, as recorded by Norris ${ }^{5}$, found the bird breeding in "clumps of aspen trees and Norway pines, where the ground was covered with a thick growth of dry pine grass."

About Monadnock, Gerald Thayer writes that the Tennessee Warbler is "very rare, and seemingly irregular. It haunts blossoming apple trees, big elms, and roadside copses of mixed deciduous second growth. This most un-warbler-colored little Warbler seems to have pretty nearly the same general habits and demeanor as the nervous, yellow-breasted Nashville,-though it is perhaps a little less restless, -and the only one of its call-notes I have heard is almost exactly like the Nashville's least peculiar call." (Thayer, MS.)

Song.- "Its song begins with a note like chipiti, chipiti repeated a dozen or more times, with increasing rapidity, then suddenly changed into a mere twitter." (Seton ${ }^{1}$.)

"Often sings in migration a very loud song, beginning with a sawing two-noted trill, rather harsh and very staccato, but hesitating 
in character, increasing to a rapid trill, almost exactly like a Chipping Sparrow's. A noticeable but not musical song." (Farwell, MS.)

"The Tennessee is easily discovered and identified by its peculiar song;-a twittering, semi-trilled, rather prolonged utterance of three parts, not very unlike some of the weaker and buzzier strains of the American Goldfinch's song. Its tone is ambiguous-hard to place between full and feeble, wheezy and clear. On the whole, however, the song is a decidedly noticeable one. Having heard the Tennessee but seldom, I know only one main song, with no important variations, and cannot even describe that one very closely." (Thayer, MS.)

Nesting Site.-Little appears to be known about the nesting habits of this Warbler. Norris ${ }^{5}$ recording the observations of Allan Brooks in British Columbia, writes: "The nests were always on the ground, sometimes at the foot of a small service berry bush or twig. They were all arched over by the dry pine grass of the preceeding year; this year's growth having just commenced."

Nest.- "The nest is small and loosely constructed, being quite flat. It is composed outwardly of a few leaves, a little moss, and a good deal of fine grass, lined only with the latter material." (Norris ${ }^{5}$.)

Eggs.-4. "The eggs seem to differ in appearance from any of the same genus that I have seen, and may be thus described: Creamy white, finely speckled all over the surface with reddish brown, and also marked with larger spots of the same color, more heavily at the larger end. There are also a number of spots of light lilac which are not conspicuous. They measure $.57 \times .48 ; .65 \times .46 ; .59 \times .47 ; .61 \times .46 . "$ (Norris. ${ }^{5}$ )

Nesting Dates.-Bangor, Me., June 4 (Knight) ; Caribou, B. C., June 15 , newly hatched young (Norris).

\section{BIOGRAPHICAL REFERENCES}

(1) C. J. Maynard, Birds of Coos Co., N. H., and Oxford Co., Me., Proc. Bost. Soc., N. H., XIV, I87I, 7. (2) C. Hart Merriam, Birds of the Adirondack Region, Bull. Nutt. Orn. Club, VI, 188I, 227. (3) ERnest Thompson Seton, Birds of Manitoba, Proc. U. S. N. M., I89I, 617. (4) W. FAxon, On the Summer Birds of Berkshire County, Massachusetts, Auk, VI, I889, 102. (5) J. Parker Norris, Jr., Nesting of the Tennessee Warbler in British Columbia, Auk, XIX, I902, 88.

\section{ORANGE-CROWNED WARBLER}

VERMIVORA CELATA CELATA (Say) Plate VII

Distinguishing Characters.-General color dusky olive-green, the underparts obscurely streaked; adult $\delta$, and often $\$$, with an orange-brown crown- 


\section{Plate VII}

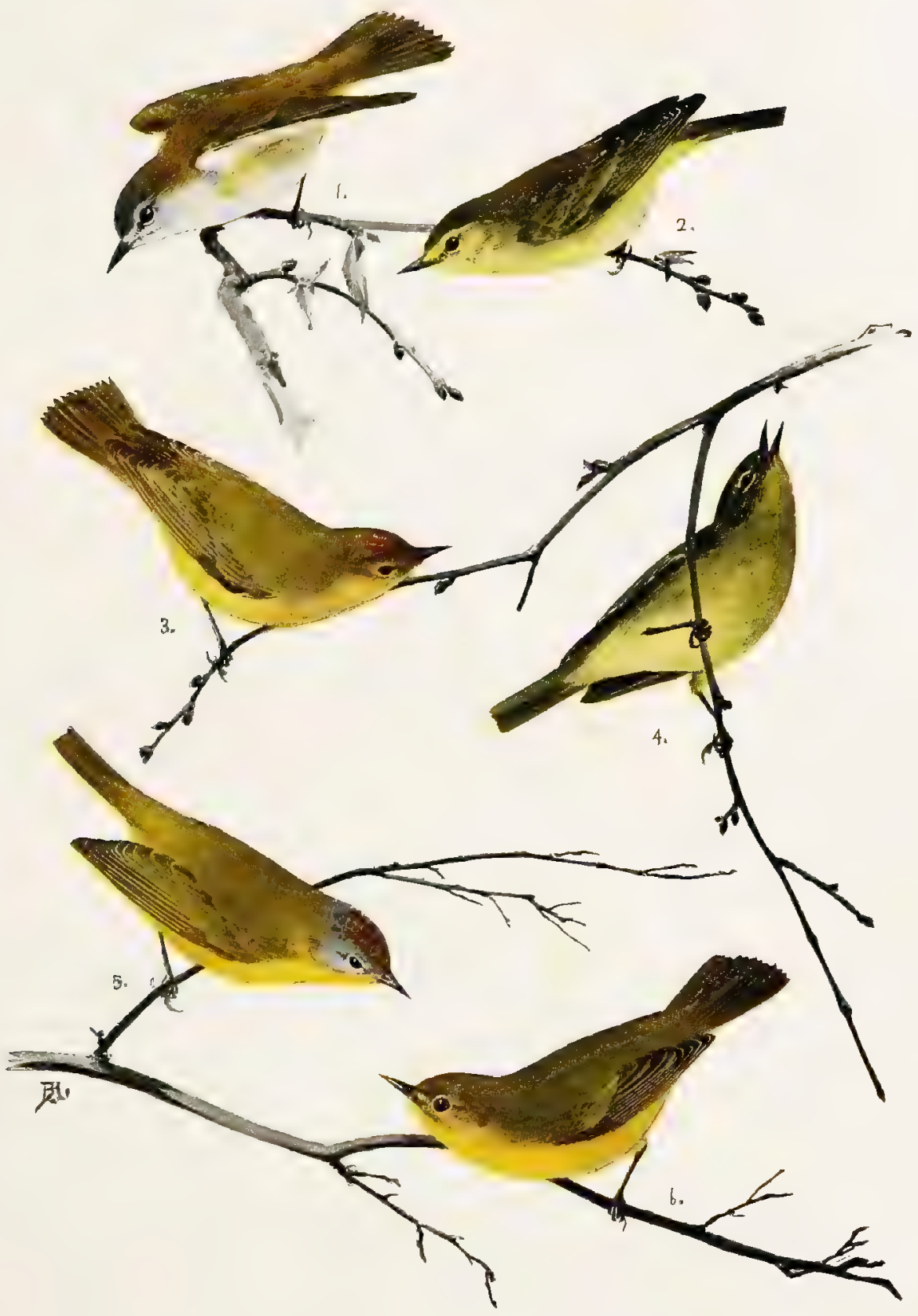

1. Tennessee Warbler, Male.

2. Tenmessee Warbler, Female

3. Orange-crowned Warbler, Male.
4. Orange-Crowned Warbler, Female

5. Nashville Warbler, Male.

6. Nashyille Warbler, Female. 
. 
patch; virtually no white in wings or tail. For comparison with young of Bachman's Warbler see under that species. Length (skin), 4.50; wing, 2.45; tail, 1.90; bill, .40.

Adult ơ, Spring.-Upper parts olive-green tipped with grayish, except on rump; an orange-brown crown-patch tipped with olive-green and gray; eyering and a narrow line from bill to above eye, yellow or yellowish; tail externally olive-green, inner margin of inner vane of outer feathers often whiteedged; wings edged with olive-green, their bend yellow; underparts dusky greenish yellow indistinctly streaked.

Adult ơ, Fall.-Similar to above, but grayish tips to feathers above and below longer, making the bird duskier.

Young $\delta^{*}$, Fall.-Similar to adult $\delta^{*}$ in Fall, but crown-patch very small or entirely absent.

Adult \%, Spring.-Similar to adult $\delta$ in Spring, but crown-patch smaller or wanting.

Adult $q$, Fall.-Similar to adult $q$ in Spring, but grayish tips to feathers above and below longer, making the bird duskier. absent.

Young $q$, Fall.-Similar to adult $q$ in Fall, but crown-patch always (?)

Nestling.- "Above dull olive, or grayish olive, becoming more olive-greenish or russet-olive on rump and upper tail-coverts; middle and greater wingcoverts tipped, more or less distinctly, with paler olive or dull buffy; throat, chest, sides of breast, sides and flanks pale brownish gray; tinged with dull buffy, especially on chest; abdomen white; otherwise like adults, but without trace of tawny-ochraceous on crown". (Ridgw.)

General Distribution.-Eastern United States and northwestward to Alaska.

Summer Range.-Not uncommon breeder in Manitoba and northwestward to Alaska, except coast region north to Cook Inlet. Probably breeds locally and rarely in Wisconsin and occurs sparingly east to New England; once found breeding at Brunswick, Maine. There are no breeding records for Canada in Ontario or eastward, though the species is a rare migrant from southern Ontario to New Brunswick and south to the Gulf of Mexico.

Winter Range.-Florida and Gulf coast, and rarely north to Charleston, S. C. A specimen was taken January I, I875, at Lynn, Massachusetts.

Spring Migration.-This species winters in the south Atlantic states as far north as southern South Carolina, but northward is so rare east of the Allegheny mountains that its normal times of migration in the north Atlantic states cannot be stated with any degree of accuracy. Some of the following data refer to the western races of this bird. 


\begin{tabular}{|c|c|c|c|}
\hline PLACE & $\begin{array}{l}\text { No. of } \\
\text { years' } \\
\text { record }\end{array}$ & $\begin{array}{l}\text { Average date of } \\
\text { spring arrival }\end{array}$ & $\begin{array}{c}\text { Earliest } \\
\text { spring artival }\end{array}$ \\
\hline 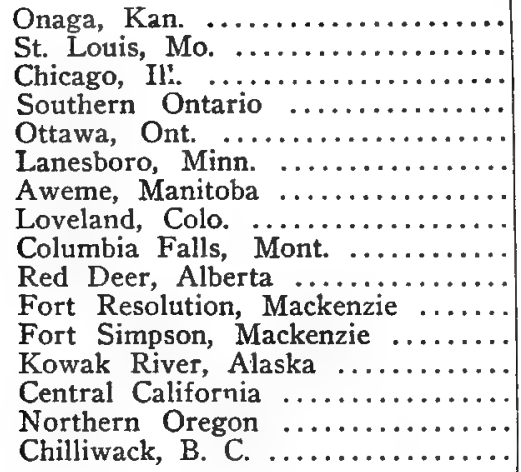 & $\begin{array}{l}5 \\
4 \\
5 \\
3 \\
2 \\
7 \\
7 \\
2 \\
5\end{array}$ & $\begin{array}{lr}\text { April } & 24 \\
\text { April } & 27 \\
\text { May } & 6 \\
\text { May } & 13 \\
\text { May } & 18 \\
\text { May } & 2 \\
\text { May } & 7 \\
\text { May } & 3 \\
\text { May } & 5\end{array}$ & 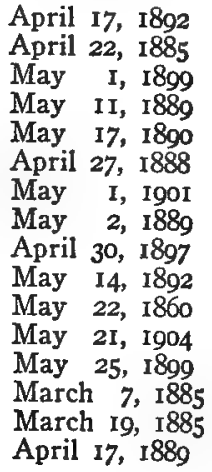 \\
\hline
\end{tabular}

Fall Migration.-

\begin{tabular}{|c|c|c|c|}
\hline PLACE & $\begin{array}{l}\text { No. of } \\
\text { years' } \\
\text { record }\end{array}$ & $\begin{array}{l}\text { Averagedate of } \\
\text { last one seen }\end{array}$ & $\begin{array}{l}\text { Iatest date of last } \\
\text { one seen }\end{array}$ \\
\hline 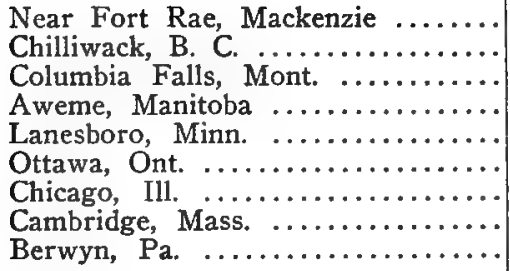 & $\begin{array}{l}2 \\
5\end{array}$ & $\begin{array}{l}\text { September } 27 \\
\text { October I } \\
\text { November } 18\end{array}$ & $\begin{array}{l}\text { August 16, I903 } \\
\text { September 5, I888 } \\
\text { September I2, I895 } \\
\text { October 3, 1901 } \\
\text { October 6, I89I } \\
\text { September 30, I889 } \\
\text { October I, I896 } \\
\text { November 28, 1901 } \\
\text { October 12, I894 }\end{array}$ \\
\hline
\end{tabular}

The Bird and its Haunts.-During the winter I have found the Orange-crowned Warbler a not uncommon inhabitant of the live-oaks in middle Florida where its sharp chip soon becomes recognizable. In Mississippi, at this season, Allison (MS.) says that "its favorite haunts are usually wooded yards or parks, where the evergreen live oak and magnolia can be found; but I have seen it most commonly among the small trees on the border of rich mixed woods, above an undergrowth of switch cane. Coniferous trees it seems not to care for, though I have seen it in the cypress swamps."

The bird's migration route in the spring appears to pass through the Mississippi valley and it is rare or unknown at this time of the year in the north Atlantic States. During the fall, however, it is not infrequently found there, Brewster's ${ }^{3}$ records of nine individuals seen in his garden in Cambridge, in November, showing that it is both more common and later than was previously supposed. 
Very little appears to have been written about the habits of this form of the Orange-crown in its summer home. Near Carberry, Manitoba, Seton ${ }^{2}$ says it is a common summer resident in the wooded sections, "moving about continually among the topmost twigs of the trees and uttering its little ditty about once every half minute." About the Great Slave Lake, Kennicott (B. B. \& R., I., 204) found the bird nesting among clumps of low bushes. In northern Alaska, Nelson ${ }^{2}$ states that the Orange-crown is a common summer resident of wooded regions, straggling southward as an autumn migrant to the shores of Behring Sea and Kotzebue Sound.

Song.- "Its song is much like that of the Chipping Sparrow, but more musical and in a higher key." (Seton.)

"Their song, only heard during the mating and breeding season, is a simple lay-a few sweet trills uttered in a spirited manner, and abruptly ending on a rising scale." (Goss, Birds of Kansas.)

"The only note heard is a sharp, persistent, chipping, many times repeated, as the bird moves about the tree, often moving its wings restlessly, like a Kinglet." (Allison, MS.)

"The song is full and strong, not very high pitched, and ends abruptly on a rising scale. My note book renders it chee chee chee chw' chw'. The first three syllables rapidly uttered, the last two more slowly. One heard late in the season sang more nearly like $\mathrm{Mr}$. Thompson's description: chip-e, chip-e, chip-e, chip-e, chip-e, but with the first vowel changed to $e$, thus eliminating what would appear to be a marked similarity to the song of Chippy. Even in this song the ending is retained." (Jones.)

Eggs.-“Average size $.64 \times .46$, white or creamy white, finely specked chiefly on the larger end with reddish or chestnut brown." (Davie.)

The eggs undoubtedly closely resemble those of the Lutescent Warbler.

\section{BIOGRAPHICAL REFERENCES}

(I) E. W. Nelson, Report on Natural History Collections made in Alaska, 200. (2) ERnest THompson Seton, Birds of Manitoba, Proc. U. S. N. M., I891, 6r6. (3) WM. Brewster, Birds of the Cambridge Region, 324.

\section{ROCKy MOUntain ORange-CROWN}

hELMINTHOHILA CELATA ORESTERA (Ober.)

Subspecific Characters.-Intermediate in color between Helminthophila celata celata and $H$. c. lutescens; yellower than former, not so yellow as the latter; in size larger than lutescens, and virtually agreeing with eolata. 
Average measurements of the three forms, given by Oberholser are as follows :

$\begin{array}{lcccr} & \text { Wing. } & \text { Tail. } & \begin{array}{c}\text { Exposed } \\ \text { culmen. }\end{array} & \text { Tarsus. } \\ \text { H. c. celata } & 2.42 & 1.93 & .38 & .69 \\ \text { H. c. orestera } & 2.49 & 1.98 & .40 & .72 \\ \text { H. c. lutescens } & 2.34 & 1.84 & .38 & .69\end{array}$

Summer Range.-Breeds in the mountains from Arizona (Mt. Graham), southern California (Panamint Mts.), north to British Columbia.

Winter Range.-Southward to Lower California and southern Mexico. In migration casually eastward to Minneseta (Ft. Snelling) and Pennsylvania (Williamsport), (cf. Oberholser).

Note.-This form is now considered inseparable from $V$, c. celata.

\section{LUTESCENT WARBLER}

\section{VERMIVORA CELATA LUTESCENS (Ridew.)}

Subspecific Characters. - Similar to $V$. c. orestera, but smaller and decidedly yellower. In life, breeding birds impress one as being yellow rather than olive-green birds; the underparts being strong, if somewhat dusky, yellow.

Nestling.-Brownish olive above; dusky yellow-olive below; wing-coverts with ochraceous tips forming two bars.

General Distribution.-Pacific Coast region.

Summer Range.-Mountains of southern California (Los Angeles Co.) north through the Sierras and coast ranges to Cook Inlet, Alaska.

Winter Range.-From southern California and Arizona southward into Mexico.

The Bird and its Haunts.-Compared with our eastern Orangecrown, the Pacific coast form is distinctly a yellow bird, and is consequently much more conspicuous than true celata. Walter Fisher (MS.) contributes the following sketch of it in its haunts: "Chaparral hillsides and brushy open woods are the favorite haunts of the Lutescent Warbler. Its nest is built on or near the ground, usually in a bramble tangle or under a rooty bank, and the bird itself hunts near the ground, flitting here and there through the miniature jungle of wild lilacs, baccharis and hazel bushes. Its dull greenish color harmonizes with the dusty summer foliage of our California chaparral, and with the fallen leaves and tangle of stems that constitute its normal background. It impresses one chiefly by its lack of any distinctive markings, and the young of the year, particularly, approach that tint 
which has been facetiously called 'museum color'. Ordinarily the crown-patch is invisible as the little fellow fidgets among the undergrowth, but at a distance of three feet Mr. W. L. Finley was able to distinguish it when the bird ruffled its feathers in alarm."

Song.- "In March they begin to sing their simple trill, which is rather musical and audible for a long distance." (Finley ${ }^{1}$.)

Nesting Site. - "Nests on the ground, on dry hillsides overgrown with brush." (Bowles, MS.) Finley ${ }^{1}$ mentions nests found "under some dry ferns in the bank of a little hollow. $* * *$ on a hillside under a fir tree, placed on the ground in a tangle of grass and brier. * * * In an arrow-wood bush three feet from the ground and amid a bunch of sprouts, and in a bush two feet up."

Nest.- "Loosely made of dry leaves and grasses lined with fine grass and a little hair" (Carriger, Sonoma County, California, C. W. C.).

Eggs.-3 to 5, usually 4. Ground color white to creamy white spotted and specked with reddish brown and lilac-gray more heavily at the larger end, slightly tending to wreathe, with very few specimen: showing blotches. Size; average, $.66 \times 5$ I. The eggs of this bird show very little variation in size, one set of four showing the remarkable variation of only $\mathrm{I}-\mathrm{IOO}$ of an inch in length and none in breadth, three eggs measuring .64x.50 and one .63x.50. (Figs. 26-28.)

Nesting Dates.-Dublin, Alameda Co., Calif., April 5; Sonoma, Calif., June 7 (C.W.C.) ; Tacoma, Wash., May 3-May 28 (Borwles).

\section{Btographical References}

(I) W. L. Finley, The Lutescent Warbler [in Oregon], Condor, VI, 1904, 131.

\section{DUSKY WARBLER}

\section{VERMIVORA CELATA SORDIDA (ToWns.)}

Subspecific Characters.-Similar to $V$. c. lutescens but darker, more heavily tipped above, duskier more strongly streaked below; wing averaging slightly shorter, the bill and tail slightly longer. Wing, 2.20; tail, 2.00; bill, .40.

General Distribution.-Santa Barbara Islands, California, and adjoining mainland.

Summer Range.-Santa Barbara Islands.

Winter Range.-Santa Barbara Islands and adjoining mainland. (Grinnell ${ }^{2}$.)

The Bird and its Haunts.-In their summer home on San Clemente Island, Grinnell' says: "Dusky Warblers were quite numerous in the weed-patches and brush along the ravines nearly to the beaches. But 
later, when most of the plants were dry and dead, they were confined to the cherry thickets along the cañons. Their song and habits were similar to those of the Lutescent Warbler of the mainland."

According to the same author ${ }^{2}$ the Dusky Warbler "appears in the vicinity of Pasadena in the oak regions and along the arroyos in large numbers during August, and even by the middle of July. Remains in diminishing numbers through the winter; the latest specimen noted in the spring was secured by me, Feb, 29, '96."

Eggs. - The eggs of this race resemble those of the Lutescent Warbler.

\section{BIOGRAPHICAL REFERENCES}

(I) J. Grinnell, Publication I, Pasadena Acad. Sci., 20. (2) Ibid., II, 44.

\section{NASHVILle WARBLeR}

VERMIVORA RUBRICAPILLA RUBRICAPILLA (Wils.) Plate VII

Distinguishing Characters.-Adults with the head gray, the $\delta$, and often $q$, with a partially concealed chestnut crown-patch; no white tail-patches or wingbars. Length (skin), 4.30 ; wing, 2.35 ; tail, 1.80 ; bill, .36 .

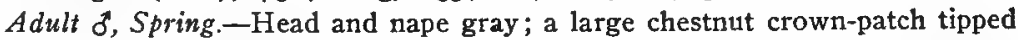
with gray; eye-ring white, loral region white or, at times, yellow; back olivegreen, the rump brighter; tail, externally, olive-green, without white patches but inner web of outer feathers sometimes margined with white; wings, externally, olive-green, no wing-bars, the bend yellow; under-parts and crissum yellow, the lower belly whitish.

Adult d", Fall.-Similar to last but head browner, crown-patch more broadly tipped, back grayer, breast with a brownish tinge; belly with whitish tips to feathers.

Young d, Fall.-Similar to adult $\delta^{\prime \prime}$ in Fall, but chestnut crown-patch much smaller or wanting entirely.

Adult \%, Spring.-Similar to adult $\delta$ in Spring, but with chestnut in crown less in extent or entirely wanting (absent in half the specimens examined); underparts paler.

Adult ?, Fall.-Similar to last, but crown browner, the chestnut patch, when present, more broadly tipped, the back grayer, the breast tinged with brown, the feathers of belly tipped with white.

Young + , Fall.-Similar to adult $q$ in Fall, but chestnut crown-patch rarely present.

Nestling.-Above dusky olive-green, sometimes broadly edged with dark brown; wing-coverts tipped with buff, forming two well-marked wing-bands; breast and flanks dusky brownish-yellow, belly clear pale yellow.

General Distribution.-Eastern North America, but rare or lacking in the southeastern states.

Summer Range.-The Nashville Warbler breeds more commonly in New England than elsewhere; less commonly north to Nova Scotia 
(Cape Breton Island), Quebec (Gaspé Bay), central Ontario, and Athabasca (Cumberland House); the southern limit of the breeding range is found in New Jersey (Englewood, casual), Pennsylvania (Dingman's Ferry, Pike County), northern Illinois, Nebraska (Nebraska City). East of the Allegheny Mountains it is scarcely known south of Maryland, nor in the Gulf states east of Texas. Accidental in Greenland.

Winter Range.-Southern Texas to southern Mexico and possibly Guatemala.

Spring Migration.-Wintering principally in Mexico, the Nashville Warblers of New England seem to reach their summer home by a migration route that shuns the lowlands of the southeastern United States. The species is almost unknown in this district south of Virginia. Records for the western form of this species are here included.

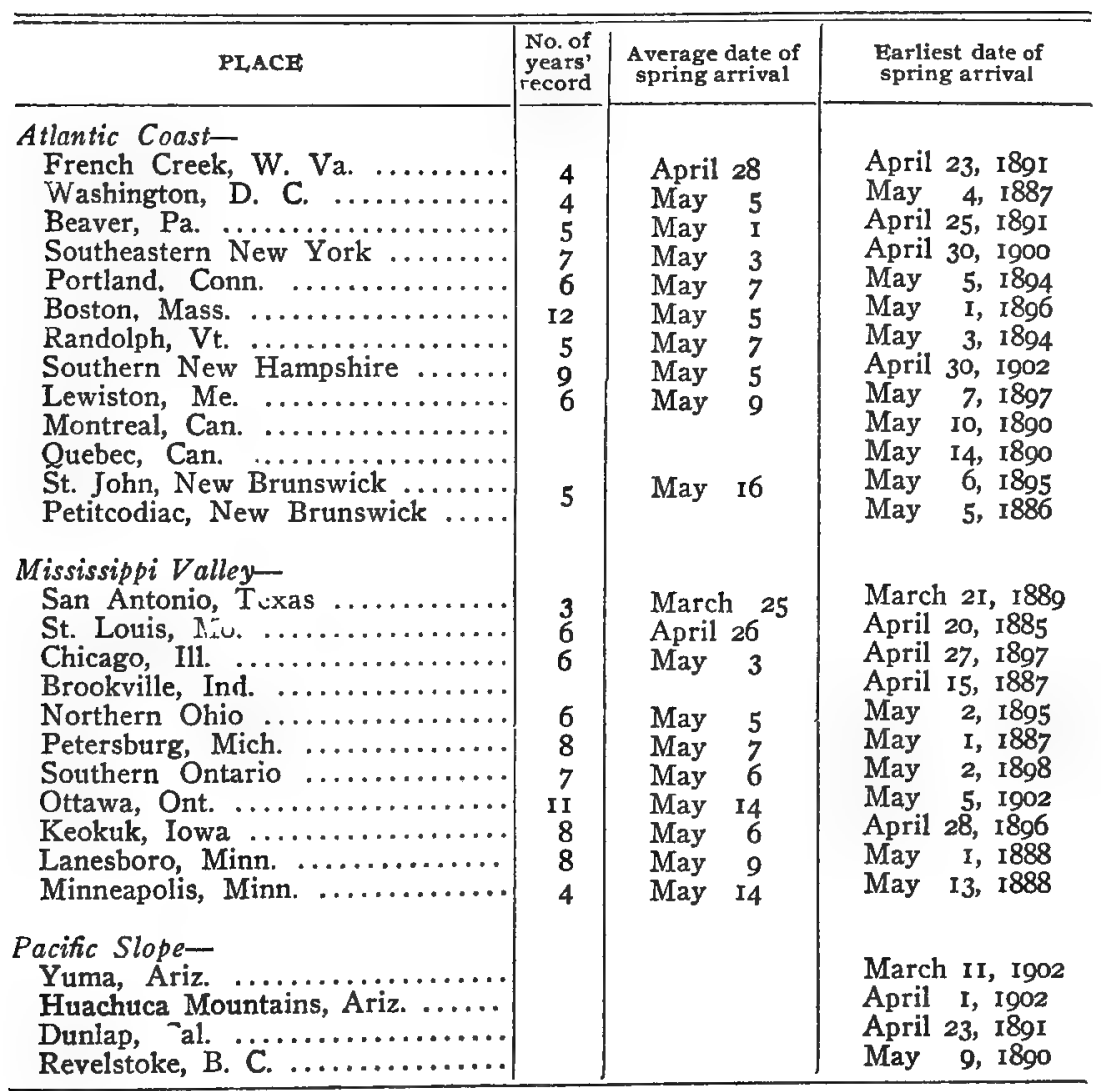


Fall Migration.-The arrival of migrants south of their breeding grounds has been noted at Chicago, Ill., August 16, I896; Beaver, Pa., September 5, 1903; Ossining, N. Y., August II ; Englewood, N. J., August 26, I887; Washington, D. C., September 5; French Creek, W. Va., September 7, I890; St. Louis, Mo., September 17, 1885, and at Gainesville, Texas, October I I, I885.

\begin{tabular}{|c|c|c|c|}
\hline PLACE & $\left\{\begin{array}{l}\text { No. of } \\
\text { years' } \\
\text { eco d }\end{array}\right.$ & $\begin{array}{l}\text { Average date of } \\
\text { last one seen }\end{array}$ & $\begin{array}{l}\text { Latest date of last } \\
\text { one seen }\end{array}$ \\
\hline 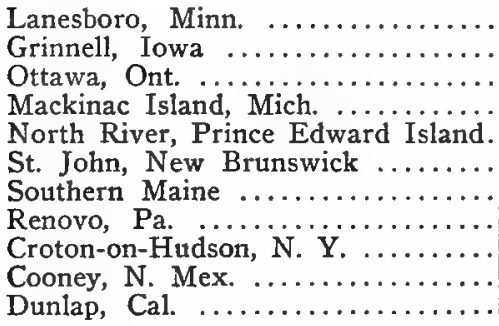 & $\begin{array}{l}3 \\
5 \\
7 \\
2\end{array}$ & $\begin{array}{l}\text { September } 27 \\
\text { September } 20 \\
\text { September } 2 \\
\text { September II } \\
\text { September } 26 \\
\text { October } 3\end{array}$ & $\begin{array}{l}\text { September 29, 1889 } \\
\text { October 1, I886 } \\
\text { October 10, 1900 } \\
\text { September 24, 1889 } \\
\text { August 10, 1887 } \\
\text { September 5, 1895 } \\
\text { September 27, 1902 } \\
\text { October 3, 1902 } \\
\text { October 7, 1888 } \\
\text { September 30, 1889 } \\
\text { October 12, 1890 }\end{array}$ \\
\hline
\end{tabular}

The Bird and its Haunts.-Wilson, the discoverer of this species, found only the three specimens, taken near Nashville, Tennessee, on which his description was based; and, in the early part of the last century it was considered a rare bird. Brewster, quoting Samuel Cabot, says that soon after 1836 "a few birds began to appear every season. They increased in numbers, gradually but steadily, until they had become so common that in 1842 he obtained ten specimens in the course of a single morning."

Recounting his own experience in the Cambridge region, Brewster ${ }^{5}$ adds: "In I868, and for some fifteen years later, I found Nashville Warblers breeding rather numerously in Waltham, Lexington, Arlington and Belmont, usually in dry and somewhat barren tracts sparsely covered with gray birches, oaks or red cedars, or with scattered pitch pines. A few birds continued to occupy certain of these stations, but in all of the towns just mentioned the Nashville Warbler is less common and decidedly less generally distributed in summer now than it was twenty-five or thirty years ago."

Gerald Thayer writes: "Birch Warbler' would be a good name for this bird as it appears in the Monadnock region where it breeds abundantly. For here it is nowhere so common as in abandoned fields and mountain pastures half smothered by small gray birches. From the airy upper story of these low and often dense birch copses the Nashvilles sing; and among the club-mosses and ferns, and the hard- 
hacks and other scrubby bushes at their bases and around their borders, the Nashvilles build their nests. But such is merely their most characteristic home. They are so common and widespread that it is hard to get out of earshot of their song during the breeding season. Dark spruce woods they do not favor, nor big, mixed virgin timber; but even in these places, one is likely to find them wherever there is a little 'oasis' of sunlight and smaller deciduous growth. They are fairly common among the scanty spruces, mountain ashes and white birches of the rocky upper ridge of Mt. Monadnock, almost to the top-3,I69 feet.

"The Nashville's proper domain or 'beat', during the breeding season, lies between the ground and the tops of the lower treesmainly deciduous trees. He is a little, active, foliage-colored Warbler, un-showily yellow-breasted, inconspicuously gray-headed (except for a yellow throat, and a rufous crown-spot which scarcely shows at all) with a dim white eye-ring, but without white tail-spots, wing-bars or any other bold markings. In demeanor it is one of the most nervously agile and restless of the gleaning Warblers." (Thayer, MS.)

Song.- "The Nashville has at least two main perch-songs, and a flight-song, all subject to a good deal of variation. It belongs decidedly among the full-voiced Warblers;-the Yellow, Magnolia, Blackthroated Green, Chestnut-side, Hooded, Canadian, etc., on the one hand, as compared with the Parula, Blackburnian, Cape May, Black and White, Blackpoll, Bay-breast, etc., on the other. Its commoner perch-song consists of a string of six or eight or more, lively, rapid notes, suddenly congested into a pleasant, rolling twitter, lower in key than the first part of the song, and about half as long. In the other perch-song, the notes of what correspond to the rolling twitter are separate and richer, and the second part of the song is longer and more noticeable than the first, whose notes are few and slurred, while the whole is more languidly delivered. The differences are hard to describe intelligibly; but in reality they are pronounced and constant. The flight-song, a fairly common performance in late summer, is sung from the height of five to forty feet above the (usually low) tree-tops. It is like the commoner perch-songs, but more hurried, and slightly elaborated,--often with a few chippings added, at both ends. Among the Nashville's calls a very small, dry chip, and a more metallic, louder chip, somewhat Water-Thrush-like, are noteworthy. It also chippers like a young Warbler or a Black-throated Green." (Thayer, MS.) 
Miss Paddock sends six renderings of the Nashville's song and writes: "The first half of the Nashville's song is sibilant, the last half is a twitter. I cannot agree with Mr. Matthews that the first part is always 'lame-legged', though it is often so."
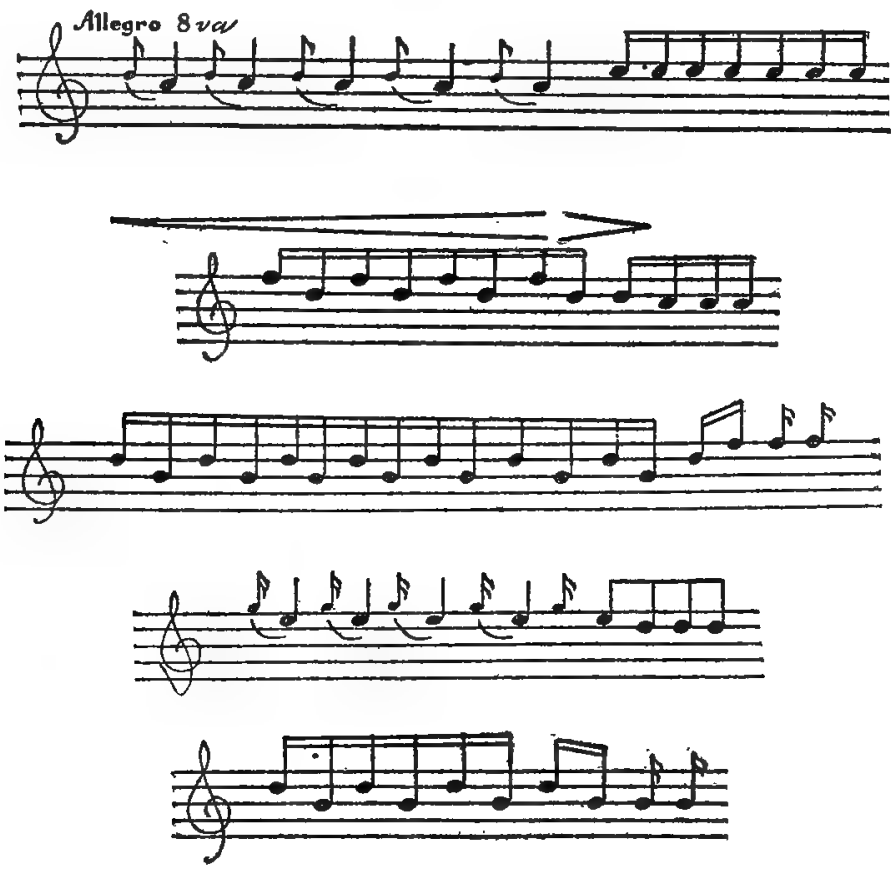

"A very peculiar song, unlike the usual quality, and in leisurely fashion, ran as follows: The tempo was regular and all the notes seemed to utter the syllables chip, chip, chip."

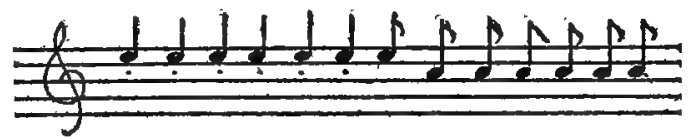

Nesting Site.-The nest is apparently always placed on the ground, the character of the situation being indicated by the following quotations: "the side of a knoll well concealed by brakes and brush. * * * on the roots of a small bush that grew from the side of a knoll" (Morrell ); "under a shrub or tree much after the fashion of the Black and White Warbler" (Bowles"); "the nests I have found have uniformly been in the side of sphagnum tussocks, and well sunken out of sight from above, so that one must stoop to look into them" (Preston ${ }^{2}$ ). Nests found by Spaulding at Lancaster, N. H., were in the side of grassy knolls. 
Nest.-After stating that in Massachusetts the site selected resembles that chosen by the Black and White Warbler, Bowles ${ }^{4}$ adds: "the material, however, is somewhat different, consisting of moss, dry leaves, grass and pine-needles, and lined with pine-needles and grass, instead of horse-hair, which is almost invariably used by Mniotilta. Spaulding describes New Hampshire nests as made of moss and fine grasses lined with rootlets, while nests found by Preston ${ }^{2}$ in Minnesota were composed of the "soft stems of a slender Juncus and some were lined with deer's hair."

Eggs.-4 or 5. Ground color white to creamy white specked and spotted with reddish brown and lilac of varying shades forming a more or less distinct wreath about large end. This egg and that of the Pileolated Warbler approach each other closely. Size; a typical set of five measures $.62 \times .46, .63 \times .46, .65 \times .48, .62 \times .47$ and $.63 \times .46$; other specimens measure the same. (Figs. 23-25.)

Nesting Dates.-New Haven, Conn., May 3o-June 8 (Bishop); Cambridge, Mass., full sets, first laying, May 25-June I (Brewster); Lancaster, N. H., May 25-June 8 (Spaulding); Bangor, Maine, June 3-June 6; Fort Kent, Maine, July Io (Knight) ; Detroit, Mich., May 30 (J.P.N.).

\section{Biographical REFERENCES}

(I) J. P. N[OrRIs], A Series of Eggs of the Nashville Warbler, Orn. and Oöl., XV, I890, 23. (2) J. W. Preston, A Glimpse of the Nashville Warbler [in Minn.], Orn. and Oöl., XVI, I891, 89. (3) C. H. MorRerL, Nesting of the Nashville Warbler [in Maine], Nidologist, III, 1896, 125. (4) J. H. Bowles, Nesting Habits of the Nashville Warbler [in Mass.], Osprey, I, I896, 20. (5) WM. BREWSTER, Birds of the Cambridge Region, 323 .

\section{Calaveras Warbler}

\section{VERMIVORA RUBRICAPILLA GUTTURALIS (RIdgw.)}

Subspecific Characters.-Similar to Vermivora r. rubricapilla, but rump and upper tail-coverts brighter, more yellow; underparts richer, deeper yellow.

General Distribution.-Western United States.

Summer Range.-High mountains, from the Sierra Nevada (Calaveras Co., Calif.) to British Columbia (Vernon, Nelson, Okanagan district, etc.), eastward to eastern Oregon (Fort Klamath, northern Idaho (Fort Sherman), etc. (Ridgw.).

Winter Range.-Southern California to southern Mexico; east in migration to central Texas.

The Bird and its Haunts.-Although the Calaveras Warbler is very rare or wanting in the Rocky Mountains, it is locally common in 
British Columbia and southward in the Sierras; this brighter western form having been described under the subspecific name gutturalis in 1874 .

Of this bird, as it occurs in California, Walter Fisher writes: "The Calaveras Warbler is a characteristic denizen of the chaparral and is found on both slopes of the Sierra Nevadas about as far south as Mt. Whitney. It frequents the belts of the yellow, sugar, and Jeffrey pines, and ranges up into the red fir zone. During the height of the nesting season one may see them flitting about among thickets of manzanita, wild cherry, huckleberry, oak and buck brush, almost always in song; and while the female is assiduously hunting among the dense cover of bushes, the male is often singing in a pine or fir, far above mundane household cares.

"These Warblers are conspicuous fellows, the yellow underparts showing in bold contrast to the gray crown and cheeks, and olive-green upper-parts. It is likely that the brilliant mountain sunshine heightens the color effect. I have observed this Warbler at lower altitudes on the west slope among small black oaks, in company with Hermit Warblers, from which it can be readily distinguished by the absence of yellow cheeks and black throat." (Fisher, MS.)

Nesting Site.- "Nests on the ground, on the dry, open prairies at the foot of a small bush." (Bowles, MS.)

Eggs.-The eggs of this bird in all respects are the same as those of the Nashville Warbler.

Nesting Dates.-Tacoma, Wash., April $28 \%$ building; June $\mathbf{2}_{\boldsymbol{\psi}}$ three fresh eggs (Bowles).

\section{VIRGINIA'S WARBLER \\ VERMIVORA VIRGINIA (Baird) Plate VI}

Distinguishing Characters.-General color gray; crown-patch chestnut, upper and under tail-coverts and breast-patch yellow. Length (skin), 4.20; wing, 2.40; tail, 1.85 ; bill, .40.

Adult d", Spring.-Crown-patch chestnut tipped with gray; cheeks and back brownish gray, eye-ring white; rump and upper tail-coverts dull yellow; tail fuscous, outer pair of feathers usually margined with white on the inner web; wings margined with gray, no white bars; below grayish white, breastpatch and under tail-coverts yellow.

Adult 6", Fall.-Similar to above but crown-patch more broadly tipped, underparts more buffy.

Young o, Fall.-Not seen.

Adult \&, Spring.-Similar to adult $\delta$ in Spring, but chestnut and yellow areas somewhat paler and more restricted. 


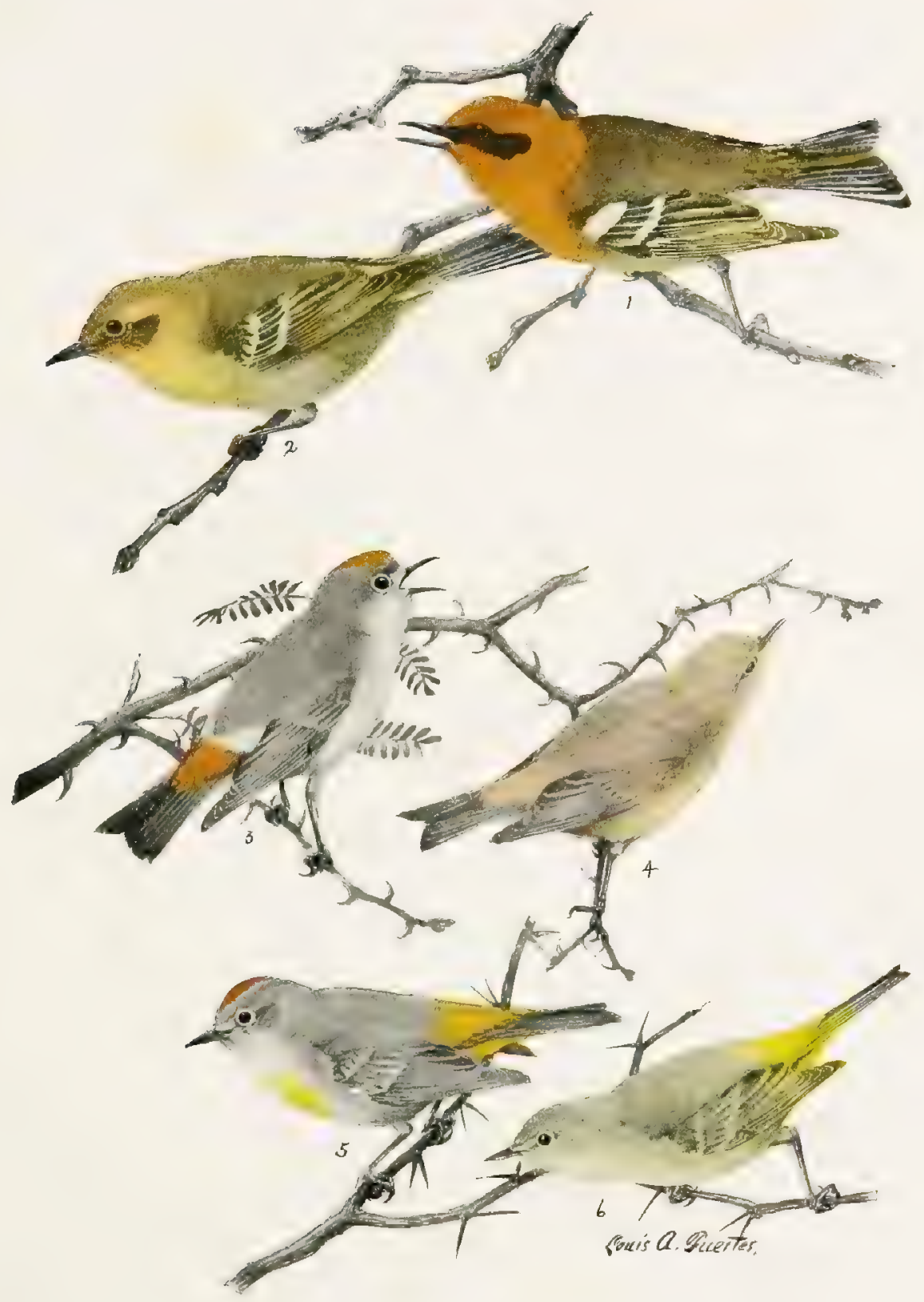

1. Olive Warbler, Adult Male.

2. Olive Warbler, Adult Female

3. Lucy's Warbler, Adult.
4. Lucy's Warbler, Young.

5. Virginta's Warbler, Adult.

6. Virginia's Warbler, Young. 

Adult 9, Fall.-Similar to adult $q$ in Spring but slightly browner above, crest tipped with brownish gray, yellow of breast with whitish, flanks browner.

Young $q$, Fall.-Similar to adult $q$ in Spring but crown-patch nearly obsolete, rump and under tail-coverts duller, under parts buffier, no yellow breastpatch.

Nestling.-Above grayish brown; throat and breast paler, belly whitish; upper and under tail-coverts saffron; wings and tail as in young $\delta$, greater and median coverts brownish gray narrowly but sharply tipped with buffy.

General Distribution.-Rocky Mountains of the United States, north to Colorado (common), Utah (Wasatch Mts., Salt Lake City) and Nevada (East Humboldt Mountains). Winters in Mexico.

Migration.-The first migrant was seen at Cooney, New Mex., April Io, I889; Huachuca, Ariz., April 10, I902; Beulah, Colo., May 6, I905; Monon, Colo., May 3, I905.

The Bird and its Haunts._-"Virginia's Warbler was discovered at Cantonment Burgwyn in New Mexico, by Dr. W. W. Anderson, and first described, in 1860 , by Professor Baird who dedicated it to the wife of the discoverer. The type specimen remained unique until 1864, when the present writer took a second example at Fort Whipple, on the fifteenth of August; this was a young bird very likely bred in the vicinity. Shortly afterward, 1869, Mr. Ridgway ascertained that the bird was abundant in the East Humboldt and Wahsatch Mountains, where it was breeding in thickets of scrub oak. ***

"Mr. C. E. Aiken shortly afterward extended the known range of the species to include the eastern foothills of the Rocky Mountains in Colorado, where it breeds. This excellent observer found it in various parts of the State, but especially along the eastern base of the mountains, where, in its favorite haunts, it sometimes outnumbers all other Warblers put together. It is a shy and timid species, generally darting, with its sharp note of alarm, into its place of concealment when approached. In summer it frequents the scrub of the hillsides, at any elevation up to about 7,500 feet, but during the migrations it is found indifferently in the pine forests and among the cottonwoods and willows along the streams." (Coues.)

"This species is quite common in the pine regions throughout Arizona, but I have not seen it at a lower elevation than 5,000 feet. Unlike other Warblers in this section, they keep almost entirely in the underbrush, where they are continually on the move and at the same time uttering a quick chirp as if in distress." (Howard ${ }^{2}$.)

Song.- "The male is very musical during the nesting season, uttering his swee ditty continually as he skips through the bushes in 
search of his morning repast; or having satisfied his appetite, he mounts to the top of some tree in the neighborhood of his nest, and repeats at regular intervals a song of remarkable fullness for a bird of such minute proportions." (Aiken.)

"Ordinary note, a sharp chip; song simple but various (deceptively so); common forms are che'-we-che'-we-che'-we-che'-we,-wit-awit-wit-wit (these terminal notes being partially characteristic of Helminthophag(e) and che-we'-che-we'-che-zere'-che'-a-che'-ache'." (Minot. ${ }^{3}$ )

Nesting Site.-Nests found by Howard and Judson were on the ground under a bush or bunch of grass. A nest found by W. G. Smith at Estes Park, Colorado, was "under a rocky ledge, sunken in the ground and well hidden." (C.W.C.)

Nest.-Nests collected by Howard" were made of "fine straws, rootlets and fibers, loosely put together."

Eggs.-4 or 5, rarely 5. Ground color white lightly wreathed around the larger end with specks and spots of reddish and purplish brown, a few scattering specks of the same colors over rest of egg. Size; average, .66x.49. A set of four, from Estes Park, Colorado, show very regular measurements: .66x.49, .66x.49, .66x.50 and $.67 \times .49$. (Figs. 21,22.)

Nesting Dates.-Arizona, May I7 (Judson); Estes Park, Colo., June $20(C . W . C$.$) .$

\section{Biographical References}

(I) W. B. Judson, Nesting of Virginia's Warbler, Osprey, III, 1898, 54. (2) C. W. Howard, Summer Resident Warblers of Arizona, Bull. Cooper Orn. Club (=Condor), I, I899, 63. (3) H. D. Minot, Notes on Colorado Birds, Bull. Nutt. Orn. Club, V, 1880, 226.

\section{LUCY'S WARBLER \\ VERMIVORA LUCIE (Cooper) Plate VI}

Distinguishing Characters.-General color gray, crown-patch and upper tail-coverts chestnut. Length (skin), 3.80 ; wing, 2.20 ; tail, 1.65; bill, .38.

Adult of, Spring.-Crown largely chestnut with more or less pronounced gray tips which wear off in the breeding season; back gray; upper tail-coverts chestnut; tail fuscous, outer feathers with a dull white patch, white sometimes extending to margin of inner vane of second feather; wings gray, no white bars; cheeks and underparts dusky white more or less tinged with buff.

Adult o", Fall.-Similar to last "but above tinged with brown, the chestnut crown-patch concealed by very broad brownish gray tips to the feathers; underparts pale brownish buff, becoming white, or nearly so, on the abdomen" (Ridgw.).

Young d, Fall.-Not seen. 
Adult 9 , Spring.-Similar to adult $\delta$ in Spring but with the chestnut of crown and tail-coverts averaging paler in color and less in extent.

Adult + , Fall.-Not seen.

Young , F Fall. - Not seen.

Nestling.-No crown-patch; crown and back brownish gray; upper taicoverts cinnamon; wing-coverts and tertials edged with cinnamon; below white washed with buffy.

General Distrbution.-Western United States, breeds commonly in Arizona and rarely north to the lower Santa Clara Valley, southwestern Utah. Winters in northwestern Mexico.

Migration.-Its arrival in Arizona was noted at Fort Lowell, March 20, I902; Oracle, April 1, 1899; Fort Mojave, March 25; Whipple Barracks, March 31, I892, and in the Huachuca Mountains, April 8, I902.

The Bird and its Haunts. - The restricted range of this species has brought it within the field experience of comparatively few ornithologists. Discovered by J. G. Cooper at Fort Mojave, Arizona, March 25, I86I, where it was not uncommon in the mesquite chaparral, it was taken two years later by Holden and in April, 1865, was found by Coues at Fort Whipple.

The nest was first found by Bendire at Tucson, Arizona, on May 19, 1872, additional examples being discovered by Stephens, as recorded by Brewster ${ }^{1}$, at the same locality nine years later.

Coues described the Lucy's Warblers which came under hi: observation as "rather timid, retiring birds, likely to be long overlooked in the thickets and copses to which they seem to be much attached." Stephens, however, states that "although active and restless they were not at all shy." He adds that "they were more abundant among the mesquites than any other species and their tseeping could be heard on every side. They were continually in motion, flying from tree to tree, and occasionally visiting some low brush in the vicinity."

Howard ${ }^{2}$ writes that Lucy's Warbler is fairly common along the river bottoms throughout southern Arizona, especially in the mesquite and willow thickets.

Song.-The song of Lucy's Warbler does not appear to have been described.

Nesting Site.-Recording Stephens' observations on the nesting habits of this Warbler in Arizona, Brewster ${ }^{1}$ states that the site was "variable; the characteristic place, like that of the specimen discovered by Captain Bendire, was behind the loosened bark of a large tree, but use was frequently made of old Woodpecker's nests, knot-holes, and in short, all sorts of crevices." One pair appropri- 
ated a deserted Verdin's nest using it without apparent repairs or alterations. Howard" records a similar instance and adds: "most of the nests were in mesquite trees, in natural cavities or behind pieces of loose bark, ranging in height from two to twenty feet, but, as a rule, they are within easy reach."

Nest._."The nests are very frail affairs and are made of fine straws, vegetable fibers and leaves, with a lining of feathers and hair." (Howard".)

Eggs. -3 to 5 , usually 3 or 4 . Ground color white, handsomely wreathed around the large end with specks, spots, and small blotches of reddish brown, umber, and lavender; in some cases the markings are sparingly distributed over all the egg, the rule, however, is a well-defined wreath around the large end. Probably averaging the smallest of North American Warblers' eggs. Size; average, .59x.44; extremes, .6Ix.45, .56x.43. (Figs. I8-20.)

Nesting Dates.-Phoenix, Ariz., April 19 (C.W. C); Tucson, Ariz., April 28-June II (Stephens).

\section{BIOGRAPHiCAL ReFERENCES}

(1) WM. Brewster. On a Collection of Birds lately made by Mr. F. Stephens in Arizona, Bull. Nutt. Orn. Club, VII, I882, 82. (2) O. W. Howard. Summer Resident Warblers of Arizona, Bull. Cooper Orn. Club, (=Condor), I, I899, 37.

\section{Genus COMPSOTHLYPIS Cabanis}

Our two species of this genus are small bluish birds with a short, wedge-shaped, sharply pointed, slightly curved, unnotched bill, of which the upper mandible is blackish, the lower, whitish; the rictal bristles are short but evident; the wing is about .70 inches longer than the tail and has the four outer primaries of nearly equal length, the tail-feathers are narrow and of about equal length, the outer ones being conspicuously marked with white; the feet are dark, the tarsus is much longer than the middle toe and nail, the hind toe-nail is nearly as long as the toe.

Compsothlypis contains three species, C. graysoni of Socorro Island, Mexico, C. pitiayumi, ranging from Brazil to the Lower Rio Grande and separated into half a dozen geographical races, of which our $C$. nigrilora is the most northern, and $C$. americana of the eastern United States. 'moss.'

Our species nest in hanging bunches of Usnea or Tillandsia 


\section{Southern Parula Warbler}

\section{COMPSOTHLYPIS AMERICAN AMERICANA (Linn.)}

Subspecific Characters-Similar to $C$. a. usnee but with less black about the lores, throat in $\delta$ with more yellow, the blackish throat band very narrow or poorly defined; $q$ not distinguishable from $q$ of usnece. Smaller and with a slightly larger bill than usnece from the North Atlantic States; larger than specimens of usnece from the lower Mississippi valley and Texas. Wing, 2.25; tail, 1.6o; bill, .38.

General Distribution.-Southeastern United States.

Summer Range.-Southeastern Atlantic and eastern Gulf states west along the coast region to Alabama; north to southern New York. Ridgway refers to this form occasional specimens from as far north as Sing Sing and Shelter Island, N. Y., and even Cape Cod, Mass., and as far west as Mount Carmel, Ills., and Rockwood, Tenn. A breeding bird from Cæsar's Head in the mountains of western North Carolina is typical americana. The form as fully developed, is frequently Austroriparian, specimens from the Carolinian fauna being largely intermediate between it and usnece.

Winter Range.-Central Florida south to the West Indies.

The Bird and its Haunts.-About March $\mathrm{I}$, in northern Florida, when the blossoming cypress, maple and red-bud announce the coming of spring the quaint sizzling trill of the newly arrived Parula Warbler is one of the most characteristic bird voices of the season. Possibly among these migrants there may be representatives of the more northern form of this bird, but if the singer's drowsy little lay appeals to you as it does to me you will not stop to inquire the exact shade of his coat but will greet him as the author of one of the most welcome bits of bird music in the Florida spring.

The abundance of the Spanish 'moss' (Tillandsia) in which this southern Parula nests is accountable for its being a more common and uniformly distributed bird than is the northern Parula. When migrating it is often found feeding amid the blossoms of the cypress, while the quantity of 'moss' usually pendant from these water-loving trees makes them a favorite summer home. The Parula also frequents the deciduous 'hammocks' but not, so far as I have observed, the pines.

Song.-I am unable to say whether there is any difference in the song of the Northern and Southern Parulas but I imagine that the quaint, attractive, little gurgling sizzle chip-er, chip-er chip-er, chee$e e-e e-e e$, which is first heard in Florida about March I, is uttered by the southern form, though I do not detect in its notes any difference from those of the northern bird. 
Nesting Site.-Although specimens of Compsothlypis from Mississippi are nearer usnece than americana, the following description of their nest and its site is more applicable to the later than to the former. "The invariable nesting site is a clump of Spanish moss -where this is to be had; I have not observed nests from beyond the range of this plant. The nest is generally placed near the branch from which the long filaments of the 'moss' depend, so that it is well concealed. The height from the ground varies from about eight feet upwards. The site is not used a second year; whether for a second brood or not, I cannot say.

Nest.-The nest is nearly hemispherical in shape, opening directly upward. The usual material, in lower Louisiana, is thistle-down, which is abundant during the nesting season. Animal hairs are not used, I think. A nest from Bay St. Louis was composed of the very black horse-hair-like inner fiber resulting from the decay of Tillandsia." (Allison, MS.)

Eggs. -3 to 5, usually 4. Ground color white to creamy white, somewhat glossy, marked with reddish brown, chestnut, and grayish tints, tending to form a wreath around the large end; the markings are coarse and well-defined. These eggs vary in size and shape to a marked degree. Size; average, .67x.48. Two extreme sets of 4 eggs each measure $.75 \times .50, .76 \times .50, .77 \times .50$ and $.65 \times .47, .61 \times .44, .64 \times .46$. (Figs. 3I,32.)

Nesting Dates.-Bay St. Louis, Miss., May 8, young about ready to leave nest-August newly fledged young (Allison). (Doubtless referable to C. usnece); Mt. Pleasant, S. C., April I5 (Wayne).

\section{NORTHERN PARUla WARBLER}

\section{COMPSOTHLYPIS AMERICANA USNEA (Brewst.) Plate VIII}

Distinguishing Characters.-General color above bluish, center of back yellowish; two conspicuous white wing-bars. Length (skin), 4.00; wing, 2.40; tail, 1.65 ; bill, .38.

Adult of, Spring.-Upperparts grayish blue, center of back yellowish green; lores black, eye-ring with a white spot above and another below the eye; tail edged with bluish, outer two or three feathers with a white patch on the inner web near the tip; wings edged with bluish, median and greater coverts broadly tipped with white; sides of the throat grayish blue much restricting the browntinged yellow of chin and upper throat, lower throat with a more or less welldefined band of bluish black often tinged with brownish and tipped with yellow, this bordered posteriorly by a less well-defined brown, yellow-tipped area which, in turn, is bordered by clear yellow; belly white the sides grayish, often with more or less brownish chestnut. 

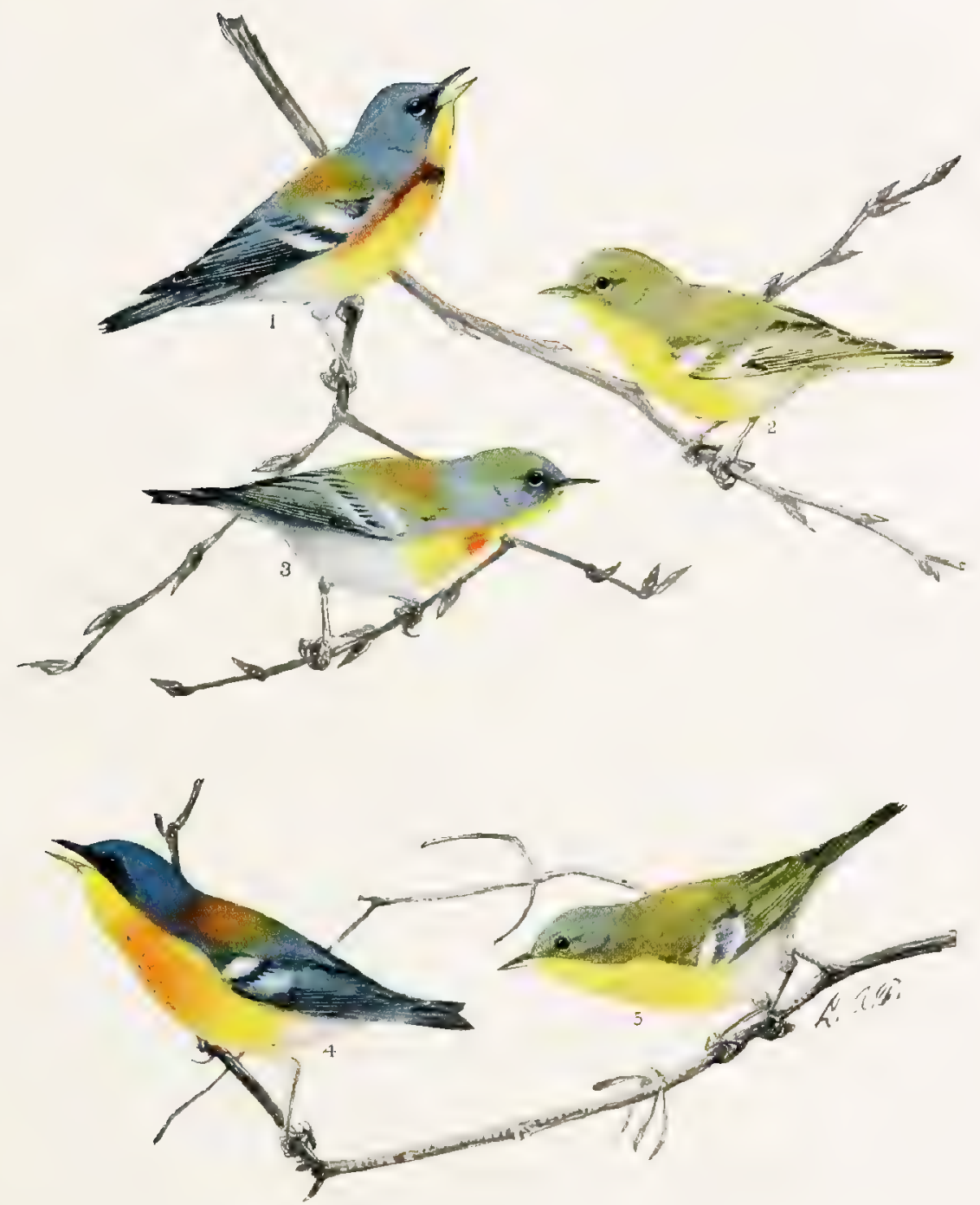

1. Parula Warbler, adult Mare.

3. Parula Warbler, Adult female.

2. Parula Warblek, Young Female.

4. Sennett's Warblek, Adult Male.

5. Sennett's Warbler, Adult Female.

(ONE-HALF NATURAL SIZE.) 


$$
+
$$


Adult d, Fall.-Similar to adult $\delta$ in Spring but blue areas more or less tipped with greenish, the throat bands with yellow; more white about the eyes and lores.

Young $\delta^{*}$, Fall.-Similar to adult $\delta$ in Fall but with the blue areas still more heavily tipped with greenish, the blackish throat band less pronounced or absent.

Adult ㅇ, Spring.-Similar to adult $\sigma^{*}$ in Spring but blue areas duller and with more or less greenish wash; blackish throat-band usually absent, brown breast-band much reduced, paler, or absent; sides grayish usually without chestnut.

Adult $q$, Fall.-Similar to adult $q$ in Spring but blue areas greener, the breast with still less brown.

Young 9, Fall.-Similar to adult $q$ in Fall but with no brown on breast.

Nestling.-Above brownish gray with a tinge of green; below grayish white; two white wing-bars.

General Distribution.-Eastern Texas, Mississippi Valley, and north Atlantic States.

Summer Range.-Gulf States east to Alabama, Mississippi Valley as far west, casually, as eastern Nebraska (Havelock, April zo, I9oI), South Dakota (Black Hills), Wyoming (Cheyenne, May 30, I888), Colorado (Fountain, May II, I870) ; north to northern Wisconsin, northeastern Minnesota (St. Louis Co.,), Michigan (Spectacle Reef); east through central Ontario (Ottawa, Algonquin Park), Prince Edward Island, New Brunswick (rare or local), Nova Scotia, northern Maine; south to southern New England and casually further and along the Alleghenies to North Carolina.

The apparent derivation of the New England birds from the Mississippi Valley is paralleled by the distribution of Geothlypis trichas trichas.

Winter Range.-Mexico and Central America.

Spring Migration.-Records from the South Atlantic States doubtless relate to both the southern Parula (Compsothlypis americana americana) and the northern Parula (C. a. usnece); those from the northern States and Mississippi Valley to the northern Parula only.

\begin{tabular}{|c|c|c|c|}
\hline PLACE & 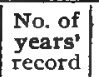 & $\begin{array}{l}\text { Average date of } \\
\text { spring arrival }\end{array}$ & $\begin{array}{l}\text { Earliest date of } \\
\text { spring arrival }\end{array}$ \\
\hline 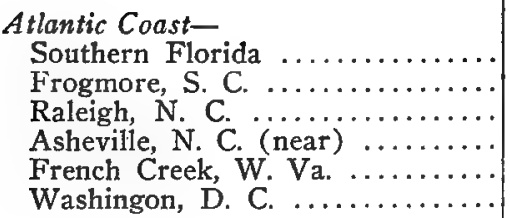 & $\begin{array}{r}3 \\
4 \\
13 \\
5 \\
4 \\
8\end{array}$ & $\begin{array}{lr}\text { March } 5 \\
\text { March } 23 \\
\text { April } 8 \\
\text { April } 15 \\
\text { April } 22 \\
\text { April } 25\end{array}$ & $\begin{array}{ll}\text { March } & \text { 3, } \\
\text { March 5, } & \text { I889 } \\
\text { April 1, } 1889 \\
\text { April 9, } 1893 \\
\text { April I9, } 1893 \\
\text { April I9, } 1891\end{array}$ \\
\hline
\end{tabular}




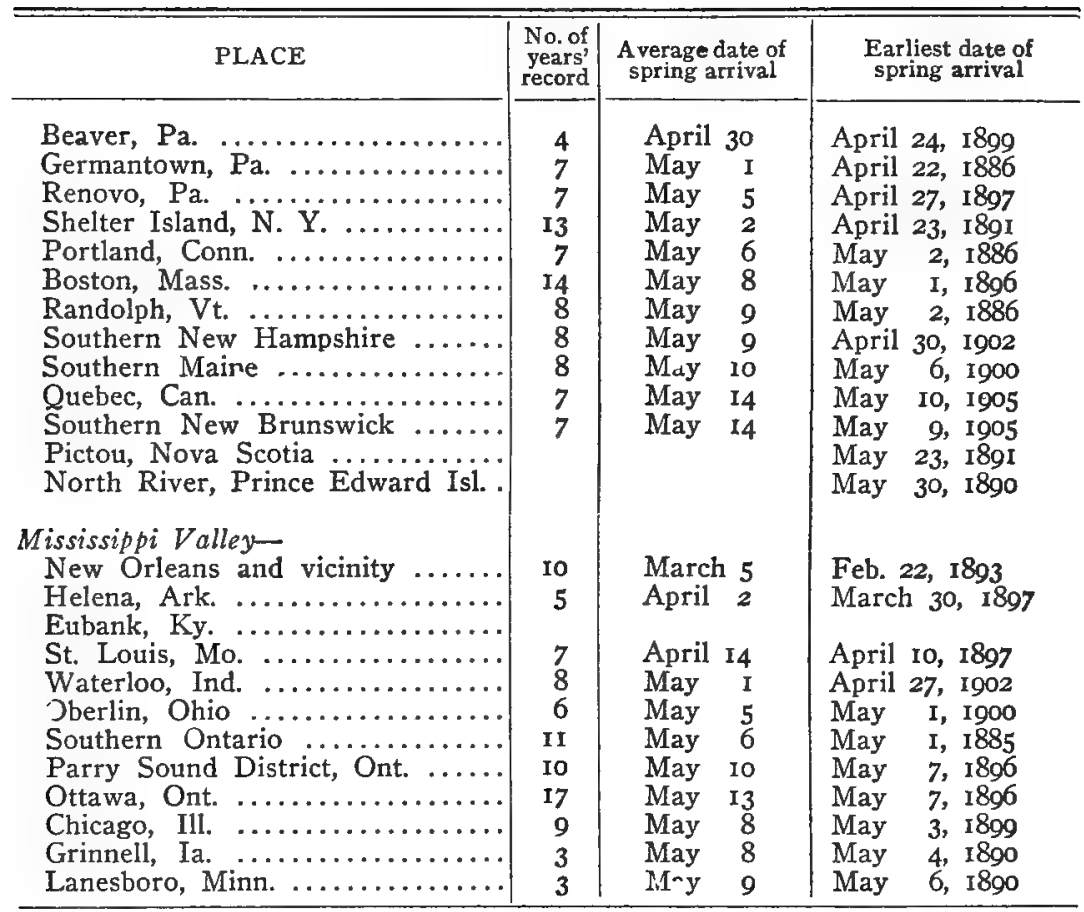

\section{Fall Migration.-}

\begin{tabular}{|c|c|c|c|}
\hline PLACE & $\begin{array}{l}\text { No. of } \\
\text { years' }\end{array}$ & $\begin{array}{l}\text { Average date of } \\
\text { last one seen }\end{array}$ & $\begin{array}{l}\text { Latest date of last } \\
\text { one seen }\end{array}$ \\
\hline 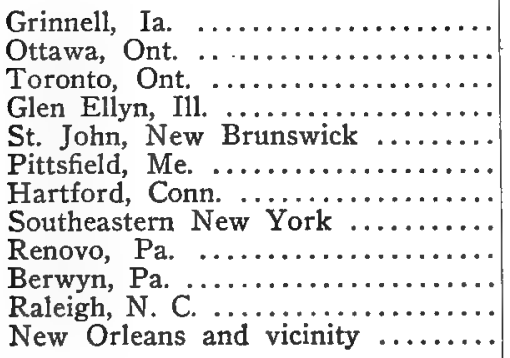 & $\begin{array}{l}3 \\
3 \\
2 \\
\\
4 \\
3 \\
4 \\
5 \\
5 \\
9 \\
4\end{array}$ & $\begin{array}{l}\text { September } 20 \\
\text { September } 11 \\
\text { September } 28 \\
\text { September } 24 \\
\text { October I3 } \\
\text { October } 7 \\
\text { October } 8 \\
\text { October } 15 \\
\text { October 10 } \\
\text { October } 18\end{array}$ & $\begin{array}{l}\text { September 21, } 1887 \\
\text { September 13, } 1889 \\
\text { September } 28,1898 \\
\text { October 1, 1897 } \\
\text { September } 17,1889 \\
\text { September 30, 1898 } \\
\text { October 20, 1900 } \\
\text { October 12, 1891 } \\
\text { October 12, 1901 } \\
\text { October 31, 1893 } \\
\text { October 14, 1890 } \\
\text { October 26, } 1890\end{array}$ \\
\hline
\end{tabular}

The Bird and its Haunts.- During its migration this is a generally distributed species preferring, however, deciduous to coniferous trees-except as it visits cypresses-but when settled for the summer we may look for it only where the usnea moss grows in which it builds its nest. 
Although this moss is parasitic on many kinds of trees and bushes, it requires a moist, humid atmosphere and, in consequence, our Warbler makes its home in wet, swampy places. The restriction of the moss to comparatively limited areas often induces a number of pairs of Parulas to nest near one another. Rawson ${ }^{5}$ mentions a swamp near Norwich, Connecticut, containing seventy-five pairs.

Some difficulty may be experienced in identifying fall specimens, but in the spring the Parula is unquestionably a blue bird and as such likely to be confused with few other Warblers. Furthermore, its conspicuous wing-bars allied to its small size and chickadee-like (hence the name Parula, a diminutive of Parus, a titmouse) habit of feeding while hanging back downward, are good field characters.

Gerald Thayer writes that the Parula is "common about the base of Mt. Monadnock in woodland bogs where the trees-firs and spruces and red maples, etc.,-are thickly hung with usnea moss. But we have also found several pairs of breeding Parulas in drier virgin woods and old second growth where usnea was rare. The only nest I have seen was in an usnea swamp, about twenty feet up in a bearded, scrawny, two-thirds-dead fir balsam. It was not only made of usnea, but made of a long, free-hanging usnea beard looped up and spliced onto itself, thus forming a suspended basket-nest with a roof,--and a small side entrance. It was big for the size of the birds, and suggested a European Long-tailed Tit's nest. In certain views from the ground, it showed globose and dark against the sky. The three eggs lay on a scanty bed of wild cherry stems-the only 'imported' building material the nest contained.

"The Parula is less nervous in its movements than most of our Warblers, and it is also among the tamest of them. Its 'beat' lies between the forest under-scrub and the tops of all but the very highest trees. A blue-gray, black-cheeked Warbler, with conspicuous white wing-marks, much white in the tail, and a transverse dusky smudge, sometimes partly reddish brown, on its yellow breast-such is the adult male Parula. His greenish yellow saddle being almost of one shade with the encompassing blue-gray, is very inconspicuous in life." (Thayer, $M S$.)

Song.- "The Parula is weak-voiced, and its call notes, as far as I know, are slight and barely peculiar; but it has at least three main songs, with a great range of variations. All may be recognized, or at least distinguished from the weak songs of the Dendroice, like the Blackburnian and Bay-breast, by their beady, buzzy tone. In phrasing, in everything but this tone-quality, certain variations of the Parula's 
and of the Blackburnian's songs very nearly meet and overlap: but the tell-tale tones remains unchanged,--wheezy and beady in the one, smooth as glass in the other. Commonest of the Northern Parula's three main songs is probably the short, unbroken buzz, uttered on an evenly-ascending scale, and ending abruptly, with a slight accentuation of the final note. Next is that which begins with several notes of the same beady character, but clearly separated, and finishes, likewise on an ascending scale, with a brief congested buzz. The third main song is based on an inversion of the second-a buzz followed by a few separate drawled notes, high-pitched like the buzz-ending of the two other songs. All three vary and intervary perplexingly." (Thayer, $M S$.) Miss Paddock describes the Parula's song as "a rapid trill ending explosively" and writes it as follows:

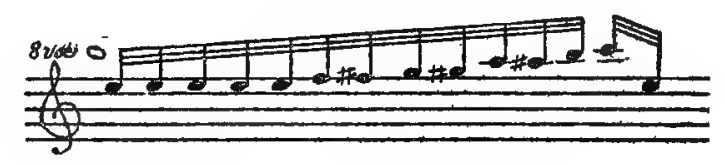

Nesting Site.-In a hanging bunch of usnea moss from three to thirty or more feet above the ground; more rarely "at the end of a drooping spruce branch" ( $\operatorname{Jacobs}^{9}$.)

Nest.-As a rule, the bird selects a favorable bunch of moss, gathers or weaves the bottom together, lines it scantily, or not at all, with fine grasses and forms an entrance at one side. Brewster ${ }^{6}$, however, describes a nest taken at Stoneham, Mass., which in shape and manner of attachment resembled a Baltimore Oriole's nest. No bunches of Usnea large enough for use in the usual manner, being available, the builder had apparently gathered bits of the moss here and there with which to construct a home.

A nest found by $\mathrm{Jacobs}^{\theta}$, at Blacksville, West Virginia, appears to differ from the usual type. It was "well concealed among twigs at the end of a drooping spruce branch, nine feet up. *** The composition was chiefly of fine grasses, with a slight mixture of Usnea moss, vegetable fiber, and small bits of wool." A second nest, similarly placed, resembled the first but "contained a goodly supply of hickory catkins and hair, as well as some fine rootlets in the lining."

Eggs.-The eggs resemble those of the Southern Parula.

Nesting Dates.--New Haven, Conn., May I8-June I4 (Bishop);

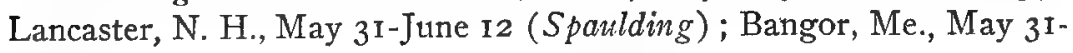


June 17 (Knight); Ann Arbor, Mich. (near), May I2 (Wood); Becker Co., Minn., May 28 (C. W. C.)

\section{BIOGRAPHICAL REFERENCES}

(I) T. M. BreWER, Am. Nat., I, I867, I17; XVII, I875, 439. (2) TRIPPE, Am. Nat., II, I868, I77. (3) W. W. Worthington, Blue Yellow-backed Warbler Nesting on Shelter Island, Orn. and Oöl., VI, I88I, 62. (4) C. H. Andros, The Blue Yellow-backed Warbler, Orn. and Oöl., IX, 1884, I47. (5) J. M. W. [ $=$ C. L. Rawson], Norwich, Conn., The Parula Warbler-Its Nest and Eggs, Orn. and Oöl., XIII, I888, I. (6) WM. BREWSTER, An Unusual Nest of the Parula Warbler, Orn. and Oöl., XIII, I888, 46. (7) J. H. Bowles, Notes on the Parula Warbler, Nidologist, II, I895, 63. (8) M. L. C. WILDE, Nesting of the Parula Warbler (Compsothlypis americana) in Cape May County, New Jersey, Auk, XIV, 1897, 289. (9) J. W. JACOBS, Some Notes on the Summer Birds of Monongalia Co., West Virginia, Gleanings, (published by author at Waynesburg, Pa.), IV, 9.

\section{SENNETT'S WARBLER}

\section{COMPSOTHLYPIS PITIAYUMI NIGRILORA (Coues) Plate VIII}

Distinguishing Characters.-Similar to Compsothlypis a. americana but cheeks black; underparts yellow becoming white on the lower belly; breast tinged with orange brown and without black; no white about eye; sides of throat, at junction of yellow and black, with traces of white. Length (skin), 3.90; wing, 2.00; tail, I.50; bill, .38.

General Distribution.-Breeds in Northeastern Mexico and along the lower Rio Grande in Texas. It winters in Mexico and has been taken the last week of February, I880, on the Rio Grande near Hidalgo.

The Bird and its Haunts.-At the time of its discovery by $\mathrm{Mr}$. Sennett in the Rio Grande Valley, this bird was supposed to be a distinct species; it proves, however, to be the most northern representative of a form of Parula Warbler which ranges over the greater part of South America and northward through Central America and Mexico to the lower Rio Grande. There it evidently resembles our Southern Parula in habits, living, Merrill ${ }^{3}$ says, "among thick woods and near the edges of lagoons where there is Spanish moss."

Nesting Site.-Merrill ${ }^{2}$ found a nest near Brownsville, Texas, eight feet from the ground in a bunch of Spanish 'moss.' Sennett ${ }^{1}$ records one from Lomita, on the Rio Grande, which was placed in a "mistletoe-like orchid" ten fect from the ground.

Nest.-Merrill's nest evidently resembles that of the Parula Warbler in the southern states, being constructed in the Spanish moss and lined with a few horse-hairs. Sennett describes his nest as "con 
structed very simply, being formed by parting the gray leaves of the orchid and digging into its center from the side, a cavity of some two inches in diameter being made with an opening of one-and-a-quarter inches. The bottom and sides are lined pretty well up with short cottony wood fibers, forming a fine matting for the eggs to rest upon." The identity of this nest, however, does not seem to have been satisfactorily established.

Eggs.-Similar to those of the Parula Warbler.

Nesting Dates.-Brownesville, Texas, July 5, nest with three young (Merrill); Lomita, Texas, May I7, nest with one egg (Sennett).

\section{BIOGRAPHICAL REFERENCES}

(I) G. B. Sennetr, Bull. U. S. Geol. and Geog. Surv. Terr., IV, 1878, 12. (2) Ibid., V, I897, 384 . (3) J. C. MerRILL, Notes on the Ornithology of Southern Texas, etc., Proc. U. S. Nat. Mus., I, I878, 123.

\section{Genus PEUCEDRAMUS Coues}

The single species contained in this genus has, by most authors, been placed under Dendroica, but it obviously has as much claim to generic distinction as several other Warblers which are conceded that rank and I follow Mr. Ridgway in recognizing Peucedramus as generically separable from Dendroica. From Dendroica it differs chiefly in its slenderer, more rounded bill, proportionately longer wings (about I.00 inch longer than the tail) and decidedly forked tail, the central tail-feathers being more than .25 inches shorter than the outer ones.

In general color and pattern of coloration Peucedramus is markedly unlike Dendroica, from all the species of which the male differs in requiring two years to acquire adult plumage.

\section{OLIVE WARBLER}

\section{PEUCEDRAMUS OLIVACEUS (Girand) Plate VI}

Distinguishing Characters.-Outer vane of outer tail-feather in part white; adult $\delta$ with whole head and neck orange-brown, a broad black band through the eye; young $\delta$ and $q$ with the same parts yellowish, a dusky eye-band. Length (skin), 4.90; wing, 3.00 ; tail, 2.00 ; bill, .45.

Adult 3 ', Spring.-Head, neck and breast orange-brown, a broad black band through the eye; back grayish olive-green; tail black, the other pair of feathers white on both webs except at the end, the next pair narrowly white on the outer web and largely white on the inner web, the third usually with some white on the inner web; wings black, narrowly edged with olive-green: 
fourth to seventh primaries white on outer web at base, greater and median coverts broadly tipped with white; center of belly white, sides gray.

Adult of, Fall.-Similar to adult $\delta$ in Spring but head and neck duller, back more olive, sides browner.

Young o, Fall.-Not distinguishable from young $q$ in Fall.

Young d", Spring.-Not distinguishable in color from adult $q$ in Spring, the adult plumage evidently not being acquired until the second Fall, at least.

Adult \&, Spring.-Crown and nape dull olive-yellow, a broad dusky band through the eye; back olive-gray; basal half of outer web of outer tail-feather white, inner web largely white, next feather sometimes with white on the inner web; wings as in $\delta$ but white areas smaller; throat and breast dull yellowish; belly white, sides gray.

Adult \&, Fall.-Similar to adult $q$ in Spring but crown tipped with grayish, the throat and breast with buffy, the sides, with brownish; white tips to greater wing-coverts with some yellowish.

Young $q$, Fall.-Similar to adult $q$ in Fall but crown and nape grayer; ear-coverts duskier, throat and breast paler.

Nestling.-Above dusky olive-brown, a buffy postocular mark passes behind the auriculars to the side of the throat; greater wing-coverts tipped with yellowish, median coverts, with white; throat and breast buffy or pale greenish; belly white, sides brownish gray.

General Distribution.-Breeds from Guatemala north to southern Arizona. Winters in the highlands of Mexico and Guatemala. A few may winter in southern Arizona, as one was taken there February 21 .

Migration.-The arrival of the first was noted April 6, 1902, in the Huachuca Mountains, Arizona.

The Bird and its Haunts.-This species was first definitely recorded from the United States by $\mathrm{H}$. W. Henshaw who secured three specimens, on Mt. Graham, Arizona, in September, I874. In March, I880, Stephens, as quoted by $B^{2}$, ${ }^{2}{ }^{1}$, found it apparently not uncommon in the Chiricahua Mountains, where, fourteen years later, Price ${ }^{2}$ first discovered it nesting. Three nests were subsequently taken by Howard ${ }^{3}$ in the Huachuca Mountains, making a total of four which have thus far been recorded.

The Olive Warbler is a bird of open pine forests where in general habits it reminds one strongly of the Pine Warbler. During the last week in April, I897, I found it to be an abundant inhabitant of the pines at Las Vigas, in the state of Vera Cruz, Mexico, at an altitude of 8,000 feet. Young of the year were already on the wing. It fed leisurely among the terminal branches creeping or hopping along the twigs without displaying the activity of the fluttering Warblers. Occasionally it descended to the ground for food, but I do not recall seeing it cling to the trunk of a tree as a Pine Warbler does at times. 
Song.- "A liquid, quirt, quirt, quirt, in a descending scale." (Price ${ }^{2}$ ). The call-note of the Olive Warbler as I heard at Las Vigas, Vera Cruz, Mexico, late in April when the birds were feeding young out of the nest, is a rapid whistled peto closely resembling the call of the Tufted Titmouse.

Nesting Site.-Our knowledge of the nesting habits of this species is based on the studies of Price and Howard in the mountains of southern Arizona, where four nests have been found in pines saddled on a limb from thirty to fifty feet from the ground, and in a red fir in the fork of a large limb about thirty feet up.

Nest.- "The nests are very beautiful affairs and are built very much like those of the Blue-gray Gnatcatcher, and are composed of bits of moss, lichens, fir blossoms and spider webs with a lining of fine rootlets." (Howard ${ }^{3}$.)

Eggs.-4. "The eggs are ovate in shape, the shell is fine grained and without lustre. The ground color is sage green and the eggs are heavily blotched and spotted, especially about the larger end, with clove and sepia brown, and lighter shades of drab and olive gray. They bear no resemblance to the known eggs of any of our Warblers. They measure .65x.49, .65x.49, .65x.48, .63x.48." (Price.) (Figs. 37,38, Childs Coll.)

Nesting Date.-Huachuca Mts., Arizona, June I2 (Howard).

\section{BIOGRapHical References}

(I) Wm. Brewster, On a Collection of Birds lately made by Mr. F. Stephens in Arizona, Bull. Nutt. Orn. Club, VII, I882, I35. (2) W. W. PrICE, Nest and Eggs of the Olive Warbler, Auk, XII, I895, I7. (3) O. W. Howard, Summer Resident Warblers of Arizona, Bull. Cooper Orn. Club (=Condor), I, $1899,37$.

\section{Genus DENDROICA Gray}

This, the largest genus of the family, contains the true Wood Warblers. Among so many species there is, as might be expected, much variation and the extremes in Dendroica, could one dispose of the intermediates, might readily be placed in different genera. As a whole, however, Dendroica may be known by its comparatively short (except in $D$. dominica) rounded, notched bill with slightly curved culmen, and short, but evident rictal bristles. The wing is generally less than .80 inches longer than the tail; the four outer primaries are of about equal length. The tarsus is longer than the middle toe and nail, the nail of the hind-toe is nearly as long as the toe. 
Plate IX

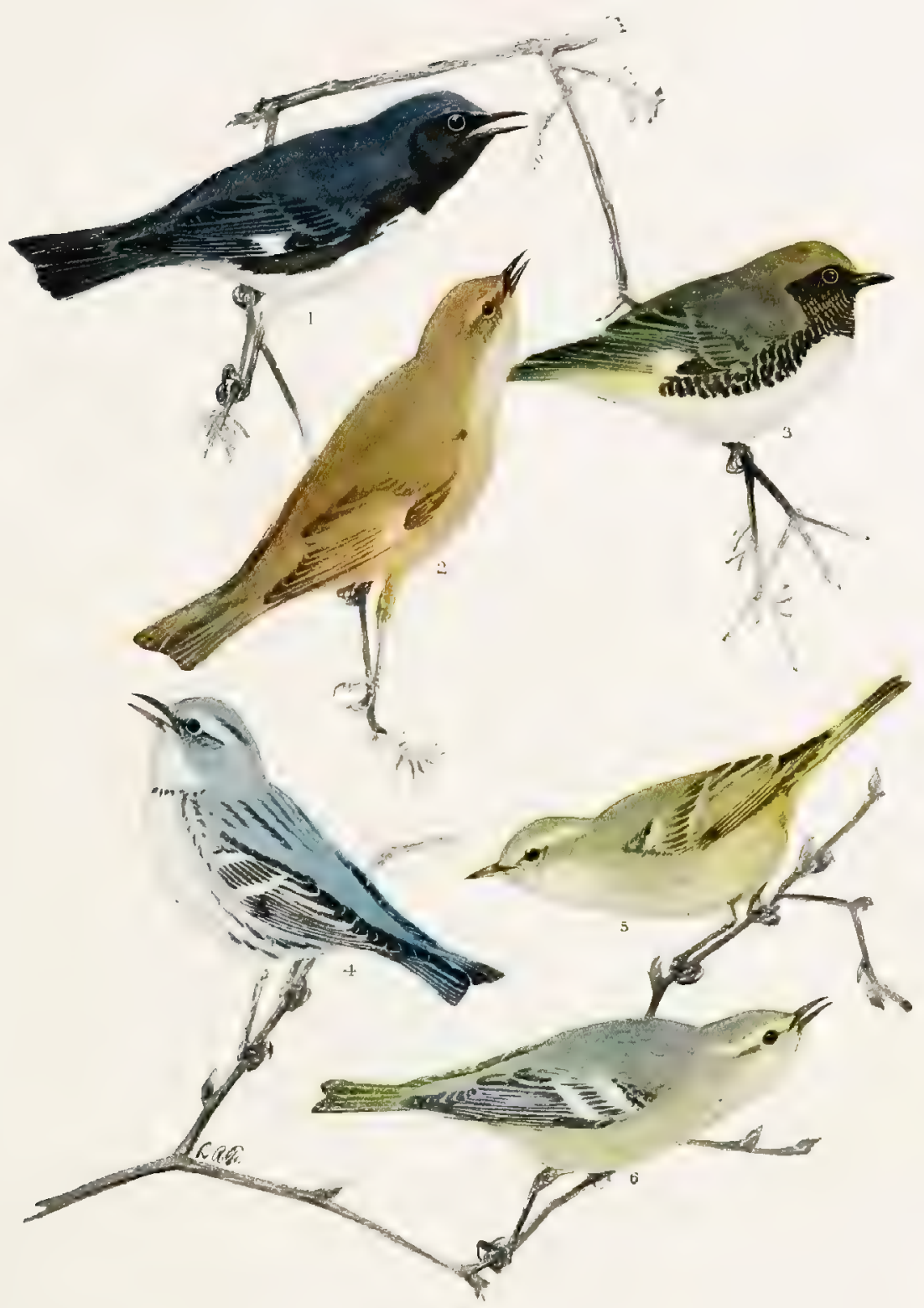

1. Black-throated Blue Warbler, Adult Male,

4. Cerulean Warbler, Adult Male.

2. Black-throated Blue Warbleir, Auult Female

5. Cerulean Warblek, Adult Female.

3. Black-throated Blue Warbler, Young Male.

6. Cerulean Warbier, Young Male. (ONE-HALF NATURAL SIZE.) 
. 
There is no pronounced type of color in Dendroica but nearly all the species have wing-bars and all have white patches in the tail, except $D$. estiva and its allies which have the tail marked with yellow. As a rule, the sexes are unlike in color but in dominica, gracie, kirtlandi, and discolor there is little sexual difference in plumage and in palmarum the sexes cannot be distinguished with certainty.

All but kirtlandi and palmarum nest in trees or bushes, these two species alone nesting on the ground; a habit which may account for the strong brown or gray tone of their dorsal plumage.

Dendroica contains some thirty-four species of which twentythree enter our limits, the remainder inhabiting Mexico, Central America, and chiefly, the West Indies. Eastern North America has by far the larger number of these brightly colored birds, no less than fifteen of the twenty-three species occurring in the Atlantic States but not in the Pacific States.

Six species are western, and only one, D. astiva, ( which in its more or less closely related forms is found wherever Dendroica occurs) ranges from the Atlantic to the Pacific.

\section{YELLOW WARBLER \\ DENDROICA FSTIVA ÆSTIVA (Gmel.) Plate I}

Distinguishing Characters-A yellow bird; no white anywhere, inner webs of nearly all the tail-feathers largely yellow. Young females are obscure olive birds but may be known by the yellow tail markings. Length (skin), 4.60; wing, 2.45 ; tail, I.90; bill, .40.

Adult do, Spring.-Crown rich golden yellow sometimes with traces of reddish brown; back greenish yellow, rump yellower; tail blackish margined with yellow, inner webs of all but central feathers yellow, except at tip; wings blackish edged with yellow, the coverts widely margined with yellow; underparts rich golden yellow, breast and sides conspicuously streaked with reddish brown.

Adult d, Fall.-Resembling adult $\sigma^{*}$ in Spring but crown but little brighter than back, underparts less heavily streaked, the streaks at times wholly absent.

Young d, Fall.-Resembling adult $\delta$ in Fall but without streaks below.

Adult \&, Spring.-Much less yellow than $\delta^{*}$; above yellowish olive-green, upper tail-coverts brighter; tail-feathers with yellow on inner webs as in $\sigma^{\prime \prime}$; wings margined with yellow; below uniform yellow with few if any streaks.

Adult \%, Fall.-Not distinguishable from young of in Fall.

Young , Fall.-Less yellow above than adult $P$ in Fall, only two or three outer tail-feathers with yellow on inner web; underparts pale dusky yellow, unstreaked.

Nestling.-Above brownish olive, below whitish tinged with pale yellow.

General Distribution.-North America, except southwestern part, British Columbia, Alaska, Florida, southern Georgia, the upper por- 
tions of the eastern mountains, such parts of the western mountains as are above 6,000 to 8,000 feet, and the barren grounds of the Arctic.

Summer Range.-Breeds throughout its range in the United States and Canada.

Winter Range.-Southern Mexico to Peru and northeastern Brazil; no West Indian record.

Spring Migration.-More notes have been contributed by the observers on the Yellow Warbler than on any other species of Warbler, and the following records are an epitome of about two thousand observations during a period of more than twenty years. The winter range of the Yellow Warbler and its subspecies extends from western Mexico to Dutch Guiana, a longitudinal winter range equalled by few species. But, though occuring throughout Central America, it is absent from the West India Islands, and reaches the eastern United States in the spring by a roundabout course across the Gulf of Mexico, and is one of the later Warblers to arrive in the Gulf States.

\begin{tabular}{|c|c|c|c|}
\hline PLACE & $\begin{array}{l}\text { No. of } \\
\text { years' } \\
\text { record }\end{array}$ & $\begin{array}{l}\text { A verage date of } \\
\text { spring arrival }\end{array}$ & $\begin{array}{l}\text { Earliest date of } \\
\text { spring arrival }\end{array}$ \\
\hline 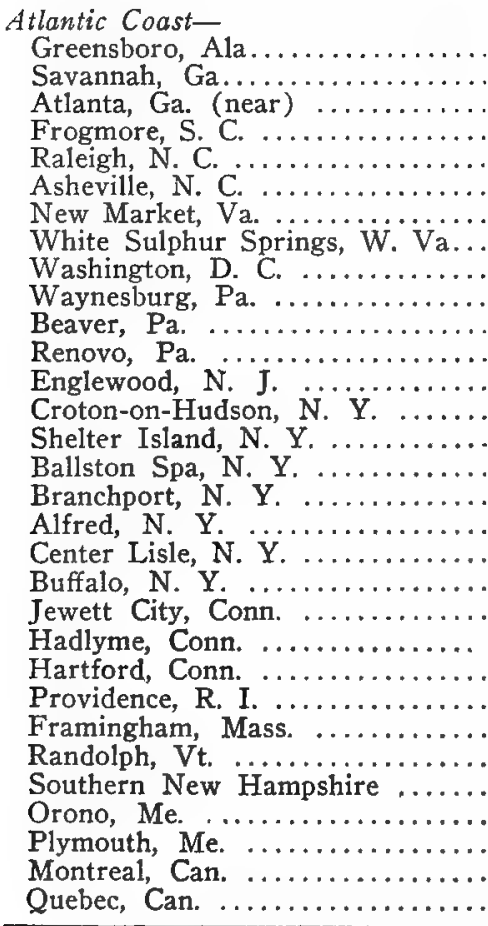 & $\begin{array}{r}14 \\
4 \\
14 \\
7 \\
7 \\
5 \\
8 \\
10 \\
8 \\
7 \\
11 \\
12 \\
10 \\
17 \\
13 \\
5 \\
16 \\
8 \\
10 \\
6 \\
10 \\
11 \\
11 \\
4 \\
12 \\
11 \\
9\end{array}$ & $\begin{array}{lr}\text { April } & \text { I7 } \\
& \\
\text { April } & 13 \\
\text { April } & 15 \\
\text { April } & 22 \\
\text { April } & 23 \\
\text { April } & 20 \\
\text { April } & 24 \\
\text { April } & 23 \\
\text { April } & 30 \\
\text { May } & 1 \\
\text { May } & 1 \\
\text { May } & 4 \\
\text { May } & 5 \\
\text { Arpil } & 29 \\
\text { May } & 2 \\
\text { May } & 3 \\
\text { May } & 1 \\
\text { May } & 4 \\
\text { May } & 3 \\
\text { May } & 5 \\
\text { May } & 4 \\
\text { May } & 2 \\
\text { May } & 9 \\
\text { May } & 10 \\
\text { May } & 11 \\
\text { May } & 14 \\
\text { May } & 10 \\
\text { May } & 15\end{array}$ & 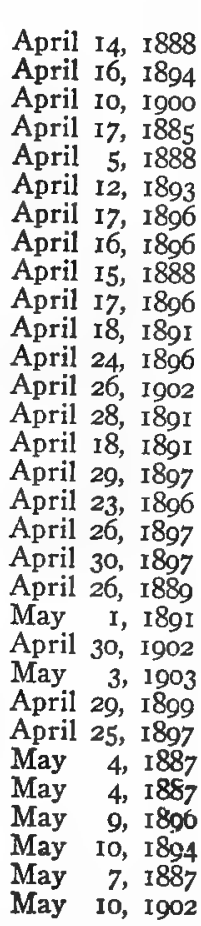 \\
\hline
\end{tabular}




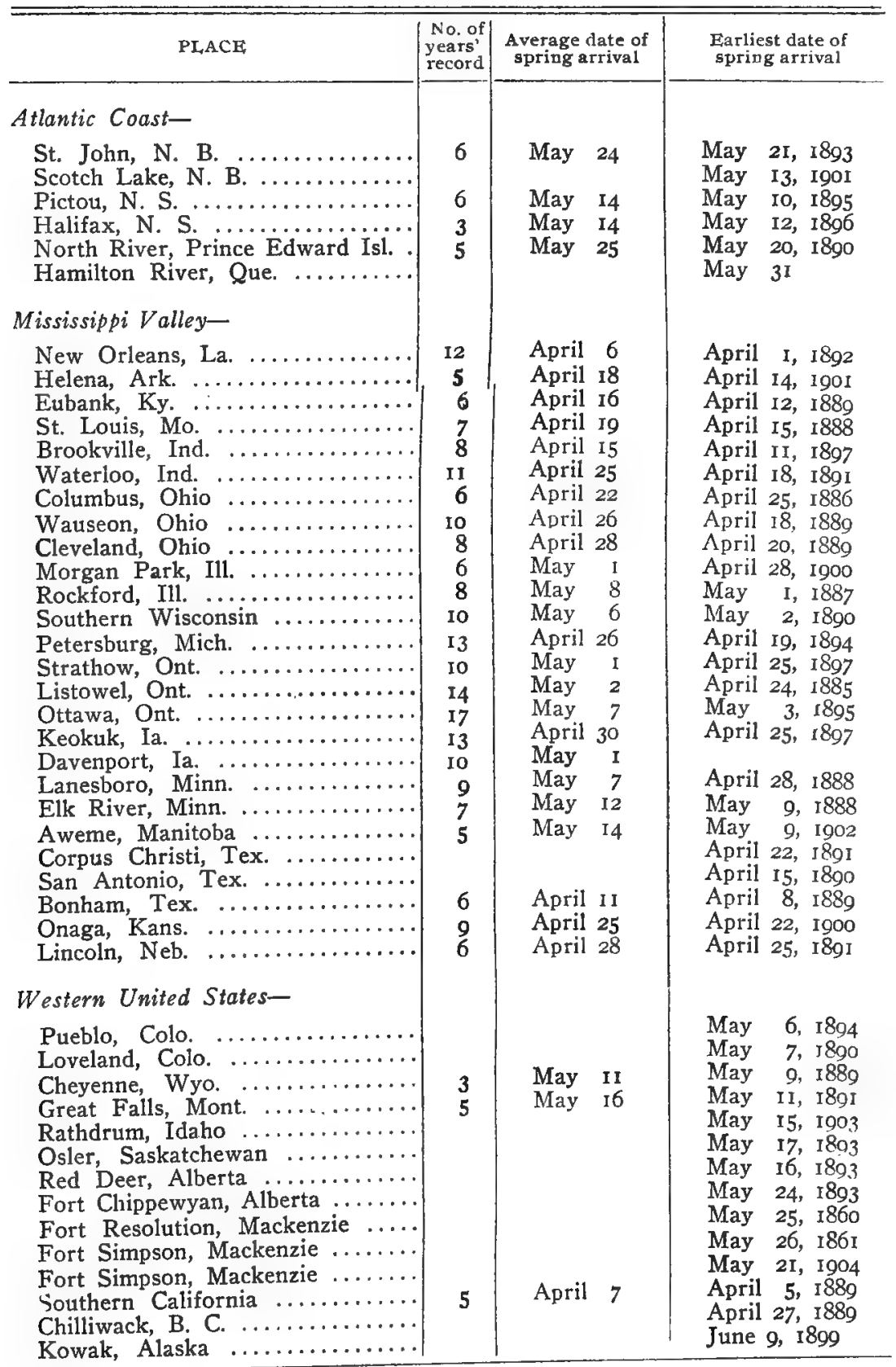


Fall Migration,-The Yellow Warbler begins its southward migration among the very earliest of the family, and fall migrants have been noted in central Florida July 20 and at Key West July 26. So rapid is the southward journey that the arrival of the first in the fall has been noted in southeastern Nicaragua August 9, 1892; San José, Costa Rica, Aug. 25, I889, and Aug. 24, I890; Bonda, Colombia, August 27, 1898 .

\begin{tabular}{|c|c|c|c|}
\hline PLACE & $\begin{array}{l}\text { No. of } \\
\text { years' } \\
\text { record }\end{array}$ & $\begin{array}{l}\text { Average date of } \\
\text { last one seen }\end{array}$ & $\begin{array}{l}\text { Letest date of } \\
\text { last one seen }\end{array}$ \\
\hline 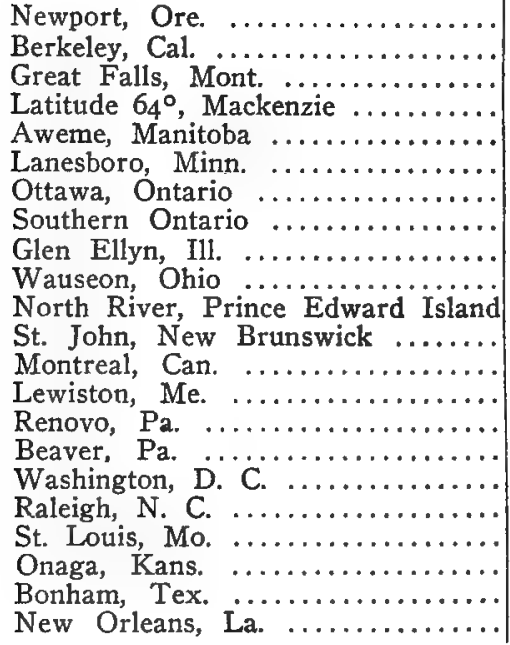 & $\begin{array}{l}3 \\
4 \\
5 \\
9 \\
2 \\
9 \\
2 \\
6 \\
4 \\
5 \\
3\end{array}$ & $\begin{array}{ll}\text { October } 5 \\
\\
\text { September } & 3 \\
\text { August I4 } & \\
\text { August } 20 & \\
\text { August 23 } & \\
\text { September } & 5 \\
\text { September } & \text { I5 } \\
\text { August 2I } & \\
& \\
\text { August 26 } & \\
\text { September } & \text { I } \\
\text { September } & 6 \\
\text { August 27 } & \end{array}$ & 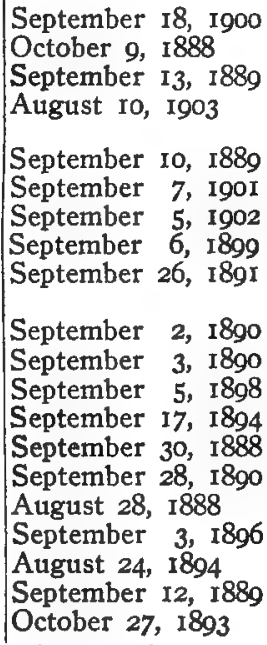 \\
\hline
\end{tabular}

The Bird and its Haunts.-The Yellow Warbler is a bit of feathered sunshine. In his plumes dwells the gold of the sun, in his voice its brightness and good cheer. We have not to seek him in the depths of the forest, the haunt of nearly all his congeners, he comes to us and makes his home near ours. And so because of his beauty and sociability, the Yellow Warbler has become the best known member of his family. Known, indeed, to many who are not aware that he has a large number of near relatives some of whom are even more attractive.

The habit of nesting in fruit and shade trees and lawn or garden shrubbery is, of course, of recent origin, and the bird is by no means so abundant in growth of this type as it is in willows near water, where the Yellow Warbler seems as much a part of the tree as its own foliage. In smaller numbers it frequents also other open growths 
and, indeed, one may find it in almost any trees except those of the deep woods.

Walter Fisher writes that "in California the Yellow Warbler is common during Spring and early Summer among the willows, poplars, and alders that line most of the streams and dry water-courses of the lowlands; and it is found also at lower altitudes in the mountains, about as high as the black oak ranges. Its song and characteristic chip are heard almost continually in willow thickets of bottom lands, where the birds move busily to and fro in the tree tops." (Fisher, MS.)

It is remarkable that although Warblers are imposed upon by the Cowbird more than any other birds, the Yellow Warbler alone appears to resent the intrusion of the strange egg, so unlike that of any other Warbler, and to have a definite method of avoiding its incubation. The building of a platform or second nest-bottom over the unwelcome egg may with this species be called a habit and numerous cases are on record where the unfortunate Warbler has been visited three times by the Cowbird and has built as many floors to its home, sealing, as it were, the unwelcome contribution.

Song.- "While there is no little variability there is little likelihood of confounding any of the variations with other species. Now it is sreet sweet sweet sweet sweeter sweeter, now sweet sweet sweet sweetie, again wee-chee, we-chee, wee-i-u; once more wee-chee, chee, chee, chur-wee. Over all presides the bird's distinct individuality. In all the variations I have heard the penultimate syllable is at a higher pitch, if the last phrase be three syllabled, lower if the last phrase be two syllabled. There is also a tendency to an increase in cadence to the last. The whole song is forcible and loud, but smooth and pleasing. It will be seen that in each variation there are two parts, though the last may be but a double syllable.

"There is no second song period, because singing does not cease until the last of July or the first week in August. It should be remarked, however, that there is a marked decrease in singing after the middle of July, at least in northern Ohio. Sometimes individuals are heard singing after the middle of August for a few days" (Jones.)

"There are two common call-notes used in the fall. The song is more often heard in spring than the call-notes, and is rarely or never uttered in the fall. The commoner of these two notes is the $d z t$ uttered by many Warblers; the other is a softer, less decisive chip, much like that uttered by the Parula and Prairie Warblers. The song is generally uttered while the singer moves slowly about among the branches; it is simple, but lively and pleasing, resembling 
the following, with a descending intonation: Tsweet, tsweet, tsweettsee-tsee-tsee-tsee-tsee-tsee. The only note I have heard uttered in flight is the sibilant chirp mentioned above, one of the characteristic sounds of late summer." (Allison, MS.)

Nesting Site.-Usually in bushes, saplings, or briers three to eight feet up, but not infrequently in trees as high as forty feet up.

Nest.-Compact, symmetrical, and well-woven, of silver-gray hempen fibers and fine grasses with a conspictous amount of plantdown; lined with cottony plant-down, fine grasses, sometimes hair or a few feathers. Bowles states that nests of this species found at Tacoma, Washington, often have a heavy lining of feathers. This is the only bird that has the habit of building a second and, when the necessity arises, a third story to its nest to cover the unwelcome egg of the Cowbird.

Eggs.-4 or 5, usually 4, in a large series of sets, one containing 6 eggs occurs, but two-thirds have four eggs each. Ground color ranges from grayish and greenish white to a rich green shade, over this are markings of umber brown, blackish, lilac-gray, and purplishbrown in all varieties of spots, splashes, and blotches, always tending to wreathe around the large end, but many are heavily marked all over. Size; average, .68x.50; extremes, .75x.52, .60x.48, .73x.53, .62x.47. (Figs. 39-41.)

Nesting Dates.-Burning Springs, W. Va., May I4 (C.W.C.); Waynesburg, Pa., May I4-June Io (Jacobs); New York City, May 20-July 4 (building) (F. M. C.) ; New Haven, Conn., May 20-June 30 (Bishop); Cambridge,Mass., full sets, first laying, May 23-30 (Brewster); Lancaster, N. H., June 7 (Spaulding); Bangor, Me., May 29-June 30 (Knight); Listowel, Ont., June I-June 22 (Kells); Oberlin, O., May I-June I (Jones); Jasper Co., Ia., May I6 (C. W. C.) ; Boulder, Colo., June 5 (C.W.C.); Denver, Colo., June 6 (Dille) ; San Jose, Calif., April 5 (C.W.C.) ; Tacoma, Wash., May 24-June I7 (Bowles); Ann Arbor, Mich., May 5, Ypsilanti, Mich., June 23 (Wood).

\section{Biographical References}

(1) C. J. Morrison, Yellow Warbler vs. Cowbird. Orn. and Oöl., IX, I884, I24. (2) J. P. N. [ORRIS], Eggs of the Western Yellow (=Yellow) Warbler, Orn. and Oöl., XII, I887, I85. (3) A. B. Dunning, Yellow Warbler (in E. Mass.), Oölogist, IX, 1892, 35. (4) N. F. Posson, Incessancy of the Yellow Warbler's Song, Ibid., IX, I892, 65. (5) Morris Gibis, The BlossomEater, Nidologist, II, $1894,48$. 
Plate X

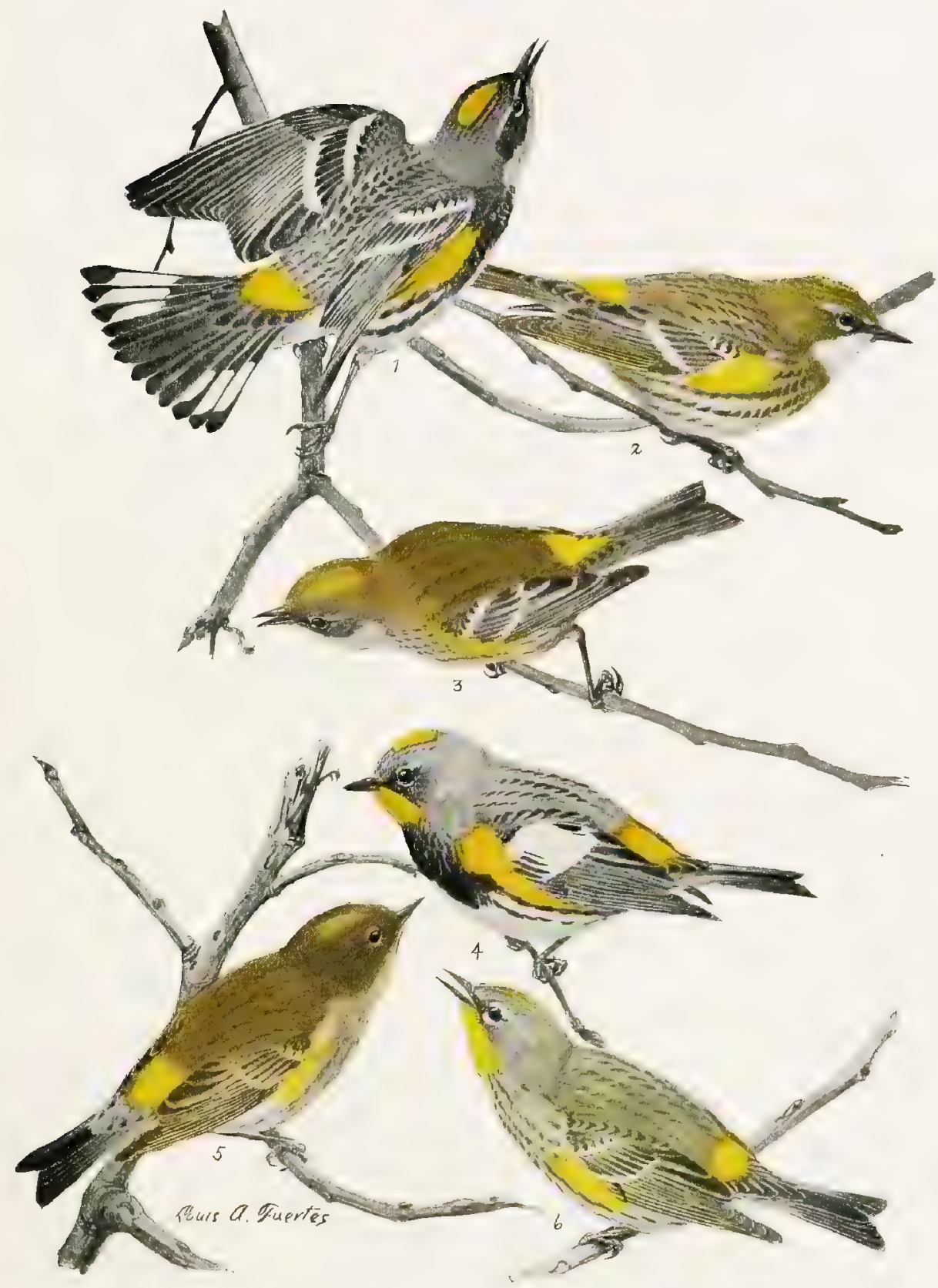

1. Myrtle Warblek, Adult Male.

2. Mrrtle Warbler, Adult Female,

3. Myrtle. Warbier, Young.
4. Audubon's Wakblek, Adult Male.

5. Audubon's Warbler, Adult Female.

6. Audubon's Warbler, Young. 


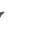




\section{SONORA YELLOW WARBLER \\ DENDROICA ESTIVA SONORANA Brewst.}

Subspecific Characters.-Resembles Dendroica astiva estiva but adult o paler above, the back yellower, the feathers usually with dark shaft streaks; the tail with more yellow, all the feathers, including the central pair being yellow at the base on both webs; streaks below finer, less numerous, sometimes barely evident.

Adult $q$ grayer above and below than adult $q$ astiva, the underparts sometimes grayish tinged with green.

General Distribution.-Southwestern United States and northwestern Mexico.

Summer Range.-Western Texas (Frontera, Fort Hancock, etc.,) southern New Mexico, southern Arizona, and southward into northwestern Mexico (Ridgre.).

Winter Range.-Mexico southward to Nicaragua.

The Bird and its Haunts.-This southwestern form of the Yellow Warbler resembles the eastern bird in habits and, like it, shows a marked preference for willows. Owing to the aridity of the country in which it lives, suitable haunts are less common than in the east and the bird is proportionately less numerous.

Nesting Site.-Along the San Pedro River in southern Arizona, Howard" found "several nests placed in willow and mesquite trees, generally in upright forks from ten to twenty-five feet up."

Nest.- "The nests are very much like those of the Yellow Warbler." (Howard ${ }^{1}$.)

Eggs.-Usually 4. Ground color, in the sets I have examine1, has been paler than in eggs of the Yellow Warbler, but the markings are the same. Size; a typical set of four measures, .70x.5 I, .70x.50, $.68 \times .52, .69 \times .51$.

\section{BIOGRAPHICAL REFERENCES}

(I) O. W. Howard, Summer Resident Warblers of Arizona, Bull. Cooper Orn. Club (=Condor), I, I899, 39.

\section{ALASKAN YELLOW WARBLER}

DENDROICA ESTIVA RUBIGINOSA (Pall.)

Subspecific Characters.-Similar to Dendroica astiva astiva but slightly smaller, adult $\sigma^{7}$ darker above, the crown of nearly the same color as the back, only the forehead yellower; the rump more nearly the color of the back than in astiva. 
Adult $q$ and young darker (greener, less yellow) above than those of estiva. Wing, 2.40; tail, 1.70; bill, .40.

General Distribution.-British Columbia and Alaska.

Summer Range.-Vancouver Island northward through British Columbia and Alaska, both on the coast and in the interior.

Winter Range.-Migrates southward through California and winters in Mexico and Central America.

The Bird and its Haunts.-In his admirable work on Alaskan birds Nelson ${ }^{1}$ writes, "This is perhaps the most abundant Warbler throughout Alaska. It is found everywhere in the wooded interior, or the bushy borders of the water-courses, or frequenting the scattered clumps of stunted alders. $* * *$ Its lively presence, even among the pleasant surroundings of the south, lends animation to the scene, and even more impressive is its presence under the dismal skies and in the damp, depressing climate of the north, where such visitants are only too rare."

Nesting Site._- "Breeds on the shores of the Arctic Ocean wherever it can find a willow or alder patch wherein to place its nest and shelter its young. *** It is the only Warbler, with the exception of the Black-capped Flycatcher (Sylvania pusilla pileolata), which nests in the alder-thickets in the vicinity of St. Michaels." (Nelson ${ }^{1}$.)

Nest.-The nest does not appear to have been described. Doubtless it resembles that of Dendroica estiva cestiva.

Eggs.-No authentic sets of this bird's eggs are recorded, but doubtless they resemble those of the Yellow Warbler.

Biographical References

(1) E. W. Nelson, Natural History Collections made in Alaska, x887, 201. (These notes are given under the name Dendroica astiva, the Alaskan form not being recognized until 1897. )

\section{California Yellow Warbler DENDROICA FSTIVA BREWSTERI Grinn.}

Subspecific Characters.-"Resembling Dendroica astiva astiva, from which it differs in smaller size, paler (or less brightly yellow) coloration, and, in the male, narrower streaking on under surface; differs from Dendroica astiva rubiginosa in smaller size and yellower coloration, and from Dendroica cestiva sonorana in smaller size and much darker coloration." Male, wing, 2.45 ; tail, 1.96; female wing, 2.33 ; tail, 1.93. Grinnell, Condor, 1903, 72.

General Distribution._-"Breeds in Transition and Upper Sonoran Zones, west of the Cascades and the Sierra Nevada, from Washington to Southern California; winter home unknown." (A. O. U.) 


\section{MANGROVE WARBLER}

\section{DENDROICA BRYANTI CASTANEICEPS Ridgw. Plate I}

Distinguishing Characters.-Adult $\delta$ with head all around and throat reddish chestnut; both sexes with yellow on inner webs of two or more tailfeathers. Length (skin), 4.65 ; wing, 2.40 ; tail, 1.80 ; bill, .45 .

Adult d, Spring.-Head all around and throat reddish chestnut; back yellow olive-green, the rump brighter; inner webs of all but central tail-feathers largely yellow; wings black margined with yellow; underparts, except throat, rich yellow faintly streaked with reddish brown.

Adult d", Fall.--Not seen.

Young d.-Not seen.

Adult \&, Spring.-Above olive-green, much darker and greener than in $\delta$; tail black the two outer feathers with large yellow patches on the inner web near the tip; wings black margined with greenish yellow; below uniform pale, dull yellow.

Adult 9 , Fall.-Not distinguishable from adult 9 in Spring.

Young ‥-Above grayish olive-green, rump brighter; tail blackish, externally greenish, webs of all but central feathers narrowly margined with yellow; wings and their coverts blackish, quills margined, coverts tipped with dull greenish; below whitish more or less washed or obscurely streaked with yellow, the under tail-coverts pale yellow.

Nestling.-Not seen.

General Distribution.-A non-migratory species resident in western Mexico and Lower California north to Magdalena Bay.

The Bird and its Haunts.-The observations of Belding1, Bryant ${ }^{2}$. and Frazar ${ }^{3}$ show that in Lower California this Pacific Coast form is found only in the red mangroves (Rhizophora mangle) and it is, consequently, of local distribution.

Belding records it from La Paz, Pichalinque Bay and Espiritu Island where he considered it resident. At $\mathrm{La} \mathrm{Paz}$ he found it to be common, but in March, I889, Frazar could secure only eight specimens there. Bryant observed it in Magdalena Bay and on Santa Margarita Island.

\section{BIOGRAPHICAL REFERENCES}

(I) L. Berding, Catalogue of a Collection of Birds made at Various Points along the Western Coast of Lower California, Proc. U. S. Nat. Mus., V, 1883, 536. (2) W. Bryant, A Catalogue of the Birds of Lower California, Proc. Calif. Acad. Sci., and Ser. II, I889, 309. (3) Wm. Brewster, Birds of the Cape Region of Lower California, Bull. Mus. Comp. Zoölogy, XLI, 1902, I8r.

\section{MAGNOLIA WARBLER} DENDROICA MAGNOLIA (Wils.) Plate XI

Distinguishing Characters.-Adults of both sexes have the crown and nape gray, a white stripe behind the eye, the rump yellow, the white patches 
of the tail near the center, instead of at the end of the feather. The black bases of the tail feathers are concealed by the crissum and, seen from below, the tail appears to be white broadly tipped with black. In young birds the white is much decreased in extent but its position in the tail, together with the yellow rump, is diagnostic. Length (skin), 4.50; wing, 2.30; tail, I.95; bill, .35.

Adult ס", Spring.-Crown and nape bluish gray, a white line behind the eye and a white mark on the lower part of eye-ring; frontlet, cheeks and back black, the latter sometimes with olive and becoming greenish towards the yellow rump; upper tail-coverts black; tail black, all but the central part of feathers with a white patch on the inner half of the web about half-way to the tip; wings blackish edged with gray, the median and greater coverts broadly marked with white forming a conspicuous white wing-patch; below yellow becoming white on the crissum, the throat unmarked, a black band on the upper breast from which run rows of heavy black streaks on the sides.

Adult $\delta$, Fall.-Quite unlike adult $\delta$ in Spring; crown and nape brownish gray; eye-ring whitish; back olive-green more or less indistinctly streaked with black; rump yellow; tail as in Spring; wing-coverts tipped with white forming two white bars; below yellow, sides with partly concealed black streaks, upper breast with a faint dusky band.

Young $\delta^{*}$, Fall.-Similar to adult $\delta^{*}$ in Fall and not always distinguishable from it, but black streaks of back and sides averaging lighter.

Adult $q$, Spring.-Similar to adult $\delta$ in Spring but crown not so bluish gray or cheeks so pronouncedly black; back olive-green spotted with black; yellow of rump paler; upper tail-coverts broadly tipped with gray; wing-coverts with less white, at times merely tipped not margined; black streaks below lighter, less apt to form a band on the upper breast.

Adult + , Fall.-Crown browner than that of adult $q$ in Spring, a whitish eye-ring but no white stripe behind eye; cheeks much like crown; back brownish olive-green with a few partly concealed black streaks posteriorly; white on wing-coverts less pronounced and with a brownish tinge; sides with a few partly concealed black streaks; the dusky band on upper breast well developed. In this plumage resembling young $\delta^{*}$ in Fall but wing-coverts browner and with less white.

Young +, Fall.-Resembling adult + in Fall but the crown and back browner, the black streaks above usually wanting, the rump less clearly yellow, the streaks on the sides finer, less prominent.

Nestling.-Above brown, sometimes ruddy in tone, indistinctly streaked with black; breast dusky brown; belly whitish streaked with blackish; wingcoverts tipped with buffy.

General Distribution.-Eastern North America; north to Newfoundland and the Mackenzie; west to the Plains.

Summer Range.-The higher parts of Massachusetts (Berkshire Co.), northern New York (Oneida Co.), northern Michigan, northern Minnesota and southern Assiniboia northward. It also breeds not uncommonly in the higher portions of the Alleghenies of eastern Pennsylvania and on the highest mountains of western Maryland. It is 
a rare migrant west to eastern Nebraska and has occurred accidentally in Colorado (Denver, May 17, I873, Fort Lyon, May 17, I884, Denver, May 17, 1888), California (Santa Barbara Island, May 15, I897, Los Angeles, October 21, I897, and October 5, I90I), and several times in British Columbia.

Winter Range.-Mexico to Panama; casual in the West Indies. Spring Migration.-

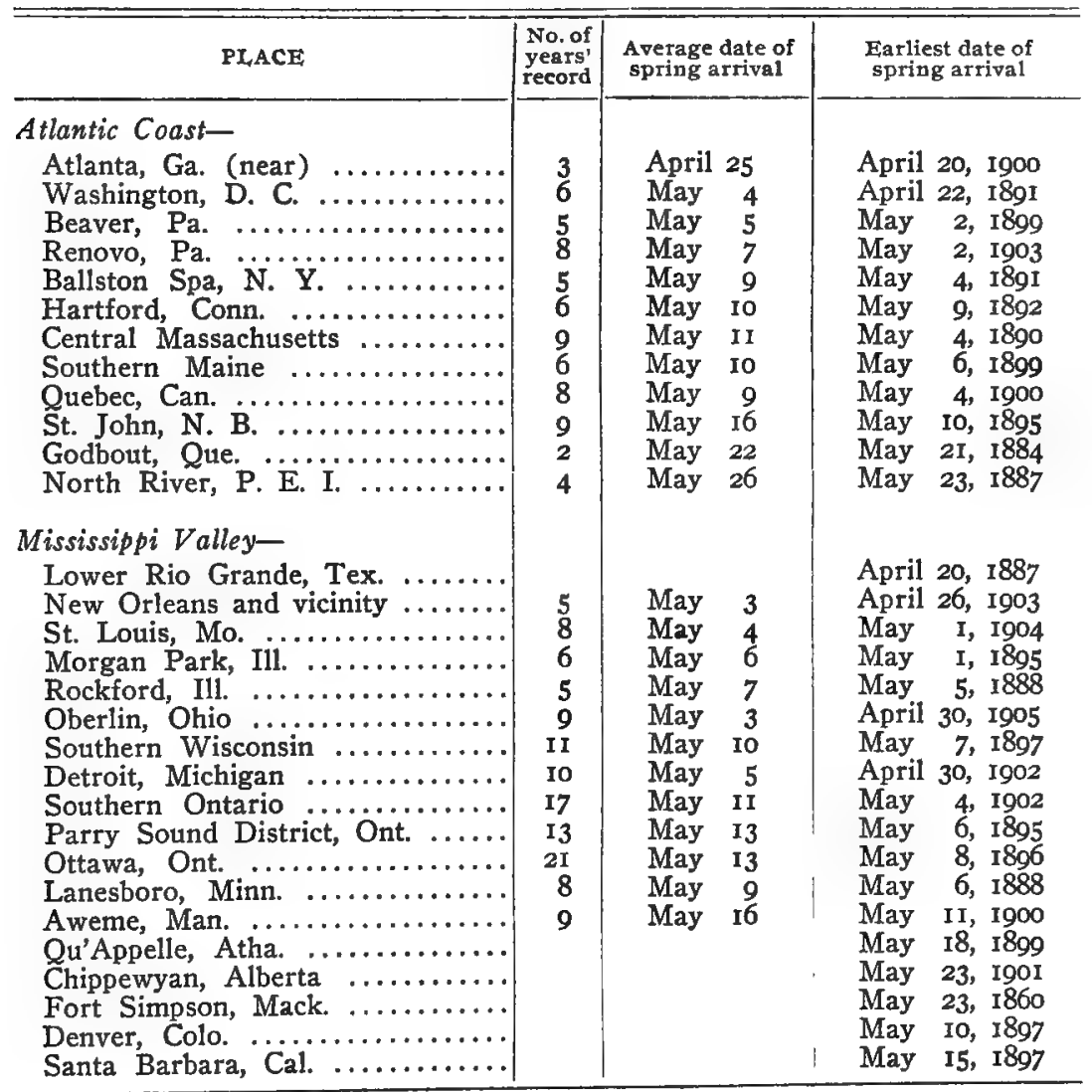

Fall Migration.-

\begin{tabular}{|c|c|c|c|}
\hline $\mathrm{PL}_{\mathrm{ACE}}$ & $\begin{array}{l}\text { No of } \\
\text { years" } \\
\text { record }\end{array}$ & $\begin{array}{l}\text { Average date of } \\
\text { first one seen }\end{array}$ & $\begin{array}{l}\text { Earliest date of } \\
\text { first one seen }\end{array}$ \\
\hline $\begin{array}{l}\text { Lanesboro, Minn. } \ldots \ldots \ldots \ldots \ldots \ldots \ldots \\
\text { Glen Ellyn, Ill. } \ldots \ldots \ldots \ldots \ldots \ldots \ldots \ldots \\
\text { Englewood, N. J. } \ldots \ldots \ldots \ldots \ldots \ldots \ldots \\
\text { Washington, D. C. } \ldots \ldots \ldots \ldots \ldots \ldots \\
\text { Raleigh, N. C. } \ldots \ldots \ldots \ldots \ldots \ldots \\
\text { New Orleans and vicinity } \ldots \ldots \ldots \ldots\end{array}$ & $\begin{array}{l}6 \\
3 \\
4 \\
3 \\
4\end{array}$ & $\begin{array}{r}\text { August 22 } \\
\text { August } 23 \\
\text { August } 22 \\
\text { September I3 } \\
\text { September 19 }\end{array}$ & $\begin{array}{r}\text { August 12, 1887 } \\
\text { August 12, 1896 } \\
\text { August 16, 1887 } \\
\text { August 16, 1886 } \\
\text { September 11, 1889 } \\
\text { September 13, 1899 }\end{array}$ \\
\hline
\end{tabular}




\begin{tabular}{|c|c|c|c|}
\hline PLACE & $\begin{array}{l}\text { No. of } \\
\text { years } \\
\text { record }\end{array}$ & $\begin{array}{c}\text { Average date of } \\
\text { last one seen }\end{array}$ & $\begin{array}{l}\text { L,atest date of } \\
\text { last one seen }\end{array}$ \\
\hline 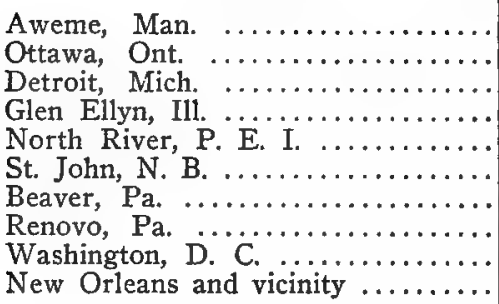 & $\begin{array}{r}3 \\
12 \\
7 \\
4 \\
4 \\
5 \\
6 \\
4 \\
4\end{array}$ & $\begin{array}{ll}\text { September } & 17 \\
\text { September } & 26 \\
\text { September } & 29 \\
\text { August } & 21 \\
\text { September } & 3 \\
\text { September } & 24 \\
\text { September } & 26 \\
\text { October } & 2 \\
\text { October } & 24\end{array}$ & $\begin{array}{l}\text { September 17, 1900 } \\
\text { September 19, I895 } \\
\text { October 5, 1905 } \\
\text { October 9, I894 } \\
\text { September 8, I890 } \\
\text { September } 7,1890 \\
\text { October 3, I891 } \\
\text { October 5, 1902 } \\
\text { October 10, } 1,1895 \\
\text { November }\end{array}$ \\
\hline
\end{tabular}

The Bird and its Haunts. - In this day of numerous bird manuals, keys, etc., book knowledge of a bird usually precedes our actual meeting with the species in life and we are more or less prepared for the encounter; but before the day of these publications the embryo ornithologist was sometimes thrilled by the 'discovery' of birds which, as far as he was aware, no one had ever seen before.

William Brewster's ${ }^{2}$ monograph of the Magnolia Warbler contains a description of such an experience which we are sure will appeal to every bird lover, whether or not it has been his good fortune to begin his study of birds in a similarly memorable manner. Mr. Brewster writes: "Entering a grove of thickly growing young spruces, I sat down to rest on a mossy log. I had been there but a short time when I became conscious of faint sounds in the trees above and around me,-chirpings, twitterings, and occasionally a modest little effort at song. Watching attentively, I soon spied a movement among the branches, and a tiny bird hopped out into the light, presenting a bright yellow breast and throat for just a moment before flying into the next tree. Here was a revelation! I already knew a few of the most familiar birds, - the Robin, the Bluebird, the Sparrow, the Oriole, and some others; but it had never occurred to me that dark forests like these might be tenanted by such delicate and beautiful forms. Only the tropics surely could boast such gems."

This was before the day of 'keys'; the opera-glass had not supplanted the gun and "with enthusiasm now fairly aroused and animated with the spirit of the explorer" the young ornithologist "went at once to work to investigate, and in the course of an hour or two, my ammunition was nearly exhansted, and quite a line of poor lifeless, mutilated little birds lay along the old log. * * * Scarcely any two of my specimens were alike, and as I contemplated in amazement their varied forms and coloring, I felt like the discoverer of a 
new world, and doubted whether human eyes had ever beheld the like before. $* * *$ I can recall with sufficient distinctness for identification but a single bird of them all,-a fine adult male Black and Yellow Warbler [as this species was then called], which at the time I considered the handsomest and which I still think cannot be surpassed in beauty by any New England representative of the family."

Later, in the same paper this author states that as a spring migrant in eastern Massachusettts the Magnolia Warbler is abundant, frequenting "willow thickets near streams, ponds, and other damp places. * * * It is also not unusual to find many in the upland woods, especially where young pines or other evergreens grow thickly." In the autumn, he adds, it is less common and its haunts are then "somewhat different from those which it affects during its northward journey. We now find it most commonly on hillsides, among scrub-oaks and scattered birches and in company with such birds as the Yellow-rump (Dendroica coronata) and the Blackpoll (D. striata)."

About Monadnock, Gerald Thayer writes: "This most beautiful Warbler is a common summer bird between 2,800 and 1,000 feet, wherever there are second growth spruce woods, and especially such woods combined with bits of upland pasture. 'Spruce Warbler' wouli be an appropriate name for it in this region-quite as appropriate as 'Birch Warbler' for the Nashville. These two birds may often be found almost together on the same pasture-border; but the Magnolia keeps to the spruces (and other conifers) at least as strictly as the Nashville keeps to the birches (and other broad-leaf trees).

"The feeding-range or 'beat' of this Warbler in its chosen summer woodlands about Monadnock, lies between the tip-tops of second growth spruce trees and their lowest branches. Although not shy, it is apt to stick rather closely to the inner recesses of spruce clumps, less often showing itself on the outermost twigs than do the Blackburnian and Black-throated Green. In its movements it is fidgety and quick, and it often partly spreads its broadly and centrally white-banded tail, distinctive of the species in all plumages." (Thayer, MS.)

Song.- "The Magnolia belongs among the full-voiced Warblers, and is a versatile singer, having at least two main songs, both subject to much and notable variation. The typical form of the commoner song is peculiar and easily remembered: Wecto weeto weeétee-eet,-or Witchi, witchi, witchi tit, - the first four notes deliberate and even and comparatively low in tone, the last three hurried and higher pitched, 
with decided emphasis on the antepenult weet or witch. The other song has the same general character, and begins with nearly the same notes, but instead of ending with the sprightly, high-pitched wéetee$e e t^{\prime \prime}$, it falls off in a single perfunctory-sounding though emphatic note, of lower tone than the rest. In syllables it is like Witti witti wét,"-or weetee weetee wir. This duller song seems much less subject to variation than the sprightly one. Some of the aberrant songs, though, are as near to one type as another. One such variant I have fixed in my own recollection by the syllables Ter-whiz wee-it; and another, almost unrecognizable, by the syllables Weé-yer weéyer wee-yer. Still another beginning like Weechi wéech, ended with a hurried confusion of small notes, some low, some high. But throughout these and all the many other surprising variations I have heard about Monadnock, the characteristic tone-quality was preserved unchanged, and so were certain minor tricks, scarcely describable, of emphasis and phrasing. The tone is much like the Yellow Warbler's and also the Chestnut-side's, though distinctly different from either. In loudness it averages lower than the Yellow's, and about equal to the Chestnut-side's. In addition to several barely characteristic 'chips' the Magnolia has a most peculiar call-note. It is soft, almost song-toned, with a slight metallic ring, and at the same time sounds lisped;-tlep, tlep, reminding one of certain notes both of the American Siskin and (as Dr. G. M. Allen says) of Henslow's Sparrow." (Thayer, MS.)

Miss Paddock gives four variations of the Magnolia's song, and writes:

"The song usually ends with the falling inflection. It may always do so when the two records ending on the high note were where I failed to catch the very last note."
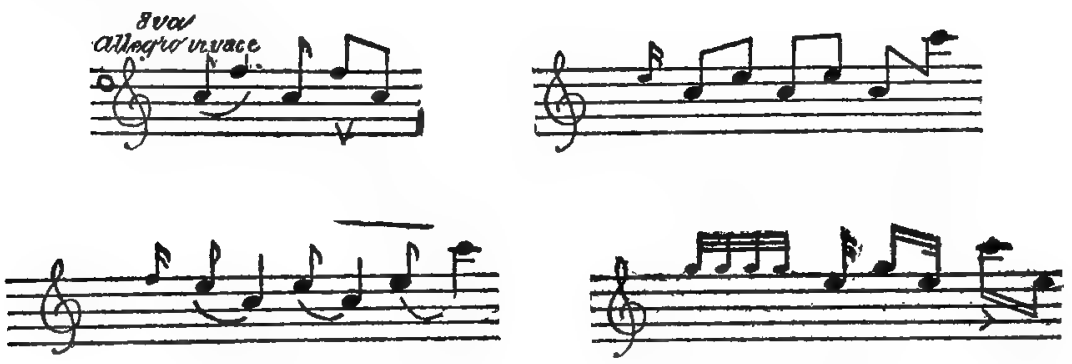

"This last preceded by three or four 'chips' like the chatter of the Chickadee." 


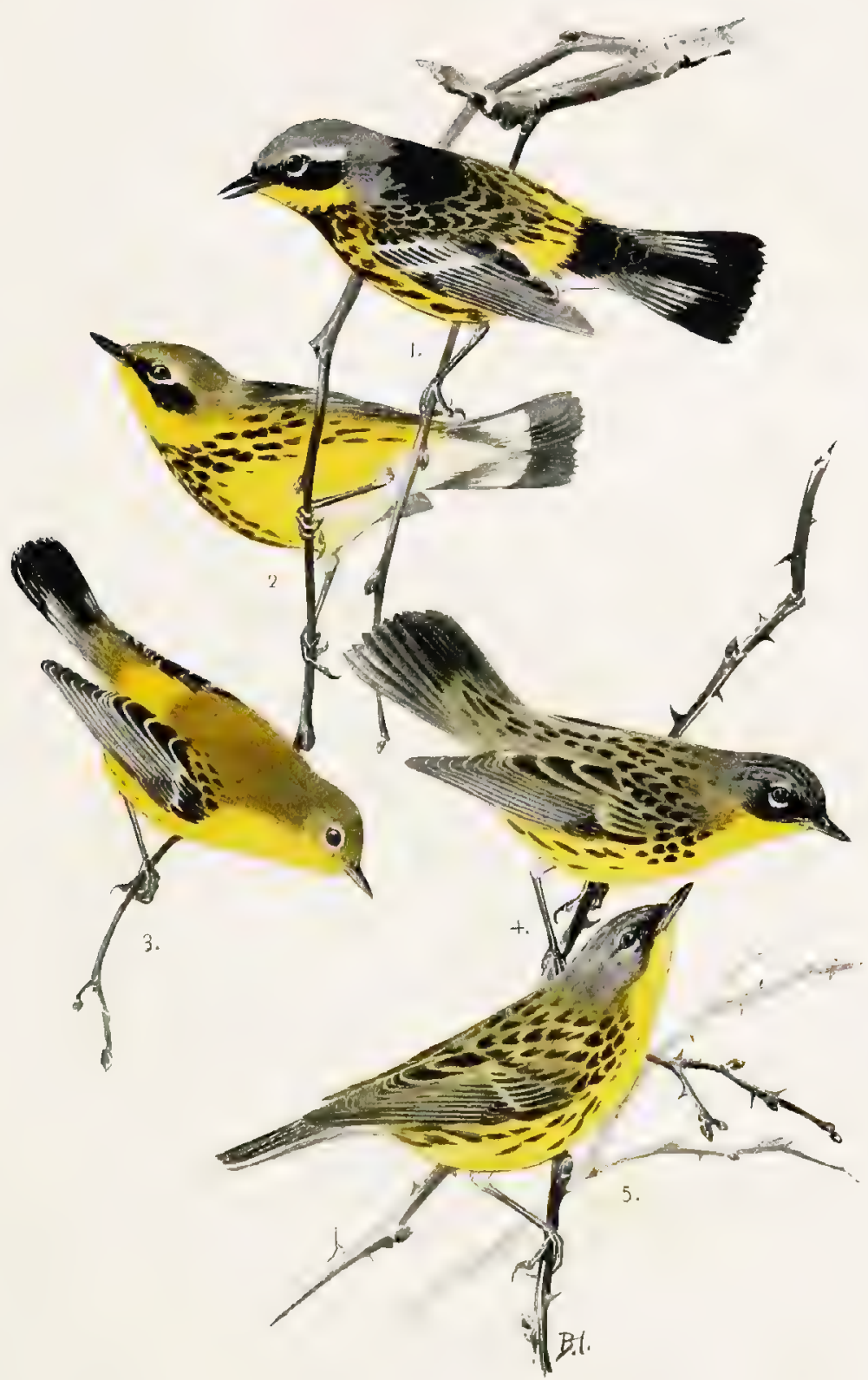

1. Magnolia Warbler, Male.

2. Magnolia Warbier, Female
3. Magnolia Warbler, Young and Adult in Fali. 4. KiKTLAND's WakBLLK, MaLE.

5. Kirtland's Warbler, Female.

(ONE-HALF NATURAL SIZE.) 


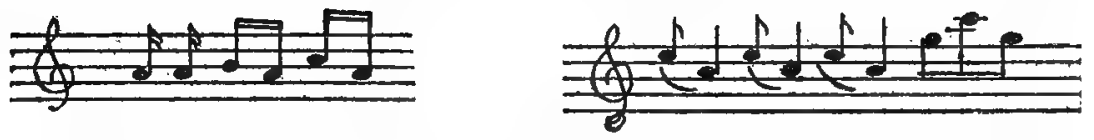

Nesting Site.- "The nest is usually placed in a small fir or spruce and rarely at a greater elevation than five or six feet. The average height would probably not exceed four feet, and I have found some barely twelve inches above the ground. It is usually laid somewhat loosely among the horizontal twigs from which it can in most cases be lifted intact $* * *$ Exceptional situations are the interior of the woods, where, in some cases, the nest is placed in the top of a young hemlock ten or fifteen feet up. In one instance I found a nest on a horizontal spruce limb in the very heart of the forest, and at least thirty-five feet above the ground." (Brewster ${ }^{2}$.)

A large amount of data from northern New England confirms Brewster's observations in regard to the normal nesting site of this species in that region, but Simpson ${ }^{6}$ states that in the mountains of Pennsylvania, at Warren, the great majority of nests are built about ten to twelve feet up in the tops of small hemlocks or out on the branches of larger trees.

At Branchport, New York, Burtch (MS.) finds the nest "in hemlocks usually on a horizontal limb from eight to twenty feet up and over an opening in the woods. Several nests were found in the top of little hemlock saplings from one to five feet from the ground. One nest was found by Mr. C. F. Stone in a birch sapling, this being the only instance to my knowledge of its nesting in a tree other than a hemlock."

Nest.-Nests in Mr. Brewster's collection from northern New England are made of small coniferous twigs, which project over the edges in irregular fashion, pine needles, grasses, bits of down or spider's webbing, lined with fine, dull black, hair-like rootlets, often so abundantly as to make the nest interiorly black in marked contrast to the brown exterior.

Burtch (MS.) describes the nest as "loosely constructed of fine hemlock twigs, with sometimes a few weeds, lined with fine black rootlets, hair, or fine dead grass, usually decorated with fern down."

Eggs.-3 to 6, usually 4. Ground color of average specimen is dull creamy white, over this are spots and blotches of many shades of reddish brown, hazel, and chestnut, in some specimens purplish and pale lavender, but in nearly all cases the egg is heavily marked on the large end in form of a well defined wreath. Size; average, $65 \times .48$; extremes measure $.61 \times .45, .72 \times .45, .66 \times .5$ r. (Figs. 52-54.) 
Nesting Dates.-Warren, Pa., first week in June (Simpson); Branchport, N. Y., June 2-June 24 (Burtch) ; Lancaster, N. H., May 24-June 20 (Spaulding); Bangor, Me., May zo-June I6 (Knight); Grand Menan, N. B., June 8 (J.P. N.)-July I (C.W.C.).

\section{BIographical REFERENCES}

(I) C. J. Maynard, A Catalogue of the Birds of Coos Co., N. H., and Oxford Co., Maine, Proc. Bost. Soc. Nat. Hist., XIV, 1871, 367. (2) WM. BREwSTER, The Black-and-Yellow Warbler (in New England), Bull. Nutt. Orn. Club, II, I877, I. (3) J. P. N[oRRIs], A Series of Eggs of Dendroica maculosa, Orn. and Oöl., XII, 1887, 177. (4) C. H. ANDros, The Black and Yellow Warbler at Grand Menan, Orn. and Oöl., XII, 1887, 182. (5) S. E. WhIre, Birds Observed on Mackinac Island, Michigan, Auk, X, 1893, 228. (6) R. B. Simpson, The Magnolia Warbler (at Warren, Pa.), Nidologist, II, 1895, I64. (7) L. M. TerRILL, Summer Warblers in Compton County, Quebec, Ottawa Naturalist, XVIII, I904, I50. (8) B. HoAG, Nesting of the Magnolia Warbler (in N. Y.), Nidologist, I, I894, 87. (See also HigGins, Ibid., 106.)

\section{CAPE MAY WARBLER}

\section{DENDROICA TIGRINA (Gmel.) Plate XVI}

Distinguishing Characters.-Adult $\delta$ with chestnut ear-patches; adult $q$ and young grayish olive above, the rump much brighter, below whitish, streaked, the breast more or less yellow. Length (skin), 4.50; wing, 2.55; tail, I.90; bill, .40.

Adult d", Spring.-Crown black more or less edged with olive and often with traces of chestnut on the forehead; ear-coverts chestnut, this color sometimes tinging the well-marked yellow superciliary line; sides of the neck yellow with a tendency to spread to the nape; back olive-green spotted with black, rump clear yellow or greenish yellow; tail black edged with olive the inner webs of two to three outer feathers with white patches near the tip; wings black edged with olive-green, median coverts white except at base, outer margins of greater coverts usually white or greenish gray; below yellow, heavily streaked with black, fading to white on the lower belly, the throat generally tinged with chestnut.

Adult $\delta^{*}$, Fall.-Similar to adult $\delta^{*}$ in Spring but widely margined with grayish above, and with whitish below.

Young $\delta^{A}$, Fall.-No chestnut ear-patches or black crown; crown and back grayish olive-green with some more or less concealed black spots, rump dukky yellow; tail as in adult; median wing-coverts grayish white, outer margins of greater coverts greenish gray; yellow below less bright than in adult, streaks less pronounced, all the feathers margined with whitish.

Adult o, Spring.-Above grayish olive, grayer than in young $\delta$, forehead usually with black spots, line over eye yellowish; rump olive-green; tail with less white than in $\sigma^{\prime}$; median and greater wing-coverts margined with grayish white, not forming conspicuous bars; below whitish, breast tinged with yellow and, with the sides, conspicuously streaked with black. 
Adult 9 , Fall.-Similar to adult 9 in Spring but yellow of rump and breast stronger, the black streaks obscured by whitish edgings.

Young + , Fall-Similar to adult $q$ in Fall but with less yellow; streaks below less sharply defined.

Nestling.-Dusky olive-brown above, dusky grayish below, faintly tinged with buffy on breast and sides.

General Distribution.-Eastern North America; north to Nova Scotia and Hudson Bay; west to the Mississippi.

Summer Range.-The greater number summer in Canada north to Nova Scotia, New Brunswick, Hudson Bay and almost to Great Slave Lake; a smaller number nest in the northern United States, in Maine (Oxford and Washington Counties), New Hampshire (Umbagog), northern Michigan, northern Minnesota, Manitoba, and Assiniboia (Yorktown). A few are said to breed in the Island of Jamaica. The western limit of the usual range of the species can be marked approximately by a line drawn from Florida to sonthern Missouri and up the Mississippi River to Minnesota. West of this district it has been taken casually in Louisiana (New Orleans, April I890), Mississippi (Tishomingo County, May 4, I904), Nebraska (Alda, May I2, 1883, Omaha, May 24, I893), Iowa, (Iowa City, November 27).

Spring Migration.-

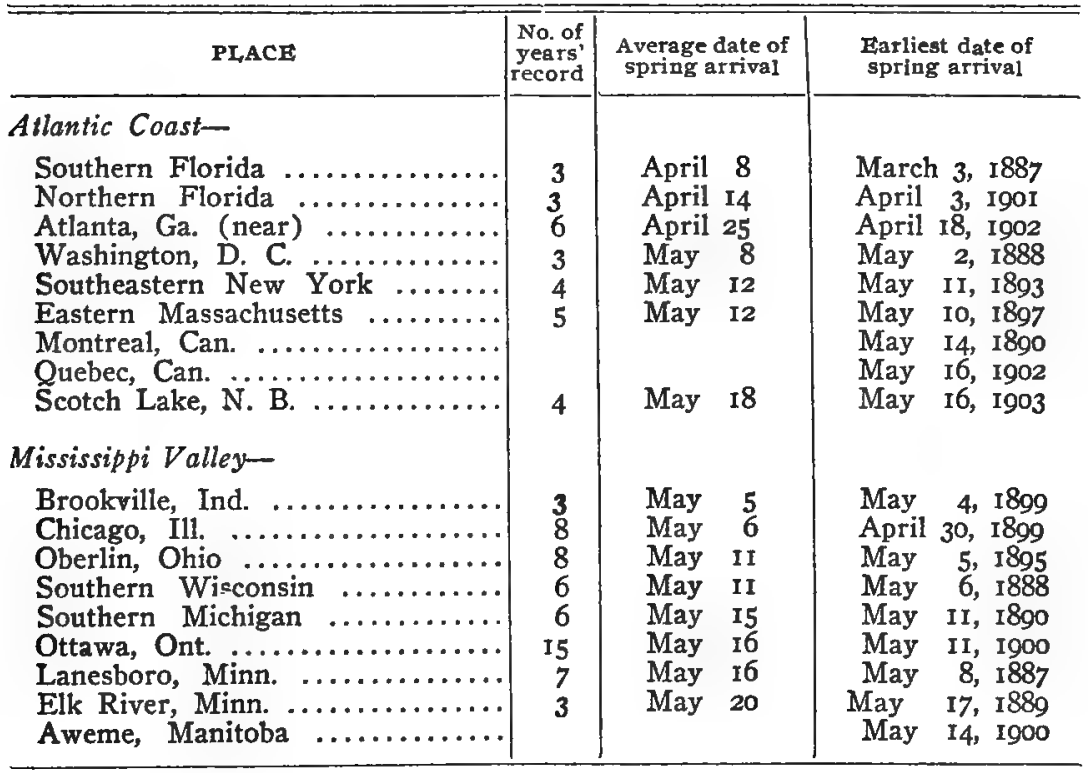


Fall Migration.-

\begin{tabular}{|c|c|c|c|}
\hline PLACE & $\begin{array}{l}\text { No. of } \\
\text { years' } \\
\text { record }\end{array}$ & $\begin{array}{l}\text { Average date of } \\
\text { first one seen }\end{array}$ & $\begin{array}{l}\text { Earliest date of } \\
\text { first one seen }\end{array}$ \\
\hline 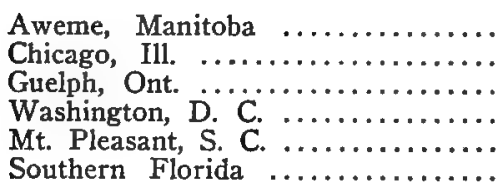 & & & $\begin{array}{l}\text { August } 23,1901 \\
\text { August } 20,1896 \\
\text { August } 23,1904 \\
\text { August 25, 1890 } \\
\text { September } 8,1898 \\
\text { September I7, } 1887\end{array}$ \\
\hline
\end{tabular}

\begin{tabular}{|c|c|c|c|}
\hline PIACE & $\begin{array}{l}\text { No. of } \\
\text { years' } \\
\text { record }\end{array}$ & $\begin{array}{l}\text { Average date of } \\
\text { last one seen }\end{array}$ & $\begin{array}{l}\text { Latest date of } \\
\text { last one seen }\end{array}$ \\
\hline 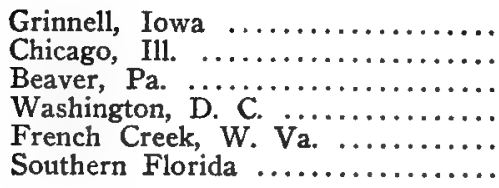 & & & $\begin{array}{l}\text { September } 17,1886 \\
\text { September 21, 1896 } \\
\text { September } 24,1889 \\
\text { October 14, I888 } \\
\text { October 21, 1891 } \\
\text { November } 7,1891\end{array}$ \\
\hline
\end{tabular}

Winter Range.-West Indies; accidental in Yucatan and Central America.

The Bird and Its Haunts.-The beauty and rarity of the Cape May Warbler make it one of the most eagerly sought for members of its family. To have seen a 'Cape May' stamps the day's outing with a memorable distinction. I still recall the particular tree and hour in which, over twenty years ago, I discovered with uncontrolled exultation my first Cape May-a fully adult male. One sees the dull plumaged fall birds with no little satisfaction but they never receive the enthusiastic welcome of the exquisitely colored spring male.

In early May in Florida, I have seen this species actually common, feeding in weedy patches among a rank growth of pokeberries. It seemed like wanton extravagance on the part of nature to bring so many of these generally rare creatures within one's experience in a single morning. Both on the east and west coasts of the State the bird is at times a common migrant, possibly bound for its summer home by way of the Mississippi Valley, where it is more numerous than in the north Atlantic States.

Butler ${ }^{2}$ writes that some years in Indiana, "they are found upon the drier uplands, among the oak woods, where they generally keep among the lower branches or upon the high bushes and smaller trees. They are not very active, but keep persistently hunting insects. At 
other times, we find them among our orchards, even coming into towns where they occupy themselves catching insects among the foliage and about the blossoms of all kinds of fruit and shade trees."

Brewster" states that about Cambridge the Cape May is "one of the very rarest of Warblers which visit us with any degree of regularity, especially if we also consider ( $I$ ) that it is one of the most strikingly colored and easily identified of them all; (2) that it is a rather loud and very persistent singer; and (3) that, when with us, it is given to frequenting isolated trees near houses."

The last-named habit is confirmed by Gerald Thayer's observations at Scarborough, in the lower Hudson Valley, where he writes that migrant Cape Mays "haunted a few big Norway spruces on our home lawn for two or three days, acting about like Blackburnians, but sticking strangely close to one or two special trees."

We know comparatively little about the Cape May on its nesting grounds. Maynard" writes that in northwestern Maine "they lived in the tops of the high coniferous trees." It was in this region, in 1871, that H. B. Bailey first found a nest, which was, however, destroyed before the set was completed, and J. W. Banks, as recorded by Chamberlain ${ }^{1}$, appears to have first secured the Cape May's nest and eggs.

Mr. Chamberlain" writes, "The birds seen at Edmundton [New Brunswick] were invariably on the topmost branches of the tallest evergreens (usually spruces) growing in the neighborhood. * * * As the birds were constantly singing, their general whereabouts was easily discovered, but no small amount of patient searching was required to catch sight of them." Subsequently, however, as quoted beyond, the bird was found to nest in a low cedar.

The reported breeding of this species in Jamaica and San Domingo remains unconfirmed.

Song._-"Two, at least, of the Cape May's songs, as I heard them freely uttered by three or four migrant males on the east bank of the Hudson River in the spring of I900, are of a thin and penetrating tone, much like the Black and White Warbler's. Nor does the resemblance stop there: the whole utterance, in tone, phrasing, and accentuation, strongly suggests the Black and White's shorter song; and in their most kindred variations the two might be hard to distinguish. Hence the rule, if you hear a queer-sounding Black and White, in spring, or in the North Woods, by all means look him up. On the other hand, the Cape May's singing is near akin to the Blackpoll's,--very near to some forms of it. But the notes are shorter, a little louder, less 
'thin,' and more run-together. They have also a slightly 'impure,' or double tone,-a quality from which the fine-spun notes of the Blackpoll are peculiarly free. Again, the 'swell and fall,' so characteristic of the Blackpoll's common song, is lacking in the Cape May's, which is merely accelerated a little toward the end. All this applies to one of the Cape May's two (or more?) main songs. The other, more like the Black and White's, has each of the six or eight main syllables longer-drawn-out, and split into barely-severed halves" (Thayer, MS.).

"I have only heard them sing one or two springs; a thin, rather sweet squeak repeated several times. In May, 1897, it impressed me as one of the thinnest and least musical of the Warbler songs." (Farwell, MS.)

Nesting Site.-Too little is known about the nesting habits of this species to warrant general statements. A nest found by Banks ${ }^{1}$ at St. Johns, N. B., was placed near the tip of a branch of a low cedar less than three feet from the ground and was "well-screened from observation."

Nest.-The walls of the nest above mentioned are "composed of minute twigs of dried spruce, grasses, and strawberry vines, with spider's webbing interwoven with coarse fabrics and knotted with numerous little balls, which are bound upon the surface. ***The exterior is rather roughly made, but is more compact, and bears evidence of more art than is shown in the nest of the Magnolia Warbler which it somewhat resembles. The interior, however, is much more neatly and artistically formed in the Cape May's than in its congener's. The lining is composed entirely of horse-hair, and this is laid with precision, and shaped into a prettily formed cup, the brim being turned with exquisite grace. The dimensions of the nest are, outside, 2 I-4 inches high and $23-4$ to 3 inches across the mouth; inside, I I-4 inches deep and I 3-4 inches wide." (Chamber$\operatorname{lain}^{1}$.)

Eggs.-4. "The eggs are of much the same dull white groundcolor, of a slightly ashen hue, as that of the Magnolia. The form of the egg is different, however, the Cape May's being less pyriform -the point less acute. The markings are of light and dark lilac, and yellowish and reddish tints of brown; the brown being on the surface and the lilac underneath the coatings of the shell producing the various shades. As a rule the spots are circular and very smallmany being quite minute-and are irregularly distributed, no two eggs bearing the same pattern, though in all four there is decided tendency to concentration in a ring near the large end; but on some 
there are spots over the larger part of the entire shell while the small end of others is immaculate. The measurements are .69x.49, .65x.49, .66x.49, .66x.48." (Chamberlain.) (Figs. 35,36. Childs Coll.) Nesting Dates.-St. Johns, N. B., June i6 (Chamberlain).

\section{BIOGRA PHICAL REFERENCES}

(1) M. Chamberlain, Nesting Habits of the Cape May Warbler. [in New Brunswick], Auk, II, 1885, 33. (2) A. W. Butler, Birds of Indiana, I043. (3) C. J. Maynard, Warblers of New England, 15. (4) WM. Brewster, Birds of the Cambridge Region, 331.

\section{BLACK-THROATED BLUE WARBLER}

DENDROICA CARULESCENS CARULESCENS (Gmel.) Plate IX

Distinguishing Characters.-The $\delta$, whether adult or young may always be known by its black throat and blue back. In the adult $q$ the white spot on the primaries above the primary coverts, is diagnostic. In the young $q$ this spot is much reduced and at times not evident and such specimens possess no obvious distinguishing mark. The bird in the hand, however, may be identified by the bluish tone of the tail feathers in connection with other features described beyond. Length (skin), 4.50; wing, 2.50; tail, 2.00; bill, .35.

Adult o', Spring.-Upperparts dark grayish blue, the back and inner tailcoverts at times with more or less black; tail black edged with blue, the three outer feathers with large white patches near the tip of the inner web, the next two usually with more or less white on the margin of the inner web; wings black edged with blue; all but the outer primary with more or less white basally, this on the second to seventh or eighth primaries appears as a conspicuous white spot at the end of the primary coverts; cheeks, throat, and sides black, rest of underparts white.

Adult d", Fall.-Only slightly different from above; the back very narrowly tipped with greenish, the throat and sides with white; black of throat apparently somewhat less in extent.

Young $\delta$, Spring.-Young of the previous year may be distinguished from fully mature males by remains of the greenish edgings generally to be found on the upperparts, and particularly by the browner green-edged wing feathers, which are evidently worn for one year.

Adult \&, Spring.-Above dusky olive-green with a more or less evident bluish tinge strongest on crown and upper tail-coverts; a narrow whitish line from bill over eye, lower and upper part of eye-ring whitish; tail fuscous margined with grayish blue, the outer feathers usually with white patches; wings fuscous margined with greenish; a white spot at the base of the primaries at the end of the primary coverts generally evident but sometimes (in immature specimens?) barely visible; underparts pale buffy yellowish or whitish, the sides darker, the throat and sides of the breast rarely dusky.

Adult $q$, Fall.-Indistinguishable in color from adult $q$ in Spring.

Young $\&$, Fall.-Similar to adult $q$ in Fall but greener above, where without trace of blue, dingy yellowish below, line over eye yellowish, white wing-spot never large and conspicuous and sometimes concealed by the primary coverts; white in tail much reduced. 
Nestling o $^{*}$-Above brownish olive-green, lores black, auriculars blackish, a whitish superciliary line; throat and breast somewhat paler than back or dusky yellowish, belly whitish or yellowish white; tail as in young $\delta$, black edged with blue and marked with white; wings as in young d, black the feathers edged with blue or greenish with a white patch at the base of the primaries; wing-coverts like back, edged with brownish.

Nestling 9.-Paler than nestling $\delta$, no black in lores or auriculars; below as in nestling $d$, wings and tail as in young Fall $q$, greater and median wingcoverts like back, edged with brownish.

General Distribution.-Eastern North America; north to Newfoundland and Hudson Bay; west to the Mississippi River.

Summer Range.-Common as a breeder in the southern portion of Quebec and south in the mountains to Maryland; less common north to Newfoundland, northeastern Quebec, and northern Ontario. Outside of the mountains it breeds south through northern New England to Massachusetts (Berkshire) and Connecticut (Eastford), to New York (Oneida and Hamilton Counties), southern Michigan (Detroit), northwestern Michigan (Porcupine Mountains), and northern Minnesota.

South of the breeding range it occurs rarely west of the Mississippi in Iowa and Missouri; accidentally in Nebraska (Lincoln, Omaha, West Point), Kansas (Finney Co., October I7, I89I), Colorado (Denver, May 24, I888, Yuma, September 19, I904), New Mexico (Gallinas Mountains, October 8, I904,) and California (Farallones, November I7, I886).

Winter Range.-The West Indies north to Florida (Key West). Accidental in Guatemala and Colombia.

Spring Migration.-

\begin{tabular}{|c|c|c|c|}
\hline PLACE & $\begin{array}{l}\text { No. of } \\
\text { years' } \\
\text { record }\end{array}$ & $\begin{array}{l}\text { Average date of } \\
\text { spring arrival }\end{array}$ & $\begin{array}{l}\text { Earliest date of } \\
\text { spring arrival }\end{array}$ \\
\hline \multicolumn{4}{|l|}{ Atlantic Coast- } \\
\hline 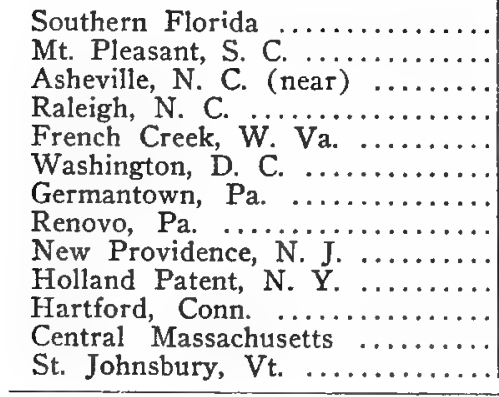 & $\begin{array}{r}6 \\
\text { I I } \\
4 \\
7 \\
7 \\
9 \\
6 \\
7 \\
5 \\
\text { I I } \\
6 \\
\end{array}$ & $\begin{array}{lr}\text { April } & 24 \\
\text { April } & 27 \\
\text { April } & 29 \\
\text { May } & 2 \\
\text { May } & 6 \\
\text { May } & 3 \\
\text { May } & 6 \\
\text { May } & 7 \\
\text { May } & \text { I0 } \\
\text { May } & 8 \\
\text { May } & 9 \\
\end{array}$ & 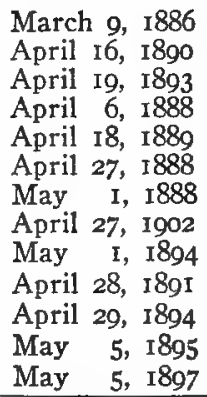 \\
\hline
\end{tabular}




\begin{tabular}{|c|c|c|c|c|c|}
\hline \multirow{2}{*}{$\begin{array}{l}\text { PLACE } \\
\text { Lewiston, Me. } \ldots \ldots \ldots \ldots \ldots \ldots \ldots \\
\text { Quebec, Can. } \ldots \ldots \ldots \ldots \ldots \ldots \ldots \\
\text { Central New Brunswick } \ldots \ldots \ldots\end{array}$} & \multirow{2}{*}{$\begin{array}{c}\begin{array}{c}\text { No. of } \\
\text { years' } \\
\text { record }\end{array} \\
5 \\
5 \\
8\end{array}$} & \multicolumn{2}{|c|}{$\begin{array}{l}\text { Average date of } \\
\text { spring arriva1 }\end{array}$} & \multicolumn{2}{|c|}{$\begin{array}{l}\text { Earliest date of } \\
\text { spring arrival }\end{array}$} \\
\hline & & $\begin{array}{l}\text { May } \\
\text { May } \\
\text { May }\end{array}$ & $\begin{array}{l}\text { I3 } \\
\text { II } \\
\text { I4 }\end{array}$ & $\begin{array}{l}\text { May } \\
\text { May } \\
\text { May }\end{array}$ & $\begin{array}{ll}7, & 1900 \\
7, & 1900 \\
9, & 1904\end{array}$ \\
\hline \multicolumn{6}{|l|}{ Mississippi Valley- } \\
\hline 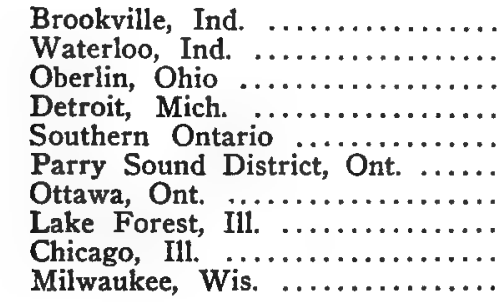 & $\begin{array}{r}6 \\
9 \\
7 \\
10 \\
15 \\
12 \\
20 \\
6 \\
12 \\
9\end{array}$ & $\begin{array}{l}\text { April } \\
\text { May } \\
\text { May } \\
\text { May } \\
\text { May } \\
\text { May } \\
\text { May } \\
\text { May } \\
\text { May } \\
\text { May }\end{array}$ & $\begin{array}{r}30 \\
5 \\
2 \\
4 \\
8 \\
10 \\
11 \\
6 \\
7 \\
9\end{array}$ & $\begin{array}{l}\text { April } \\
\text { May } \\
\text { April } \\
\text { May } \\
\text { May } \\
\text { May } \\
\text { May } \\
\text { May } \\
\text { May } \\
\text { May }\end{array}$ & $\begin{array}{rr}26, & 1894 \\
1, & 1895 \\
27, & 1896 \\
1, & 1894 \\
2, & 1887 \\
6, & 1899 \\
6, & 1890 \\
2, & 1905 \\
2, & 1902 \\
2, & 1892\end{array}$ \\
\hline
\end{tabular}

Fall Migration-

\begin{tabular}{|c|c|c|c|}
\hline PLACE & $\left|\begin{array}{l}\text { No. of } \\
\text { years } \\
\text { record }\end{array}\right|$ & $\begin{array}{c}\text { Average date of } \\
\text { first one seen }\end{array}$ & $\begin{array}{l}\text { Earliest date of } \\
\text { first one seen }\end{array}$ \\
\hline 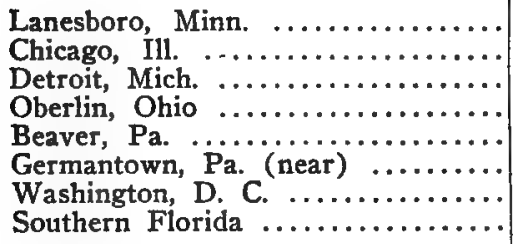 & $\begin{array}{r}3 \\
7 \\
10 \\
3 \\
4 \\
6\end{array}$ & $\begin{array}{lr}\text { September } & 26 \\
\text { September } & 1 \\
\text { September } & \text { 10 } \\
\text { September } & 7 \\
\text { September } & 9 \\
\text { September } & \text { 13 }\end{array}$ & $\begin{array}{l}\text { September } 24,1890 \\
\text { August 25, 1898 } \\
\text { September 2, } 1905 \\
\text { September 1, } 1005 \\
\text { August 28, 1889 } \\
\text { September 8, } 1898 \\
\text { August 21, 1887 } \\
\text { September 3, } 1885\end{array}$ \\
\hline PLACE & $\begin{array}{l}\text { No. of } \\
\text { years } \\
\text { record }\end{array}$ & $\begin{array}{l}\text { Average date of } \\
\text { last one seen }\end{array}$ & $\begin{array}{l}\text { Latest date of } \\
\text { last one seen }\end{array}$ \\
\hline 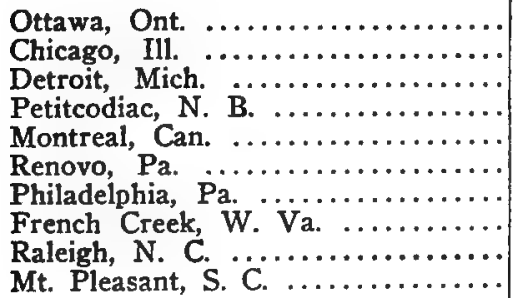 & $\begin{array}{r}4 \\
7 \\
10\end{array}$ & \begin{tabular}{|lr|}
\multicolumn{2}{|l|}{ September 29} \\
October & I \\
October & 3 \\
& \\
October & 6 \\
October & 10 \\
October & 9 \\
October & I7
\end{tabular} & $\begin{array}{l}\text { October 7, 1900 } \\
\text { October 10, 1897 } \\
\text { October 15, 1905 } \\
\text { September 5, 1886 } \\
\text { September 24, 1887 } \\
\text { October 11, I897 } \\
\text { October 21, 1888 } \\
\text { October 15, 1890 } \\
\text { November 19, 1885 } \\
\text { December 6 }\end{array}$ \\
\hline
\end{tabular}

The Bird and its Haunts.-The sharply contrasted black and white areas and dark blue back, which characterize the male Blackthroated Blue, are so unlike the colors of any other Warbler that the bird may be known at a glance. Fortunately the adult wears his plumage throughout the year and, contrary to the usual rule, the young male closely resembles him. The female, however, is as 
obscure as the male is conspicuous and were it not for the white spot at the base of the primaries, would have no prominent distinguishing mark. But in the young female even this is sometimes so small as to be concealed by the primary coverts and, in this plumage, the Black-throated Blue is one of the most difficult Warblers to identify. Where the range of this species penetrates the Canadian life-zone with its coniferous forests it nests in growth of this character but south of these limits its summer home is in deciduous woods.

Gerald Thayer writes that about Monadnock the Black-throated Blue is "a bird of the ampler deciduous undergrowth in deep, moist woods-mixed virgin timber or very old second growth. It is peculiarly partial to these woodland conditions, and is common wherever they occur, especially between the altitudes of 1,000 and 2,500 feet. Creeping yew is aimost always common in woods where these Warblers breed, and they sometimes, perhaps often, nest in a clump of it. "In its movements the Black-throated Blue is more deliberate than many of its relatives, but it has at the same time a somewhat Redstart-like way of 'spiriting' itself from one perch to another, and, while perched, of partly opening its white-mooned wings;-a habit and a marking shared by the boldly blue-and-black-and-white- males and the dimly green and yellowish females and young. It is among the tamest of our Warblers." (Thayer, MS.)

Egbert Bagg, of Utica, writes: "This bird is a common summer resident in the southwestern part of our New York wilderness and it is there, both in the wilderness and along its outskirts, that I have come to know it as one of my bird friends. In these fastnesses of the woods birds appear to be scarce. The wilderness is so great and so impassable that the number of birds seen is small, when they are attending to their duties in breeding season. Quite the contrary is the fact when they are migrating, and $I$ have seen birds in as great numbers, during May, in the wilderness, as I ever saw them anywhere; hundreds, I presume thousands, passing our camp for several days at a time. But a month later in the same locality hardly a bird will be seen. But even at this time a careful observer will find the species of which I am writing not uncommon in these woods. The males will be seen rather high up in the trees, but the females are but little in evidence.

"It was a long time after I discovered that these birds were common summer residents before I found my first nest, and when I did find it, its location was so uncommon, (as later discoveries showed) that it actually hindered rather than helped the discovery of others. 
It was on a high bluff covered with spruce timber and with but little underbrush and was placed in the top of an overturned and dead spruce about eighteen inches from the ground. On June I3, it contained three eggs which hatched on the next day. I never found another nest in the spruce timber and I never found another in open woods, that is, free from underbrush, nor in any location corresponding to this dead tree-top. After several years searching with some success, I think it is safe to say that this species builds in hardwood forests, where the large timber stands somewhat openly, but where all space is grown up with dense undergrowth of hardwood saplings and brush with large leaves. I also think that the breeding spots are very local, and that one may pass through many miles of forest and not find a pair of these birds; but when just the right kind of hardwood knoll is found, several pairs may be looked for within a short distance. My facts are rather meagre for this deduction, but this is my belief." (Bagg, MS.)

At Branchport, N. Y., Burtch says that this species is "a rare but regular summer resident. It may be found in the mixed growths of oaks, maple, beech, chestnut and hemlock where the undergrowth is quite thick." (Burtch, MS.)

The first known nest of the Black-throated Blue Warbler was discovered by John Burroughs ${ }^{5}$ early in July, 187I, at Roxbury, Delaware County, N. Y. It contained four fledged young and one egg. The latter, with the nest, is described by Brewer (B. B. and R., History of N. A. Birds, I, 257) while in 'Locusts and Wild Honey' Burroughs gives a description of the hunt for the nest which could have been written only by a born birds' nester.

Song.- "There is not a more regularly and amply versatile singer among our eastern Warblers than the Black-throated Blue. It has at least four main songs, on which it is forever playing notable variations. Of these four, two end on a sharply-ascending scale, and two are almost monotones. Zwee zwee zwee, is a book rendering, and a fairly good one, of the commoner monotone song. The other, of two notes only, has almost the form and emphasis of the Blue-winged Warbler's explosive little shorter song, Swee-chirrrr!, but is louder and somewhat more languid, with the characteristic and unmistakable full-voiced huskiness of the Black-throated Blue. It might be syllabled Wher weeeee. The second half, in addition to being more emphatic, is a little bit lower in key. Of the other two songs, the commoner one is like the syllables Wheer, wheer, wheeee,-rather deliberately uttered,- the first two notes almost alike, the final drawled 
note decidedly higher pitched and also louder. This is the commonest of the four songs in the breeding season near Monadnock. The fourth song begins with a long string of short, hurried notes, like Hi-hi-hi-hi$h i-h i-h i$ culminating at last in the high-pitched, long-drawn wheeee. All four songs, -and, as far as my experience goes, the many variations from them and between them, have, either throughout or in part, the tell-tale tone-quality of huskiness or beadiness in a fullstrength Warbler-voice;-an almost peculiar characteristic of the Black-throated Blue's. In addition to some rather non-committal small call-notes, it has some that are peculiarly its own. The queerest of these I have heard from the male only. It is a weak, insect-like, grating, but low-toned Bzzz bzzz bzzz bzzz bzzz several times repeated in pretty quick succession;-an utterance which, if it came from any other Warbler, might be taken for a song, but so totally unlike all the Black-throated Blue's unmistakably sung performances, that it cannot be more than a call-note or complaint." (Thayer, MS.)

Miss Paddock sends three notations and writes: "This song is hard to express in musical notation. It is an insect-like buzzing note repeated three or four times with a rising inflection. It sounds a little like the breath sucked through the teeth; or like one note of the Blackthroated Green's song."
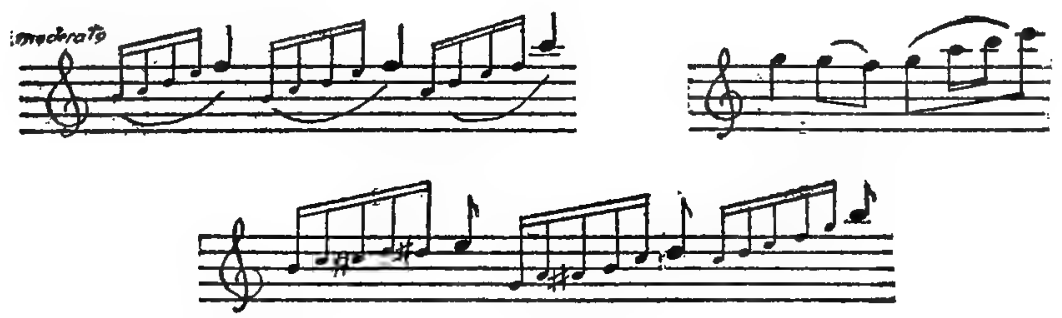

Nesting Site.-Nests found by Jones ${ }^{1}$ at Eastford, Connecticut, were in laurel not over eighteen inches up, while, in northern New York, $\mathrm{Bagg}^{\mathrm{s}}$ found the species nesting in little maples at about one foot from the ground. Nests found by Burtch (MS.) at Branchport, New York, were built in birch saplings eighteen and twenty inches from the ground, and in a blackberry bush fourteen inches from the ground. Near Utica, New York, Egbert Bagg writes that: "the nest is placed in an upright fork of some shrub, quite near the ground, from a foot to three feet from it. The female sits close and allows an observer every opportunity to identify her. The male generally appears, especially if the female leaves the nest, but 


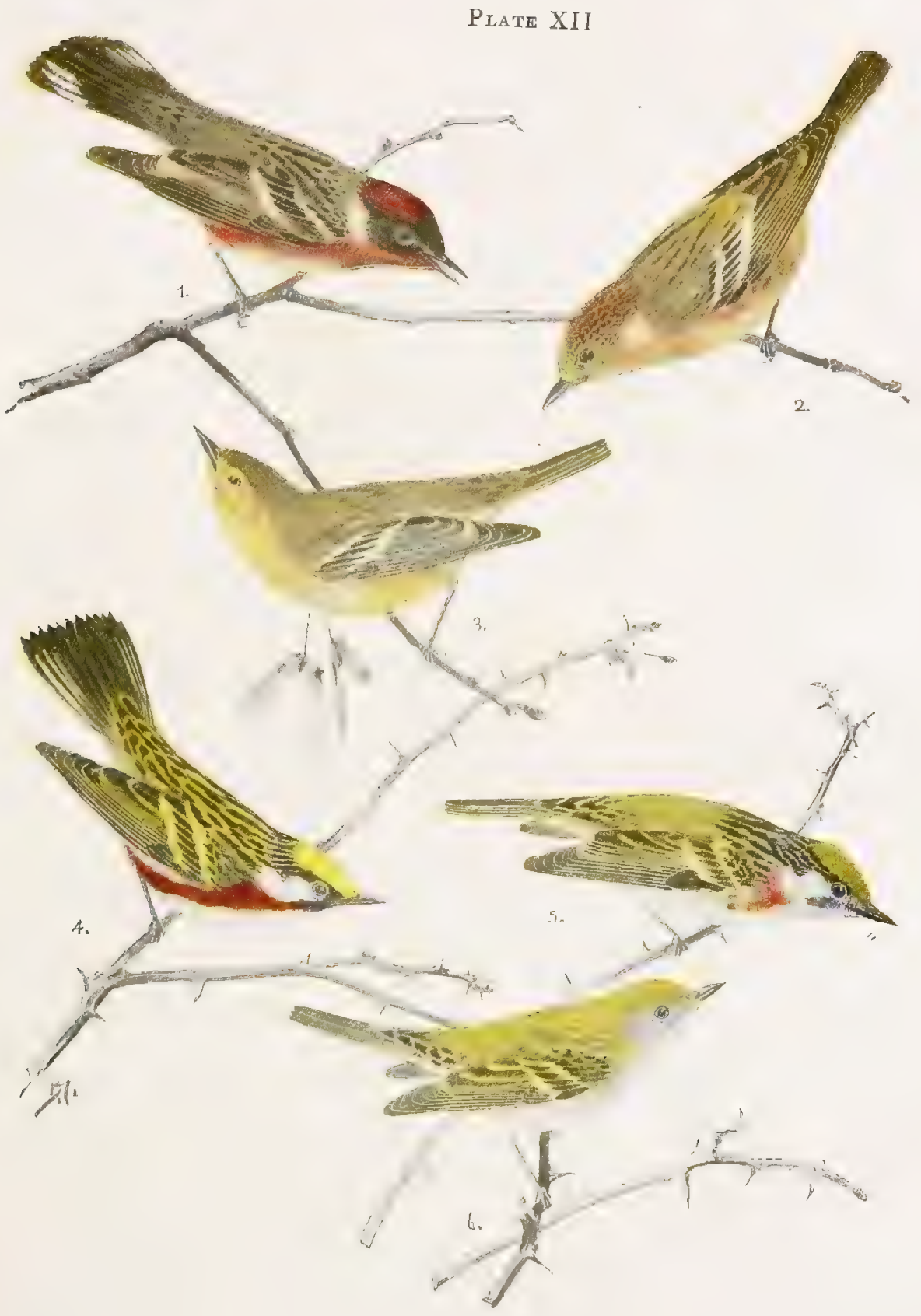

1. Bay-breasted Warbifr, Mate.

2. Bay-breasted WARBLER, Female.

3. Bay-breasted Warbler, Young.
4. Chestant sided Warblek, Male.

5. Chestnut-Sidti Warbler, Female.

6. Cirestnut-sided Warbler, Young. 

Brewster states that in northern New England the nest is usually built in a yew (Taxus canadensis).

Nest.-The nest of this species may readily be distinguished from that of other Warblers by its bulkiness, rough exterior covered with pieces of pithy wood, inner bark fibers or birch bark. Jones, ${ }^{1}$ nests were made outwardly of "what appears to be the dry bark of the grapevine, with a few twigs and roots. This is covered in many places with a reddish wooly substance, apparently the outer covering of some species of cocoon. The inside is composed of small black roots and hair."

Bagg's Utica nests are described by him as follows: "The nests are beautiful structures, rather loosely put together on the outside but neatly lined and finished within. All those I have seen had one peculiarity, there entered into the outside construction considerable rotten wood nearly white in color, so that the nest looked quite light colored. One nest contained a few 'birch curls' giving it the same white appearance. A typical nest, before me is composed largely of the rotten wood held together with strips of inner bark of deciduous trees and fibers of weed stalks and grasses. It is neatly lined with fine black roots, entirely, and this lining seems to be almost universal, though one nest had some of the finer quills of our common porcupine (even large enough for their barbs to be visible to the naked eye). This sort of lining might be satisfactory to the old bird, protected by her coat of feathers, but would seem to be somewhat danyerous to her naked fledglings.

"The measurements of this nest are, diameter, outside, $3^{\mathrm{T}} / 2$ inches, inside, $2 \frac{1}{4}$ inches; height, outside, 5 inches; depth, inside, $I \frac{1}{2}$ inches." (Bagg, MS.)

The nests found by Burtch (MS.) are described by him as composed of strips of partially decayed bark, and white birch or grapevine bark lined with fine black rootlets and vegetable fibers.

Eggs.-3 or 4, usually 4. Ground color, buffy white to light greenish white spotted and blotched with light and dark reddish brown and lavender, in some specimens forming a wreath around large end in others quite evenly marked over entire egg. Size; average of three sets, .66x.5I. (Figs. 45-47.)

Nesting Dates.-Litchfield, Conn., June 8 (Bishop); Branchport, N. Y., June II (Burtch) ; Lancaster, N. H., June I9 (Spaulding); Bangor, Me., June ro (Knight) ; Listowel, Ont., May 27-June 9 (Kells); Kalamazoo Co., Mich., May 29, Westnedge, (Barrozes). 


\section{BIOGRAPHICAL REFERENCES}

(I) C. M. Jones, On the Breeding of the Black-throated Blue Warbler (Dendroica carulescens) in Connecticut, Bull. Nutt. Orn. Club, I, I876, II; Orn, and Oöl., VI, 188I, 49; IX, 1884, 30. (2) W. L. KeLLS, Nesting of the Black-throated Blue Warbler (in Ontario), Orn. and Oöl., XII, 1887, 76; XIV, 1869, 170; Ottawa Nat., XVI, I902, 181. (3) EGBERT BAGG, Nesting of the Black-throated Blue Warbler ( in N. N. Y.), Orn. and Oöl., XII, I887, 90. (4) O. W. KNIGHT, Contributions to the Life History of the Black-throated Blue Warbler, Journ. Maine Orn. Club, VIII, I906, 33. (5) JoHn Burroughs, Birds' Nesting, in Locusts and Wild Honey, Riverside Edition, I895, I8I.

\section{CAIRNS' WARBLER \\ DENDROICA CARULESCENS CAIRNSI Coues}

Subspecific Characters.-Similar to Dendroica c. carulescens but $\delta$ with the back always more or less spotted with black, sometimes the center of the back being entirely black. Adult $q$ generally darker. While specimens of true carulescens carulescens not infrequently show more or less black in the back cairnsi is very rarely without this character.

General Distribution.-Higher parts of the southern Alleghenies.

Summer Range.-Higher parts of the Alleghenies northward to Pennsylvania. (Blue Knob, Sugar Loaf, Mt. Rainsburg,) south to Georgia.

Winter Range.-West Indies.

The Bird and its Haunts.- This southern Alleghenian form of the Black-throated Blue Warbler was named by Dr. Coues for the late John S. Cairns to whom we are chiefly indebted for our knowledge of its life history. Cairns ${ }^{2}$ writes: "High up on the heavily timbered mountain ranges of western North Carolina is the summer home of the Black-throated Blue Warbler. [The bird had not been subspecifically separated when Cairns wrote.] Here, in precipitous ravines, amid tangled vines and moss-covered logs, where the sun's rays never penetrate the rank vegetation and the air is always cool, dwells the happy little creature, filling the woods from dawn to twilight with its song. * * * These birds are a local race; breeding from one generation to another. They arrive from the south nearly ten days earlier than those that pass through the valleys on their northward migration. It is common to observe migrants through the valleys while breeders on the higher mountains are already nest-building and rearing their young."

Nesting Site._- Nesting begins early in May and continues until the end of June. The nests are placed in various shrubs, such as laurel, wild gooseberry, and chestnut, but the blue cohosh or papooseroot (Caulophyllum thalictroides) seems to be the favorite. These thick 
weeds grow rapidly to a height of from three to five feet, entirely hiding the ground, and thus afford the birds considerable protection. * * * "The nests are never placed over three feet from the ground; usually about eighteen inches; one I examined was only six inches." (Cairns ${ }^{2}$.)

Nest.-"The nests show little variation in their construction, though some are more substantially built than others. Exteriorly they are composed of rhododendron or grapevine bark, interwoven with birch-bark, moss, spider-webs, and occasionally bits of rotten wood. The interior is neatly lined with hair-like moss, resembling fine black roots, mixed with a few sprays of bright red moss, forming a strikingly beautiful contrast to the pearly eggs. The female gathers all the materials, and builds rapidly, usually completing a nest in from four to six days if the weather is favorable. She is usually accompanied by the male, which, however, does not assist her in any way." (Cairns. ${ }^{2}$ )

Eggs.-3 or 4, usually 4. The eggs of this subspecies, which have been examined, do not differ from those of the foregoing; a typical set from Craggy Mountain, Buncombe Co., N. C., measures $.62 \times .53, .66 x .53, .66 \times .53$.

Nesting Date.-Buncombe Co., N. C., May 2I (C.W.C.).

\section{BIOGRAPHICAL. REFERENCES}

(I) S. B. LADD, Nesting of the Black-throated Blue Warbler, in Buncombe Co., N. C., Orn. and Oöl., XVII, I892, I29. (2) J. S. CAIRNS, The Summer Home of Dendroica carulescens. Papers Presented to the World's Congress on Ornithology, Chicago, 1896, 136.

\section{MYRTLE WARBLER DENDROICA CORONATA (Linn.) Plate $X$}

Distinguishing Characters.-In any plumage this Warbler may be distinguished from all other Warblers, except Audubon's Warbler, by the yellow patches on crown, rump and both sides of the breast. In the young $q$ the latter marks are sometimes obsolete but their general brown color above, yellow crown-patch, and rump are fistinctive. From Audubon's Warbler, without regard to the color of the thruat, it differs in having as a rule only two or three, instead of four outer tail-feathers marked with white. (But see beyond under auduboni.) Length (skin), 5.10; wing, 2.90; tail, 2.10; bill, .35.

Adult d', Spring.-Center of crown, rump, and sides of breast with a yellow patch; above bluish gray streaked with black, cheeks black a white line over eye; lower part of eye-ring white; tail black edged with gray the outer three (rarely four) feathers with white patches near tip of inner web; throat white; breast black more or less streaked and tipped with white; center of belly and crissum white, flanks streaked with black. This plumage begins to appear in March and is not, as a rule, completed before late April or early May. 
Adult ठै, Fall--Quite unlike $\delta$ in Spring; crown and back grayish brown; the latter indistinctly streaked with black; yellow of crown more or less concealed by brownish tips; rump bright yellow, upper tail-coverts and tail as in Spring 8 ; median and greater wing-coverts margined with brownish; cheeks mixed with brownish; underparts white, the breast washed with brownish and, with sides, with partly concealed black streaks; yellow patches at sides of breast less pronounced than in Spring.

Young $\delta^{*}$, Fall,-Similar to adult $\delta$ in Fall but browner above, the yellow crown-patch sometimes nearly hidden; the underparts less heavily streaked, the breast patches less pronounced.

Adult \&, Spring.-Generally resembling the adult $\delta$ in Fall but with the black streaks above and below more sharply defined, the wing-bars white, the cheeks blacker.

Adult ${ }^{\circ}$, Fall.-Resembles young $d *$ in Fall but averages browner and less streaked, the edgings to the wing-coverts browner.

Young + , Fall.-Not always to be distinguished from the adult $q$ in Fall but the yellow crown and breast-patches average smaller and the latter are sometimes barely evident or wanting.

Nestling.-Strikingly different from the nestlings of other Mniotiltida, except those of $D$. auduboni. Above brown streaked with black and edged with buffy; below white heavily and definitely streaked with black; greater and median wing-coverts tipped with white.

General Distribution.-North America; north to Labrador and Alaska.

Summer Range.-Breeds commonly north almost to the limit of tree growth from Labrador to Alaska, and thence south to southern Maine, the mountains of New Hampshire and Vermont, and the Adirondacks; less commonly in the Catskills and the more elevated portions of Massachusetts; has bred casually in the lower districts of Massachusetts (Springfield, Winchendon), and of New York (Utica, Buffalo); reported as breeding once at Havre-deGrace, Maryland. The regular breeding range extends westward from the Adirondacks, through central Ontario (Ottawa) to northern Michigan (Porcupine Mountains), northern Minnesota, Manitoba and westward to British Columbia and northward to Alaska.

Winter Range.-Mexico and Central America to Panama; the Greater Antilles, the Bahamas, all of southern United States and north to southeastern Kansas, southern Illinois, southern Indiana and northern New Jersey. Along the Atlantic coast and a few miles inland, it occurs with more or less frequency as far north as Massachusetts and even to Cape Elizabeth, Maine. In the western United States the Myrtle Warbler is a common migrant on the plains and not rare at the foothills of the Rockies. It is almost absent from the western slope of these mountains, but reappears again on the Pacific Coast as a rare 
migrant in Oregon and Washington, and a not uncommon winter resident from central California to Los Angeles.

Spring Migration.-

\begin{tabular}{|c|c|c|c|}
\hline PI,ACE & $\begin{array}{l}\text { No. of } \\
\text { years' } \\
\text { record }\end{array}$ & $\begin{array}{l}\text { Average date of } \\
\text { spring arrival }\end{array}$ & $\begin{array}{l}\text { Earliest date of } \\
\text { spring arrival }\end{array}$ \\
\hline \multicolumn{4}{|l|}{ Atlantic Coast- } \\
\hline 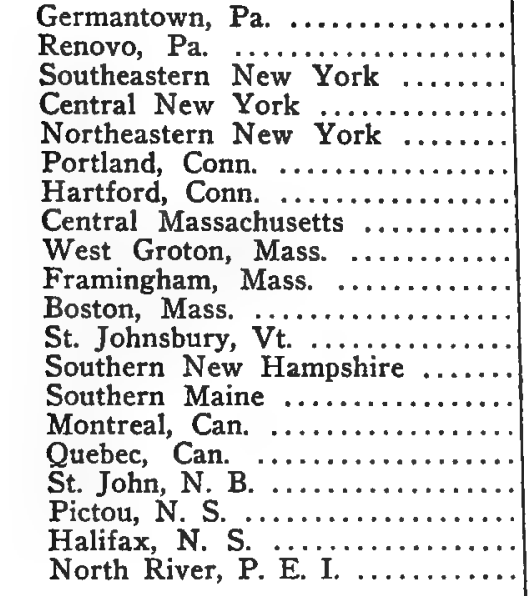 & $\begin{array}{r}5 \\
\text { I2 } \\
5 \\
\text { II } \\
8 \\
6 \\
10 \\
\text { II } \\
7 \\
8 \\
\text { II } \\
5 \\
7 \\
14 \\
4 \\
10 \\
11 \\
10 \\
4 \\
4\end{array}$ & $\begin{array}{lr}\text { April } & 27 \\
\text { April } & 30 \\
\text { April } & 25 \\
\text { May } & 1 \\
\text { May } & 2 \\
\text { April } & 27 \\
\text { April } & 26 \\
\text { April } & 28 \\
\text { April } & 24 \\
\text { April } & 20 \\
\text { April } & 22 \\
\text { April } & 27 \\
\text { April } & 23 \\
\text { April } & 23 \\
\text { May } & 7 \\
\text { May } & 6 \\
\text { April } & 23 \\
\text { April } & 30 \\
\text { May } & 2 \\
\text { April } & 26\end{array}$ & $\begin{array}{l}\text { April 10, } 1886 \\
\text { April 27, } 1902 \\
\text { April 2, } 1890 \\
\text { April 24, } 1891 \\
\text { April 29, } 1890 \\
\text { March 30, } 1903 \\
\text { April 8, } 1893 \\
\text { April 22, } 1893 \\
\text { April 18, } 1897 \\
\text { April 17, } 1896 \\
\text { April 13, } 1896 \\
\text { April 12, } 1903 \\
\text { March 20, } 1900 \\
\text { April 19, } 1891 \\
\text { May 3, } 1890 \\
\text { April 30, } 1896 \\
\text { April 15, } 1897 \\
\text { April 25, } 1892 \\
\text { April 26, } 1896 \\
\text { April 24, } 1891\end{array}$ \\
\hline \multicolumn{4}{|l|}{ Mississippi Valley- } \\
\hline 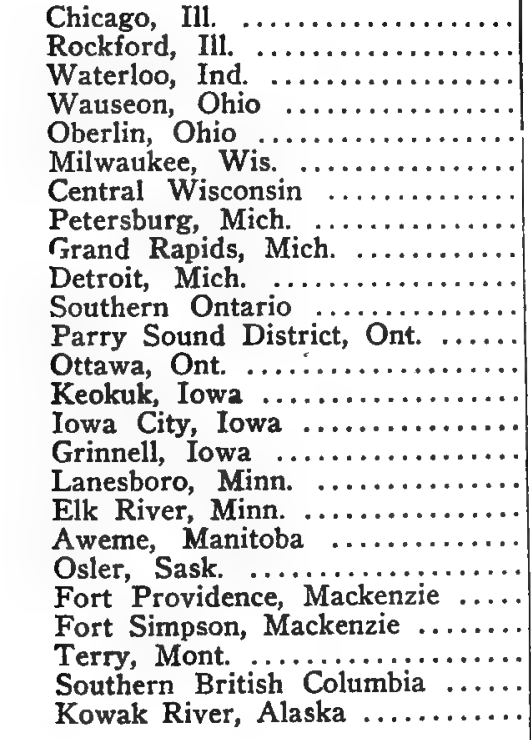 & $\begin{array}{r}9 \\
6 \\
10 \\
7 \\
8 \\
10 \\
11 \\
13 \\
5 \\
13 \\
13 \\
8 \\
15 \\
10 \\
7 \\
5 \\
9 \\
7 \\
8\end{array}$ & $\begin{array}{lr}\text { April } 16 \\
\text { April } & 15 \\
\text { April } & 23 \\
\text { April } 29 \\
\text { April } 24 \\
\text { April } 18 \\
\text { April } & 19 \\
\text { April } & 25 \\
\text { April } & 16 \\
\text { April } & 28 \\
\text { April } & 29 \\
\text { May } & 2 \\
\text { May } & 2 \\
\text { April } 20 \\
\text { April } 20 \\
\text { April } & 18 \\
\text { April } & 16 \\
\text { April } & 16 \\
\text { April } & 23 \\
& \end{array}$ & 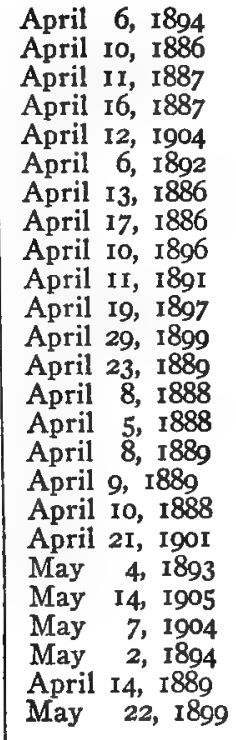 \\
\hline
\end{tabular}


Fall Migration.-

\begin{tabular}{|c|c|c|c|}
\hline PIACE & $\begin{array}{c}\text { No. of } \\
\text { years' } \\
\text { record }\end{array}$ & $\begin{array}{l}\text { Average date of } \\
\text { first one seen }\end{array}$ & $\begin{array}{l}\text { Earliest date of } \\
\text { first one seen }\end{array}$ \\
\hline 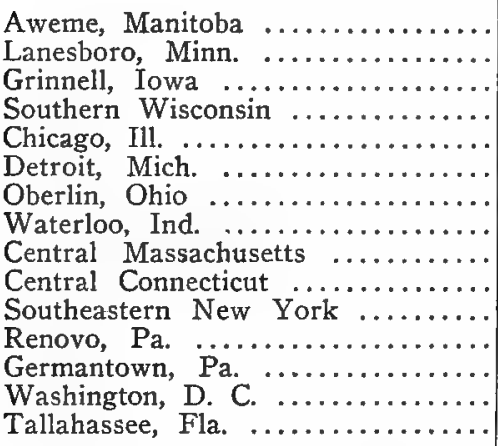 & $\begin{array}{r}3 \\
7 \\
4 \\
5 \\
6 \\
11 \\
4 \\
4 \\
4 \\
4 \\
8 \\
4 \\
6 \\
3\end{array}$ & $\begin{array}{ll}\text { September } 1 \text { I } \\
\text { September } 22 \\
\text { September } 23 \\
\text { September } 25 \\
\text { September } 27 \\
\text { September } 28 \\
\text { September } 27 \\
\text { October } 3 \\
\text { September } 23 \\
\text { October } 7 \\
\text { October } 5 \\
\text { September } 26 \\
\text { September } 27 \\
\text { October I }\end{array}$ & $\begin{array}{l}\text { September 7, I902 } \\
\text { September 15, 1887 } \\
\text { September 6, I885 } \\
\text { September 18, I902 } \\
\text { September 25, I899 } \\
\text { September 16, I889 } \\
\text { September 2, I901 } \\
\text { October 2, I891 } \\
\text { September I3, I892 } \\
\text { September 20, I888 } \\
\text { September 29, I893 } \\
\text { September 23, I900 } \\
\text { September 22, I888 } \\
\text { September 30, I890 } \\
\text { October I6, I904 }\end{array}$ \\
\hline
\end{tabular}

\begin{tabular}{|c|c|c|c|}
\hline PI,ACE & $\begin{array}{c}\text { No. of } \\
\text { years' } \\
\text { record }\end{array}$ & $\begin{array}{l}\text { Average date of } \\
\text { last one seen }\end{array}$ & $\begin{array}{l}\text { Latest date of } \\
\text { last one seen }\end{array}$ \\
\hline 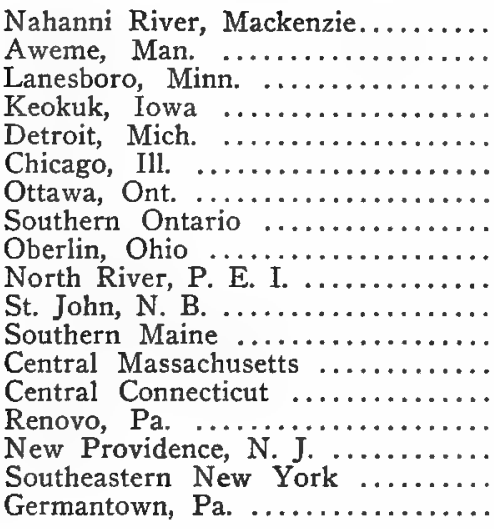 & $\begin{array}{r}6 \\
7 \\
4 \\
12 \\
6 \\
9 \\
7 \\
4 \\
6 \\
8 \\
8 \\
4 \\
5 \\
7 \\
5 \\
5\end{array}$ & $\begin{array}{l}\text { October } 10 \\
\text { October } 22 \\
\text { October } 18 \\
\text { October } 17 \\
\text { October } 23 \\
\text { October } 23 \\
\text { October } 24 \\
\text { October } 26 \\
\text { October } 23 \\
\text { October } 17 \\
\text { October } 19 \\
\text { October } 26 \\
\text { October } 25 \\
\text { October } 23 \\
\text { November } 12 \\
\text { November } 9\end{array}$ & $\begin{array}{l}\text { October I5, I903 } \\
\text { October I4, I900 } \\
\text { October 28, I887 } \\
\text { October 26, I897 } \\
\text { November I9, I904 } \\
\text { October 3I, I897 } \\
\text { November } 3,1888 \\
\text { November } 8,1898 \\
\text { November 2, } 1899 \\
\text { October I5, I888 } \\
\text { November 4, I891 } \\
\text { October 24, I892 } \\
\text { October 22, I899 } \\
\text { October 30, I900 } \\
\text { October 29, I900 } \\
\text { October 29, I892 } \\
\text { November 20, I89I } \\
\text { November 20, I886 }\end{array}$ \\
\hline
\end{tabular}

The Bird and its Haunts.-The Yellow Warbler was the first, the Myrtle, the second member of the genus Dendroica whose acquaintances I made in life. The experience is doubtless not unusual for this Warbler is so abundant, so generally distributed, and so conspicuous, that even as a migrant it cannot fail to attract the attention of any one looking for birds. Furthermore, it appears to travel leisurely and, under certain conditions, often winters in numbers far north of the winter home of the warblers which pass this season in the United States. 

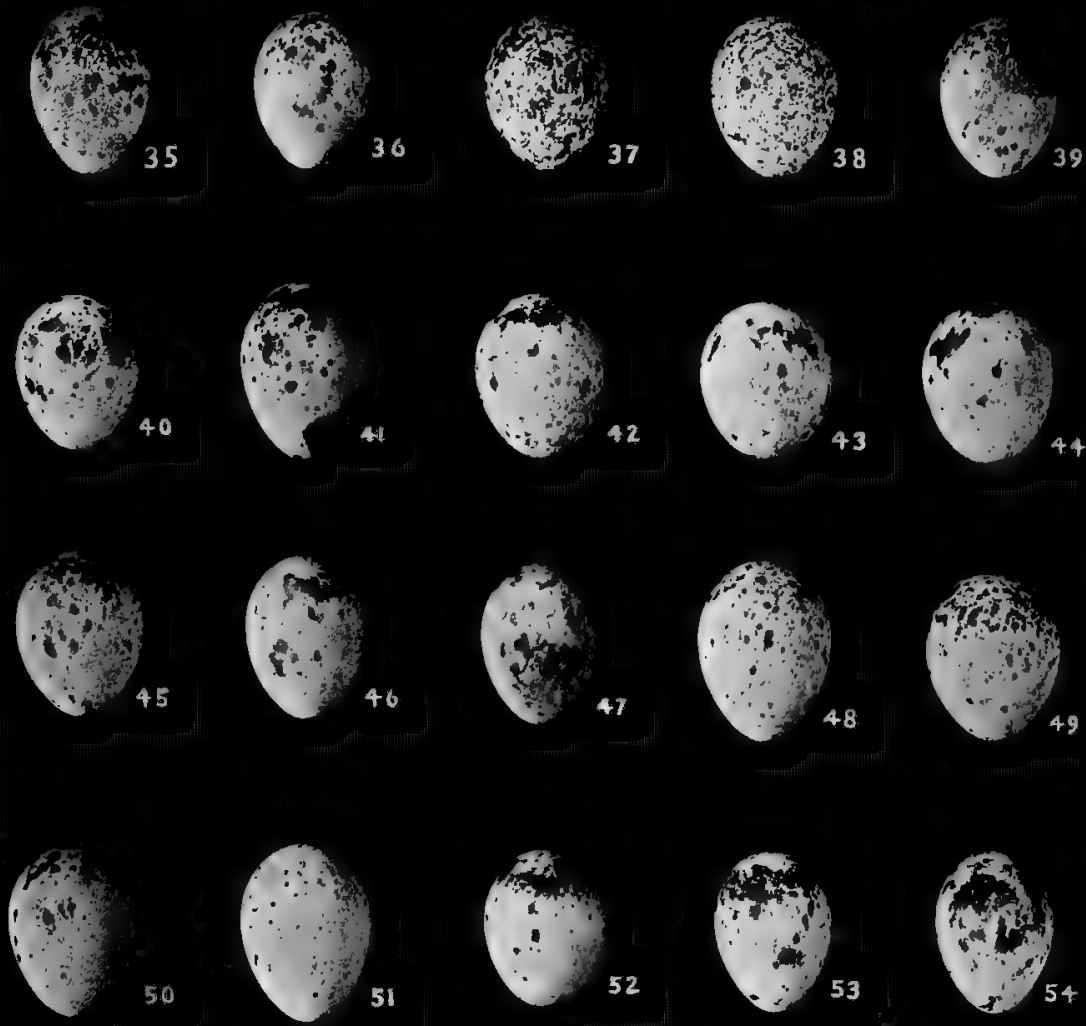

52
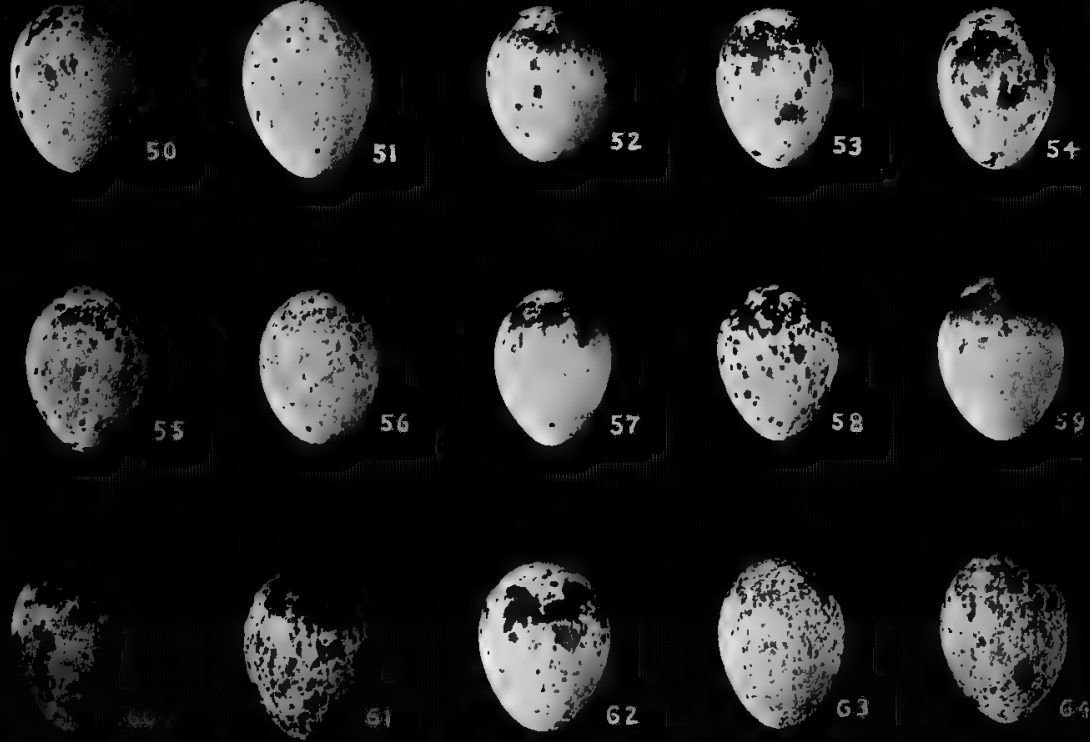

I':gs. 35, 36. Cape May Warbler.

‘) 3\%, 38. Olive Warbler.

“ 39-41. Yellow Warbler.

"42-44. Bryant's Warbler.

، 45-4\%, Black-throated Blue Warbler.

“ 48, 49. Myrtle Warbler.
Figs. 50,51. Audubon's Warbler.

"52-54. Magnolia Warbler.

" 55,56. Cerulean Warbler.

“ 57-50. Chestnut-sided Warbler.

“ 60,61. Bay-breasted Warbler.

“ 62-64. Blackpoll Warbler. 

In the spring the Myrtle Warbler is often found in the woods, but in autumn it is rather a bird of bushy second growths, scrubs, and hedgerows, where its characteristic tchip and the flash of its yellow rump seem as much a part of the season as the peek of White-throated Sparrows or twitter of Juncos. Especially is it to be found in numbers where the myrtle or bayberries-after which it is named-flourish; the supply of these berries generally determining the bird's presence or absence, during the winter. At this season insects' eggs or larvæ are also eaten, the bird at times frequenting our homes to glean from the cocoons placed in sheltered crevices about our buildings.

In the summer the Myrtle Warbler dwells in coniferous growths. Gerald Thayer writes that it is "a regular breeder in the Monadnock region, common among the scattered spruces on the mountain's rocky ridge, and on the higher of the neighboring hills, but uncommon in the intervening lower country ( $1,500-1000$ feet). During both migrations it is by long odds our most abundant Warbler,- everywhere, high and low. A big, brisk, tame, restless Warbler; the first to reach Monadnock in the spring and the last to leave in the fall. It ranges from the ground and low bushes to tree-tops, in scrub-lands and halfopen woods, avoiding the deep forests. Recognizable even in dingiest immature plumage by its neatly-defined bright yellow rump." (Thayer, MS.)

In Louisiana, in winter, Allison states that "open woods, preferably not of coniferous trees, are its typical haunts; but the bare, open fields, the thick roadside hedge of Cherokee rose or Osage orange-in both of which these birds roost in large numbers-the weeds and shrubs in neglected city lots; the trees and shrubbery of yards and parks, all invite Myrtle Warblers. Perhaps the place where a Wood Warbler is least to be expected is the sandy sea-beach; but along the shores of the Gulf I have often seen them flitting along, alighting sometimes on the sand, sometimes on half-buried logs and posts. They make frequent fly-catching excursions from these perches, after the manner of the American Redstart." (Allison, MS.)

Song.-The Myrtle Warbler has an easily recognizable and characteristic tchip or tchep, which, once learned, readily identifies the species. (But see also under D. cerulea.)

"Two call-notes are common; the first, serving to announce the arrival of the bird in fall, and used through much of the winter-not at all or but little, in spring-is uttered in flight. It resembles the syllable sweet uttered with rising inflection. The second is of rather 
deeper tone than most of our Warbler notes; it is less used in flight, but is probably the most familiar bird-voice with us in winter; it is somewhat difficult to render, being rather variable; perhaps the syllable $p s i t$ is the best rendering. The song is not often heard before the end of February, never in the fall and early winter, and is ordinarily not very frequent, even in March and April. It is uttered from a rest, and is of rather an erratic character-not unlike that of the Sycamore Warbler, but brighter and more varied, though not longer." (Allison, MS.)

"The Myrtle is a full-voiced Warbler. It chips like almost all the rest, but it also loudly tcheps, as probably no other New England Warbler does. Its common summer song about Monadnock is a loud and silvery 'sleigh-bell' trill,-a vivid, sprightly utterance, -often more or less broken up into separate notes, particularly in its diminuendo termination. If it were a little fuller, and more evenly sustained, it would be hard to tell from kindred variations of the Junco's song, its commonest companion and accompaniment among the rocks and spruce-trees of Monadnock. Sometimes, especially in spring, this Warbler sings quite differently; a deliberate phrase of three or four or five well-separated syllables, having the usual tone and volume, but lacking, sometimes only in part, the jingling tremulo. Of this song there are at least two main forms, both of which vary a good deal, and also intergrade with the summer jingle." (Thayer, MS.)

Miss Paddock presents four renderings of the Myrtle Warbler's song.
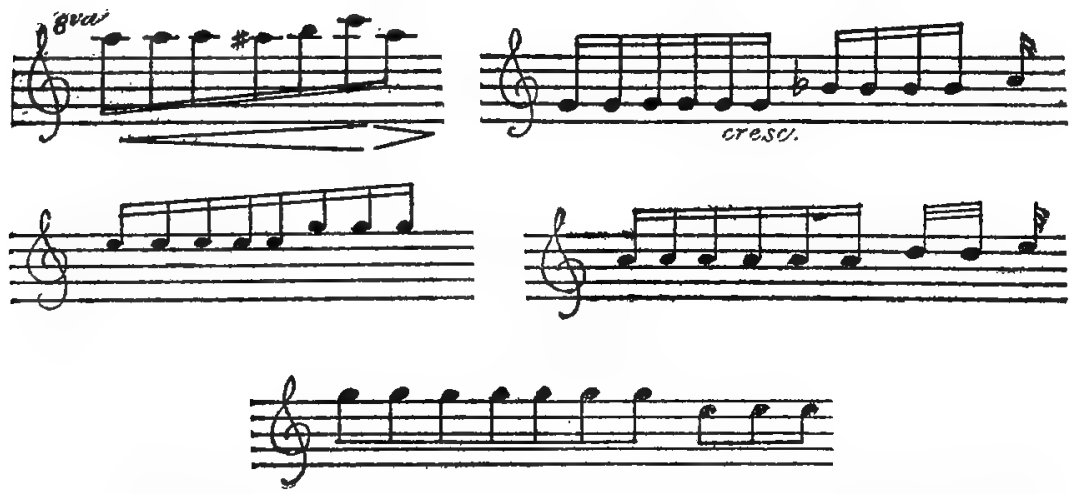

Nesting Site.-Generally about four feet up in small coniferous trees, but sometimes as high as twenty feet. (Maynard.)

Nest.-The Myrtle Warbler builds a loosely made, bulky nest of rather large twigs of conifers, dried grass stems, lichens, weed-stalks, 
etc., lined with hair, rootlets, and a large number of feathers; this feather lining and the coarse character of the nest apparently being diagnostic.

Terrill ${ }^{2}$ describes the nest as "very substantial and warmly built" and "composed chiefly of dead spruce twigs with a few grasses and rootlets, bound with spiders' silk and thickly lined with feathers and animal hair."

Eggs.-3 to 5, usually 4. Ground color dull white to creamy white spotted and blotched with various shades of reddish brown, pale lavender, and a few marks of purplish black; in most cases a wreath around large end. Size; average, .70x.53, extremes measure $.75 \times .55, .64 \times .5$ I. (Figs. 48,49 .)

Nesting Dates.-Lancaster, N. H., May 31-June 7 (Spaulding); Bangor, Me., May 30-June 6 (Knight); Listowel, Ont., June 8 (Kells) ; Porcupine Mts., Mich., July I6, adults with young, (Barrows).

\section{Biographical References}

(1) W. L. Kerls, The Myrtle Warbler (in Ontario), Ottawa Nat., XVI, 1902, I44. (2) L. M. TERRIL, Summer Warblers in Compton County, Quebec, Ibid., XVIII, 1904, 15 I.

\section{AUDUBON'S WARBLER}

\section{DENDROICA AUDUBONI AUDUBONI (Towns.) Plate $X$}

Distinguishing Characters. - With a general resemblance to Dendroica coronata but with the throat usually yellow the outer four tail-feathers marked with white. In some young females the yellow of throat is barely evident or wholly absent but almost invariably they may be distinguished from $D$. coronata by having four instead of three outer tail-feathers with white. I have seen but one specimen of auduboni having only three outer tail-feathers with white, but in this, a young female, the amount of white was so in excess of that which is found in coronata of the same age and sex that the bird's identity was unquestionable. Length (skin), 5.10; wing, 3.00 ; tail, 2.30; bill, .40.

Adult d, Spring.-Above bluish gray streaked with black, crown-patch and rump bright yellow; upper and lower portions of eye-ring white, cheeks bluish gray; tail black edged with gray the outer four or five feathers with a white patch near the tip; wings black edged with gray the median wingcoverts broadly tipped, the greater coverts tipped and, externally, widely margined with white forming a white patch in the wing; throat and sides of the breast yellow; breast black more or less edged with gray, white of belly dividing the black posteriorly; flanks white streaked with black. (This plumage is usually acquired in April.)

Adult $\delta$, Fall.-Quite unlike $\delta^{*}$ in Spring: crown and back grayish brown the latter indistinctly streaked with black; yellow of crown more or less concealed by brownish tips; rump bright yellow; tail as in Spring; margins to wing-coverts more or less brownish; throat yellowish white tinged with buff 
and spotted basally with black, a yellow tuft on each side of the breast, flanks indistinctly streaked with black; belly white.

Young $\delta$, Fall.-Similar to adult $\delta$ in Fall but browner above, the streaks less pronounced; yellow of throat paler and with yellow on sides less pronounced; breast and sides browner, the black markings less evident.

Adult $q$, Spring.-With a general resemblance to the adult $d$ in Fall, but crown-patch often tipped with black, the rump paler, the breast somewhat blacker.

Adult $\$$, Fall.-Not certainly distinguishable from young $\delta$ in Fall.

Young $q$, Fall.-Resembles adult $q$ in Fall but is browner above, the streaks and crown-patch less evident; breast browner, throat with less yellow or, rarely, with none at all; white in tail diminished in amount but nearly always reaching to fourth feather.

Nestling.-Resembling nestling of Dendroica coronata; above brown streaked with black and white; below white streaked with black; wings and tail as in young $\delta^{*}$ in Fall, but greater coverts tipped and not margined with whitish.

General Distribution.-Western United States; north to British Columbia and South Dakota; east to the Plains.

Summer Range.-This is one of the most common Warblers of the Pacific slope; it breeds from southern California (San Bernardino Mountains), and New Mexico (Wheeler Park, Tres Piedras), north to British Columbia (I58-Mile House), Alberta (Calgary), Montana and South Dakota (Black Hills); east to northeastern Nebraska (Sioux Co.), and western Texas (Fort Davis, Guadalupe Mountains). Accidental in Massachusetts (Cambridge, November I5, I876) and in Pennsylvania (Chester Co., November 8, 1899).

Winter Range.-Guatemala and Mexico, north to the Rio Grande; through most of the valleys of California to southern Oregon and rarely to southern British Columbia.

Spring Migration.-

\begin{tabular}{|c|c|c|c|}
\hline PLACE: & $\begin{array}{l}\text { No. of } \\
\text { years } \\
\text { record }\end{array}$ & $\begin{array}{l}\text { Average date of } \\
\text { spring arrival }\end{array}$ & $\begin{array}{l}\text { Earliest date of } \\
\text { spring arrival }\end{array}$ \\
\hline 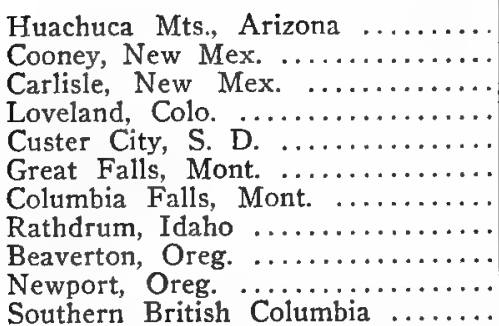 & $\begin{array}{l}2 \\
2 \\
2 \\
4\end{array}$ & $\begin{array}{l}\text { April } 21 \\
\text { May } 2 \\
\text { April } 29 \\
\text { April } 23 \\
\\
\text { March 21 } \\
\text { March 20 }\end{array}$ & $\begin{array}{l}\text { April 19, 1890 } \\
\text { March 6, 1903 } \\
\text { April 9, } 1889 \\
\text { April 17, } 1890 \\
\text { May 2, 1896, 1897 } \\
\text { April 28, 1890 } \\
\text { April 21, 1895 } \\
\text { April 15, I899 } \\
\text { March 9, I885 } \\
\text { February 13, 1897 } \\
\text { March I7 }\end{array}$ \\
\hline
\end{tabular}


Fall Migration.-In August the mountain breeding birds begin to descend to lower altitudes and during September reappear on the plains. The earliest migrants move south of the breeding range in the last week of September and enter Mexico soon after the first of October. The northern part of the range in Montana is deserted about the Ioth of October.

The Bird and its Haunts.-Audubon's Warbler is the Myrtle Warbler of the west. It is the same hardy, active bird with a similar characteristic tchip and conspicuously yellow-patched rump.

In Colorado, Keyser" says "this species inhabits all the upper mountain valleys and on the steep slopes of the western as well as on the eastern side of the Divide, I had the Audubon Warblers often at my elbow. In summer they make their homes at an altitude of seven to eleven thousand feet and are partial to pine timber; indeed, I think I never found them elsewhere save occasionally among the quaking asps."

Walter Fisher writes that in California "in winter, Audubon's Warblers invade the warmer valleys of the western, and are particularly abundant in the southern part of the state, where they are perhaps more in evidence than any other birds. They take possession of orchards, arroyos, open plains, and even hot hillsides among chamiso and yuccas, and ply their fly-catching trade with great singleness of purpose. They burst from sycamore tops and dash after minute insects, hover, and zigzag as skillfully as any Flycatcher. During these very frequent sallies the yellow rump-patch is more or less visible and serves as a convenient mark for identification. The white markings of wings and tail are even more conspicuous and useful for this purpose.

"During the breeding season auduboni retires to the higher mountains and lives among firs and pines of the Canadian zone. The breast now acquires two conspicuous black patches which contrast beautifully with the yellow throat. The favorite hunting grounds of this Warbler are among firs, pines, and incense cedars, or occasionally in willow copses. The male is of a particularly musical disposition, providing a rather monotonous flow of notes to which the ear is soon likely to become insensible. Wherever Calaveras and Audubon Warblers are abundant silence is banished from the mountains." (Fisher, MS.)

Song.-The call-note of this species resembles the characteristic tchip of its eastern representative, the Myrtle Warbler.

Bowles ${ }^{4}$ describes the song as "a short though pleasing little warble, surprisingly feeble for so large a bird, and in no way equal to that of its smaller relative the Yellow Warbler (D. estiva)." 
Nesting Site.-In Estes Park, Colorado, the nest is saddled on the limb of a pine or spruce eight to thirty-five feet from the ground, sometimes near the trunk, at others ten feet out. Bowles (MS.) writes that at Tacoma, Washington, this species "nests invariably in fir trees on a limb, from four to fifty feet, but usually about twenty feet up." In Arizona, Howard ${ }^{3}$ states that a nest placed fifteen feet up in a fir tree was unusually low for this species, and records a second nest as fifty feet up in a sugar pine twelve feet out from the trunk. At Fort Sherman, Idaho, however, a majority of the nests found by Merrill" "were in deciduous trees and bushes generally but a few feet from the ground."

Nest.- "Loosely constructed of weed-stems and tops, and strips of bark, lined with fine weeds and horse-hair." (Estes Park, Colo.) "The nest is a well built bulky structure, the largest of any of our Warblers', measuring externally 3.5 inches in width by 2.5 inches in depth. *** It is very handsome, as a rule, being built of fir twigs, everlasting weed, rootlets, moss, and dried grass with a thick lining of horse-hair and feathers." (Bowles ${ }^{4}$.)

"The nests are very loosely constructed being composed almost entirely of loose straws with a few feathers and hair for lining." $\left(H_{0} w a r d^{3}\right.$.) "Such nests as were found here, while varying considerably as to exterior, agree in having a lining in which black horse hairs are conspicuous, and in which feathers are loosely attached, not well woven in as is usual in most small nests." (Merrill ${ }^{2}$.)

Eggs. -3 to 5, usually 4. Ground color varies from dull white or greenish white to bluish white, spotted and blotched with olivebrown, lilac, purplish brown and lavender, very sparingly in some types, quite boldly in others, but usually forming more or less of a wreath around large end. Size; average, .72x.54, extremes measure $.74 \times .53, .69 \times .55, .72 \times .51, .72 \times .56$. (Figs. 50,51.)

Nesting Dates.-Colorado, between 7,600-8,600 feet altitude, June I6 (Dille); Tacoma, Wash., April 22, four eggs ready to hatch-June 26 four eggs fresh. (Bowles).

\section{Brographical References}

(1) H. W. Henshaw, Zoöl. Exp. W. Iooth Merid., 1875, I94. (2) J. C. MerRILl, Birds of Fort Sherman, Idaho, Auk, XV, 1898, 18. (3) O. W. Howard, Summer Resident Warblers of Arizona, Bull. Cooper Orn. Club (=Condor), I, I899, 64. (4) J. H. Bowles, The Audubon Warbler in Washington, Condor, IV, I902, 118. (5) L. KEYSER, Birds of the Rockies, 62. 


\section{BLACK-FRONTED WARBLER \\ DENDROICA AUDUBONI NIGRIFRONS (Brewst.)}

Subspecific Characters.-Similar to D. a. auduboni but larger and more widely streaked with black; the Spring $\sigma$ with the forehead, cheeks, and sides of crown black; black below extending to the belly and without grayish tips. Wing, 3.10; tail, 2.35 ; bill, .40.

General Distribution.-High Sierras of western Mexico north to Arizona.

Summer Range.-High Sierras of northwestern Mexico from Durango north to the Chiricahua, Huachuca and Santa Catalina Mountains, southern Arizona.

Winter Range.-Western Mexico.

Spring Migration.-Huachuca Mountains, Arizona, April 5, 1903, May 9, 1902.

The Bird and its Haunts.-Discovered by Frazar in the Sierra Madre of Chihuahua in 1888 (Brewster ${ }^{1}$ ), this subspecies was added to our fauna in 1894 by Price who took eleven specimens in the Huachuca and Chiricahua Mountains of southern Arizona (Loomis ${ }^{2}$ ). Ridgway records an intermediate breeding male from mountains near the head of Pecos River, New Mexico.

\section{Biographical References}

(I) WM. Brewster, Descriptions of Supposed New Birds from Western North America and Mexico, The Auk, VI, 1889, 94. (See also colored plate, No. I, in Ibid., IX, I892.) (2) L. M. LoomIs, An Addition to the A. O. U. Check-List, Auk, XVIII, Ig0I, I Io.

\section{BLACK-THROATED GRay WaRbleR}

\section{DENDROICA NIGRESCENS (Towns.) Plate XIII}

Distinguishing Characters.-The general gray color, black or black and white throat and entire absence of yellow, except the spot before the eye readily distinguish this species. Length (skin), 4.30; wing, 2.40; tail, 2.00; bill, .40.

Adult ठ', Spring.-Crown largely or entirely black; cheeks black bordered by white below; a broad white line behind the eye, a yellow spot before it; back gray, its center streaked with black; tail edged with gray, the two outer feathers largely white on both webs, third feather white on the inner web at the end; wings edged with gray, the secondaries internally margined with white, the greater and median coverts broadly tipped with white forming two conspicuous bars; throat and upper breast black (rarely mottled with white) sharply defined from rest of underparts, which are white; sides streaked with black.

Adult б, Fall.-Similar to adult of in Spring but upperparts and cheeks more or less margined with brownish gray; throat margined with white, sides washed with brown, the black streakings obscured. 
Young $\delta^{*}$, Fall.-Similar to adult $\delta^{*}$ in Fall but generally no black in back, chin white, throat usually more or less mottled with white, sides browner, no white on secondaries.

Adult 9 , Spring.-Similar to adult $\delta$ in Spring and sometimes not distinguishable from it, but, as a rule, with less black on the head, back browner and less heavily streaked; wings and tail browner and with less white; throat and upper breast mottled with black and white.

Adult , Fall.-Similar to adult $q$ in Spring but upperparts and cheeks washed with grayish brown, black of throat margined with white, sides tinged with brown, the black streakings obscured.

Young + , Fall.-Not certainly distinguishable from adult $q$ in Fall but often with less black.

Nestling.-Above brownish gray, a broad whitish postocular stripe; below gray, belly white, breast lightly streaked; wings and tail as in young.

General Distribution.-Western United States.

Summer Range.-Breeds from northern Lower California, southern California, southern Arizona and New Mexico; north to British Columbia and east to central Colorado (Idaho Springs).

Winter Range.-Winters in Mexico.

Spring Migration.- The species enters southern California the first week in April and reaches southern British Columbia the third week in the month. The earliest dates in southern Arizona and southern New Mexico are included between April 6 and April 9; while the species appears in the northern portion of its Colorado range early in May.

Fall Migration.-The last birds do not leave central California until the first week in October and the species does not desert the State until after the middle of the month.

The Bird and its Haunts._-"These birds are very plentiful during the breeding season in the mountains of southern Arizona. They may be found from an altitude of 4,000 to 9,000 feet, but are more common in the oak belt, from 4,000 to 7,000 feet altitude, where a great many of them breed. Nevertheless, comparatively few nests are found. I believe the reason for this is, because, unlike other Warblers, these birds do not have a note of alarm nor do they show any signs of breeding. The birds are constantly on the jump, apparently catching insects. Even when flushed from the nest they will hop about in their usual unconcerned manner." (Howard ${ }^{3}$.)

Of this Warbler in California Walter Fisher writes: "The Blackthroated Gray goes about its affairs in a quiet business-like manner suggesting the Lutescent Warbler, and differs, therefore, in temperament from both the Calaveras and Audubon Warblers which are always in evidence. It lives in chaparral such as deer brush, wild lilac 


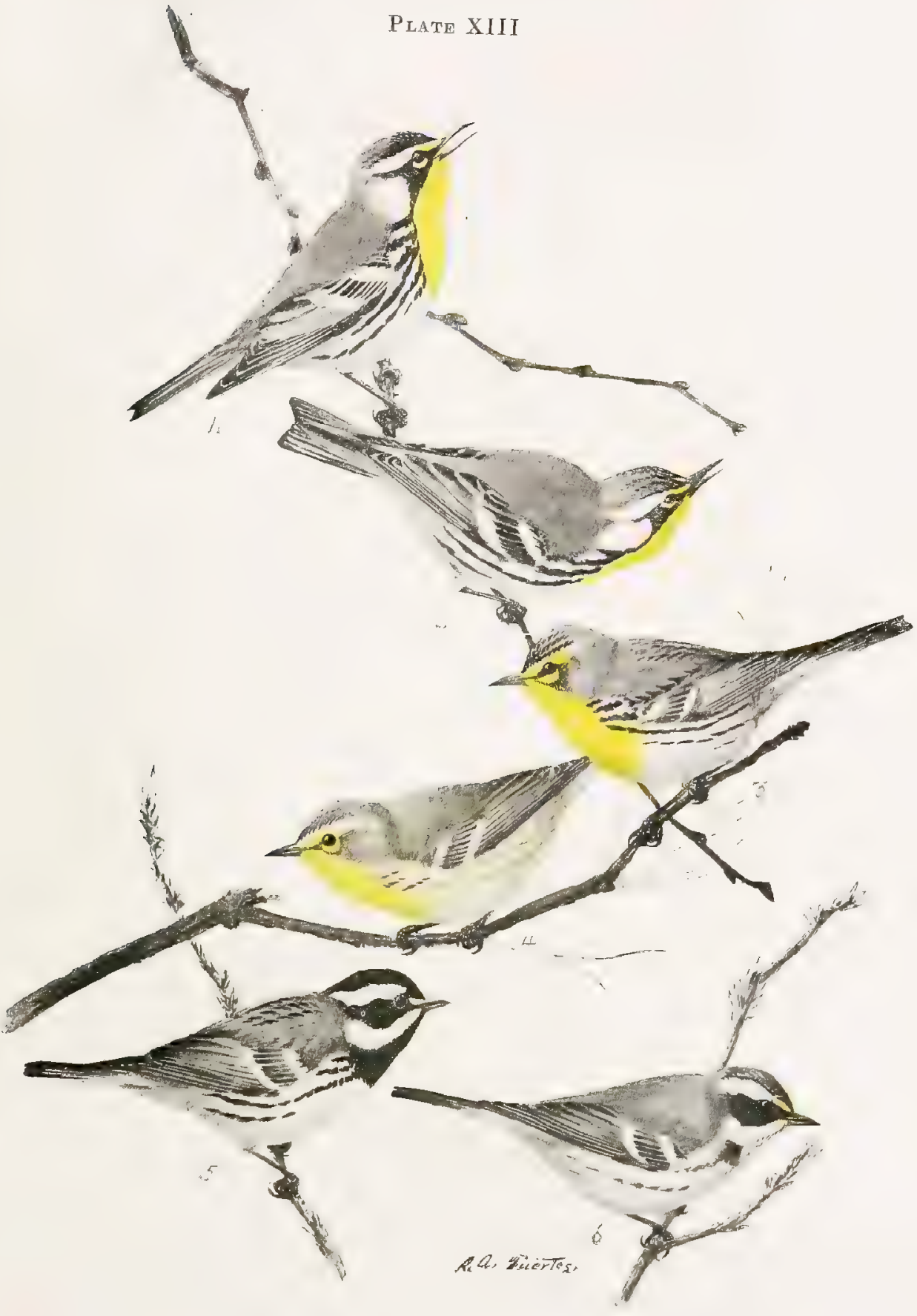

1. Yellow-throated Warbler, Male.

2. Yfllow-throated Warbeer, Female.

4. Grace's Warbler, Female.

3. Grace's Warbler, MaIE

5. Black-throated Gray Wareler, Male,

6. Black-throated Gray Warbier, Female. 

of various species, scrub oak, and sometimes, particularly in the humid coast districts, among evergreens. It is fond of the neighborhood of clearings where it works constantly and carefully among low growth. A'shough it does not force itself upon one's attention it is a very active bird and during the day must cover considerable territory." (Fisher, $M S$.)

Bowles ${ }^{4}$, writing from Oregon, says that in habits the Blackthroated Gray suggests both the Black-throated Green and Prairie Warblers. Like the former, it likes tall trees with a preference for scattered conifers having a bushy undergrowth. Like the Prairie it prefers high and dry places, though it does not object to a swamp if the ground beneath the nest is dry.

Two pairs this writer watched while building "had the same way of going about it. The male followed the female very closely, scolding almost continuously, or perhaps making suggestions, as she did not seem to mind it and gathered materials and acted very much as if he was not there. This continuous scolding generally seems to indicate nest-building and is apparently the only direct method of finding the nest."

Near Pyramid Lake, in western Nevada, I found the Blackthroated Gray in stunted junipers.

Song.- "Its song is a simple Warbler lay, zee-ee-zee-ee, ze, ze, ze, with the quiet woodsy quality of virens and carulescens, so soothing to the ear." (Bailey.)

Nesting Site.-In Arizona Howard ${ }^{3}$ found many nests of this species in dense thickets of scrub oak in the fork of the larger limbs quite often within reach of the ground, while other nests were placed high up in the pines. In the Sierras of California, Barlow ${ }^{2}$, recording Carriger's observations, states that several nests "were found in the deer brush at from five to nine feet up and two were placed in pines, one twelve feet up on a small limb, and another fifty-two feet up on a horizontal limb."

In Oregon, Prill ${ }^{1}$ writes that "the nest is placed in some small fir, generally not over five or six feet high; while Bowles ${ }^{4}$ finds the nest of this species "from three feet and three inches to twenty-five feet from the ground, oaks seeming the favorite in southern Oregon and fir near Tacoma."

Nest.-Howard" describes the nests as "very compact, of a deep cup shape, much like those of the Yellow Warbler. The nesting material varies according to locality."

Prill ${ }^{1}$ writes that the nest is "made of fine grass, profusely lined 
with feathers." Bowles" states that "the nests externally are about $3 \times 2 \frac{3}{4}$ inches and internally $\mathrm{I} \times \mathrm{3} \times \mathrm{3}$ in diameter and depth. They are composed externally of grass and weed-stalks that must be several seasons old, being bleached, and very soft moss and feathers; lined with feathers (one had evidently been lined from a dead Steller Jay), horse, cow, and rabbit hair or fur, and sometimes the very fine stems of flowers of some kind of moss."

Eggs.-3 or 4, usually 4. Ground color white to very pale greenish white, delicately marked with specks and spots of red-brown, purplish, and under shell markings of pale lavender, forming a welldefined wreath around the large end with few spots and specks sparingly distributed over rest of the egg. Size; average, .69x.50. (Figs. 69-7I.)

Nesting Dates.-Mountains north of Pasadena, Calif., May 19, four small young in nest; June 26, three eggs incubated (Grinnell); Fyffe, Eldorado Co., Calif., June 5 (C.W. C.) ; Tacoma, Wash., May I4-June 24 (Bowles).

\section{Biographical Reftirences}

(1) A. G. PriLl, Black-throated Gray Warbler, (in Oregon), Oölogist, IX, I892, I28. (2) C. BARLow, The Nesting Haunts of the Black-throated Gray Warbler (in Calif.), Bull. Cooper Orn. Club (=Condor), I, 1899, 96. (3) O. W. How ARd, Summer Resident Warblers of Arizona, Bull. Cooper Orn. Club (=Condor), I, I899, 64. (4) C. W. BowLes, Notes on the Black-throated Gray Warbler (in Oregon), Condor, IV, 1902, 82. (5) W. L. Finley, Two Oregon Warblers, The Condor. VI, 1904, 3 I.

\section{TOWNSEND'S WARBLER}

\section{DENDROICA TOWNSENDI (Towns.) Plate XV}

Distinguishing Characters.-The adult $\delta^{*}$ in Spring may be known by its black throat and crown and black cheeks surrounded by yellow lines; in other plumages the yellow or yellowish throat, black spots or bases to feathers of crown, yellow mark below eye and dusky or olive cheeks, surrounded by yellow, are characteristic. Length (skin), 4.60; wing, 2.60 ; tail, r.95; bill, .35 .

Adult ס", Spring.-Crown black, rest of upperparts olive-green spotted with black; a black band through the cheeks bordered above by a yellow superciliary line, below by a yellow stripe on the side of the throat which broadens into a yellow patch on the side of the neck; a yellow spot under eye; tail margined with grayish, both webs of two outer feathers largely white, the inner web of third to fourth feather with white at the end; wings margined with grayish; end half of median coverts white, greater coverts tipped with white forming two conspicuous bands; throat and upper breast black, lower breast yellow, belly white, sides streaked with black.

Adult d, Fall--Similar to adult $\sigma^{\prime \prime}$ in Spring but black areas nearly concealed by olive-green tips; black cheeks with slight greenish tips; black on 
throat patch, widely tipped with yellow and in part replaced by yellow; sides less heavily streaked.

Young of, Fall.-Similar to adult $d$ in Fall but with less black above on throat and on sides; cheek-band more olive.

Adult \%, Spring.-Similar to adult $\delta$ in Spring but crown olive-green spotted with black, little or no black in back; less white in tail, the outer web of only the outer feather with white; wing-bars narrower, cheeks more olive; throat and breast obscurely marked with black which appears more clearly on the sides of the breast, belly white.

Adult 9 , Fall.-Similar to adult $\delta$ in Spring but darker above, black markings less evident, sides tinged with brownish.

Young $q$, Fall.-Similar to adult $q$ in Fall but with less black on head and throat.

Nestling.-Above brown, a broad buffy superciliary line; breast evidently brownish, belly white but molt too far progressed to permit of complete description.

General Distribution.-Western North America, north to Alaska, east to Colorado.

Summer Range.-From mountains of southern California(?) and Oregon north to Sitka, Alaska, and the upper Yukon Valley; east to Idaho (Fort Sherman) and western Colorado; in migration it ranges to the eastern foothills of Colorado (Loveland) and to western Texas, (San Angelo) ; accidental in Pennsylvania (Coatesville, May 12, I868).

Winter Range.-Mexico and Guatemala; a few sometimes as far north as southern California.

Spring Migration.-Migrants from Mexico begin to enter Califormia April I4 to 20. The earliest noted in I888 at Chilliwack, B. C., was on May I9, but the usual date of arrival is probably several days earlier, for the average date of the first birds seen during five years at Columbia Falls, Mont., is May 7, varying from May 4, 1897 to May I I, I896. First arrivals have been noted on April 9, in the Huachuca Mountains of Arizona; Loveland, Colo., May I I, I889 and at Great Falls, Mont., May 28, 1890.

Fall Migration.-None of Townsend's Warblers was seen at Columbia Falls, Mont., after August I7, 1895, nor at Chilliwack, B. C., later than September I2, 1888.

The Bird and its Haunts.-Very little information concerning the habits of this bird appears to have been recorded. At Fort Sherman, Idaho, where it evidently nests, Merrill found it haunting the tops of large firs, flitting restlessly from tree to tree at a height which made identification difficult. At Glacier, Alaska, Bishop states that "it was tolerably common in the dense woods of spruce and fir and unquestionably nesting; altogether we noticed about twenty individuals during 
our stay." Macoun 4 , quoting Spreadborough, says they are common on Vancouver Island and nest in the Douglas firs. Woodcock ${ }^{5}$, quoting Anthony, says that at Beaverton, Oregon, Townsend's Warbler is not at all rare in second growths of fir. In California, Grinnell states, it is a "common winter visitant to the Santa Cruz district, and sparingly elsewhere west of the Sierras; occurs more widely during migration."

Song.- "This usually consists of five notes-deé deé deé-dě dě all, especially the first three, uttered in the peculiar harsh drawl of $D$. virens. Later in the season the song changes somewhat at times." (Merrill ${ }^{2}$.)

Nest and Eggs.-June 7, 1875 , Bendire ${ }^{1}$ took what he believed to be the nest and eggs of this species in southwestern Oregon. It was placed among several willow shoots about four feet from the ground. Th.e identification, however, was incomplete. Spreadborough, as quoted above, states that this Warbler nests in the Douglas firs on Vancouver Island, but no further details are given.

The data accompanying a set of four eggs in the collection of J. Lewis Childs, reads as follows: June I2, 1892, Collected by Walter Raine, Vancouver, B. C., "on a branch of Willow four feet from ground." Mr. Childs writes: "I give you herewith the information regarding the nest and set of eggs of Townsend's Warbler, as per your request of the 15 th. The four eggs measure respectively .70x.50, $.72 \times .52$, .70x.5I, .68x.5I. Color, light ashen gray, heavily blotched, specked and marbled dull rufous-brown; eggs showing wide variation in extent of color, all having more or less of it on all parts with a predominance at the large end. The color on the large end of one egg is almost solid, on another very sparse. The eggs may be said to be fairly distinct, not resembling those of any other species of Warbler, and none, excepting possibly Cape May and Hermit, show so much color. Nest neat and firm, made entirely of fine grasses (no hair of any sort) with some downy substance and vegetable fiber on the outside. Inside measurement, width 2 inches, depth, I I-2 inches." (Figs. 97-99, Childs Coll.)

\section{Biographical References}

(1) C. E. BendiRe, Notes on Some of the Birds found in Southeastern Oregon, etc., Proc. Bost. Soc. Nat. Hist., I877, II4. (2) J. C. MerrILl, Notes on the Birds of Fort Sherman, Idaho, Auk, XV, 1898, 19. (3) L. B. Bishop, Birds of the Yukon Region, N. A. Fauna, No. I9, Ig0o, go. (4) J. Macour, Cat. of Canadian Birds, III, 63I. (5) A. R. Woopcock, Birds of Oregon, 87. (6) J. Grinneli, Check-List of California Birds, 65. 


\section{Black-throated Green Warbler \\ DENDROICA VIRENS (Gmel.) Plate XIV}

Distinguishing Characters.-The yellow cheeks, bright olive-green back with few or no black streaks, the largely white outer web of the outer tail-feather; the black throat of the adult male and yellow or yellowish throat of the female and young are the distinguishing marks of this species. Length (skin), 4.40; wing, 2.45 ; tail, 1.95; bill, .40.

Adult o", Spring.-Above bright olive-green the back often with more or less concealed black spots; forehead yellowish, line over eye and cheeks yellow, lores and postocular streak dusky; tail margined with grayish, both webs of the two outer feathers largely white, third to fifth feathers with white at end of inner web; wings margined with grayish, end half of median coverts white, greater coverts tipped with white forming two conspicuous bars; throat and breast black; belly white usually more or less tinged with yellow; sides heavily streaked with black.

Adult $\delta^{*}$, Fall.-Similar to adult $\delta^{*}$ in Spring but black of throat conspicuously tipped, and of sides, margined with white or yellowish.

Young ${ }^{*}$, Fall.-Similar to adult $\delta$ in Fall but back more rarely with black, chin and upper throat yellow, not black, less black on sides.

Adult + , Spring.-Similar to adult $\delta$ in Spring but somewhat duller above, less white in tail, in some specimens outer web of only outer tail-feathers white, white wing-bars narrower; chin and throat yellow, breast black tipped with white or yellowish, sides streaked with black; belly white usually tinged with yellow. Resembling young male in Fall but duller in color and the more worn plumage gives the black of breast a more patchy appearance.

Adult,+ Fall.-Similar to adult $q$ in Spring but somewhat brighter in color the black of breast more evenly and widely tipped with whitish, the black streaks on sides less evident.

Young $q$, Fall.-Similar to adult $q$ in Fall but duller above, the breast dusky yellow with little or no black.

Nestling.-Above brown, below whitish streaked with dusky, a brownish white line over eye; wings and tail as in young.

General Distribution.-Eastern North America; north to Newfoundland and Athabasca; west to the Plains.

Summer Range._-The region of the Gulf of St. Lawrence, Newfoundland, and west to northern Alberta and southwestern Alberta marks the northern limit of the range of this species. It breeds south to Minnesota, Wisconsin (Jefferson County), Michigan (Crawford, Oscoda, and Iosco Counties), New York (Oneida County), Massachusetts (Cambridge, Springfield, Martha's Vineyard, etc.), northwestern Connecticut and, less commonly, northern Long Island and northern New Jersey; south in the Alleghenies, it breeds through Pennsylvania to South Carolina. In passing to its summer home it ranges west to western Minnesota, eastern Nebraska (Omaha, Florence, Neligh), eastern Kansas (Onaga) and eastern Texas; rare west of the heavy forest area of the Mississippi Valley. 
Winter Range.-Mexico to Panama; casual or accidental in the West Indies.

Spring Migration.-

\begin{tabular}{|c|c|c|c|}
\hline PL,ACF & $\begin{array}{l}\text { No. of } \\
\text { years } \\
\text { record }\end{array}$ & $\begin{array}{l}\text { Average date of } \\
\text { spring arrival }\end{array}$ & $\begin{array}{l}\text { Earliest date of } \\
\text { epring arrival }\end{array}$ \\
\hline \multicolumn{4}{|l|}{ Allantic Coast- } \\
\hline 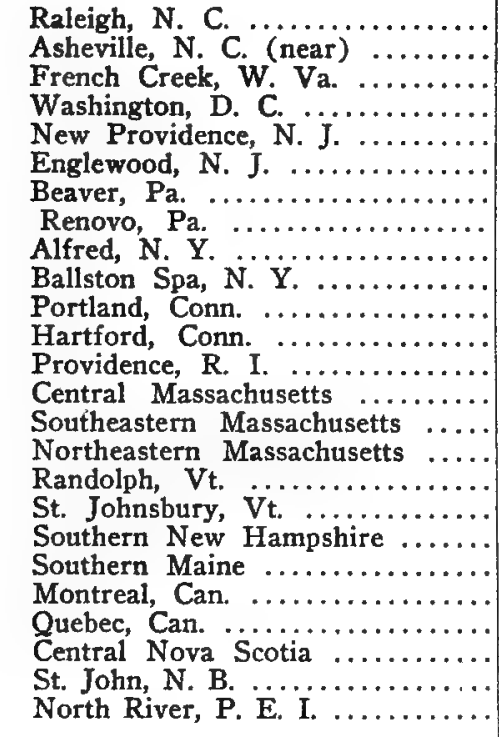 & $\begin{array}{r}9 \\
4 \\
4 \\
7 \\
7 \\
6 \\
6 \\
10 \\
15 \\
7 \\
6 \\
7 \\
4 \\
13 \\
12 \\
16 \\
6 \\
6 \\
7 \\
8 \\
4 \\
11 \\
4 \\
12 \\
3\end{array}$ & $\begin{array}{lr}\text { March } & 27 \\
\text { April } & 28 \\
\text { April } & 16 \\
\text { April } & 25 \\
\text { April } & 30 \\
\text { April } & 30 \\
\text { April } & 30 \\
\text { April } & 26 \\
\text { May } & 1 \\
\text { May } & 8 \\
\text { May } & 4 \\
\text { May } & 2 \\
\text { May } & 3 \\
\text { May } & 1 \\
\text { May } & 1 \\
\text { May } & 1 \\
\text { May } & 8 \\
\text { May } & 9 \\
\text { May } & 3 \\
\text { May } & 6 \\
\text { May } & 11 \\
\text { May } & 10 \\
\text { May } & 13 \\
\text { May } & 13 \\
\text { May } & 17\end{array}$ & 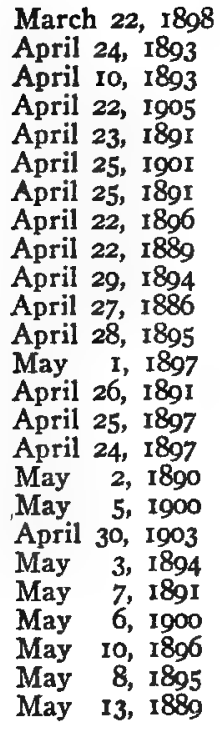 \\
\hline \multicolumn{4}{|l|}{ Mississippi Valley- } \\
\hline 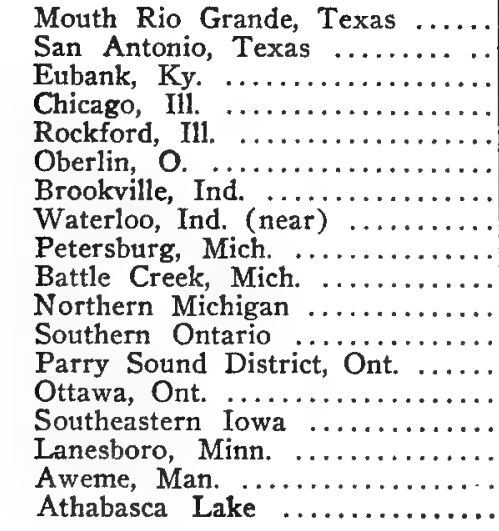 & $\begin{array}{r}7 \\
4 \\
4 \\
12 \\
5 \\
5 \\
10 \\
5 \\
9 \\
10 \\
6 \\
2 \\
12 \\
9 \\
18 \\
6 \\
3\end{array}$ & $\begin{array}{lr}\text { March } & 22 \\
\text { March } & 24 \\
\text { April } & \text { II } \\
\text { May } & \text { I } \\
\text { May } & 3 \\
\text { April } & 28 \\
\text { April } & 29 \\
\text { May } & \text { I } \\
\text { May } & 2 \\
\text { May } & 3 \\
\text { May } & 23 \\
\text { May } & \text { I } \\
\text { May } & 6 \\
\text { May } & \text { I3 } \\
\text { May } & 5 \\
\text { May } & 7\end{array}$ & 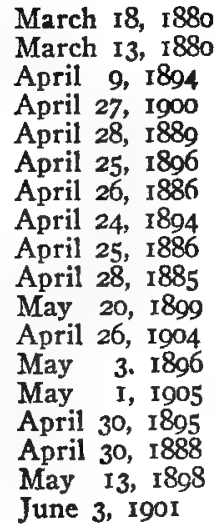 \\
\hline
\end{tabular}


Fall Migration.-

\begin{tabular}{|c|c|c|c|}
\hline PL,ACE & $\mid \begin{array}{l}\text { No. of } \\
\text { years' } \\
\text { record }\end{array}$ & $\begin{array}{l}\text { Average date of } \\
\text { last one seen }\end{array}$ & $\begin{array}{l}\text { Latest date of } \\
\text { last one seen }\end{array}$ \\
\hline 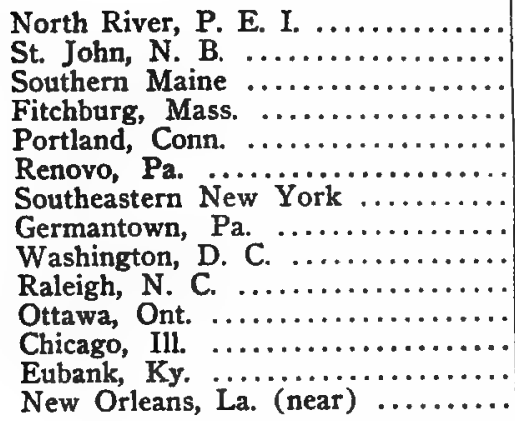 & $\begin{array}{l}4 \\
6 \\
7\end{array}$ & $\begin{array}{lr}\text { September } & 5 \\
\text { September } & 13 \\
\text { September } & 27 \\
& \\
\text { October } & 4 \\
\text { October } & 7 \\
\text { October } 8 \\
\\
\text { October } 8 \\
\text { September } & 27 \\
\text { September } & 27\end{array}$ & $\begin{array}{l}\text { September 13, } 1890 \\
\text { September 25, } 1891 \\
\text { October 2, 1898 } \\
\text { October 9, 1898 } \\
\text { October 20, 1888 } \\
\text { October 15, 1887 } \\
\text { October 12, 1899 } \\
\text { October 18, } 1888 \\
\text { October 20, 1890 } \\
\text { October 16, 1893 } \\
\text { October 8, 1887 } \\
\text { October 12, 1894 } \\
\text { October 14, 1891 } \\
\text { October 28, } 1899\end{array}$ \\
\hline
\end{tabular}

The Bird and its Haunts.- Singing freely while he travels, one need not follow the Black-throated Green to his northern home to hear the delicious, little lazy drawl which, near New York, marks the opening days of Warbler time. Now we may find him almost anywhere there are trees, but, arrived on his nesting ground, he shows a marked preference for conifers.

About Cambridge, Mass., where the Black-throated Green is among the most abundant summer Warblers, Brewster ${ }^{6}$ writes that its favorite haunts "are extensive, well-matured woods of white pines, and rocky pastures growing up to pitch pines or to Virginia junipers."

About Monadnock, Gerald Thayer writes, the Black-throated Green is "a very common or abundant summer bird through all the region, high and low; ranging from the pine woods of the lowest valleys to the half open copses of spruce and mountain ash along Monadnock's rocky ridge,-2,500 to 3,169 feet. High upon the mountain, however, it is less common than the Myrtle, or even the Nashville. Though decidedly a forest Warbler, it favors second growth, and pasture-bordering copses, rather than the very heavy timber, and is particularly partial to dry white pine woods. Its 'beat' lies between the sunlit tops of middle-sized pines, spruce and other trees, and their bottom branches on the outer borders of the groves. The deeply shaded wood-interiors it seems rather to avoid; and it is a great haunter, especially while singing, of the spindling tops of fair-sized conifers. Active, restless, but very tame, it is a noticeable little bird wherever it occurs, particularly in the clearly-marked costume of the adult male, whose almost fleckless yellow cheeks often lead chance observers to describe it as yelloze-headed." (Thayer, MS.) 
At Branchport, N. Y., Verdi Burtch says the Black-throated Green "is found during the nesting season in all of our larger gullies. I have found twenty or more nests during the past three seasons, and all have been in hemlocks. The birds are close sitters and will not leave the nest until one gets almost close enough to touch them. When flushed from the nest they usually drop nearly to the ground, then sail to a nearby bush, gradually coming back near one. Usually they are quiet but sometimes they chip a little." (Burtch, MS.)

Song.- "The familiar two main songs of this common Warbler are subject to surprising individual-or rather, idiosyncratic,-variation. Most of the individuals in a region sing nearly alike,-showing, indeed, an unusual fixitude of song-form, but about one in forty does queer tricks with his voice. Among the commonest of these tricks is the introduction into all or part of the song of a pronounced quaver or tremulo. But the phrasing as well as the tone-quality is highly subject to these occasional vagaries. The song is sometimes disguised almost past recognition. Although the Black-throated Green is preëminently a full-voiced Warbler, its voice has a certain quality of huskiness,-like the Black-throated Blue's, but much less obtrusively noticeable: and rather enhancing than marring the quier sweetness of the song. One of the two main utterances is remarkable for its deliberate and highly-modulated enunciation; the other not. The deliberate song, of five (sometimes six or eight) notes, is the one usually described in books; but here about Monadnock the other is at least as often uttered, and in mid-summer is the commoner of the two. The differences between them are suggested, though feebly, by the two phrases: Sweer sweerr, swi-ni swee (the first and last accented notes the highestpitched), and $W i$-wi-wi-wi-wi-wi-wi, wer-zuéee (last note highestpitched as well as most emphatic). The first phrase represents, of course, the more highly modulated song. Two at least of this Warbler's call-notes are fairly characteristic, a plainly Dendroicine but rather loud and full-toned tsip and a reduplicated smaller chip, often running into 'chippering', like that of many young but few other adult Warblers." (Thayer, MS.)

Miss Paddock presents the following renderings:

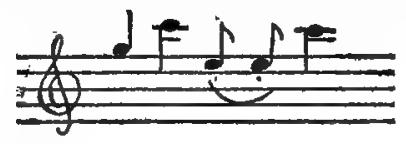


"Sometimes the last note is omitted, as follows:"

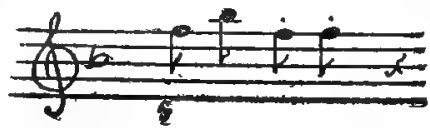

"Below is a second distinct song and the same bird will sometimes sing one form several times and then change to the other. The fourth note of it has an entirely different quality from the other four; a harsh buzzing sound as though the breath were drawn in."

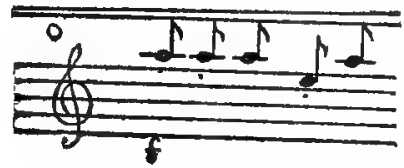

Nesting Site.-Coniferous trees are most frequently chosen by this species but it selects also an alder or birch. The height of the site from the ground depends largely upon the nature of the bird's haunts; when, for example, it lives among scrubby spruces, the nest, as might be expected, is low, at times within three feet of the ground; but under suitable conditions the nest may be as high as forty feet well out on a horizontal limb.

Burtch writes that at Branchport, N. Y, he has found twenty or more nests and all have been in hemlocks. Two were in little rudimentary limbs against the body of slender trees, the others were variously situated on horizontal or drooping limbs from three to twelve feet from the body of the tree and from ten to forty feet from the ground. A nest found at Closter, N. J., the most southern sea-level breeding locality recorded, was placed in a most unusual site. It is described as "between the stems of a skunk cabbage plant and fastened to a catbriar and the twigs of a dead bush, and was about fourteen inches from the ground, in a very wet part of the swamp." (Bowdish ${ }^{6}$.)

Nest.-The almost woven exterior of small hemlock twigs appears to be characteristic of the nest of this species.

"The compact and deeply cupped nest is usually composed of fine dead hemlock twigs lined with hair and rootlets, and, sometimes, feathers or a fine dead grass and fine strips of bark, white birch bark occasionally being used. It sometimes has attached to the exterior little bunches of yellowish wooly substance, and a white fluffy material resembling spiders' silk." (Burtch, $M S$.)

Eggs.-Almost invariably 4 in number. Ground color ranges from white to creamy white and grayish white, rather heavily marked with fine specks and spots: few blotches occur of cinnamon-rufous, 
chestnut brown, purplish and lilac-gray, with under shell markings of lavender, forming well-defined wreathes around large end. Some eggs are heavily wreathed with very few scattering spots, others have numerous specks over entire egg. Size; average .65X.5I, extremes $.70 \times .49, .58 \times .53$. (Figs. 74-76.)

Nesting Dates.-New Haven, Conn., May 21-June 17 (Bishop); Cambridge, Mass., full sets, first laying, June 5-Io (Brewster) ; Lancaster, N. H., June 2 (Spaulding); Bangor, Me., May 30-July I (Knight) ; Grand Menan, N. B., June I4 (J.P. N.) ; Ottawa Co., Mich., May I5, building, (Gunn) ; July I I, feeding young, Widmann (Barrows).

\section{BIOGRAPHICAL REFERENCES}

(I) JонN N. Clark, Nesting of the Black-throated Green Warbler (at Saybrook, Ct.), Orn. and Oöl., XII, 1887, 22. (2) E. A. CAPEN, The Blackthroated Green Warbler at Grand Menan, Orn. and Oöl., XIII, I888, 59. (3) J. P. N[orkis], A Series of Eggs of the Black-throated Green Warbler, Orn. and Oöl., XVI, 52. (4) WM. L. Kells, Nesting of Some Canadian Warblers, Ottawa Naturalist, XVII, Ig03, 68. (5) Lewis M. TeRRILL, Summer Warblers in Compton County, Quebec, Ottawa Naturalist, XVIII, 1904, I49. (6) B. S. Bowbish, Some Breeding Warblers of Demarest, N. J., Auk, XXIII, I906, 17. (7) WM. Brewster, Birds of the Cambridge Region, 34I.

\section{GOLDEN-CHEEKED WARBLER}

DENDROICA CHRYSOPARIA Scl. and Sulv. Plate XIV

Distinguishing Characters.-The Golden-cheeked Warbler is to be confused only with the Black-throated Green Warbler. Adults of both sexes are sufficiently unlike not to require detailed comparison. Young fémales may be distinguished by the fact that in chrysoparia the belly is white while in virens it is tinged with yellow. Length (skin), 4.60; wing, 2.50; tail, 2.10; bill, .40.

Adult 6", Spring.-Median frontal stripe yellow, rest of upperparts shining jet black without olive markings; tail blackish two outer feathers largely white on inner web apically, and on outer web, basally, third feather with white on inner web only, less in extent; wings edged with grayish the median coverts broadly, the greater coverts more narrowly tipped with white; cheeks and line over eye yellow; a blackish line through eye from bill to nape; throat and upper breast black; sides heavily streaked with black, rest of underparts white.

Adult $\delta^{\circ}$, Fall.-Not seen, doubtless not materially different from adult $\delta$ in Spring.

Young of, Fall.-Resembles adult $q$ in Spring but is more heavily streaked above, the yellow of the sides of the head is brighter and more extended, the throat and upper breast are black tipped with yellow or whitish.

Young d, Spring.-Similar to young $d$ in Fall but tips on black of throat and sides smaller or absent; upperparts with narrower greenish edgings. 


\section{PuATE XIV}

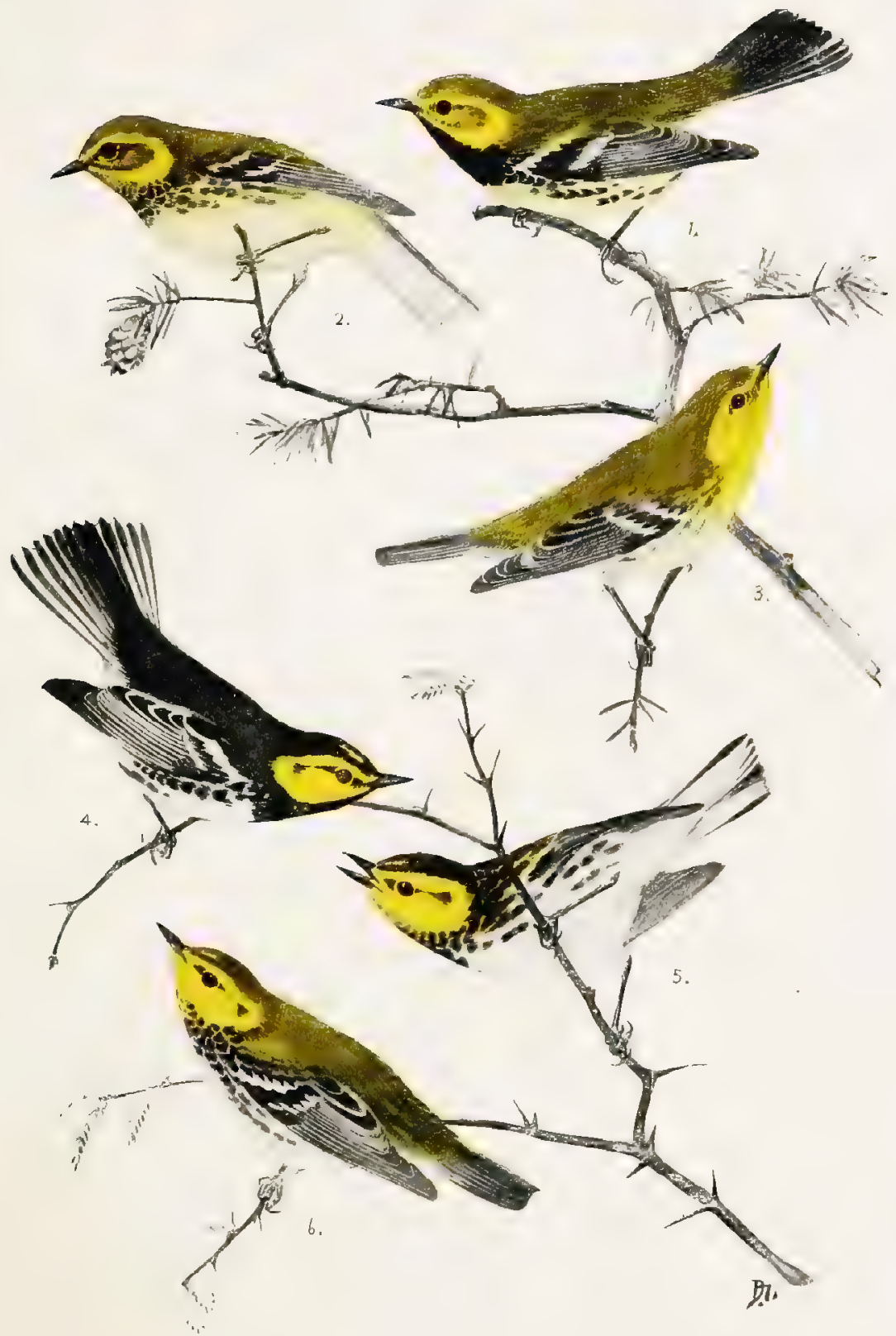

3. Black-throated Green Warbler, Adult Male.

4. Golden-cheered Warbler, Adult Male,

2. Black throated Green Warbler, Adult Female.

5. Colden cheered Warbler, Adult Female

3. Black-throated Green Warbler, Young Female.

6. GOLDEN-CHEERED WARELER, YOUNG FEMAL-. 

Between this plumage in which the back is streaked with olive-green and the black of throat or breast tipped with yellowish or whitish and that in which the back and breast are solidly jet black, there is, in Spring specimens, every degree of intergradation, probably in part due to individual variation, but it seems unlikely that the jet black back is acquired before the first post-breeding molt.

Adult $q$, String.-Above olive-green, both crown and back streaked with black; a partly concealed median frontal streak; a broad yellow line from bill over eye; cheeks and sides of neck yellow, a dusky transocular streak which sometimes extends backward and upward to the nape; tail with less white than in $\delta$, wings as in $\delta$ but grayer; chin and throat yellow with more or less blackish intermixed; upper breast black more or less tipped or mottled with whitish extending into black streaks on the sides; lower breast and belly white. Like young $\delta^{t}$ in Fall but with less black above and on throat.

Adult $\$$, Fall.-Not seen.

Young $q$, Fall.-Similar to adult $q$ in Spring but with few or no streaks above, the yellow of the sides of the head duller and more restricted; the throat white with little or no yellow; the breast dusky, the feathers basally more or less blackish; sides less heavily streaked with black and with a brownish wash. Resembles Black-throated Green $\rho$ in Fall, but lacks yellow wash below.

Nestling.-Above dusky brownish gray, a faintly suggested grayish superciliary line; below grayish the throat and breast grayer, the sides and belly whiter, the former obscurely streaked with dusky, wing-coverts brownish gray narrowly tipped with whitish.

General Distribution.-Central Texas southward.

Summer Range.-South Central Texas. (See Attwater's remarks beyond.)

Winter Range.-Southern Mexico and Guatemala.

Spring Migration.-Its arrival near San Antonio, Texas, was noted March 13, 1895; March 10, 1896; March 9, 1897; March 13, I898; March I4, I900; March 16, I903; March 15, I904; March I6, I905; average March I3.

The Bird and its Haunts.-The limited range of the Goldencheeked Warbler has given few ornithologists the privilege of studying it. Mr. H. P. Attwater, of Texas, when living at San Antonio, near this bird's summer home, took advantage of this opportunity to study its habits with such satisfactory results that, thanks to his efforts, we have a more complete biography of this bird than of many commoner, more widely distributed species. The following observations were prepared by $\mathrm{Mr}$. Attwater for use in the present connection:

"The summer home of the Golden-cheeked Warbler in the United States is confined to certain portions of the counties in south-central Texas, embraced in the timbered parts of the 'Edwards Plateau' region. Throughout this region numerous valleys and deep cañons, 
with steep, rocky sides, have been cut by erosion, leaving peaks and terraced hills, intersected with ravines, gorges and defiles, presenting wild picturesque mountainous scenery.

"The Golden-cheek is not a bird of the forest, being seldom met with in the tall timbered areas in the wider valleys along the rivers, or in the tall trees which fringe the streams in the cañons; but its favorite haunts are among the smaller growth of trees, on the rough wooded hillsides, and which covers the slopes and 'points' leading up from the cañons, and the boulder strewn ridges or 'divides' which separate the heads of the creeks. The trees which compose this growth consist chiefly of mountain cedar (juniper), Spanish or mountain oak, black oak, and live oak on the higher ground, and live oak and Spanish oak clumps or thickets on the lower flats among the foothills, interspersed in some localities with dwarf walnut, pecan and hackberry. All these trees grow on an average from to to 20 feet high, the cedar often forming almost impenetrable 'brakes'. Whatever space remains among the oaks and cedars is generally covered with shin oak brush, which is a characteristic feature of the region. The cedar or juniper appears to possess some peculiar attraction for this bird for they are seldom found at any great distance from cedar localities, and they seem to divide the greater part of their time between the cedars and Spanish oaks, searching for insects, with occasional visits to other oaks, walnuts, etc., but seldom descending as low as the shin oak brush, which averages four to five feet. It is quite probable that future observations will show, that some favorite insect food which comprises a portion of their 'bill of fare', is found among the cedar foliage.

"The song of the male is the first unmistakable notification of its arrival and within a few days it is quite common and the females are also observed. In the localities described the Golden-cheeked Warbler is by no means a rare bird, and it is by far the most abundant of the few Warblers which breed in the same region. In the shaded and watered cañons a few Kentuckys and Parulas are always found nesting, and occasionally a Sycamore and Black and White Warbler, but they are all rare breeding birds, compared with the Golden-cheek.

"Like most of the same sex of other Warblers the female of this species is very shy, and seldom noticed except when an intruder disturbs the nest or when feeding the young after leaving it, but the male Golden-cheeked Warbler is by no means a shy bird. He keeps continually flying from tree to tree in search of insects, and on fine days uttering his song at short intervals from early dawn until after 
sundown, and before nest building begins shows little alarm upon being approached. I have stood under a tree a number of times within five or six feet of a wandering male Golden-cheek, which appeared as pleased and interested in watching $m e$ as $I$ was in observing him. Seemingly he was desirous of assisting me to describe his song in my note-book, by very obligingly repeating it frequently for my special benefit.

"The young birds out of the nest, which are being fed by the parents late in April and early in May, are from early nests which have escaped destruction by 'northers' on account of their sheltered positions and situations, and it is possible that then another nest is built and a second brood reared. Nests with fresh eggs are seldom found after the middle of May. During June the family groups wander about together, chiefly in the cañons and along the lower hillsides, keeping together till the young are old enough to take care of themselves. While being fed by the parents the 'twittering' of the young birds is continually heard, with the cautious 'tick, tick' alarm notes of the female when enemies approach. Early in July they begin to scatter, as most of the young birds are then able to shift for themselves. By the middle of July most of the old males have stopped singing, and by the end of July old and young have disappeared from their usual haunts. I have noticed a few stragglers during the first two weeks in August, and all probably leave before September first.

Song.- "It would be difficult to describe the Golden-cheek's song with any real satisfaction. It varies somewhat, being uttered much more rapidly by some individuals than by others. At a distance only the louder parts are heard, so that it sounds somewhat different than when heard at close quarters. The hurried song might be given as tweah, tweah, twee-sy, with some individuals introducing an extra note or two, and the slower or more deliberate style twee-ah, eseah, eachy. After the young leave the nests the males gradually stop singing, and at this period sometimes only use a part of the regular song.

Nesting Site.- "Of over fifty nests of this bird which I have examined, most of them were securely placed in perpendicular forks of the main limbs of cedar trees, about two-thirds up in the tree; average fifteen feet from the ground. My highest record is twenty-one feet, and lowest six feet. I have also found them in similar positions in small black oak, mountain oak, walnut and pecan trees. The majority of nests are undoubtedly built in cedar trees, and resemble the limbs on which they are placed, on account of cedar bark being chiefly used for the outsides of the nests. The nests were all care- 
fully fixed, in forks or crotches, with very substantial foundations of nest material, and are all very similar in appearance. The favorite nesting haunts are isolated patches or clumps of scrubby cedars, with scant foliage, on the summits of the scarped cañon slopes, and in the thick cedar 'brakes'. In cedar the older growth of trees is always selected, and no attempt at concealment is made. I have never found a nest in a young thrifty cedar with thick foliage.

"The male is always to be heard singing in the vicinity of the nest, and the old nesting localities, and occasionally the same tree is selected apparently and returned to one year after another.

Nest.- "The outside of the nest is chiefly cedar bark strips, with a few weed stalk fibers, woven with spider webs and cocoons, lined with fine grass-tops, horse hair, goat hair and feathers, those of the Quail and Cardinal being most commonly selected, and especially the latter. The cavities of six nests measured average 1.60 inches across by 1.80 inches deep.

Eggs.—"The eggs are usually 3 or 4 the latter being a full set, my only higher record is finding one nest which contained five young. Occasionally a nest is found which also includes a Cowbird's egg. Nest building commences very soon after the birds arrive, and nests with full sets of fresh eggs are found about April 15. I have early records of four eggs hard set on April II, 1904, and the young birds ready to leave the nest on April 24. The cold freezing 'spells' and rough storms, or 'northers', which frequently occur during the latter part of March and during April must often interfere with nesting arrangements, and to this cause $I$ attribute the frequent finding in April and early part of May of so many forsaken nests, either empty or containing $I$ or 2 stale eggs. The trees having been thrashed for several days at a time by rough winds, sometimes accompanied by hail storms, and the nests soaked and more or less disarranged no doubt causes the birds to desert them.

"The eggs vary considerably in size, shape and markings. The average for $3 \mathrm{I}$ eggs now in my collection, is $.66 \mathrm{x} .5 \mathrm{I}$, the three largest eggs measuring .72x.51, .70x.54, and .71x.53, and the three smallest $.61 \times .49, .62 \times .54, .62 \times .50$. The eggs are plain white with sometimes a slight gloss, and quite thickly splashed chiefly around the large end with spots, specks, blotches and occasionally streaks, of various shades of dark reddish brown, mixed with lilac and lavender." (Attwater, MS.)

Nesting Dates.-Comal Co., Texas, March ro (C. W. C.)-June $27(J . P . N$.$) .$ 
Biographical References

(1) J. P. N[ORRIs], A Series of Eggs of the Golden-cheeked Warbler, Orn. and Oöl., XIV, I889, 68. (2) N. C. Brown, A Reconnoissance in Southern Texas, Bull. Nutt. Orn. Club, VII, I882, 36. (3) H. P. Atrwater, List of Birds observed in the Vicinity of San Antonio, Bexar County, Texas, Auk, IX, I892, 34I.

\section{HERMIT WARBLER}

\section{DENDROICA OCCIDENTALIS (Towns.) Plate XV}

Distinguishing Characters.-The adult of may be known by its yellow head, and black throat, whitish, virtually unstreaked sides, while the latter character, in connection with yellow cheeks and yellow or basally yellow crown feathers, will distinguish birds in other plumage. Length (skin), 4.60; wing, 1.55; tail, I.95; bill, .40.

Adult $\delta$, Spring.-Top and sides of head yellow, hindhead and nape with more or less black; back black margined with grayish; tail black margined with gray, both webs of outer feathers largely white, inner web of third feather white at end; wings margined with gray; median coverts broadly tipped with white the greater coverts terminally margined with whitish; throat black, rest of underparts soiled white, the sides rarely with a few streaks.

Adult ơ, Fall.-Similar to adult $\sigma^{*}$ in Spring but head with more black, back more widely margined with olive, throat veiled with whitish, sides browner.

Young $\delta$, Fall.-Similar to adult $\delta$ in Fall but with black above largely replaced by olive-green; sides of head duskier; throat buffy instead of black; sides browner.

Adult + , Spring.-Similar to adult $\delta$ in Spring but with less yellow on head, back olive-gray often without black streaks, less white in tail, wing-bars browner, throat usually yellow bordered posteriorly with black, sometimes largely whitish, rarely all black, white below browner.

Adult $q$, Fall.-Similar to adult $q$ in Spring but greener above, yellow of head and streaks in back (when present) more obscured, throat markings more or less concealed with buffy.

Young $q$, Fall.-Similar to adult $q$ in Fall but upperparts chiefly dark, grayish olive-green, forehead basally yellow; sides of head and chin yellowish, rest of underparts buffy white. Closely resembles young $\sigma^{*}$ in Fall but has less yellow and no black on head but that of shaft streaks.

Nestling.-Above brownish gray; breast grayish, belly whitish washed with brownish and tipped with blackish; a whitish postocular streak.

General Distribution.-Pacific Coast region.

Summer Range.-Breeds in the higher mountains of California and north to southern British Columbia.

Winter Range.-Mexico and Guatemala.

Spring Migration.-Enters the United States in April being reported from Oracle, Arizona, April 12, I899, and the Huachuca Mountains, Arizona, April 9, r902. Records of the earliest birds seen in California are Campo, April 27, I877, and Julian, April 25, 1884. 
A Hermit Warbler was noted at Burrard Inlet, British Columbia, April 20, I885.

Fall Migration.- In the fall the species has been noted as late as September 22, in Arizona, and October 9, in California.

The Bird and its Haunts.-Of this beautiful Warbler as it is found in California Walter Fisher writes: "I have observed this Warbler among dense conifers and in open glades of young black oaks in the Sierra Nevada Mountains. But it is preëminently a bird of the coniferous forests although it may wander longer or shorter distances from them. The yellow sides of the head, sharply contrasted with the black throat and that with the white underparts, form a combination of markings which render confusion of this species with any other well nigh impossible. The song is also different from that of any other Warbler of the region, and has been translated by the words zeegle-zeegle-zeegle, zeek. It is not loud, yet carries for a considerable distance.

"Hermit Warblers are not so abundant in a region as the Calaveras and Audubon may be, but sometimes in the late summer, migrations of young take place at comparatively high altitudes in the Sierra Nevada. During these 'waves' young birds are abundant among Murray pines, from about 6,000 to 8,000 feet, and they move along silently except for an occasional cheep, as they search among cones and needles for their food." (Fisher, MS.)

At Beaverton, Oregon, A. W. Anthony reports this bird not rare in second growth firs; and about Tacoma, Washington, Bowles ${ }^{6}$ records it as a regular but far from common summer resident. It frequents the tops of the giant firs, where at a height of from two to three hundred feet from the ground, it is studied with difficulty amid the dense vegetation. "About the middle of July both young and old assemble in good sized flocks and frequent the water holes in the smaller growths of timber. At such times I have never seen them associating with any other kinds of birds."

Song.-Barlow ${ }^{5}$ records the call-note of this species, as it was heard by him in the Sierras of Eldorado County, Calif., as a weak tseet, while the song though not loud "would penetrate through the woods quite a distance and very much resembled $t$ sit, $t$ sit, $t$ sit, $t$ sit, chee chee chee, the first four syllables being uttered with a gradual and uniform speed, ending quickly with the chee chee chee. It was quite distinct from any of the other Warbler songs, and wherever it was heard the little musician was usually traced to some pine tree where he would be found nervously hopping about." 
Nesting Site.-Three nests discovered by Allen and recorded by Brewster $^{2}$ were placed in 'pitch pines', from twenty-five to forty feet above the ground, on thick, scraggy limbs, where it would have been impossible to find them except by watching the birds. Beck ${ }^{8}$ found a nest in Eldorado County, California, forty feet from the ground in a slender pine at the end of the limb, and Barlow ${ }^{4}$ records a nest found by Carriger at Fyffe, California, only two-and-a-half feet up in a cedar sapling; and another from the same locality, twelve feet up near the top of a small cedar. Barlow ${ }^{5}$, however, found a nest fortyfive feet up in a yellow pine near the end of the limb.

Nest.-Brewster" describes a Blue Cañon nest as "composed of the fibrous stalks of herbaceous plants, fine dead twigs, lichens (Evernia vulpina), and a little cotton twine, and is lined with the soft inner bark of some coniferous tree and fine long hairs apparently from the tail of a squirrel. The bright, yellow Evernia, sprinkled rather plentifully about the rim, gives a touch of color to the otherwise cold gray tone of the exterior and contrasts agreeably with the warm, reddish brown lining. Although the materials are coarse, and wadded, rather than woven, together, the general effect of the nest is neat and tasteful. It does not resemble any other Warbler's nest that I have seen, but rather recalls the nest of some Fringilline bird, being perhaps, most like that of the Lark Finch. It measures externally 4.50 inches in width by 2 inches in depth. The cavity is I.25 inches deep by 2.50 inches wide at the top. The walls at the rim average nearly an inch in thickness." Barlow" describes his nest as "very prettily constructed, the bottom layer being of light grayish weed-stems, bleached pine needles, and other light materials held securely together by cobwebs and woolly substances. The nest cavity is lined with strips of red cedar bark (Libocedrus) and the ends, instead of being woven smoothly, project out of the nest. The inner lining is of a fine brownish fiber resembling shreds of soap-root."

Eggs.-Barlow ${ }^{5}$ describes a set of 4 eggs as spotted, chiefly in wreaths at the large end, with varying shades of lilac, brown and chestnut. They measure, .66x.52, .68x.53, .67x.53 and $.67 \times .53$.

Nesting Dates.-Blue Cañon, Calif., June 2, two eggs (Brewster); Eldorado Co., Calif., June ro (Beck) ; Fyffe, Calif., June 8, four eggs badly incubated (Barlow) ; Tacoma, Wash., June II, Ig05-only nest found, rather rare and very local. June 2I female seen feeding young recently from nest (Bowles).

\section{Biographical References}

(1) L. Berding, A Partial List of the Birds of Central California, Proc. 
U. S. N. M., I, I878, 405. (2) WM. BREWSTER, Discovery of the Nest and Eggs of the Western Warbler (in Blue Cañon, Cal.), Auk, IV, I887, I66. (3) R. H. Beck, Nesting of the Hermit Warbler (in Eldorado County, Cal.), Nidologist, IV, 1897, 79. (4) C. BARLOW, Another Chapter on the Nesting of Dendroica occidentalis, and other Sierra Notes, Bull. Cooper Orn. Club (=Condor), I, I899, 59. (5) C. BARLow, Nesting of the Hermit Warbler in the Sierra Nevada Mountains, California, Auk, XVI, I899, 156; Condor, III, 1901, 179. (6) J. H. Bowles, The Hermit Warbler in Washington, Condor, VIII, I906, 40.

\section{Cerulean Warbler DENDROICA CERULEA (Wils.) Plate IX}

Distinguishing Characters. - The adult o may be known by its bright blue upperparts and white underparts with a breast band; the $q$ and young are usually tinged with blue above, the tail always showing traces of blue; they have two wing-bars, a whitish or yellowish line over the eye, and the underparts whitish or pale lemon white. In this plumage they are to be confused only with the young of Compsothlypis, which has the breast and back much deeper yellow, and no line above the eye. Length (skin), 4.30; wing, 2.70; tail, I.70; bill, .40.

Adult d" Spring.-Above grayish cerulean, brighter on the crown, crown and back streaked with black; upper tail-coverts black broadly tipped with blue; cheeks grayish blue with sometimes a rather poorly defined stripe behind the eye which rarely reaches forward to the bill; tail black edged with grayish blue, all but the middle feathers with white patches on the inner web near the tip, the middle feathers there margined with white; wings black edged with grayish blue, median and greater coverts widely tipped with white forming two conspicuous bars; below white, a bluish black breast band, sides streaked with bluish black.

Adult d', Fall.-Similar to adult $\delta$ in Spring but breast-band incomplete, showing only at sides of breast. (Only one specimen examined.)

Young $\delta$, Fall.-Above dull bluish gray heavily washed with bright olivegreen; upper tail-coverts black, as in adult $d$; tail as in adult $\delta^{*}$ but with less white; wings edged with greenish and with two white bars; underparts whitish tinged with yellow and with a suggestion of streaks on the sides.

Adult +, Spring.-Above grayish blue brighter on the head, the back strongly tinged with green; a more or less distinct whitish or yellowish line over the eye; upper tail-coverts grayish tipped with bluish; the wing-coverts broadly tipped with white; underparts whitish or pale yellowish with sometimes a suggestion of streaks on the sides. Resembles young $\delta$ in Fall but is bluer above and has the upper tail-coverts gray instead of black.

Adult $q$, Fall.-Similar to adult $q$ in Spring but greener above and yellow below (?). I have not seen a Fall female of which the age had been determined and cannot, therefore, certainly distinguish between specimens of young $q$ and adult $q$ taken at this season.

Young + Fall.-See above.

Nestling.- "Above uniform brownish gray (deep drab-gray), the pileum divided longitudinally by a broad median stripe of grayish white; sides of head 


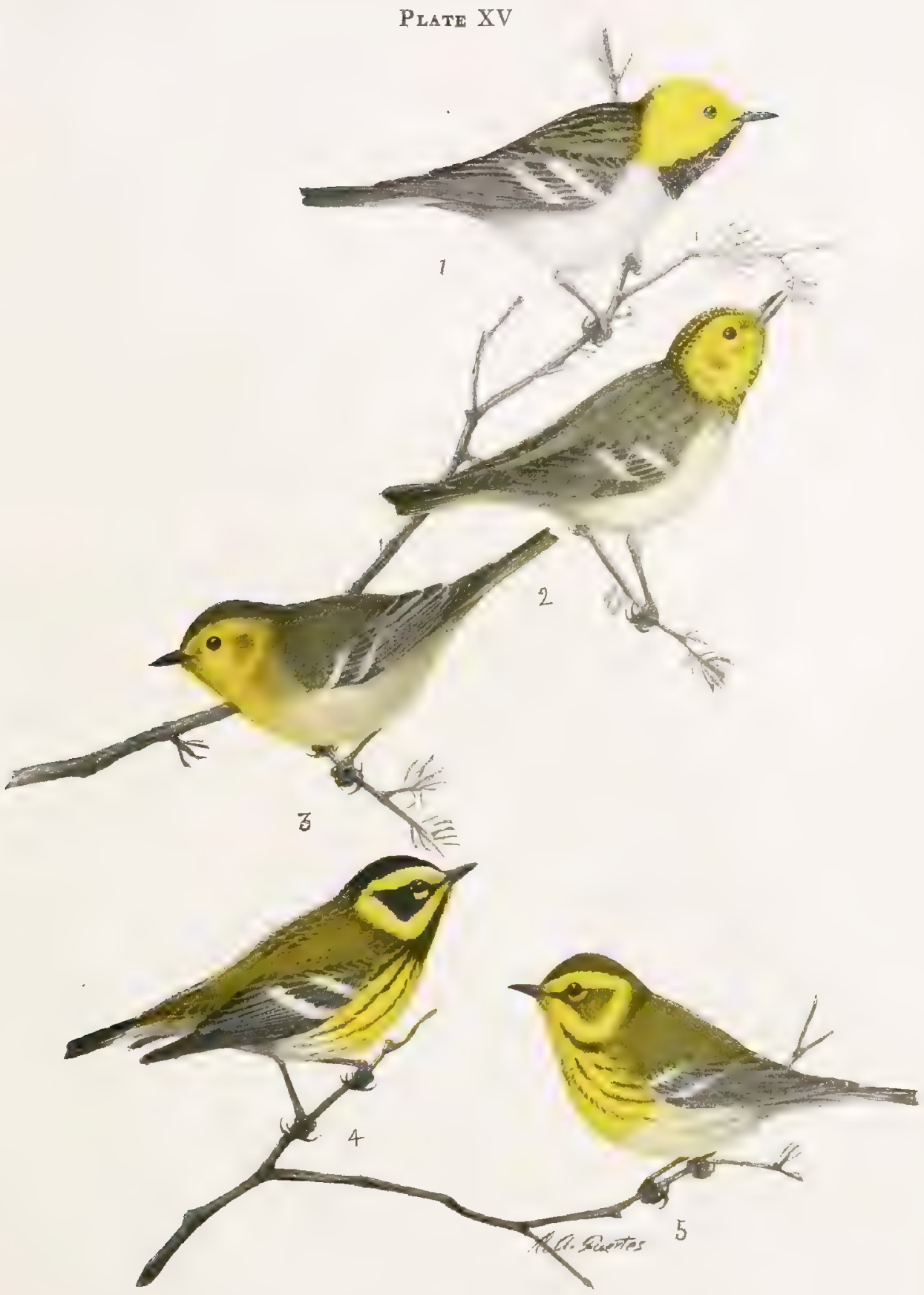

1. Hermit Warbler, Male.

3. Hermit Warbler, Young.

2. Hermit Warbler, Female.

4. Jownsend's Warbler, Male.

5. Townsend's Warbler, Female.

(ONE-HALF NATURAL SIZE.) 


$$
\text { * }
$$


(including a broad superciliary stripe) and entire underparts white; a narrow postocular stripe of deep drab-gray; wings as in adults, but edgings greenish rather than bluish." (Ridgw.).

General Distribution.-Eastern United States; north to New York; west nearly to the Plains.

Summer Range.-Principally the valley of the Ohio River; thence east to Virginia (Natural Bridge), West Virginia (White Sulphur Springs), Maryland (Baltimore), Delaware (Choptank River), Pennsylvania (Williamsport, East Penn.), and central New York (Auburn, Baldwinsville). It has occurred casually in New Jersey (Boonton, September 1887), southeastern New York (West Point, May 17, 1875; New York City, May 5, r886), Connecticut (Suffield, June I2, I875, Seymour, May Io, I888), and Rhode Island (Providence, May 22, I878, Pawtucket, May 22, I879, Lonsdale, May I4, I893). North of the Ohio valley, it ranges to southern Ontario (Plover Mills), southern Michigan, (Lansing, Detroit), southern Wisconsin (Lake Koshkonong, Milwaukee, Racine, Two Rivers), and southern Minnesota (Lanesboro); west to eastern Nebraska (Omaha), eastern Kansas (Onaga), and eastern Texas (Texarkana); accidental at Denver, Colo., and Rio Mimbres, New Mexico. The southern limits of its regular breeding range are the mountains of Virginia and Tennessee; but it has been known to breed irregularly at Greensboro, Ala., Franklin and St. Tammany Parishes, La., and in the Creek and Cherokee Nations, Okla.

\begin{tabular}{|c|c|c|c|c|}
\hline PL,ACE & $\left|\begin{array}{l}\text { No. of } \\
\text { years' } \\
\text { recotd }\end{array}\right|$ & $\begin{array}{c}\text { Average } \\
\text { spring }\end{array}$ & $\begin{array}{l}\text { date of } \\
\text { urival }\end{array}$ & $\begin{array}{l}\text { Earliest date of } \\
\text { spring arrival }\end{array}$ \\
\hline 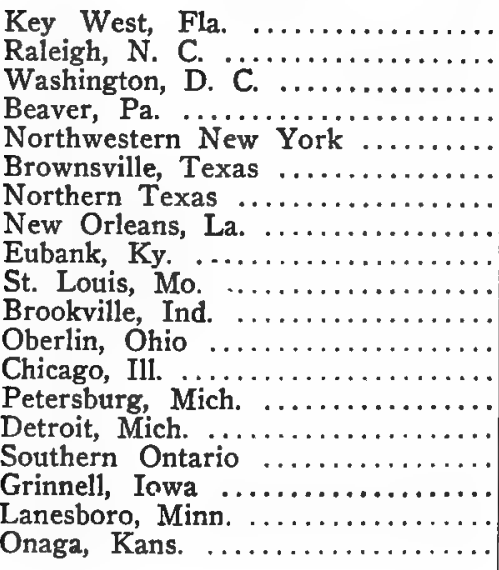 & $\begin{array}{r}4 \\
6 \\
3 \\
\\
3 \\
2 \\
5 \\
5 \\
6 \\
9 \\
4 \\
10 \\
7 \\
6\end{array}$ & $\begin{array}{l}\text { May } \\
\text { May } \\
\text { May } \\
\text { April } \\
\text { April } \\
\text { April } \\
\text { April } \\
\text { April } \\
\text { May } \\
\text { May } \\
\text { May } \\
\text { May } \\
\text { May }\end{array}$ & $\begin{array}{r}8 \\
1 \\
7 \\
19 \\
9 \\
9 \\
15 \\
17 \\
27 \\
3 \\
14 \\
2 \\
5 \\
7\end{array}$ & 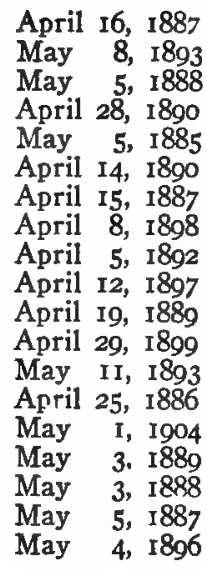 \\
\hline
\end{tabular}


Winter Range.-Western South America from Panama to Peru.

Spring Migration.-In migration this species shuns the south Atlantic States and the West Indies (except casually), passes through Central America east of Mexico, and enters the United States principally in the Mississippi Valley.

Fall Migration.-The Cerulean Warbler is one of the earliest to start south and reaches the coast of Louisiana and Mississippi on dates ranging, in different years, from July 12 to 29 . The birds are most numerous there early in August. The latest migrants have been noted at London, Ontario, September I, I900; Livonia, Mich., September I, I892; Beaver, Pa., September I4, I889; Berwyn, Pa., September 27, I889; Eubank, Ky., September I4, I887; Chester County, S. C., as late as October 22.

The Bird and its Haunts. - The Cerulean Warbler is distinguished alike by its color and by its geographical distribution. No other Warbler resembles it in plumage, none has a similar range. Like certain other Mississippi Valley birds it appears to be gradually extending its range eastward through central New York and possibly it may eventwally reach the maple groves of Vermont.

Although locally abundant as far east as central New York the bird, true to its route of range extension, migrates southward through the Mississippi Valley and along the Alleghenies, being so rare on the Atlantic seaboard, except in Delaware, as to be considered almost "accidental."

In Mississippi, Allison writes, the Cerulean is "a typical wood Warbler; it prefers rich mixed woods, its metropolis in migration being the upland beech woods. On the coast it is common in woods of oak and hickory, but shows no objection to pine."

Near St. Louis, Mo., where Smith ${ }^{6}$ has found upwards of forty nests in a season, the bird frequents sycamores. In the White Water Valley of southeastern Indiana, where Butler ${ }^{3}$ considers the bird to be as abundant as anywhere within its range, this Warbler is found more frequently along the river valleys and upon hillsides than upon the upland; they prefer the more open woodland, especially that in which the prevailing timber is sugar-naple, elm and linden. They are not gregarious and where found appear to be evenly distributed. They are seldom found nearer the ground than twenty feet, ranging from this height to the tops of the tallest trees. *** When high in the trees they may be easily mistaken for Flycatchers, and when lower down, among the larger branches, their habits remind one of the Titmouse and Creeper. 
About Branchport, N. Y., Verdi Burtch reports the Cerulean as locally abundant in mixed growths of oak and maple with a few birch and hickory. The female, which, as usual, incubates unaided, is a very close sitter seldom leaving the nest before one is near to her. On one occasion, in spite of his best efforts to prevent her, a bird returned to the nest three or four times while he was examining its contents.

Song.-Brewster ${ }^{1}$ compares the song to that of the Parula Warbler but remarks "that of the latter bird has, however, at least two regular variations; in one, beginning low down, he rolls his guttural little trill quickly and evenly up the scale, ending, apparently, only when he can get no higher; in the other, the commencement of this trill is broken or divided into syllables, like $z e e, z e e, z e e, z e-e e-e e-e e p$. This latter variation is the one used by $D$. carulea, and I could detect little or no difference in the songs of dozens of individuals. At best it is a modest little strain. *** In addition to the song, they utter the almost universal Dendroicine lisp, and also, the characteristic tchep of $D$. coronata, which I had previously supposed entirely peculiar to that bird."

"Six different writers agree in their descriptions of this bird's song. It consists of two distinct parts, the first of several definite single syllables with a comma pause between each two, followed by a trilled syllable of about double the length of the first part. There is thus a marked resemblance to Parula's song. The syllables tse, tse, $t s e, t s e, t e-e-e-e-e-e-e-e-e$, serve to recall it to mind. The song rolls up the scale quietly and evenly. The effect is less delicate than Parula's song, yet not more wiry. A larger song from a larger bird.

"My notes indicate that this Warbler sings from his arrival in the first week in May until the third week in May, and again during the last of June and first week of July. I have never heard it sing during the fall migrations and find no record of a song period then." (Jones.)

"The Cerulean is an incessant singer. It nests here and several pairs are always here through June. The song is sweet, but rather husky, and has a soft, wheeling, whirring, rolling quality to it. The common song is of four notes all on one key, the last ones a quick, upward, chromatic run, ending in a soft burr-r-r. May 24, 1905, I heard a very unusual song. The form was like the Redstart's shreeshree-shree, but the voice was the soft one of the Cerulean. He sang many times and never gave the upward run." (Farwell, MS.)

Nesting Site.-Smith ${ }^{6}$ records the site near St Louis as from forty to seventy-five feet up in sycamores, saddled on a limb well out from the trunk. In southeastern Indiana, Butler ${ }^{8}$ found the nests 
placed "in the fork of a limb at some distance from the body (of the tree) and at from twenty-five to fifty feet from the ground." Nests found by Saunders ${ }^{7}$ in the western peninsula of Ontario were in basswood, maple, oak or elm trees at from thirty to fifty-five feet from the ground. In Baltimore County, Maryland, a nest was found by Kirkwood $^{8}$ in a tulip tree, forty-eight feet six inches up and fifteen feet out from the body of the tree.

Burtch (MS.) writes that at Branchport, N. Y., where the bird is locally common, "the nest is usually placed on a horizontal branch or drooping branch of an elm, ranging from twenty-five to sixty feet from the ground, and from four, to fifteen, or eighteen feet from the body of the tree over an opening. A nest found June 4, 1905, was in the topmost branches of an elm over sixty feet up, and way out on the branch. There was a nest of a Red-eyed Vireo in middle of same tree and twelve feet from the nest of Cerulean."

Nest.- "The nest very closely resembles a typical nest of Traill's Flycatcher, only smaller, being made of precisely the same materials both inside and out." (Smith ${ }^{6}$.) A nest from Monroe County, N. Y., is "neatly and compactly built, consisting externally of fine dry grasses of an ashen tint bound firmly together with spiders' silk, to which are affixed a few bits of whitish lichen; it is lined with strips of bark and fine grasses of a reddish brown color. The nest is gray externally and brown within." (Allen ${ }^{2}$.

Saunders" describes the nest as extremely shallow and "mainly composed of grasses and a few bark fibers, with a scanty lining of black horse-hairs. * * * The whole is covered with the same silvery gray bark strips the Redstart uses so freely, with some intermingling of cobwebs, both bark strips and cobwebs having the appearance of being put on while wet."

Burtch (Branchport, N. Y.), writes that "the nest is always saddled on a fork of a good-sized limb, much like that of a Wood Pewee. It is well-made and very handsome, composed, of fine strips of bark, lined with a fine red fiber, which may be very finely shredded grapevine bark. Sometimes blossom stems or dead grass are used for lining. The walls, where they touch the branch, are very thin, usually nothing but the lining. The nests are usually profusely covered with grayish lichens held in place with spiders' webs."

Eggs.-3 or 4, usually 4. Ground color a pale bluish or greenish white spotted and speckled with reddish brown and lavender pretty well over entire egg. Size; a typical set of 4 measures .69x.52, .70x.52, $.69 \times .52$ and $.69 \times .52$. (Figs. 55,56.) 
Nesting Dates.-Yates Co., N. Y., May 3I (C.W.C.) ; Waynesburg, Pa., May 24 only record (Jacobs) ; Oberlin, O., May I5-June I5 (Jones) ; Washtenaw County, May I5, Hyde-July I5, feeding young, Covert (Barrows); London, Ont., June II (Saunders); Ann Arbor, Mich., May 20 (Wood).

\section{BIographical REFERENCES}

(I) WM. Brewster, Some Observations on the Birds of Ritchie County, West Virginia, Ann. Lyc. Nat. Hist. N. Y., XI, 1875, I34. (2) J. A. Allen, Nest and Eggs of the Cerulean Warbler, Bull. Nutt. Orn. Club, IV, 1879, 25. (3) A. W. Butler, The Cerulean Warbler (in Indiana), Orn. and Oöl., IX, 1884, 27. (4) S. F. Ratabun, The Cerulean Warbler (near Auburn, N. Y.), Orn. and Oöl., IX, 1884, 28. (5) E. Reinecke, Cerulean Warbler (near Buffalo, N. Y.), Oölogist, IX, 1892, 264. (6) P. W. SmitH, JR., Nesting of the Cerulean Warbler (near St. Louis, Mo.), Orn. and Oöl., XVIII, I893, 5. (7) W. E. SAUNders, Nesting Habits of the Cerulean Warbler (in W. Ontario), Auk, XVII, I900, 358. (8) F. C. KIRKwoon, The Cerulean Warbler as a Summer Resident in Baltimore County, Maryland, Auk, XVIII, I90I, I37. (9) Lynds Jones, The Cerulean Warbler, (in Ohio), Wilson Bull., XVI, I904, 3 .

\section{BLACKBURNIAN WARBLER}

\section{DENDROICA FUSCA (Mull.) Plate III}

Distinguishing Characters.-The adult $\sigma^{*}$ in Spring has the center of the crown, line over eye, sides of neck and breast flaming orange; in the adult $b$ in Fall and adult $q$ in Spring these parts are dull orange or yellowish orange, in young birds these areas are still duller. Birds in the last-named plumage may cause some difficulty in identifying but the marks named, in connection with a brownish, obscurely streaked back, and generally white outer web of the basal half of the outer tail-feather, should be diagnostic. Length (skin), 4.60; wing, 2.65 ; tail, 1.95 ; bill, .40.

Adult d", Spring.-Center of crown, streak below eye, line over eye to 2 patch on the side of the neck orange, ear-coverts and lores black; upperparts black, the back streaked with white which, in some specimens, is tinged with orange; tail black, edged with grayish, the inner web of the two to four outer feathers largely white, the outer web white at the base, the next feather usually with a white spot near the tip of the inner web; wings black edged with sage; the median coverts white, outer greater coverts tipped with white, the inner greater coverts with white margin or wholly white, forming a large white patch in the wing; throat and breast flaming orange usually deeper than that of crown, this color generally suffusing the whitish abdomen, sides streaked with black.

Adult $\delta^{2}$, Fall-Similar to aduit $\sigma^{*}$ in Spring but the orange much paler and veiled with buffy tips; the black markings widely bordered with brownish; wings with two white bars, not forming a patch.

Young $\sigma^{*}$, Fall.-Similar to adult $\sigma^{*}$ in Fall but orange markings less pronounced and still paler, becoming dull yellow; black markings less pronounced and mixed widely with grayish olive or olive-brown. 
Adult $q$, Spring.-Similar to young $\delta$ in Fall but orange averaging deepes in color and more evident in crown; belly whiter.

Adult $q$, Fall.-Similar to adult $q$ in Spring but orange areas still paler, crown spot barely evident, upperparts browner, belly more suffused the breast color being less sharply defined posteriorly.

Young + , Fall.-Not certainly distinguishable from adult $q$ in Fall but breast averaging paler, in some specimens nearly white; white in tail mucb reduced, the base of the outer web of the outer tail-feather rarely fuscous like the end.

Nestling.-Above brown the back streaked with black and margined witb buffy; a broad buffy white line from the eye to the nape; below white, the throat and breast suffused with buff and brownish, the latter with blackish spots extending to the sides.

General Distribution.-Eastern North America; north to the Gulf of St. Lawrence and Manitoba; west to the Plains.

Summer Range.-Southern Canada from Cape Breton, through central Ontario to Manitoba and south to Massachusetts (Berkshire, Greenfield, Holyoke, Chester, Winchendon, Roxbury, Concord, Lexington and Sudbury), northwestern Connecticut (probably), New York (Lewis and Oneida Counties), northern Michigan (Porcupine Mountains), Wisconsin (Jefferson and Manitowoc Counties) and northern Minnesota. In the Allegheny Mountains a few Blackburnian Warblers breed in Pennsylvania and south to North Carolina. It occurs west to the plains of eastern Texas (Boerne), eastern Kansas (Leavenworth) and eastern Nebraska (West Point, Omaha); accidental in Utah (Ogden, September I87I) and New Mexico (Fort Bayard, May).

Winter Range.-Central Mexico to Venezuela ard Peru; casual in the West Indies.

Spring Migration.-

\begin{tabular}{|c|c|c|c|}
\hline PLACE & $\begin{array}{l}\text { No. of } \\
\text { years' } \\
\text { record }\end{array}$ & $\begin{array}{l}\text { A verage date of } \\
\text { spring arrival }\end{array}$ & $\begin{array}{l}\text { Earliest date of } \\
\text { spring arrival }\end{array}$ \\
\hline 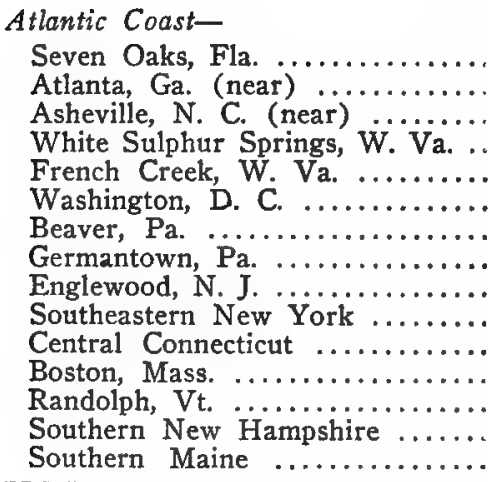 & $\begin{array}{l}3 \\
5 \\
5 \\
5 \\
6 \\
4 \\
5 \\
3 \\
6 \\
8 \\
7 \\
7 \\
9 \\
6\end{array}$ & $\begin{array}{lr}\text { April } & 17 \\
\text { April } & 14 \\
\text { April } & 22 \\
\text { April } & 28 \\
\text { May } & 5 \\
\text { May } & 4 \\
\text { May } & 7 \\
\text { May } & 10 \\
\text { May } & 10 \\
\text { May } & 10 \\
\text { May } & 10 \\
\text { May } & 7 \\
\text { May } & 8 \\
\text { May } & 16\end{array}$ & $\begin{array}{lr}\text { April } 10,1902 \\
\text { April } 2,1895 \\
\text { April 10, } 1893 \\
\text { April } 17,1893 \\
\text { April } 23,1891 \\
\text { April } 30,1905 \\
\text { April } 30,1902 \\
\text { April } 28,1890 \\
\text { May } 7,1897 \\
\text { April } 30,1900 \\
\text { May } 6,1891 \\
\text { May } 6,1897 \\
\text { May } 2,1890 \\
\text { May } 3,1902 \\
\text { May } 10,1900\end{array}$ \\
\hline
\end{tabular}



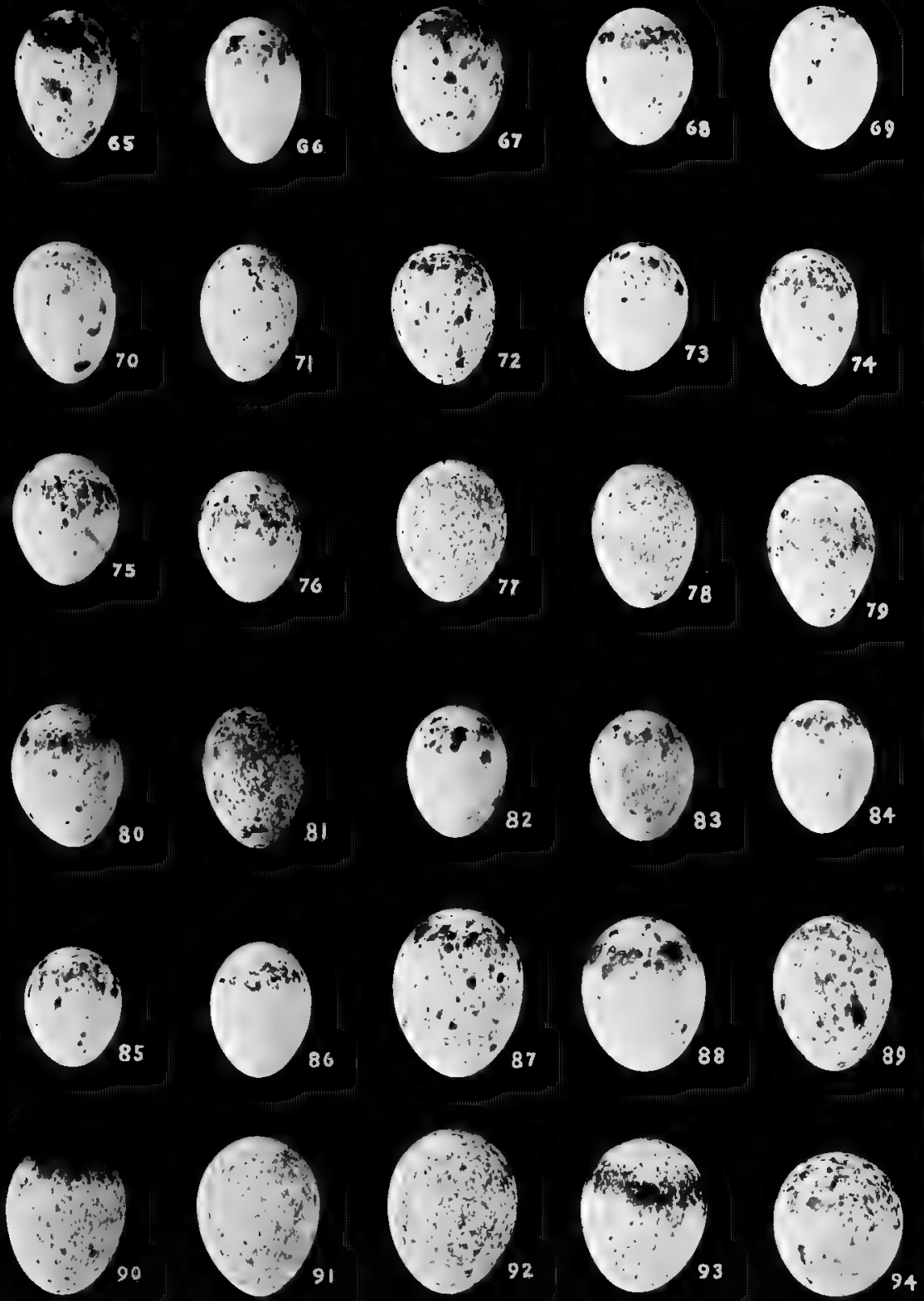

Figs. 65, 66. Blackburnian Warbler.

“ 67, 68, Yellow-tliroated Warbler.

“ 69- 1 . Black-throated Gray Warbler.

- 72,73. Golden-cheeked Warbler.

“ 74-76. Black-throated Green Warbler.

“ 77, 78, Kirtland's Warbler.
Figs. 79-81. Pine Warbler.

“ 82, 83. Yellow Palm Warbler.

“ 84-86. Prairie Warbler.

“ 87,88 . Oven-bird.

" 89-91. Northern Water-Thrush.

" 92-94. Louisiana Water-Thrush. 


$$
\text { , }
$$


Spring Migration.-(continued.)

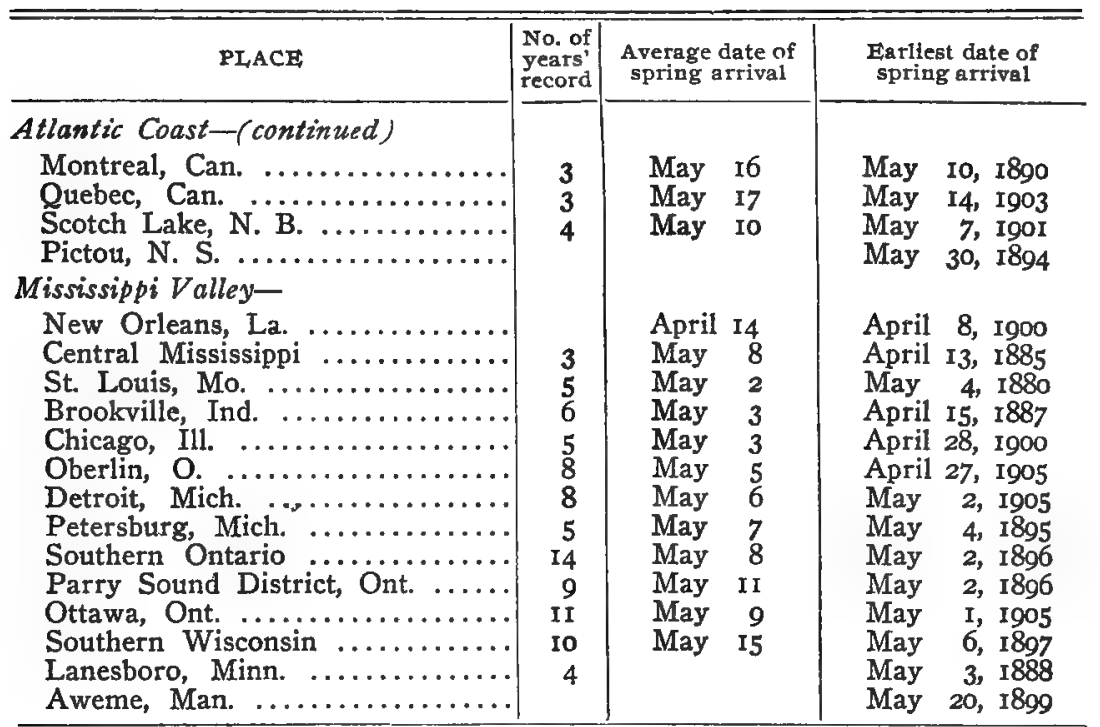

Fall Migration.-

\begin{tabular}{|c|c|c|c|}
\hline PLACE & $\begin{array}{l}\text { No. of } \\
\text { years' } \\
\text { record }\end{array}$ & $\begin{array}{l}\text { Average date of } \\
\text { first onle seen }\end{array}$ & $\begin{array}{l}\text { Farliest date of } \\
\text { first one seen }\end{array}$ \\
\hline 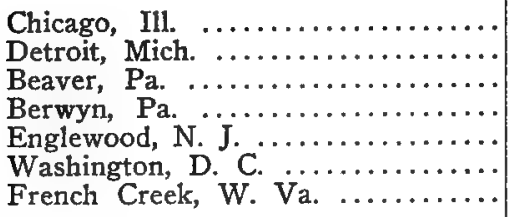 & $\begin{array}{l}6 \\
4 \\
5\end{array}$ & $\begin{array}{l}\text { August } 22 \\
\text { August } 28 \\
\text { September } 9 \\
\text { August } 23 \\
\text { September } 8\end{array}$ & $\begin{array}{l}\text { August 12, 1900 } \\
\text { August 20, 1905 } \\
\text { September 7, 1903 } \\
\text { August } 23,1888 \\
\text { August 11, 1887 } \\
\text { August 15, 1886 } \\
\text { September } 7,1890\end{array}$ \\
\hline PLACE & $\begin{array}{l}\text { No. of } \\
\text { years' } \\
\text { record }\end{array}$ & $\begin{array}{l}\text { Average date of } \\
\text { last one seen }\end{array}$ & $\begin{array}{l}\text { Earliest date of } \\
\text { last one seen }\end{array}$ \\
\hline 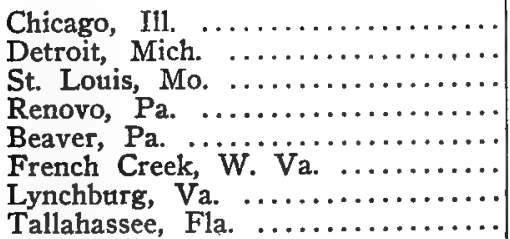 & $\begin{array}{l}5 \\
6 \\
2 \\
8 \\
4 \\
4\end{array}$ & $\begin{array}{l}\text { September } 9 \\
\text { September I7 } \\
\text { October } 3 \\
\text { September I2 } \\
\text { September } 20 \\
\text { September } 18\end{array}$ & $\begin{array}{l}\text { September } 22,1899 \\
\text { September } 30,1893 \\
\text { October 5, I905 } \\
\text { September 25, } 1899 \\
\text { September 23, } 1899 \\
\text { September 25, } 1889 \\
\text { October 9, } 1898 \\
\text { October 26, } 1904\end{array}$ \\
\hline
\end{tabular}

The Bird and its Haunts.-This beautiful Warbler is, as a rule, sufficiently uncommon to make a meeting with it an always noteworthy experience. At Monadnock, however, Gerald Thayer reports it to be "a very common summer resident. It is one of the four deepwood Warblers of this region, the other three being the Black-throated 
Blue, the Northern Parula and the Canada. While all the other summer Warblers of Monadnock seem better pleased with various sorts of lighter timber, these four are commonest in the small remaining tracts of primeval woodland, and in the heaviest and oldest second growth. But despite this general community of habit, each of the four has marked minor idiosyncrasies. The Blackburnian favors very big trees, particularly hemlocks, and spends most of its life high above the ground. The Parula is most at home in boggy woods, where the ground is covered deep with sphagnum and the stunted trees are veiled in dangling Usnea; the Black-throated Blue haunts the heavy undergrowth in drier woods; while the sweet voiced Canada, -also, and even more strictly, a bird of the deciduous undergrowth,is partial to damp hillside woods and brook-meshed swales, but, as a rule avoids the spongy bogs in which Parulas and pitcher-plants most flourish. But the preeminent forest Warbler of the group is the Blackburnian, the lover of deep mixed growth and the upper branches of the biggest conifers. It is rather a restless and quick-moving Warbler, though not shy, and without any (?) very peculiar tricks of pose or gesture."

At Branchport, N. Y., Burtch writes that the Blackburnian is a rare summer resident breeding in hemlocks along gullies in company with Black-throated Green and Magnolia Warblers. In northern Minnesota, according to Preston, it favors the black spruce, singing from some high conspicuous perch, or feeding while ascending from branch to branch to the "cone-clad top, from which it falls lightly to another tree, and so continues the search."

Song.- "Its voice is thin, but, unlike the Parula's, exquisitely smooth, in all the many variations of its two (or more) main songs. One of these two, in my experience, is much less changeable than the other. This is the simpler one, which may be syllabled Tsivvi, tsivvi, tsivvi, tsivvi; or a variation,-Sissi-vit, sissi-vit, sissi vit, sissi vit;deliberately, almost languidly uttered, in both cases, with a fine, 'kinglety,' sibilant voice-tone. The other common song, though it begins in much the same way, is more hurried throughout, and ends, on a sharply-ascending scale, with a sort of explosion of small, crowded notes. Both utterances vary widely, and the one last described is about the most changeable of all the Warblers' songs I know. Even the tone-quality is not quite constant, for though it never, in my experience, varies toward huskiness, it does occasionally range toward full-voiced richness. Thus I have heard a Blackburnian that began his otherwise normal song with two or three clear notes much like those of the most full and smooth-voiced performance of the 
American Redstart's, and another that began so much like a Nashville that I had to hear him several times, near by, to be convinced that there was not a Nashville chiming in. Sometimes, again, tone and delivery are varied toward excessive languidness; and scme times, contrariwise, toward sharp, wiry 'thinness'. The Blackburnian's call-notes are small and scantily peculiar;-at least, I have never learned to recognize them surely, among kindred 'chippings'." (Thayer, MS.)

Miss Paddock describes the song as "very shrill and fine, growing even more shrill and wiry as it rises toward the end," and renders it as follows:

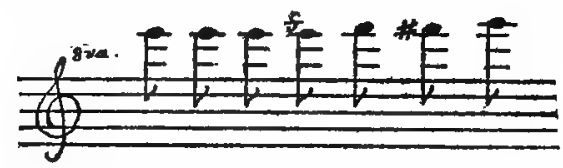

J. W. Preston writes that in northern Minnesota during May and early June the males, perched upon "a dry and broken branch of some tall, old hemlock" will sit and sing for hours. He describes the song as somewhat resembling the Black-throated Green's, but as "richer and more lively."

Nesting Site.-A nest found by A. J. Dayan at Lyon's Falls, N. Y., was saddled on a horizontal limb eighty-four feet from the ground and about ten feet from the trunk. (Merriam ${ }^{1}$.) Bowles ${ }^{8}$ describes a nest found in New Hampshire, as placed in a sugar maple, sixty feet from the ground, on a limb seven feet from the body of the tree. Two nests found by Preston ${ }^{2}$ in Minnesota, were respectively in a hemlock twenty feet up and against the tree, and in a black spruce thirty feet up far out on the tip of a branch.

Two nests, found at Branchport, N. Y., (Burtch, MS.) were placed in hemlocks, one of them being thirty-five feet from the ground and six feet from the tree-trunk.

Nest.-Dayan's nest is described by Merriam as "large, substantial, and very compact. It consists almost entirely of a thick and densely woven mat of the soft down of the cat-tail (Typha latifolia), with seeds attached, and is lined with fine lichens, horse-hair, and a piece of white thread. On the outside is an irregular covering of small twigs and rootlets, with here and there a stem of moss or a bit of lichen." Bowles" describes the nest as "composed of hemlock twigs, rootlets, a few pine needles and bits of Usnea all woven rather loosely together and thinly lined with horse-hair." Preston's ${ }^{2}$ nests had a light platform of dead spruce twigs with Usnea interwoven, and lined with finely 
shredded inner bark of the basswood, a few horse, and a number of deer's hairs. The rim is Usnea matted and twined together. The exterior is flecked all over with fluffs of cottony spiders' webbing.

Burtch's nest is described by him as. "loosely constructed of fine hemlock twigs and a few pieces of weed-bark lined with fine red fiber such as the Magnolia Warbler and Redstart use. The nest resembles that of the Magnolia Warbler very closely, but lacks the woolly decorations."

Eggs.-4. Grayish white or bluish white distinctly and obscurely spotted, speckled, and blotched with cinnamon brown or olive-brown. Size, average, $68 \times$ x.50. (Figs. 65,66.)

Nesting Lates.-Branchport, N. Y., May 24 (Burtch); Lyons Falls, Lewis Co., N. Y., June 2 (Merriam) ; Lancaster, N. H., June 4-I5 (Spaulding) ; Bangor, Me., June 5-June I5 (Knight); Kalamazoo C.o., Mich., June 2, B. F. Syke (Barrows).

\section{BIOGRAPHICAL REFERENCES}

(1) C. Haxr Merriam, Nest and Eggs of the Blackburnian Warbler, (in N. N. Y.), Auk, II, I885, I03. (2) J. W. Preston, The Blackburnian Warbler at Home, (N. Minn.), Orn. and Oöl., XIV, 1889, 34. (3) J. H. Bowles, Notes on the Blackburnian Warbler, (in So. N. H.), Oölogist, XII, I895, 64.

\section{YELLOW-THROATED WARBLER DENDROICA DOMINICA DOMINICA (Linn.) Plate XIII}

Distinguishing Characters.-At all seasons adults and young may be known by their yellow throat, black cheeks, and bluish gray or brownish gray back. Length (skin), 4.80 ; wing, 2.60 ; tail, I.95; bill, .50.

Adult d, Spring.-Black of forehead reaching back on sides of crown and sometimes occupying most of crown, a small white median spot on forehead; line from above eye to bill yellow, stripe behind eye and patch on sides of neck white; back gray rarely (I have seen but one specimen) with a few black spots; tail black margined with gray the outer three to five feathers with white patches on the inner web at the end; wings black margined with gray, the greater and median coverts broadly tipped with white forming two unusually conspicuous bars; throat and breast yellow bordered by black which extends in streaks along the sides; belly white.

Adult $\delta^{*}$, Fall.-Similar to adult $\delta^{*}$ in Spring but upperparts and sides washed with brownish.

Young of, Fall.-Resembling adult $\delta$ in Fall.

Adult + , Spring.-Similar to adult $\delta$ in Spring but with less black on the head, sides of throat, and neck.

Adult 9 , Fall.--Similar to adult $q$ in Spring but back and sides brownish.

Young + , Fall.-Similar to adult $q$ in Fall but brown on back and sides stronger, belly and white line behind eye with a brownish wash; black areas less distinct. 
Nestling.-Above brownish gray, a whitish line behind eye and a white spot below it; auriculars dusky; below white obscurely but finely streaked with dusky.

General Distribution.-Eastern United States east of the Alleghenies; north to Maryland.

Summer Range.-From northern Florida, east of the Allegheny Mountains, north regularly to Virginia; occasional in Maryland and on the Choptank River in southeastern Delaware; accidental in Pennsylvania (Beaver, Chester, and Delaware Counties), New Jersey (Trenton, May 29, I860), New York (Crow Hill, L. I.), Connecticut (Hartford and New Haven), Massachusetts (Dedham, November 4, 1866). North in the interior to West Virginia (Kanawha Co.).

Winter Range.-Florida-rarely South Carolina-the Bahamas and the Greater Antilles; casual in Yucatan.

Spring Migration.-Wintering so abundantly in southern Florida, but little can be said of the migration of the Yellow-throated Warbler in the Gulf states. The northward movement begins early in March, Gainesville, Fla., being reached March 2 and Jacksonville, Fla., March 5. The average date of arrival for fifteen years at Raleigh, N. C., is March 26, earliest March I3, I89o; the average at Asheville, N. C., for four years is April 21, the earliest April I3, I893.

Fall Migration.-The Yellow-throated Warbler is one of the very earliest fall migrants beginning its southward movement by the middle of summer (Key West, Fla., July 25) and reaching Cuba the latter part of July. The last one noted at Washington, D. C., was September, 4, I890; at Raleigh, N. C., September I7, I886, and many migrants continue to pass through Florida during the whole month of October.

The Bird and its Haunts.-About the first of March a new voice is added to the swelling chorus of bird music in middle Florida. It is no lisping lay, heard only by attentive ears, but a loud, ringing song which stands out with strongly characterized distinctness. After the lapse of twenty years I well recall the excitement with which I first heard it and my vain efforts to discover the singer in the upper branches of a heavily timbered, densely undergrown, wet 'hammock' of magnolia, maple, hickory, bay and other deciduous trees.

As the migration progressed the bird became abundant in the cypresses and often visited neighboring pines where it could be observed to better advantage. Even here, however, it is by no means so readily observed as are more active Warblers. When singing it remains in one position for many consecutive minutes, and at all times it is comparatively deliberate in its movements resembling the Pine Warbler rather than the fluttering Warblers in its manner of feeding. 
At St. Mary's, Georgia, Brewster ${ }^{1}$ found that the favorite abode of this species was the open piney woods. Their movements, he says, "are much slower than those of Mniotilta, and there is much less of that crouching, creeping motion. They do, indeed, spend much of their time searching the larger branches for food, but it is more in the manner of the Pine Warbler, and their motion is rather a hopping than a creeping one. I have never seen them ascend the trees from the roots to the topmost branches, as Audubon relates, but I occasionally observed one clinging against the main trunk, for a moment, to seize an insect, as will the Bluebird and many of the Warblers. Their huntingground is for the most part, however, among the higher branches, and a considerable part of their time is spent at the extremities of the limbs, searching for food among the pine needles."

Near Charleston, Wayne ${ }^{2}$ records this Warbler as a permanent resident inhabiting mixed woods and live oaks where there is an abundance of Spanish moss; and at Raleigh, where it is a summer resident only, Brimley states "while it is more or less numerous in large tracts of pines and in all mixed woods containing large pines, it cannot be called plentiful anywhere."

Song.-Although I have long been familiar with the song of this species it was not until the spring of 1905 that I was impressed with its resemblance to the song of Seiurus motacilla. It is not so much the form of the notes, ching-ching-ching, chicker-cher-wee, as their wild, ringing, carrying quality which recalls the song of the Water-Thrush. The bird pauses to sing at intervals in its search for food, and the consequent frequent change of place together with the ventriloquial character of its notes makes it difficult to place the singer.

The Yellow-throat's song is also compared with that of the Indigo Bunting and not without reason. In any event, it is not likely to escape the attention of the unobservant and, in Florida, after March I, when it begins to sing, it is one of the conspicuous songsters of the localities it favors.

Nesting Site.-A nest found by Brewster ${ }^{1}$ was thirty-five feet up in a southern pine, set flatly, not saddled, on a horizontal limb "nearly midway between the juncture with the main trunk and the extremity of the twigs, and was attached to the rough bark by silky fibers."

After finding thirteen nests at from twenty to ninety feet from the ground (usually about forty-five feet up and three to twelve feet from the trunk of the tree, Brimley ${ }^{4}$ states that this species selects for a site "a horizontal limb usually, but not always, of a tall thin pine. Sometimes it builds its nest where the limb forks, but more often right 
on the limb, attached only to the limb itself or else laced to small twigs as well."

A nest described by M'Laughlin ${ }^{3}$ from Statesville, N. C., was similarly placed but was only nineteen feet from the ground. Nests found by Wayne ${ }^{2}$, near Charleston, S. C., however, were placed in bunches of Spanish moss (Tillandsia) in live-oak or gum trees at a height of fifteen to fifty feet.

Nest.-Brewster's ${ }^{1}$ nest "is composed externally of a few short twigs and strips of bark bound together by Spanish moss (Tillandsia usneoides) and silky down from plants. The lining consists of a few hair-like filaments of moss and soft cottony vegetable down. The whole structure is firmly and neatly compacted." Brimley describes the nest as "usually much like a Pine Warbler's in general character, but lacks the black grapevine bark which gives the latter such a dark appearance, and is also usually compact, especially about the rim. The materials of which it is composed are weed stems, strips of trumpetvine bark, fine grass and caterpillar silk; the lining is of horse-hair or feathers or both."

Wayne $^{2}$ describes his nests as "built of fine grass, weeds, snakeskins, feathers, and lined with the flower of the moss; in one of the nests there is a quantity of cotton."

Eggs. -4 or 5, very rarely 5. Ground color a dull greenish graywhite, in a large series the peculiar color of the markings seem to tinge the ground color; the markings are very mixed, numerous under shell marks, in the form of blotches and specks, of pale lavender and purplish gray overlaid with heavier surface markings of wine-red, umber and deeper shades of purplish gray and blackish. The heaviest markings are at the larger end, which is sometimes well wreathed, with many spots and specks over rest of egg. Size; average, .69x.52, extremes measure $.74 \times .55, .66 \times .5 \mathrm{I}, .70 \times .56$. (Figs. 67,68 .)

Nesting Dates.-Charleston, S. C., April 2-a second brood late in May. (Wayne) ; Raleigh, N. C., April 22-May 26 (C.W. C.).

\section{BIOGRAPHICAL REFERENCES}

(I) WM. BREWSTER, The Yellow-throated Warbler (in Georgia), Bull. Nutt. Orn. Club, II, 1877, ro2. (2) A. T. WAyne, Nesting of the Yellowthroated Warbler (in So. Car.), Orn. and Oöl., XII, I887, I69; XIII, I888, I6r. (3) R. B. M'Laughlin, Nesting of the Yellow-throated Warbler (in Nor. Car.), Orn. and Oöl., XII, I887, I71. (4) C. S. Brimley, Nesting of the Yellow-throated Warbler, at Raleigh, N. C., Orn. and Oöl., XIV, 1889, 15I; Auk, VII, 18go, 323. 


\section{SYCAMORE WARBLER}

DENDROICA DOMINICA ALBILORA RIdgw.

Subspecific Characters.-Similar to Dendroica $d$. dominica but bill smaller, line from above eye to bill generally white or but slightly tinged with yellow, never strongly yellow as in dominica; white patches on tail-feathers averaging larger. Wing, 2.60 ; tail, $1.95 ;$ bill, .45.

General Distribution.-Mississippi Valley.

Summer Range.-From the Gulf of Mexico north to Ohio (Cleveland, Mt. Vernon, Rockport), southern Michigan (Detroit, Petersburg), and southern Wisconsin (Racine, Lake Koshkonong); west to southeastern Nebraska (Nemaha River), and eastern Kansas (Neosho Falls); east through the Alleghenies to western South Carolina.

Winter Range.-Southern Mexico to Costa Rica.

Spring Migration.-At New Orleans the Sycamore Warbler is one of the earliest spring migrants. Dates of arrival are March II, I894, March 9, 1895, March 7, 1896, and March 12, 1898. At Helena, Ark., the first arrivals were noted on April I4, I895, and April I0, I897; at St. Louis, April 4, I884. April 6, I885, April 12, I886, April Io, I887, and April I3, I888; in central Indiana about the middle of April; in southern Michigan about April 20. A migrant was noted at Soto del Marina, Tamaulipas, March I, 1902.

Fall Migration.-In the fall the Mississippi Valley form is, like the eastern, an early migrant, being one of the first birds to return in autumn to the Rio Grande of Texas. It is recorded as arriving at Orizaba, Mexico, August Io; Chiapas, Mexico, August I3; Colima, Mexico, in August; Dueñas, Guatemala, by the middle of August; Bonacca Island, Honduras, and Truxillo, on the mainland, in September; and at San Jose, Costa Rica, October 4. In the northern part of its range it lingers somewhat later than the eastern form. The last to pass southward do not leave Indiana and Missouri until well into October.

The Bird and its Haunts.-This slightly differentiated Mississippi Valley form of the Yellow-throated Warbler resembles the Atlantic Coast bird in habits. In the Galveston region of Texas, Nehrling states that it is a rare summer resident in the high moss-grown forest trees of the river bottoms. Allison writes that in southern Louisiana, "it has a strong liking for woods shrouded in heavy festoons of Spanish moss, and, therefore, keeps much to the cypress swamps; but it is common in the less damp woods in the same regions; on the northern shores of Lake Pontchartrain it spreads slightly from the cypress swamp into the pines. It is essentially a bird of the larger trees, and swampy forest may be considered its typical habitat." (Allison, MS.) 
In Illinois, Ridgway" states "the Sycamore Warbler is a common summer resident in the bottom lands, where, according to the writer's experience, it lives chiefly in the large sycamore trees along or near water courses," and Butler ${ }^{2}$ in Indiana finds it in similar localities.

Song.- "The call-note is a rather lively chipping, like that of an agitated Parula Warbler, or perhaps somewhat more like that of Pine Warbler. The song is like the Indigo Bunting's, much softened, and and with a falling cadence all the way through; thus: See-wee, seewee, see-wee, swee, swee, swee, swee, - the last four notes uttered more rapidly, but becoming fainter, until the last one is very indistinct." (Allison, MS.)

Nesting Site._- "In a fork far out on a high limb, usually in a sycamore." (Butler ${ }^{2}$ ).

Eggs.-Not distinguishable from the eggs of the preceding.

\section{Biographical RefERENCES}

(I) R. Ridgway, Birds of Illinois, I50. (2) A. W. Butler, Birds of Indiana, I065.

\section{GRACE'S WARBLER \\ DENDROICA GRACIÆ GRACI}

Distinguishing Characters.-At all seasons adults and young may be known by their yellow throat, gray auriculars, and bluish gray or brownish gray back. The resemblance to $D$. dominica is striking but the lack of black in the cheeks and its ustal presence in the back, of adults, at least, the yellow, instead of white mark below the eye, etc. are distinguishing marks of gracic. Length (skin), 4.50; wing, 2.55; tail, 2.00 ; bill, .38.

Adult d, Spring.-Above bluish gray, crown with black spots which form a stripe along its sides, lores dusky, spot below eye yellow; broad line from bill to above eye yellow terminating in white just behind the eye; center of back usually spotted with black; tail black edged with gray; two outer tailfeathers largely white the outer webs usually white except at tip and base, third feather spotted with white on inner web near tip; wings margined with gray, the greater and median coverts tipped with white forming two conspicuous bars; throat and breast yellow sharply defined from the white underparts; sides streaked with black.

Adult d, Fall.-Similar to adult $\delta$ in Spring but upperparts washed with brown, the black marks of crown, back, and sides obscured.

Young $\delta^{A}$, Fall.-Similar to adult $\delta^{*}$ in Fall but browner above and on sides and belly, little or no black in back, less on crown and sides.

Adult +, Spring.-Similar to adult $d$ in Spring but browner above, few or no streaks in back; crown and sides with less black; yellow duller.

Adult $q$, Fall.-Similar to adult $q$ in Spring but browner above, black markings more or less concealed by brownish tips. Not certainly distinguishable from adult $\sigma$ in Fall.

Young \&, Fall.-Resembling young $d$ in Fall. 
Nestling.-Above dusky grayish brown with an olive tint; below grayish or white the breast, and even belly and sides spotted with blackish; wingcoverts blackish or grayish, conspicuously tipped with whitish.

General Distribution.-Southwestern United States and northwestern Mexico.

Summer Range.-Breeds in northern Mexico and in the mountains of New Mexico and Arizona, north to Colorado (La Plata County); accidental in north central Colorado (Loveland, April 25, 1889), and in California (Santa Paula, Ventura Co., May 3, r881).

Winter Range.-Northern Mexico.

Spring Migration.-Arrivals have been noted in Arizona as follows: Fort Whipple, April 24, 1865, Pima Co., April 22, 1885, Huachuca Mountains, April 27, 1902, April 12, 1903.

The Bird and its Haunts.-If the spring or summer visitor to the Grand Cañon will explore the neighboring yellow pine forests he will find Grace's Warbler a not uncommon inhabitant of tree-tops, so high that no small amount of looking will be required to complete a satisfactory identification.

Discovered by Dr. Coues on the summit of Whipple's Pass, New Mexico, July 2, I864, and named by him for his sister, Grace's Warbler is now known as a common summer resident of the pine forests of Arizona, and New Mexico and southward into Mexico. Its nest was not discovered, however, until I890, when H. H. Keays, as recorded by Ladd, found it breeding in Yavapai Co., Arizona.

Grace's Warbler has several relatives so near that they are doubtless geographical representatives whose distribution seems to throw some light on the tropical (particularly West Indian) origin and subsequent northern dispersal of the Mniotiltidæ. To the southward it is replaced by the slightly differentiated $D . g$. decora, which reaches Honduras, in the east Dendroica dominica is its probable representative, while in Porto Rico and St. Lucia it finds surprisingly near allies in Dendroica adelaide and Dendroica delicata, respectively.

Song.- "Its song is a sweet warble, frequently uttered from the lower pine boughs." (Mearns).

Nesting Site.-A nest found by H. Keays in Yavapai County, Arizona, was placed on a limb of a pine sixty feet up. Two nests recorded by Howard ${ }^{2}$ were placed respectively in a pine and in a red fir at the extremity of a limb some fifty feet up.

Nest.-Keays' nest is described by Ladd" as "very compact; outside diameter 3 inches by I I-2 inches high; inside diameter 1 3-4 inches by I I-4 inches deep. The body of this nest is composed of horse-hair strings and vegetable fibers. The most abundant vegetable 
material interwoven consists of the staminate catkins and bud scales of Quercus emoryi. There is also some wool, vegetable down, and insect webbing, in which there are entangled the exuvix of some caterpillar. Attached to the outside was a small staminate cone of some species of Pinus. Nest well lined with feathers and horse-hair."

Eggs.-A set of three eggs is Jescribed by Ladd" as "ground color creamy white, marked over entire surface, but more heavily at larger end, where they form a wreath, with light umber and occasional specks of dark chestnut; lilac shell-markings at large end only." Size ; .5 Ix.70, .50x.69, .50x.68.

Nesting Dates.-Yavapai Co., Arizona, June 23 (Ladd).

\section{BIOGRAPHICAL REFERENCES}

(I) S. B. LADD, Description of Nest and Eggs of Dendroica gracie, Auk, VIII, I89I, 3I4. (2) O. W. HoWARd, Summer Resident Warblers of Arizona, Bull. Cooper Orn. Club (=Condor), I, 1899, 39.

\section{Chestnut-sided WARBLeR DENDROICA PENSYlVANICA (Linn.) Plate XII}

Distinguishing Characters.-Adults of both sexes may be known by their chestnut sides, yellowish wing-bars, yellow or yellowish crowns, the wholly different young by bright greenish yellow upperparts, yellow wing-bars, white eye-ring, grayish cheeks and underparts. Length (skin), 4.50; wing, 2.50; tail, I.95; bill, .35.

Adult d", Spring.-Crown yellow, forehead white; back greenish yellow broadly streaked with black, the nape grayish; tail black margined with gray the three outer feathers with white patches at the end of the inner web; primaries margined with grayish, inner flight-feathers with yellowish, median coverts tipped, greater coverts tipped and margined with yellowish; ear-coverts and sides of neck white enclosed by a black post-ocular stripe and black patch below the eye and on the side of the throat, from the latter springs a bright chestnut stripe which, broadening, passes along the sides to the flank, rest of underparts white.

Adult $\delta$, Fall.-Above bright greenish yellow indistinctly streaked on back and rump; tail and wings as in Spring $\delta$, whole side of head gray, eye-ring white; the sides and flanks chestnut, rest of underparts white.

Young $\delta$, Fall.-Similar to adult $\delta$ in Fall but with less, or no chestnut on sides.

Adult q, Spring.-Similar to adult $o^{A}$ in Spring but duller, black areas less pronounced, tail and wings browner, chestnut stripes less developed.

Adult + , Fall.-Similar to young of in Fall.

Young $q$, Fall.-Similar to adult $q$ in Fall but always without chestnut on sides.

Nestling.-Above brown indistinctly streaked with black; below pale brownish, the belly white; wings and tail as in young, the coverts tipped with buffy.

General Distribution.-Eastern North America; north to Newfoundland and the Saskatchewan; west to the Plains. 
Summer Range.-One of the commonest breeding Warblers in New England, New York, Pennsylvania and south in the mountains to South Carolina. Outside of the mountains it breeds south to southern New Jersey (Sea Isle City), northern Ohio, Indiana (La Porte Co.), Iowa (Mahaska Co.), and to eastern Nebraska (Omaha); casual in summer in Missouri (St. Louis and Munger), and southern Illinois (Fox Prairie, Richland Co.) ; accidental in Wyoming (Cheyenne, May 23, I889); breeds north to Newfoundland, Ontario and the Saskatchewan.

Winter Range.-Guatemala to Panama.

Migration.-The Chestnut-sided Warbler passes through eastern Mexico and the Gulf States from northwestern Florida to eastern Texas. It is casual in southern Florida and the Bahamas.

Spring Migration.-

\begin{tabular}{|c|c|c|c|}
\hline PLACE & $\begin{array}{l}\text { No. of } \\
\text { yenrs' } \\
\text { record }\end{array}$ & $\begin{array}{l}\text { Average đate of } \\
\text { spring artival }\end{array}$ & $\begin{array}{l}\text { Eiarliest date of } \\
\text { spring arrival }\end{array}$ \\
\hline \multicolumn{4}{|l|}{ Atlantic Coast- } \\
\hline 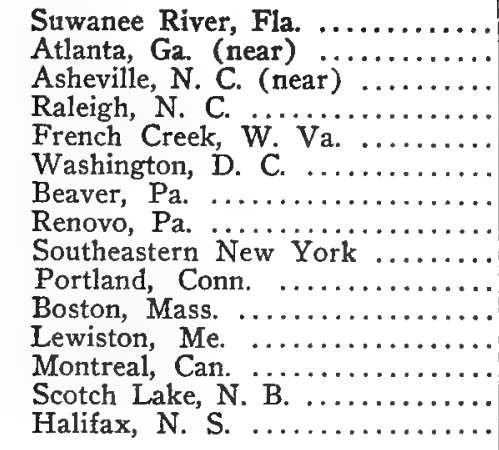 & $\begin{array}{r}8 \\
3 \\
2 \\
5 \\
5 \\
5 \\
9 \\
14 \\
6 \\
14 \\
8 \\
6 \\
6\end{array}$ & $\begin{array}{lr}\text { April } & 28 \\
\text { April } & 26 \\
\text { April } & 28 \\
\text { May } & 2 \\
\text { May } & 3 \\
\text { May } & 2 \\
\text { May } & 3 \\
\text { May } & 6 \\
\text { May } & 7 \\
\text { May } & 6 \\
\text { May } & 12 \\
\text { May } & 17 \\
\text { May } & 23\end{array}$ & $\begin{array}{lr}\text { April } 10,1892 \\
\text { April } 17,1896 \\
\text { April } 22,1902 \\
\text { April } 27,1886 \\
\text { April } 30,1890 \\
\text { April } 24,1905 \\
\text { May } 1,1902 \\
\text { April } 30,1901 \\
\text { May } 2,1899 \\
\text { May } & 4,1887 \\
\text { May } & 2,1897 \\
\text { May } & 7,1899 \\
\text { May } & 11,1889 \\
\text { May } & 18,1897 \\
\text { May } 24, & 2895\end{array}$ \\
\hline \multicolumn{4}{|l|}{ Mississippi Valley- } \\
\hline 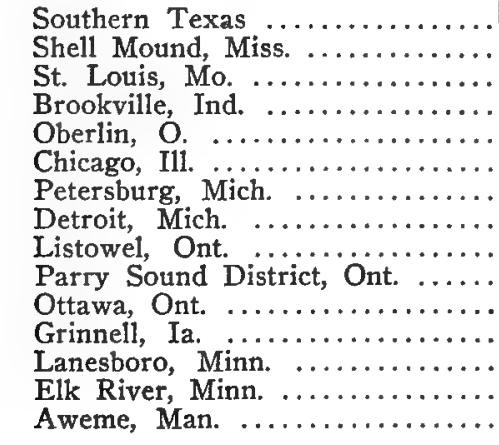 & $\begin{array}{r}3 \\
6 \\
4 \\
9 \\
6 \\
10 \\
9 \\
13 \\
13 \\
18 \\
5 \\
9 \\
7 \\
4\end{array}$ & $\begin{array}{lr}\text { April } & 20 \\
\text { May } & 3 \\
\text { May } & 4 \\
\text { May } & 4 \\
\text { May } & 6 \\
\text { May } & 6 \\
\text { May } & 6 \\
\text { May } & 6 \\
\text { May } & 11 \\
\text { May } & 14 \\
\text { May } & 5 \\
\text { May } & 9 \\
\text { May } & 14 \\
\text { May } & 20\end{array}$ & $\begin{array}{lr}\text { April } 17,1890 \\
\text { April } 15,1892 \\
\text { April } 27,1883 \\
\text { May } 2,1881 \\
\text { May } & 2,1900 \\
\text { May } 2,1896 \\
\text { April } 28,1889 \\
\text { April } 29,1897 \\
\text { May } 2,1900 \\
\text { May } & 8,1889 \\
\text { May } & 6,1905 \\
\text { May } & 1,1887 \\
\text { May } & 4,1890 \\
\text { May } & 7,1887 \\
\text { May } 18,1897\end{array}$ \\
\hline
\end{tabular}




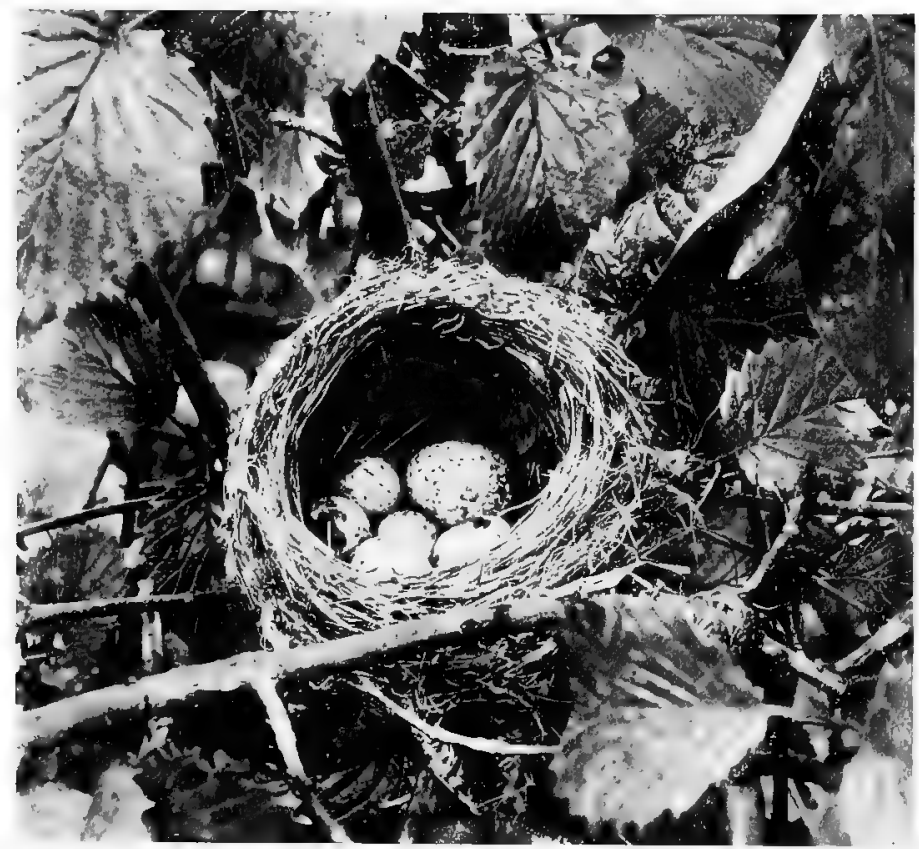

NFST AND FIVF EGGS OF TITE YELLOW WIRTI,TR, WITIT ONF FGG OF TIIF COWIBIR. Photographed by ALBERT Momtis, at Wethersfield, Conn.

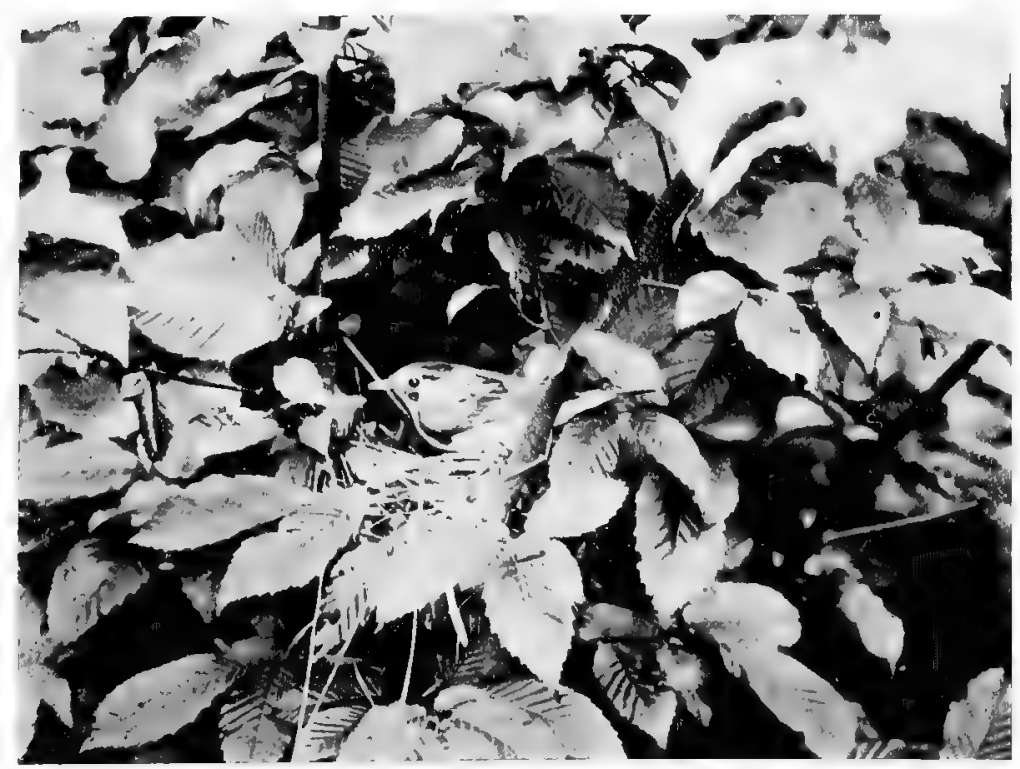

CHESTNU'T.SIDED WARBLER AND NEST.

Pliotographed by Alber? Morgan, at Wetliersfield, Conn. 


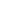


Fall Migration.-

\begin{tabular}{|c|c|c|c|}
\hline PLACE & $\left|\begin{array}{l}\text { No. of } \\
\text { years' } \\
\text { record }\end{array}\right|$ & $\begin{array}{l}\text { Average date of } \\
\text { last one seen }\end{array}$ & $\begin{array}{l}\text { L,atest date of } \\
\text { last one seen }\end{array}$ \\
\hline 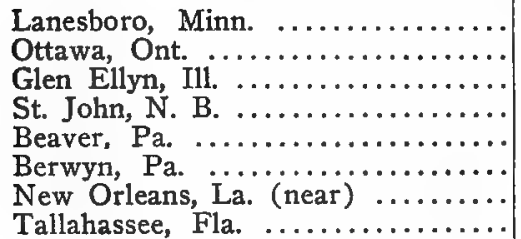 & $\begin{array}{l}4 \\
5 \\
6\end{array}$ & $\begin{array}{l}\text { September } 8 \\
\text { August } 23 \\
\text { September } 19 \\
\text { September } 23\end{array}$ & $\begin{array}{l}\text { September 15, 1889 } \\
\text { September 12, } 1885 \\
\text { September 26, } 1895 \\
\text { September 10, I895 } \\
\text { October I, I890 } \\
\text { October 8, I891 } \\
\text { October 10, I896 } \\
\text { October I3, 1904 }\end{array}$ \\
\hline
\end{tabular}

The Bird and its Haunts.-The regret occasioned by the decrease in the numbers of wood-inhabiting birds following the destruction of the forests in which they lived, is in a measure tempered by a knowledge of the fact that their places will be filled by other species. The Chestnut-sided Warbler, for example, considered by Wilson and Audubon to be a rare species, is now abundant, and we may believe that this change in numbers is due largely to the development of those scrub and second growths in which the bird delights.

In my own experience, covering the past twenty-five years, at Englewood, N. J., I have seen this Warbler become established as an increasingly common summer resident, and at East Orange, in the same state, Dugmore ${ }^{6}$ writes "What has been most noticeable about the bird-life of this particular locality is the rapid and steady increase of the Chestnut-sided Warbler." In the summer of 1897 , he adds, he did not observe a single specimen but in Igoo they had become comparatively common.

About Cambridge, Mass., Brewster ${ }^{\beta}$, quoting Dr. Samuel Cabot, says that this species was very rare in eastern Massachusetts prior to 1835 , but that it gradually and steadily increased in numbers after that date. Brewster adds "they nest chiefly on the edges of upland woods, in neglected fields and pastures, along the courses of brooks, and on country roadsides. In general terms they may be said to occupy most of the country which the Yellow Warblers avoid, but in a few localities the two species breed together in the same thickets. Both birds, as a rule, shun evergreen trees, although the Chestnutsided Warbler occasionally frequents white pine woods in late summer, especially when it is consorting in 'mixed flocks' with such pineloving species as the Chickadee and the Black-throated Green Warbler."

Gerald Thayer writes that the Chestnut-sided is "an abundant roadside and brush-land Warbler throughout the Monadnock region, but on the mountain itself is not common above 2,000 feet, or there- 
abouts. Its 'beat' lies between the ground and the tops of small deciduous trees. The few nests I have seen have all been between two and five feet from the ground, in bushes. The adults' peculiar markings and droop-winged, perk-tailed, and deep-chested attitudes are too well known to bear dwelling on here. Though potentially quick moving, the Chestnut-side is by no means restless, as Warblers go,often spending many minutes at a time in one small tree,-and it is one of the tamest of the tame." (Thayer, MS ).

Herrick's ${ }^{7}$ detailed studies of the nesting habits of the Chestnut-side show how little we know as yet of the more intimate, personal side of the home-life of Warblers.

Song.- "The Chestnut-side, a full-voiced Warbler, has at least two main songs, both of which, but particularly the more liquid and less articulate one, are subject to wide variation. Both types of song are too liquid to be well suggested by English syllables, except for the clearly enunciated ending of one of them,-wee-chew. Twit-a-wit-a-wit-a-wit-wee-chew! is something like the phrasing of the whole of this song, except that it fails to express the soft fluency of the first part. The other song is an elaboration of this initial rolling warble, with the wee-chew left off. Hardly any two Chestnutsides sing this inarticulate song alike, and almost every individual plays noticeable variations on his own version of it. In addition to all this, the Chestnut-side is a mocker. One we used to hear, that regularly began his wee-chew song with a loud, long, rattling trill, almost indistinguishable from the more fluent song of the Sparrow; and another, that lived near Catbirds, used several unmistakable notes of Catbird song. One of the Chestnut-side's two or three or more small call-notes is characteristic,--the others scantily so, if at all." (Thayer, MS.)

Miss Paddock writes that the first two of the songs given below are usual. They are uttered with much energy and decided accent. The last two songs are more like the Redstart's but are without accent, and sound as if sung with closed mouth.

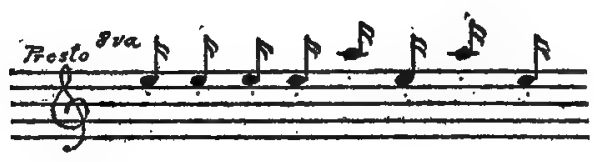



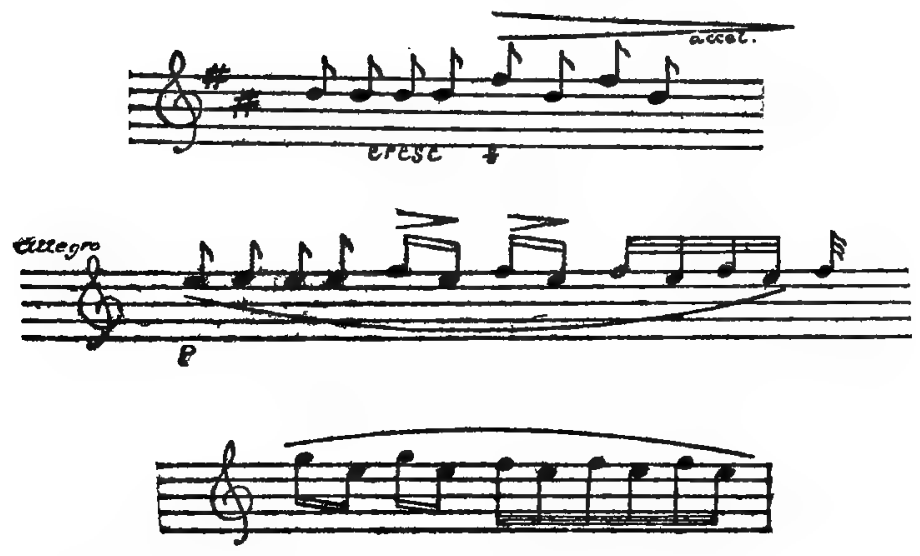

Nesting-Site.-Throughout its range this species appears to nest in low bushes, saplings or briers, at from one to six, but usually about two feet from the ground.

Nest.-The nest is externally rather roughly maje of coarse grasses, strippings of weed-stalks, plant fibers, bunches of spiders' webbing, and some plant down, finely and thickly lined with brown rootlets, grasses and horse-hair.

Eggs.-4 or 5, usually 4, rarely 5. Ground color white to creamy white, beautifully marked, in most cases, with chestnut, varying shades of brown, lavender, and purplish brown and blackish, either in the form of a wreath or a conglomerate mass of spots on large end there being very few scattering spots over rest of egg. Some specimens of the egg of this species closely approach many eggs of the Yellow, Magnolia, Myrtle, and Prairie Warblers. Size; average .66x.49; extremes measure .6IX.47, .7 Ix.5I, .66x.46 and .69x.52. (Figs. 57-59.)

Nesting Dates.-New York City, May 29-two broods, one day from nest. (F.M.C.); New Haven, Conn., May 23-July 22, young just out of nest. (Bishop); Cambridge, Mass., full sets, first laying, May 26-June 5 (Brewster); Lancaster, N. H., May 26-June 6 (C. W. C.) ; Bangor, Me., June 4-July 4 (Knight) ; Listowel, Ont., May 21-June I8 (Kells); Ann Arbor, Mich., May 20 (Wood).

\section{BiograpHICAL REFERENCES}

(I) W. L. KeLls, Nesting of the Chestnut-sided Warbler, (in Ontario), Oölogist, IV, I887, II; Ottawa Naturalist, XV, 1902, 225. (2) CHardes L. Phincrps, The Chestnut-sided Warbler (at Taunton, Mass.), Oölogist, IX, I892, 165. (3) Morris GiBBS, Nesting Habits of the Chestnut-sided Warbler (in Mich.), Oölogist, XI, I894, 33I. (4) L. M. TerRILl, Summer Warblers in 
Compton County, Quebec, Ottawa Naturalist, XVIII, 1904, I52. (5) A. R. Dugmore, The Increase of the Chestnut-sided Warbler, Bird-Lore, IV, 1902, 77. (6) WM. BREWSTER, Birds of the Cambridge Region, 336. (7) F. H. HERRICK, Home Life of Wild Birds, Rev. Ed., 1905, I89, 222, 236 ,240.

\section{BAY-BREASTED WARBLER}

\section{DENDROICA CASTANEA (Wils.) Plate XII}

Distinguishing Characters. - The adult $\delta^{A}$ in Spring may be known by its chestnut crown, breast, and sides, black face, and buffy spot at the side of the neck; the adult $q$ in Spring by more or less chestnut in crown, on breast, and sides, a grayish back streaked with black. Fall adults show more or less chestnut on the sides but young of both sexes are singularly like the young of Dendroica striata, which see. Length (skin), 5.00; wing, 2.90; tail, 2.10; bill .40 .

Adult o", Spring.-Crown chestnut, forehead, lores, and cheeks black, a large buffy space on the side of the neck sometimes spreading to the nape; back grayish buff streaked with black; rump grayer; tail margined with gray, the outer two to three feathers with white patches at the end of the inner web; wings margined with olive-gray; the greater and median coverts broadly tipped with white; throat, upper breast, and sides chestnut; rest of underparts buffy white.

Adult o', Fall.-Upperparts olive-green more or less streaked with black, the crown usually with some concealed chestnut; tail and wings as in Spring but coverts tinged with yellowish; underparts whitish the throat tinged with yellowish, the breast, belly, and under tail-coverts with buffy; sides with more or less chestnut.

Young $\delta^{*}$, Fall.-Similar to adult od in Fall but with no chestnut in crown, upperparts less streaked, little or no chestnut on sides; buff suffusion weaker.

Adult + , Spring.-Similar to adult $\delta^{*}$ in Spring but chestnut of crown mixed with black; forehead and cheeks gray and black; chestnut on throat and sides much fainter or appearing in patches only.

Adult , Fall.-Resembling adult $\delta^{*}$ in Fall.

Young $\$$, Fall.-Resembling young $\delta$ in Fall, but without trace of chestnut.

Nestling.-Above grayish olive, the head sometimes paler, nearly buffy, back heavily spotted with wedge-shaped black marks; below whitish thickly spotted with rounded black marks; median wing-coverts broadly tipped with white or buffy white on both webs, the greater coverts, on only the outer web.

General Distribution.-Eastern North America; north to Newfoundland and Hudson Bay; west to a little beyond the Mississippi River.

Summer Range.-Northern New England; New Hampshire (White Mountains, Lake Umbagog), Maine (Franklin, Penobscot, and Washington Counties), northern Ontario and, probably, northern Minnesota, north to Newfoundland, Hudson Bay and Saskatchewan.

Winter Range.-Panama and Colombia.

Spring Migration.-On the way to its summer home, the bird 
shuns Mexico, the West Indies, and the United States south of Virginia, east of the Allegheny Mountains; the great bulk passes north through the Mississippi Valley, west to eastern Texas (Corpus Christi, Port Bolivar), Missouri (Freistatt), and Iowa (Grinnell); casual or accidental in South Dakota (May I888), Montana (Big Sandy, May 24, 1903), and Alberta (Medicine Hat).

Spring Migration.-

\begin{tabular}{|c|c|c|c|}
\hline PLACE & $\begin{array}{l}\text { No. of } \\
\text { years' } \\
\text { record }\end{array}$ & $\begin{array}{l}\text { Average date of } \\
\text { spring arrival }\end{array}$ & $\begin{array}{l}\text { Farliest date of } \\
\text { spring arrival }\end{array}$ \\
\hline \multicolumn{4}{|l|}{ Atlantic Coast- } \\
\hline 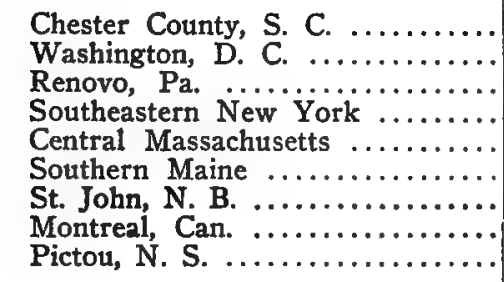 & $\begin{array}{l}\mathbf{5} \\
6 \\
5 \\
9 \\
6 \\
6 \\
\mathbf{3}\end{array}$ & $\begin{array}{l}\text { May I2 } \\
\text { May } 13 \\
\text { May } 8 \\
\text { May I6 } \\
\text { May I8 } \\
\text { May } 21 \\
\text { May } 23\end{array}$ & $\begin{array}{l}\text { May } 5,1888 \\
\text { May } 9,1903 \\
\text { May } 11,1897 \\
\text { May } 3,1899 \\
\text { May } 8,1895 \\
\text { May } 15,1889 \\
\text { May } 19,1891 \\
\text { May } 23,1895\end{array}$ \\
\hline \multicolumn{4}{|l|}{ Mississippi Valley- } \\
\hline 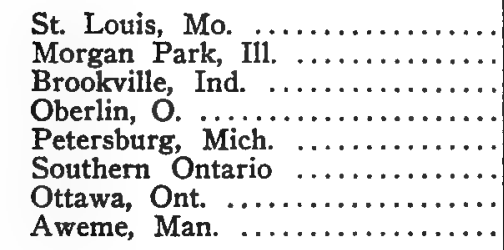 & $\begin{array}{r}4 \\
5 \\
3 \\
7 \\
6 \\
12 \\
16 \\
3\end{array}$ & $\begin{array}{lr}\text { May } & 7 \\
\text { May } & 5 \\
\text { May } & 8 \\
\text { May } & 8 \\
\text { May I3 } \\
\text { May I2 } \\
\text { May I7 } \\
\text { May } 16\end{array}$ & $\begin{array}{lr}\text { May } & 3,1883 \\
\text { May } & 2,1900 \\
\text { May } 2,1884 \\
\text { May } 4,1902 \\
\text { May } 10,1893 \\
\text { May } 6,1889 \\
\text { May } 11,1886 \\
\text { May } 13,1899\end{array}$ \\
\hline
\end{tabular}

Fall Migration.-

\begin{tabular}{|c|c|c|c|}
\hline PL,ACE & $\begin{array}{l}\overline{\text { No. of }} \\
\text { years' } \\
\text { record }\end{array}$ & $\begin{array}{l}\text { Average date of } \\
\text { last one seen }\end{array}$ & $\begin{array}{l}\text { Iatest date of } \\
\text { last one sten }\end{array}$ \\
\hline 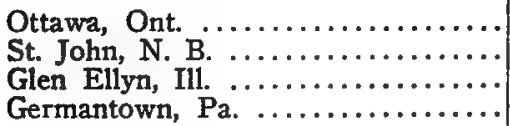 & $\begin{array}{l}3 \\
7 \\
3\end{array}$ & $\begin{array}{l}\text { September } 8 \\
\text { September } 18 \\
\text { September } 28\end{array}$ & $\begin{array}{l}\text { September I6, } 1888 \\
\text { September I, I890 } \\
\text { October 4, } 1897 \\
\text { October 19, } 1885\end{array}$ \\
\hline
\end{tabular}

The Bird and its Haunts.-Although close observation will reveal the presence of Bay-breasts during both the spring and fall migrations, they are generally to be classed among the rarer Warblers the mere sight of which is stimulating. Occasionally, however, the weather so affects their migration that they come en masse and for a brief period are actually abundant. On the morning of May 27, 1872, 
Brewster ${ }^{2}$ saw "upwards of forty" Bay-breasts near Cambridge, Mass. Usually, however, he remarks, they "occur singly and in dense woods, especially such as consist largely of white pines, hemlocks or other coniferous trees."

"The southward flight of Bay-breasts," this author continues, "sometimes begins as early as August 23 and usually lasts nearly through September. At this season the birds are given to frequenting gray birches and dense, swampy maple woods and are nearly always found in company with Blackpoll Warblers."

The Bay-breast, Gerald Thayer writes, is "often common at Monadnock in the spring migration, and may possibly breed here. Apparently it is never common in the fall. It associates often with Blackpolls, in loose bands, which drift through the scrub-lands and forest-borders like bands of Titmice. But the Bay-breasts usually leave Monadnock for the north at least a week before the Blackpolls.

"Bay-breasts and Blackpolls alike are rather big and rather duskily-adorned Warblers, and both have an almost vireo-like leisureliness of movement. Adult male Bay-breasts in life are apt to look very dark; - heavily clouded with deep brown and gray, relieved by a conspicuously bright, big, white-buff spot on each side of the fore-neck. Females look much like female Blackpolls, but are grayer-less green -and usually show some blurred pale chestnut flecks on their sides. The call-notes of these two twin-like species (Bay-breast and Blackpoll) I have never learned to tell apart. They are fine and sharp, but sometimes louder than the average Dendroicine tsipping." (Thayer $M S$.)

About Umbagog, where it breeds, Maynard ${ }^{1}$ found the Baybreast the most abundant Warbler. It inhabited all the wooded sections and frequented the tops of tall trees.

Song.- "Heard from migrants the Bay-breast's song is a poor, weak, monotonous saw-filing note" (Farwell, MS.)

Widmann records the full song at St. Louis, on September 26, I897.

"In a grouping based on songs, the Bay-breast should stand in a quintette with the Blackburnian, the Blackpoll, the Black and White and the Cape May. These five heard singing together in the same trees, as I have heard them on the Hudson River, make "confusion worse than death' for any bird-student but the most adept. But with patience and a good ear one can learn to differentiate them surely. All five are thin-voiced, 'sibilant', singers; but each has its own slight, prevailing peculiarity of tone, in addition to the differences, varied 
but never wholly violated, of phrasing and accentuation. The Baybreast's singing, in the spring at least, is the most liquid and inarticulate of the lot, and sometimes the loudest. It varies greatly, from the bases of at least two and probably three clearly distinct main songs. In one of these, the six or more barely-separated lisping notes are all alike in volume, accentuation, tone, and speed. They are slightly louder than the average Blackpoll notes, and not quite so smooth in tone. Another song begins in about the same way, but ends with three or four clearly-separated louder notes, which have a more nearly full-voiced ring. A third, uncommon, song, which I have all but surely traced to the Bay-breast, is louder throughout, and otherwise very different. It begins with about ten penetrating notes, in close-knit couplets like those of the Black and White's shorter song, and of much the same tone, but louder; and it ends, abruptly, with a single, lower-toned, much richer note, like a fragment of Oven-bird song." (Thayer, MS.)

Nesting Site.-Nests recorded by Maynard ${ }^{1}$ were placed on the horizontal branch of a hemlock fifteen and twenty feet from the ground and five or six feet from the trunk of the tree.

Nest.-The nest of the Bay-breasted Warbler is characterized by large size, and the irregularity of outline given to it by the long coniferous twigs which compose its exterior.

Maynard describes a nest as "composed outwardly of fine dead twigs, from the larch, among which are scattered a little of the long tree-moss. It is very smoothly and neatly lined with black, fibrous roots, the seed-stalks of a species of ground moss, a few hairs of Lepus americana, and a single piece of green moss that grows in damp woods."

Eggs.-Doubtless usually 4. Maynard ${ }^{1}$ describes one of a set of three eggs as "bluish green, thickly spotted with brown over the entire surface, with a ring of nearly confluent blotches of brown and lilac at the larger end." A second egg is similar but has some amber spots in the ring around the larger end and, the smaller end is immaculate. The third egg "is less spotted than the others, and has a few brown lines on the larger end." These eggs measure .7Ix.53, .65x.50, .70x.50. (Figs. 60,6I Childs Coll.)

Nesting Dates.-Bangor, Me., June I5, one egg, very rare. (Knight); Listowel, Ont., June 9-June 14. (Kells).

Biographical ReFERENCES

(I) C. J. Maynard, Birds of Coos County, N. H., and Oxford County, Me., Proc. Bost. Soc. Nat. Hist., XIV, 1871, 364. (2) WM. BREWSTER, Birds of the Cambridge Region, 338. 


\title{
BLACKPOLL WARBLER
}

\author{
DENDROICA STRIATA (Forst.) Plate II
}

Distinguishing Characters. -The adult $\delta$ in Spring may be known by its black crown, white cheeks, and gray, black-striped back; the adult $q$ in Spring, by the grayish olive, black streaked upperparts, white or yellow-tinged underparts with black streaks on the sides; Fall birds of all ages and sexes are olive-green above, indistinctly streaked; the wing-bars are white; the underparts greenish yellow obscurely streaked. Specimens in this plumage are curiously like the young of Dendroica castanea and the two cannot certainly be distinguished in nature. The differences between the two are as follows: the upperparts in striata are duller and more streaked, the wings are edged with a yellowgreen in place of gray-green; the underparts are yellowish instead of buffy and are more or less streaked; the under tail-coverts are white instead of buffy; the feet and legs in striata are paler. Some specimens of castanea, however, are to be distinguished from striata only by a slight suffusion of buff on the flanks and under tail-coverts. Length (skin), 5.00; wing, 2.90; tail, 2.05; bill, .40.

Adult 6, Spring.-Crown black, back gray, whitish on the nape, streaked with black; tail blackish edged with gray, two to three outer feathers with white patches at the end of the inner web; wings edged with greenish, the coverts tipped with white forming two wing-bars, the tertials margined with white; cheeks white; underparts white, the sides from base of bill to flanks, heavily streaked with black.

Adult d*, Fall.-Wholly unlike o in Spring, no black cap; upperparts olive-green more or less streaked with black; feathers of crown with black centers; tail as in Spring but slightly browner; wings and their coverts edged with greenish, coverts tipped with white more or less tinged with yellow; underparts washed with yellowish the belly whiter, the sides with more or less concealed black stripes.

Young d, Fall.-Similar to adult $\sigma^{*}$ in Fall and not certainly distinguishable from it in life; crown feathers without pronounced black centers, sides streaked with dusky.

Adult 9, Spring.-Upperparts grayish olive-green streaked with black from bill to rump; a faint grayish nuchal band; tail much as in ${ }^{n}$; wings edged with greenish, the greater and median coverts tipped with white or yellowish white; underparts white; breast and sides often tinged with yellow; side of throat and of breast lightly streaked with black. Resembles adult $\delta$ in Fall but is grayer above and whiter below, the black streaks everywhere better defined.

Adult and young 9 , Fall.-Resemble young $\delta$ in Fall and are not certainly distinguishable from it, but average whiter below.

Nestling.-Above grayish olive or olive-gray spotted with black, wedgeshaped shaft-marks; below whitish with rounded spots; greater and median wing-coverts blackish, median coverts subapically white on both webs, greater coverts on outer web, the white narrowly tipped with black. Resembles the nestling of $D$. castanea in conspicuous spotting of the upper, and underparts but apparently differs from it in the black tips of the wing-coverts. 
General Distribution.-Eastern North America; north to the limit of tree growth, Labrador to Alaska; west to the Rocky Mountains.

Summer Range.-Principally in Canada, but a few nest south to northern Maine (Franklin and Washington Counties), the mountains of New Hampshire, Vermont, and New York, and, probably, to northern Minnesota (Leach Lake). The southernmost breeding record is at Seven Lakes, near Manitou, Colorado, at an altitude of II,000 feet. The Blackpoll occurs sparingly in Colorado, less commonly in New Mexico (in migration) and northwest through Montana to Yukon and Alaska.

Winter Range.-Northern South America to Ecuador, Guiana and eastern Brazil.

Spring Migration.-No Blackpoll Warbler seems to spend the winter north of South America, while the southernmost breeding grounds are in northern New York and central Colorado. Therefore, no Blackpoll Warbler can have a migration route less than twenty-five hundred miles in length, and the extremes of the range-Alaska and Brazil are twice that distance apart. It is one of the very few Warblers that migrate directly across the West Indies from South America to Florida. This species is correctly considered one of the latest migrating Warblers, and is seldom seen in the Gulf states before the last week in April. It makes the trip from Florida to Maine at twice the speed of the Black and White Warbler, and the individuals that nest in Alaska travel at an average speed of not less than seventy-five miles per day.

\begin{tabular}{|c|c|c|c|}
\hline PLACE & $\left|\begin{array}{l}\text { No. of } \\
\text { years' } \\
\text { record }\end{array}\right|$ & $\begin{array}{l}\text { Average date of } \\
\text { spring arrival }\end{array}$ & $\begin{array}{l}\text { Earliest date of } \\
\text { spring arrival }\end{array}$ \\
\hline \multicolumn{4}{|l|}{ Atlantic Coast- } \\
\hline 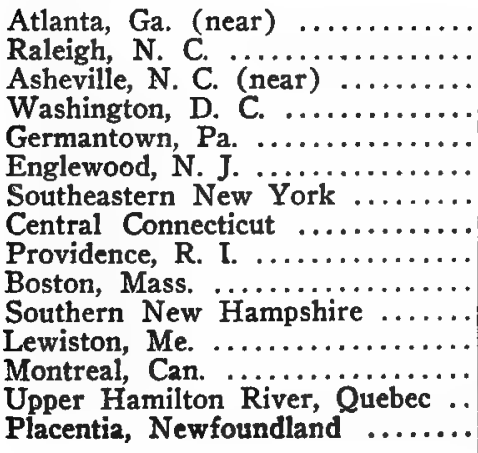 & $\begin{array}{r}6 \\
11 \\
5 \\
7 \\
6 \\
5 \\
14 \\
11 \\
6 \\
14 \\
9 \\
6\end{array}$ & $\begin{array}{lr}\text { April } & 25 \\
\text { May } & 2 \\
\text { May } & 5 \\
\text { May } & 6 \\
\text { May } & 8 \\
\text { May } & 14 \\
\text { May } & 15 \\
\text { May } & 15 \\
\text { May } & 15 \\
\text { May } & 17 \\
\text { May } & 21 \\
\text { May } & 23\end{array}$ & 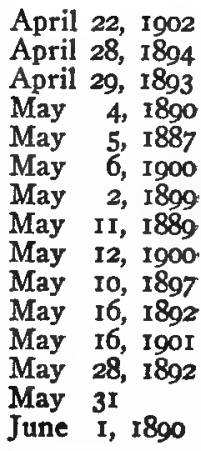 \\
\hline
\end{tabular}




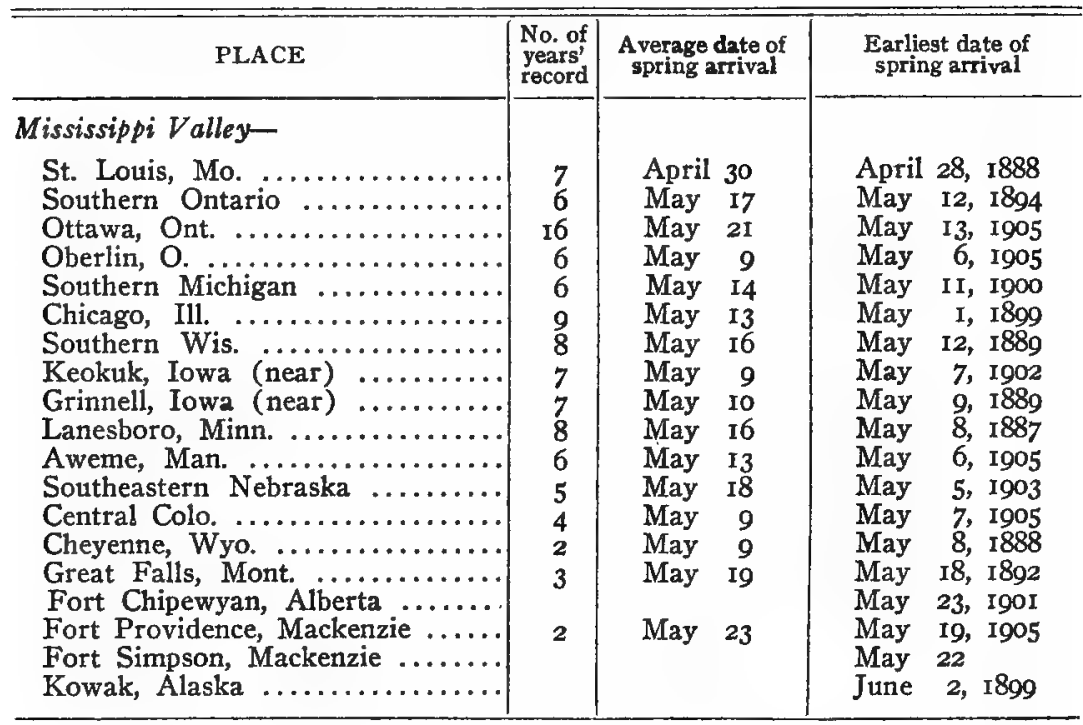

Fall Migration.-Moving northward late in the spring, the Blackpoll Warbler is almost equally late on its return. It starts south late in August and reaches northern South America the first week in October.

\begin{tabular}{|c|c|c|c|}
\hline PLACE & $\begin{array}{l}\text { No. of } \\
\text { years' } \\
\text { record }\end{array}$ & $\begin{array}{l}\text { Average date of } \\
\text { first one seen }\end{array}$ & $\begin{array}{l}\text { Earliest date of } \\
\text { first one seen }\end{array}$ \\
\hline 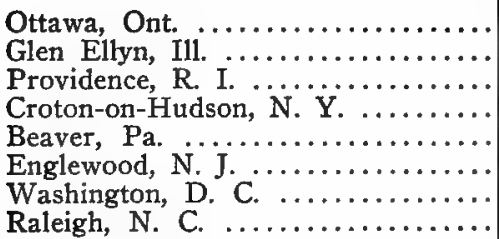 & $\begin{array}{l}7 \\
3 \\
5 \\
6 \\
3 \\
7\end{array}$ & $\begin{array}{lr}\text { September } & 3 \\
\text { September } & \text { 18 } \\
\text { September } & \text { I7 } \\
\text { September } & \mathbf{5} \\
\text { September } & \mathbf{5} \\
\text { October } 2 & \end{array}$ & $\begin{array}{l}\text { August 9, 1893 } \\
\text { August 23, 1897 } \\
\text { September 16, 1900 } \\
\text { September 12, I888 } \\
\text { August 27, 1891 } \\
\text { August 30, 1887 } \\
\text { September 1, I889 } \\
\text { September } 24\end{array}$ \\
\hline
\end{tabular}

\begin{tabular}{|c|c|c|c|}
\hline PLACE & $\begin{array}{l}\text { No. of } \\
\text { years' } \\
\text { record }\end{array}$ & $\begin{array}{l}\text { A verage date of } \\
\text { last one seen }\end{array}$ & $\begin{array}{l}\text { Latest date of } \\
\text { last one seen }\end{array}$ \\
\hline 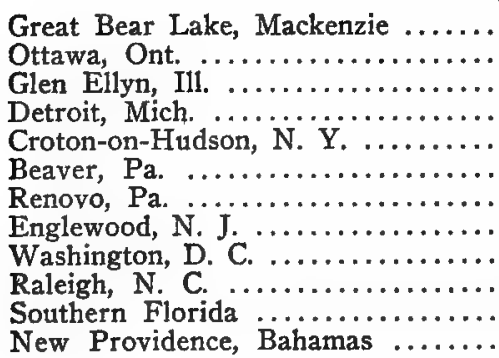 & $\begin{array}{r}3 \\
7 \\
\text { II } \\
\mathbf{3} \\
7 \\
6 \\
3\end{array}$ & $\begin{array}{l}\text { September 19 } \\
\text { September I7 } \\
\text { October 9 } \\
\text { October 12 } \\
\text { October 19 } \\
\text { October } 20 \\
\text { October } 6 \\
\text { November II }\end{array}$ & $\begin{array}{l}\text { August 29, 1904 } \\
\text { September 27, } 1889 \\
\text { September 25, } 1898 \\
\text { October 16, I904 } \\
\text { October 26, I888 } \\
\text { October 21, I900 } \\
\text { October 27, 1896 } \\
\text { October 8, 1885 } \\
\text { October 20, 1889 } \\
\text { November 5, 1886 } \\
\text { November 16, I887 } \\
\text { November 26, } 1898\end{array}$ \\
\hline
\end{tabular}


The Bird and its Haunts.-Although the Blackpoll is by no means the last Warbler to arrive in the spring it is usually the last of the transients to leave us for a more northern summer home, the length of its stay combined with its abundance, making its passage one of the most pronounced features of the vernal migration. It is as deliberate in actions as it is in traveling, a fact which may either account for or may be accounted for by its extreme fatness at this season.

In the fall the adults of both sexes take the inconspicuous plumage of the young of the year when all are the subjects of much patient scrutiny by the opera-glass student. They are, however, only to be confused with the young of the Bay-breast from which they differ as described above. Still some of the individuals of the latter are too much like the Blackpoll to be distinguished in life.

While a true Wood Warbler, the migrating Blackpoll host is so numerous that stragglers, or even whole divisions, are found far from the main army in our orchards and gardens and, in the fall, as Brewster remarks, "they are often seen flitting along fences and stone walls that traverse open country or feeding on the ground in company with various species of Sparrows, in grain stubbles and weed-infested fields."

At Monadnock, Gerald Thayer writes, the Blackpoll is abundant in the fall and common in the spring, when "it is most dilatory of all the late lingering migrants, staying sometimes till near the middle of June, not only in the spruce and tamarack swamps about the mountain, but even in the big street elm trees of the town of Keene, in the neighboring low valley country ( 500 feet). While it lives in these elms, it is a most persistent singer." (Thayer, MS.)

In the summer I have found the Blackpoll to be an abundant resident of the stunted spruce woods on the Magdalen Islands, a type of growth which, when nesting, it also frequents in other localities.

Song.- "A succession of hesitating, staccato, unmusical notes varying greatly in volume. The notes separated, not combined in twos, as in the Black and White Warbler's song." (Farwell, MS.)

"Sometimes the tempo is so accelerated as to constitute a rapid, sibilant, trill. The crescendo and diminuendo effects, however, are always present, as far as I have observed." (Fuertes, MS.)

"Although some phases of the Blackpoll's very changeable song are much like variations of the songs of other members of the Warbler quintette above mentioned, its usual performance is decidedly different. Not so much in tone,- - though that has its peculiarities,-as in delivery and phrasing. It is a string of from six to twelve or more, short, equal and equally-divided sibilant notes, cobweb-thin and glassy-clear,-uttered 
rather fast; the whole song smoothly swelling in volume to the middle, or the second third, and then smoothly falling off. This should perhaps be called the one main song, but the variations from it are many and pronounced. Its syllables vary in number from four to fifteen or more; they are sometimes uttered very hurriedly and close together-a song like a trembling wire-and sometimes they are deliberately and distinctly enunciated. Occasionally these two styles of delivery are combined in one utterance. Again, the song's characteristic 'swell and fall' in volume is sometimes, though seldom, wholly wanting; and the shorter versions are often crescendo to the end. So, sometimes, is that one of the Blackburnian's songs which gives him a place in the quintette. But this is always (?) more deliberately uttered than even the most languid song of any of the other four species, and its notes, unlike the Blackpoll's, are in couplets. Like the Blackpoll's, on the other hand, they have a perfectly smooth tone;--though they are less piercingly fine." (Thayer, MS.)

Miss Paddock writes: "There is always a distinct crescendo and diminuendo which makes the sound seem to drift. It resembles the sound children make by striking the closed hand on the knees to make the "money rattle." "

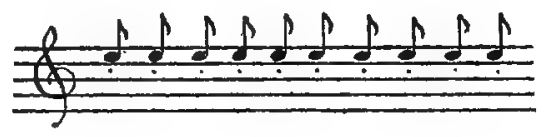

"At very close range a double quality can be distinguished as follows:"

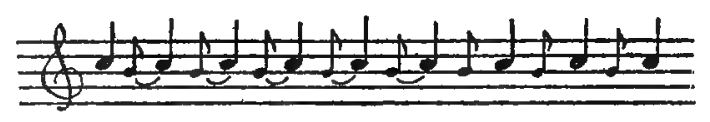

"I once heard this unusual song from a Blackpoll;"

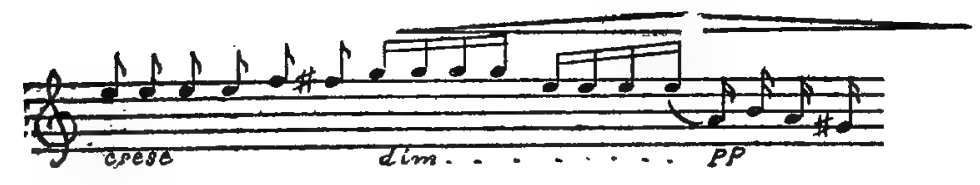

Nesting Site.-In the Island of Grand Menan this species nests in spruce trees from one to ten, but usually about five feet up. (Norris ${ }^{1}$ ). In the Magdalen Islands, where the birds are abundant, they nest in the stunted spruces at an average of about four feet. 


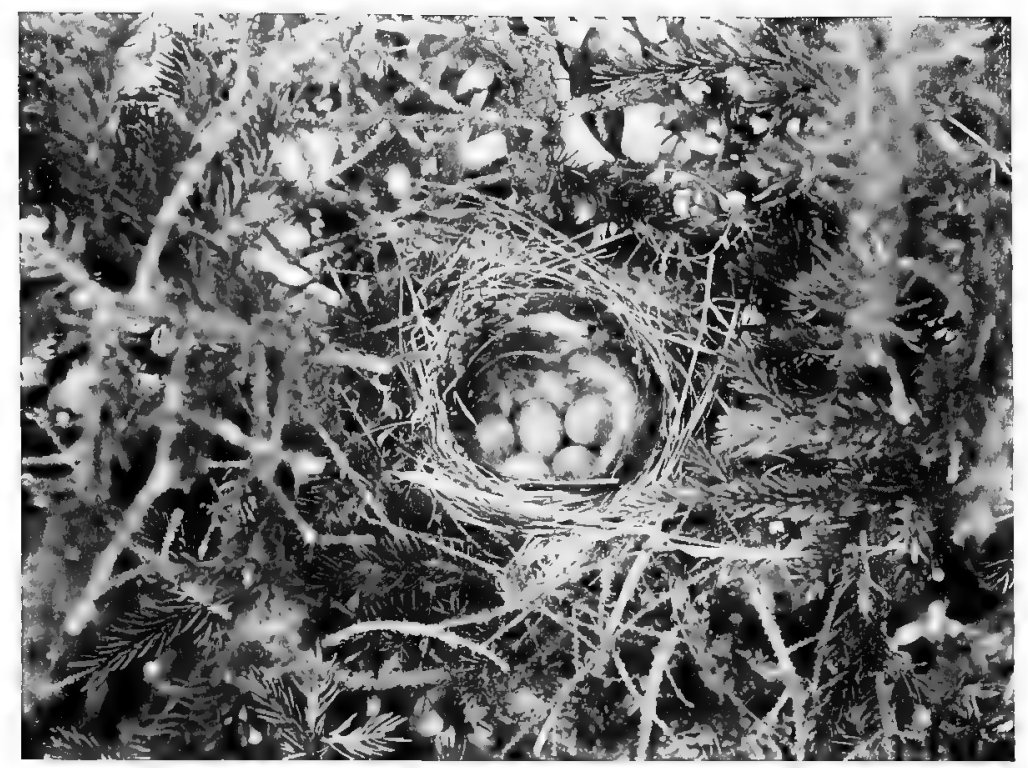

NEST AND IGGS OF BLACKPOLL WARBLER.

Photographed by H. K. JoB, in the Magdalen IsIands.

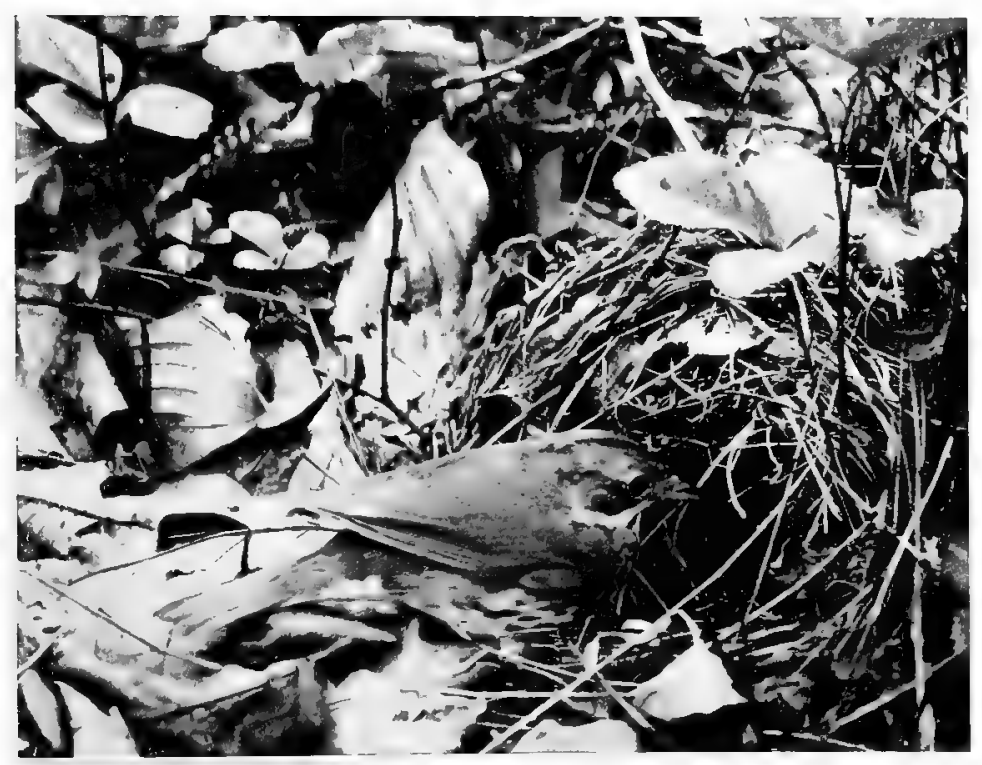

OVEN-BIRD AT ENTRANCE TO NEST, ABOUT TO FEED YOUNG. Photographed by Frank M. Chapman, at Englewood, N. J. 

Nest-“"Outside depth I.75; inside depth I.Io; outside diameter, 3.75; inside diameter, 2.00. Composed of grasses, roots, a little lichen and a few small twigs of spruce fir. Lined with fine grass, and over this is placed a thick lining of soft white feathers, apparently belonging to the domestic goose." (Norris' Grand Menan specimens.)

Eggs.-4 or 5. Ground color white, creamy white to dull grayish white, speckled, spotted, and blotched with various shades of reddish brown, lilac, and purplish gray, in most cases forming a wreath around large end but many eggs are well marked all over. A rather dull colored egg, but the markings are bold and well defined. Size; average, .7Ix.52; extremes measire $.74 \times .52, .67 \times .53, .69 \times .50$ and .70x.54. (Figs. 62-64.)

Nesting Dates.-Lancaster, N. H., June 28 (Spaulding) ; Bangor, Me., probably breeds about June 2o, but no nests yet found. (Knight); Grand Menan, N. B., June II-June $20(J . P . N$.).

\section{Biographical ReFERenCes}

(I) J. P. N[orRIs], A Series of Eggs of the Blackpoll Warbler, Orn. and Oöl., XV, I890, 4I.

\section{PINE WARBLER}

\section{DENDROICA VIGORSI VIGORSI (Aud.) Plate XXIV}

Distinguishing Characters.-In the adult $\delta^{*}$ of this comparatively large Warbler the underparts, except the lower belly, are bright greenish yellow, the breast, particularly in worn plumage, often being obscurely streaked, the upperparts bright yellowish green; the wing-bars soiled whitish. The adult $Z$ is dusky olive above with a decided brownish tinge, soiled whitish below the breast tinged with yellow. In the young the upperparts are decidedly brown, the wing-coverts are brownish white but well-defined and will serve to distinguish the species from several species of Helminthophila which it superficially resembles. Length (skin), 5.00 ; wing, 2.80 ; taill, 2.20 ; bill, .42.

Adult d, Spring.-Above bright yellow-green; narrow line from bill over eye yellow; inner webs of two outer tail-feathers with white patches at end; outer web of outer feather usually white basally; wings margined with grayish, the median coverts tipped, the greater coverts terminally margined with soiled whitish; underparts bright greenish yellow becoming white on the belly, the breast sometimes obscurely streaked.

Adult dó, Fall--Similar to adult $\delta$ in Spring but browner above, slightly veiled with whitish below.

Young o", Fall.-Not appreciably different from adult o in Fall.

Adult o, Spring.-Much duller than the $\delta$; above dusky olive-green tinged with brownish, the nape grayish, no yellow about eye, cheeks grayish, tail with less white, wing-bars less pronounced than in $\delta^{\prime \prime}$; underparts soiled gray. ish white, the breast more or less tinged with yellow, the flanks with brownish.

Adult $q$, Fall- Similar to adult $q$ in Spring but browner above and on flanks; yellow on breast veiled with whitish; wing-bars browner. 
Young + , Fall.-Still browner than the adult $q$ in Fall; often no pronounced greenish above or yellow below.

Nestling.-Above warm grayish brown, eye-ring white; breast strongly washed with the same color the throat grayer, the belly whiter.

General Distribution.-Eastern North America; north to New Brunswick and Saskatchewan; west nearly to the Plains.

Summer Range.-Southern Florida and the Gulf States to southern Canada from New Brunswick through central Ontario (Ottawa, Muskoka), to Manitoba (Lake Winnipeg) and Saskatchewan (Carlton); in this northern part of the range the species is quite rare, except locally. In the region of the Plains, where pine forests are lacking, it is a rather rare migrant. Nearer the Mississippi River and thence to the Atlantic Ocean, its presence during the breeding season is largely governed by the extent of pine timber. Hence in summer, it is more common in the Southern States and the pitch and white pine districts of southern New England, than in the middle hard-wood districts, throughout which, from about latitude 37 degrees northward, it is known to most observers as a more or less common migrant and to a few as a rather rare summer resident.

Winter Range.-This is one of the few Warblers of the eastern United States whose winter home is included in its breeding range. During the winter season the Pine Warbler occupies approximately the southern third of the breeding range; hence it is not surprising that the birds are found to be more common there in winter than at any other time of the year. From North Carolina and southern Illinois southward, it is common in winter in the pines; occasional north in winter to Massachusetts (Framingham, December 5, 189I ; January I, 1882; Duxbury, December 15, 1890). Casual in the Bermudas, at Revelstoke, B. C., and at Matamoras, Mexico.

Spring Migration: Atlantic Coast.-The records of spring migration from the winter home are neither regular nor numerous, but the following notes on the arrival of the first birds will give a fair idea of the general movement:

Lynchburg, Va., March 30, I901; Washington, D. C., average April 3; Renovo, Pa., April 18, r894; Englewood, N. J., April I8, 1900; Portland, Conn., average April I7; Durham, N. H., average April 26; southwestern Maine, average April 20; Petitcodiac, N. B., May I9, 1887; Pictou, N. S., May 19, I894; North River, P. E. I., May 2, I889.

Mississippi Valley.-Nashville, Tenn., March 24, 1902; Bowling Green, Ky., April 20, 1902 ; central Indiana, average April 25; southwestern Ontario, average May 4; Ottawa, Ont., average May I7; St. 
Louis, Mo., April 21, I883, April 16, I888, April II, I896; southwestern Iowa, average April 27; Lanesboro, Minn., average May 2; Aweme, Man., May 2I, IgO2.

Fall Migration.-The last Pine Warbler seen at Aweme, Man., in 1902, was on September 2; the average of the last seen in southwestern Maine, is September 25, and the latest October 4, 1896. The earliest migrants reach Washington, D. C., the last week in August, and the rear guard passes central Indiana and Washington between October Io and 20.

The Bird and its Haunts.-The pine barrens of Florida have no more characteristic bird than this abundant Warbler. Even on frosty mornings one may hear its trilled monotone rising distinctly above the accompaniment of Palm Warbler chips, Bluebird whistles, and Nuthatch chatter. By February I they are singing in numbers and to one who is much in the pines, their voice becomes as much an audible expression of the mood of the trees as the sighing of the wind through their branches. The bird ranges from the ground to the tree-tops, and is at all times deliberate in movements, picking its way slowly along the branches or even clinging to the trunk itself, its plumage generally being more or less soiled with pitch.

While the Pine Warbler has one of the most extended breeding ranges among Warblers, it is never found nesting in other than pines, and even during its migrations it is seen in other growths with comparative infrequency. At West Englewood, N. J., where there are virtually no pines, I have seen it only twice.

Gerald Thayer puts it very well when he says: "Never was a bird more patly named than the Pine Warbler. Except when migrating, it sticks to pine woods as a cockle-bur sticks to a dog's tail. There is even a sort of gummy sluggishness about its movements, as it skulks among the pitchy branches, crawling along their stems, and doing little of the agile twig-skipping, characteristic of its tribe. In the breeding season, the Pine Warbler's 'beat' lies between the middles and tops of big and medium-sized pine trees; but during migrations it is extended to scrubby deciduous copses and to apple orchards.

"A rather big, rather sluggish, rather dingy Warbler, its costume is almost an epitome of inornate American Wood Warbler coloration. Even less characteristically than the Yellow Warbler does this bird belong to the breeding avifauna of Mt. Monadnock proper. But it is fairly common no further away than Keene (ten miles), in riverbordering groves of big white pines; and one or two singing males wander to Monadnock's northern base about mid-summer, or earlier, 
almost every year. So it is more than likely an occasional pair has bred here." (Thayer, MS.)

Song.-The sweet trill of the Pine Warbler is one of the most characteristic bird notes in the great pine forests of the south. In Florida the birds are in full song by February $I$ and are frequently heard during the winter.

"The song is a rather slow, monotonous trill; the key varies much, being sometimes lower than that of any other Warbler song with which I am familiar, and always lower than that of the Worm-eating, which it somewhat resembles in other respects. I have heard the songs in these two keys following each other so closely that it seemed probable they were executed by the same bird. These songs are uttered at all seasons, I think; certainly not more than a few weeks in December mark a cessation.

"The ordinary call-note is a rather soft, lisping, chirp somewhat like that of the Parula Warbler. During courtship, and while the young are being fed, a rapid and insistent chipping is common. Some pugnacity is displayed by the males during courtship; but no obvious attempt is made to show superior advantages in color or song; indeed, the commonest note then appears to be the rapid chipping I have mentioned." (Allison, MS.)

"Its common song is clear and sweet; an unbroken, fluent trill, with a tone and character at once distinguishable from those of other trilling wood-birds of New England;- the Junco, Chipping Sparrow, Myrtle Warbler, etc. It is uttered on an even scale, but is often crescendo in its first half and diminuendo in its second. I have heard no other song from this Warbler, and no important variations of this one, either in New England or in the South. The bird seems to be about the least versatile singer of its tribe." (Thayer, MS.)

Nesting Site.- "In this section (Statesville, N. C.) the nest is usually placed on a horizontal limb thirty-but varying from eight to fifty-feet from the ground." (M'Laughlin'.) "The nest is always placed in a pine, the two species (Pinus mitis and $P$-taeda) being used about equally, but the situation varies a great deal. It may be on a horizontal limb, or built among the small twigs toward the end of the limb; in whichever position, it is put there to stay and takes a good deal of pulling to get it away. It may be close to the trunk or as far off as fifteen feet. The height too varies from twelve to eighty feet, the usual height being from thirty to fifty feet." (Brimley".)

Nest.- "The outer portion consists of long, thin strips of bark 
from grapevines, bits of dead weeds and the stems of dry oak leaves, intermixed with a very fine silken web or cocoon which the bird gathers from openings in the pine bark; web of the caterpillar is also often used. It lines freely with feathers using a respectable quantity of horse-hair and dead tops of sedge also. The bottom consists mostly of feathers, and, on the whole, the nest is quite warm and neatly built." (M'Laughlin'.) "The time occupied in building the nest and laying the four eggs is fourteen days provided the weather is favorable. * * * The female Pine Warbler gathers material from the trunks and limbs of trees and from the ground, and from both near the nest and as far as several hundred yards. * * * The female does most of the building but on one occasion we observed the male assisting her. As a rule, however, he merely accompanies her in her journeys, keeping a little way off and singing assiduously his own individual song. * * * The nest is solid and deep. It is constructed of weed stems, horse-hair and feathers. The dark-colored grapevine bark on the outside gives it an appearance characteristic of this species. A good deal of caterpillar's silk also is used, as well as small cocoons." (Brimley.)

Nesting Dates.-Charleston, S. C., March 28-May I3 (Wayne); Raleigh, N. C., March 24 (Brimley); New Haven, Conn., July 4, young in nest. (Bishop); Cambridge, Mass., full sets, first laying, May 20-30 (Brewster) ; Bangor, Me., June 2, seen taking food to inaccessible nest, either for mate or young (Knight); Porcupine Mts., Mich., July 19, adults feed young, Wood (Barrows).

Eggs.-Usually 4, rarely 5. Ground color varies from a dull creamy white to grayish or bluish gray-white, about 90 per cent. in a large series, are heavily wreathed around large end but, in all cases, the markings are bold and heavy; they consist of specks, spots and blotches, in some cases much run together, of many shades of lilacgray, reddish brown, burnt umber, purplish brown and blackish with under shell-markings of lavender and grayish. Size; average .72x.54, extremes measure $.77 \times .55, .64 \times .52$, .7IX.51, .65X.5I. (Figs. 79-8I.)

\section{BrograpHical REFERENCES}

(I) R. B. M'Laughlin, Nesting of the Pine-Creeping Warbler, (in Nor. Car.), Orn. and Oöl., XII, 1887, I7I. (2) C. S. BrImLeY, Nesting of the Pine Warbler in 1888, (in Nor. Car.), Orn. and Oöl., XIII, 1888, 89; (3) XIV, 1889, I57; (4) On the Breeding Habits of Dendroica vigorsii at Raleigh, N. C., Auk, VIII, I891, 199. (5) J. P. N[ORRIs], A Series of Eggs of the Pine Warbler, Orn. and Oöl., XIV, r889, 130. (6) J. W. P. SMrTHwiCK, Nesting and other Habits of the Pine Warbler in eastern North Carolina, Orn. and Oöl., XVI, I891, IIg. 


\section{KIRTLAND'S WARBLER \\ DENDROICA KIRTLANDI Baird Plate XI}

Distinguishing Characters.-Kirtland's Warbler may be known by its large size, slate-colored or grayish crown, brown, black-streaked back, pale yellow underparts and streaked sides. Length (skin), 5.10; wing, 2.75; tail, 2.30; bill, .42.

Adult do, Spring.-Crown and nape slaty finely streaked with black; cheeks and frontlet black or blackish, eye-ring with white on upper and lower portions; back grayish broadly streaked with black; tail edged with grayish the inner web of two outer feathers with white patches at end; wings fuscous-brown edged with grayish; wing-coverts blacker margined with brownish or soiled white; below pale yellow, breast slightly spotted, sides heavily streaked with black; flanks tinged with brown.

Adult \&, Spring.-Similar to adult $\delta$ but lores and cheeks grayish; black streaks less pronounced, less white in the tail.

Adults in Fall.-Fall specimens of both sexes have the upperparts much browner than in Spring, the wings more broadly margined and browner, the flanks with a stronger brownish wash.

Nestling.-Not seen.

General Distribution.-Southeastern United States; northwest to Minnesota; west to the Mississippi River.

Summer Range.-All the known breeding records of Kirtland's Warbler come from a restricted area in north central Michigan comprising Oscoda, Crawford, and Roscommon Counties.

$W$ inter Range.-The Bahama Islands.

Spring Migration.-This, the rarest of American Warblers, has been taken at West Jupiter, Fla., April I9 and 27, I897; Cumberland Island, Ga., April 12, I902; St. Helena Island, S. C., April 27 and May 3, I886; St. Louis, Mo., May 8, I885; Wabash, Ind., May 4, I892, May 7, 1895; Richmond,Ind., May I3, 1905 ; near Chicago, Ill., May I7, I894, May 22, I899; Rockford, Ill., May 25, I894; Lake Koshkonong, Wis, May 24, I893; Cleveland O., May (?) 1860, May 4 and I2, I880, May I3, I851, May I5; Cincinnati, O., May I872; Oberlin, O., May II, I900; May 9 1904; Kalamazoo, Mich., May I5, I885; Ann Arbor, Mich., May I4, I902, May 15, I875, May 16, I879, May I8, I888; Battle Creek, Mich., May I I, I883; Mackinac Island, Mich., May 2I, I885; Toronto, Ont; May I6, I900; Minneapolis, Minn., May 13, 1892 .

Fall Migration.-In the fall this species has been noted near Ironton, Ohio, August 28, I902; Fort Meyer, Virginia, September 25, I887; Chester, S. C., October II, I888; and at Mount Pleasant, S. C., October 29, 1903.

The Bird and its Haunts.--Over fifty years have passed since this species was discovered but it still remains the rarest of North American 
Warblers. In I $898 \mathrm{I}^{1}$ estimated that sixty-eight specimens of it were known, of which twenty had been taken in the United States, the remaining forty-eight in the Bahamas, to which islands it is apparently restricted in the winter.

At this time the bird's breeding habits were still unknown, but in June, 1903, its nest was discovered by Norman A. Wood ${ }^{2}$ in Oscoda County, Michigan. The following year in the same county, a nest with three eggs was taken June 6, by R. A. Brown and J. A. Parmelee, and, on June I5, a nest with four eggs by E. Arnold ${ }^{4}$. The appended biography, contributed by Mr. Wood, is based on his own studies in 1903, and those of Brown and Parmelee in 1904.

"This bird is of local distribution, living and nesting on the high, sandy, jack-pine plains of Crawford, Oscoda, Roscommon, and probably, Otsego and Montmorency Counties, Michigan. It may breed also in the Upper Peninsula of Michigan and in northern Wisconsin and Minnesota. It is unevenly distributed throughout the counties named, only occurring in colonies, and these are from two to ten miles apart. I have hunted over hundreds of acres of seemingly favorable ground, and failed to find a single pair. This Warbler is a very graceful walker and seems equally at home on trees or on the ground, where the habit of bobbing its tail is very characteristic.

"Incubation seems to be performed by the female alone and she seems to feed herself while incubating. When the young were newly hatched, I have seen the male carry as food a white moth, that is common on the small jack pines, and deer flies, but I could not tell if the female ate them or fed the young with them.

"The female is a close sitter and left the nest only when I was within two or three feet of it. When flushed she fluttered off with open wings and tail trying to lead me after her, failing in this she came back and circled about the nest uttering a sharp chip-chip, even alighting on the toe of Mr. Parmelee's shoe as he sat near the nest.

"On July 8-11, 1903, when but a few days old, the young seemed to have no fear of me, but on the morning of the 14th, when I tried to take a photograph of the nest, they scampered out and quickly hid in the thick cover, and I had to put them back a number of times before they would stay. I think they leave the nest at twelve or eighteen days of age. Both parents brought food to the nest, but the female came oftener and was more fearless than the male.

Song.- "This Warbler has several distinct songs, all of which belong to the whistling type and have the clear ringing quality of the Oriole's. The usual perch, while singing, is the top of a dead stub or limb of stch a tree in the vicinity of its home. At short intervals 
you will hear the song and see the singer with wings slightly lowered, tail drooping, and plumage fluffed, but with the body erect and head thrown back, uttering earnestly and very forcibly Chip-chip-che chee chee-r-r-r. The first two notes are soft and short, the next three uttered rapidly, increasing in volume and ending in a clear ringing whistle on the $r$. The male of a pair that seemed to be courting (See Bull. Mich. Orn. Club, Vol. V, I904, 6.) had a different song, more like Wichy-chee-chee-chee-r-r. This song was not so loud and ringing but was very sweet and clear. This male lit and sang low down in the jack pines many times. One male, with a worm in his bill, sang, at intervals of fifty or sixty seconds, a song which sounded like Ch-ch-che-che-che-ah, the ah long drawn out. When I found the nest, this male came down to the tops of the small jack pines and sang rapidly as though much excited by my presence, and this song seemed then to take a scolding tone, like Che-che che-chee-zrich-a-a. All of the males have a sharp call note chip-chip; and the females the same chip only lower and softer.

"On the morning of May 6, 1905, near Ann Arbor, I had the pleasure of hearing a fine male sing a different song of the same general character, but softer and not given with the intense earnestness of the breeding bird. It sounded as though he was singing to himself and not at you. It had much of the $r$ and $z$ quality and I give it tsip-tsip, chze-chze-e-e. In its summer home it sings from morning till night; only not so frequently through the heat of the day, from the time of arrival in May, and through June it is in full song, and when I left on July I5, it was still singing. They leave their summer home the first of August, when the females and young start south. The males are content to linger and old ones were seen as late as August 20, 1903, and September 3, 1904. These were the last ones seen by Mr. Parmelee, who lives near their nesting grounds.

Nesting Site._-_The nesting site (See photographs in Bull. Mich. Orn. Club, Vol. V, 1904, pp. 4, 7, II) is usually in a dense growth of small Jack pine and scrub oak; not always at the foot of one of these trees but as a rule, under one and protected by its shade. Here the bird excavates a site and in this hole builds its nest, the top about even with the ground, sometimes with a rim, making the nest cupshaped.

Nest.- "These birds return each year to their chosen locality and no doubt to a spot near the site of the previous year. About fourteen inches from the nest shown in the Bulletin is a nest of the year before. In June 1904, all of the colonies described in the Bulletin contained 
more individuals than in 1903 . Mr. Parmelee, who observed them, says the male does not help to build the nest but sits near by and sings all of the time.

"The nest is made of soft bark, strips of vegetable fiber, and dead grass, with dead flower stems of arbutus and weeds, which make the outside firm. It is lined with fine, dead grass, old pine needles, and, lastly, with horse and cattle hair.

Nesting Dates.- "There is much variation in the time of nesting. I have the first nest with complete set of three eggs ever taken; it was found in Oscoda County, June 6, 1904, the earliest recorded nesting date. On July 7, I903, I flushed a female at work on a nest site, but, possibly, her first nest may have been destroyed. The average is from June 15 to 20 , although I am sure it varies with each season.

Eggs.- "The eggs in a set vary from 3 to 5 the usual number being 4 , only two sets of 3 are recorded, while of 5 we have three nests recorded, and eight at least of 4 . Only one brood is reared each year. Second sets are no doubt laid to replace a first set which has been destroyed." (N.A. Wood, MS.)

\section{BIOGRAPHICAL REFERENCES}

(I) F. M. Chapman, Kirtland's Warbler, Auk, XV, I898, 289 . (2) N. A. Wood, Discovery of the Breeding Area of Kirtland's Warbler, Bull. Mich. Orn. Club, V, 1904, I. (3) C. C. Adams, The Migration Route of Kirtland's Warbler, Bull. Mich. Orn. Club, V, 1904, I4. (4) E. ARNoLd, Nesting of Kirtland's Warbler in northern Michigan, I904, Bull. Mich. Orn. Club, V, 1904, 67.

\section{PRAIRIE WARBLeR DENDROICA DISCOLOR (Vieill.) Plate I}

Distinguishing Characters.-The adult $\delta$, and, usually the adult $q$, may be known by the reddish chestnut dorsal spots, while the small size, entirely yellow underparts, more or less streaked sides, and yellowish wing-bars will identify most specimens without regard to age. Length (skin), 4.20; wing, 2.20; tail, 1.90; bill, .35.

Adult d", Spring.-Above bright olive-green the center of the back spotted with reddish chestnut; line over, and space below eye yellow, a blackish streak through eye; outer tail-feather largely white on both webs, second and third feathers white at end of inner web; wings edged with greenish the median and greater coverts edged with dusky yellowish; underparts entirely yellow, a black crescent at the side of the throat, sides streaked with black.

Adult o", Fall.-Similar to adult o in Spring but reddish chestnut spots in back more or less concealed by olive-green tips to feathers.

Young d", Fall.-Similar to adult of but chestnut marks in back small or wanting, cheeks grayish, line over eye less distinct black marks much reduced or absent, wing-bars duller, less white in tail. 
Adult $q$, Spring.--Similar to adult $\delta$ but chestnut back marks much reduced or wanting, back duller, black markings less pronounced (better defined than in young $\delta^{\prime)}$ wing-bars duller. In very worn plumage (late summer) the upperparts become grayish, the underparts whitish.

Adult $q$, Fall.-Similar to adult $q$ in Spring but back with a grayish bloom, cheeks grayer, line over eye less distinct, black markings less pronounced.

Young $q$, Fall.-Similar to adult $q$ but no chestnut in back, cheeks still grayer, black marks faint and dusky or entirely absent.

Nestling.-Above olive-grayish brown; below whitish the breast dusky; a faint grayish line over the eye; wing-coverts blackish tipped with buffy.

General Distribution.-Eastern United States; north to southern New England and Michigan; west to the Plains.

Summer Range.-The Prairie Warbler is a bird of middle altitudes, shunning the mountains above a thousand feet and rare in the low coastal region of the Gulf States. Along the Atlantic slope it is common from the northern Bahamas and Florida north to Pennsylvania, but north of Philadelphia, it is found, as a rule, only near the coast; common locally in Connecticut, Rhode Island, and eastern Massachusetts, where it is characteristic of the barberry districts (Plymouth and Bristol Counties, Martha's Vineyard) ; casual or accidental in New Hampshire (Hollis, June 28, I884, August 23, 1876, September 4, 1876; Manchester, spring, rgo I), Ontario (Toronto, May I I, Ig0o; Mt. Forest, May I3, I905), Michigan (Port Huron, May 20, I900; Ottawa County, May 26, I879; Montcalm County), Wisconsin, (Racine, Lake Koshkonong). The western range extends regularly to eastern Nebraska ( West Point, Omaha), eastern Kansas, rarely to southern Mississippi (Beauvoir), Louisiana (West Baton Rouge Parish), and Texas (Gainesville).

Winter Range.-The Greater Antilles, the Bahamas and the southern half of Florida.

Spring Migration.-From its winter home in the West Indies and Florida, the Prairie Warbler begins to move northward early in March, though the full tide of migration does not start until the last of the month.

\begin{tabular}{|c|c|c|c|}
\hline PLACE & $\mid \begin{array}{l}\text { No. of } \\
\text { years' } \\
\text { record }\end{array}$ & $\begin{array}{l}\text { Average date of } \\
\text { spring arrival }\end{array}$ & $\begin{array}{l}\text { Earliest date of } \\
\text { spring arrival }\end{array}$ \\
\hline 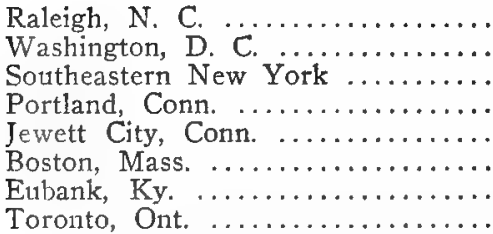 & $\begin{array}{r}16 \\
5 \\
14 \\
4 \\
10 \\
8 \\
7\end{array}$ & $\begin{array}{lr}\text { April } & \text { I5 } \\
\text { April } & 22 \\
\text { May } & 4 \\
\text { May } & 6 \\
\text { May } & 7 \\
\text { May } & 8 \\
\text { April } & 20\end{array}$ & $\begin{array}{l}\text { April } 6,1892 \\
\text { April } 19,1891 \\
\text { May I, } 1891 \\
\text { April } 27,1888 \\
\text { May I, } 1896 \\
\text { May 4, } 1891 \\
\text { April I3, I893 } \\
\text { May I1, } 1900\end{array}$ \\
\hline
\end{tabular}


The latest records of striking the southern lighthouses are in the first half of May and the earliest spring date is March 7. Th' 1s the period of spring migration in the southern United States extends through more than nine weeks.

Fall Migration.-The southward migration occupies more time than the northward, and lasts from the middle of August to the first week in November. Some dates of the last ones noted are at Taunton, Mass., Sept. I5, I887; Shelter Island Heights, N. Y., Sept. 19, I90I; Washington, D. C., September 4, I887; Raleigh N. C., September 9; Frogmore, S. C., September 30, I886; Fowey Rocks Lighthouse, Florida, November 6, I891.

The records indicate that the southern breeding birds spend about tive months in the summer home, at least as long in the winter home and the remainder of the year in migration. Even the northern nesting birds remain for four months at the breeding grounds.

The Bird and its Haunts.-The Prairie Warbler is reported as abundant by various observers from Florida to Massachusetts, nevertheless it is so local in habit that, even as a migrant, it is entirely wanting over large areas. At Englewood, N. J., there are many scrubby tracts apparently suitable for its occupation, nevertheless the Prairie Warbler remains the only member of its family among those which might be expected to occur, which I have yet to find there.

At Columbus, S. C., this species is the commonest Warbler, inhabiting partially cleared oak and hickory lands. (Taylor, MS.) In Virginia it breeds in bushy second growths of hickory, dogwood, and laurel, with scattered pines and cedars (Coues). In southern New Jersey it is an abundant summer resident of the Pine Barrens (Stone), and in New England it resorts to old cedar-grown pastures and hillsides with an undergrowth of barberry. On Prospect Hill, near Cambridge, Mass., Brewster ${ }^{4}$ notes an exception to this custom, the birds there frequenting sprout growths and building their nests in sapling oaks and maples.

Continuing, Brewster gives a pleasing picture of the bird's haunts : "Many and delightful were the days I used to spend looking for nests of the Prairie Warbler in the hill pastures of Arlington and Belmont. These breezy uplands are attractive at every season, but most so in early June when the barberry bushes blossom. This is the time when our Prairie Warblers have full sets of fresh eggs. A search for their nests among the handsome, dome-shaped barberry bushes, covered with young foliage of the tenderest green, and with graceful, pendant clusters of golden yellow flowers that fill the air with 
fragrance and attract myriads of droning bees, is a fascinating and memorable experience, whatever be its material results."

Song.-Dr. Coues' unique characterization of the song of the Prairie Warbler as suggesting the plaint of a mouse with the toothache, has a certain aptness which those who are familiar with the song will recognize. It is to me one of the most easily recognized anr remembered of Warbler's songs.

"The ordinary call-note resembles the softer of the two chirps uttered by the Yellow Warbler, but is perhaps more slowly uttered. The song, uttered in spring, by the male, which sits, during the performance, with the head held vertically upward, and the tail straight down, is a lisping trill much like that of the Parula Warbler in its general character; but it has a wiry quality that at once distinguishes it. Once I heard another song, of which I have record only as a queer, interrupted song, instead of the usual wiry trill." (Allison, MS.)

Nesting Site.-At Raleigh, N. C., Brimley ${ }^{3}$ states that this species "delights in sunny hillsides covered with bushes and saplings, building its nest in one of these at a height of from one to twelve feet from the ground, but usually about three or four feet high. $* * *$ Unlike some localities where this bird nests mainly in pine saplings, here sweet gums are [given] the preference, with elm next best, nests being only found very occasionally in pines."

Near Washington, D. C., Coures ${ }^{1}$ found that the nests were built in an upright or oblique crotch, preferably one formed in part by the main stem of a bush, from one and a half to five feet from the ground, in a rather open, scrubby, hilly locality."

They "were placed preferably in hickory and dogwood bushes. Only three nests were found in the young pines, and one in a cedar bush." (Coues.)

At Saybrook, Conn., J. N. Clark (C.W.C.) found many nests of this species in hilly pastures frequently in small junipers about three feet from the ground.

Nest.-All the nests of this species which I have examined are characterized by the presence of a large amount of buff fern down which is tightly woven or felted into their walls.

Brimley" describes the nest as "a beautiful structure, usually being largely composed of rabbit tobacco, a kind of gray-leaved, wild everlasting very much used by birds in nest-building, and lined with soft materials."

Coues $^{1}$ writes "exceptions aside, the Prairie Warbler's nest may be characterized as a neat, cup-shaped structure, with a firm some- 
what contracted brim, composed of vegetable down or soft fiber mixed with some fine straws and a few leaves or feathers, lined with hair and very fine straws."

Eggs.-3 to 5, usually 4. Ground color white to pale greenish white marked with specks, spots and small blotches of chestnut-brown, burnt umber, purplish brown and many under shell-markings of lavender grayish. In some types the markings form beautiful wreathes about the large end with the rest of the egg comparatively clear of spots; others have the wreath very indistinct and many scattering spots and specks over the entire egg; a few extremes, in a large series, have the wreath around the small end. Size; average .64x.49; extremes measure .69x.51, .55x.47. (Figs. 84-86.)

Nesting Dates.-Savannah, Ga., April 25 (C.W. C.) ; Raleigh, N. C., May I6 (Brimley); New Haven, Conn., May 27-June 25 (Bishop) ${ }^{+}$; Cambridge, Mass., full sets, first laying, May 28-June 5 (Brewster) ; Ottawa Co., Mich., May 26, Gibbs (Barrows).

\section{Btographical References}

(I) E. B. Coues, Nesting of the Prairie Warbler in the Vicinity of Washington, D. C., Auk, V, I888, 405. (2) H. K. JAMisoN, Nesting of the Prairie Warbler in Fairfax Co., Va., Orn. and Oöl., XIV, I889, 85. (3) C. S. Brimley, Nesting of the Prairie Warbler at Raleigh, N. C., Orn. and Oöl., XV, I89o, 165. (4) WM. Brewster, Birds of the Cambridge Region, 346.

\section{PALM WARBLER}

\section{DENDROICA PALMARUM PALMARUM (Gmel.) Plate XVI}

Distinguishing Characters.-In adults of both sexes the reddish chestnut crown and yellow throat are diagnostic; while young and winter adults may be known by their brown, more or less streaked upperparts, yellowish upper, and yellow under tail-coverts, streaked underparts, white line over eye, and other characters. Length (skin), 4.70; wing, 2.60 ; tail, 2.05 ; bill, .40 .

Adult d, Spring.-Crown reddish chestnut, line from bill over eye yellow; back olive grayish brown obscurely streaked, upper tail-coverts yellowish; two outer tail-feathers with sharply. defined white patches at tips of inner webs; wing-coverts edged with brownish gray not forming conspicuous bars; throat and upper breast yellow rest of underparts grayish white more or less suffused with yellow, sides brownish, throat and sides streaked with reddish chestnut, under tail-coverts yellow.

Adult đै, Fall.-Similar to adult of in Spring but chestnut crown widely tipped with brown, line over eye white or whitish, throat and upper breast suffused with yellow, or whitish without yellow, rest of underparts suffused with yellow, streaks below blacker

Young ס, Fall.-Similar to adult of in Fall but crown with less or even no chestnut, throat usually without yellow. 
Adult and young $9 .-$ Not certainly to be distinguished from the $d$ of corresponding age.

Nestling.-Not seen.

General Distribution.-Florida, Mississippi Valley, and interior of British America; rare but regular migrant on the Atlantic coast, chiefly in fall.

Summer Range.-Interior of British America north of Manitoba and west of Hudson Bay. Accidental in Colorado (Denver, June 20, I89I), Montana (Great Falls, Sept. I8, I889), and California (Pacific Grove, Oct. 9, I8g6).

Winter Range.-Florida (abundant in Alachua Co.) southward to the West Indies; Yucatan.

Spring Migration.-The Palm Warbler has been separated into two sub-species, of which Dendroica palmarum palmarum ranges west of the Alleghenies, while Dendroica palmarum hypochrysea, the Yellow Palm Warbler, occurs along the Atlantic slope. In the following notes, the locality will serve as a general guide to the particular form referred to.

\begin{tabular}{|c|c|c|c|}
\hline PLACE & $\begin{array}{l}\text { No. of } \\
\text { years } \\
\text { record }\end{array}$ & $\begin{array}{l}\text { Average date of } \\
\text { spring arrival }\end{array}$ & $\begin{array}{l}\text { Harliest date of } \\
\text { spring arrival }\end{array}$ \\
\hline \multicolumn{4}{|l|}{ Atlantic Coast- } \\
\hline 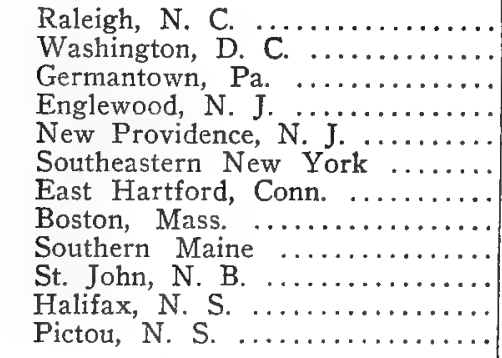 & $\begin{array}{r}7 \\
6 \\
4 \\
4 \\
5 \\
5 \\
6 \\
\text { II } \\
\text { IO } \\
\text { II } \\
4 \\
8\end{array}$ & $\begin{array}{l}\text { March } 31 \\
\text { April } 6 \\
\text { April I4 } \\
\text { April I4 } \\
\text { April I7 } \\
\text { April I8 } \\
\text { April } 16 \\
\text { April I8 } \\
\text { April } 23 \\
\text { April } 20 \\
\text { April } 27 \\
\text { May I }\end{array}$ & 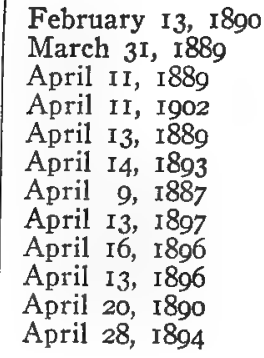 \\
\hline \multicolumn{4}{|l|}{ Mississippi Valley- } \\
\hline 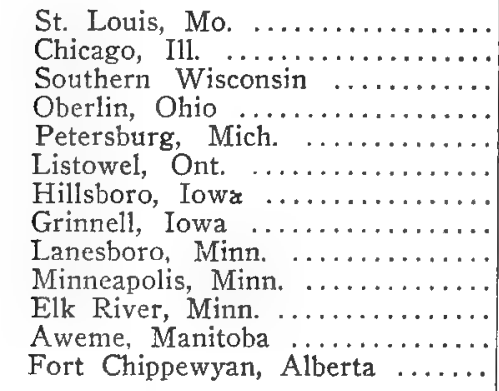 & $\begin{array}{r}4 \\
10 \\
8 \\
8 \\
10 \\
5 \\
5 \\
5 \\
10 \\
5 \\
4 \\
6\end{array}$ & $\begin{array}{lr}\text { April } & \text { I5 } \\
\text { April } & 25 \\
\text { April } & 30 \\
\text { April } & 30 \\
\text { April } & 30 \\
\text { May } & 2 \\
\text { April } & 22 \\
\text { April } & 26 \\
\text { April } & 27 \\
\text { April } & 30 \\
\text { May } & 3 \\
\text { May } & 7\end{array}$ & $\begin{array}{lr}\text { April } 5,1882 \\
\text { April } 17,1897 \\
\text { April } 22,1886 \\
\text { April 24, } 1897 \\
\text { April 26, } 1894 \\
\text { April } 28,1894 \\
\text { April } 14,1896 \\
\text { April } 22,1888 \\
\text { April } 23,1890 \\
\text { April } 27,1889 \\
\text { May 1, } 1886 \\
\text { May } 3,1901 \\
\text { May 23, } 1901\end{array}$ \\
\hline
\end{tabular}




\section{Plate XVI}

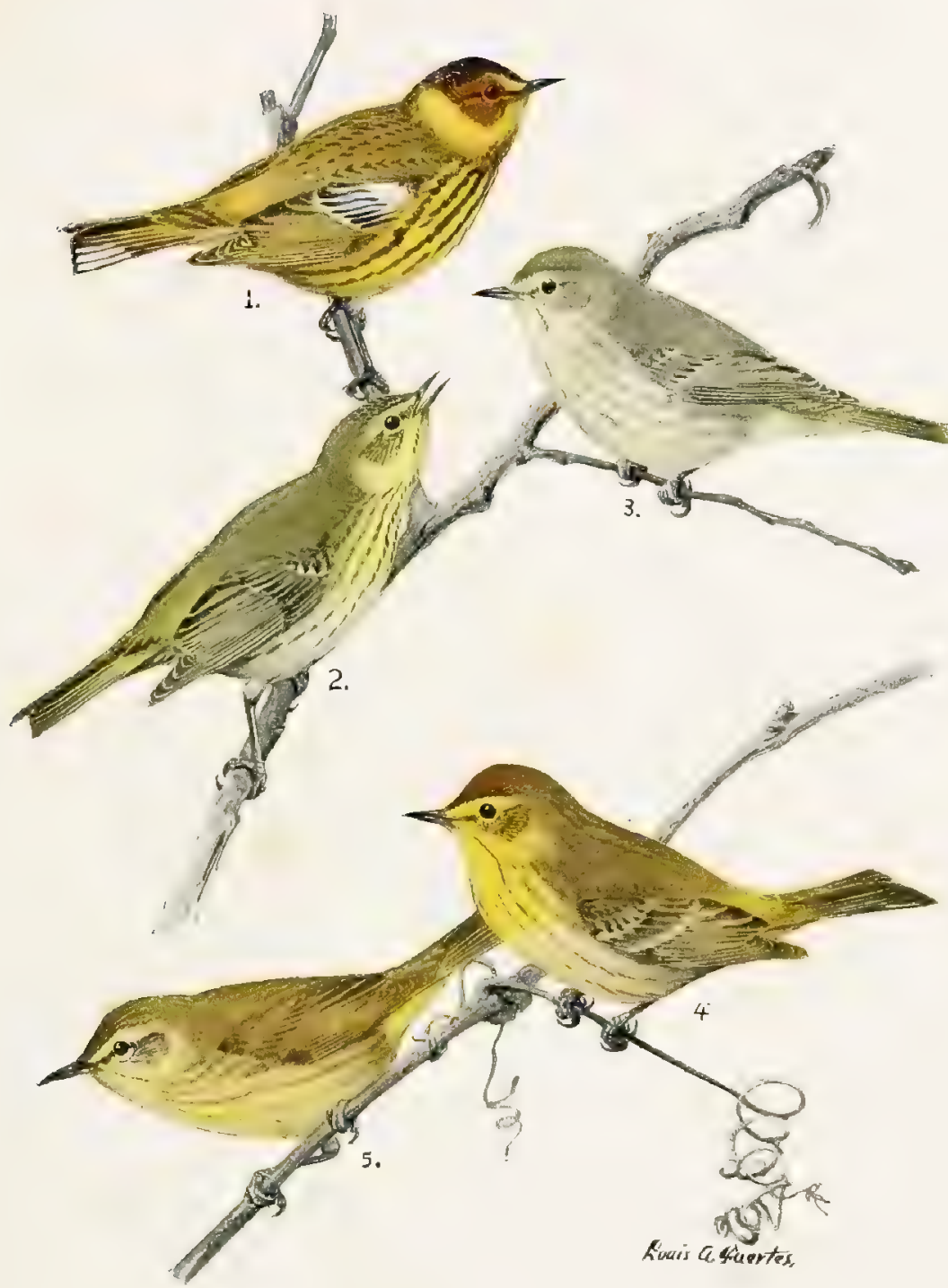

1. Cape May Warbler, Adult Male.

2. Cape May Warbler, Adult Female.

4. Palm Warblek, AuUlt.

3. Cape May Warbler, Young Femalf.

(ONE-HALF NATURAL SIZ̈E, ) 

Fall Migration.-

\begin{tabular}{|c|c|c|c|}
\hline PLACE & $\begin{array}{l}\text { No. of } \\
\text { years' } \\
\text { record }\end{array}$ & $\begin{array}{l}\text { Average date of } \\
\text { first one seen }\end{array}$ & $\begin{array}{l}\text { Earliest date of } \\
\text { frst one seen }\end{array}$ \\
\hline 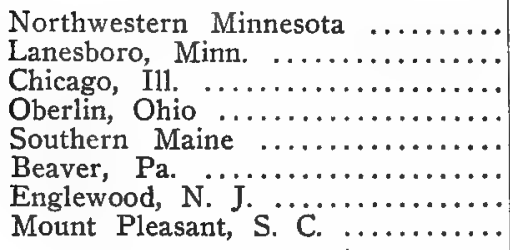 & $\begin{array}{l}2 \\
2 \\
3 \\
5 \\
6 \\
4\end{array}$ & $\begin{array}{ll}\text { September } & 10 \\
\text { September } & 18 \\
\text { September } & 15 \\
\text { September } 26 \\
\text { September } 28 \\
\text { September } 13\end{array}$ & $\begin{array}{lrr}\text { September } 9, & 1896 \\
\text { September } 17, & 1888 \\
\text { September } 4, & 1900 \\
\text { September } 16, & 1898 \\
\text { September } 19, & 1392 \\
\text { September } 7, & 1889 \\
\text { September } 26, & 1886 \\
\text { September } 7, & 1896\end{array}$ \\
\hline PL,ACE & $\mid \begin{array}{l}\text { No. of } \\
\text { years' } \\
\text { record }\end{array}$ & $\begin{array}{l}\text { Average date of } \\
\text { last one seen }\end{array}$ & $\begin{array}{l}\text { L,atest date of } \\
\text { last one seen }\end{array}$ \\
\hline 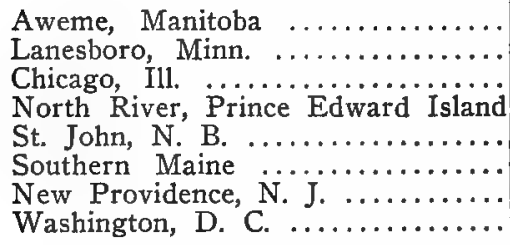 & $\begin{array}{l}6 \\
4 \\
6 \\
3 \\
7 \\
3\end{array}$ & $\begin{array}{l}\text { September } 30 \\
\text { October I } \\
\text { October } 9 \\
\text { October I3 } \\
\text { October 13 } \\
\text { October I2 }\end{array}$ & $\begin{array}{l}\text { October 6, } 190 \text { I } \\
\text { October 3, I890 } \\
\text { October 18, 1896 } \\
\text { September 15, I887 } \\
\text { October 18, I896 } \\
\text { October 20, } 1892 \\
\text { October 18, } 1894 \\
\text { October 19, I890 }\end{array}$ \\
\hline
\end{tabular}

The Bird and its Haunts.-The Palm Warblers, including under this head both the present species and its eastern representative, hypochrysea, are strikingly unlike all but one of their congeners in color, in actions, and in choice of both haunts and nesting site. Kirtland's Warbler is the only other member of the genus which nests on the ground, and this species, singularly enough, is the only other Dendroica which has the habit of tail-wagging.

It is this motion in connection with the bird's occurrence in old fields, that causes it to be likened to the Titlark or Pipit; the latter, however, is purely terrestrial, rarely if ever alighting in bushes or on fences, etc., as is the custom of this Warbler.

During the winter, and indeed, until May I, the Palm Warbler is one of the commonest birds in Florida. It inhabits not only the pineries, old fields, and fence-rows, but is common in gardens and even visits the streets of the towns, its oft-repeated chip and wagging tail impressing themselves on the memory as characteristic features of Finrida's winter bird-life.

Allison writes that "about New Orleans, this Warbler is found on open ground, roadsides, pastures, etc.,-with small bushes, clumps of Dalmetto. or occasional willow trees. In Tishomingo County I 
found it abundant in syring on hillsides covered with a low growth of $V$ accinium. It is distinctly a bird of the ground and the low growth, and I have never seen it perch twenty feet above the ground." (Allison, MS.)

Northward through the Mississippi Valley this species is a common migrant, but it nests so much farther north than the Yellow Palm that we know but little of its habits during the summer.

In September and October the Palm Warbler occurs as a rare but regular migrant in the Atlantic States. Brewster records an individual seen by Hoffman at Belmont, Mass., December 6, I902.

Song.- "The trill remains as a prominent feature, but the note is no longer a true chip. Better tsee tsee tsee tsee. with a distinct swell. Each syllable should be given a half double utterance except at the middle of the swell, where the greater effort seems to completely coalesce the half double quality into one distinct syllable. There is a little similarity to the song of Myrtle Warbler, but lacking the liquid quality of that species." (Jones.)

Nesting Site.-A nest containing five young was found by Kennicott at Fort Resolution, June I8, on the ground, in a hummock, at the foot of a small spruce (B. B. \& R. I, 275).

Eggs.--"Yellowish or creamy white, spotted chiefly around the larger end with brown and purple." (Bailey, Birds W. U. S.)

\section{YELLOW PALM WARBLER \\ DENDROICA PALMARUM HYPOCHRYSEA Ridgw.}

Subspecific Characters.-Similar to Dendroica palmarum palmarum but larger, upperparts more olive, underparts entirely yellow, the streaks browner, line over eye yellow at all seasons. In winter the yellow below is more or less veiled with whitish but I have seen few specimens that were not sufficiently unlike $D$. p. palmarum to be distinguished in life. Length (skin), 4.80; wing, 2.70; tail, 2.IO; bill, .40.

Nestling.-Above olive-brown strongly streaked with black; beluw whitish strongly and evenly streaked with black, except on lower abdomen; median and greater wing-coverts edged with brownish and tipped with buffy forming more conspicuous bars than in the young in Fall plumage.

General Distribution.-Eastern North America.

Summer Range.-From Bangor, Maine, and Nova Scotia northward to Labrador, east of Hudson Bay.

Winter Range.-From North Carolina south to the Florida Keys, west to Louisiana, rare in the West Indies.

The Bird and its Haunts.- So far as habits are concerned this bird agrees with its Mississippi Valley representative, Dendroica $p$. palmarum. It is apparently less abundant than that iorm which, 
although it is found commonly in the West Indies in winter, is still more numerous in the United States than hypochrysea, which rarely ventures beyond our limits. About Gainesville, Fla., an occasional individual of the Yellow Palm was seen with the loose flocks of palmarum, fifteen of the former to at least several thousands of the latter being observed there during a single winter.

Brewster says: "Yellow Palm Warblers visit the Cambridge region with unfailing regularity in spring and autumn, although their numbers vary greatly from year to year. *** In spring they associate freely with Myrtle Warblers, and hence frequent much the same places, although they resort rather less to upland woods and are even more given to haunting thickets near water, and to venture out into fields and pastures where they sometimes occur hundreds of yards from any cover. Their favorite haunts in autumn are barren tracts sparsely covered with gray birches."

Gerald Thayer writes: "Earliest among Monadnock's springarriving Warblers is the Myrtle and close behind it comes this beautiful, ruddy-crowned, golden-browed, and red-streaked, golden-breasted 'tail-tipper' of field-borders and bushy roadsides; a bird of the semiopen ground and the first tier of scattered woody growth above it.

"With a methodic regularity which almost saves the action from the look of nervousness, his greenish tail is forever swinging up and down. Ducks and Motmots, and some other birds really wag their tail, from side to side; but it is a far commoner trick to jerk or wave it up and down, as is the way of the Yellow Palm and Palm and several other eastern Warblers. The two 'Palms' come nearest to being 'continuous performers' of the trick, but even they have occasional lapses into quietness, in the midst of their flitting and feeding." (Thayer, MS.)

O. W. Knight ${ }^{2}$, who first discovered this species breeding in the United States, writes that in Maine, in the nesting season, this species "may be confidently looked for in sphagnum-hackmatack bogs with open stretches, within the Canadian fauna sections of the State. So far as known, the birds are found in what may be perhaps termed loosely aggregated colonies."

Song.-Knight ${ }^{1}$ writes that in Maine the song is heard until well into June. "It consists of a series of trills which may be rendered tsee tsee tsee tsee tsee, and the call and alarm notes are mere chips uttered with various intonations" $\left(K n i g h t^{1}\right)$.

"The Yellow Palm sometimes sings freely on migration. As one hears it then, it ranks low in the scale of full-voiced Warblers, or 
perhaps midway between them and the weak-voiced, for its tones, though clear and sweet, are by no means loud. It has at least two main songs, both varying a good deal. Both are chiefly trills, one slower and fuller-toned, the other much quicker and 'thinner.' To both, but most often and most fully to the louder song, separate, twittered notes are sometimes added, at the beginning and end, or sometimes at the beginning or the end alone. The trill in all its variations has a delicate softness of tone, and a hint of brokenness and hesitancy in delivery, which clearly separates it from all (?) other trill-songs of New England birds. The migrant Yellow Palm's commonest call is a rather weak tsip, small and fine, but with a touch of softness, a recognizable though scantily peculiar little note. But the bird makes other, more subdued and ambiguous lisps" (Thayer, MS.)

Nesting Site.-Knight ${ }^{2}$ records nests found near Bangor, Maine, in the following situations: at the base of a small spruce imbedded in sphagnum moss or a tuft of grass; at the foot of a small fir bush; between two small bushes, and four inches from the ground in a small spruce bush.

Nest.-The same author describes the nest as "composed of fine dry sedges and grasses, lined with a very few feathers and one or two horse-hairs. Its external diameter was three inches and its internal diameter at the top two inches. Its depth outside was two and a half inches and the depth inside one inch."

Eggs.-4 or 5. Knight" describes a set of 5 as of "a buffy white color, spotted with brown and lilac. The spots are thicker toward the larger end, and tend to form an irregular wreath." Size; .63x.50, $.64 \times .50, .65 \times .48, .62 \times .48, .65 \times .49$. (Figs. 82,83.)

Nesting Dates.-Bangor, Me., May 30 , nest with newly hatched young-June 26 , two eggs, incubated about four days. (Knight).

\section{Biographical References}

(I) O. W. KNigut, The Nest and Eggs of the Yellow Palm Warbler, (in Maine), Nidologist, II, I895, I40; (2) Contributions to the Life History of the Yellow Palm Warbler, Journ. Me. Orn. Soc., VI, I904, 36. (3) WM. BREWSTER, Birds of the Cambridge Region, 345 .

\section{Genus SEIURUS Swainson}

The three members of this genus are, comparatively speaking, large birds with rather slender, straight, notched, rounded bills (more compressed in $S$. aurocapillus) and heavily streaked underparts. Rictal bristles are barely evident. The wing is long, averaging an inch or more longer than the tail ; the three outer primaries are longest and of 
about the same length; the tail is square or slightly notched; the feet are pale or brownish, the tarsus nearly an inch in length.

The Seiuri are distinguished among the Warblers for their superficial resemblance to the Thrushes, due to the spotting of the underparts. Their plumage is without wing-bars or tail-patches, and, as in other dull-colored species of this family, the sexes are alike. All are terrestrial, walking birds and two have the habit of wagging or tipping the tail.

One of the three species is restricted to the Eastern United States, the other two range westward to the Rocky Mountains and northwestward to Alaska.

\section{OVEN-BIRD \\ SEIURUS AUROCAPILLUS (Linn.) Plate XVII}

Distinguishing Characters.-Large size, white, heavily streaked underparts, and orange-brown, black-margined crown are the principal distinguishing characters of the Oven-bird. Length (skin), 5.50; wing, 3.00; tail, 2.20 ; bill, .50.

Adult ठ", Spring.-Crown orange-brown inconspicuously tipped with brownish and bordered laterally by two pronounced black stripes extending from the bill to the nape; back, wings, and tail brownish olive-green, no white wingbars or tail-patches, but tips of outer tail-feathers sometimes narrowly whitish or brownish and wing-coverts occasionally margined with buffy; below white, the throat unspotted but bordered by black lines; breast and sides heavily streaked with black, the flanks washed with the color of the back.

Adult $\delta^{\prime \prime}$, Fall.-Similar to adult $\delta$ in Spring but colors deeper and richer, brownish tips to orange crown wider, breast, in some specimens, with a brownish wash.

Young $\delta^{*}$, Fall.-Indistinguishable from adult $\delta^{*}$ in Fall.

Adult + , Spring.-Resembles adult $\delta^{*}$ in Spring but the orange crown averages paler and more widely tipped with brownish.

Adult + , Fall.-Differs from adult $q$ in Spring in the same manner that the adult $\sigma^{*}$ in Fall differs from adult $\sigma^{*}$ in Spring.

Nestling.-Above bright cinnamon-brown streaked with black, the black crown-stripes of the adult sometimes evident; breast and sides paler than back, faintly streaked with black, belly white; wings and tail as in adult but wing-coverts black and tipped with rusty.

General Distribution.-Eastern North America; north to Newfoundland and Alaska; west to the Rocky Mountains.

Summer Range.-The southern limits of the regular breeding range are found in Virginia, Kentucky, Missouri, and Kansas, south in the Allegheny Mountains to South Carolina; accidental in Colorado (Denver, June, I862; Ramah, June 5, I898), Montana (Fort Keogh, July 23, I888), British Columbia (Esquimault). A few are said to breed in the northern Bahamas. The species breeds north almost to the limit of trees in Newfoundland, Hudson Bay, and Alaska. 
Winter Range.-Western Mexico to northern South America; most of the West Indies, the Bahamas, the southern half of Florida and, casually, southern South Carolina and southern Louisiana.

Spring Migration.-

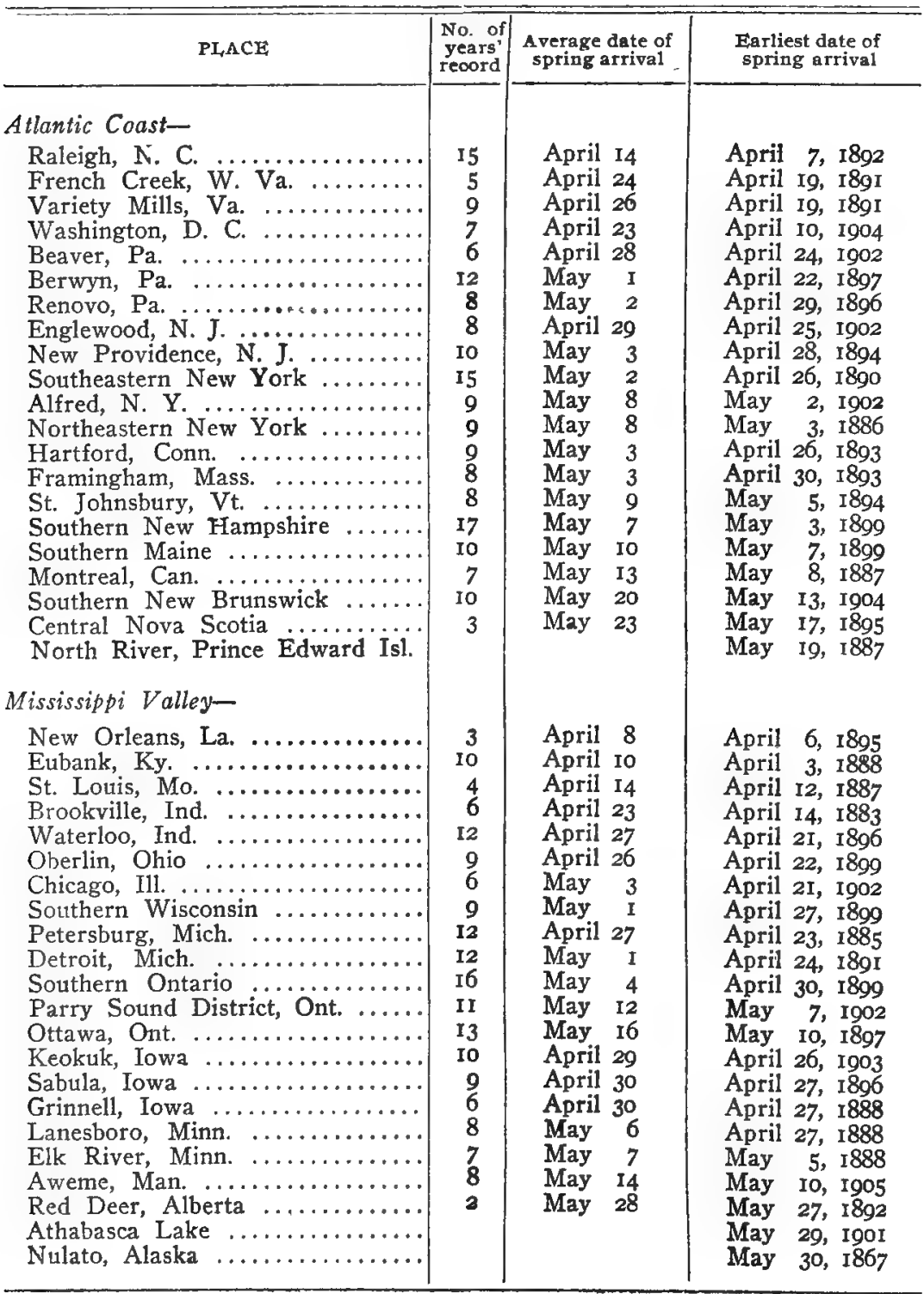




\begin{tabular}{|c|c|c|c|}
\hline PL,ACE & $\begin{array}{l}\text { No. of } \\
\text { years' } \\
\text { record }\end{array}$ & $\begin{array}{l}\text { Average date of } \\
\text { last one seen }\end{array}$ & $\begin{array}{l}\text { Latest date of } \\
\text { last one seen }\end{array}$ \\
\hline 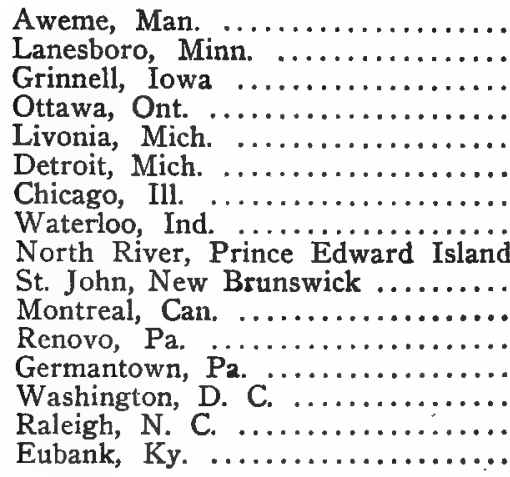 & $\begin{array}{r}5 \\
2 \\
5 \\
4 \\
3 \\
12 \\
7 \\
4 \\
2 \\
2 \\
-6 \\
5\end{array}$ & $\begin{array}{l}\text { September 13 } \\
\text { September } 18 \\
\text { September 13 } \\
\text { September } 23 \\
\text { September 18 } \\
\text { September } 29 \\
\text { September } 28 \\
\text { October } 2 \\
\text { August } 26 \\
\text { September } 24 \\
\text { October } 5 \\
\text { October } 7\end{array}$ & $\begin{array}{l}\text { September 23, I899 } \\
\text { September 22, I888 } \\
\text { September 16, 1885 } \\
\text { September 29, I900 } \\
\text { September 24, I891 } \\
\text { October 12, I905 } \\
\text { September 30, 1898 } \\
\text { October 7, I887 } \\
\text { September 2, I888 } \\
\text { September 29, I 1991 } \\
\text { September 14, 1887 } \\
\text { October 7, 1902 } \\
\text { October 9, I887 } \\
\text { October 17, I890 } \\
\text { October 23, 1885 } \\
\text { October 27, 1886 }\end{array}$ \\
\hline
\end{tabular}

The Bird and its Haunts.-At Englewood, N. J., the Oven-bird prefers dry, rather open, deciduous woods; but it is by no means confined to them, being also found in low, swampy forest lands with heavy undergrowth. Passing most of its time on or near the ground, the Oven-bird, in spite of its abundance, would not attract our notice were it not for its loud, frequently repeated, unmistakable song, and its sharp, readily recognizable chip. The bird utters this note with irritating persistency as long as one remains in the vicinity of its nest; its quickly aroused suspicions making it by no means easy to study its home-life closely.

Like other members of this genus, the Oven-bird is a walker but it lacks the tail-wagging habit so characteristic of its congeners. With tail often slightly raised and wings drooped, it steps daintily over the leaves in its search for food, stopping at times to mount to the lower tree branches, there to utter its song with great earnestness.

The Oven-bird's nest, seen from above, is so like the leaves among which it is placed that, as a rule, it is found only when a too close approach frightens the sitting bird, who, slipping from her snug home, trails pitifully over the leaves at one's feet.

Morris Gibbs ${ }^{1}$ describes a courtship scene in which the male Ovenbird flew singing above the female, who was perched on the ground, "describing every form of flight except that of regular sailing; first dashing through space to the edge of the glade, which was probably twenty feet across; then rising to the tops of the bushes, he would flutter, half fall towards his prospective mate. On a sudden he 
would flutter directly upward as we often see the English Sparrow or House Wren do, and reaching a height of twenty feet or more, dash about the clearing in varying circles, ever tending in his flight toward the object of his extravagant attention. She, in the meanwhile, sat silent and evidently interested in the performance. Suddenly the male dropped beside her, and alternately dashing and wheeling about, but continually on the move and always revolving about her, gave evidence of his adoration by a series of hops, dignified struts, droopings of the head and tail, elevation of the wings and crest, which would have done credit to both the Turkey and the Ruffed Grouse. While on the ground, the song was kept up with the usual vigor, but the interruption by the coarser, common notes was more frequent and the bird stopped in its struts in order to utter the notes which apparently caused him more effort than did the more beautiful song. The appearance of a third party on the scene, probably also a lover, caused the first performer to dash into the brush much to my disappointment."

Song.-Formerly, singing Oven-birds said, to my ear, with remarkable distinctness and decision, téacher, téacher, etc., in the ustal crescendo chant, but as I now hear the song the accent is placed on the last syllable. The call-note is a fine, small cheep, which, when one is near the bird's nest is uttered with irritating persistence.

The Oven-bird's flight song is one of the remarkable vocal performances among the Warblers. It is a wild outpouring of jumbled notes over which the bird seems to have no control and is often concluded with the common teachér song.

"Widely and intimately known though the Oven-bird is, there seem to be no written accounts either of the occasional strange vagaries of its perch-singing, or of the abundance and regularity of its nocturnal free-air flight-singing. Here in southwestern New Hampshire, its full flight-song,- delivered often from a height of a hundred or more feet above the tree-tops-is one of the commonest night-sounds, from early May to September. Indeed, we are apt to hear Ovenbirds singing high overhead the night before their first spring appearance in our daylit woods, and the same performance is often the last token we have of their presence in late September. Of course, this song is often uttered in the daytime, too,-especially at late afternoon, -but never so commonly as in the moonlit nights of mid-summer. Even on pitch-dark nights it is not uncommon, but then as a rule, the birds don't go so high,-sometimes singing fairly amid the tree-tops. This flight-song is a combination of the ustal Teacher, teacher, per- 
formance, uttered rather rapidly and wildly, with a medley of very different, hurried, warbling notes. The full utterance ustually begins as the bird poises, fluttering, at its greatest height; and ends, obscurely, as if smothered by the rushing air,-as the bird shoots downward with half-shut wings into the forest. But the performance is often heralded by a few sharp, reduplicated call-notes, and sometimes by a few preluding scraps of song as the eager singer darts upwatd from perch to perch and launches himself into open air. The full flight-song itself varies comparatively little, in my experience. The regular perch-song, too, Teacher, teacher, etc., is far more constant than are those of most Wood Warblers. Its tone-quality is, I believe, practically changeless, but its volume, speed and accentuation vary somewhat. Often, for instance, it is accented on the second syllable of each teacher, instead of on the first; and the whole song is sometimes uttered very softly-almost in a whisper-as is the case with most bird-songs.

"Strangest of all the aberrant utterances of the Oven-bird I have ever heard was a two-minute-long, practically unbroken gush of barely subdued flight-song, delivered by a bird quietly perching about twenty feet above the ground. This astonishing performance I witnessed on May 5, 1905, in a scrubby roadside forest near Monadnock's northern base. Having finished one round of his seeming endless carol, the 'possessed' Warbler changed his perch and began again, but after singing as before for about a minute, took wing and dashed off horizontally through the forest, singing as he went, till he passed out of my hearing. In the course of these three minutes of singing he had repeated the complete flight-song, omitting none of the regular elaborations, more than thirty times; and for the most part there had been no apparent break, no moment's pause, between the repetitions. Such prolonged swift singing would be a remarkable achievement for any bird, and puts the Oven-bird, potentially at least, very high in the list of avine songsters. That same May, in the same region, I heard three other perfectly distinct, surprising innovations of Oven-bird-song. One was like the syllables Cher-wuitchy wher, cher wutchy wher, terchér;-sung in a tone softer than that of the common teacher song. and slightly double-noted. Another was like Chock, ter-chér, chi-wi, the first note being merely the common deeper-toned call-note,-like the booming cluck of the Chipmunk,-and the others having a nearly normal teacher tone, though decidedly different in form and accentuation, and delicately varied one from another. This phrase I heard repeated many times, without noticeable change, and always with the 
chock used as a song-note. The fourth kind of abnormal song was in some ways the most remarkable of all, inasmuch as it contained hardly a suggestion of any Oven-bird notes, and was quite unrecognizable. Nothing short of watching the bird sing, at close range, and on various perches, could have convinced me of the song's true authorship. Fortunately, I had just these essential opportunities. There, on low branches, walked and sat the little orange-crowned rascal, singing, over and over again, a fluid, warbling song, rich-toned and sweet, though not very loud, and lasting only about five seconds. It suggested a Fox Sparrow singing somewhat in undertone, or a Purple Finch heard at a little distance. But, taken all together, these queer perchsung performances are but rare breaks in the abundant monotony of the Oven-bird's regular singing. Each of those I have described is as yet unique of its kind, in my experience" (Thayer, MS.)

Miss Paddock sends the following notation and writes:

"The words usually given for this song, teacher teacher, seem to me to be begun with the second syllable thus: cher-tea cher-tea cher-tea."

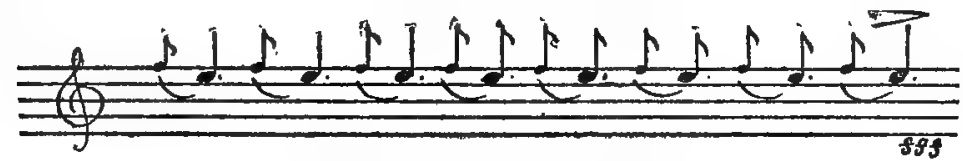

pe-chee pe-chee pe-chee pe-chee.

"Toward the end of June the song of this bird, which has been so constantly accentuated through our woodlands for two months, becomes less frequent, and though heard into July, comparatively few individuals sing through the month. In some seasons I have missed it after the first week. $* * *$ July 23 is my latest date.

"The second song-period occurs in August, and is transient and irregular; with varying seasons shifting a little to either side of the middle of the month" (Bicknell.)

Nesting Site.-Norris ${ }^{2}$ records a nest of the Oven-bird found at Weaverville, N. C., in the "end of a large pine log," but with this exception I know of no instance of the Oven-bird's departing from its habit of building on the ground. The site selected may be at the foot of a bush or tree or simply among dead leaves in more open spaces.

"The wooded upland, hillside or lowland are all alike to this bird. The nest is placed at the foot of a small bush or sprout of the huckleberry, laurel, dogwood, chestnut, sassafras, blackberry, or beside some debris. I can discover no particular significance in the position of the entrance in relation to exposure." (Burns, MS.) 
Nest.-The nest is unique in shape among the Warblers and its resemblance to an old Dutch oven has given the bird its name. It is completely arched with a flattened roof, the entrance being at one side. It is composed largely of dried leaves and leaf skeletons, with occasionally bits of moss, and is rather coarsely lined with grasses, blossom stalks, etc.

"Outwardly the nest is composed of dead grass, weed-stems, and bushy heads of the walking or tumbling grass; wild grapevine bark, strips of chestnut bark lining, dead and decayed leaf stems and leaves of the chestnut, oak, beech, maple, cherry, dogwood and hickory, principally the first two. Rarely bits of the hair moss and small dead twigs enter into the body of the nest. The chief difference, however, is in the quantity of grass or leaves. The structure is lined sparsely with long black horse-hair in almost every instance. In twenty per cent an additional underlining of grass and weed stems, and, in one instance, of grass stems alone. I have seen two nests in which a few long white horse-hairs appeared with the black, one with a few wild strawberry runners, and another in which oak blossoms were admixed. The nest is usually arched, the substructure or nest proper is sunk in the carpet of leaves to the level of the lower edge of the entrance hole. The mode of construction does not vary from the ordinary bird architecture. The outer framework of stems is bent over and work proceeds inward at which both sexes work more or less. Any little interference at this stage often results in the desertion of the incompleted structure. I have observed the frail straw arch erected by eleven A. M. and the whole edifice lined and completed within two days. The entrance measures r.20-1.70x2.00-2.20 inches, being wider than high." (Burns MS.)

Eggs.-4 or 5, in even proportions, 5 being as common a number as 4. Ground color a rather glossy white to creamy, over which are specks, spots and blotches of reddish brown, lilac-gray and dark chestnut, with under shell markings of lavender distributed in varying degrees; some are handsomely wreathed about large end with scattering marks over rest of egg, others have the large end completely covered with numerous spots and specks, while others are quite evenly marked over all the surface, but more heavily at the large end. Size; average, .79x.63; extremes, .88x.64, .68x.55, .87x.69. (Figs. 87,88.)

Nesting Dates.-Weaverville, N. C. May 7-June I (C. W. C.); West Chester, Pa., May 25-June 8 (Jackson) ; Waynesburg, Pa., May I5-June 29 (Jacobs) ; New York City, May 20-July 5, two-thirds incubated $(F . M . C$.$) ; Granville, N. Y., May 15$ (J.P.N.); New Haven, 
Conn., May 20-July Io (Bishop) ; Cambridge, Mass., full sets, first laying, May 25-June 5 (Brewster); Lancaster, N. H., June 2-June 5 (Spaulding) ; Bangor, Me., May 30-June 9 (Knight) ; Listowel, Ont., May 24-June 26 (Kells) ; Kalamazoo Co., Mich., May 27, Gibbs (Barrowes); Oberlin, O., May Io-June I5 (Jones).

\section{BIOGRAPHICAL REFERENCES}

(I) M. GrbBs, Song of the Golden-crowned Thrush, Orn. and Oöl., X, 1885, Igr. (2) J. P. N. [ORRIS], A Series of Eggs of the Oven-bird, Orn. and Oöl., XVII, 1892, 65. (3) C. T. Butrers, The Oven-bird [in Mass.], Nidologist, III, I896, I3I. (4) W. L. Kells, The Oven-bird, Ottawa Naturalist, XV, I902, 232.

\section{LOUISIANA WATER-THRUSH}

SEIURUS MOTACILla (Vieill.) Plate XVII

Distinguishing Characters. - The only Warbler with which this species is likely to be confused is Seiurus n. noveboracensis and its western form notabilis. It differs from the former as noted under that species, from the latter it may be known by its unspotted throat and buffy flanks. Length (skin), 5.60; wing, 3.25 ; tail, 2.10 ; bill, .55 .

Adult d", Spring.-Upperparts olive or olive-brown, the crown averaging darker the upper tail-coverts browner; wings and tail slightly browner than back and without white markings, the outer tail-feathers, however, are sometimes narrowly tipped with whitish; a conspicuous white line from bill over eye to nape; lower eye-lid white; below white, the flanks and crissum, and sometimes sides of breast, more or less strongly buff; dusky lines at sides of throat; throat usually unmarked, sometimes with a few inconspicuous olive tips to feathers; breast and sides heavily streaked with the color of the back.

Adult $\sigma^{*}$, Fall.-Not distinguishable, as a rule, from adult $\sigma^{*}$ in Spring but with the buff of underparts averaging deeper.

Young $\delta^{\prime}$, Fall.-Not distinguishable from adult $\delta^{A}$ in Fall.

Adult and young ?.-Resemble ${ }^{\prime}$ in plumage.

Nestling.-Above sooty olive-brown, a white superciliary stripe, conspicuous behind, faint before, the eye; breast and sides streaked with blackish, sides and crissum washed with buff; wings and tail as in adult but wing-coverts tipped with rusty.

General Distribution.-Eastern United States; north to New England and Minnesota; west to the Plains.

Summer Range.-The Louisiana Water-Thrush breeds throughout its range in the United States, which extends north to Massachusetts (Sheffield, June I I, I896; Springfield, July 28, I895; Mount Tom, April 28, I869; Leveritt, May I8, I871; Amherst, July I2, 1886), New York (Lake George, May 8, I877, and May 16, 1881), Ontario (Toronto, London, Guelph), Michigan (Detroit), Wisconsin (Delavan, May 18, I900; Milwaukee County, April 25, I897, Lake Koshkonong), and Minnesota (Red Wing). 


\section{Plate XVII}

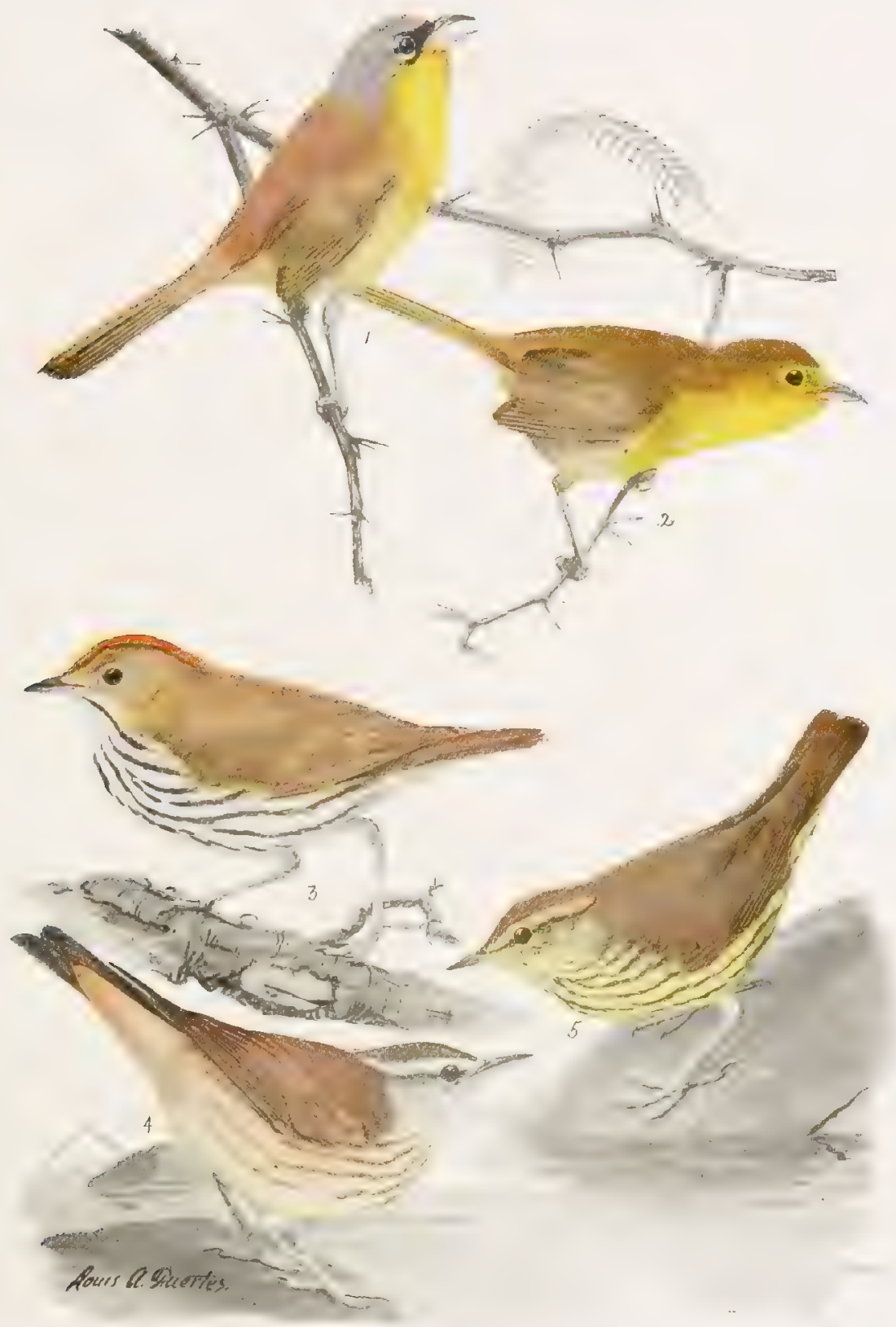

1. Rio Grande Yellow-throat, Male.

3. Ovengird, Adult,

2. Rio Grande Yellow-thrort, Female

4. Louisiana Water-Thrush, Adult, 5. Northern Water-Thruin, Adult. (ONE-HALF NATURAL SIZE.) 

Its western range is found in eastern Nebraska (Lincoln, Beatrice), eastern Kansas (Manhattan, Onaga) and, sparingly, in eastern Texas (Boerne); accidental in Maine (Norway, 1865, Waterville, May, I865).

Winter Range.- Mexico to Colombia, South America; most of the West Indies and the Bahamas.

Spring Migration.-

\begin{tabular}{|c|c|c|c|}
\hline PL,ACE & $\begin{array}{l}\text { No. of } \\
\text { years' } \\
\text { record }\end{array}$ & $\begin{array}{l}\text { Average date of } \\
\text { spring arrival }\end{array}$ & $\begin{array}{l}\text { Earliest date of } \\
\text { spring arrival }\end{array}$ \\
\hline \multicolumn{4}{|l|}{ Atlantic Coast- } \\
\hline Gainesville, Fla. $\ldots$ & & & March 8, I887 \\
\hline $\begin{array}{l}\text { Mt. Pleasant, S. C. . . } \\
\text { Raleigh, N. C. ...... }\end{array}$ & II & March 3I & $\begin{array}{ll}\text { March } 21, & 1904 \\
\text { March } 26, & \text { I889 }\end{array}$ \\
\hline Asheville, N. C. (near) & 5 & March 28 & March 25,1894 \\
\hline French Creek, W. Va. . & 4 & April 3 & March 27,1890 \\
\hline Washington, D. C. ..... & 5 & April II & April 2, I905 \\
\hline Waynesburg, Pa. ........... & 4 & April I3 & April 8, I894 \\
\hline Englewood, N. J. ...... & 7 & April I7 & April I4, I886 \\
\hline Renovo, Pa. & 7 & April 23 & April II, I9OI \\
\hline Portland, Conn. ........... & 3 & April I7 & April I3, I892 \\
\hline \multicolumn{4}{|l|}{ Mississippi Valley- } \\
\hline New Orleans, La. & & & April 2, 1898 \\
\hline Eubank, Ky. & 9 & March 27 & March 24, I889 \\
\hline St. Louis, Mo. & 6 & April 8 & March 29, I884 \\
\hline Waterloo, Ind. & 5 & April 7 & April 5,1893 \\
\hline Oberlin, Ohio & 4 & April I4 & March 28, 1904 \\
\hline Petersburg, Mich. ............. & 9 & April I7 & April 4, I890 \\
\hline Lanesboro, Minn. .... & 9 & April 22 & April 18, I887 \\
\hline
\end{tabular}

Fall Migration-

\begin{tabular}{|c|c|c|c|}
\hline PL,ACE & $\left|\begin{array}{l}\text { No. of } \\
\text { years' } \\
\text { record }\end{array}\right|$ & $\begin{array}{l}\text { Average date of } \\
\text { last one seen }\end{array}$ & $\begin{array}{l}\text { Latest date of } \\
\text { last one seen }\end{array}$ \\
\hline 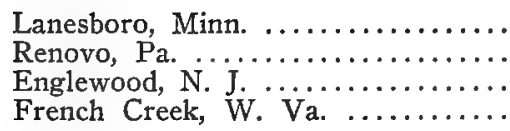 & $\begin{array}{l}3 \\
6\end{array}$ & $\begin{array}{l}\text { August } 3 \\
\text { September } 8\end{array}$ & $\begin{array}{l}\text { August 26, I888 } \\
\text { September 30, I903 } \\
\text { October 2, I885 } \\
\text { October } 7,1890\end{array}$ \\
\hline
\end{tabular}

The Bird and its Haunts.-This shy, elusive creature seems to me more like some untameable spirit of the woods than a bird. Cautiously we may follow his sharp, decisive call or wild, ringing, almost startling song, through the luxuriant undergrowth only to hear them repeated from some point far ahead or even behind us; and, if by good fortune, we should get a glimpse of his nervously teetered body, before we have time for one satisfactory look he is off-not to the cover of the nearby bushes, but on a low, darting flight that takes him speedily out of sight. 
The Water-Thrush inhabits not only watered bottom-land forests, where moss-covered logs and rank undergrowth give an almost tropical character to the surroundings, but is also found on hillside and mountain streams where the woods are more open below. Always, however, he requires water, and his food is largely secured from the shores of streams or muddy banks of pools. Even when at ease the bird seems controlled by a sense of restlessness, and not only when walking, but when perching, constantly teeters its body. Both the movement and the bird itself suggest the Dipper (Cinclus) but the Dipper is more of a bobber, the whole body moving from the knees, while the Water-Thrush is a tilter or teeterer, its longer tail accentuating this type of motion.

Allison (MS.) writes that the typical breeding haunt of the Louisiana Water-Thrush in Mississippi, "is the bank of a clear, running stream, flowing over white sand and pebbles; the smaller streams are generally chosen, but creeks and small rivers are not without their Water-Thrushes. The southern limit of its breeding range seems to be determined by the presence of such streams, and therefore probably does not extend to the Gulf coast."

Song.-In recent years I have been impressed with the similarity between the song of this species and that of Dendroica dominica. The song of Seiurus is louder and wilder but as sung by the individuals which have come to my attention it is less musical than that of dominica which lacks the concluding twitter characteristic of the Water-Thrush song. The flight-song of this species is a thrilling performance which carries the bird above the tree-tops in uncontrollable musical ecstacy. The call-note resembles that of Seiurus noveboracensis but to my ear is slightly louder.

William Brewster describes the song of this species as "somewhat like that of $S$. noveboracensis, being quite as loud, almost as rapid, and commencing in nearly the same way but lacking the beautiful crescendo termination, and altogether, a less fine performance. Represented by words it would be nearly as follows: pseur, pseur, per see ser."

"The call-note is not distinguishable from that of $S$. noveboracensis. The song-uttered, it seems, only at the breeding-ground in the breeding season-is remarkably fine, being very loud, clear, and far-reaching. It is generally uttered from a perch very near, or over, the water,-not from the ground." (Allison, MS.)

"The song varies a good deal. May II, I897, I heard a song of eight notes as follows: first two low, next two high, then four low, and 
more rapid. On April 20, 1902, I heard a song which, except for the three opening notes, I never would have recognized. The first three notes were the usual clear, piercing, Water-Thursh notes; but the rest was an intricate jumble of fine notes far softer, and of an entirely different quality. This song was repeated several times. On May I4. I904, I heard a song consisting of three notes, wee-wee-wee, then whitchee, whit-chee, followed by a confused and less loud jumble." (Farwell, MS.)

Nesting Site.-The nest is placed in the bank of a stream or among the upturned roots of a fallen tree.

"The nest is placed in a little nook in the bank, usually a hole scraped out by the bird, from one to six feet above running water." (Burtch, MS.)

Nest.-The nest is generally a loosely made bulky structure filling the cavity or niche in which it is placed, and externally is composed largely of dried leaves, coarse grasses, and rootlets, with often bits of moss; the lining consists chiefly of coarse grasses. "The nest is made on a mat of dead leaves, moss, and dead grass, lined with rootlets, dead grass or dead pine leaves. I have sometimes found a few hemlock twigs in the nest. May 2r, I899, I saw a male feeding the female which was sitting on five eggs two of which were just hatching." (Burtch, MS.)

Eggs. -4 to 6 usually 5, rarely 4 or 6 ; in a carefully selected series of 45 sets, 4 are of 6 eggs each, 35 of 5 and the balance of 4 . Ground color white to creamy white; the markings vary greatly, many shades of chestnut-brown, cinnamon-rufous, lilac-gray, with lavender under shell markings, which are distributed over the egg in all manner of specks, spots, blotches and conglomerate masses either in a zone, wreath or solid mass of spots on large end; the rest of the egg is well marked also, but the spots become fewer and less decided toward the small end. Size; average, .77x.6r ; extremes, $.84 x .65, .72 \times .58$. (Figs. 92-94.)

Nesting Dates.-Walke, N. C., April 22; Waynesburg, Pa., May 5 , five eggs on point of hatching-June 8, last date for eggs of first laying (Jacobs) ; New York City, May I I (F.M.C.) ; Branchport, N. Y., May 6-July I (Burtch); New Haven, Conn., May 6-June io (Bishop): Oberlin, O., April I5-June Io (Jones); Lake Co., Illinois, June I I (Gault) ; Petersburg, Mich., May 5, Trombly (Barrozws).

\section{BIOGRAPHICAL REFERENCES}

(I) WM. Brewster, Some Observations on the Birds of Ritchie County, West Virginia, Ann. Lyc. N. Y., XI, 1875, 136; (2) Nesting ef the Largebilled Water-Thrush, (in Indiana), Bull. Nutt. Orn. Club, III, I878, I33. 
F. T. JENKs, Large-billed Water-Thrush, [in R. I.], Orn. and Oöl., VII, I882, II4. (4) J. N. Clark, Large-billed Water-Thrush, (in Conn.), Orn. and Oöl., VII, 1882, I45. (5) R. B. M'LAUGHLIN, Nesting of the Louisiana Water-Thrush, [in Nor. Car.], Orn. and Oöl., XII, I887, I74. (See also Brimley, Ibid., XIV, I69.). (6) J. P. N. [0RRIs], A Series of Eggs of the Louisiana Water-Thrush, Orn. and Oöl., XV, I890, 53.

\section{NORTHERN WATER-THRUSH}

SEIURUS NOVEBORACENSIS NOVEBORACENSIS (Gmel.) Plate XVII

Distinguishing Characters.-The uniform dark olive upperparts, including the wings and tail, which are without white markings, yellowish or buffy yellow line over the eye, sulphur yellow, heavily streaked underparts are the principal distinguishing marks of this species. From Seiurus motacilla it may be known by its usually yellowish or buffy, instead of distinctly white superciliary line, its sulphur yellow underparts streaked with black, not with olive or blackish, and its spotted throat. Length (skin), 5.25; wing, 2.95; tail, 2.05 ; bill, .50.

Adult o, Spring.-Upperparts, wings and tail olive or olive-brown; outer tail-feathers rarely with white at tips; forehead with a more or less faint whitish or buffy median line; a conspicuous yellowish whitish, or buffy line from bill over eye to nape; underparts quite uniformly sulphur yellow, the throat, breast and sides streaked with black, the flanks washed with the color of the back.

Adult $\delta$, Fall.-Practically indistinguishable from the adult $\delta$ in Spring but the superciliary line averages buffier.

Young $\sigma^{*}$, Fall.-Not distinguishable from the adult $\delta$ in Fall.

Adult and young .. - Resemble $\sigma^{*}$ in plumage.

Nestling.-Above olive-brown tipped with rusty and obscurely spotted with black; a yellowish superciliary line; below sulphur yellow, throat, breast and sides heavily streaked with black and with more or less rusty wash; wings and tail much as in adult but wing-coverts tipped with rusty.

General Distribution.-Eastern North America.

Summer Range.-Maine, northern New Hampshire (Lake Umbagog, Ossipee, Dublin), northern Vermont (Burlington), Pennsylvania (Clearfield, Crawford, Clinton, Elk, Cambria, Center and Lycoming Counties), mountains of West Virginia, southern Michigan southern Wisconsin, Minnesota (Red Wing).

Winter Range.-Florida southward through the West Indies, Central America, and northern South America.

Spring Migration.--The more western records refer to the western form of this bird. (See page 23x.)

The Bird and its Haunts.-When, during the migrations, a Water-Thrush is seen in one's garden or some other locality quite unlike the normal haunts of the species, one may be reasonably sure that it is this species rather than Seiurus motacilla. The former, in my experience, is at all times less shy and retiring and may be observed at short range by the exercise of a little caution. 
Spring Migration.-

\begin{tabular}{|c|c|c|c|}
\hline PLACE & $\mid \begin{array}{l}\text { No. of } \\
\text { years' } \\
\text { record }\end{array}$ & $\begin{array}{l}\text { Average date of } \\
\text { spring arrival }\end{array}$ & $\begin{array}{l}\text { Earliest date of } \\
\text { first one seen }\end{array}$ \\
\hline \multicolumn{4}{|l|}{ Atlantic Coast- } \\
\hline Raleigh, N. C.... & 8 & April 24 & April 18, 1894 \\
\hline Washington, $\mathrm{D} . \mathrm{C} \ldots \ldots \ldots \ldots \ldots$ & 5 & April 30 & April 24,1904 \\
\hline Germantown, Pa. $\ldots \ldots \ldots \ldots \ldots$ & 5 & May 6 & May $\quad 4,1888$ \\
\hline 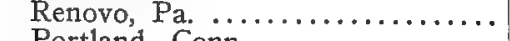 & 5 & May & May I, 1897 \\
\hline & 4 & May & May I, I89I \\
\hline 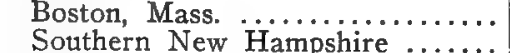 & 5 & May & May 2, I896 \\
\hline 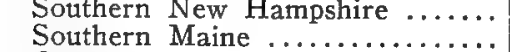 & $\begin{array}{l}4 \\
6\end{array}$ & $\begin{array}{lr}\text { May } & 7 \\
\text { May } & \text { Io }\end{array}$ & $\begin{array}{ll}\text { May } & 3,1902 \\
\text { May } & 7,1002\end{array}$ \\
\hline Quebec, Can. .. & 6 & May 7 & 2,1902 \\
\hline Scotch Lake, N. B......... & 6 & May I2 & 6,1905 \\
\hline Lake Mistassini, Que. .......... & & & May 19,1885 \\
\hline Hamilton River, Labrador ... & & & May 3I \\
\hline \multicolumn{4}{|l|}{ Mississippi River- } \\
\hline St, Louis, Mo. .. & 6 & March 27 & April 21, $188_{3}$ \\
\hline Waterloo, Ind. ... & 5 & April 26 & April $23, \mathrm{r} 886$ \\
\hline Oberlin, Ohio $\ldots \ldots \ldots \ldots \ldots \ldots$ & 7 & April 29 & April 26, 1904 \\
\hline $\begin{array}{l}\text { Listowel, Ont. } \ldots \ldots \ldots \ldots \ldots \ldots \ldots \ldots \\
\text { Guelph, Ont. }\end{array}$ & $\begin{array}{r}12 \\
8\end{array}$ & $\begin{array}{l}\text { April } 28 \\
\text { April } 30\end{array}$ & April 25, 1896 \\
\hline 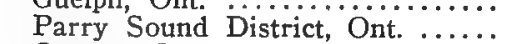 & 7 & May 5 & $\begin{array}{l}\text { Apt11 28, } 1905 \\
\text { May 2, } 1897\end{array}$ \\
\hline Ottawa, Ont. ............. & 3 & May Io & 8,1905 \\
\hline Detroit, Mich. & 6 & May & April 28, 1886 \\
\hline Southern Wisconsin. & 8 & May & April 27, rgor \\
\hline Keokuk, Ia. & 6 & May & April 30,1895 \\
\hline Lanesboro, Minn. & 9 & May & April 30,1890 \\
\hline Northwestern Minnesota .. & 4 & May & 3,1890 \\
\hline Aweme, Man. $. . . \ldots \ldots \ldots .$. & 4 & May & 7,1896 \\
\hline Minneapolis, Minn. ........ & 5 & May I5 & May 12,1902 \\
\hline Fort Simpson, Mackenzie . & 3 & May Ig & May I4, I904 \\
\hline Columbia Falls, Mont. ...... & 5 & May 20 & May 18,1895 \\
\hline
\end{tabular}

Fall Migration.-

\begin{tabular}{|c|c|c|c|}
\hline PLACE & $\left|\begin{array}{l}\text { No. of } \\
\text { years' } \\
\text { record }\end{array}\right|$ & $\begin{array}{l}\text { Average date of } \\
\text { first one seen }\end{array}$ & $\begin{array}{l}\text { Earliest date of } \\
\text { first one seen }\end{array}$ \\
\hline 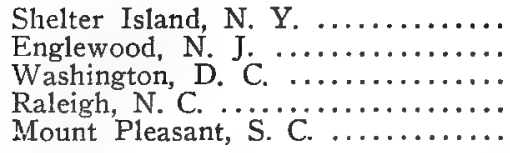 & $\begin{array}{l}4 \\
3 \\
4 \\
8\end{array}$ & $\begin{array}{l}\text { August i6 } \\
\text { August i4 } \\
\text { August } 5 \\
\text { August in }\end{array}$ & $\begin{array}{l}\text { August } 1 \mathrm{I}, \quad 1896 \\
\text { August } 8,1897 \\
\text { July } 28, \quad 1889 \\
\text { July } 29, \quad 1893 \\
\text { July } 27, \quad 1897\end{array}$ \\
\hline PLACE & $\left|\begin{array}{l}\text { No. of } \\
\text { years' } \\
\text { record }\end{array}\right|$ & $\begin{array}{l}\text { Average date of } \\
\text { last one seen }\end{array}$ & $\begin{array}{l}\text { Latest date of } \\
\text { last one seen }\end{array}$ \\
\hline 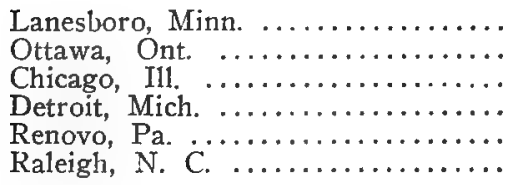 & $\begin{array}{l}3 \\
2 \\
8 \\
6 \\
4 \\
6\end{array}$ & $\begin{array}{l}\text { September } 22 \\
\text { September } 16 \\
\text { September } 20 \\
\text { September } 26 \\
\text { October } 3 \\
\text { October I }\end{array}$ & $\begin{array}{l}\text { September 24, I889 } \\
\text { September I7, I891 } \\
\text { October I, I895 } \\
\text { October 8, 1905 } \\
\text { October 5, 1902 } \\
\text { October 6, 1894 }\end{array}$ \\
\hline
\end{tabular}


I recall a Northern Water-Thrush which boarded a steamer on which I was sailing from Tampico, Mexico, to Havana, when we were about midway between these two points. The bird, apparently quite at home, hopped about the steamer's deck, entered the Captain's cabin, as though to examine the charts, and when we approached the coast of Cuba, disappeared, doubtless resuming its more northern flight.

Brewster ${ }^{3}$ says that at Cambridge they never fail to visit his garden in "both spring and autumn, occurring there most numerously in August, when I have known as many as six or seven to be present at one time. We meet with them oftenest and most abundantly, however, in dense thickets covering swampy or, at least, very low, damp ground, usually not far from water. In the Fresh Pond swamps and along the willow-shaded causeway that crosses Rock Meadow, they literally swarm for days in succession at the height of the spring migration. The loud, rapid, musical songs of the males may then be heard coming from several directions at once, and the birds be seen darting from thicket to thicket or walking demurely about the edges of shallow pools, tilting their tails incessantly."

Gerald Thayer (MS.) writes: "This brilliant songster of the wilderness is a local and uncommon summer resident about Monadnock's northern base haunting some of the deep woodland bogs where Parulas are commonest, and the borders of a few big brooks in the heavier and drier forest. Like the Oven-bird and the Louisiana WaterThrush, it is for the most part a ground bird and a walker. Its nest I have never seen, though I've spent many midsummer afternoons, mosquito-tortured, in its nesting places, watching it trip about among black puddles, and hearing its vivid sudden song. Though our bird is less shy than the southern kind, it is, in my experience, out and away the shyest Warbler of the North Woods."

Song.-The Water-Thrush is one of the notable musicians among the Warblers. While its song lacks the ringing wildness of that of Seiurus motacilla I have come to agree with the opinion quoted from William Brewster under that species, that noveboracensis is the finer singer of the two.

The sharp, steely alarm-note, clink, is perhaps not quite so penetrating as the essentially similar call of Seiurus motacilla. So far as my experience goes the Prothonotary is the only other Warbler with a similar call-note.

"At its best the song of this species is not quite so fine, perhaps, as that of Seiurus motacilla-it is very different, and has a rare grace and vigor of its own. Like the Oven-bird the Northern Water- 
Thrush makes up for a great general regularity of singing by an occasional wide lapse into variation. Its flight-song, a performance relatively far less common than the Oven-bird's (?), seems to be nearly changeless. It is like the common perch-song, but quicker and longer, and 'framed' in a hurried jumble of half-call-hali-song notes; - the whole delivered as the bird dashes horizontally through or barely above the woods. Most notable among the few important variations of its perch-song I have heard was a long, liquid strain seemingly made up of at least three united repetitions of the regular utterances, going unusually fast, in a thinner tone, and intersprinkled with sharp notes of 'chippering,' unlike the common call-notes. The typical perch-song itself is hard to describe in words. A ringing, bubbling warble, swift and emphatic, made up of two parts, barely divided, the second lower-toned and diminuendo. The common call-note is a ringing chip, somewhat less loud and emphatic than that of the Louisiana Water-Thrush, but more so than that of any other (?) northern Warbler." (Thayer, MS.)

Nesting Site.-The nest is placed on the ground among the roots of an upturned tree, in cavities under stumps, in the side of a bank, or in similar situations.

"The typical nest is placed at the base of an ash or elm tree in the thick moss, close in a crotch between the roots or where a root projects out leaving a cavity under it, also at the base of moss-covered stumps usually but a few inches above the water. A nest found May 22, 1904, was at base of a moss-covered stump, and there was a Song Sparrow's nest two feet above in the same stump. A nest found May 22, 1903, was under a moss-covered log and could not be seen without getting down on my knees." (Burtch, MS.)

Nest.-Nests from Maine are externally composed almost wholly of a green moss with a slight admixture of bits of leaves, grasses, bark, or twigs, and are thickly enough lined with the brown blossom stalk of a species of moss, to make the color of the interior contrast strongly with that of the exterior.

"The nests are made entirely of moss with the moss blossom stems for lining, so are not easy to find as they look to be part of the moss in which they are imbedded." (Burtch, MS.)

Eggs.-Usually 4 or 5, about evenly divided. Ground color creamy white, specked, spotted and blotched with cinnamon-rufous, hazel and lavender gray, more or less inclining to wreathe about the large end, though in some cases the markings combine to almost cover the large end, over rest of egg the markings are quite profuse but 
never very close together; one extreme set of five eggs show the wreath about the small end. Size; average, .77x.60, extremes, .81x.61, 73x.58, .74x.63. (Figs. 89-91.)

Nesting Dates.-Branchport, N. Y., May I8-May 30 (Burtch); Lancaster, N. H., June 9, full-grown young following parents (Spaulding) ; Pittsfield, Me., May 28-June 9, young about two weeks old. (Knight) ; Listowel, Ont., May 20-June ro (Kells).

\section{BIOGRAPHICAL REFERENCES}

(I) W. L. Kelis, Nesting of Some Canadian Warblers, Ottawa Naturalist, $\mathrm{XV}$, 1902, 228. (2) J. M. SWAIN, Contributions to the Life-History of the Water-Thrush, Journ. Me. Orn. Soc., VI, I904, 70. (3) Wm. BreWSTER, Birds of the Cambridge Region, 349.

\section{GRINNELL'S WATER-THRUSH}

\section{SEIURUS NOVEBORACENSIS NOTABILIS Ridew.}

Subspecific Characters.-Similar to $S$. noveboracensis noveboracensis, but larger, bill longer, upperparts darker, less olive; line over eye and the underparts whiter. Wing, 3.10; tail, 2.20; bill, .52.

General Distribution.-Interior of North America northwest to Alaska, southeast to Florida.

Summer Range.-Western Nebraska (Sioux City), northern Minnesota northwest to Alaska, west to British Columbia. The western line of the district in which the species is common during migration is found from Nebraska southward at the edge of the Plains; to the westward it has been taken casually in Arizona (near Camp Crittenden, August 1874; Catalina Mountains, September 2, I884; Tucson, May 4, I88I ; Huachuca Mountains, August 3I, I903), Colorado (Denver May 12, I873; Fort Lyon, May 6, 1886; Boulder, May I4, I904), Wyoming (Lake Como, May I0, I878; Cheyenne, Fort Bridger), Utah (Lower Santa Clara Valley, May Ir, I891), Idaho (Hellgate), Washington (Camp Moogie).

In migration occurs eastward casually to New Jersey, District of Columbia, and more commonly in the southeastern Atlantic States.

Winter Range.-The West Indies, Mexico, Central America and northern South America.

The Bird and its Haunts.-This western form of the WaterThrush resembles in habits the closely related Northern Water-Thrush.

Nelson says that in Alaska it is abundant in the interior as well as at the mouth of the Yukon, "in fact, is one of the most commion bush-frequenting birds throughout the entire fur countries, extending north even beyond tree limit." 
Biographical ReFERENCES

(I) W. L. KeLLs, Grinnell's Water-Thrush (in British Columbia), Nidologist, I, 1894, 42, 58. (2) E. W. Nerson, Report on Nat. Hist. Coll. made in Alaska, 204 (the bird is given as Seiurus noveboracensis).

\section{Genus OPORORNIS Baird}

Compared with Geothlypis, Oporornis (taking $O$. agilis as the type) has the wing much longer and more pointed, the tail decidedly less rounded. The wing is at least three and a half, instead of two and three-fourths times as long as the tarsus, the outer primary is usually the longest, the outer tail-feathers are but little the shortest, the hindtoe is as long as its claw.

While admitting the characters which distinguish Oporornis agilts from Geothlypis most systematists have treated Oporornis as a subgenus of Geothlypis because of the existence of several species possessing intermediate characters. The attempt, however, to force Oporornis into Geothlypis negatives any description emphasizing the well-marked structural features which prevail in that genus and, at the same time, prevents the proper description of the generic characters which distinguish Oporornis. It seems desirable, therefore, to recognize both genera and to place the intermediate species with those forms to which they appear to be most nearly related. Of these intermediate species the Kentucky Warbler has invariably been placed in Oporornis, while the Mourning and Macgillivray's Warbler have usually been grouped with Geothlypis. Mr. Ridgway, however, on the basis of their general coloration, more pointed wing and longer outer primary, includes them in Oporomis and I have little doubt of the correctness of his decision.

Under this ruling the genus contains four species, three of which are eastern and one western in its distribution.

\section{KENTUCKY WARBLER \\ OPORORNIS FORMOSUS (Wils.) Plate XVIII}

Distinguishing Characters.-The Kentucky Warbler may always be known by its entirely yellow underparts, absence of white in wings and tail, yellow line over the eye, black or blackish on crown and sides of throat. Length (skin), 5.00 ; wing, 2.65 ; tail, 2.00 ; bill, .45.

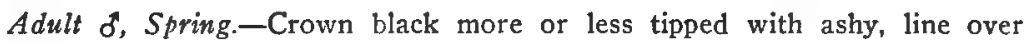
and around back of eye yellow, rest of upperparts, wings and tail olive-green, outer vane of outer primary grayish, bend of wing yellow; underparts from chin to crissum bright yellow, lores, cheeks, and band at side of throat black. 
Adult o", Fall.-Similar to adult $\delta^{t}$ in Spring but gray edgings to crown feathers wider and more numerous, black at sides of throat tipped with yellowish.

Young $\delta^{*}$, Fall.-Similar to adult $\delta$ in Fall but crown more heavily tipped, tips browner, black areas less pronounced.

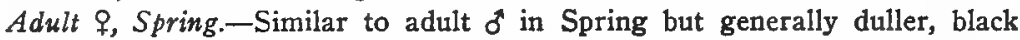
areas blackish or only dusky and more heavily tipped, tips brownish or olive.

Adult $q$ and Young $q$, Fall.-I have no Fall females with both age and sex accurately determined. The material at hand, however, indicates a difference in females taken at that season similar to that observed in the male.

Nestling.-Resembling nestling of $G$. trichas; the greater and median wingcoverts are like the back and are tipped with rusty.

General Distribution.-Eastern United States; north to New York and Minnesota; west almost to the Plains.

Summer Range.-The Kentucky Warbler is a forest lover and makes its chief home in the heaviest timbered regions and dark, damp woods of the central Mississippi Valley. Eastward it breeds more or less locally from North Carolina to the lower Hudson Valley (Sing Sing, Pleasantville) and to Pennsylvania (Chester, Delaware, and Beaver Counties); occurs casually north to Connecticut (Suffield, August 16, I876, Lyme).

There is a single record of its breeding in South Carolina (Cæasar's Head) and four records of its occurence during migration in Florida. The Kentucky Warbler is common in the state from which it takes its name, and in the watershed of the Ohio River and its tributaries. It is uncommon north of this region, but is found as far as Lake Erie-accidental in Quebec, southern Ontario (near London, May, I898), southern Michigan, southern Wisconsin (Racine, May Io, 185r, Lake Koshkonong) and southern Minnesota.

The western limit of its range is reached in southeastern Nebraska (Omaha, Lincoln, Peru) and thence through eastern Kansas (Leavenworth, Atchison, Manhattan) to eastern Texas (Navarro County, San Antonio; in migration at Corpus Christi).

Though not uncommon in favorable localities along the streams of these states, it is not nearly so abundant as in the Ohio Valley.

It breeds principally below an elevation of $I, \infty 00$ feet, but at Asheville, N.C., it breeds at 2,000 feet altitude, and has been noted up to 3,500 feet.

Winter Range.-Southern Mexico to Colombia, South America. Accidental in the West Indies.

Fall Migration.-The southward movement begins the last of July, and on October 7 the species has been taken at the extreme southern limit of its known range in Colombia, South America. Some 


\section{Plate XVIII}

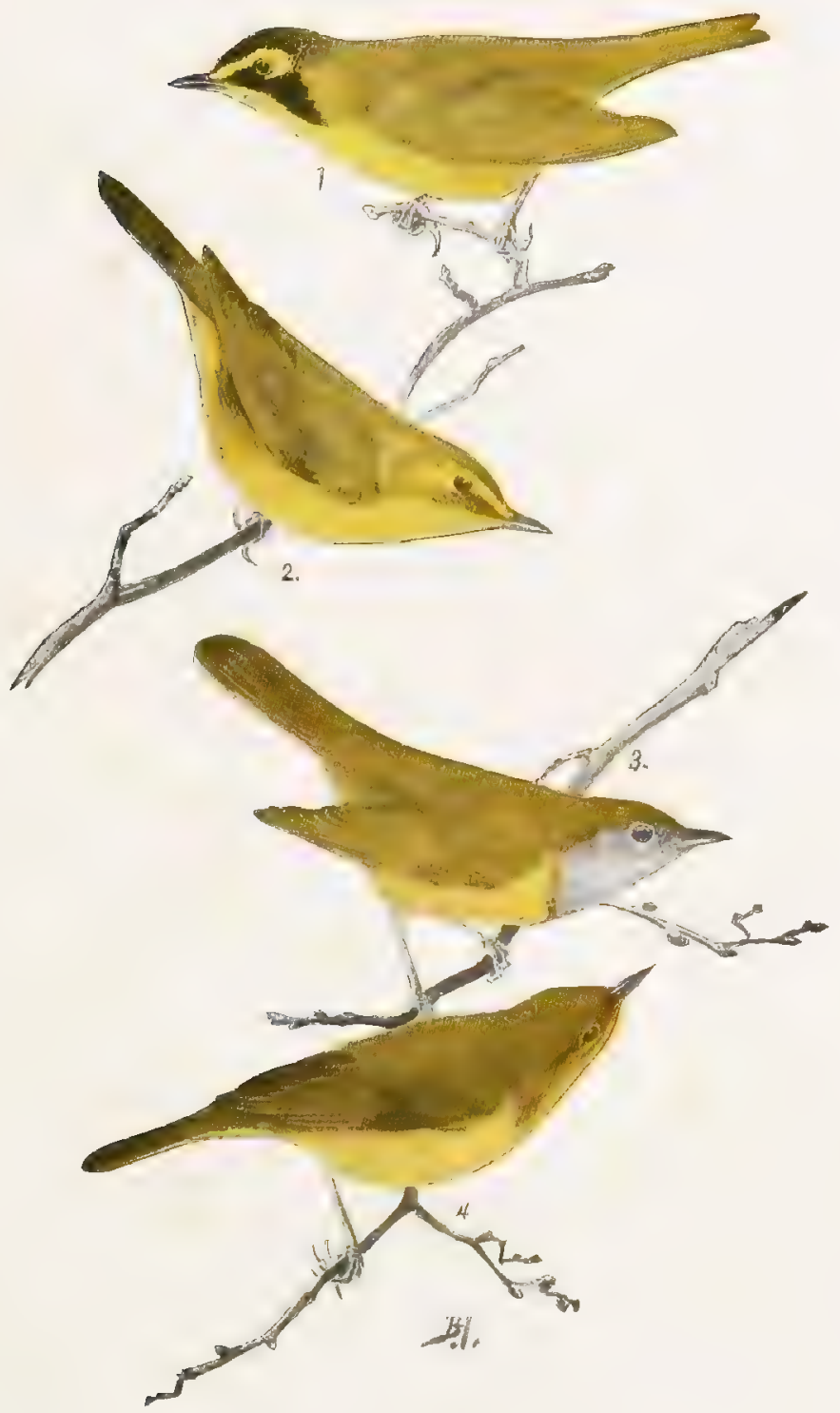

1. Kentucky Warblek, Male,

3. Connecicut Warhler, Mare.

2. Kentucky Warblek, Female.

4. Connelitur Warbielr, Female, 

records of the latest observations are at Berwyn, Pa., September 4, I896; Beaver, Pa., September 13, I888; Cadiz, Ohio, September 23, I900; Eubank, Ky., September 6, I888; Raleigh, N. C., September 12, I894; New Orleans, La., October 19, 1895.

Spring Migration.-

\begin{tabular}{|c|c|c|c|}
\hline PI,ACE & $\mid \begin{array}{l}\text { No. of } \\
\text { years' } \\
\text { record }\end{array}$ & $\begin{array}{l}\text { Average date of } \\
\text { spring arrival }\end{array}$ & $\begin{array}{l}\text { Earliest date of } \\
\text { spring arrival }\end{array}$ \\
\hline 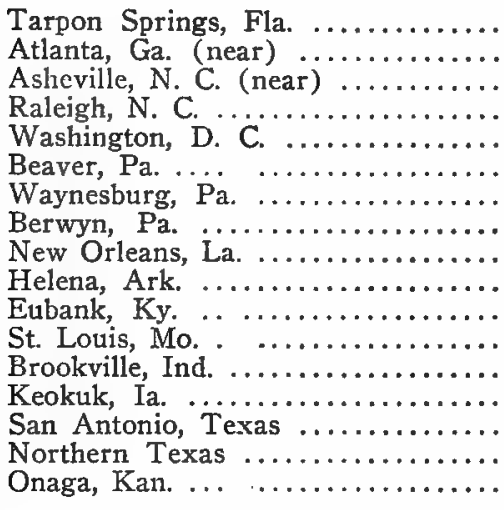 & $\begin{array}{l}6 \\
3 \\
7 \\
4 \\
2 \\
\\
6 \\
4 \\
8 \\
9 \\
4 \\
4 \\
4 \\
5 \\
7 \\
9\end{array}$ & $\begin{array}{lr}\text { April } & 7 \\
\text { April } & 2 \mathrm{I} \\
\text { May } & 1 \\
\text { May } & 2 \\
\text { May } & 1 \\
& \\
\text { May } & 7 \\
\text { April } & \text { I } \\
\text { April } & 20 \\
\text { April } & 21 \\
\text { April } & 24 \\
\text { May } & 6 \\
\text { May } & 7 \\
\text { April } & \text { I4 } \\
\text { April } & \text { I5 } \\
\text { May } & 5\end{array}$ & 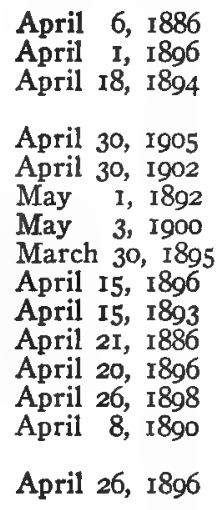 \\
\hline
\end{tabular}

The Bird and its Haunts.-My own experience with this Warbler, which in habits suggests both the Yellow-throat (trichas) and Ovenbird, is confined to the west side of the Hudson River, at Englewood, N. J. Here, on the western slope of the Palisades, in moist woods with a fairly heavy undergrowth, it is not uncommon, though it is virtually unknown in the apparently favorable woods growing in the valleys to the west. During the nesting season, the loud, musical song of the male readily betrays his whereabouts, and one may watch it with ease as it frequently utters its notes from a perch at a height of twenty feet or thereabouts, descending at intervals to walk about on the ground and search for food.

At Berwyn, Pennsylvania, Burns (MS.) writes: "The Kentucky Warbler is usually one of our commonest summer residents, though apt to be rather irregular in abundance now and then. During the season of 1897 , it became abundant, falling off to about half the number the following year. It is here an inhabitant of the overgrown clearings, swampy thickets, and the borders of woodland; a bird of the south, loving the luxuriant undergrowths of spicewood, ferns, mandrake, skunk cabbage, and other shade-loving plants of rank growth. 
"It is very cunning in the concealment of its home, usually running quietly from the nest before the intruder is within ten or twenty feet, protesting as it becomes visible at a safe distance, and as it seems always to be chipping around, significance cannot always be attached to its actions. When the mate appears the object of their suspicions may be circled at a safe distance from bush to bush and bush to ground, several times in the course of half an hour, and then one bird may slip unseen to the nest, while the other lingers a little longer to keep up the deception, retiring at last to some distant part of the woods, or perhaps it may gradually lessen the volume of protesting notes until it becomes silent, and with apparent content, settle on what one confidently thinks must be the nest, only to flush it from an empty bunch of weeds.

"The eyes of the young are opened on the fifth day and in two instances birds left the nest on the eighth day. If the too inquisitive observer is noticed lurking around, the frantic female will frequently drive the young from the nest prematurely. The male, while protesting vigorously, seldom approaches as closely as the female."

In Mississippi, Allison (MS.) writes that the Kentucky Warbler inhabits "undergrowth in damp, or, at least, heavily shaded, woods. It may frequent the thickets of rose-bay (Illicium) and the tangle of bamboo briers on the Gulf coast, the varied tangled growth along the creeks and rivers of the higher regions, or the brakes of switchcane; but it always selects a low, thick growth, where it feeds almost entirely on the ground."

Song.-With the Kentucky Warbler singing is a serious performance to which he gives his entire attention. I quote from my 'Handbook': "His song is entirely unlike that of any other Warbler. It is a loud, clearly whistled performance of five, six, or seven notes -tur-dle, tur-dle, tur-dle-resembling in tone some of the calls of the Carolina Wren. Even in the woods it may be heard at a distance of about one hundred and fifty yards.

"In the height of the breeding season this Warbler is a most persistent singer. On one occasion, at Englewood, N. J., I watched a male for three hours. During this period, with the exception of five interruptions of less than forty-five seconds each, he sang with the greatest regularity once every twelve seconds Thus, allowing for the brief intervals of silence, he sang about 875 times, or some 5,250 notes. I found him singing, and when I departed he showed no signs of ceasing." 
'The call-note is a low-pitched 'chuck,' with some of the querulous quality of a Flycatcher's note; in fact it considerably resembles the note of the Phobe. The song is much like that of the Carolina Wren, but less lively and ringing: ter-wheeter-wheeter-wheeter-wheeterwheeter,--with falling inflection. I have never heard it in fall." (Allison, MS.)

"The song is a loud, clear and sweetly whistled peer-ry, repeated tapidly four or five times. Often, though less frequently, a che che che peer-ry pecr-ry peer-ry. When first heard it is stiggestive of the song of the Cardinal or Carolina Wren. During the nesting season it is an incessant singer from the lower branches of the sapling in which it is constantly moving or as often from the ground where it is at its best, walking about with an air and dignity not often attained by small birds. The song continues from arrival until June 27 -June 23 , and one was heard August 7, (1902). Most persistent the first four weeks, however, when near its haunts, one is seldom out of hearing of one or more singers. A flight song is sometimes delivered about dusk during the height of the breeding period. It is indescribable. The alarm note is a metallic chip, chcck, or chuck, more or less rapidly repeated, and to a critical ear easily : cognizable. The bird appears to be free from that ever present nervousness of some of our Wood Warblers, exhibiting perfect self possession on almost all occasions. In May I896, I heard several birds, possibly transients, sing Too-dle too-dle too-dle too-dle (erroneously transposed with the breeding song in Warbler Songs, Wilson Bulletin p. 47). On this occasion the birds were not in full song on arrival." (Burns, MS.)

Nesting Site.-On the ground ustally at the foot of a bush or among plants, sometimes in bushes or on low sweeping limbs within a few inches of the ground.

"The nest is often placed in the most unexpected places: It may be on top of the ground at the foot of a beech, spice-bush, dog-wood, sweet birch, or black haw sprout; under a fallen bough, or perhaps just off the wet earth between the ground forks of a bunch of spicewood, winter fern, Spanish needles or other weeds; or less frequently, in the midst of a patch of wild sarsaparilla, mandrake or other annuals, with nothing to turn aside the crushing foot of man or beast. It is usually well concealed by the surrounding vegetation while in a comparatively open spot, and if not directly in an abandoned cartroad, not far from some woodland footpath, public road, or the edge of the woods." (Burns, MS.) 
Nest.-A nest from Englewood, N. J., is very bulky. An outer wrapping of several layers of dead leaves encases a wall of weed stalks while the heavy lining consists of black rootlets. A nest from Wheatland, Indiana, essentially agrees with this New Jersey specimen.

"A rather bulky and loosely constructed nest, outwardly of somewhat ragged dead leaves of the chestnut, beech, cherry, maple, white, black, and chestnut oak, a few weed or grass stems, an occasional strip of wild grapevine bark, and, once, many green leaves of the dogwood, and, in another example, several oak blossoms; usually followed by an inner layer of bright, clean dead leaves of the beech, lined with black rootlets and in fully half of the nests examined, a few long black horse-hairs. In one instance the lining was of light-colored rootlets. Another nest, so well hidden in a patch of woodplants that I accidentally trod upon it while actually searching for it, was a most frail affair built exclusively of grasses, lined with black rootlets, however.

"During the nest building period the birds are so extremely jealous and watchful, deserting the site rather than be spied upon, that I have been unable so far to follow this interesting period to a finish. The male unquestionably aids his mate." (Burns, MS.)

Eggs. - 4 or 5, in about even proportions. Ground color white, in some cases very glossy, spotted and specked, rarely blotched, with burnt umber, cinnamon-rufous and lilac-gray, seldom if ever showing under shell markings; in most cases the markings are heavier at the large end, sometimes in a mass, sometimes well wreathed, and in other types evenly distributed over entire egg. Size; average, $.74 x .58$; extremes, $.79 x .60, .69 x .57, .73 \times .54$. (Figs. 100,101.)

Nesting Dates.-Buncombe Co., N. C., May 23 (C.W. C.); West Chester, Pa., May 27 (Jackson); Chester Co., Pa., June 25 (J.P.N.); Waynesburg, Pa., May I8-June Io (Jacobs) ; New York City, June IJune I2 $(F M . C$.); Dunklin Co., Mo., May I5 (C.W.C.).

\section{Btographical REFERENCES}

(1) WM. Brewster, Observations on the Birds of Ritchie County, West Virginia, Ann. Lyc. Nat. Hist. N. Y., XI, I875, I37. (2) F. T. JeN Ks, Kentucky Warbler, its Nesting Habits, [in Ind.], Orn. and Oöl., VI, I88I, 49. (3) D. E. L[ANTz], The Kentucky Warbler, [in Kansas], Orn. and Oö1., X, 1885, I9. (4) T. A. JAckson, Nesting of the Kentucky Warbler [in S. E. Pa.], Orn. and Oöl, XII, I887, 43. (5) J. P. NorRIs, JR., Nesting of the Kentucky Warbler in Chester County, Penn., Orn. and Oöl., XIV, I889, I04. (6) Ibid., XV, I890, I45. (7) Ibid., Nidologist, I, I894, I65. (8) J. P. N[oRRrs], A Series of Eggs of the Kentucky Warbler, Orn. and Oöl., XVII, r892, I. 


\title{
Connecticut Warbler
}

\author{
OPORORNIS AGILIS (Wils.) Plate XVIII
}

Distinguishing Characters.-The adult $\delta^{*}$ is to be confused only with the adult $\delta$ of the Mourning and Macgillivray's Warbler from both of which it is distinguished by its larger size, complete white eye-ring, and absence of black on the breast. The young $\delta$ and $q$ may be known from the corresponding sex and age of the Mourning and Macgillivray's Warblers by their large size, browner breast, and more conspicuous, complete eye-ring. Length (skin), 4.90; wing, 2.75 ; tail, 1.85 ; bill, .48 .

Adult d", Spring.-Upperparts olive-green with a brownish tinge, the crown more or less slaty gray; wings and tail like back and without white markings, bend of wing yellow; a complete white eye-ring; sides of head, throat and upper breast slaty gray paler on the throat, rest of underparts, including crissum, yellow, the sides olive-green.

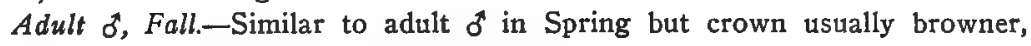
gray of breast faintly tipped with brownish.

Young $\delta$, Fall.-Similar to adult $\delta$ but crown olive washed with brown, slaty gray of throat and cheeks replaced by yellowish brown paler on the throat; eye-ring tinged with buffy.

Adult \&, Spring.-Similar to adult o but crown brownish olive-green, cheeks, throat and upper-breast brownish paler on throat. Similar to young ot in Fall, but crown more olive.

Adult $q$, Fall.-Similar to adult $q$ in Spring but upperparts and breast browner.

Young 9 , Fall.-Not distinguishable from adult $q$ in Fall.

Nestling.-Not seen.

General Distribution._Eastern United States; north to Manitoba; west to the Mississippi River.

Summer Range.-Summer records of the Connecticut Warbler are rare. There is a single record of its breeding in Manitoba; it was found located for the summer in a tamarack swamp near Hickory, Aitkin County, Minn., where it was seen from June 2I onward; it was seen in July on the St. Louis River in eastern Minnesota, and, therefore, probably breeds in that locality; it is claimed to breed not uncommonly in southern Wisconsin; old with young were seen on the Porcupine Mountains, northern Michigan, July 27, 1904, and undoubtedly bred there.

Winter Range.-Northern South America; the West Indies in migration.

Spring Migration.-This is one of the few species that seems to travel different routes during the two yearly migrations. The spring migration is through Florida to the Mississippi Valley and thence north to the breeding grounds. The few records of spring migration note the arrival of this species in southern Florida May 4-r9; northern Florida, May Io-II; Chester County, S. C., May Io; St. 
Louis, Mo., May I4-22 ; English Lake, Ind., May 4, 1891 ; Oberlin, O., May 7, I904; Glen Ellyn, Ill., May 12, I896; southern Michigan, May I7, I894; southern Ontario, May I6, I892.

Fall Migration.-The vicinity of Chicago is one of the few places visited by the Connecticut Warbler during both spring and fall migration. Here the average period of fall occurrence is from August 3I to September Io, with extremes of August 30 and September I7. The path of fall migration passes principally east of the Allegheny Mountians and some dates of occurrence along the Atlantic slope are at Saco, Me., September 8-I 5; Shelburne, N. H., September I4; Pittsford, Vermont, September 20 ; Portland, Conn., September I7 to October I; southeastern New York, August 26 to October I2; Englewood, N. J., September 3 to October I I ; Washington, D. C., August 28 to October I2; Raleigh, N. C., October 14-24; southern Forida, October 9. So far as known, the Connecticut Warbler has not been recorded anywhere during the half of the year from October 22 to April 9.

The Bird and its Haunts.-During the spring migration the Connecticut Warbler seems to be confined to the Mississippi Valley where, at this season, as well as in the fall, it is generally considered a rare bird. In its return migration, however, it is often common in the Atlantic states. At this time they may usually be found in low, damp woods with abundant undergrowth, though not infrequently they are flushed from weedy growths bordering hedgerows some distance from the woods. They are now excessively fat, no other Warbler, as far as I am aware, approaching them in this respect. While, locally Connecticut Warblers seem to come in flights, being common some years and rare others, the census of light-housestriking Warblers shows that the bird is a regular autumnal visitor.

At Cambridge, Brewster ${ }^{5}$ writes: "We used to find Connecticut Warblers oftenest among the thickets of clethra, Andromeda ligustrina, shad-bush and black alder, which formed a dense swamp, and in the beds of touch-me-not (Impatiens) that covered some of its wetter portions. They were also given to frequenting the banks of numerous intersecting ditches, especially where the deadly nightshade, clinging to the stems of the bushes, trailed its gray-green foliage and coral-red berries over the black mud or coffee-colored water. In such places they often literally swarmed, but so retiring and elusive were they that by anyone unacquainted with their habits they might easily have been overlooked. They spent most of their time on the ground under or among rank vegetation, where they 
would often remain securely hidden until nearly trodden on. Indeed we learned eventually that the only certain method of starting all the birds that a thicket contained was to beat the place closely and systematically many times in succession. When flushed they would usually fly up into the low bushes and sit there motioness in thrushlike attitudes, gazing at us intently with their large dark eyes. If further disturbed, they were nearly sure to take long flights to distant parts of the swamp During cloudy weather we sometimes found them feeding with Blackpoll Warblers in the tops of large willows, fifty or sixty feet above the ground. The earliest date on which they were ever seen by us was September 7, and the last stragglers usually departed for the south before the Ist of October. They never appeared in spring, nor is there a single record in which I have full confidence of their occurrence at that season in any part of Massachusetts."

At Monadnock, Gerald Thayer (MS.) writes that the Connecticut Warbler is "sometimes fairly common at Monadnock in the fall, from mid-September to early October, in bushy roadside copses and damp thickets in and near woods. In spring it is very rare here, we have seen only two or three in the course of a dozen years."

With Brewster he comments on the bird's thrush-like appearance, saying: "As it appears about Monadnock in the Autumn, the Connecticut has a curiously quiet and thrush-like demeanor. Starting up from the ground, where it has been walking, it stops on a low perch and sits dead still for several seconds, sometimes for a half minute or more, before moving on, and then it usually flies rather far. The only note I have ever heard from it is a very quick, sharp call, with a clipped-short metallic ring, plink, easily remembered and differentiated among Warbler chips. In immature plumage, as we commonly see it, it looks very dark, and shows no definite markings whatever beyond the rather conspicuous white eye-ring, which adds to the effect of thrush-likeness."

According to Ernest Seton ${ }^{1}$, who alone has found the Connecticut breeding, the bird, in Manitoba, summers in tamarac swamps. Gault's observations in Aitkin County, Minn., indicate the breeding of the species in similar localities at that place, while the taking of fledglings by Warren ${ }^{8}$, on August Io, near Palmer, in the Upper Peninsula of Michigan, considerably extends the probable nesting range of the species. Warren remarks that at this point he saw over fifty Connecticut Warblers on August 29, an observation which suggests that the species is much more common in the Mississippi Valley than existing records would lead us to believe. 
Song.-I have never heard the song of this species. The call-note, however, is a sharp, characteristic peek. Ernest Seton ${ }^{1}$ writes that the song "may be suggested by the syllables beecher-beecher-beecherbeecher-beecher-beecher. It is like the song of the Golden-crowned Thrush [=Oven-bird], but differs in being in the same pitch throughout. * * *

"Besides the song already recorded I have noted another type; it nearly resembles the syllables fru-chapple fru-chapple fru-chapple whoit, and is uttered in a loud, ringing voice, quite unlike the weak, hurried lisping of the Wood Warbler * * * ."

"On first hearing the song it reminded me strongly of the Northern Yellow-throat's. It is, however, more vigorous and resonant than the Yellow-throat's. It does not repeat the song very often. The description fru-chapple fru-chapple fru-chapple, whoit, is good. Or, sometimes, it seems to say too-too-zehit. He shakes his body all over when he sings and his wings and tail vibrate furiously." (Farrell, MS.)

Nesting Site.-On the ground $\left(\right.$ Seton $\left.^{1}\right)$.

Nest.-What appears to be the only authentic nest of this species was found by Ernest Seton ${ }^{1}$ near Carberry, Manitoba, June 2I, I883. It is described by him as being "composed entirely of fine grass."

Eggs.-The nest discovered by Seton contained 4 eggs. Their color before being blown is described as "a delicate creamy white, with a few spots of lilac-purple, brown, and black, inclined to form a ring at the large end." Size; $.75 \times .56$.

Nesting Dates.-Porcupine Mts., Ontonagon Co., Mich., July 27, female with bare abdomen and young of year, Maclean (Barrows).

\section{BIOGRAPHICAL REFERENCES}

(1) E. T. Seton, Nest and Habits of the Connecticut Warbler, [in Manitoba], Auk, I, I884, I92. (See also Proc. U. S. N. M., XIII, I8go, 621. (2) W. L. Colnins, Note on Oporornis agilis, [near Philadelphia], Bull. Nutt. Orn. Club, V, I880, 50. (3) O. B. WARREN, Notes from the Upper Peninsula of Michigan, Auk, XII, I895, 192. (4) B. T. GAULT, Geothlypis agilis, A Possible Breeder in Northern Minnesota, Auk, XIV, 1897, 222. (5) WM. BREWSTER, Birds of the Cambridge Region, 35 I.

\section{MOURNING WARBLER OPORORNIS PHILADELPHIA ( $\mathbb{W}$ ils.) Plate XIX}

Distinguishing Characters.-The Mourning and Macgillivray's Warblers closely resemble one another but may be distinguished by the following characters; the adult $\delta$ Mourning has no white in the eye-ring, the lores are blackish, the breast jet black with few or no grayish tips at its junction with the yellow of the underparts; the adult $\delta$ Macgillivray's has a white mark in the 


\section{Plate XiX}

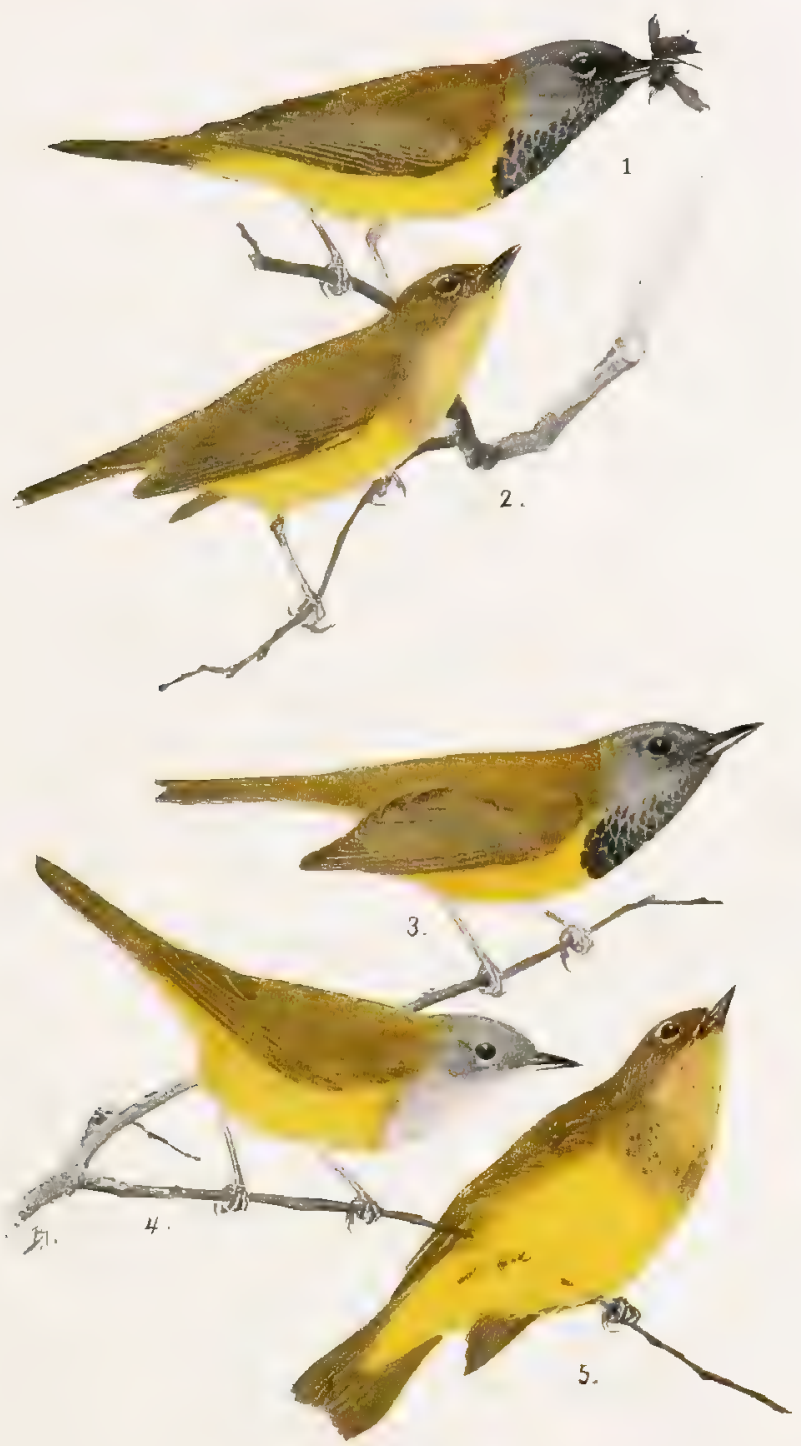

1. Macgilliveay's Warblek, Male.

3. Mourning Wareler, Matf.

2. MacGillivray"s Warbler, Female.

4. Mourning Wardier, Female.

5. Mourning Warbier, Young Male. 

eye-ring above and below the eye, the lores are black, the breast slate-black, usually widely and more or less evenly tipped with grayish. The $q$ and young $\delta$ of these species can be less readily determined since in such specimens the Mourning develops a more or less well-marked whitish eye-ring. It is, however, usually incomplete and this fact in connection with the bird's shorter tail will serve to separate it from Macgillivray's. Length (skin), 4.90; wing, 2.50; tail, 2.00 ; bill, .45 .

Adult o", Spring.-Head bluish slate, back, wings, and tail olive-green, no white markings, no white eye-ring; lores gray or blackish; throat heavily tipped with gray, these tips gradually decreasing in width posteriorly, leaving, usually, a black area on the breast at its junction with the yellow of the rest of the underparts, sides greenish.

Adult ơ, Fall.-No specimens in early Fall plumage seen, but judging from G. tolmiei, similar to adult $\delta$ in Spring but throat and breast more widely tipped with whitish, the crown tipped with brownish.

Young of, Fall.-Similar to adult $\delta$ in Spring but crown brownish olivegreen slightly browner than back, a nearly complete whitish eye-ring, throat and upper breast yellowish, the former paler, the feathers of the latter dusky or blackich basally.

Adult \&, Spring.-Similar to adult $\delta$ in Spring but bluish slate of head and olive of back browner; an inconspicuous whitish or gray eye-ring; throat and upper breast brownish gray.

Adult ㅇ, Fall. - Not seen.

Young $q$, Fall.-Above uniform olive-green, head without trace of gray; below yellow, throat with a more or less evident trace of dusky, sides greenish; eye-ring less distinctly whitish than in adult $q$.

Nestling.-Above dark olive-brown, browner than in nestling of Geothlypis trichas, sides and breast 2 more yellow brown, belly yellowish buff, median and greater wing-coverts tipped with cinnamon-brown.

General Distribution.-Eastern North America; north to Nova Scotia and Manitoba; west almost to the Plains.

Summer Range.-The Mourning Warbler is most common in summer near the northern limit of its range, in Manitoba, northern Minnesota, and central Ontario; and less common in eastern Assiniboia. It is not uncommon as a breeder in Michigan (Porcupine Mountains). southern Ontario (Toronto, Guelph), northern New York (Oneida, Niagara, Ontario Counties), Vermont (Londonderry, Townsend), New Hampshire (Mt. Moosilauke, North Woodstock, Intervale), Massachusetts (Berkshire County), Maine (Franklin County), New Brunswick, Prince Edward Island and Nova Scotia. It breeds also in the Catskills and in some of the mountains of Pennsylvania (Westmoreland, Sullivan, Cambria, Clinton Counties), and West Virginia (spruce belt).

With the exception of a probably accidental occurrence in South Carolina, it has not been recorded outside the mountains at any time of the year in the Atlantic and Gulf States from North Carolina to 
Mississippi. It is a rare migrant in Louisiana, but is fairly common in migration in Texas, and has been noted in eastern Kansas (Topeka, Neosho Falls), eastern Nebraska (Omaha, Neligh), and eastern North Dakota (Cando).

Its distribution in the United States is, therefore, fan-shaped. Touching the Gulf of Mexico along the coast of Louisiana and Texas, a distance of six hundred miles, the lines of migration extend north to Manitoba and northeast along the west side of the Alleghenies to New Brunswick, Nova Scotia and the Magdalen Islands. The east and west extension of the breeding ground is nearly two thousand miles.

Winter Range.-Nicaragua to Ecuador.

Spring Migration.-The Mourning Warbler is one of the latest of the family to arrive from its winter home in Central and South America. It probably reaches the United States late in April or the first week in May.

\begin{tabular}{|c|c|c|c|c|c|}
\hline PLACE & \begin{tabular}{|l} 
No. of \\
years' \\
record
\end{tabular} & $\begin{array}{c}\text { Average d } \\
\text { spring at }\end{array}$ & $\begin{array}{l}\text { date of } \\
\text { irrival }\end{array}$ & $\begin{array}{l}\text { Earlie } \\
\text { sprin }\end{array}$ & $\begin{array}{l}\text { st date of } \\
\text { g arrival }\end{array}$ \\
\hline 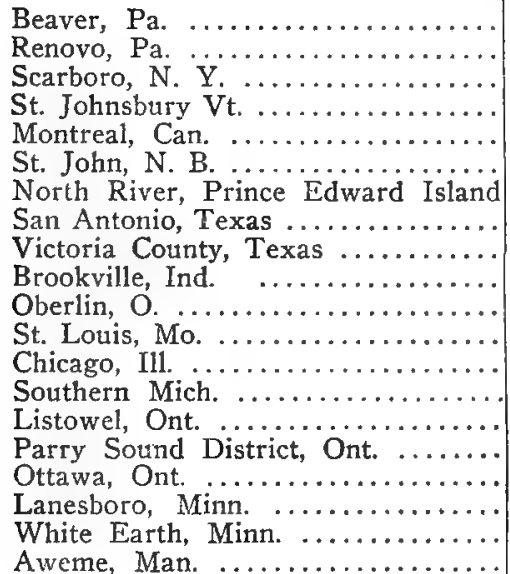 & $\begin{array}{r}6 \\
6 \\
7 \\
4 \\
13 \\
8 \\
10 \\
8\end{array}$ & $\begin{array}{l}\text { May } \\
\text { May } \\
\text { May } \\
\text { May } \\
\text { May } \\
\text { May } \\
\text { May } \\
\text { May }\end{array}$ & $\begin{array}{r}7 \\
15 \\
19 \\
17 \\
17 \\
22 \\
23 \\
18\end{array}$ & $\begin{array}{l}\text { May } \\
\text { May } \\
\text { May } \\
\text { May } \\
\text { May } \\
\text { May } \\
\text { June } \\
\text { April } \\
\text { May } \\
\text { May } \\
\text { May } \\
\text { May } \\
\text { May } \\
\text { May } \\
\text { May } \\
\text { May } \\
\text { May } \\
\text { May } \\
\text { May } \\
\text { May }\end{array}$ & $\begin{array}{rr}6, & 1902 \\
4, & 1896 \\
9, & 1897 \\
20, & 1900 \\
30, & 1888 \\
24, & 1891 \\
15, & 1888 \\
24, & 1890 \\
3, & 1887 \\
7, & 1881 \\
5, & 1899 \\
10, & 1886 \\
17, & 1902 \\
14, & 1892 \\
8, & 1900 \\
17, & 1895 \\
10, & 1891 \\
13, & 1886 \\
18, & 1885 \\
23, & 1900\end{array}$ \\
\hline
\end{tabular}

Fall Migration.--An unusually early migrant was seen at Lanesboro, Minn., July I, I888. The species moves south in July and August, and reaches Costa Rica the first of September. The last has been noted at Ottawa, Ont., August 28, 1896; North River, Prince Edward Island, September 3, I890; Cleveland, Ohio, September 26, I896; Renovo, Pa., September 26, I899; Cambridge, Mass., September 30; New Orleans, La., October 7, 1896. 
The Bird and its Haunts.-Both while nesting and when migrating, the Mourning Warbler appears to be a more or less rare bird throughout its range. At Englewood, I know it only as an occasional late spring migrant and have no record of it in the fall.

At Cambridge, according to Brewster ${ }^{-5}$, there are definite records of the occurrence of but fifteen individuals of this species of which only two were observed in the fall. Most of the birds, Brewster states, "were found either in swampy thickets or among dense shrubbery in gardens."

At Monadnock, Gerald Thayer (MS.) writes, the Mourning Warbler is rare, "we have seen several here in the spring and one or two in autumn. It may possibly breed here. Its call-notes I have never heard, wittingly, and its full-voiced, highly-modulated singing I have heard too seldom to warrant my attempting a detailed description of it. In migration, it is a somewhat shy and quick-moving Warbler, like a Yellow-throat with a dash of Water-Thrush blood. It hops about in thickets like a Yellow-throat, but is prone to visit also the overgrowth of deciduous woods and hedge-rows. The first one I ever saw I shot from the top of a seventy-foot maple, whither it had flown from a blossoming apple tree. The Mourning has also manners in common with its close cousin the Connecticut, notably the habit of stopping very short and sitting quite still for a few seconds."

In Maine, Swain ${ }^{4}$ writes, the Mourning Warbler's nesting haunts are in "dense underbrush on the margin of some lowland woods or second growth swamps or on some hillside covered with brush, near a deep wooded ravine."

At Branchport, N. Y., Burtch (MS.) says a favorite nesting resort is a bushy clearing with an abundance of blackberry briars, and I have found the bird, in June, in a similar location in northern Cayuga County, N. Y.

Song.- "The males would sit for a long time on the limb of a dead tree, motionless, but for lite occasional utterance of their brief song. In quality their song is much like that of the Maryland Yellow-throat; but the song, as I heard it, consists of five notes, the first three just alike, followed by two others, louder and fuller. The whole is loud, clear and ringing and forms an interesting song. * * * " (Roberts ${ }^{1}$ )

"In quality and style this Warbler's songs bears a strong resemblance to that of the Water-Thrush, the variations having the same general quality, but the song is considerably less in volume and lacks the wild thrill of the Water-Thrush. The song which I have heard most frequently is tee te-o te-o te-o we-se, the last couplet accented and much 
higher pitched. A less common form slightly resembles the crescendo chant of Oven-bird, but is weaker. It is rather a swell than a crescendo. Dr. Merriam describes a variation which I have never heard: 'trúe 'true 'trúe 'tru' 'toó, the last and next to the last syllables with falling inflection and more softly. The song is clear and whistling.

"Song is incessant during the northward movement, but there is apparently none on the return journey." (Jones.)

Miss Paddock sends four renderings and writes: "The quality is very full and rich and the rhythm unmistakable."
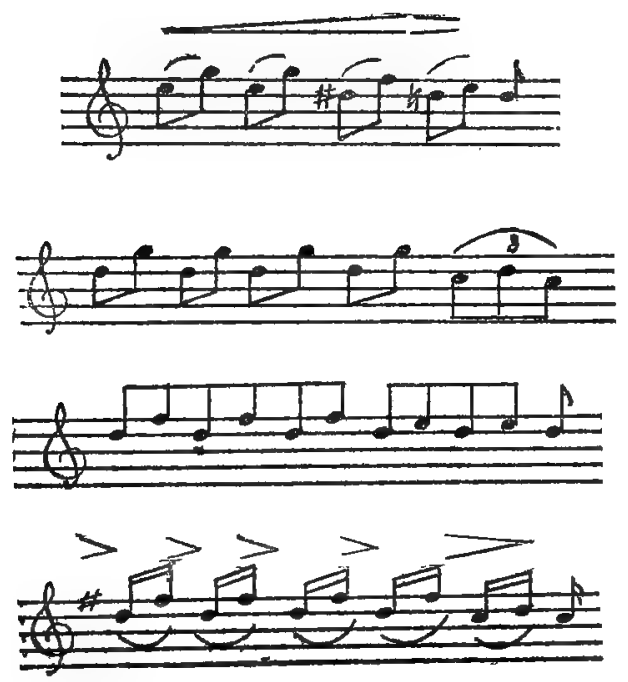

Nesting Site.-In briars or weedy growths in thickets usually six to twenty inches above the ground.

Nest.-Swain ${ }^{4}$ describes a Maine nest as bulky but neat and compact, made externally of dry leaves and vine stalks with an inner wall of dead, coarse, flat-bladed grass, with finer grasses and a few weed stalks, all through this wall a few small, dead white maple leaves being interwoven. The lining was composed of fine grasses and a few horsehairs.

A nest found by Tabor $^{3}$ in northern Cayuga County, N. Y., is "composed of weed stalks with layers of leaves mixed in, and is lined with fine black rootlets."

Eggs.-Usually 4. Ground color white, sparingly spotted and blotched with rufous red, brownish and light hazel in form of an indistinct wreath about large end and few scattering marks over rest of 
egg. Size; a typical set of four measure .7IX.56, .70x.55, .74x.56, $.73 \times .55$. (Figs. 102, 103.)

Nesting Dates.-Lancaster, N. H., June 8 (Spaulding); between Athens and Hartland, Me., June I6 (Knight); Listowel, Ont., June 3-June I4 (Kells) ; Kalkuska Co., Mich., June 7, Dunham-Ontonagon Co., nestlings, July I5, Peet (Barrows).

\section{BIOGRAPHiCAL RefERENCES}

(I) T. S. Roberts, A Partial List of the Birds of St. Louis and Lake Counties, Minn., Rep. Geol. and Nat. Hist. Surv. Minn. for 1879, 158. (2) W. L. KeLLs, Nesting of the Mourning Warbler, (in Ontario), Orn. and Oöl., XIV, 1889, 4; Ottawa Naturalist, XVIII, I904, 65. (3) E. G. TABOR, Nrsting of the Mourning Warbler, Orn. and Ö̈l., XV, I890, 68. (4) J. M. SwaIN, Contributions to the Life-History of the Mourning Warbler, Journ. Me. Orn. Soc., VII, 1905, 14. (5) WM. Brewster, Birds of the Cambridge Region, 353.

\section{MACGILLIVRAY'S WARBLER}

\section{OPORORNIS TOLMIEI (Towns.) Plate XIX}

Distinguishing Characters.-For a comparison of this species with the Connecticut and Mourning Warblers, see those species. Length (skin), 5.00; wing, 2.50; tail, 2.10; bill, .45.

Adult 8 , Spring.-Head bluish slate, back olive-green, wings and tail olivegreen without white markings; a white mark above and another below the eye, lores black; throat and upper breast blackish or slaty-black rather evenly and widely tipped with grayish white, rest of underparts yellow, the sides greenish.

Adult $\delta^{\circ}$, Fall.-Similar to adult $\delta^{A}$ in Spring but crown tipped with brownish, throat more widely tipped with grayish.

Young $\delta^{*}$, Fall.-Similar to adult $\delta^{*}$ in Fall but crown olive-brown without slate, lores grayish or brownish, throat and breast yellowish or brownish gray.

Adult $q$, Spring.-Similar to adult of in Spring but bluish slate of head and olive of back browner; white eye-marks less conspicuous, cheeks and lores grayish, throat and breast gray slightly tinged with brown.

Adult $q$, Fall.-Similar to adult $q$ in Spring but crown brown, browner than back, throat with brownish tinge more pronounced. Not certainly distinguishable from young $\delta$ in Fall.

Young $q$, Fall.-like adult $q$ in Fall but throat averaging browner.

Nestling.-Not seen.

General Distribution.-Western United States.

Summer Range.-A common and characteristic species of the western United States, breeding from New Mexico and Arizona to British Columbia; it occurs east regularly to the foothills of the Rockies and occasionally far out on the Plains to North Dakota (Musselshell 
River), western Nebraska (Sioux County), southeastern Colorado (Springfield) and central Texas (Gainesville, San Antonio).

Winter Range.-Lower California to Colombia, South America.

Spring Migration.-The earliest migrants of Macgillivray's Warbler seen in the Huachuca Mountains, Arizona, were recorded April II, I902. In southern California a few have been seen as early as the last of March, but the general time of arrival in the southern part of the state is the first ten days in April. The average date of arrival in northern Colorado is May I3; at Cheyenne, Wyo., May 14, and at Great Falls, Mont., May 28. Some records of the first birds noted are: Dayton, Ore., about May 2; Camp Harney, Ore., about May I ; Portland, Ore., April 29, I897; Olympia, Wash., April 12, 1904; Tacoma, Wash., April I6, I905; southern British Columbia, average of three years, May 5, earliest, May 2, 1905.

The Bird and its Haunts.-Macgillivray's Warbler is a generally common bird in favorable localities throughout the west, $I$ have found it even in the midst of the Wyoming sage plains, where a few willows bordered a snow-born stream. Undergrowth of some kind it requires but the scrub of a dry hillside apparently answers its wants as well as the bushes near water. It is much less demonstrative than a Yellowthroat (Geothlypis) and seems to try to avoid being seen either by remaining in cover or by a quick low flight to more distant cover, and were not its song too pronounced to be overlooked the bird might easily escape attention.

In California, Walter Fisher (MS) writes: "This is a very quiet little bird and is common in the Sierra Nevada Mountains among prickly ceanothus, deer-brush, wild cherry, and clumps of willow, often frequenting the vicinity of water, but as often found far from it. It lives in much the same country that is occupied by the Calaveras Warbler, from which it may be readily distinguished by its gray head and more retiring habits. There is something wren-like in the way Macgillivray's Warbler moves through its miniature jungle, shyly eyes the observer, and then vanishes noiselessly."

Song.- "Their ordinary song-notes, chee-chee-chee-chee, I could not positively discriminate from those of Wilson's Black-cap [ $=W i l$ sonia $p$. pileolata], when the two sang on either side of me in a thicket. To these cheé-che-chu, or a few terminal notes, may be added. Sometimes, however, in May, this little Warbler has a fit of ecstasy, and, with a short, nervous flight bursts into sweet song, although not so liquid as his eastern cousin's." (Minot ${ }^{1}$.)

Nesting Site.-The nest is generally placed in briars or small bushes from six inches to two feet from the ground, but Minot ${ }^{1}$ re- 
cords an unusually situated one from Colorado, as built in a scrub oak five feet from the ground.

Nest.-Minot ${ }^{1}$ describes the nest as recalling a coarse type of Chestnut-sided Warbler architecture. Nests in the Crandall collection from Colorado are composed of grasses and rootlets lined with hair; while a nest from California is described as small and loosely made, composed of grasses, principally 'wild oats,' lined with fine grasses and a little hair.

Eggs. -3 to 5, usually 4, very rarely 5. Ground color white to slightly creamy, marked with many shades of brown, dark lilac, rufous, purplish black and numerous under shell spots of lavender; these markings occur in the form of specks, spots, blotches, in some cases much run together, and irregular lines, heavier at the larger end where they often form an indistinct wreath; in many types the smaller half of the egg is almost devoid of markings. Size; average, .71x.52; extremes measure .66x.50 and .77x.56. (Figs. 104-106.)

Nesting Dates.-Estes Park, Colo., June I5 ( C.W. C.); Sonoma, Calif., May 2 ( $C . W . C$.) ; Tacoma, Wash., June II-I8 (Bozoles).

\section{BiograyHical ReFERENCES}

(I) H. D. Minor, Notes on Colorado Birds, Bull. Nutt. Orn. Club, V, $\mathrm{I} 880,227$.

\section{Genus GEOTHLYPIS Cabanis}

Geothlypis is characterized chiefly by its short wing and rounded tail. The wing in our species is never more than .25 inches longer than the tail and sometimes equals it in length, and averages only two and three-fourths times as long as the tarsus; the outer primary is always shorter than the second and the outer tail-feather is about .25 inches shorter than the longest; the tarsus is longer than middle-toe and nail, the hind-toe not so long as its nail.

As here restricted, Geothlypis contains about twelve species, only two of which are North American, while one is Bahaman and the others range southward through Mexico to Argentina.

The species of Geothlypis appear to respond to the influences of their environment more readily than do other North American Warblers. Seven forms of the Bahaman bird are recognized and of our $G$. trichas an equal number are current. In several instances, however, the great individual variation which characterizes these birds, so obscures their subspecific differences that identification is often attended with much uncertainty.

The distribution of the Bahaman forms presents a problem of exceptional interest. Ridgway (Bull. U. S. N. M., 50, II, pp. 675-7) records no less than three of the seven forms described from these islands from the single island of New Providence, but, if as has been 
currently believed, the Bahaman races are all representatives of a single species, the occurrence of three of these races on one small island indicates either extreme localization or specific distinctness.

\section{MARYLAND YELLOW-THROAT \\ GEOTHLYPIS TRICHAS TRICHAS (Linn.) Plate XX}

Distinguishing Characters.-This species and its several races may always be distinguished from other North American Warblers by the characters given under the genus Geothlypis. The black 'mask' of the males is an unmistakable mark and while this is lacking in the female she possesses enough of the Yellowthroat individuality of manner to be easily recognized in life.

Adult 8 ', Spring.-A broad, black 'mask' across the forehead and on the sides of the head bordered posteriorly by bluish gray; upperparts olive-green with a grayish or a brownish tinge strongest on the hindhead; wings and tail, externally, olive-green without white patches or bars, bend of wing yellow, outer vane of outer primary whitish; throat and breast yellow, belly whitish generally more or less tinged with yellow, sides brownish, under tail-coverts yellow.

Adult d, Fall-_Similar to adult d in Spring but browner above and on sides, forehead and auriculars more or less tipped with grayish, the gray of forehead and crown tipped with brown.

Young d", Fall.-With a general resemblance to the adult $q$ in Fall but with more or less black basally, grayish tipped feathers in the auriculars and below the eye, and, in some specimens, a few in the forehead; lores dusky yellowish. The adult plumage is acquired by partial molt the following Spring.

Adult 9, Spring.-No black 'mask'; above olive-green washed with grayish or with brownish, brightest on the forehead where sometimes distinctly reddish brown; rump and upper tail-coverts greener; tail and wings, externally, olivegreen without white patches or bars, bend of the wing yellow, outer vane of outer primary whitish, eye-ring whitish; throat and upper breast yellow or yellowish in varying amount, belly whitish more or less buffy, sides brownish, under tail-coverts yellowish.

Adult + , Fall.-Similar to adult $q$ in Spring but browner above, on sides and on belly; throat and upper breast yellower, the yellow washed with buffy.

Young , Fall--Upperparts uniform brownish olive-green; throat faintly tinged with yellow or buffy without yellow; belly whitish washed with buff or yellowish; sides brownish. Like adult $Q$ in Fall but forehead not noticeably browner than back, throat and upper breast much paler.

Nestling.-Above olive-brown, browner in some specimens, greener in others wing-coverts tipped with cinnamon; below dusky yellowish olive, belly and under tail-coverts yellower and without dusky wash.

General Distribution.-Eastern North America.

Summer Range.-Eastern North America west to the Great Plains region, north from the northern part of the Austroriparian fauna to Manitoba and southern Labrador. 


\section{Plate XX}

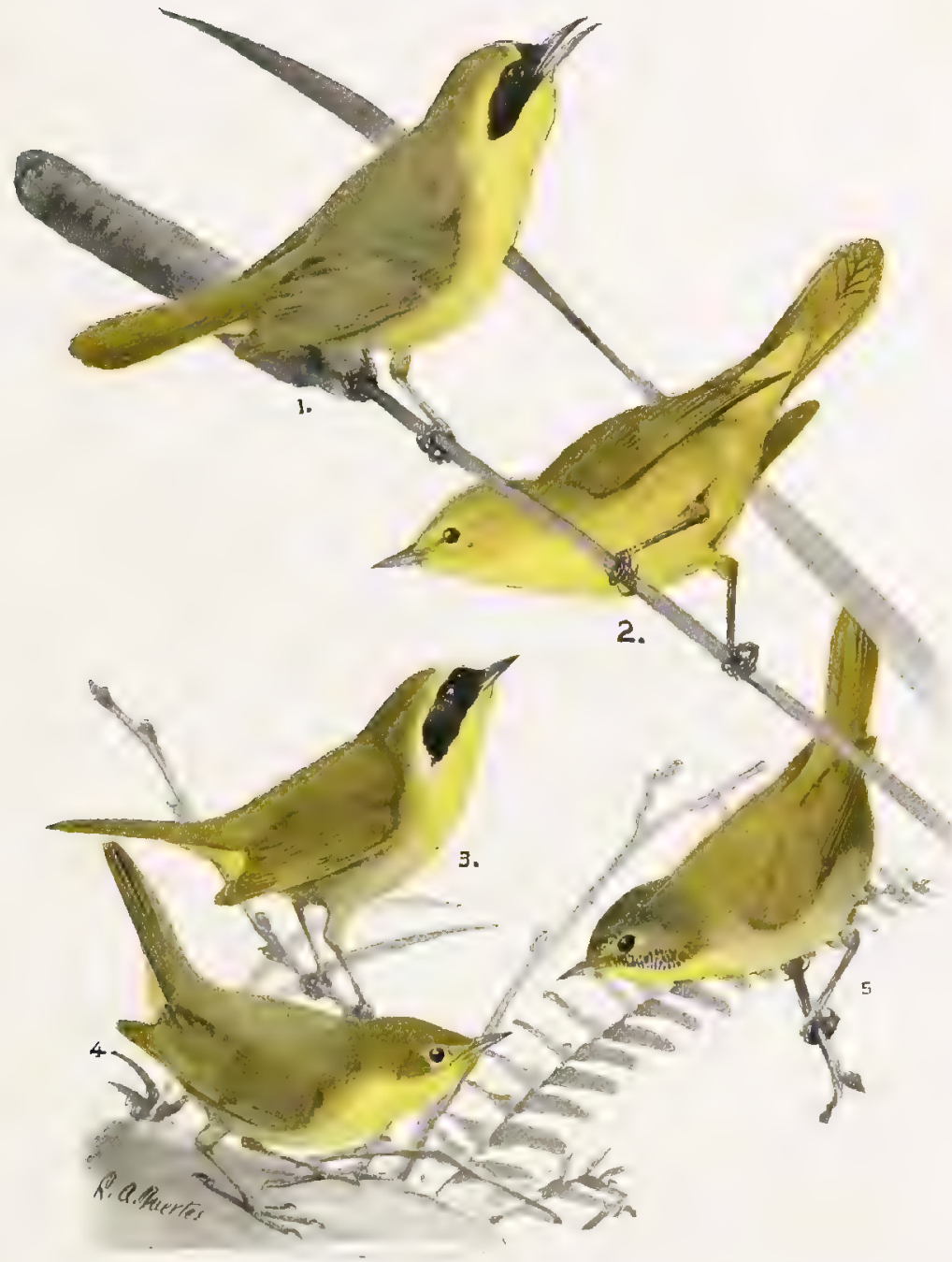

1. Belding's Yellow-throat, Adult Male. 3. Maryland Yellow-throai, Adult Male,

2. Belding's Ýellow-thrioat, Adult Female. 4. Maryland Yellow-throat, Adult Female. 5. Maryland Yellow-throat, Young Male. (ONE-HALF NATURAL SIZE.) 

Winter Range.-From the Gulf States to the Bahamas, Greater Antilles, Mexico, and Central America.

Spring Migration.-It is not possible to apportion the migration notes with any degree of accuracy among the various subspecies of Yellow-throats. Locality must, therefore, be taken as an index to identity.

\begin{tabular}{|c|c|c|c|}
\hline PLACE & $\left|\begin{array}{l}\text { No. of } \\
\text { years } \\
\text { record }\end{array}\right|$ & $\begin{array}{l}\text { Average date of } \\
\text { spring arrival }\end{array}$ & $\begin{array}{l}\text { Earliest date of } \\
\text { spring arival }\end{array}$ \\
\hline \multicolumn{4}{|l|}{ Atlantic Coast- } \\
\hline Raleigh, N. C. .... & I3 & \multirow{2}{*}{$\begin{array}{l}\text { March } 30 \\
\text { April 2I }\end{array}$} & \multirow{2}{*}{$\begin{array}{l}\text { March 20, } 1894 \\
\text { April 18, 1888 }\end{array}$} \\
\hline Washington, D. C. ............ & 9 & & \\
\hline Beaver, $\mathrm{Pa} . \ldots \ldots \ldots \ldots \ldots \ldots \ldots$ & 6 & May 4 & April 30, 1899 \\
\hline Renovo, Pa. ................. & 8 & May 4 & May 2, I900 \\
\hline Germantown, $\mathrm{Pa} . \ldots \ldots \ldots \ldots \ldots$ & 5 & April 29 & April 24, I886 \\
\hline 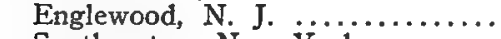 & 7 & May 4 & April 30,1902 \\
\hline Southeastern New York ......... & 14 & May & April 30,1900 \\
\hline Jewett City, Conn. ............... & 8 & May & April 29, 1902 \\
\hline Boston, Mass. $\ldots \ldots \ldots \ldots \ldots \ldots$ & I5 & May & May $\quad 2,1896$ \\
\hline Southern New Hampshire ....... & 9 & May II & May 6, 1902 \\
\hline Southern Maine...$\ldots \ldots \ldots \ldots$ & Io & May 14 & May $\quad 7,1902$ \\
\hline 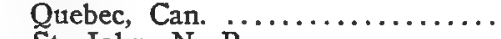 & 7 & May 17 & May I3, I899 \\
\hline St. John, N. B. . $\ldots \ldots \ldots \ldots \ldots$ & II & May 18 & May II, I888 \\
\hline $\begin{array}{l}\text { Central Nova Scotia } \\
\text { North River, Prince Edward Isl. }\end{array}$ & $\mathbf{5}$ & May 25 & $\begin{array}{ll}\text { May } & 18,1896 \\
\text { June } & 6,1891\end{array}$ \\
\hline \multicolumn{4}{|l|}{ Mississippi Valley- } \\
\hline Rodney, Miss. ................ & 3 & March 28 & March 25, 1890 \\
\hline Helena, Ark. . & 7 & \multirow{2}{*}{$\begin{array}{l}\text { April I5 } \\
\text { April I5 }\end{array}$} & \multirow{2}{*}{$\begin{array}{l}\text { April 9, } 1898 \\
\text { April 10, } 1802\end{array}$} \\
\hline Eubank, Ky. .................. & 6 & & \\
\hline St. Louis, Mo. ................ & 7 & April 18 & \multirow{2}{*}{ April 14, 1887} \\
\hline Brookville, Ind. . .......... & 5 & \multirow{2}{*}{$\begin{array}{l}\text { April } 26 \\
\text { April } 25\end{array}$} & \\
\hline Waterloo, Ind. . ............... & Io & & April 19, r891 \\
\hline Wauseon, Ohio .. & 7 & April 30 & \multirow{2}{*}{$\begin{array}{l}\text { April } 26,1891 \\
\text { April } 26,1800\end{array}$} \\
\hline Oberlin, Ohio ....... & Io & April 29 & \\
\hline Chicago, Ill. .............. & 4 & May I & $\begin{array}{l}\text { April 26, } 1899 \\
\text { April } 27,1902\end{array}$ \\
\hline Petersburg, Mich. . ......... & II & May & April 24, 1886 \\
\hline Southern Ontario $: \ldots \ldots \ldots \ldots$ & I5 & May 8 & May $\quad 3$, rgor \\
\hline Parry Sound District, Ont. ....... & 9 & May 18 & \multirow{2}{*}{ May I3, I 899} \\
\hline Ottawa, Ont. .................. & 9 & \multirow{2}{*}{ May I6 } & \\
\hline Keokuk, Iowa & 8 & & April 23, 1893 \\
\hline Grinnell, Iowa & 6 & April 30 & April 22, 1890 \\
\hline Lanesboro, Minn. ............... & 7 & May & April 30,1888 \\
\hline Elk River, Minn. ............... & 7 & May I2 & May $\quad 9,1890$ \\
\hline Aweme, Man. ..... & 5 & May 22 & May 18, 1902 \\
\hline Western United States- & & & \\
\hline Onaga, Kans. .... & 7 & April 28 & April 23, 1896 \\
\hline Cheyenne, Wyo & 2 & May II & 9, 1889 \\
\hline Great Falls, Mont. .. & 3 & May 12 & May 10,1892 \\
\hline Columbia Falls, Mont. . & 4 & May 10 & May 9, I895 \\
\hline 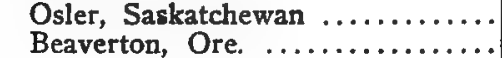 & & & May 25, 1893 \\
\hline Southern British Columbia ... & 3 & April 6 & April 4, 1889 \\
\hline
\end{tabular}


Fall Migration.-

\begin{tabular}{|c|c|c|c|}
\hline PLACE & $\begin{array}{c}\text { No. of } \\
\text { years' } \\
\text { record }\end{array}$ & $\begin{array}{l}\text { Average date of } \\
\text { last one seen }\end{array}$ & $\begin{array}{l}\text { Latest date of } \\
\text { last one soen }\end{array}$ \\
\hline 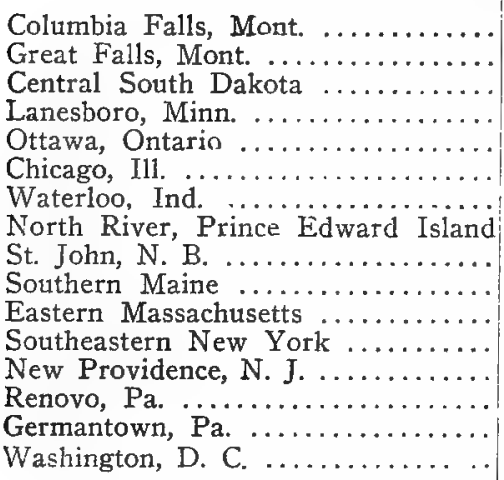 & $\begin{array}{l}4 \\
7 \\
4 \\
4 \\
3 \\
4 \\
8 \\
6 \\
5 \\
5 \\
6 \\
5 \\
5\end{array}$ & 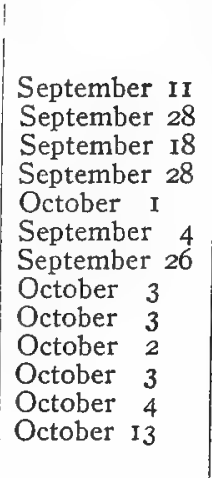 & $\begin{array}{l}\text { September 24, } 1896 \\
\text { October 5, I889 } \\
\text { September I5, I902 } \\
\text { October 5, I885 } \\
\text { September 27, I889 } \\
\text { October 2, 1894 } \\
\text { October 8, I887 } \\
\text { September I I, I887 } \\
\text { October 3, I891 } \\
\text { October I3, I90I } \\
\text { October II, I895 } \\
\text { October I4, I887 } \\
\text { October 23, I891 } \\
\text { October 6, I899 } \\
\text { October 30, I888 } \\
\text { October 20, 1890 }\end{array}$ \\
\hline
\end{tabular}

The Bird and Its Hannts.-The Yellow-throat, for a Warbler, is possessed of unusual individuality. This is due not only to its mode of life and peculiar markings, but more particularly to its responsiveness. The tree-top Warblers pass us by without so much as a chirp of recognition, but the Yellow-throat is evidently interested in us; his notes are interrogative and so clearly occasioned by our presence that they seem to be actually addressed to us. With nervous animation the bird hops here and there, appearing and disappearing, its bright eyes shining through its black mask, its personality so distinct, that one is tempted to believe it a feather-clad sprite of the bushes. The bird, however, is far from being confined to bushy tracts, wet or dry, in the woods or out, but is distinctly partial to cat-tail meadows, a trait far more pronounced in its western relatives.

It is difficult to believe that this haunter of thickets mounts high in the sky to pursue its air-line flight to or from its summer home, but the large number of Yellow-throats included among the victims of lighthouses show that, like other retiring birds, it is a night migrant.

At Berwyn, Pa., F. L. Burns (MS.) writes that the Yellow-throat is "a common summer inhabitant of the open swampy thickets, damp woods, and to a lesser degree, the borders of the dense upland second growth. It is more often met with in the upland clearings during August and September, than earlier in the season.

"Incubation seems to be performed by the female alone. I have found her on the nest at almost all hours of the day. When flushed she seems very timid and usually keeps well hidden. Often she flies from the nest with whirring wings and always dives into the under- 
growth. All attempts to ascertain the period of incubation and of the time the young are in the nest have met with disaster. I have seen parents with young in family groups up to July 25 .

"On June ro, I897, I found a nest containing apparently one large nestling unfledged-a close look showed it to be a very fat Cow-bird, and under it were two puny young of the owner, one dead and the other scarcely larger than when hatched. A little later in the day I duplicated this experience as far as nest and contents were concerned, except that both young of the owner were alive, though as small and weak as the one in the first nest."

At Branchport, N. Y., Burtch (MS.) writes that the Yellow-throat "is common in wet woods or swamps where the grass grows in rank tufts. It is found in Potter Swamp with the Water-Thrush in the more open places and along the edges. The birds are very energetic and lively and make their presence known the moment one enters their territory, when they spring up from the ground uttering their alarm note and, after looking at you to satisfy their curiosity, they disappear in the bushes."

Song.- The call-note of this species is a characteristic, impatient pit, chit, quit or chack; the song, while variable has a certain rhythm which readily lends itself to syllabification though few writers agree as to what the bird seems to say. Hence we have witchery witchery witchery; rapity rapity rapity; rap-pittitty rap-pittitty, rap-pittitty rap; what a pity, what a pity, what a pity, pit; I beseech you, I beseech you, I beseech you; witch-a-weé-o, witch-a-weé-o, witch-a-weé-o; wee-seeseé-see, wee-see-seé-see, wee-see-seé-see, etc. The songster himself however, can be identified without difficulty and may best be left to render his own music.

The flight song, uttered as the bird springs a few feet into the air, is a confused stuttering jumble of notes often followed by the normal song as the bird returns to its perch.

"There is probably a dual season of song with this species, which is obscured by variation in the singing-time of individuals. Though it usually remains in song all through the summer, in the last weeks of July and the first of August singing is less general and less spirited than either before or after. Often after the middle of August songs will be louder and more frequent than for weeks previously. Singing may cease at any time from about the middle of August to the end of the month, or first part of September (August 12 and 19, to September 3, 4, II and I3); but September singing is unusual." (Bicknell ${ }^{2}$ ). 
"A whistled wichity wichity wichity about describes the common song. On May 8, I8g8, half a dozen Yellow-throats temporarily located in the corner of a swamp, uttered unusual songs. One male sang che-e-e-e-e-e like the Worm-eating Warbler. The five other males, no females noted, sang che-a-we-a che-a-we-a che-a-we-a occasionally transposing the syllables -we-a-che-a. The alarm note is a reedy tsip or chip, not to be mistaken for that of any other of our Warblers. The period of song is from arrival or shortly after, to about June II-20, when they appear to be less active, until July 2-6 to July IoAugust 2." (Burns, MS.)

"The Yellow-throat is a full-voiced and rather irregular singer. Not only does its prevalent song-form vary greatly with regions, but different individuals in the same region have notable peculiarities of utterance, both constant and occasional. The typical form of its song around Monadnock sounds to me like Witty-titty, witty-titty, etc., but this type is often widely varied from. Still, the Yellow-throat seems to be a bird with one rather than two or more main songs. Like the Chestnut-side, it sometimes mocks, or seems to mock, other birds. Queerly enough, in the only case of this I was ever witness to, the bird mimicked was a Swamp Sparrow, just as with the Chestnut-side. The imitation was equally adequate and convincing, and was repeated many times;-a long, loud, rattling Swamp Sparrow trill, ending with a few normal witti-titty notes of Yellow-throat song. Like the Chestnutside, too, this bird lived among Swamp Sparrows. Their clear chant seems to be peculiarly catching.

"Among the Yellow-throat's several peculiar call-notes, none is more characteristic than the grating, wren-like Brrrrr-a little, long-drawn snarl,-which does not seem often to have been described. Its flight-song, uttered from a height of five to fifty feet above the bush-tops, is made, like the Oven-bird's, of a hurried jumble of ordinary song and different song and call-notes. It is uttered oftenest in late summer, but is far from rare throughout the breeding season, from April onwards." (Thayer, MS.)

Miss Paddock sends four notations:
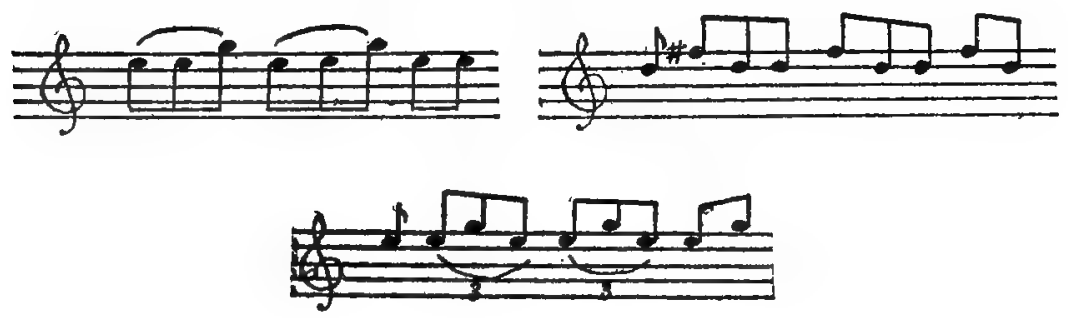


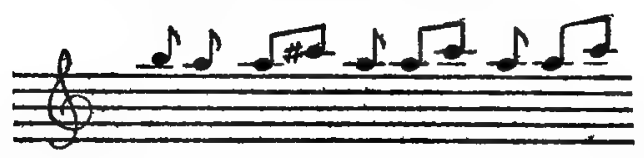

Nesting Site.-On the ground, at the base of a bush or bunch of weeds, often in a clump of weeds or tussock of grass, sometimes in bushes or briery tangles as high as five feet from the ground.

Nest.-The nest is bulky and loosely made. Externally it is composed of coarse grasses, leaves, grapevine bark, weed-shreds, etc., internally, of fine grasses and, sometimes, horse-hairs.

Eggs. 4 or 5, usually 4. Ground color a clear glossy white, marked with specks, spots, blotches and in some cases irregular hairlike lines of reddish brown, dark umber and purplish black, the latter appearing in heavy blotches of color; some specimens are very sparingly marked, others more profusely, the markings being mostly confined to the large end in form of a wreath more or less well defined, only in a few examples do the markings occur over rest of egg. Size; average, .7Ix.54; extremes, .76x.56, .60x.50. (Figs. 107-ro9.)

Nesting Dates.-West Chester, Pa., May 26-June ro (Jackson); Waynesburg, Pa., May I8-June 2 (Jacobs) ; New York City, May 25June 15 (F. M. C.) ; New Haven, Conn., May 28-June 18 (Bishop); Cambridge, Mass., full sets, first laying, May 25-June 5 (Brewster); Lancaster, N. H., June 3-2I (Spaulding) ; Bangor, Me., May 28-June I2 (Knight); Listowel, Ont., June 9-22 (Kells); Oberlin, O., May 5June 20 (Jones); Milton Tp., Du Page Co., Ills., May 25 (Gault).

\section{Btographical ReTERENCES}

C. S. Phirlips, The Maryland Yellow-throat (in Mass.), Young Oölogist, I, 1884, 156. (2) E. P. Bicknerl, A Study of the Singing of our Birds, Auk, I, I884, 215. (3) J. P. N[ORRIs], A Series of Eggs of the Maryland Yellowthroat, Orn. and Oöl., XVI, I89r, 150.

\section{FLORIDA Yellow-THROAT GEOTHLYPIS TRICHAS IGNOTA (Chap.)}

Subspecific Characters. - Similar to Geothlypis t. trichas but with longer tarsus, tail, and bill; wing more rounded, outer primary shorter than sixth from it; adult $d$ with yellow below of a deeper shade and greater extent; flanks darker, richer brown; upperparts browner, particularly the hindhead; facial mask wider, its grayish margin usually broader. Adult $q$ darker above, throat and upper breast yellower, flanks browner than in $q$ of trichas. Ad. $\delta$, wing, 2.25 ; tail, 2.32 ; tarsus, .84 ; bill, .50 .

General Distribution.-Southeastern United States and Gulf coast to Texas. 
Summer Range.-Florida west along the coast to Louisiana and doubtless northeastern Texas; north along the coast to the Dismal Swamp, Virginia.

Winter Range.--South Carolina to Cuba.

The Bird and its Haunts.-In Florida this resident form of the Yellow-throat is so commonly found only in scrub palmettos that it is known as the 'Palmetto Bird.' I have also found it about the bushy borders of 'bay-galls' surrounded by scrub palmetto, while in the Kissimnee region it lives in the lower growth (largely young palms) of cabbage palms.

In Virginia W. Palmer found this bird in cypress swamps and canebrakes. In Mississippi Allison (MS.) writes that it frequents "heavy thickets of blackberry, trumpet creeper, and the other wayside vines of the South; rank weeds; hedges of Cherokee rose;-in short, all thickets not shaded by woods, attract this Warbler. On the Gulf coast, it is frequent in thickets of reeds in the salt marshes."

Song.-The song of this bird, as I have heard it in Florida, is full and strong and while unmistakably that of a Yellow-throat, is still recognizably different from that of the Yellow-throats about New York City.

"The usual note is a drawling chip, sometimes prolonged as if the bird were exhausted. The song is generally uttered from a perch more elevated than the low thicket in which most of the time is spent, and the singer elevates the head and depresses the tail in the manner of a wren; it is variously rendered, but the most poetic and accurate version is, Witchery, witchery, witchery often somewhat extended: Witchercheree, witcher-cheree, witcher-cheree. There is considerable individual variation. It is uttered all through the spring and summer; but in early spring a more elaborate song, reminding me somewhat of the Hooded Warbler's, is rather frequent. The flight song begins as the singer launches forth from his thicket, reaches its climax at a height of fifteen or twenty feet, when the head is thrown back as when singing at rest, and gradually dies away as the bird sinks down with rapidly vibrating wings; it resembles the following: Chee, chee, chee, chee, chewitchery, witchery, witchery, witchery." (Allison, MS.)

Eggs.-4 or 5. Ground color, markings, etc., the same as in the Northern Yellow-throat. Size; an average set of 4 eggs from Florida measures, .7IX.55, .70x.53,.71x.54, .72x.55.

Nesting Dates.-Charleston, S. C., May 9-June II (Wayne).

\section{Btographical References}

(I) Elzroatr Coues, Proc. Acad. Nat. Sci., Phila., 1871, 20. 

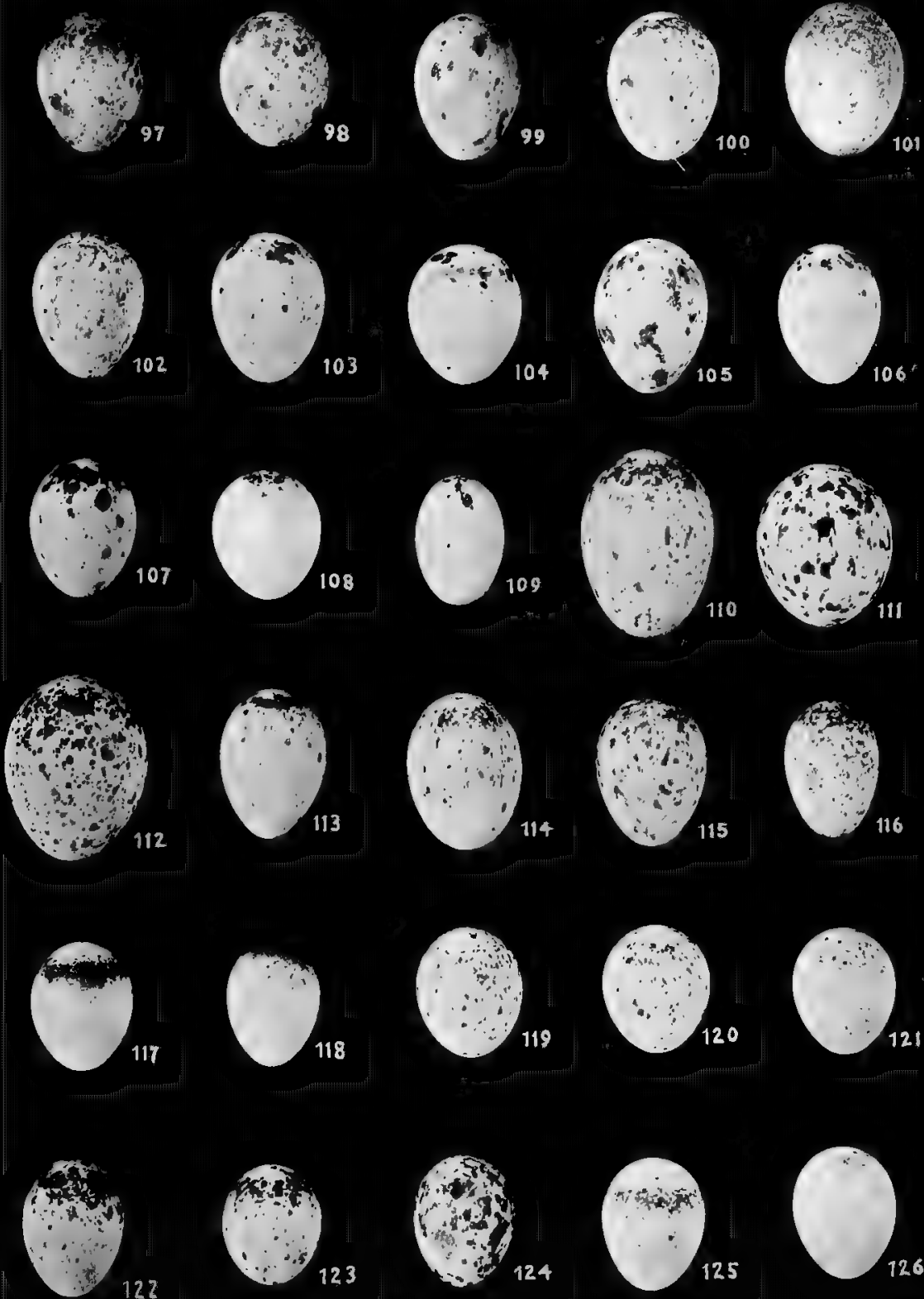

Figs. 97- 99. Townsend's Warbler.

“ 100, 101. Kentucky Warbler.

“ 102, 103. Mourning Warbler.

“ 104-106. Macgillivray's Warbler.

“ 107-109. Maryland Yellow-throat.

، 110-112. Yellow-breasted Chat.
Figs. 113-115. Hooded Warbler.

"116-118. Pileolated Warbler.

" 119-121. Canada Warbler.

“ 122-124. American Redstart.

“ 125, 126. Painted Redstart. 


$$
\text { . }
$$




\section{WESTERN YELLOW-THROAT \\ GEOTHLYPIS TRICHAS OCCIDENTALIS Brewst.}

Subspecific Characters.-The largest and most richly colored of our Yellowthroats; the underparts are often continuously orange-yellow from throat to crissum, the sides being brownish, the belly washed with the same color. As a rule, however, the belly shows some buffy whitish, though rarely as much as in trichas; the back averagès grayer than in trichas, but the main character of this form is the broad, nearly white but sometimes yellow-tinged, posterior border of the black mask of breeding specimens. Arizona specimens average, wing, 2.30; tail, 2.10; bill, .44. A specimen from Fort Custer measures, wing, 2.38 ; tail, 2.20 ; bill, .42 .

General Range.-Western United States.

Summer Range.-Northern Mexico, north to the Canadian border, east to the Great Plains, west to California, reaching the coast in the southern half of the state. The bird's exact relations with $G$. t. arizela in California remain to be deternined.

Winter Range.-Southern California (there a permanent resident $=G$. $t$. scirpicola Grinnell), and the Mexican border south into Mexico.

The Bird and its Haunts. - In its general habits the Western Yellow-throat so closely resembles its eastern relatives that observers have considered a statement to this effect, all that was necessary in recording its status. Cooke states that in Colorado it is a common summer resident almost confined to the plains, though it has been found breeding as high as 9,000 feet.

At Flathead Lake, Montana, Silloway lists it as not uncommon in the bushes along Crow Creek, and common in the bushes and weeds of Daphnia Pond. In Nevada, Ridgway "found this bird abundant in all the bushy localities in the vicinity of water, but it was confined to the lower portions, never being seen high up on the mountains, nor even in the lower portions of the mountain cañons." (B. B. \& R.)

Walter Fisher, however, writes that it occurs about Lake Tahoe, his statement of its status in California being as follows: "The Western Yellow-throat ranges into California by way of the back-door and occurs very locally the whole length of the state, east of the Sierra Nevada Mountains. It pushes westward into the Shasta Valley, north of Mount Shasta, and ascends the Sierras as high as about 6,ooo feet (Lake Tahoe). In the coast district of southern California, south of latitude $35^{\circ}$, it is a permanent resident of the freshwater tule beds, this resident form having been separated under the name scirpicola. Wherever the tule or bulrush is found whether in marshes or by streams, lakes, or even spring-holes, the Yellow-throat takes up its 
abode, many miles of arid unfavorable country often separating neighboring colonies."

Eggs.-4 or 5, usually 4. Ground color and markings the same in all respects as in the eastern subspecies. Size; a set of 4 from Utah measures, $.74 \times .54, .74 \times .54, .73 \times .54$ and $.75 \times .54$.

\section{PACIFIC YelLOW-THROAT \\ GEOTHLYPIS TRICHAS ARIZELA Ober.}

Subspecific Characters.-In Oregon, as far east, at least, as the Klamath Lakes, Washington, and British Columbia the breeding Yellow-throat shows an approach to the eastern form in the decrease in yellow on the underparts, and the somewhat narrower margin of the grayish border to the black mask. These characters, however, are variable, some specimens having the mask border fully as wide as in extreme examples of occidentalis though it averages a shade bluer in color.

In central California, whether in the interior or on the coast, the name arizela can be applied with no precision. Breeding specimens from Stockton may be referred to either arizela or occidentalis and, in fact, have been referred to both. A breeding bird from Monterey is assuredly to be referred to occidentalis rather than to arizela.

Specimens from Westminster, Ducks, Revelstoke, and Banff exhibit the intermediate character which distinguishes arizela and it may possibly prove to be desirable to restrict this name to the Yellow-throats breeding at the northern part of the range of occidentalis. Wing, 2.20; tail, 2.10; bill, .42.

General Distribution.-Northwestern United States and southern British Columbia.

Summer Range.-Northern California, Oregon, Washington, and southern British Columbia eastward, at least, to Banff. (See, however, under a discussion of the bird's characters.)

Winter Range.-Mexico.

The Bird and its Haunts.-In the vast tule -grown areas of the Klamath Lake region this bird was even more abundant than I have ever found the eastern form, which, it may be added, it resembles in actions.

Walter Fisher (MS.) writes of this form: "In California the Pacific Yellow-throat breeds in favorable spots west of the Sierra Nevada and north of the Tehachapi Mountains. Like other Yellow-throats it is local in occurrence, frequenting tule patches that border sloughs, lakes or sluggish rivers. In the northwest coast district the patches of high grass and tule are usually of limited extent, so that the colonies are small, but along the sloughs of Clear Lake the birds are abundant."

Song.- The song resembles in form that of the eastern Yellowthroat but differs from it sufficiently to sound somewhat strange and unfamiliar to ears accustomed to the song of North Atlantic coast birds 
Eggs.-3 to 5, usually 4. The eggs of this subspecies are not so profusely marked and average somewhat smaller than those of the eastern forms; more of the irregular hair like lines, so common to eggs of the Orioles and Blackbirds, occur in some examples, forming a regular network about the large end, the rest of the egg being almost entirely free from markings. Size; average, .70x.53.

Nesting Dates.-Tacoma, Wash., May 4, half incubated-June Io, one-third incubated (Bowles).

\section{Biographical References}

(I) J. C. MerRILl, Birds of Fort Klamath, Oregon, Auk, V, I888, 362. (2) W. L. Finley, Two Oregon Warblers, Condor, VI, Ig04, 3I. (3) A. W. Johnson, Notes on Unusual Nesting Sites of the Pacific Yellow-throat, Condor, VI, I904, I29.

\section{Salt Marsh Yellow-throat GEOTHLYPIS TRICHAS SINUOSA Grinnell}

Subspecific Characters. -This small race of the Yellow-throat appears to resemble specimens of Geothlypis trichas arizela having the posterior border to the black mask narrower and darker than in occidentalis. It may always be known, however, by its small size. Wing, 2.00 ; tail, r.80; bill, .40.

General Distribution.-Permanent resident of the salt marshes about San Francisco Bay.

The Bird and its Haunts.-This is not only the smallest of the Yellow-throats, but it has the most restricted range. Walter Fisher (MS.) writes: "This race dwells in the salt marshes surrounding San Francisco Bay, California. These diminutive, rather deeply-colored birds are found in the tulés and tall grasses bordering the almost innumerable sloughs which meander the broad salicornia-covered flats. It is a permanent resident, whereas the Yellow-throat which occurs in fresh-water swamps to the north and south, is a migratory race."

Eggs.-4. The eggs of this race resemble in character those of Geothlypis trichas occidentalis.

\section{BELDING'S YELLOW-THROAT GEOTHLYPIS BELDINGI RIdgway}

Distinguishing Characters.-A black masked Yellow-throat much larger than any member of the G. trichas group, with the mask of the bordered posteriorly by yellow. Length (skin), 5.75 ; wing, 2.70 ; tail, 2.40 ; bill, .60.

Adult d, Spring.-A broad band across the forehead and on the cheeks and ear-coverts black, bordered behind by yellow; rest of upperparts, wings and tail olive-green, no white markings; underparts entirely yellow. In about 
one-half the large number of specimens examined the black of the head is wider on the left side than on the right, its posterior margin, therefore, passing diagonally from right to left.

Adult $\sigma^{\star}$, Fall.-Similar to adult $\delta$ in Spring but back browner, nape and flanks strongly washed with brown which partly conceals the yellow behind the black 'mask'.

Young $\sigma^{*}$, Fall.-Like the adult $\sigma^{*}$ in Fall but black band on forehead not so wide, and tipped posteriorly with grayish. There is, however, much less difference than in $G$. trichas, the black cheeks being acquired by beldingi in the first Fall.

Adult $\uparrow$, Spring.-Above olive-green, forehead more yellow; below yellow becoming paler on the abdomen and more olive on the flanks.

Adult $q$, Fall.-Similar to adult $q$ in Spring but browner above, especially on crown, sides strongly washed with brownish.

Young $q$, Fall.-Resembles aduit $q$ in Fall.

Nestling.-Above grayish cinnamon-brown; below brownish white; wingcoverts fuscous tipped with rusty buff. Paler and less olive above than nestling of trichas.

General Distribution.-Resident in Lower California, northward to San Ignacio on the west coast and Comondu on the east coast. (Brezester ${ }^{3}$.)

The Bird and its Haunts.-At San José del Cabo, Lower California, Frazar, as recorded by Brewster ${ }^{\ddot{ }}$, found this well-differentiated form of Yellow-throat an abundant inhabitant of rushes often where the water was three or four feet deep.

At Comondu, Bryant" found it common, keeping "mainly within the bulrushes and bushes of the creek.'

Song.-Brewster ${ }^{3}$, quoting Frazar, says that "the song resembles that of the Maryland [=Northern] Yellow-throat, but is so much heavier and fuller that it can be easily recognized." He adds that "the bird occasionally mounts into the air and sings on the wing."

Bryant $^{2}$ writes: "I frequently heard them singing, sometimes in the top of a low tree. Their notes are rather loud and quite clear, an interval of a few seconds occurring between each song."

Nesting Site.-Loosely woven in cat-tails. (Bryant ${ }^{\mathbf{2}}$.).

Nest.-Bryant ${ }^{1}$ describes a nest found at Comondu as resembling some Song Sparrows' nests and being thinly lined with fine fiber and horse hair.

Eggs.-The nests discovered by Bryant contained from two to four eggs each, but the set of two was probably abnormal. These eggs are described as "white, with shell-spots and dots of lilac-gray and a few surface spots and pencilings of black." Size; as given by Bryant (converted from millimeters), average, .77x.59; extremes $.76 \times .59, .77 \times .57, .77 \times .61$ 
Nesting Date.-Comondu, Lower California, March 25 (Bryant).

\section{BIOGRApHICAL REFERENCES}

(1) W. L. Bryant, A Catalogue of the Birds of Lower Calif., Proc. Calif. Acad. Sci. 2nd Ser. II, I889, 20. (2) Ibid., 310. (3) Wm. BreWster, Birds of the Cape Region of Lower California, Bull. Mus. Comp. Zoöl., XLI, 1902, 187.

\section{Genus CHAMATHLYPIS Ridgway}

Chamethlypis appears to be a connectant between Icteria and Geothlypis. In general appearance it suggests Geothlypis but the bill is stouter and strongly decurved, in fact, chat-like; the wing is even more rounded than in Geothlypis but the tail is decidedly longer than in that genus. The two known species inhabit Central America and Mexico and one of them reaches our limits on the Lower Rio Grande.

\section{Rio Grande Yellow-throat}

CHAMathlyPIS POLIOCEPHALA POLIOCEPhala (Baird) Plate XVII

Distinguishing Characters.-The heavy, curved bill, slaty head and black lores, in connection with the yellow throat, distinguish this species from any other of our Warblers. Length (skin), 5.25; wing, 2.15; tail, 2.35; bill, .50.

Adult б, Spring.-Crown slaty with a slight olive wash, lores black, this color extending below the eye; a white mark on eye-ring above and below the eye; back, wings and tail olive-green without white markings, bend of wing yellow; throat and breast bright yellow becoming paler on the belly and brownish on the flanks.

Adult d, Fall.-"Similar to the Spring and Summer plumage, but plumage softer, more blended; back, etc., more buffy olive or bright olive-brown; feathers of pileum (at least the occiput) tipped with brown, and flanks more decidedly buffy." (Ridgw.)

Young o", Fall.-_Similar in general to the adult plumage, but duller, the pileum concolor with back, or nearly so, and lores dull brownish gray or dusky, not distinctly different from color of pileum." (Ridgw.)

Adult and young P.-Resemble young $\delta$ in Fall.

Nestling.-Not seen.

General Distribution.-Northeastern Mexico north to Brownsville, Texas.

The Bird and its Haunts.-Nothing appears to have been written concerning the habits of this species.

\section{Genus ICTERIA Vieillot}

Icteria virens, the single species in this genus, is our largest member of the family Mniotiltida. In addition to size it is further distin- 
guished by its short, stout, vertically compressed, strongly arched, unnotched bill; rounded wings, as short as or shorter than the tail, and rounded tail.

Icteria is found throughout the greater part of the United States, and breeds southward to the Valley of Mexico. It appears not to occur in Florida or the West Indies.

\section{Yellow-BREasted Chat}

\section{ICTERIA VIRENS VIRENS (LIno.) Plate XXI}

Distinguishing Characters.-The Chat is the largest of our Warblers and, in connection with its size, may be known by its large bill, white line from the base of bill and bright yellow throat and breast. Length (skin), 6.40; wing, 2.95; tail, 2.90 ; bill, .55.

Adult 8 , Spring.-Upperparts, wings, and tail olive-green; bend of wing and under wing-coverts yellow; line from nostril over eye, upper and lower portions of eye-ring, and a short line from lower mandible at the side of the throat, white; lores black; auriculars grayish; throat and breast bright yellow, lower abdomen and crissum white, the flanks olive or brownish; bill shining black.

Adult d, Fall.-Similar to adult $\delta$ in Spring but slightly greener above, flanks and crissum browner; upper mandible brownish, lower, horn color.

Young $\delta^{*}$, Fall.-Similar to adult $\delta$ in Fall but lores grayer.

Adult \&, Spring.-Not always distinguishable from adult $\delta$ in Spring but generally duller in color, lores grayish, the lower mandible basally paler.

Young $\&$, Fall.-Not seen, doubtless closely resembles young $\delta$ in Fall.

Nestling.-Above dull brownish gray with an olive tinge; a narrow white superciliary line; wings and tail dull olive-green; throat and belly white, flanks brownish, breast with an olive-gray band.

General Distribution.-Eastern United States.

Summer Range.-Chats do not occur in Florida, but from northern Georgia and the Gulf states, and west to the Plains, they are common north to southern New York and Iowa; they also occur less commonly to southern New England, Massachusetts (rare and local), Vermont (Pownal, June I6, I896), Maine (accidental, Portland, North Bridgton, Elliott), New York (Albany, West Seneca, Oneida, Orleans, and Yates Counties), Ohio (Oberlin), southern Ontario (Hamilton, Waterdown, Point Pelee), Michigan (Detroit, Grosse Pointe Farms), Wisconsin (Stevens Point), Minnesota.

Winter Range.-Mexico to Costa Rica.

Spring Migration.-The summer home of the Chat extends from the Atlantic to the Pacific. The species has been separated into an eastern and a western form, and in the following tables, the notes for Colorado and the Pacific Coast refer to the western form (Icteria virens longicauda), the rest to the eastern form (Icteria virens virens.) 


\section{Plate XXI}

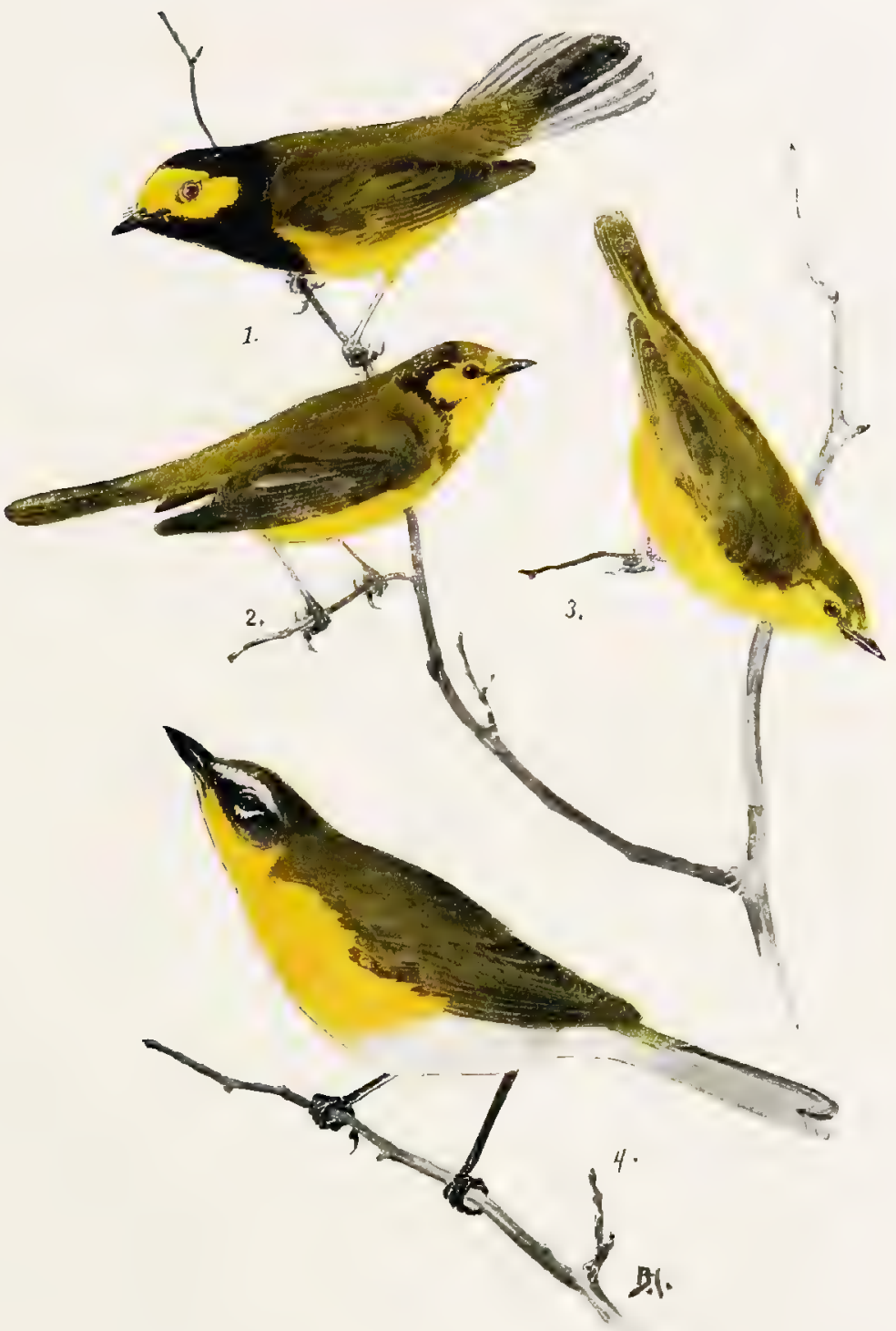

1. Hooded Warbler, Male.

2. Hooded Warbier, Adult Female.
3. Hooded Warbler, Young Female.

4. Yellow-beneasted Cha!, Aoult. 


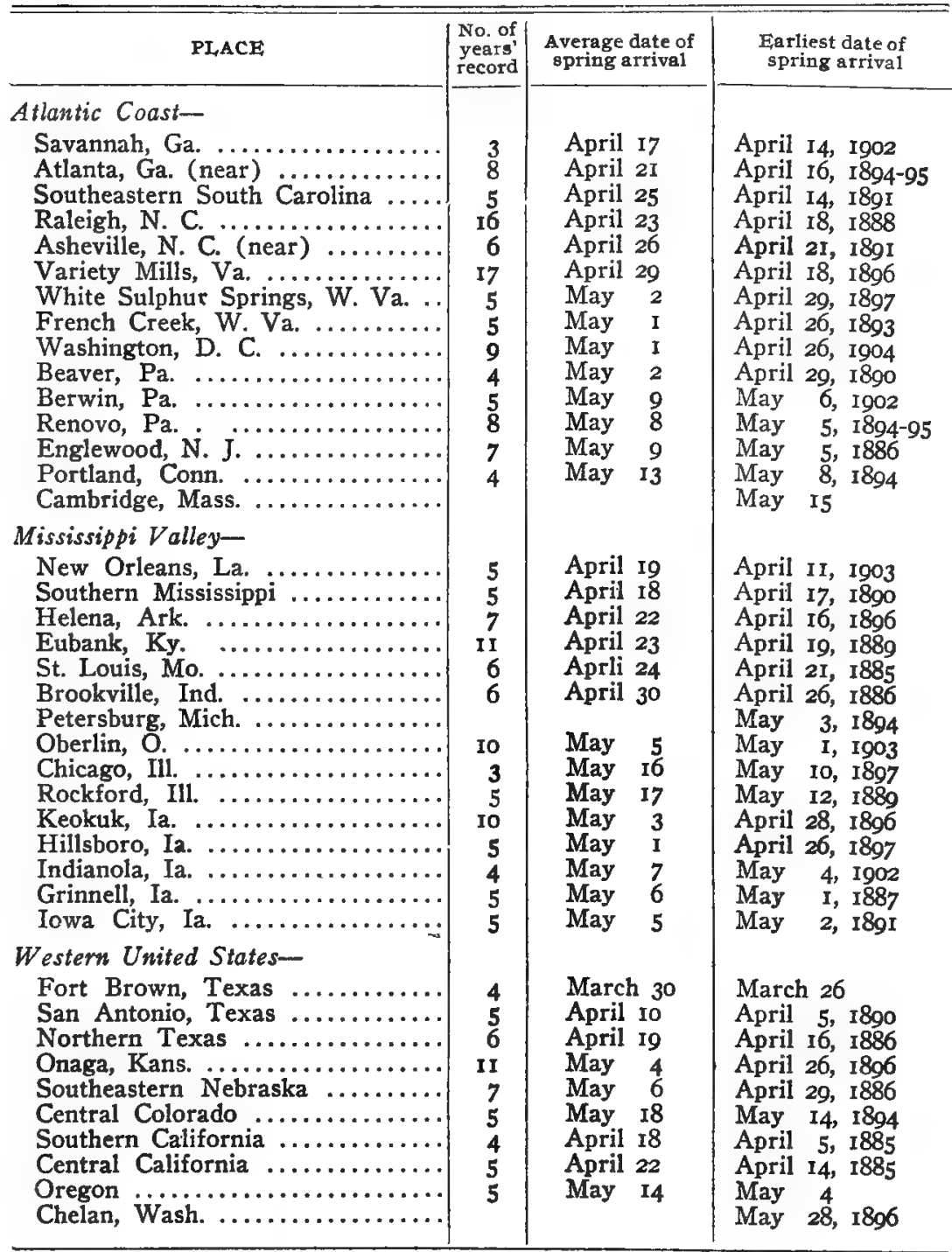

Fall Migration.-The Chat migrates early. It deserts the northern limit of its range in August and by the first of September few are left north of 39 degrees latitude. Some dates of the last noted are at Englewood, N. J., August 29, I885; Renovo, Pa., September 21, I897; Berwyn, Pa., September 2, 1898; Washington, D. C., September 19, I886; Raleigh, N. C., September I, 1888; Brookville, Ind., September 7, 1886; Bicknell, Ind., September 27, I894; Chicago, Ills., August I6, 
I895; Hillsboro, Ia., September 4, I898; Onaga, Kan., September 2I, 1897; New Orleans, La., September 12, 1899; Bonham, Texas., September 20, I889.

The Bird and its Haunts.-Assuredly no other Warbler, and indeed few of our passerine birds, are possessed of the Chat's individuality. Its characteristics of form, habits, and notes are exceptionally pronounced and, in consequence, we have here a bird of more than usual interest.

Although the Chat avoids rather than seeks observation, he by no means shuns the haunts of man and when favorable cover was available I have known these birds to nest in a village. Generally, however, the tangled undergrowth which the Chat requires disappears as the human population increases and, for the Chat, only the waste places are left. Not only does the dense, often briery growth, which this bird requires, develop more freely near water but here, because of the often less habitable nature of the ground, it is left longest and for these reasons one generally finds the Chat in wet or swampy places, though he evidently is quite as contented in upland thickets, when they are available.

No small part of the impression the Chat creates is due to the nature of his haunts. In them he has the bird student at complete disarlvantage. When seemingly almost within reach he is still invisible; and one might well imagine that he intentionally led us through the most impenetrable part of his home merely to enjoy our futile efforts to see him. To the Chat, therefore, more than to any other American bird, might be applied Wordsworth's familiar lines:

"O Cuckoo! Shall I call thee bird Or but a wandering voice?"

If, however, you would see the Chat satisfactorily, fight him with his own fire. Seat yourself in the thicket where as pursuer you are at the bird's mercy, and with pursed lips squeak gently but persistently. Soon there will be an answering chut, and with due patience and discretion you may induce this elusive creature to appear before you.

I do not recail a more suspicious bird than the Chat. Even the Crow's innate caution is sometimes forgotten; but a Chat is always on guard. So far as I am aware, no one has as yet succeeded in photographing a Chat on its nest. F. L. Burns (MS.) writes that "the nest is watched very closely although its owner is seldom flushed from it, while a disturbed nest will almost invariably be deserted after the bird has pierced or broken its eggs. While the Cowbird frequently 
deposits her egg in the Chat's nest it is never incubated but is destroyed by the bird with her own."

Song.-As a vocalist the Chat is unique among the Warblers, and indeed, so far as my experience goes, among birds at large. No description does justice to his singular medley of calls and whistles. Heard at night, when, especially if it be moonlight, the Chat often sings freely, the performance takes high rank among the songs of North American birds; not for its fluency or spiritual quality, but for its striking originality. The Chat's calls are an emphatic chut chut and an intense, concentrated kee-yuck.

"Regularly up to the middle of July, and sometimes through the third or even fourth week of the month, this species continues in song. Imperfect songs may be heard in early August, but rarely later, although my record extends to August 14. Dates of fairly perfect final songs range between July 15 and August I." (Bicknell ${ }^{2}$ ).

"The voice of this bird is flexible to an almost unlimited degree. It has no notes suggesting its place among the Warblers. Perhaps the commonest note is a harsh, rather nasal, chuck, often prolonged into chuck-uck. The song is almost impossible to describe; it begins with two slow, deep notes; then follows one high-pitched and interrogative note; then several, rapid and even, and from that point on to the end, I have never been able to give any rendering of the clucking and gurgling that completes the long song. As far as I have described, it may be rendered thus: Quoort-quoort! whee? whew-whew-whew!

"It is generally uttered from a perch at or near the top of a small tree among the thickets; but often the bird mounts high into the largest tree available-but never far from the heavy undergrowth,-utters part of the song there, then launches into the air, wings held high, and flapping slowly, almost meeting over the back; legs dangling, and tail wagging extravagantly up and down. Singing madly, he lets himself slowly down, and finally drops into the thicket." (Allison, MS.).

"His love song is a woodland idyl and makes up for much of his short comings. From some elevated perch from which he can survey the surrounding waste for a considerable distance he flings himself into the air, straight up he goes on fluttering wings-legs dangling, head raised, his whole being tense, and spasmodic with ecstasy. As he rises he pours forth a flood of musical gurgles, and whistles that drop from him in silvery cascades to the ground, like sounds of fairy chimes. As he reaches the apex of his flight, his wings redouble their beatings, working straight up and down, while the legs hanging limply down, 
remind the observer of drawings we sometimes see from the brushes of Japanese artists. He holds his hovering position for an instant then the music gradually dies away and as he sinks toward the ground, he regains his natural poise, and seeks another perch like that from which he started." (Taverner ${ }^{3}$.)

Nesting Site.-The nest is placed in a small bush or sapling, or among briers at from one to five, but, usually, about three feet from the ground.

Nest.-Nests from near New York are coarse, bulky but rather compact structures made chiefly of dried grasses, leaves, grapevine and inner bark, and all lined chiefly with fine grasses. The use of coarse grasses exteriorly and the absence of rootlets in the lining appear to be characteristic.

Eggs.-3 to 5, usually 4, very rarely 5. Ground color a clear white sometimes tinged with pinkish; again a greenish shade is noticeable; the majority of specimens show a high gloss; the markings consist, for the most part, of specks and spots, but often good sized blotches occur, these are either well distributed over the entire egg or clouded together at the large end usually in form of a wreath, they are of varying shades of reddish, cinnamon rufous and chestnut with under shell spots of lavender, in most specimens the markings are very bold and well defined. Size; average, .88x.68; extremes, $.96 x .71, .74 x .60, .86 x .72, .76 x .68$. (Figs. I10-112.)

Nesting Dates.-Chatham Co., Ga., May 7 ; Augusta, Ga., June 23 (C. W. C.) ; Iredell Co., N. C., May I7 (C.W.C.); West Chester, Pa., May 23-June 6 (Jackson); Waynesburg, Pa., May ro-July 2 (Jacobs); New York City, May 23-July 6 (F.M. C.); New Haven, Conn., May 22-July 7 (Bishop); Oberlin, O., May I5-July I5 (Jones); Monroe Co., Mich., May 26, Trombly (Barrows).

\section{BIOGRAPHical REFreENCES}

(1) WM. BREWSTER, Observations on the Birds of Ritchie County, West Virginia, Ann. Lyc. Nat. Hist., N. Y., XI, I875, 137. (2) E. P. BicknelL, A Study of the Singing of Our Birds, Auk, I, I884, 216. (3) P. A. TAVERNER, The Yellow-breasted Chat; a Character Sketch, Bird-Lore, VIII, 1906, I3I.

\section{Long-TAiled Chat}

\section{ICTERIA VIRENS LONGICAUDA (Lawreace)}

Subspecific Characters.-Similar to Icteria virens virens but wings and tail longer, bill more slender, upperparts grayer, yellow averaging deeper, white stripe at side of throat more extended, sometimes passing behind auriculars Wing, 3.10; tail, 3.40; bill, .57.

General Distribution.-Western United States. 
Summer Range.-Northern Mexico, west to the Pacific; east to the Plains; north to North Dakota (Musselshell River), southern Montana (Missouri and Yellowstone Rivers), British Columbia (Sumas, Okanagan).

Winter Range.-Mexico to Costa Rica.

The Bird and its Haunts.-This slightly differentiated form of the Chat is a locally common bird throughout the west. So far as my experience goes its habits differ in no respect from those of the eastern birds. At Sargents, California, where the growth bordering the river is strongly eastern in its general character, the bird was not uncommon, while in the scrubby pastures in the Klamath River Valley at Beswick, and the bushy hillsides of the town of Klamath Falls, in Oregon, it was as numerous as I have ever found its eastern relative.

Nesting Site.-The nest is placed in small bushes or saplings or among briers usually at a height of from two to three feet.

Nest.-Nests from Fort Davis, Texas, are described as composed of "dry leaves, strips of reeds and dry grasses without a different lining." ( $C . W . C$.) Sonoma County, California, nests are described as made of dead leaves and grasses and lined with finer grasses. (C. W. C.)

Eggs.-_imilar to those of the Yellow-breasted Chat, showing the same variation, but averaging a trifle smaller.

Nesting Dates.-Comal Co., Texas, April 2; Fort Davis, Texas, July I6 (C. W. C.); Tucson, Ariz., June 2 (Stephens); San Jose, Calif., May I8 (C.W. C.)

\section{Genus WILSONIA Bonaparte}

In correlation with its flycatching habits Wilsonia has a flat bill and conspicuously developed rictal bristles. Measured at the nostrils the bill is as wide or wider than it is high. The wing is less than .50 inches longer than the tail, the second, third, and fourth primaries are longest, the outer tail-feathers are slightly the shortest; the feet are pale, the tarsus but little longer than the middle-toe and claw.

Omitting Sylvania meridionalis (Pelz.), of Colombia and Ecuador, which probably does not belong to this genus, Wilsonia contains three species, two of which are eastern, while the third, $W$. pusilla, ranges across the continent; an eastern, a Rocky Mountain, and a Pacific Coast form being recognized.

\section{HOODED WARBLER \\ WILSONIA CITRINA (Bodd.) Plato XXI}

Distinguishing Characters.-The male of this beautiful species cannot be mistaken for any other Warbler; the female may be known by its entirely 
yellow underparts (the throat often blackish), yellow cheeks, absence of white wing-bars, and largely white outer tail-feathers. Length (skin), 490; wing, 2.50; tail, 2.20; bill, 40 .

Adult ot, Spring.-Forehead and cheeks bright yellow, crown and nape shining black spreading laterally and connected with the black throat, rest of upperparts olive-green; two outer tail-feathers largely white on inner web, third to fourth feathers with a variable amount of white; no wing bars; black of upper breast sharply defined from yellow of the rest of underparts, fianks slightly greenish; bill black.

Adult d" Fall.-Similar to adult o in Spring, but bill brownish.

Young $\delta$, Fall.-Similar to adult $\delta$ in Fall, but black of throat, and, to a lesser degree of nape, narrowly tipped with yellowish, chin yellower.

Adult + , Spring.-Similar to the $\delta$ but duller, the yellow of crown and cheeks more or less washed or obscured with dusky; the black 'hood' usually but partly developed on the crown and nape, indicated by a narrow line bordering the auriculars, and a blackish wash on the throat or upper breast. In nine out of thirty specimens the black is entirely wanting, in one it is nearly as welldeveloped as in a young $d$ in the Fall, in two it is well-developed only on the crown and nape, while the remaining eighteen specimens are variously intermediate.

Adult , Fall.-Not distinguishable from adult $\$$ in Spring.

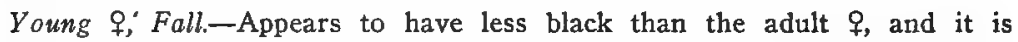
possible that the development of the 'hood' in the female is dependent upon age.

Nestling.-Above yellowish brown, breast paler, the belly pale straw yellow; wing-coverts edged with brownish.

General Distribution.-Eastern United States; north to Massachusetts and Wisconsin; west nearly to the Plains.

Summer Range.-With the exception of Texas and Florida, this species breeds throughout its range in the United States. It is an abundant breeder in the eastern portion of the lower Mississippi Valley; less common west of the river to eastern Kansas (Leavenworth), southeastern Nebraska (Nemaha River), north to southern Wisconsin (Milwaukee), central Michigan, southern Ontario (Port Rowan, Hamilton, Cataraqui), central New York (Oneida, Cayuga, and Wayne Counties). Casual in Massachusetts (Brookline, June 25, I879; Provincetown, June 25, I888; Taunton, May 8, I888; Framingham, October I5, I893), and Rhode Island (Kingston). In migration it is common in northern Florida, rare in the southern part, and occurs in eastern Texas to San Antonio and Waco. Accidentai in southern Minnesota (Heron Lake, May 16, I889), northeastern New York (Lewis County, September 9, 1878), and southern Maine (Falmouth, September 9, I904).

Winter Range.-Mexico to Panama. 
Spring Migration.-From its winter home the species reaches the United States by a flight across the Gulf of Mexico, avoiding the West Indies and (for the most part) southern Florida.

\begin{tabular}{|c|c|c|c|}
\hline PI,ACE & $\mid \begin{array}{l}\text { No. of } \\
\text { Years' } \\
\text { record }\end{array}$ & $\begin{array}{l}\text { Average date of } \\
\text { spring arrival }\end{array}$ & $\begin{array}{l}\text { Earliest date of } \\
\text { spring arrival }\end{array}$ \\
\hline \multicolumn{4}{|l|}{ Atlantic Coast- } \\
\hline Northern Florida & 6 & March 28 & March 19,1885 \\
\hline Southeastern Georgia .... & 3 & April 4 & March 29, 1902 \\
\hline Atlanta, Ga. (near) ..... & 9 & April 10 & April 3, Ig02 \\
\hline Raleigh, N. C. $\ldots \ldots \ldots \ldots$ & 14 & April 18 & April 10, 1893 \\
\hline Asheville, N. C. (near) ... & 7 & April Ig & April 12, 1893 \\
\hline Lynchburg, Va. ........ & 4 & April 29 & April 23, I900 \\
\hline French Creek, W. Va. .. & 7 & April I7 & April 20, I89I \\
\hline Washington, D. C. ..... & 5 & May 2 & April 27, 1892 \\
\hline Englewood, N. J. ......... & 7 & May & May 2,1897 \\
\hline Renóvo, Pa. ............ & 4 & May 13 & May Io, I9OI \\
\hline \multicolumn{4}{|l|}{ Mississippi Valley- } \\
\hline New Orleans, La. & 10 & March 22 & March I3, I897 \\
\hline Southern Mississippi & 3 & March 30 & March 22, I902 \\
\hline Helena, Ark. ............. & 7 & April I I & April 3, I898 \\
\hline Eubank, Ky, $\ldots \ldots \ldots \ldots \ldots$ & 7 & April I4 & April 8, 18go \\
\hline St. Lotis, Mo. .. & 6 & April 23 & April I7, I883 \\
\hline Central Indiana & 6 & Apr11 29 & \\
\hline Keokuk, Ia... & $\begin{array}{l}4 \\
5\end{array}$ & May Io & May 5,1898 \\
\hline
\end{tabular}

The Hooded Warbler has also been taken at Chicago, I1l., April 28, I884, and May 3, I895, and at Grinnell, Ia., May I8, 1888. The Texas dates are at Refugio County, March 30, 1898, March 13, 1899; San Antonio, March 31, 1890, April 7, 1894; Bee County, April 3, I886, April Io, I887.

Fall Migration.-The fall migration is hardly in full swing before the latter part of August. The earliest dates at Key West, Fla., are August 30, 1887, and August 19, I889; at Truxillo, Honduras, September 26, 1887 , and in southeastern Nicaragua, September 24, 1892. The bulk leave the northern breeding grounds by the middle of September and the last have been noted at Renovo, $\mathrm{Pa}$., Sepember 26, I900, October 13, I903; Beaver, Pa., September 25, I890, October 3, I891 ; Englewood, N. J., September 15, 1886; Washington, D. C. September 15, 1890; French Creek, W. Va., September 29, I892; Lynchburg, Va., October Io, I899; Raleigh, N. C., October I, I89I ; Asheville, N. C., September 20, I890, Sedan, Ind., October 5, I893; Brookville, Ind., October 20, I884; Eubank, Ky., September 29, I889; New Orleans, La., October 19, 1895 and 1897 , October 25, 1899. The latest record for the United States is the-probably accidental-occurrence of this species at Germantown, Pa., November I9, 1887. 
The Bird and its Haunts.-To my mind there is no Warbler to which that much misused word "lovely," may be so aptly applied as to the present species. Its beauty of plumage, charm of voice, and gentleness of demeanor, make it indeed not only a lovely, but a truly lovable bird. Doubtless, also, the nature of the Hooded Warbler's haunts increase its attractiveness, not merely because these wellwatered woodlands are in themselves inviting, but because they bring the bird down to our level. This creates a sense of companionship which we do not feel with the birds ranging high above us, and at the same time it permits us to see this exquisitely clad creature under most favorable conditions.

As we approach the bird's nest she protests with a chirp which one soon learns to recognize. It is not the sharp, insistent note of the Oven-bird, but of a milder tone uttered as the bird flits from bush to bush displaying her white outer tail feathers in flight or jetting them when perching. The male often ascends to a height of twenty to forty feet, his song being more frequently delivered from a perch well above the undergrowth than from the undergrowth itself.

In Mississippi, Allison (MS.) writes, that the Hooded Warbler inhabits "low, heavily shaded woods, with thick undergrowth. Where convenient cover, such as a brake of switch-cane, extends to the border of the woods, the bird has no objection to an open, light, situation; and along the Gulf coast, where the only swampy situations are the narrow 'bay-galls,' the thickets of rose-bay (Illicium) and azalea afford sufficient seclusion for a few. Damp woods such as are afforded by river and creek bottoms, however, are more favored."

The same writer adds: "I find the following note on the behavior of the males during courtship (New Orleans, Apr. 28): 'We saw * * * a very interesting fight between two male Hooded Warblers, for the possession of a female; the two began the contest in a tree, fluttered down into the mud and water, and the upper one, who had the other by the head, was in a fair way to drown or disable his opponent, when we frightened them off."

Song.-The song of the Hooded Warbler is distinguished by an easy, sliding gracefulness. To my ear the words you must come to the woods or you won't see me, uttered quickly, and made to run one into the other exactly fit the bird's more prolonged vocal efforts, though they are far from agreeing with the attempts at syllabification of others. The call is a high, sharp cheep, easily recognized after it has been learned. 


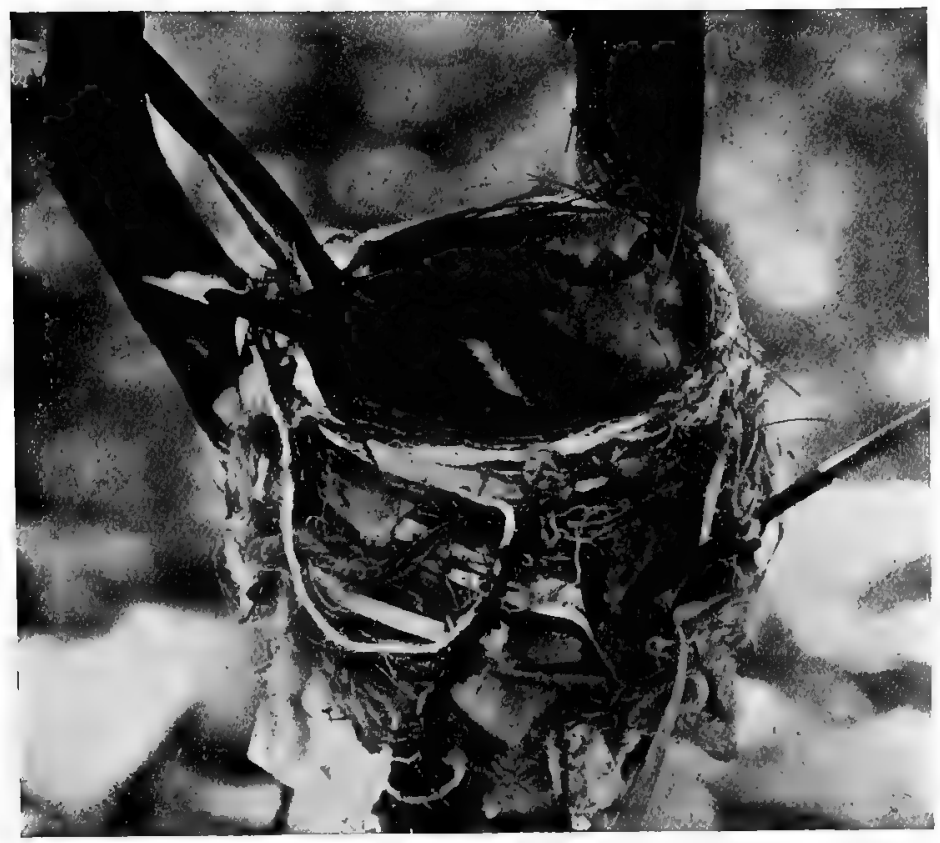

AMERICAN REDSTART ON NEST.

Plotographed by T. L. Hankinson, at Ithaca, N. I.

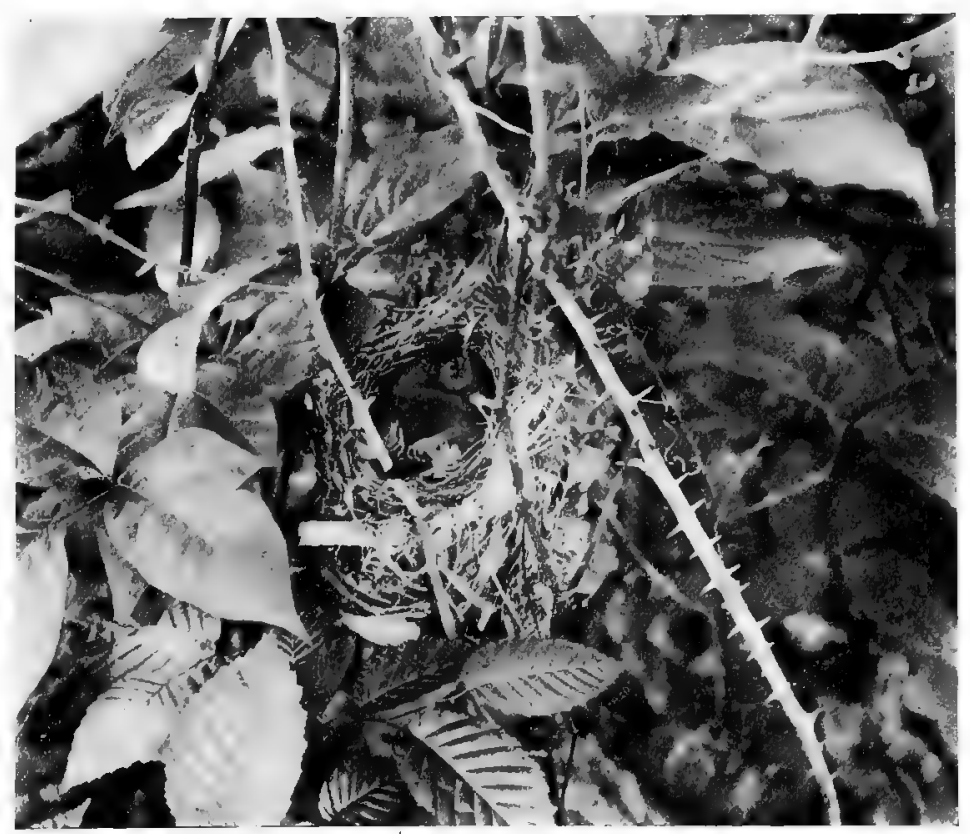

FOODED WARBLER ON NEST.

Photographed by Frank M. Chapman, at Englewood, N. J. 

"The first song-period of this species seems rarely to pass early July-latest dates July ro and I5. Perfect songs heard in the fourth week of August locate the second song period." (Bicknell ${ }^{5}$.)

"The usual note is a clear and nervous, but not metallic, chirp. Little sound of any kind is made in the fall, when the chirp is more subdued. There are two common songs, both uttered on every possible occasion in spring, when the woods are ringing with them. The most frequent is a short one of four syllables, Se-zwhit, se-wheer; the longer song may be rendered, Whee-zohee-wheé-a-whećr,", accented as marked. A sharper, very clear-cut chirp is sometimes to be heard late in the evening, about dusk." (Allison, MS.).

Nesting Site.-The nest is placed in a small bush or sapling at from one to five, but usually about three feet from the ground. At the southern limit of the bird's nesting range canes are generally chosen, at the northern limit laurel is frequently selected. Where neither of these growths is present various species of bushes or saplings are used.

Nest.-Nests from near New York are generally compactly built with a well-woven rim and composed largely of soft inner bark and sometimes plant-down with often an outer wrapping of dead leaves and leaf skeletons, and are lined with fine grasses.

Nests from South Carolina are described as made of cane leaves, lined with dry weeds and rootlets or black 'moss,' possibly the dead, inner fiber of Tillandsia.

Eggs.-3 to 5, usually 4, very rarely 5. Ground color white to creamy white, well wreathed about the large end with spots and small blotches of deep, rich chestnut red, purplish red and lilac-gray, with under shell markings of pale lavender; sometimes the markings extend very sparingly over the entire egg, but this is rare, and only the lighter shades occur. Size; average, .73x.54, extremes, $80 \times .55$, $.67 \times .52, .76 x .58, .68 \times .48$. (Figs. I I3-I I 5.)

Nesting Dates.-Charleston, S. C., April 30-June 26, three eggs, small embryos (Wayne) ; Bertie Co., N. C.,, May 9; Waynesburg, Pa., June 6, only two records (Jacobs) ; New York City, May 26-June I5 (F. M. C.) ; New Haven, Conn., May 27-June 24 (Bishop); Kalamazoo Co., Mich., June Io, Gibbs-Macatawa, Ottawa Co., August 22, feeding two young Cowbirds, Smith (Barrows).

\section{Biographical References}

(I) WM. Brewster, Observations on the Birds of Ritchie County, West Virginia, Ann. Lyc. Nat. Hist., N. Y., XI, 1875, 138. (2) J. N. Clark, Hooded Warblers, Nesting in Southern Connecticut, Orn. and Oöl., VI, I88I, 9, I02. 
(3) J. P. N[orrIs], A Series of Eggs of Myiodioctes mitratus, Orn. and Oöl., XII, 200. (4) A. B. Blackmore, The Hooded Warbler (in La.), Oölogist, XII, I895. (5) E. P. Bicknell, A Study of the Singing of Our Birds, Auk, I, I884, 216.

\section{WILSON'S WARBLER \\ WILSONIA PUSILla PUSILlA (Wils.) Plate XXII}

Distinguishing Characters.-The $\delta$ and generally also the $q$, may be known by its black cap, entirely yellow underparts, and absence of white in the wings and tail. Females in which the cap is lacking (young?) resemble the young Hooded Warbler but are smaller and have no white in the tail. Length (skin), 4.25 ; wing, 2.10 ; tail, 2.00 ; bill, .32.

Adult o", Spring.-Crown shining black, forehead, cheeks, including line over eye, bright yellow; rest of upperparts bright olive-green; wings and tail narrowly edged with same color and without white marks; underparts entirely bright yellow; upper mandible brownish black, lower, flesh color.

Adult $\delta^{\prime}$, Fall.-Similar to adult $\delta$ in Spring but black cap narrowly tipped with olive.

Young o, Fall.-Similar to adult $\delta$ in Fall but cap more widely tipped with olive, yellow of forehead and above eye duller.

Adult 옹 Spring.-Sometimes not distinguishable from adult $\delta^{\prime \prime}$ in Spring but ustally with black cap less sharply defined and conspicuously tipped with olive-green; yellow duller. In this plumage closely resembles young $\delta$ in Fall.

Adult $q$, Fall.-Similar to adult $q$ in Spring but crown more widely tipped with olive-green.

Young $q$, Fall.-Similar to adult $q$ in Fall, but black cap absent, or if present, so broadly tipped with olive-green as to be concealed.

Nestling.-Above hair-brown, breast lighter, belly yellowish white, the sides brownish, lesser and median wing-coverts tipped with brown-tinged white forming two well-marked wing-bars.

General Distribution.-Eastern North America.

Summer Range.-Principally in Canada, a few nesting in northern Maine (casually south to Pittsfield, Me., and accidentally at Lancaster, N. H.), central Ontario (Ottawa, Madoc, Lansdowne), northern Minnesota, Manitoba and Hudson Bay region. Casual in the Rocky Mountain region during migrations.

Winter Range.-Mexico to Panama; accidental once in the West Indies.

Fall Migration.-Some dates of the last one seen are at Newport, Ore., August 30, I900; Berkeley, Cal., September I7, I888; Columbia Falls, Mont., September I4, I894; Cheyenne, Wyo., September II, 1888; Cooney, New Mex., October 9, I889; Aweme, Man., average six years September 8; Lanesboro, Minn., average of four years September 20, latest September 25, I887; Grinnell, Ia., average four years September 2I, latest September 25, 1888; Ottawa, Ont., 
average four years September I9, latest September 29, I890; Pictou, N. S., August 24, 1894; St. John, N. B., September 17, I896; Renovo, $\mathrm{Pa}$, average six years, September 21, latest September 30, 1895; Germantown, Pa., October I5, 1889.

Spring Migration.-The locality will be sufficient to indicate which form of this species the following notes refer to:

\begin{tabular}{|c|c|c|c|}
\hline $\mathrm{PL}_{1} \mathrm{ACE}$ & $\mid \begin{array}{c}\text { No. of } \\
\text { years' } \\
\text { record }\end{array}$ & $\begin{array}{l}\text { Average date of } \\
\text { spring arrival }\end{array}$ & $\begin{array}{l}\text { Earliest date of } \\
\text { sprivg arrival }\end{array}$ \\
\hline \multicolumn{4}{|l|}{ Atlantic Coast- } \\
\hline Rising Fawn, Ga. .. & & & May $\quad$ I, 1885 \\
\hline Raleigh, N. C. $\ldots \ldots \ldots$ & 3 & May I3 & May II, 1893 \\
\hline French Creek, W. Va. ............ & 2 & May Io & May $\quad 9,1893$ \\
\hline 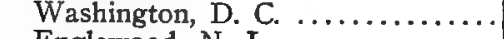 & 6 & May 9 & May 7,1905 \\
\hline 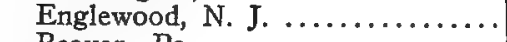 & 3 & May I3 & May II, Igoz \\
\hline Beaver, $P a . \quad \ldots \ldots \ldots \ldots \ldots \ldots$ & 6 & May I5 & May $\quad 8,1889$ \\
\hline East Hartford, Conn. ........... & 7 & May I3 & May Io, I894 \\
\hline Eastern Massachusetts ........... & Io & May I7 & May Io, I 897 \\
\hline Southern New Hampshire ....... & 6 & May I7 & May I3, I898 \\
\hline Southern New Brunswick ....... & 7 & May 26 & May 19,1887 \\
\hline 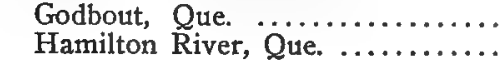 & & & June 3, I 884 \\
\hline \multicolumn{4}{|l|}{ Mississippi Valley- } \\
\hline St. Louis, Mo. .. & 5 & May & April 29, $188_{5}$ \\
\hline Chicago, Ill. ....... & 9 & May I4 & May 10,1902 \\
\hline Waterloo, Ind. . . . . . . . . & 6 & May I5 & May 10,1903 \\
\hline Oberlin, $0, \ldots \ldots \ldots \ldots \ldots \ldots$ & 4 & May I 4 & May 5,1902 \\
\hline Southern Michigan...$\ldots \ldots \ldots$ & 8 & May I7 & May I I, I 888 \\
\hline Ottawa, Ont. $\ldots \ldots \ldots \ldots \ldots \ldots$ & I9 & May 20 & May I4, I893 \\
\hline Mouth Rio Grande, Tex. ........ & 2 & April 28 & April 26, I878 \\
\hline Grinnell, Ia $\ldots \ldots \ldots \ldots \ldots \ldots \ldots$ & 5 & May II & May $\quad 4,1890$ \\
\hline Lanesboro, Minn. ........... & 9 & May 8 & 2,1887 \\
\hline Elk River, Minn. .............. & 4 & May I4 & May II, I886 \\
\hline Aweme, Man. . . . . . . . . . . . & 6 & May I5 & May II, I904 \\
\hline Ft. Chippewyan, Alberta & 2 & May 26 & May 23, I90I \\
\hline \multicolumn{4}{|l|}{ Western America- } \\
\hline Southern Arizona ... & & & April 12, 1902 \\
\hline $\begin{array}{l}\text { Northern Colorado ... } \\
\text { Great Falls, Mont. ... }\end{array}$ & 6 & May I2 & May Io, I905 \\
\hline Kowak, Alaska. & $\because 2$ & May 25 & 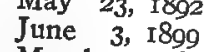 \\
\hline Central California ... & 4 & March 30 & March 23, I889 \\
\hline Southwestern British Columbia .. & 3 & May & May 3,1889 \\
\hline
\end{tabular}

The Bird and its Haunts.-As a migrant I find Wilson's Warbler usually in bushes bordering woodland waters. At the northern base of Monadnock, Gerald Thayer (M.S.) writes: "This jaunty little Warbler-flycatcher is often common in the spring migration, from the 9th to the end of May. It haunts damp alder-copses, orchards, and small deciduous second growth along roadsides, and seems to avoid the upper parts of the mountain and of the surrounding hills. 
"In actions, call-notes and song, this is a decidedly individual little bird. Like the Canada, it is both a gleaner and a darting flycatcher, but it has a more perky restlessness of manner than the Canada. It twitches its tail up and down, not methodically and almost uninterruptedly, like the Palm Warbler, but with spasmodic irregularity. Now the tail will go sharply flip-flip-flipping for many seconds together, and again it will be perfectly still for a longer time. Add to this Warbler's individual manners and sufficiently peculiar notes, his very rich yellow and yellow-green coloration, relieved by a round, glossy, blue-black crown-spot (of erectile feathers) as the sole marking, and you have a bird easily identified. The females usually and the young always lack the distinguishing crown-cap; but their manners betray them."

In Maine, Morrell2 says, "Wilson's Warbler may safely be classed as one of the rarest Warblers which breed regularly in the State. It is nowhere common, even as a migrant, arriving during the second week in May with the main army of migrating Warblers. I always see it singly or in pairs, never in flocks, at this time. They are birds of the bush, never going into large woods as do the Black-throated Green and Blackburnian Warblers, but spend the summer in knolly, bushgrown pastures bordering young growths."

Song.- "The singing as a rule is done from a perch, between sallies into the air, but sometimes it is accomplished during one of the little darting flights. It is highly changeable, in everything but tonequality. Though only just loud enough, at its best, to give the bird rank among full-voiced Warblers, it has much of the ringing clarity of the Canada's and Hooded's songs. The commonest form of it, a rapid, bubbled warble, of two nearly equal parts, the second lowertoned and sometimes diminuendo, has always reminded me of a Northern Water-Thrush song. But it falls short of that utterance in vivid 'suddenness.' It is also somewhat like the Nashville's songs, particularly the less common, softer one. It is fully as clear-toned, but far less loud, and more hurriedly delivered. Sometimes the Wilson's sings only half his song,--using either of the two parts,--and the second part thus used is occasionally prolonged into a full-length song. Another regular variation is an inversion of the common twofold utterance. Again, the complete song is sometimes uttered in a very soft undertone-fairly whispered. But all these variations-all I have yet heard-seem to be based on one main song. Of call-notes, the bird has at least two perfectly distinct kinds, both fairly constant. One is a very fine, quick lisp, and the other an unusually low-toned and 
slightly harsh chut much like the Yellow-throat's commonest call, but easily distinguishable."

(Thayer, MS.).

"Rarely sings in migration. May 25, 1897 one sang repeatedly a full chord-like chee-chee-chee followed by a Goldfinch-like trill, the latter varied somewhat, but the opening notes are all usually the same. Another time I heard the jumbled warble without the clear chee-chee-chee." (Farwell, MS.)

Nesting Site.-A nest found by Spaulding ${ }^{1}$ at Lancaster, N. H., "was situated among some short bushes on a small grassy knoll in wet, swampy land. The nest was sunken in the ground and well concealed by fine swamp grass."

At Pittsfield, Maine, Morrell ${ }^{2}$ has found two nests; one was placed "at the base of a small shrub," the other was "in the side of a depression on the ground, well concealed by overhanging grass and shrubs." Swain ${ }^{3}$ records a nest, found near Bangor, Maine, "under a thick mass of grasses and weeds at the foot of an alder bush."

Nest.-Spaulding's" nest "was almost wholly of fine dry grass, lined with a very few hairs, deeply cupped and quite substantial for a Warbler." Morrell describes the first nest found by him as "mainly constructed of short pieces of grass, fairly well woven together, with a very few hairs mingled with the grass lining, and some moss and leaves exteriorly." Morrell's second nest resembled the first "with the exception of the hair, in the place of which were a few black, hairlike roots." The nest found by Swain " "was made up outside of fine dead grasses (neatly woven, yet a frail structure), lined with fine grasses and a few horse-hairs."

Eggs.-Usually 4. A set collected by Mr. F. B. Spaulding ${ }^{1}$ is described by him as follows: "The ground color of the eggs is pure white; number one has a light wreath of small dark specks about the crown, number two has the crown completely covered by larger spots, number three is the same but has in addition some large light-brown splashes over half of the egg, and number four has large light-brown splashes and spots that cover the small end."

Nesting Dates.-Lancaster, N. H., June 6 (Spaulding); Bangor, Me., June I-June I9 (Knight).

\section{BiographicAL REFERENCES}

(I) F. B. SPAulding, Nesting of Wilson's Black-capped Warbler, (in N. H.), Nidologist, II, I894, I3; cf. also Journ. Me. Orn. Soc., VI, 1904, 70. (2) C. H. Morrell, Osprey, III, 1899, 5. (3) J. M. Swain, Contributions to the Life History of Wilsm's Warbler, Journ. Me. Orn. Soc., VI, I904, 59. 


\section{Pileolated Warbler \\ WILSONIA PUSilla PILEOLATA (Pallas)}

Subspecific Characters.-Similar to Wilsonia $p$. pusilla but forehead much more intense, orange rather than yellow; olive-green of back and yellow of underparts deeper, richer; averages slightly larger.

As with Helminthophila celata orestera, the Rocky Mountain bird, while intermediate in color between Atlantic and Pacific coast specimens, is slightly larger than either. Wing, 2.25; tail, 2.00; bill, .35.

General Distribution.--Rocky Mountain region.

Summer Range.-Breeding throughout the Rocky Mountain district, from western Texas (Chisos Mountains), New Mexico (?) and Arizona (?) in higher mountains, northward to Alaska, including coast district (Kadiak, Yakutat, Sitka, etc.) as well as throughout the interior, westward to eastern Oregon (Fort Kalmath; Tillamook) and Queen Charlotte Islands, British Columbia; during migration over the whole of western North America (less commonly along the Pacific coast of United States) and eastward across the Great Plains to Minnesota (Fort Snelling, May), western Missouri (Independence), etc.

Winter Range.-Southward over whole of Mexico and Central America to Chiriqui (Boquete). (Ridgw.)

The Bird and its Haunts.-In Colorado, Cooke ${ }^{3}$ writes, this bird reaches its summer home just above timber-line by the end of June and is then the most numerous insect-eating bird at that altitude. The center of abundance during the breeding season is about $I \mathbf{I}, 000$ feet, but it has been known to breed from 6,000 to I2,000 feet.

In Alaska, Nelson" states that this Warbler is "one of the commonest of the bush-frequenting species in the north and extends its breeding range to the shores of the Arctic Ocean, where it is found breeding about Kotzebue Sound as well as along the eastern coast of Norton Sound wherever shelter is afforded."

Song.-"Song, Chee-chee-chee-chee (or this syllable repeated seven times), thus different from their song as I recall it in the East. Certain low querulous notes are indescribable." (Minot ${ }^{\mathbf{1}}$ ).

Nesting Site.-A nest found June 22, near Seven Lakes, Colorado, by Minot" "was sunken in the ground on the eastern slope or border of the swamp, at the end of a partly natural archway of long, dry grass, opening to the southward, beneath the low, spreading branch of a willow."

Nest.-The nest above mentioned is described as "composed of loose shreds, with a neat lining of fine stalks and a few hairs, and with a hollow two inches wide and scarcely half as deep." 
Eggs.-4 to 6, usually 4 or 5. Ground color white, sometimes tinged with creamy, specked and spotted with reddish brown and lavender gray, very few under shell markings; some specimens show the markings well distributed, others have them in a wreath about large end with scattering spots over rest of egg. Size: average .63x .49. Figs. (II6-II8.)

Nesting Dates.-Boulder Co., Colo,, altitude 9,500 feet, June I6 (C. W. C.).

\section{Biographical REFERENCES}

(I) H. D. Minot, Notes on Colorado Birds, Bull. Nutt. Orn. Club, V, I880, 228. (2) E. W. Nezson, Report upon Natural History Coll. made in Alaska, 204. (3) W. W. Cooke, The Birds of Colorado, I17. (The notes of both Nelson and Cooke are given under the head of "Sylvania pusilla.")

\section{Golden Pileolated Warbler WILSONIA PUSILLA CHRYSEOLA Ridgw.}

Subspecific Characters.-Similar to $W$. p. pileolata but smaller and of a still brighter, deeper yellow. Wing, 2.15; tail, r.96; bill, .32.

General Distribution.-Pacific coast district of United States and British Columbia.

Summer Range.-Breeding from southern California (San Bernardino, Los Angeles, and Ventura Counties) northward to British Columbia (New Westminster, Mount Lehman); during migration southward and eastward to eastern Oregon (Fort Klamath, May, August), Arizona (Pinal County, September, October; Lowell, April; Fort Verde, May; San Francisco Mountains, August 3I; Cienega; Tucson), Chihuahua (San Diego, April I5), Sonora (San Jose Mountains, October), and Lower California (to Cape St. Lucas). (Ridgw.)

\section{Winter Range.-Mexico and Central America.}

The Bird and Its Haunts._- "In California," Walter Fisher (MS) writes, "the Golden Pileolated Warbler frequents copses along water courses of the valleys, or willow thickets near mountain streams and meadows, and in the moist northern coast region is found almost anywhere in the luxuriant undergrowth. I have also encountered a few in manzanita chaparral, where their yellow colors harmonized perfectly with the vivid yellow-green of the sun-lit foliage. In the Sierras I have found them tame but preoccupied, as Mrs. Bailey aptly writes. One usually catches only a fleeting glimpse, when the black cap is a most excellent aid in identification."

Nesting Site.-In California, Barlow ${ }^{2}$ records this bird as building about three and one-half feet from the ground, placed upon a 
mass of drift material in the crotch of a dead limb, and in bunches of nettles, weeds or ferns; while Silliman ${ }^{3}$ writes that the nests are situated in "damp, shaded places, often in a wild blackberry vine and well hidden. They are always placed near the ground, never over five feet above. In one instance the bottom of the nest touched the ground." Emerson $^{1}$, however, records a nest found in blackberry vines eight feet from the ground.

Nest.-Barlow" describes the nest as "made of grasses, fine leaves and material gathered from debris in the creek, while the lining is of fine white rootlets or grass which resembles horse-hair." Silli$\operatorname{man}^{3}$ states that "a typical nest of this species has a loose exterior of dry leaves, bark fibers, lichens, weed-stems, roots and a few pieces of straw."

Eggs. - 3 to 5, usually 4, very rarely 5. Ground color and markings show the same range of variation as in the Pileolated Warbler, only in some extreme examples the markings in the wreath are heavier and more profuse. Size; average about the same, .64x.49; extremes $.7 \mathrm{IX} .50, .6 \mathrm{IX} .5 \mathrm{I}, .62 \mathrm{x} .46$.

Nesting Dates.-Los Angeles, Calif., April 24-May $3^{\mathrm{I}}$ (Grinnell); San Geronimo, Calif., May I (Mailliard); Tacoma, Wash., June 17 , only nest found (Bowles).

\section{Biggraphical References}

(I) W. O. EMrerson, Black-capped Yellow Warbler [in Calif.], Orn. and Oöl., VI, I88I, 62. (2) C. BarLow, The [Golden] Pileolated Warbler, Nidologist, I, 1893, 44. (3) Silliman, The [Golden] Pileolated Warbler, Nidologist, II, $1894,28$.

\section{CANADA WARBLER WILSONIA CANADENSIS (Linn.) Plate XXII}

Distinguishing Characters.-The Canadian Warbler may always be known by its gray upperparts, absence of white on wings or tail, and necklace of spots across the breast. In the adult $\delta$ these are black and conspicuous, in the $q$ and young of both sexes they are dusky and less sharply defined, but I have not seen a specimen in which they were wholly wanting. Length (skin), 5.00; wing, 2.50 ; tail, 2.20 ; bill, .40.

Adult on, Spring.-Upperparts gray, crown spotted with black, the forehead usually wholly black; line from bill to eye and eye-ring yellow; wings and tail externally the color of the back and without white markings; lores and malar stripe black, running into a band of black spots across the breast; rest of underparts yellow, crissum white.

Adult $\sigma^{*}$, Fall-_Similar to adult $\sigma^{*}$ in Spring but a faint wash of greenish on back; black breast-spots narrowly tipped with yellow. 


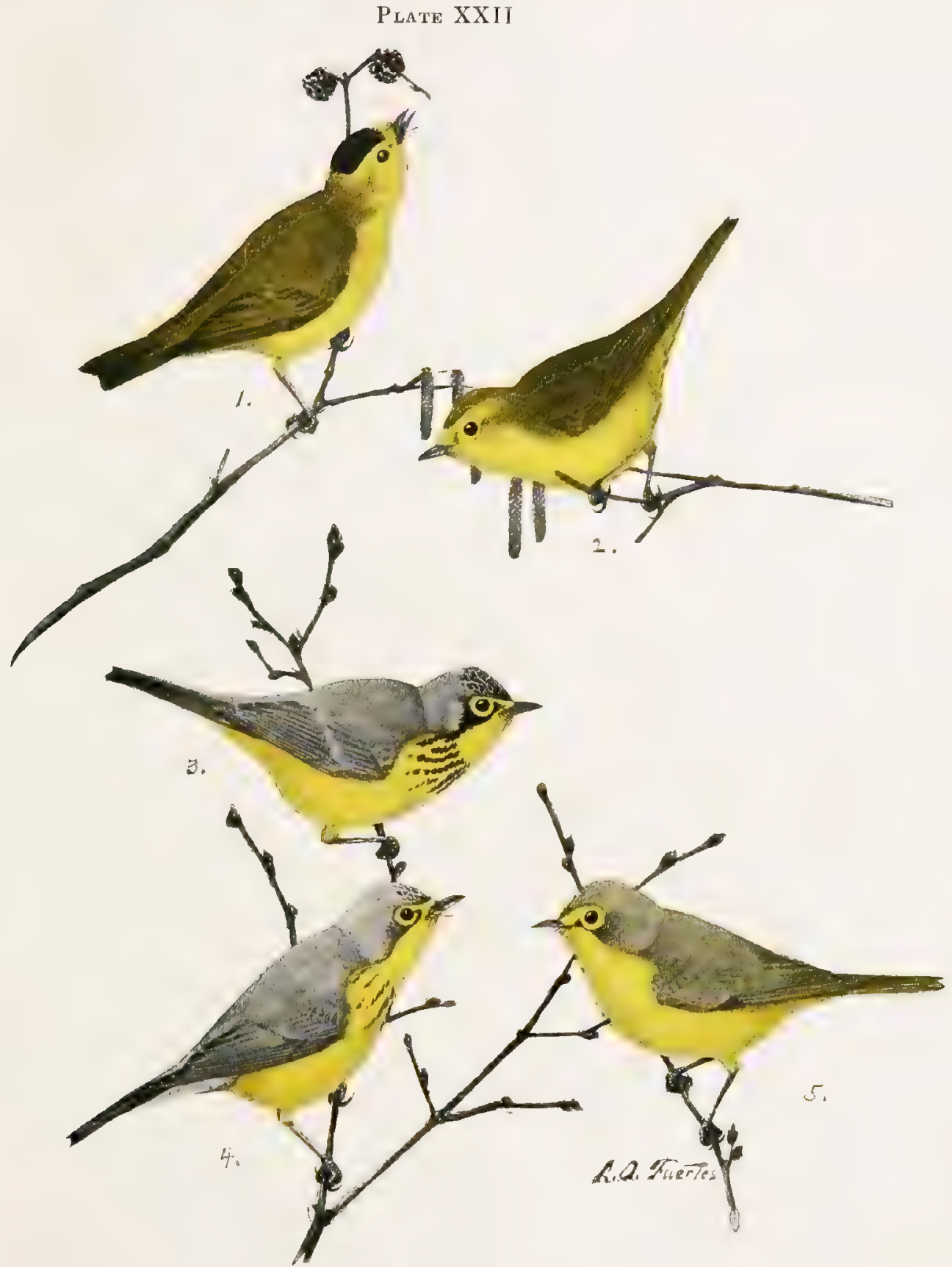

1. Wilson's Warbier, Male.

3. Canada Warbler, Auult Male.

2. Wilson's Warblen, Femaie.

4. Canada Warbler, Adul's Female.

5. Canada Warbler, Young Female.

(ONE-HALF NATURAL SIZE,) 


$$
\text { - }
$$


Young $d$, Fall.-Similar to adult $\delta$ in Fall but crown greenish without black, lores dusky, no black malar stripe, yellow duller, breast spots dusky and not sharply defined. Not certainly distinguishable from adult $\$$ in Fall.

Adult $\$$, Spring.--Similar to adult $\delta$ in Spring but duller throughout, crown gray tinged with yellowish, especially on forehead, and without black, lores dusky, no black malar stripe; breast spots dusky and not sharply defined.

Adult $q$, Fall.-Similar to adult $q$ in Spring but slightly greener above.

Young + , Fall.-Not certainly distinguishable from adult $q$ in Fall but averaging browner above especially on crown, and with the breast spots fainter.

Nestling.-Resembles nestling of Wilsonia pusilla.

General Distribution.-Eastern North America; north to Newfoundland and Athabasca; west to the Plains.

Summer Range.-Breeding principally in Canada, a few nest in the northern United States south to Massachusetts (Berkshire, Bristol, Brookline, Templeton, and Wellesley), Rhode Island (Noyes Beach, Johnston), northwestern Connecticut, central New York (Oneida County), southern Ontario (Ottawa, Kingston, London, Toronto, Guelph), central Michigan, northeastern Illinois, central Minnesota (St. Louis, Lake and Cass counties); in the Allegheny Mountains, it breeds south to North Carolina and occurs from 3,000 feet nearly to the top of the highest peaks.

The great bulk of the species passes along the Atlantic coast and westward to and including the valley of the Ohio. In the interior the bird is a rare migrant from eastern Texas (San Antonio, Gainesville), eastern Kansas (Neosho River), eastern Nebraska (Richardson County, May I875), through the valley of the Red River of the North to Manitoba. Accidental in central Texas (Concho), southern New Mexico (Fort Thorn), and eastern Colorado (Lake, May 23, I899).

Winter Range.-Guatemala to Peru.

Spring Migration.-

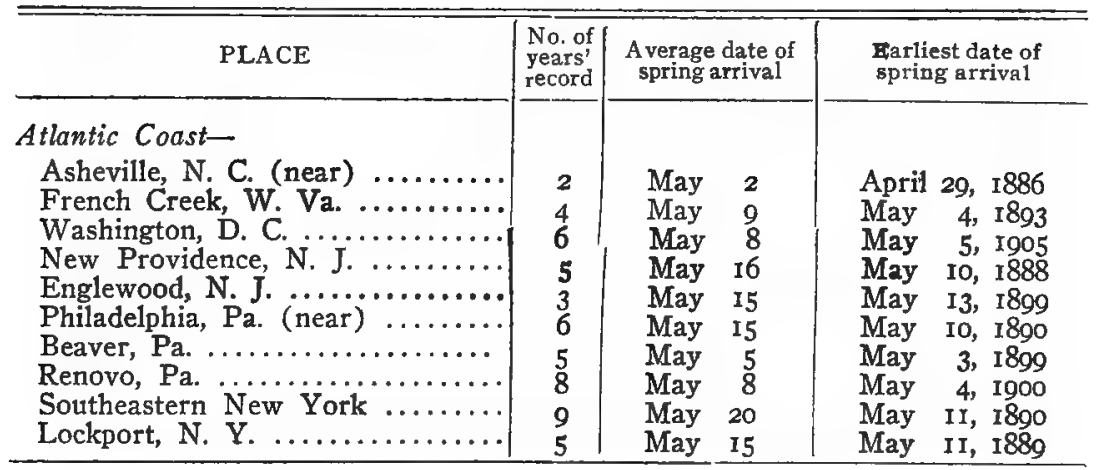


Spring Migration.-(continued $)$

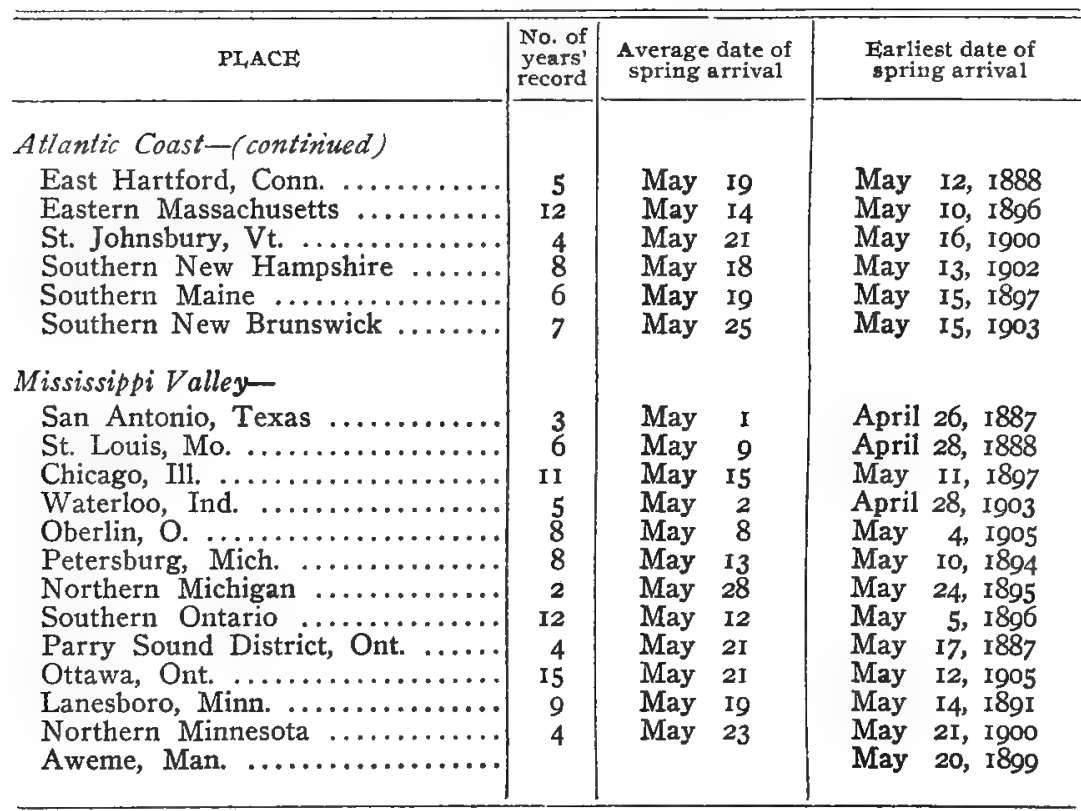

Fall Migration.-Some dates of the last birds seen are at Grand Rapids, Athabasca, August 20, I90I ; Aweme, Man., August 30, I90r ; Ottawa, Ont., September 5, 1890; Chicago, Ill., September I6, I894; Waterloo, Ind., September 28, 1902; Petitcodiac, N. B., August 2I, I886; Pittsfield, Me., September 12, I897; Amherst, Mass., September 29, I89I ; Renovo, Pa., average of seven years, August I4; Germantown, Pa., October I, I889; Englewood, N. J., October 2, I886; Bay St. Louis, Miss., October I5, I899.

The Bird and its Haunts.-As a spring migrant I find this Warbler in much the same situations Wilson's Warbler frequents; but while travelling southward in August and September, when the foliage is so much denser than that of May, it is less restricted in its choice of haunts and may be found in the tree-tops.

At Branchport, N. Y., Verdi Burtch (MS.) reports the Canadian Warbler to breed not uncommonly in two entirely different locations. While not common they are frequently found in the wettest part of Potter Swamp associated with the Northern Water-Thrush and Maryland Yellow-throat. They are also found along the gully banks usually in the lower branches or on the ground. 
Gerald Thayer writes: "I have already, in my notes on the Blackburnian, described this Warbler's breeding haunts about Monadnock. It is a bird of rich deciduous undergrowth in the deep, damp forest,a ranger between the bush-tops and low tree-branches and the ground. It avoids purely coniferous woods, and so is almost wholly wanting from the closely-spruce-clad northern slopes of Mt. Monadnock, though abundant in the deep mixed timber all about its northern base. On the eastern slopes of the mountain, where the forest is more largely deciduous, the Canada is fairly common almost up to the rocky backbone ridge, at heights of from 2,300 to 2,700 or so feet.

"The Canadian is a sprightly, wide-awake, fly-snapping Warbler, vivid in movement and in song; clearly marked and brightly colored. In actions it is like the Wilson's, a sort of mongrel between a Dendroica, an American Redstart, and a true Flycatcher. It darts after flying insects like one of the Tyrannidx, and its bill may sometimes be heard to 'click' when it seizes something; it has much of the Redstart's insistent nervousness of motion, but is a less airy 'flitter'; and, finally, it glides and gleans among leaves and twigs like a true gleaning Warbler." (Thayer, MS.)

Song.- "Sings a great deal in migration-the song is liquid, uncertain, varied, bright, sweet-sounds like the syllables t'le re, t'le re, t'le we, t'le we, t'l it wit; often begins with a little whirr or snap. (Farwell, MS.)

"Suggests to me the unfinished song of a Goldfinch more than that of a Warbler. It is very broken and energetic and also possesses a larger quality." (Fuertes, MS.).

"The strong and snappily-changeful modulation of this Warbler's clear, rippling song can scarcely be suggested by English syllables, and I shall avoid the attempt. It is one of the most delightful as well as one of the commonest summer bird-songs of the deep woods about Monadnock. It varies a good deal, but I have yet to discover that the bird has more than one constant, main song as a basis for the variations. Nevertheless, it ranks very high in the full-voiced group, as does its beautiful black-hooded relative of the South. In late summer and autumn the young male Canadas of the year often try to sing, as is the case with all or most Wood Warblers ; and,- as is also commonly the case,-their performances are obscure and queer, and barely recognizable.

"The Canada's commonest summer call-note is fairly charcteristic, having a certain peculiar little 'tang' and harshness. It sounds a little like the chack of the Yellow-throat, but is less pronouncedly different 
from the common run of Warbler 'chips.' The bird has also several slighter and less distinctive calls." (Thayer, MS.)

Miss Paddock sends notations of six songs and writes: "The rhythm is not unlike the Yellow-throat's, but its quality is different, and it is more energetic. The notes are always in triplets or groups of four."
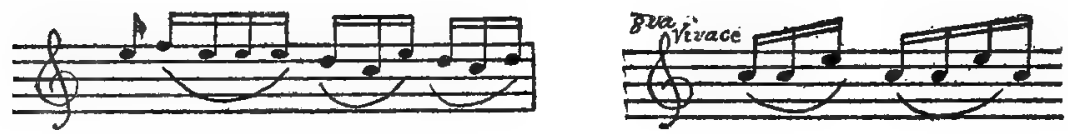

rup-it-che rup-i-chip-it
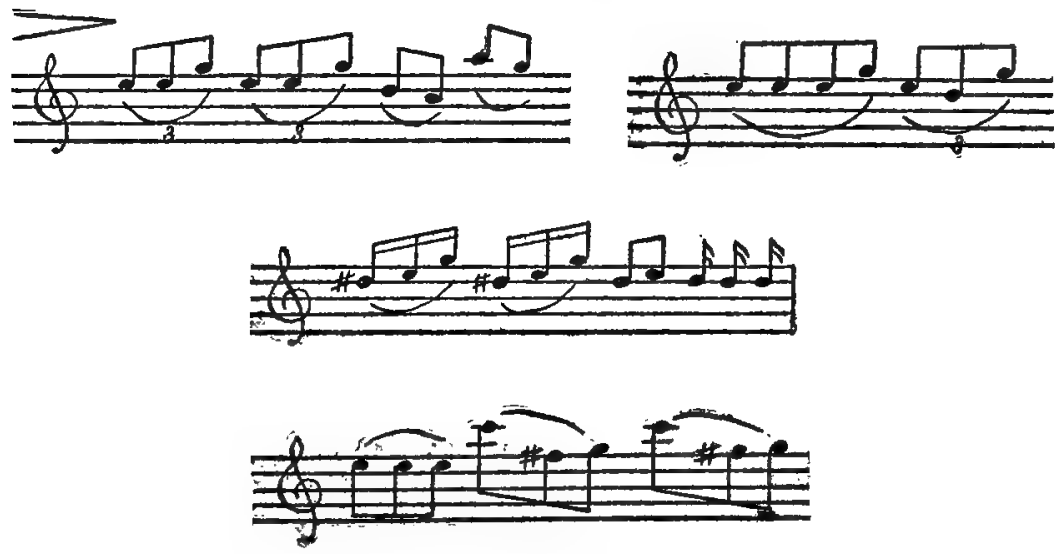

Nesting Site.-The Canada Warbler nests on the ground concealing its nest in moss or beneath roots.

Burtch (MS.) writes that "in Potter Swamp near Branchport, N. Y., the nest is usually placed under the edge of a stump or log, or in the side of a mound of moss covered with logs and brush. One nest was placed on top of a moss-covered $\log$, the lowest in a crisscross pile, another log being over it and forming a roof. In the gullies the nest is placed from ten to thirty feet above the bottom of the guliy, in a hole in the moss-covered bank."

Nest.-Burtch describes the nest as usually bulky and rather flattened, made of dead leaves and grass, lined with fine grass.

Eggs.-3 to 5, ustrally 4. Ground color and markings about like the eggs of the Pileolated Warbler, except in the present species the markings are not so profuse and less inclined to wreathe around the large end, being more evenly distributed over the entire egg. Size; average, $.67 \times .52$; extremes, $.73 \times .53, .64 \times .54, .65 \times .51$. (Figs. II9-I2r.) 
Nesting Dates.-Lancaster, N. H., June 9-June I3 (Spaulding); Bangor, Me., May 30-June 4, young a few days old (Knight); Listowel, Ont., May 22-June 18 (Kells) ; Bay City, Mich., June 2, Eddy (Barrows).

\section{Biographical REFERENCES}

(1) W. L. KelLs, Nesting of the Canadian Flycatching Warbler, (in Ontario), Orn. and Oöl., XII, 1887, 12; (2) Ibid., Ottawa Naturalist, XV, I902, 230.

\section{Genus CARDELLINA DuBus}

Although in Cardellina the bill is short and titmouse-like in character, the rictal bristles are still fairly well-developed, though less evident than in Wilsonia.

The wing is rather long, and pointed by the second, third, and fourth primaries, the first (outer) primary about equalling the fourth; the tail is long, the feathers of about the same length; the feet are dark and slender.

Cardellina rubrifrons, the only species in this genus, ranges from southern Arizona and New Mexico south to Guatemala. The sexes are virtually alike in color, an exception to the prevailing rule among brightly colored birds.

\section{RED-FACED WARBLER \\ CARDELLINA RUBRIFRONS (Giraud) Plate XXIV}

Distinguishing Characters.-This species is so unlike any other of our Warblers as to render comparison unnecessary. Length (skin), 4.80; wing, 2.70 ; tail, 2.40 ; bill, .30.

Adult d, Spring.-Forehead, cheeks, most of eye-ring, throat, upper breast and band back of auriculars bright red, crown and auriculars black, nuchal patch white, sometimes tinged with pink, back, wings and tail gray; rump white sometimes tinged with pink, median wing-coverts tipped with white; lower breast and belly tinged with pink.

Adult d" Fall.-Similar to adult $\delta$ in Spring but nape and rump often rose-tinged, back sometimes suffused with red.

Young $\delta^{\prime \prime}$, Fall.-Similar to adult $\delta^{\prime \prime}$ in Fall, but plumage sometimes with a brownish wash in places.

Adult \%, Spring.-Similar to adult $d$ in Spring and generally indistinguishable from it but red sometimes duller.

Adult \%, Fall.-Not certainly distinguishable from adult $\delta^{*}$ in Fall.

Young , Fall.-Like adult $q$ in Fall.

Nestling.-Above grayish brown; crown browner, nape buffy; rump white; throat and breast grayish brown, belly white; wing-coverts fuscous edged with brown and narrowly but distinctly tipped with buff.

General Distribution.-Mexican Tableland north to Arizona and New Mexico. 
Summer Range.-Mexican Tableland north to southern Arizona (Santa Catalina Mountains) and southern New Mexico.

Winter Range.-Mexico south to Guatemala.

Spring Migration.-Huachuca Mountains, Arizona, April 20.

The Bird and its Haunts.-This singularly colored Warbler was added to our fauna July 12,1874 , by $H$. W. Henshaw ${ }^{1}$ who found it near Camp Apache and on Mount Graham in southern Arizona. In the latter locality, later in the month, it proved to be common, "flocks of ten or fifteen being not unusual among the pines and spruces; it frequented these trees almost exclusively, only rarely being seen on the bushes that fringed the streams. Its habits are a rather strange compound, now resembling those of Warblers, again recalling the Redstart's, but more often, perhaps, bringing to mind the less graceful motions of the familiar Titmice. Their favorite hunting places appeared to be the extremities of the limbs of the spruces, over the branches of which they passed with quick motion, and a peculiar and constant sidewise jerk of the tail."

Nesting Site.-Although the nest of this species was first discovered by Mearns ${ }^{3}$ on June I9, I886, in the Mogollon Mountains, Arizona, this naturalist did not publish his observations until July, 189o. In the meantime, Price ${ }^{2}$ had found it breeding in the Huachuca Mountains, on May 31, I888, and later its nesting habits were studied by Howard ${ }^{4}$. The nests found by these ornithologists were all placed on the ground beneath a tuft of grass, a hillside being a favorite location.

Nest.-Price ${ }^{2}$ describes the nest as such a "poor attempt at nest building and made of such loose materials that it crumbled to fragments on being removed. The chief substance was fine fibrous weed stalks while the lining consisted of fine grass, rootlets, plant fibers, and a few hairs."

Eggs.-4. The set collected by Price is described by Bendire as follows: "They are ovate in shape. Their ground color is a delicate creamy white, and they are spotted with small blotches of cinnamon rufous and a few dots of heliotrope purple and pale lavender. These form a wreath around the larger end. They resemble the eggs of Helminthophila lucice and $H$. virginice to a certain extent." Size; "They measure .66x.50, .67x.50, .66x.50 and .66x.50."

\section{Biographical References}

(1) H. W. Henshaw, Zoöl. Expl. W. Iooth Merid., 21 I. (2) W. W. PRICE, Nesting of the Red-faced Warbler in the Huachuca Mountains, Southern Arizona, Auk, V, 1888, 385. (3) E. A. Mearns, Observations on the Avifauna 
of Portions of Arizona, Auk, VII, I890, 26r. (4) O. W. HowARD, Summer Resident Warblers of Arizona, Bull. Cooper Orn. Club ( $=$ Condor), I, I899, 65.

\section{Genus SETOPHAGA Swainson}

Setophaga differs but little in structure from Wilsonia and were it not for its markedly different coloration would doubtless be grouped with it by some authors. In $S$. ruticilla the bill is broader at the base, the rictal bristles longer, but this is not true of $S$. picta in which the rictal bristles average shorter than in Wilsonia. The wing is much as in Wilsonia but the tail is more rounded, the outer feathers being decidedly the shortest.

The genus contains two species of which $S$. ruticilla ranges throughout eastern North America west to the Rocky Mountains and northwest to Alaska, while $S$. picta is found from southern Arizona and New Mexico south to Honduras.

Both are distinguished for the beauty of their plumage but while the adult male of $S$. ruticilla is strikingly different from and brighter than the female, the sexes in $S$. picta are alike. Furthermore, $S$. picto dons its full plumage in the first molt, shortly after leaving the nest, while $S$. ruticilla does not acquire its mature dress until after its first nesting season, or at the leginning of its second year.

\section{REDSTART \\ SETOPHAGA RUTICILla (Linn.) Plate XXIII}

Distinguishing Characters.-No difficulty will be experienced in recognizing this strikingly marked species, the salmon or yellow markings in wings and tail alone affording a sufficient clue to its identity. But one should be careful to avoid mistaking the young male for the female, this being one of the few Warblers, in which the male does not assume its adult plumage before the first nesting season after its birth. As a rule, however, the young Spring male has some black feathers on the underparts, a character not shown by the female. Length (skin), 4.75; wing, 2.50 ; tail, 2.25 ; bill, .35 .

Adult d", Spring.-Upperparts shining black; central pair of tail-feathers black, next pair basally salmon-orange on the outer web, remaining four feathers entirely orange for basal two-thirds, the terminal third black; wings black with a band of orange, increasing in width from without inward, across their base; sides of head, throat, and breast black extending to the sides of the body; belly white, more or less tinged with orange; sides of breast brilliantly salmonorange extending backwards to flanks in decreasing amount. As might be expected, even in adult specimens, there is much variation in the intensity and extent of the orange markings.

Adult $\delta^{*}$, Fall.-Not certainly distinguishable from $\delta^{*}$ in Spring, but feathers of throat and breast often with white tips, those of back tipped with brown. 
Young ${ }^{*}$, Fall.-Generally resembles adult $q$ in Spring but the back is often more olive or more ruddy brown, and the patches at the side of the breast average deeper in tone. In some specimens the back is suffused with reddish and the breast patches are orange. I have seen two specimens (Bishop Coll.) with a few black patches showing that in some instances the bird begins to acquire adult plumage, the first Fall.

Young ơ Spring.-Similar to young o $\sigma^{*}$ in Fall but with a few black feathers on the breast and generally with additional black feathers on the chin, lores, cheeks, or crown. There is no regularity as regards the part of the breast or head in which these black feathers appear, but I have yet to see a Spring $\delta$ in which they were entirely wanting. There appears to be no transition plumage between the one just described and the mature orange and black dress which, as molting specimens in Dr. Dwight's collection seem to prove, is acquired after the first breeding season or at the beginning of the second year of the bird's life.

Adult $q$, Spring.-Crown and cheeks gray, back olive-green with a grayish tinge, upper tail-coverts blackish; basal two-thirds of three outer tail-feathers yellow their tips blackish, two-thirds of outer vane and sometimes part of inner vane of next two yellow, their end and inner pair of feathers blackish; wings brown edged with greenish, orange wing-band of adult $d$ replaced by yellow and, externally, appearing chiefly on the basal half of outer web of secondaries; underparts grayish white, the sides of the breast with yellow patches, sides of body more or less washed with same color.

Adult $q$, Fall.-Similar to adult $q$ in Spring but back more olive, throat and breast washed with buffy.

Young $q$, Fall.-Similar to adult $q$ in Fall but with less yellow in wing, in the closed wing this color being often entirely concealed.

Young $q$, Spring.-Similar to young $q$ in Fall but throat whiter.

Nestling.-Above brownish gray, crown paler, throat and breast grayer, belly whiter; wing-coverts brownish tipped with whitish.

General Distribution.-Eastern North America; north to Newfoundland, Labrador and Alaska; west to the Rocky Mountains.

Summer Range.-From its far northern home, almost to the limit of tree growth, the Redstart breeds south commonly to Maryland and Iowa, and not rarely to North Carolina, Arkansas, and Kansas. Exceptional breeding records, south of this normal breeding range are at Greensboro, Ala., Hopefield, and Jackson, Miss., and Fort Union, New Mexico. The regular western range includes Colorado, Utah, Idaho, eastern Washington and British Columbia. The species has occurred casually in Oregon (John Day River, July I, I889), California (Haywards, June 20, I88I ; Marysville Buttes, June 6, I884), Arizona (Tucson, spring; Catalina Mountains, August I2, I884), Lower California (Miraflores, La Paz).

Winter Range.-Mexico and the West Indies to Ecuador and British Guiana. 


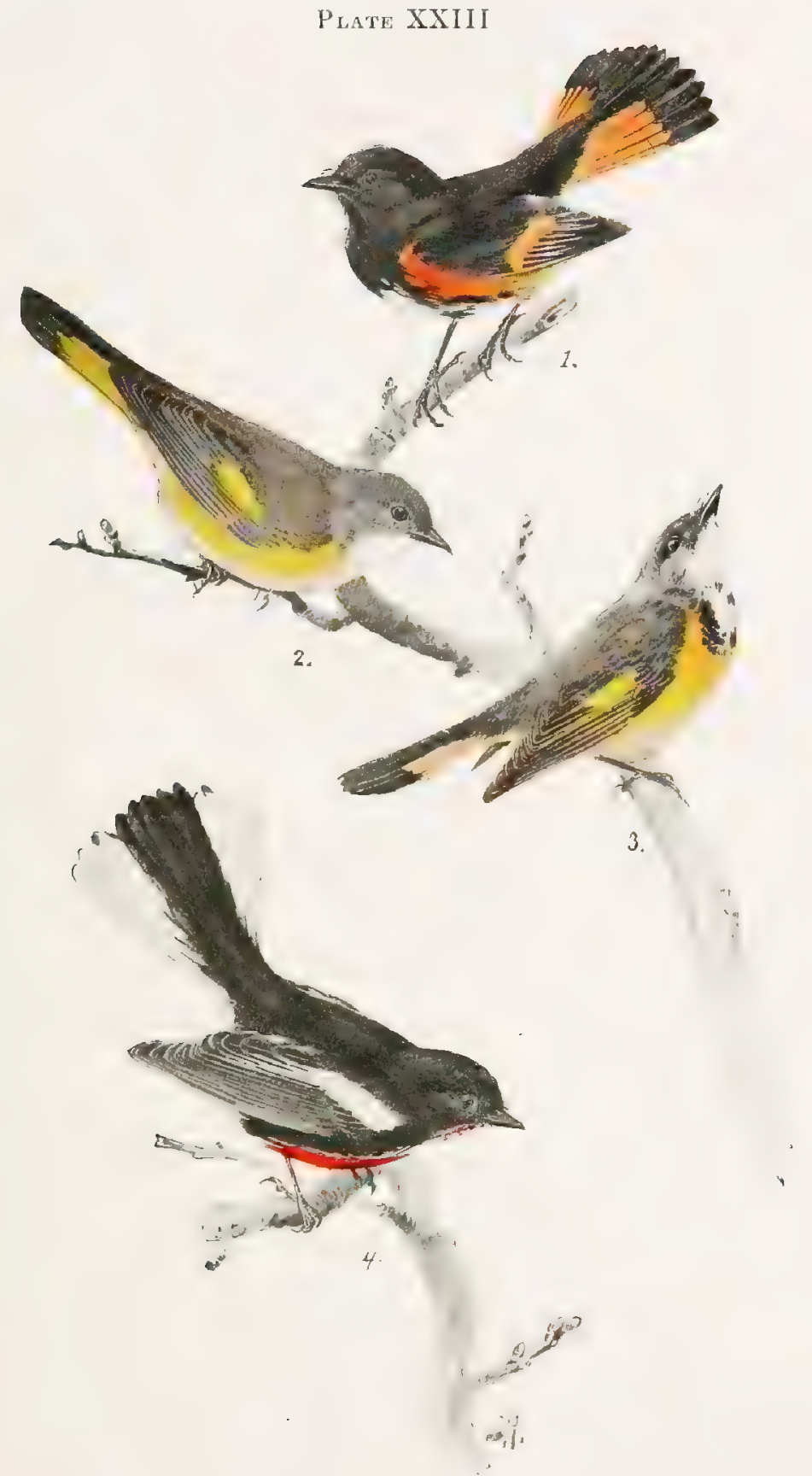

1. American Redstakt, Adult Male.
2. American Redstari, Female.

3. american Reustari, Yung Male

4. Painted Redstart, Anut $T$. 



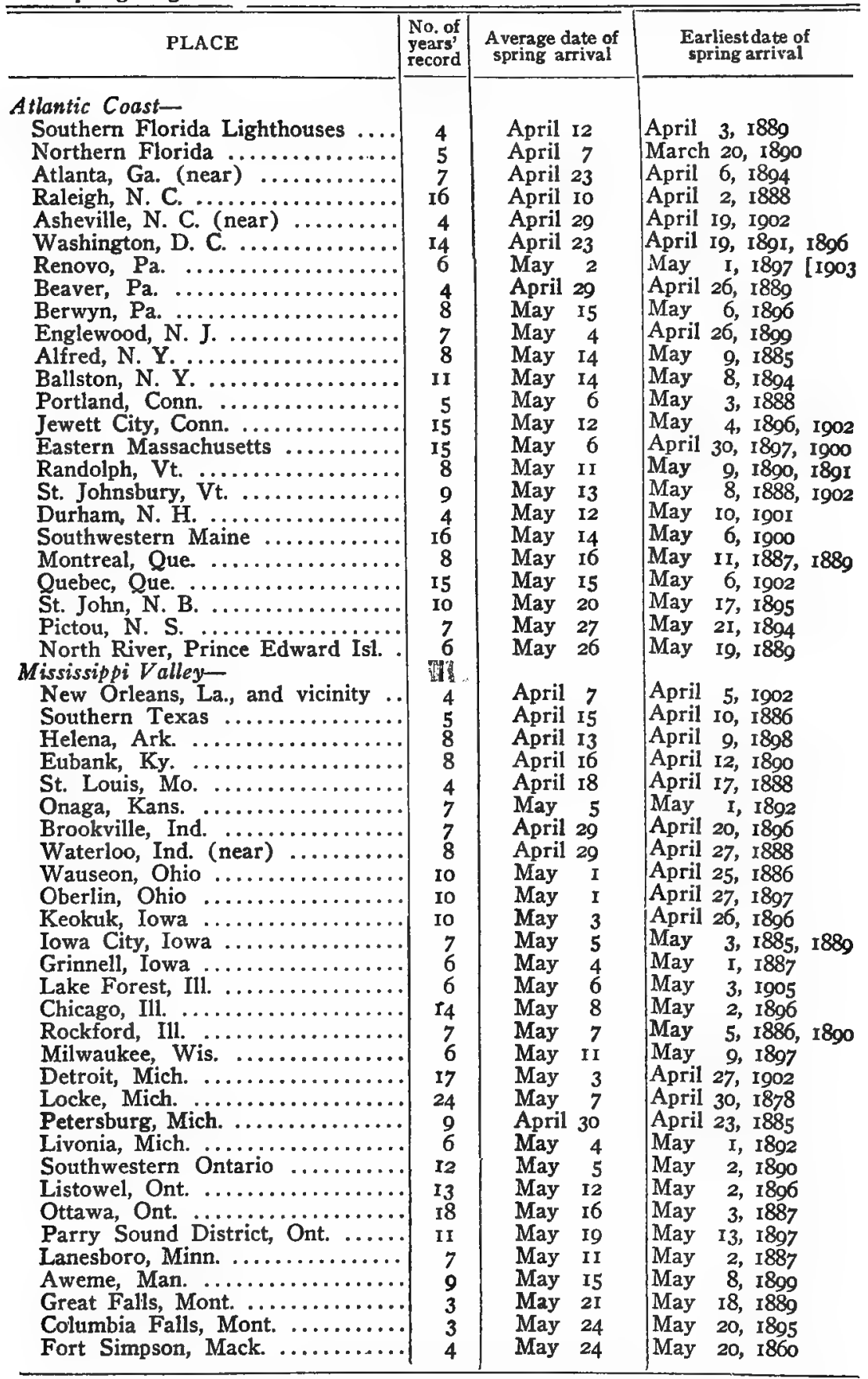


Fall Migration.-Since the Redstart breeds over most of the eastern United States, it is not possible to determine the beginning of its fall migration in that portion of its range from which were received the fullest records of spring arrival. Just south of the breeding range, in the South Atlantic and Gulf states, the dates show that the Redstart is one of the earliest of fall migrants. The earliest migrant in Chester County, South Carolina, was seen July Io; at Key West, Fla., July 22, I889, and near there, at Sombrero Key lighthouse, July 28 and 29, I886. It has been taken in Jamaica by August Io; in Costa Rica, August 13; Colombia, South America, September 2, and on the island of Antigua, Lesser Antilles, September 6. These dates are especially interesting because they prove so conclusively that the southernmost breeding birds start first in their migration, and pass at once to the southern portion of the winter range. The date of September 6, at Antigua, is interesting because the Redstart is one of the very few migrant land-birds from the United States that range throughout the West Indies, even to the Windward Islands and Trinidad; and the early date shows that the flights from island to island are interspersed with but few and short intervals of rest.

Fall migration in the Mississippi Valley is not quite so early; still the first were seen at New Orleans, La., July 21, I899, July 29, I900, and July 30, I897. The earliest migrants reach central Texas the last of August and have been noted the first of September in Mexico, nearly at the southern limit of the bird's winter range in that country.

The regular tide of migration in southeastern United States sets in early in August, and the striking of the Redstart against the Florida lighthouses has been reported on nineteen nights in that month. The largest flocks pass through the Middle Atlantic states about the middle of September, and the greatest number strike the Florida lighthouses the first half of October.

\begin{tabular}{|c|c|c|c|}
\hline PL,ACE & $\left|\begin{array}{l}\text { No. of } \\
\text { years' } \\
\text { record }\end{array}\right|$ & $\begin{array}{l}\text { Average date of } \\
\text { last one seen }\end{array}$ & $\begin{array}{l}\text { Latest date of } \\
\text { last one seen }\end{array}$ \\
\hline Atlantic Coast- & & & \\
\hline 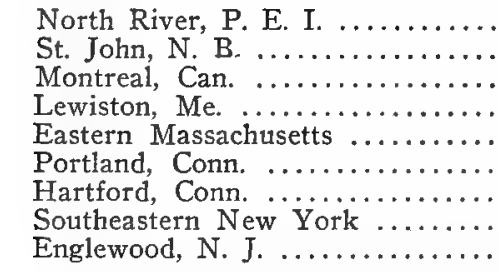 & $\begin{array}{l}3 \\
5 \\
3 \\
4 \\
4 \\
4 \\
4 \\
4 \\
4\end{array}$ & $\begin{array}{l}\text { August I7 } \\
\text { September } 5 \\
\text { August } 24 \\
\text { September I8 } \\
\text { September } 20 \\
\text { September I9 } \\
\text { October I6 } \\
\text { September } 20 \\
\text { September } 29\end{array}$ & $\begin{array}{l}\text { September } 7,1890 \\
\text { September 25, I891 } \\
\text { August 29, 1891 } \\
\text { September 27, 1898 } \\
\text { September 24, 1896 } \\
\text { September 26, I890 } \\
\text { October 26, I90I } \\
\text { September 28, 1890 } \\
\text { October 3, 1886 }\end{array}$ \\
\hline
\end{tabular}


Fall Migration.-(continued)

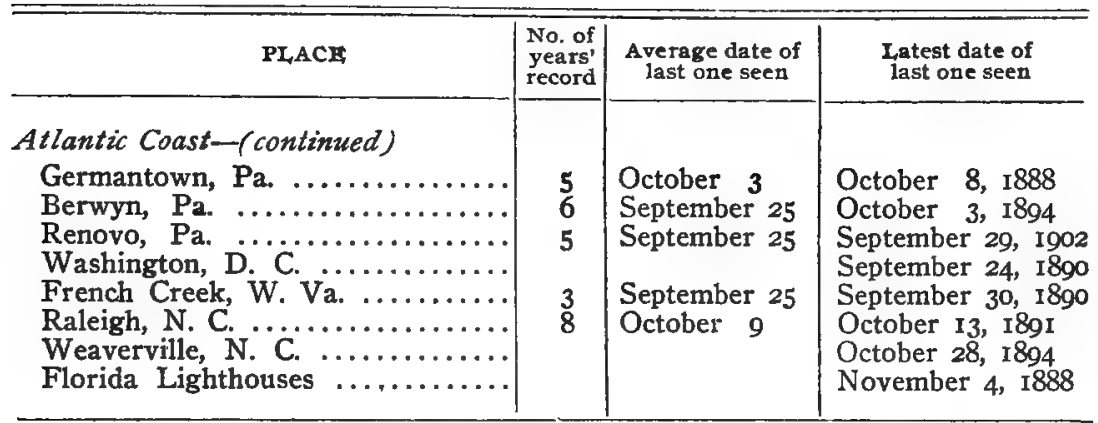

\begin{tabular}{|c|c|c|c|}
\hline PLACE & $\mid \begin{array}{c}\text { No. of } \\
\text { years' } \\
\text { record }\end{array}$ & $\begin{array}{l}\text { Average date of } \\
\text { last one seen }\end{array}$ & $\begin{array}{l}\text { Latest date of } \\
\text { last one seen }\end{array}$ \\
\hline 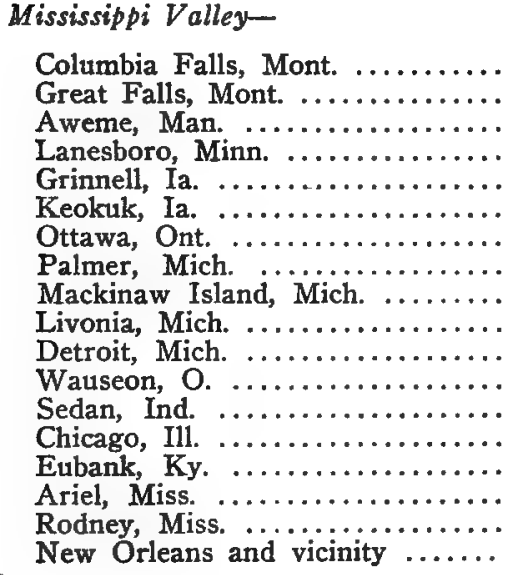 & $\begin{array}{r}3 \\
12 \\
7 \\
4 \\
8 \\
4\end{array}$ & $\begin{array}{l}\text { September } 15 \\
\text { September } 12 \\
\text { September } 20 \\
\text { September } 17 \\
\\
\text { September } 21 \\
\text { September } 28 \\
\text { September } 19 \\
\text { September I5 } \\
\text { September } 28 \\
\text { September } 19 \\
\\
\text { October 18 }\end{array}$ & 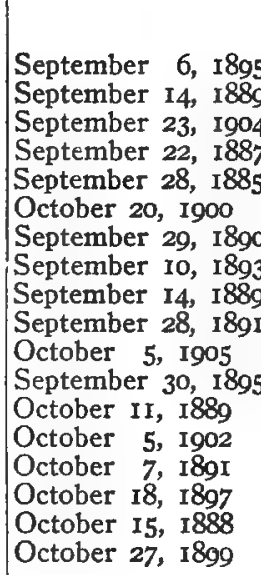 \\
\hline
\end{tabular}

The Bird and its Haunts.-With the Redstart we reach the acme of Warbler activity. If a bird exists which is more constantly in motion and in a greater variety of ways, I have yet to see it. But it is at feeding that the bird excels; not the somewhat sedate, pendulumlike wing-feeding of the true Flycatcher who, sitting quietly in wait, swings out from his perch, makes his capture and returns to his starting point, but a mad series of darts and dives and whirls, of onward rushes and as sudden stops, which yield not one insect but many and, at the same time, display the bird's brilliant plumage in a manner to set at defiance all laws of aggressive coloration. With what dainty grace he spreads his tail, half opens his wings, and pirouettes 
from limb to limb like a village belle with coquettishly held skirts tripping the mazes of a country dance!

The Redstart is at home in almost any kind of more or less open deciduous woodland, but prefers lowland woods with a sapling undergrowth. The increase in trees in towns is fortunately tempting it to widen its range, and in Cambridge, Mass., Brewster states it nests, in places, "almost if not quite so numerously as in the Fresh Pond swamps, or in the wilder parts of Arlington, Belmont, and Waverly."

At times the Redstart descends to the ground to feed. Gerald Thayer writes: "Like butterflies, of which they so much remind one, -like many of the shy, high-flying butterflies, - the usually tree-hunting Redstarts are wont at times to descend to earth to do strange scavenging work. Horse-manure, with its attendant insects, mightily attracts them, and near Monadnock it is a common thing to see them skipping about on the muck of travelled high-roads. I have known a male to spend most of his time this way, in one spot, for several days in succession."

Annie Lyman Sears of Waltham, Mass., sends an interesting study of a pair of Redstarts which on May 12, 1895, began to build a nest on the bracket above a Venetian iron work lantern hanging before the front door of her home. The female constructed the nest alone and, unaided, performed the task of incubation. Miss Sears writes: "It took (as nearly as I could tell) twelve days for the eggs to hatch. After that the male was as busy as the female in supplying the five hungry mouths with food. He never seemed at home on the nest, and after feeding the young birds, would stand on a branch of the lantern watching for his mate to return. When he saw her approaching he would utter a little cry, fly down onto the piazza or steps and sing. The female, on the contrary, after feeding the little ones, settled down on the nest and stayed till the male brought more food. They brought gnats, flies, green caterpillars, which they sometimes appeared to break up in their own mouths before giving to the young birds. Both birds became very tame, hopping about the chairs and steps and nearly alighting on our persons. The male sang constantly. The young left the nest on June 15 , and as late as July 17 , presumably the same birds were seen in charge of the male who was still feeding them."

Song.-The song of the Redstart can be readily recognized by those who know it but like so many Warblers' songs of what may be called the weechy type, loses all character when it is reduced to syllables. 
"Has several distinct songs; the zee-zee-zee with the sharp, unfinished ending, and the saw-filing one, like the Black and White Creeper's, only more robust in quality, are the two I hear the oftenest." (Farwell, MS.).

"In some years I have found this species songless soon after the beginning of July. In seasons when it thus becomes silent, singing is resumed in the first part of August and continues for two or three weeks. But the period of July silence is inconstant and sometimes singing is little interrupted through the month. When this is the case singing seems to cease finally at the end of the month, or early in August, and is followed by no supplementary song-period. *** In the summer a song is commonly heard from the Redstart which is weaker and otherwise different from the normal, and which is probably produced by immature males." (Bicknell.)

"Of all the Wood Warblers I know, the Redstart comes nearest to spoiling the rule that an adult Warbler's song can never be wholly disguised for the practiced human ear. The bird is, indeed, an almost lawlessly versatile songster, and few and far between must be the bird-students who could not be mystified by any of the occasional extreme vagaries of its singing. The fundamental tone-quality varies as widely, though not as commonly, as the form and accentuation. Time after time have I been puzzled by some perfectly new and surprising freak of Redstart song, and that after years of acquaintance with the bird's varied singing. Ranking on the whole among the full-voiced Warblers, and singing commonly in a smooth, clear tone, he will come out sometimes with a bunch of weak, buzzy notes, like an exaggeration of all that is peculiar in the Parula's song, and in almost every detail of form and delivery widely different from a normal Redstart utterance. Again, he will shrill in hair-thin, glassy notes, like a Blackpoll, or loudly wheeze like a Black-throated Blue; and sometimes he will combine one or more of these foreign song-tones in one phrase with his normal, clear, strong notes. As for the variations and strange hybridisms of his phrasing and accenting, they are quite beyond classification or description. One hears a noticeable new one every few days, in summer, if one lives among New Hampshire Redstarts. It is hard even to decide whether the bird should be said to have one main song, or two, or three, or four, or five. But I believe that three are comparatively constant, and could perhaps be traced as the bases of all the variations. To add to the confusion of the matter, the young males, for two years dull-colored, sing almost as freely as heir black-and-orange fathers; but,-especially in the first autumn,-- 
often with phrases of their own, in addition to more or less imperfect renderings of the adults' phrases. But never in any variation of the Redstarts singing have I heard an unmistakable imitation of other bird-notes, - as sometimes in the cases of the Chestnut-side and the Northern Yellow-throat. He seems merely to be a singer so laxly versatile that he occasionally chances into the song-styles of other Warblers. His two or three call-notes are more constant. The commonest one is easily recognizable, though it has much likeness to the calls of several other Warblers." (Thayer, MS.)

Miss Paddock sends notations of three songs and writes: "The Redstart's voice is shrill and penetrating with a wiry quality. There are two songs, the second less explosive and something like the Chestnut-sided Warbler's second song."

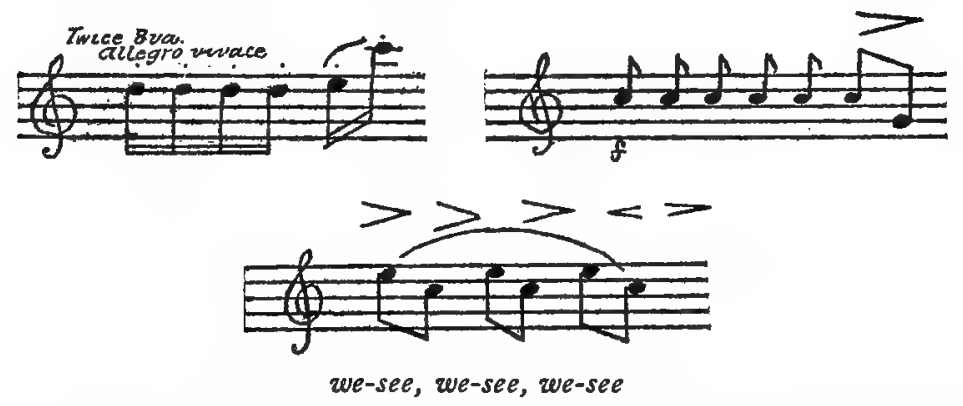

Nesting Site.-The Redstart usually selects an upright crotch from two to thirty feet high in a sapling, the average height being from eight to ten feet. Maples, beeches and elms are frequently chosen but the nest is also placed in other deciduous trees. Burtch (MS.) writes of a nest found June I0, I900, at Branchport, N. Y., which was saddled on the horizontal branch of a beech twelve feet from the ground.

Nest.-The nest is usually symmetrical in outline and compactly made. It suggests in general appearance the nest of the Yellow Warbler but contains less plant-down, or none at all. In other respects, however, the Redstart's nest is often not to be distinguished from that of $D$. astiva. Externally it is composed largely of bits of spiders' webs and silver-gray plant fibers wrapped about firmly woven inner bark shreds and grasses; the lining consists chiefly of fine grasses, brown root-like fibers, and hairs. In some instances feathers are used in the lining. (Short ${ }^{1}$.)

Burtch (MS.) describes a nest found at Branchport, N. Y., June I, I903, as composed of weed bark and dead grass, lined with fine grass and hair. It was handsomely decorated with the white egg 
cases of some insect, and with a fine, green, thread-like moss. The same writer once found a Redstart using a Red-eyed Vireo's nest.

Eggs.-3 to 5, usually 4. Ground color varies from white to creamy, grayish or greenish white; the markings consist of fine specks, spots and blotches in various shades of cinnamon-brown, lilac-gray and reddish, with very few under shell markings of lavender. The distribution of the markings is subject to considerable variation; some types are beautifully wreathed around the large end, with scattering spots over rest of egg, others are quite heavily blotched over most of the great end, and again the egg is evenly sprinkled all over. Size; average, .63x.48; extremes, .56x.48, .58x.46, .70x.48, .69x.51. (Figs. 122-124.)

Nesting Dates.-Raleigh, N. C., May I2 (C.W.C.); Waynesburg, Pa., May I9-June 6 (Jacobs); New York City, May I7-June 24 (F. M. C.) ; New Haven, Conn., May 20-June 27 (Bishop); Cambridge, Mass., full sets, first laying, June 2-8 (Brewster) ; Lancaster, N. H., May 30-June I3 (Spaulding) ; Bangor, Me., June 2-June 30 (Knight) ; Listowel, Ont., June 6-June 18 (Kells); Oberlin, O., May Io-June 20 (Jones); River Forest, Cook Co., Ills., June I (Gault); Petersburg, Mich., May 29 (C.W. C.).

\section{BIOGRAPHICAL REFERENCES}

(1) ERnest H. Short, A Study in Orange and Black, (Redstart in W. N. Y.), Oölogist, X, 1893, 185. (2) W. L. KerLs, Nesting of Some Canadian Warblers, Ottawa Naturalist, XV, 1902, 227. (3) J. C. Woon, Some Notes on the Life History of the American Redstart, Bull. Mich. Orn. Club, V, 1904, 33.

\section{PainTEd REDSTART}

SETOPHAGA PICTA PICTA Swains. Plate XXIII

Distinguishing Characters.-This bird not only differs in color from any known Warbler but the sexes are alike in plumage and the young assumes mature dress the first autumn; all facts which tend to simplify the identification of the species at any season. Length (skin), 4.75; wing, 2.75; tail, 2.50; bill, .35.

Adult do, Spring.-Above shining black, tail black the three outer feathers terminally white diminishing in amount from without inward; wings black, outer primary and secondaries edged with white, middle and greater coverts largely white forming a large white patch; throat and sides black, breast and belly scarlet, ventral region white, under tail-coverts black tipped with white.

Adult d", Fall.-Similar to adult $\delta^{n}$ in Spring.

Young ${ }^{\prime \prime}$, Fall.-Similar to adult $\delta^{A}$ in Fall.

Adult and young ?.-Similar to $d$.

Nestling.-Sooty black, the belly more or less mixed with whitish; wings and tail as in adult. 
General Distribution.-Mountains from Honduras to southern Arizona and New Mexico.

Summer Range.-Mountains of Mexico north to Santa Catalina Mountains, Arizona and Grant County, New Mexico.

Winter Range.-Mexico to Honduras.

Spring Migration.-Southern New Mexico, March 26; southern Arizona, March 15.

The Bird and its Haunts. - The Painted Redstart was added to our fauna by Major (then Lieutenant) Bendire, near Tucson, Arizona, April 4, 1872. Henshaw, who found it in the same territory, in 1873 and 1874 , states that "it appears not to inhabit the high mountains nor the extreme lowlands, but to occupy an intermediate position, and to find the rocky hills covered with sparse growth of oak most congenial to its habits. ***

"Their motions are almost an exact reflection of those of the common Redstart, which they so much resemble in form. With half shut wings and outspread tail, they pass rapidly along the limbs of trees, now and then making a sudden dart for a passing fly, which secured they again alight and resume their search. They are constantly in motion, and rarely remain in the same tree many moments. It not infrequently may be seen clinging to the trunk of a tree while it seizes a grub or minute insect which its sharp eyes have detected hidden in the bark."

Brewster ${ }^{2}$ writes that Stephens found this species at an elevation of fully 7,000 feet in the Chiricahua Mountains where it occurred most numerously among the pines; an experience differing from that of Henshaw, as recorded above.

Howard $^{3}$ found this Warbler breeding in the Santa Catalinas at between 5,000 and 8,000 feet elevation. "With their wings partly open and tail spread they may be seen hopping about on mossy banks or stumps of large trees, generally in the vicinity of a spring or waterfall; now and then they will fly up to catch some insect, much after the manner of the Flycatcher."

Nesting Site.-The nest of this species appears to have been first discovered by Herbert Brown in June I880, in the Santa Rita Mountains of Arizona. (Bryant ${ }^{1}$.) The following year it was found in the same region by Stephens, and later the bird was studied by Howard $^{3}$ and Breninger ${ }^{4}$. From the researches of these naturalists we learn that, wholly unlike its eastern relative (Setophaga ruticilla), the Painted Redstart places its nest on the ground, preferably on a bank 
Plate XXIV

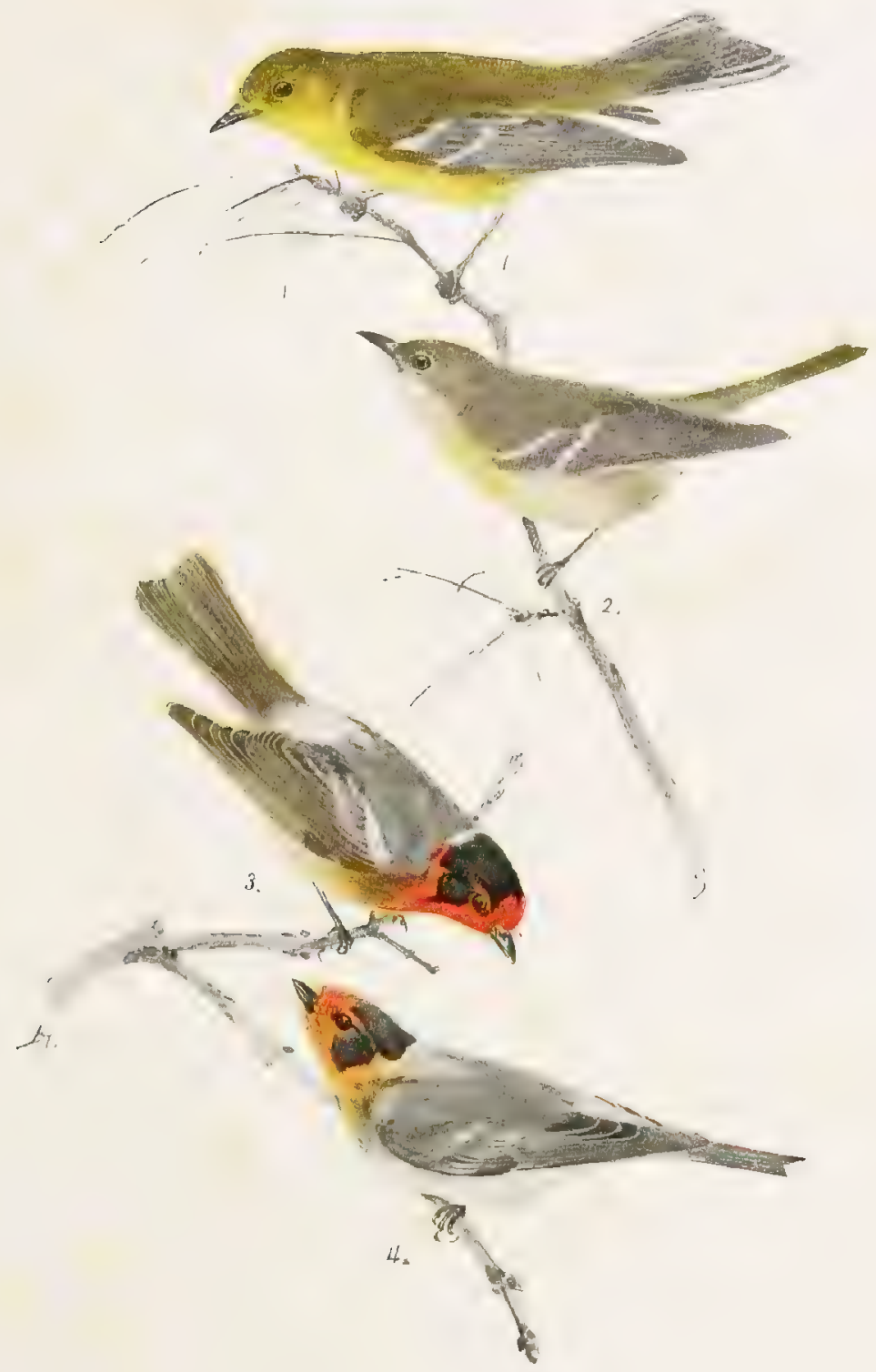

1. Pinfe Warbler, Adult Male.

2. Pine Warbier, Fifmalf.
3. Ren-fiarfed Warbler, Adult Male.

4. Red-faced Warbier, Female. 

or hillside, usually beneath a projecting rock or bunch of grass and, Howard ${ }^{3}$ adds, in the vicinity of a spring or waterfall.

Nest.-Brewster ${ }^{2}$ describes the nest as "large, flat and shallow," and as composed of bark, coarse fibers from weed-stalks, and fine bleached grasses, the latter, with a few hairs forming a simple lining; a description which seems to fit the average nest of this species.

Eggs.-Usually 4. Ground color white, finely dotted, in form of wreath around large end, with reddish brown and lavender gray, and a very few scattering dots over rest of egg. Size; a typical set of 4 measures .65x.5I, .65x.5I, .66x.5I, .64x.5I. (Figs. 125,126.)

Nesting Dates.—Santa Rita Mts., May I8 (Stephens).

\section{Biographical RefErences}

(I) W. E. Bryant, Nest and Eggs of the Painted Flycatcher (in Arizona), Bull. Nutt. Orn. Club, VI, I88I, 176. (2) WM. Brewster, On a Collection Birds lately made by Mr. F. Stephens in Arizona, Bull. Nutt. Orn. Club, VII, 1882, 140. (3) O. W. Howard, Summer Resident Warblers of Arizona, Bull. Cooper Orn. Club (=Condor), I, 1899, 65. (4) G. F. Breninger, The Painted Redstart (in Arizona), Condor, III, 1901, 147. 



\section{HYPOTHETICAL LIST}

The following list contains those Warblers whose specific validity, or whose occurrence in North America has not been definitely established.

\section{Cincinnati Warbler VERMIVORA CINCINNATIENSIS (Langdon)}

The single specimen known is generally considered to be a hybrid between Vermivora pinus and Oporornis formosus. See Langdon Journ. Cinc. Soc. Nat. Hist., III, I88o, I I9, pl. 6; Bull. Nutt. Orn. Club V, I880, 208, pl. 4; Ridgway, Ibid., 237.

\section{BREWSTER'S WARBLER VERMIVORA LEUCOBRONCHIALIS (BrewRE.)}

Apparently a hybrid of $V$. pimus and $V$. chrysoptera. See, however, page 73 , where the bird's status is discussed at length.

\section{LAWRENCE'S WARBLER VERMIVORA LAWRENCEI (Herrick)}

Doubtless a hybrid between $V$. pinus and $V$. chrysoptera. See page 72 for a discussion of its status.

\section{Carbonated Warbler DENDROICA CAR BONATA (Aud.)}

This bird is known to us only from Audubon's plate and description based on two specimens taken by him at Henderson, Kentucky, in May, I8I I (Orn. Biog., I, 308 pl. 60).

\section{SMALL-HEADED WARBLER \\ WILSONIA MICROCEPHALA (RIdgw.)}

This bird is known to us only from the descriptions and figures of Wilson and Audubon. It was described by Wilson under the name Muscicapa minuta. (Am. Orn. VI, I812, 62), but in 1838 was referred by Bonaparte to the genus Wilsonia. In 1885 Ridgway substituted the name microcephala for that of minuta, the latter proving to be preoccupied. 
Whatever may have been the original of Wilson's Muscicapa minuta there can be no question that no such bird as he described now nests, as he supposed, in New Jersey. Of Kentucky, where Audubon secured his specimen, so positive a statement is perhaps not warranted, the recent discovery in that state of the nest of Bachman's Warbler indicating that our knowledge of its bird-life is still far from complete.

\section{RED-BELLIED REDSTART \\ MYIOBORUS MINIATUS MINIATUS (Swaino.)}

A species of the Mexican tableland which was recorded from "Texas" by Giraud ('Sixteen Species Texas Birds', 1841, pl. 7, fig. 1), but the seventy years which have passed since its alleged discovery in what are now the United States make it reasonably sure that Giraud did not get his specimen north of the present Mexican boundary, and there seems to be no further excuse for extending to his record the 'benefit of the doubt.'

\section{RED WARBLER \\ ERGATICUS RUBER (Swtins.)}

Recorded from Texas by Giraud as Parus leucotis ('Sixteen Species of Texas Birds,' I84I, pl. 4, fig. I), but there appear to be no definite records north of Durango and Sinaloa. See remarks under the preceding species.

\section{BRASHER'S WARBLER \\ BASILEUTERUS CULICIVORUS BRASHERI (Giraud)}

A species of northeastern Mexico recorded from "Texas" by Giraud ('Sixteen Species of Texas Birds,' 1841, pl. 6, fig. 2), but it appears to be unknown north of Victoria, Tamaulipas. See remarks under the two preceding species.

\section{BELL'S WARBLER \\ BASILEUTERUS BELLI BELLI (Giraud)}

A species of southern Mexico recorded from "Texas" by Giraud ('Sixteen Species of Texas Birds,' I841, pl. 4, fig. 2), but it appears to be unknown north of the State of Vera Cruz. See remarks under preceding species. 


\section{N D E X}

restiva, DendRoICA estrva, migration of, I8; biography of, II3; figure of, frontispiece; eggs of figured, facing I44; nest of figured, facing 188 .

agilis, Oporornis, biography of, $24 \mathrm{I}$; figure of, facing 236.

Alaskan Yellow Warbler, biography of, I20.

albilora, Dendroica dominica, biography of, 184 .

americana, Compsothlypis americana, biography of, I03.

American Redstart, biography of, 287; figure of, facing 288; eggs of figured, facing 258; nest of figured, facing 272 .

arizela, Geothlypis trichas, biography of, 260.

auduboni, Dendroica auduboni, biography of, I47; figure of, facing 118 ; eggs of figured, facing I44.

Audubon's Warbler, biography of, I47; figure of, facing II8; eggs of figured, facing 144 .

aurocapillus, Seiurus, biography of, 219; figure of, facing 226; eggs of figured, facing 176 ; nest of figured, facing 200 .

BACHMANI VERMIVORA, biography of, 77 ; figure of, facing 64 .

Bachman's Warbler, biography of, 77; figure of, facing 64.

Basileuterus belli belli, 300 .

Basileuterus culicivorus brasheri, 300 .

Bay-breasted Warbler, biography of, 192; figure of, facing 138; eggs of figured, facing I 144 .

beldingi, Geothlypis, biography of, 26r ; figure of, facing 252 .

Belding's Yellow-throat, biography of, 261 ; figure of, facing 252.

belli, Basileuterus belli, 300 .

Bell's Warbler, 300.

brachidactyla, Geothlypis trichas, bioggraphy of, 25I; figure of, facing 252; eggs of figured, facing 258 .

brasheri, Basileuterus culicivorus, 300 .

Brasher's Warbler, 300.

Brewster's Warbler, biography of, 73; figure of, facing 72 .
Black and White Creeping Warbler, same as Black and White Warbler, which see.

Black and White Warbler, biography of, 38 ; song of, 131 ; figure of, facing 38 ; eggs of figured, facing 44.

Black and Yellow Warbler, same as Magnolia Warbler, which see.

Blackburnian Warbler, biography of, I75; song of, 200; figure of, facing 50 ; eggs of figured, facing 176.

Black-capped Flycatching Warbler, same as Wilson's Warbler, which see.

Black-fronted Warbler, biography of, I5I.

Blackpoll Warbler, mortality among, 36; biography of, 196; figure of, facing 38 ; eggs of figured, facing 144 ; nest of figured, facing 200.

Black-throated Blue Warbler, biography of, I33; figure of, facing II2; eggs of figured, facing 144 .

Black-throated Gray Warbler, biography of, I5I ; figure of, facing I52; eggs of figured, facing 176 .

Black-throated Green Warbler, biography of, 157 ; figure of, facing 162 ; eggs of figured, facing 176 .

Blue Golden-winged Warbler, same as Golden-winged Warbler, which see.

Blue Yellow-backed Warbler, same as Parula Warbler and Northern Parula Warbler, which see.

Blue-winged Warbler, biography of, 65 ; figure of, facing 72 ; eggs of figured, facing 44 .

Blue-winged Yellow Warbler, same as Blue-winged Warbler, which see.

CerUlescens, Dendroica cFrulescens, biography of, I33; figure of, facing II2; eggs of figured, facing I44.

cairnsi, Dendroica cærulescens, biography of, I40.

Cairns' Warbler, biography of, I40.

Calaveras Warbler, biography of, 97.

Canada Warbler, biography of, 280 ; figure of, facing 280 ; eggs of figured, facing 258 . 
canadensis, Wilsonia, biography of, 280 ; figure of, facing 280 ; eggs of figured, facing 258.

Canadian Warbler, same as Canada Warbler, which see.

Cape May Warbler, biography of, I28; figure of, facing 2I4; eggs of figured, facing 144 .

carbonata, Dendroica, 299.

Carbonated Warbler, 299.

Cardellina rubrifrons, biography of, 285 ; figure of, facing 296.

castanea, Dendroica, biography of, 192 ; figure of, facing I38; eggs of figured, facing 144 .

castaneiceps, Dendroica bryanti, biography of, 12I ; figure of, frontispiece; eggs of figured, facing 144.

celata, Vermivora celata, biography of, 86; figure of, facing 86.

cerulea, Dendroica, biography of, I70; figure of, facing 112; eggs of figured, facing 144 .

Cerulean Warbler, biography of, 170; figure of, facing II2; eggs of figured, facing 144 .

Chamæethlypis poliocephala poliocephala, biography of, 263 ; figure of, facing 226.

Chestnut-sided Warbler, biography of, I87; figure of, facing 138; eggs of figured, facing I44; nest of figured, facing 188 .

chryseola, Wilsonia pusilla, biography of, 279.

chrysoparia, Dendroica, biography of, 162 ; figure of, facing 162 ; eggs of figured, facing $I 76$.

chrysoptera, Vermivora, biography of, 60 ; figure of, facing 72 ; eggs of figured, facing 44 .

cincinnatiensis, Vermivora, 299.

Cincinnati Warbler, 299.

citrea, Protonotaria, biography of, 54; figure of, facing 50; eggs of figured, facing 44 ; nest of figured, facing 58 .

Compsothlypis americana americana, biography of, I03.

Compsothlypis americana usnex, biography of, 104; song, 173; figure of, facing 104; eggs of figured, facing 44 ; nest of figured, facing 58 .

Compsothlypis pitiayumi nigrilora, biography of, I09; figure of, facing 104.

Connecticut Warbler, biography of, 24I ; figure of, facing 236 .

coronata, Dendroica, biography of, I4I ; figure of, facing II8; eggs of figured, facing 144 .

Creeper, Black-and-White, same as Black and White Warbler, which see.
Dendrotca estrva Astiva, migration of, 18; biography of, II3; figure of, frontispiece; eggs of figured, facing 144 ; nest of figured, facing 188.

Dendroica æstiva rubiginosa, biography of, 120.

Dendroica æstiva sonorana, biography of, II9.

Dendroica auduboni auduboni, biography of, 147; figure of, facing I18; eggs of figured, facing I44.

Dendroica auduboni nigrifrons, biography of, I5I.

Dendroica fusca, biography of, 175; song of, 200 ; figure of, facing 50 ; eggs of figured, facing 176 .

Dendroica bryanti castaneiceps, biography of, I2I ; figure of, frontispiece; eggs of figured, facing I44.

Dendroica cærulescens cærulescens, biography of, I33; figure of, facing I 2 ; eggs of figured, facing 144.

Dendroica cærulescens cairnsi, biography of, 140.

Dendroica carbonata, 299.

Dendroica castanea, biography of, 192; figure of, facing 138 ; eggs of figured, facing I44.

Dendroica cerulea, biography of, 170; figure of, facing II2; eggs of figured, facing I44.

Dendroica chrysoparia, biography of, 162 ; figure of, facing 162 ; eggs of figured, facing 176 .

Dendroica coronata, biography of, I4I ; figure of, facing II8; eggs of figured, facing 144 .

Dendroica discolor, biography of, 209; figure of, frontispiece; eggs of figured, facing $I 76$

Dendroica dominica albilora, biography of, 184 .

Dendroica dominica dominica, biography of, I80; figure of, facing 152 ; eggs of figured, facing 176 .

Dendroica graciæ graciæ, biography of, 185 ; figure of, facing 152 .

Dendroica kirtlandi, biography of, 206; figure of, facing 126; eggs of figured, facing 176 .

Dendroica magnolia, biography of, I2r ; figure of, facing I26; eggs of figured, facing, I44.

Dendroica nigrescens, biography of, $15 \mathrm{I}$; figure of, facing 152 ; eggs of figured, facing 176 .

Dendroica occidentalis, biography of, I67; figure of, facing I7o.

Dendroica palmarum hypochrysea, biog- 
raphy of, 216; eggs of figured, facing 176.

Dendroica palmarum palmarum, biography of, 213 ; figure of, facing 214 .

Dendroica pensylvanica, biography of, 187 ; figure of, facing 138 ; eggs of figured, facing I44; nest of figured, facing 188.

Dendroica striata, mortality among, 36 ; biography of, 196 ; figure of, facing 38 ; eggs of figured, facing I44; nest of figured, facing 200 .

Dendroica tigrina, biography of, 128; figure of, facing 214 ; eggs of figured, facing 144.

Dendroica townsendi, biography of, I54; figure of, facing I70; eggs of figured, facing 258 .

Dendroica vigorsi vigorsi, biography of, 201 ; figure of, facing 296 ; eggs of figured, facing 176 .

Dendroica virens, biography of, 157 ; figured of, facing 162 ; eggs of figured, facing 176.

discolor, Dendroica, biography of, 209; figure of, frontispiece; eggs of figured, facing 176 .

dominica, Dendroica dominica, biography of, I 80 ; figure of, facing 152 ; eggs of figured, facing 176 .

Dusky Warbler, biography of, 90.

ERGATICUS RUBER, 300.

Florida YeLLOW-THROAT, same as Southern Yellow-throat, which see.

formosus Oporornis, biography of, 235 ; figure of, facing 236 ; eggs of figured, facing 258 .

GroTHLYPIS BELDINGI, biography of, 26I ; figure of, facing 252 .

Geothlypis trichas arizela, biography of, 260.

Geothlypis trichas ignota, biography of. 257.

Geothlypis trichas trichas biography of, 251 ; figure of, facing 252 ; eggs of figured, facing 258.

Geothlypis trichas occidentalis, biography of, 259.

Geothlypis trichas sinuosa, biography of, 261.

Golden-cheeked Warbler, biography of, I62; figure of, facing 162 ; eggs of figured, facing 176 .

Golden-crowned Thrush, same as Ovenbird, which see.

Golden Pileolated Warbler, biography of, 279 .

Golden Swamp Warbler, same as Prothonotary Warbler, which see.

Golden Warbler, same as Yellow Warbler, which see.
Golden-winged Warbler, biography of, 60 ; figure of, facing 72 ; eggs of figured, facing 44.

Grace's Warbler, biography of, 185 ; figure of, facing 152 .

graciæ, Dendroica gracia, biography of, 185 ; figure of, facing 152 .

Grinnell's Water-Thrush, biography of, 234.

gutturalis, Vermivora rubricapilla, biography of, 97.

HelinaIA SWAINSONI, biography of, 44 ; figure of, facing 64 ; eggs of figured, facing 44 .

Helmitheros vermivorus, biography of, 48 ; figure of, facing 64 ; eggs of figured, facing 44.

Hermit Warbler, biography of, I67; figure of, facing 170 .

Hooded Warbler, biography of, 269 ; figure of, facing 264 ; eggs of figured, facing 258 ; nest of figured, facing 272.

hypochrysea, Dendroica palmarum, biography of, 216; eggs of figured, facing 176 .

ICTERIA VIRENS LONGICAUDA, biography of, 268.

Icteria virens virens, biography of, 264; figure of, facing 264 ; eggs of figured, facing 258 .

KENTUCKY WAKBLER, biography of, 235; figure of, facing 236 ; eggs of figured, facing 258.

kirtlandi, Dendroica, biography of, 206; figure of, facing 126; eggs of figured, facing 176 .

Kirtland's Warbler, biography of, 206; figure of, facing 126; eggs of figured, facing 176 .

LARge-gilled WATER-Thrush, same as Louisiana Water-Thrush, which see.

lawrencei, Vermivora, biography of, 72; figure of, facing 72 .

Lawrence's Warbler, biography of, 72 ; figure of, facing 72 .

leucobronchialis, Vermivora, biography of, 73; figure of, facing 72 .

longicauda, Icteria virens biography of, 268.

Long-tailed Chat biography of, 268.

Louisiana Water-Thrush, biography of, 226 ; figure of, facing 226; eggs of figured, facing 176 .

luciæ, Vermivora, biography of, I00; figure of, facing 98 ; eggs of figured, facing 44.

Lucy's Warbler biography of, IOO; figure of, facing 98 ; eggs of figured, facing 44 . 
lutescens, Vermivora celata, biography of, 90 ; eggs of figured, facing 44 .

Lutescent Warbler, biography of, 90; eggs of figured, facing 44.

MAcGILlIVRAY's WARBLER, biography of, 249 ; figure of, facing 244 ; eggs of figured, facing 258 .

magnolia, Dendroica, biography of, 121 ; figure of, facing I26; eggs of figured, facing I44.

Magnolia Warbler, biography of, I2I ; figure of, facing 126 ; eggs of figured, facing 144

Mangrove Warbler, biography of, I2I ; figure of, frontispiece; eggs of figured, facing 144 .

Maryland Yellow-throat, same as Northern Yellow-throat, which see. microcephala, Wilsonia, 299.

miniatus, Myioborus miniatus, 300.

mitrata, Wilsonia, biography of, 269 ; figure of, facing 264 ; eggs of figured, facing 258 ; nest of figured, facing 272.

Mniotilta varia, biography of, 38 ; song of, I3I ; figure of, facing 38 ; eggs of figured, facing 44 .

motacilla, Seiurus, biography of, 226; figure of, facing 226; eggs of figured, facing 176 .

Mourning Warbler, biography of, 244; figure of, facing 244 ; eggs of figured, facing 258 .

Myioborus miniatus miniatus, 300.

Myrtle Bird, same as Myrtle Warbler, which see.

Myrtle Warbler, biography of, I4I ; figure of, facing II8; eggs of figured, facing I44.

NASHVILLE WARBLER, biography of, 92 ; figure of, facing 86; eggs of figured, facing 44 .

nigrescens, Dendroica, biography of, I5I; figure of, facing I52; eggs of figured, facing 176 .

nigrifrons, Dendroica auduboni, biography of, I5I.

nigrilora, Compsothlypis pitiayumi, biography of, I09; figure of, facing 104.

Northern Parula Warbler, same as Parula Warbler, which see.

Northern Water-Thrush, biography of, 230; figure of, facing 226; eggs of figured, facing 176 .

Northern Yellow-throat, biography of, $25 \mathrm{I}$; figure of, facing 252 ; eggs of figured, facing 258.

notabilis, Seiurus noveboracensis, biography of, 234. noveboracensis, Seiurus noveboracensis, biography of, 230; figure of, facing 226; eggs of figured, facing 176 .

occidentalis, Dendroica, biography of, I67; figure of, facing 170.

occidentalis, Geothlypis trichas, biography of, 259.

olivaceus, Peucedramus, biography of, IIO; figure of, facing 98 ; eggs of figured, facing I44.

Olive Warbler, biography of, IIo; figure of, facing 98; eggs of figured, facing 144 .

Oporornis agilis, biography of, 241 ; figure of, facing 236 .

Oporornis formosus, biography of, 235; figure of, facing 236 ; eggs of figured, facing 258.

Oporornis philadelphia, biography of, 244; figure of, facing 244; eggs of figured, facing 258.

Oporornis tolmiei, biography of, 249; figure of, facing 244 ; eggs of figured, facing 258 .

Orange-crowned Warbler, biography of, 86; figure of, facing 86 .

orestera, Vermivora celata, biography of, 89 .

Oven-bird, biography of, 219; figure of, facing 226; eggs of figured, facing 176 ; nest of figured, facing 200 .

PACIFIC YeLLOW-ThROAT, biography of, 260.

Painted Redstart, biography of, 295; figure of, facing 288 ; eggs of figured, facing 258.

palmarum, Dendroica palmarum, biography of, 213; figure of, facing 214 .

Palm Warbler, biography of, 213; figure of, facing 2 I4.

Parula Warbler, biography of, ro4; song of, 173; figure of, facing 104; eggs of figured, facing 44 ; nest of figured, facing 58 .

pensylvanica, Dendroica, biography of, 187; figure of, facing 138; eggs of figured, facing I44; nest of figured, facing 188 .

peregrina, Vermivora, biography of, 83; figure of, facing 86; eggs of figured, facing 44 .

Peucedramus olivaceus, biography of, IIO; figure of, facing 98 ; eggs of figured, facing I 44 .

philadelphia, Oporornis, biography of, 244 ; figure of, facing 244 ; eggs of figured, facing 258.

picta, Setophaga picta, biography of, 295 ; figure of, facing 288 ; eggs of figured, facing 258. 
pileolata, Wilsonia pusilla, biography of, 278 ; eggs of figured, facing 258.

Pileolated Warbler, biography of, 278; eggs of figured, facing 258.

Pine-Creeping Warbler, same as Pine Warbler, which see.

Pine Warbler, biography of, 20I ; figure of, facing 296 ; eggs of figured, facing 176.

pinus, Vermivora, biography of, 65 ; figure of, facing 72 ; eggs of figured, facing 44.

poliocephala, Chamæthlypis poliocephala, biography of, 263 ; figure of, facing 226.

Prairic Warbler, bography of, 209; figure of, frontispiece; eggs of figured, facing 176 .

Prothonotary Warbler, biography of, 54; figure of, facing 50 ; eggs of figured, facing 44 ; nest of figured, facing 58

Protonotaria citrea, biography of, 54; figure of, facing 50 ; eggs of figured, facing 44 ; nest of figured, facing 58.

pusilla, Wilsonia pusilla, biography of, 274; figure of, facing 280.

RED-BELLIED REDSTART, 300 .

Red-faced Warbler, biography of, 285 ; figure of, facing 296.

Red-poll Warbler, same as Palm Warbler, which see.

Red Warbler, 300.

Rio Grande Yellow throat, biography of, 263 ; figure of, faring 226.

Rocky Mountain Orange-crown, biography of, 89.

ruber, Ergaticus, 300.

rubiginosa, Dendroica æstiva, biography of, 120.

rubricapilla, Vermivora rubricapilla, biography of, 92 ; figure of, facing 86 ; eggs of figured, facing 44.

rubrifrons, Cardellina, biography of, 285 ; figure of, facing 296.

ruticilla, Setophaga, biography of, 287 ; figure of, facing 288; eggs of figured, facing 258 ; nest of figured, facing 272.

Salt Marsh Yeilow-throat, biogtaphy of, 26I.

Seiurus aurocapillus, biography of, 219; figure of, facing 226; eggs of figured, facing 176 ; nest of figured, facing 200.

Seiurus motacilla, biography of, 226 ; figure of, facing 226; eggs of figured, facing 176 .

Seiurus noveboracensis notabilis, biography of, 234.

Seiurus noveboracensis noveboracensis, biography of, 230; figure of, facing
226; eggs or ngured, facing 176 .

Sennett's Warbler, biography of, Iog; figure of, facing 104.

Setophaga picta picta, biography of, 295 ; figure of, facing 288 ; eggs of figured, facing 258.

Setophaga ruticilla, biography of, 287 ; figure of, facing 288 ; eggs of figured, facing 258; nest of figured, facing 272.

sinuosa, Geothlypis trichas, biography of, $26 \mathrm{I}$.

Small-billed Water-Thrush, same as Northern Water-Thrush, which see.

Small-headed Warbler, 299.

sonorana, Dendroica æstiva, biography of, 119

Sonora Yellow Warbler, biography of, IIg.

sordida, Vermivora celata, biography of, 90.

Southern Parula Warbler, biography of, I03.

Southern Yellow-throat, biography of, 257.

striata, Dendroica, mortality among, 36; biography of, 196; figure of, facing 38 ; eggs of figured, I44; nest of figured, facing 200.

Summer Yellow-bird, same as Yellow Warbler, which see.

swainsoni, Helinaia, biography of, 44 ; figure of, facing 64; eggs of figured, facing 44 .

Swainson's Warbler, biography of, 44; figure of, facing 64 ; eggs of figured, facing 44.

Sycamore Warbler, biography of, 184.

Tennessee WARBLeR, biography of, 83 ; figure of, facing 86; eggs of figured, facing 44 .

tigrina, Dendroica, biography of, I28; figure of, facing 2I4; eggs of figured, facing 144 .

tulmiei, Oporornis, biography of, 249 ; figure of, facing 244 ; eggs of figured, facing 258 .

Tolmie's Warbler, same as Macgillivray's Warbler, which see.

townsendi, Dendroica, biography of, 154; figure of, facing 170; eggs of figured, facing 258 .

Townsend's Warbler, biography of, I54; figure of, facing I70; eggs of figured, facing 258.

trichas, Geothlypis trichas, biography of, 257.

USNEA, COMPSOTHLYPIS AMERICANA, biography of, r04; song of, 173; figure of, facing I04; eggs of figured, facing 44 ; nest of figured, facing 58 . 
VARIA, MNIOTILTA, biography of, 38 ; song of, I3I; figure of, facing 38 ; eggs of figured, facing 44.

Vermivora bachmani, biography of, 77; figure of, facing 64 .

Vermivora celata celata, biography of, 86 ; figure of, facing 86.

Vermivora celata lutenscens, biography of, 90 ; eggs of figured, facing 44 .

Vermivora celata orestera, biography of, 89.

Vermivora celata sordida, biography of, 90.

Vermivora chrysoptera, biography of, 60 ; figure of, facing 72 ; eggs of figured, facing 44.

Vermivora cincinnatiensis, 299.

Vermivora lawrencei, biography of, 72 ; figure of, facing 72 .

Vermivora leucobronchialis, biography of, 73 ; figure of, facing 72 .

Vermivora luciæ, biography of, too; figure of, facing 98 ; eggs of figured, facing 44 .

Vermivora peregrina, biography of, 83 ; figure of, facing 86 ; eggs of figured, facing 44 .

Vermivora pinus, biography of, 65; figure of, facing 72 ; eggs of figured, facing 44 .

Vermivora rubricapilla gutturalis, biography of, 97.

Vermivora rubricapilla rubricapilla, biography of, 92 ; figure of, facing 86 ; eggs of figured, facing 44.

Vermivora virginæ, biography of, 98 ; figure of, facing 98 ; eggs of figured, facing 44 .

vermivorus, Helmitheros, biography of, 48 ; figure of, facing 64 ; eggs of figured, facing 44.

vigorsi, Dendroica vigorsi, biography of, 201 ; figure of, facing 296 ; eggs of figured, facing 176.

virens, Dendroica, biography of, 157; figure of, facing 162; eggs of figured, facing 176 .

virens, Icteria virens, biography of, 264 ; figure of, facing 264 ; eggs of figured, facing 258 . virginæ, Vermivora, biography of, 98 ; figure of, facing 98 ; eggs of figured, facing 44 .

Virginia's Warbler, biography of, 98 ; figure of, facing 98 ; eggs of figured, facing 44 .

WARBLERS, distribution of, II ; food of, 23 ; general characters of, 7 ; generic synopsis of, 38 ; migration of, 14; mortality among, 34; nesting habits of, 22 ; plumage of, 7 ; songs of, 20.

Western Yellow-throat, biography of, 259.

Wilsonia canadensis, biography of, 280 ; figure of, facing 280 ; eggs of figured, facing 258.

Wilsonia microcephala, 299.

Wilsonia citrina, biography of, 269; figure of, facing 264 ; eggs of figured, facing 258 ; nest of figured, facing 272 .

Wilsonia pusilla chryseola, biography of, 279.

Wilsonia pusilla pileolata, biography of, 278 ; eggs of figured, facing 258.

Wilsonia pusilla pusilla, biography of, 274 ; figure of, facing 280.

Wilson's Warbler, biography of, 274; figure of, facing $28 \mathrm{o}$.

Worm-eating Warbler, biography of, 48 ; figure of, facing 64 ; eggs of figured, facing 44.

YeLLOW-BREASTED Chat, biography of, 264 ; figure of, facing 264; eggs of figured, facing 258 .

Yellow Palm Warbler, biography of, 216; eggs of figured, facing 176.

Yellow Red-poll Warbler, same as Yellow Palm Warbler, which see.

Yellow-rumped Warbler, same as Myrtle Warbler, which see.

Yellow-throated Warbler, biography of, I80; figure of, facing I52; eggs of figured, facing 176 .

Yellow Warbler, migration of, I8; biography of, II3; figure of, frontispiece; eggs of figured, facing I44; nest of figured, facing 188 . 




